\title{
A PROCRIAÇÃO E O INTERESSE DA RES PUBLICA: UMA ANÁLISE DAS LEIS MATRIMONIAIS DE AUGUSTO
}

Dissertação de Mestrado apresentada ao Departamento de Direito Civil da Faculdade de Direito da Universidade de São Paulo, como requisito parcial para a obtenção de grau de Mestre, sob a orientação do Prof. Dr. Hélcio Maciel França Madeira.

Faculdade de Direito da Universidade de São Paulo

São Paulo 
Ao meu orientador, mestre e amigo, Prof. Dr. Hélcio Maciel França Madeira por todo o apoio inestimável, didático e metodológico.

À minha mãe, Raquel Maria Pagni Steinwascher, exemplo de vida cristã.

Aos meus amigos, Prof. Carlos Alexandre Böttcher, Prof. Edson Kiyoshi Nacata Junior, Profa. Dra. Eliane Maria Agati Madeira e Prof. Felipe Epprecht Douverny, cujo apoio muito auxiliou na pesquisa deste trabalho.

Este trabalho contou com o apoio institucional e financeiro da Coordenação de Aperfeiçoamento de Pessoal de Nível Superior (CAPES) - Programa de Excelência Acadêmica (PROEX). 


\section{PRINCIPAIS ABREVIATURAS*}

\section{A) FONTES}

C.

CIL.

Coll.

C. Th.

D.

FIRA

Vat. Frag.

Gai.

Inst.

L. XII Tab.

Nov.

Nov. Leon.

Nov. Maior.

Nov. Theod.

Nov. Valent.

Nov. Valer.

UE
= Codex Iustinianus

= Corpus inscriptionum latinarum

= Collatio legum Mosaicarum et Romanarum

$=$ Codex Theodosianus

= Digesta

= Fontes iuris romani anteiustiniani I a III

= Fragmenta Vaticana, in FIRA II

= Gai institutiones, in FIRA II

= Institutiones Iustiniani

= Lex XII Tabularum, in FIRA I

= Novellae Iustiniani

= Novellae Leonini

= Novellae Maioriani

= Novellae Theodosiani

= Novellae Valentiniani

= Novellae Valeriani

= Tituli ex corpore Ulpiani, in FIRA II

\footnotetext{
* Em relação à metodologia e aos aspectos formais da dissertação, esclareça-se que as traduções das Regras de Ulpiano (Ulpiani Epitome) são de G. SCIASCIA, Regras de Ulpiano - Ulpiani Liber Singularis Regularum, Bauru, EDIPRO, 2002; do livro I do Digesto de H.M.F. MADEIRA, Digesto de Justiniano - Liber Primus: Introdução ao Direito Romano, 4a ed., São Paulo, RT, 2009; das Institutas de Gaio de Justiniano de A.CôRreA - G. SCIASCIA, Manual de Direito Romano: Institutas de Gaio e de Justiniano vertidas para o português, em confronto com o texto latino, vol.2, São Paulo, Saraiva, 1951. As traduções gregas das Historiae Romanae de Dio Cassio (Lucius Claudius Cassio Dio Cocceianus) foram baseadas nas traduções de T. Spagnuolo Vigorita, Casta Domus - Un seminario sulla legislazione matrimoniale augustea, $3^{\mathrm{a}} \mathrm{ed}$. Napoli, Jovene, 2010. As demais são citadas no corpo do trabalho, salvo aquelas da própria lavra do autor.
}

Nas citações bibliográficas, para evitar-se a repetição dos elementos já citados de um mesmo autor, será feita a remissão da nota de rodapé onde a citação apareceu pela primeira vez, com as informações completas. Além disso, apenas será utilizada a forma “op.cit.” quando uma obra já foi citada na mesma nota de rodapé. 


\section{B) REVISTAS, COLEÇÕES E COLETÂNEAS}

$$
\begin{array}{ll}
\text { AG } & =\text { Archivio Giuridico “Filippo Serafini” (Modena) } \\
\text { ANRW } & =\text { Aufstieg und Niedergang der Römischen Welt (Berlin-New York) } \\
\text { BIDR } & =\text { Bulletino dell'Istituto di diritto romano “Vittorio Scialoja” (Roma) } \\
\text { CJ } & =\text { The Classical Journal (Chicago-Washington) } \\
\text { ED } & =\text { Enciclopedia del diritto (Milano) } \\
\text { Index } & =\text { Index. Quaderni camerti di studi romanistici (Camerino) } \\
\text { IURA } & =\text { Rivista internazionale di diritto romano e antico (Napoli) } \\
\text { JRS } & =\text { Journal of Roman Studies (London) } \\
\text { Labeo } & =\text { Rassegna di diritto romano (Napoli) } \\
\text { PSI } & =\text { Pubblicazioni della Società italiana di Papiri greci e latini (Firenze) } \\
\text { NNDI } & =\text { Novissimo digesto italiano (Torino) } \\
R H & =\text { Revue Historique de Droit Français et Étranger (Paris) } \\
\text { RIDA } & =\text { Revue Internationale des Droits de l'Antiquité (Bruxelles) } \\
\text { RISG } & =\text { Rivista italiana per le scienze giuridiche (Roma) } \\
\text { SDHI } & =\text { Studia et documenta historiae et iuris (Roma) } \\
\text { SSA } & =\text { Studi sassaresi (Sassari) }
\end{array}
$$




\section{SUMÁRIO}

INTRODUÇÃO.

3

PARTE I - A PROCRIAÇÃO E O MATRIMÔNIO ROMANO............................................................... 5

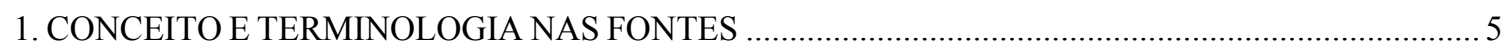

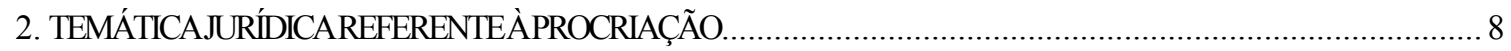

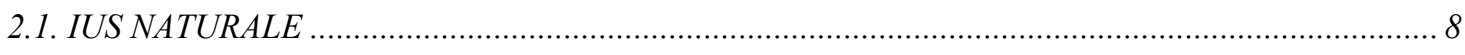

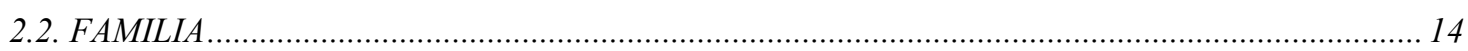

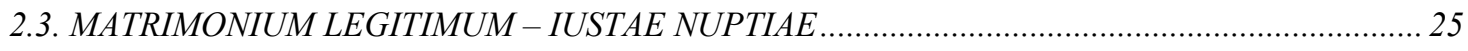

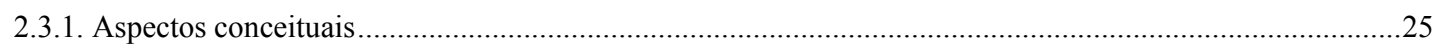

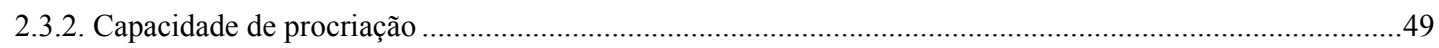

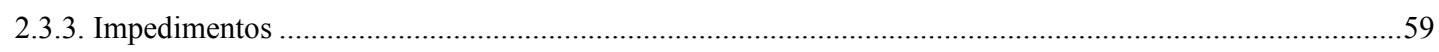

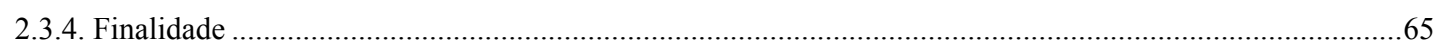

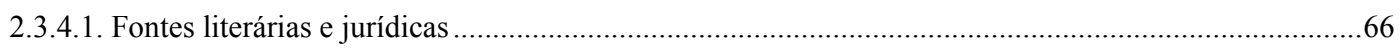

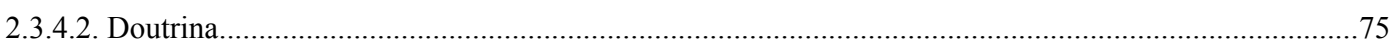

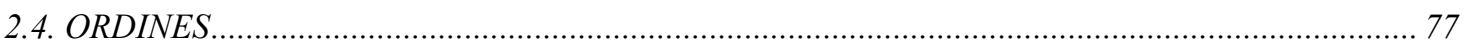

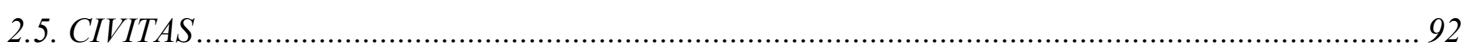

PARTE II - A PROCREATIO E A RES PUBLICA: PERÍODOS .............................................................97

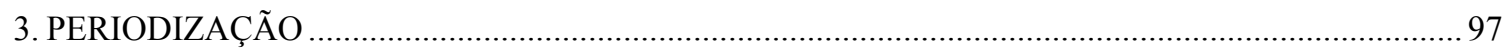

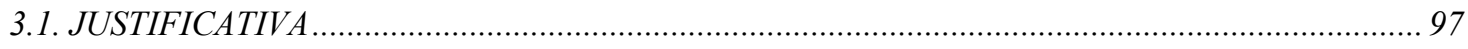

3.2. PERÍODO ANTERIOR ÀS LEIS MATRIMONIAIS DE AUGUSTO ……........................................ 100

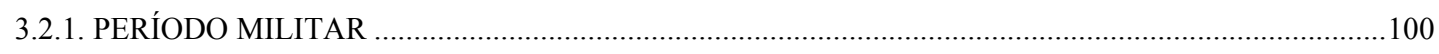

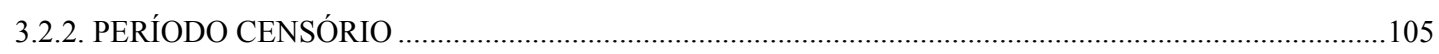

3.2.3. PERÍODO DA NEQUITIA E DOS MALI MORES …………………………………………........ 113

3.3. PERÍODO DA UNIDADE CONCEITUAL DAS LEIS MATRIMONIAIS DE AUGUSTO ............... 121

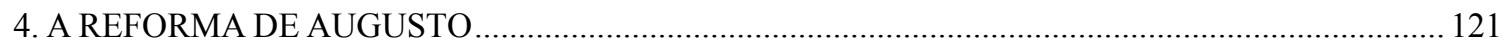

4.1. O PAPEL DOS COSTUMES E DAS LEIS COMO FONTE DE DIREITO NO PRINCIPADO: A

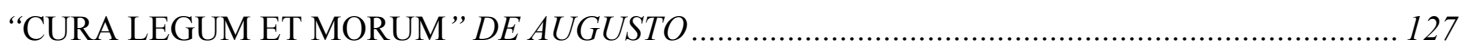

4.2. AS PRINCIPAIS CARACTERÍSTICAS DAS LEIS MATRIMONIAIS DE AUGUSTO ………….... 132

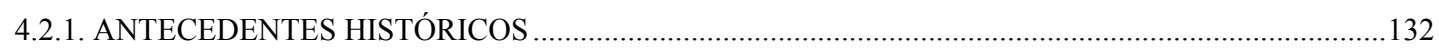

4.2.2. LEX IULIA DE MARITANDIS ORDINIBUS E LEX PAPIA POPPAEA NUPTIALIS ………………….....140

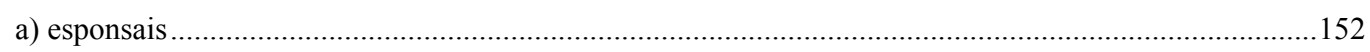

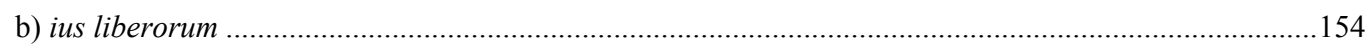

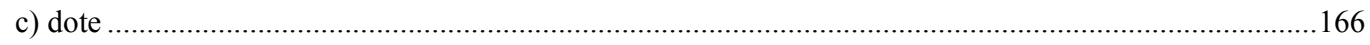

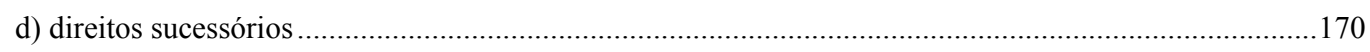

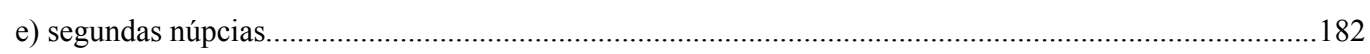

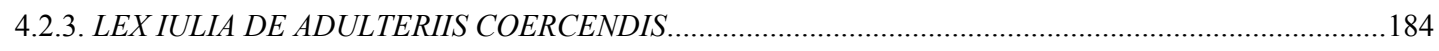

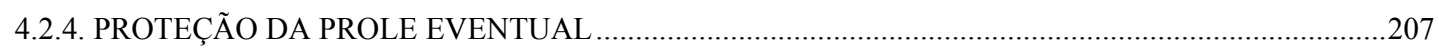

4.2.5. O LEGADO DAS LEIS MATRIMONIAIS DE AUGUSTO ………………………………………........217

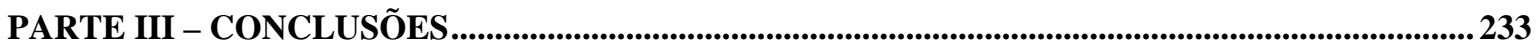


RESUMO 240

RIASSUNTO 241

BIBLIOGRAFIA . 242

ÍNDICE DE FONTES 269 ÍNDICE DE AUTORES 288 


\section{INTRODUÇÃO}

Pretende-se salientar nesta pesquisa o impacto jurídico ocasionado pelas Leis Matrimoniais de Augusto na concepção romana de casamento, em especial a importância da "procriação" na estrutura ${ }^{1}$ do matrimônio.

$\mathrm{O}$ direito e o dever à prole, como um interesse juridicamente protegido, escapam em geral da análise dos pesquisadores, enquanto se trata de elementos híbridos, entre o direito público e o direito privado, realidade que se deduz da igualmente complexa noção de matrimônio, do qual derivam.

A procriação pode interessar ao Estado tanto no sentido de proporcionar um aumento demográfico, como no sentido de favorecer o casamento. Nos dias de hoje, a exemplo disso, muitos governos, principalmente dos países europeus, preocupam-se com a baixa taxa de natalidade e procuram conceder prêmios e benefícios jurídicos às famílias com grande número de filhos. Muitas populações estão "envelhecidas", com consequente estreitamento da faixa etária dos jovens.

Outros países, por outro lado, enfrentam o problema da superpopulação, como a China, que adota rigorosas medidas de planejamento familiar.

Esta intervenção pública no casamento e na procriação pode, ainda hoje, determinar diferenças de impostos entre casados e não-casados, impondo regimes tributários diversos a solteiros, viúvos ou aos que não tem filhos. Pode, igualmente, estabelecer quotas de filhos para concessão de isenções e imunidades fiscais ou, ao contrário, para punir. ${ }^{2}$

O objetivo principal desta pesquisa será esclarecer e analisar as principais alterações ocorridas em relação à procriação e ao interesse do "Estado" romano, sobretudo no período clássico, com a promulgação das Leis Matrimonias de Augusto, além de realizar um reexame do antigo conceito de matrimônio em Roma.

A constituição da família romana tem relação direta com o seu papel de unidade social fundada no matrimônio. O início da educação de um romano, realizado dentro da

\footnotetext{
${ }^{1}$ A expressão "estrutura" do matrimônio tem sido utilizada por inúmeros autores, dentre os quais, citamos A. GuARINO, Diritto privato romano, 12 a ed., Napoli, Jovene, 2001; R. ORESTANO, La struttura giuridica del matrimonio romano - Dal Diritto Classico al Diritto Giustinianeo, Milano, Giuffrè, 1951; R. ASTOLFI, Il matrimonio nel diritto romano preclassico, Padova, CEDAM, 2000.

${ }^{2}$ No Brasil este tema praticamente não foi explorado, embora tenha sido a ele dedicado um precursor e visionário título (“A Procriação e o Interesse do Estado") na obra de F.C. PONTES DE MIRANDA, Tratado de Direito de Família, vol.1, $3^{\mathrm{a}}$ ed., São Paulo, Max Limonad, 1947, pp.95-96. O título que ora se oferece, “A
} 
família, tomava nos hábitos dos antepassados (mores maiorum) o ideal pedagógico perseguido. Esta unidade, prejudicada com o relaxamento de alguns costumes romanos, principalmente a partir da Segunda Guerra Púnica, abalou profundamente a estrutura familiar entre o final da República e o início do Principado.

Na primeira parte desta pesquisa, faz-se uma análise da terminologia de procreatio e de outros termos vinculados à procriação e à prole: proles, suboles, soboles, liber, impubes, gentes.

No capítulo segundo, sobre a temática jurídica referente à procreatio, recolhem-se os diversos temas recorrentes nas fontes romanas, em que esta assume uma posição de "princípio e fim" (ao ius naturale) ou de "elemento formador e fundamento" (à familia, ao matrimonium legitimum, aos ordines e à civitas).

O conceito de matrimônio, à luz da interpretação da História do Direito Romano, não pode prescindir do estudo sobre a fórmula presente nos inúmeros textos literários (e alguns poucos, jurídicos) para indicar a procriação como a finalidade precípua do matrimônio romano: liberorum quaerendorum [procreandorum] causa.

Na segunda parte da pesquisa, propõe-se uma periodização sobre o interesse da res publica romana na procriação, que sofreu diversas alterações desde as origens régias até o principado. Guerras de conquista, invasões, guerras civis são algumas das conjunturas que promovem o interesse no aumento demográfico, seja para nutrir exércitos, seja para repor a queda populacional (das classes senatorial e equestre). Dois períodos salientam-se: um, anterior à promulgação das Leis Matrimoniais (Demográficas, Caducárias) de Augusto, ainda incerto, não teorizado; outro, posterior, o denominado "período da unidade conceitual" das Leis Matrimoniais de Augusto, já conscientemente manipulado pelos retores e juristas.

A res publica parece interferir na autonomia dos patres na composição de suas famílias em algumas situações de crises, sejam elas econômicas, militares, morais, políticas ou demográficas. No caso das Leis matrimoniais de Augusto, oscilam as interpretações entre a proteção dos interesses da sociedade (utilitas publica), o combate à degradação dos costumes e o declínio populacional.

A reconstituição histórica do conteúdo e das finalidades de cada uma dessas leis sob o critério da utilitas rei publicae permitiu, nisi fallor, além de servir à seleção e apresentação das referidas interpretações, oferecer ao tema uma nova contribuição.

procriação e o interesse da res publica: uma análise das leis matrimoniais de Augusto" foi, pois, inteiramente nessa obra inspirado. 


\title{
PARTE I - A PROCRIAÇÃO E O MATRIMÔNIO
}

\author{
ROMANO
}

\section{CONCEITO E TERMINOLOGIA NAS FONTES}

Antes de iniciarmos a exposição do assunto a ser tratado neste trabalho, são necessários alguns esclarecimentos terminológicos, visto que a utilização de expressões modernas para o estudo de concepções políticas e jurídicas em Roma pode acarretar graves distorções. ${ }^{3}$

A origem etimológica de procreatio provém de suas raízes na palavra pro-creo (dar à luz, produzir), do verbo creo, as (criar, do poder da deusa Ceres de fazer crescer os pães, Cereris manus) e que originou o verbo procreo, as, are, avi, atum que significa procriar, engendrar, produzir. ${ }^{4}$

\footnotetext{
${ }^{3}$ Conforme P. CATAlano, Religione morale diritto nella prospettiva dello 'Ius Romanum' (Da Tertulliano ad Alfonso Maria de Liguori), in Nozione formazione ed interpretazione del diritto. Dall'Età romana alle esperienze moderne - Ricerche dedicate al professor Filippo Gallo, v.3, Napoli, Jovene, 1997, p.398: Una corretta interpretazione degli antichi giuristi deve previamente eliminare incrostazioni concettuali moderne e travisamenti linguistici volgari. Incrostazioni concettuali (variamente connesse a individualismo, statualismo, positivismo e realismo giuridico degli ultimi due secoli) le quali impediscono la comprensione dell'antica concezione dello 'ius', sono a mio avviso: la confusione tra 'validità' ed 'effetività' delle norme giuridiche; la separazione del 'diritto' della morale e della religione, e quindi del diritto cosidetto 'sacro' (o 'divino') da quello cosiddetto 'profano' (o 'laico '); la distinzione tra 'diritto oggettivo' e 'diritto soggettivo'. Il concetto di 'ius' non può essere compreso se si confondono 'validità' ed 'effettività', 'diritto' e 'fatto'. La definizione di Celso "ius est ars boni et aequi" resta l'unica definizione romana del diritto; da essa consegue la denominazione dei giuristi come 'sacerdotes iustitiae' (Ulpiano D.1,1,1pr.). La validità dello 'ius' in quanto 'ars' ("sistema") del bono e dell'equo non deriva della forza effettiva dello Stato! "Uma correta interpretação dos antigos juristas deve eliminar, previamente, "incrustações" modernas e distorções linguísticas vulgares. Incrustações conceituais (relacionadas ao individualismo, estatalismo, positivismo e realismo jurídico dos últimos dois séculos) impedem a compreensão da concepção antiga de ius. Em minha opinião, as principais incrustações são: a confusão entre "validade" e "efetividade" das normas jurídicas; a separação do "direito" da moral e da religião, e portanto, a separação do direito denominado "sacro" (ou "divino") daquele denominado "profano" (ou "laico"); a distinção entre "direito objetivo" e "direito subjetivo". O conceito de ius não pode ser compreendido se se confundem "validade" e "efetividade", "direito" e "fato". A definição de Celso "ius est ars boni et aequi" permanece como a única definição romana de direito; desta deriva a denominação dos juristas como "sacerdotes iustitiae" (Ulpiano D.1,1,1pr.). A validade do ius enquanto ars (sistema) do bom e do équo não decorre da força efetiva do Estado!".

${ }^{4}$ A palavra procreatio foi utilizada nos seguintes textos romanos: Ulp. 1 inst. D.1,1,1,3; Paul. 1 ad l. Iul. et Pap. D.23,2,44,6; Ulp. 2 de off. cons. D.25,3,5,6; Mod. 9 reg. D.31,32,6; Paul. 41 ad ed. D.37,4,6,4; Ulp. 12 ad Sab. D.38,17,1,3; Ulp. 13 ad Sab. D.38,17,2,1; Paul. 1 decret. D.50,2,9pr.; Paul. 1 ad l. Iul. et Pap. D.50,16,129; Gai. 1,77; 3,72; Inst. 1,2pr.; 1,10,13; 2,13,5; 3,2,1; 3,6,10; PS 4,5,2. Vejam-se A. ERNOUT - A. MeILlet, Dictionnaire Etymologique de la Langue Latine - Histoire des mots, vol.1, $3^{\mathrm{a} e d .}$, Paris, C.
} 
O termo proles, etimologicamente deriva do verbo alo, -is, -ere, que significa "alimentar", "nutrir" e faz alusão à noção de "recursos" referentes à vida humana, que foram acumulados por aquele que gerou muitos filhos. ${ }^{5}$

Um dos principais termos relacionado à familia e à procriação é Liber, nome do deus da procriação e que indica a situação jurídica da prole, ou seja, o nome coletivo liberi (filhos, descendentes) refere-se aos filhos que nasceram livres (ingênuos), para distinguilos dos filhos dos escravos. ${ }^{6}$

O vocábulo impubes (ou inpubes) etimologicamente ligado a puer (menino, criança) e puritas (pureza) indica a criança que não tem capacidade para procriar, os

Klincksieck, 1951, pp.480-484; M. BREAL - A. BAILly, Dictionnaire étymologique latin, 11 $1^{\mathrm{a} e d .}$. Paris, Hachette, [s.d.], pp.50 e 115; J. CEJADOR Y FrAUCA, Diccionario Etmológico-Analítico Latino-Castellano, Madrid, Sucesores de Rivadeneyra, 1926, pp.88;157-158; F. GAFFIOT, Dictionnaire Latin-Français, Paris, Hachette, 2000, p.1259; G. CIPRIANI - P. FEDELI, Vivere a Roma antica - Antologia latina per il bienio, Roma-Bari, Laterza, 1995, p.6.

${ }^{5}$ Do mesmo verbo alo, - is, - ere, deriva a palavra suboles (ou soboles) de sub + oles, que designava o "rebento" e a "descendência". Portanto, o termo proles (pro + oles) tem a mesma raiz de suboles e é sinônimo de progenies (descendência, prole). Derivada de proles é a palavra proletarius que foi utilizada para designar os cidadãos das classes mais pobres (Cic. de rep. 2,22,40). Vejam-se G. CIPRIANI - P. FeDELI, Vivere a Roma antica cit. (nota 2 supra), p.6; A. ERNOUT - A. MEILlET, Dictionnaire Etymologique cit. (nota 2 supra), pp.42-43; A. JURET, Dictionnaire Étimologique grec et latin, Macon, Protat Frères, 1942, p.70. A palavra proles é utilizada nos seguintes textos: Const. C.1,3,4,2 (361); Leo et Athem. C.5,6,8 (469); Zeno C.5,27,5pr. (477); Iust. C.6,26,9pr. (528); Iust. C.11,48,21pr. (530); C.Th. 8,4,7 (361); C.Th.16,2,27pr. (390). Suboles e sua variação soboles encontram-se em Inst. 3,2,4; 3,3,6; Ulp. 34 ad Sab. D.23,3,10,2; Pomp. 15 ad Sab. D.24,3,1; Ulp. 33 ad ed. D.24,3,22,7; Clem. 5 ad l. Iul. et Pap. D.35,1,64,1; Alex. C.2,41,1,1 (232); Leo et Anthem. C.5,1,5,3 (472); Const. 5,27,1 (336); Theod. et Valent. C.5,27,3,2 (443); Anastas. C.5,27,6pr. (517); Iust. C.5,27,8pr. (528); Iust. C.5,27,11,3 (530); Iust. C.5,27,12,3 (531); Iust. C.6,58,12pr. (532); Iust. C.6,58,14,2 (531); Iust. C.6,58,14,6 (531); Iust. C.6,58,15pr. (534); Iust. C.6,59,11,1 (529); Iust. C.7,15,3pr. (531); Iust. C.7,15,3,1 (531); Valent. et Valens. C.7,38,1; Diocl. et Max. C.8,47,2 (286); Diocl. et Max. C.8,47,5 (291); Valent., Valens. et Grat. C.8,51,2pr. (374); Theod. et Valent. C.9,49,10,2 (426); Iust. C.10,32,67,4 (529); Theod. C.11,7,7 (424); Theod. et Valent. C.11,10,5pr. (439); Honor. et Theod. C.11,48,16 (419); Iust. C.11,48,23pr. (531-534); Iust. C.11,48,23,3 (531-534); Iust. C.11,48,23,5 (531-534); C.Th. 4,6,2 (336); C.Th. 9,42,24,1 (426); C.Th. 12,1,49,1 (361); C.Th. 12,1,74pr. (371); C.Th. 12,1,93 (382); Nov. Theod. 22,2,1 e Nov. Valent. 31,2.

${ }^{6}$ Conforme G. CIPRIANI - P. Fedeli, Vivere a Roma antica cit. (nota 4 supra), p.6. Sobre o termo liberorum encontramos em Digesto 50,16 (De verborum significatione) duas interpretações, uma atribuída a Ulpiano e outra a Calístrato: Ulp. 62 ad Ed. D.50,16,56,1: 'Liberorum' appellatione continentur non tantum qui sunt in potestate, sed omnes qui sui iuris sunt, sive virilis sive feminine sexus sunt exve feminini sexus descendentes. "Na palavra 'filhos' incluem-se não apenas aqueles que se encontram sob a potestas, como também todos os que são juridicamente independentes, seja do sexo masculino, seja do sexo feminino, ou os descendentes tanto por linha masculina quanto por linha feminina"; Callist. 2 quaest. D.50,16,220pr.: 'Liberorum' appellatione nepotes et pronepotes ceterique qui ex his descendunt continentur: hos enim omnes suorum appellatione lex duodecim tabularum comprehendit. Totiens enim leges necessariam ducunt cognationem singulorum nominibus uti (veluti filii, nepotis, pronepotis ceterorumve qui ex his descendunt), quotiens non omnibus, qui post eos sunt, praestitum voluerint, sed solis his succurrent, quos nominatim enumerent. At ubi non personis certis, non quibusdam gradibus praestatur, sed omnibus, qui ex eodem genere orti sunt, liberorum appellatione comprehenduntur. "Na denominação de 'filhos' incluem-se os netos, os bisnetos e os demais que deles descendem, pois a Lei das XII Tábuas a estes compreende com o nome de "seus". Todas as vezes que as leis consideram necessária que a cognação se utilize dos nomes de cada um deles (como o de filhos, o de netos, o de bisnetos e os outros que deles descendem), elas, tantas vezes, desejarão que se dê a prestação não a todos que estão depois deles, mas socorrerão somente aos que nominalmente enumerem. Mas onde se oferece a prestação, não a certas pessoas, não a certos graus, mas a todos que nascerem daquela mesma estirpe, compreendem-se na denominação de 'filhos'.” Veja-se A. JURET, Dictionnaire Étimologique 
meninos até os quatorze anos e as meninas até os doze. A capacidade de procriar indicava a capacidade nupcial e a capacidade intelectual. ${ }^{7}$

Outro termo vinculado à procriação é gens ${ }^{8}$, de genus (origem, raça, família), a célula do "Estado" Romano primitivo, organismo político que antecedeu à civitas e que se fundamentava em uma reunião de inúmeras famílias que acreditavam ter um antepassado comum e tinham o mesmo nome gentílico (gentilicium nomen). ${ }^{9}$

grec et latin cit. (nota 5 supra), pp.70-71.

A. ERnOUT - A. MEILLET, Dictionnaire Etymologique cit. (nota 4 supra), pp.42-43, associam o termo improles (qui nondum vir est) como sinônimo de impuber, ou seja, aquele que ainda não é homem e não pode gerar. Em relação à sua capacidade intelectual e jurídica, veja-se UE 20,12: Inpubes, licet sui iuris sit, facere testamentum non potest, quoniam nondum plenum iudicium animi habet. "O impúbere, embora sui iuris, não pode fazer testamento porque ainda não tem o pleno uso da razão". Veja-se também Ulp. 18 ad ed. D.9,2,5,2; Ulp. 1 ad Sab. D.28,1,20pr.; Scaev. 3 resp. D.31,88,7; Pap. 9 resp. D.35,2,14,3; Pomp. l.s.enchr. D.50,16,239pr.; Ulp. 1 ad Sab. D.50,17,2,1; Gai.1,157; 1,179; UE 16,1-a. Outro termo que designava a prole era infans. A infantia era o período da vida da criança até os sete anos de idade e deriva do prefixo in- unido ao participio presente do verbo for-, faris que significa "falar, dizer". Portanto infans é, literalmente, "o que não fala" (qui fari non potest) e designa a incapacidade da criança em articular um som completo e compreensível, além de não poder interpretar as palavras que utiliza. O termo infans e a expressão qui fari non possunt podem ser verificadas em Ulp. 35 ad ed. D.26,7,1,2; Florent. 10 inst. D.50,16,209; Paul. 2 ad sab. D.50,17,5; Gai.3,109; Inst. 3,19,10. Vejam-se J.C. MAtos PeIXoto, Curso de Direito Romano - Tomo I - Partes introdutória e geral, Rio de Janeiro, Renovar, 1997, pp.257-259; G. CIPRIANI - P. FEDELI, Vivere a Roma antica cit. (nota 2 supra), pp.6-7; M.J.GarCía GARRIDO, v. Infans, Infantia, in Diccionario de

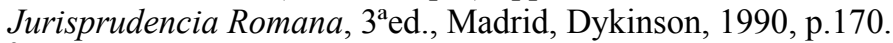

${ }^{8}$ Gigno, -is, genui, genitum, gignere: procriar, posteriormente "produzir", "causar”; genus, -eris: nascimento, raça; in-gigno: inculcar desde o nascimento; in-genuus (nascido livre); in-gener-are: engendrar. Também, genero, as (engendrar, procriar); genitalis (que gera); pro-genies (criança, rebento, descendência); ( $g$-) nasci (nascer); pre-gnas (grávida); pre-gnatio (gestação); a-gnatus (nascido de). A origem etimológica do termo genitor (pai), feminino genitrix (mãe) se aproxima do sânscrito gan (colocar no mundo); ganitar (pai); ganus (raça), gaganmi (eu procrio); janitắ (aquele que procria). Provavelmente a mesma raiz etimológica originou o grego $\gamma \tilde{v} v o \varsigma$, "aqueles que descendem de um ancestral comum masculino; raça". A gens é a identificação da família com o "Estado", ou seja, da família com caráter político. Vejam-se A. ERNOUT - A. MEILleT, Dictionnaire Etymologique cit. (nota 4 supra), pp.480-484; M. BRÉAL - A. BAILLY, Dictionnaire étymologique latin cit. (nota 4 supra), pp.50 e 115; J. CEJADOR Y FRAUCA, Diccionario Etmológico-Analítico Latino-Castellano cit. (nota 4 supra),pp.88;157-158; H.M.F.MADEIRA, O Nascituro no Direito Romano, São Paulo, Editora Nacional, 2005, p.12, nota 10; M.J.GARCÍA GARRIDO, Diccionario de Jurisprudencia Romana, v. Gens, Gentiles cit. (nota 7 supra), p.148; A. JURET, Dictionnaire Étimologique grec et latin cit. (nota 5 supra), pp.69-70.

${ }^{9}$ R.V. JHERING, Der Geist des römischen Rechts - Auf den Verschiedenen Stufen seiner Entwicklung, trad. port. Rafael Benaion, O Espirito do Direito Romano - Nas diversas fases de seu desenvolvimento, v.1, Rio de Janeiro, Alba, 1943, p.134; V. CÉSAR DA SILveIRA, v. Gens, Gentes in Dicionário de Direito Romano, v.2, São Paulo, José Bushatsky, 1957, p.284; J.C. Moreira Alves, Direito Romano, 14aed., Rio de Janeiro, Forense, 2007, p.606; C. ACCARIAS, Précis de droit romain, $4^{\mathrm{a} e d}$., t.1, Paris, Cotillon, 1886, pp.235-236. 


\title{
2. TEMÁTICA JURÍDICA REFERENTE À PROCRIAÇÃO
}

\subsection{IUS NATURALE}

\author{
No livro I do Digesto de Justiniano, Ulpiano afirma que a "união" (coniunctio)
} denominada matrimônio, é instituto de direito natural, porque ensinada a todos os seres vivos. A procriação seria um preceito estabelecido pelo ius naturale.

Para o estudo da procriação no matrimônio romano é imprescindível a análise do conceito de ius naturale disposto no Digesto (Ulp. 1 inst. D.1,1,1,3), pois encontramos a procriação como finalidade principal ${ }^{10}$ da união entre o macho e a fêmea, elemento comum à todos os animais da natureza, a coniunctio animalium:

\section{Ius $^{11}$ naturale est, quod natura omnia animalia docuit ${ }^{12}$ : nam ius istud non humani}

\footnotetext{
${ }^{10}$ O. RobledA, El Matrimonio en Derecho Romano - Esencia, requisitos de validez, éfectos, disolubilidad, Roma, Università Gregoriana, 1970, pp.61-66; R. BESNIER, L'application des lois caducaires d'Auguste d'après le gnomon de l'idiologue, in RIDA 2 (1949), p.97; C. ACCARIAS, Précis de droit romain cit. (nota 9 supra), p.203; R. ASTOLFI, Il matrimonio nel diritto romano classico, Padova, CEDAM, 2006, p.12. Segundo D. DALla - R. LAMBERTINI, Istituzioni di diritto romano, Torino, G. Giappichelli, 1996, p.103: Ci si sposa, dicono le fonti, allo scopo di avere figli: ogni unione tra persone cui in rapporto al sesso è negata la persecuzione di questo scopo non può definirsi matrimonio. "Casa-se, afirmam as fontes, com o escopo de ter filhos: toda união entre pessoas em que, relativamente ao sexo, é negada a busca deste escopo, não pode definir-se matrimônio".

${ }^{11}$ Quanto ao conceito romano de ius veja-se Ulp. 1 inst. D.1,1,1pr.: Iuri operam daturum prius nosse oportet, unde nomen iuris descendat. Est autem a iustitia appellatum: nam, ut eleganter Celsus definit, ius est ars boni et aequi. "É preciso que aquele que há de se dedicar ao direito primeiramente saiba de onde descende o nome direito [ius]. Vem, pois, de "justiça" chamado. De fato, como Celso elegantemente define, direito é a arte do bom e do justo [équo]". Sobre este conceito celsino, P. CATALANo, Diritto, soggetti, oggetti: um contributo alla pulizia concettuale sulla base di D.1,1,12, in Iuris Vincula - Studi in onore di Mario Talamanca II, Napoli, Jovene, 2001, p.113: Il concetto de 'ius', in quanto 'ars', non è riducibile alla 'scienza del diritto', bensi comprende solo l'interpretazione e l'applicazione ma anche la 'produzione' del diritto. ' $\mathrm{O}$ conceito de ius, enquanto ars, não é redutível à ciência do direito, porém compreende não apenas a interpretação e a aplicação, mas também a produção do direito".

12 M. KASER, Römisches Privatrecht, München, 1992, trad. port. de Samuel Rodrigues e Ferdinand Hämmerle, Direito Privado Romano, Lisboa, Fundação Calouste Gulbenkian, 1999, p.51, afirma que "Cícero e os juristas escolares romanos (...) designam por ius naturale ora manifestações do ius gentium que se baseiam na naturalis ratio (...), ora "princípios jurídicos" que devem valer para todos os homens (segundo este direito 'natural' também os escravos deviam ser livres) e até (...) para os animais (porque também entre eles há relações intersexuais, procriação e criação da prole)". Salienta o mesmo autor, M. KASER, Ius gentium, Köln, Böhlau, 1993, trad. esp. de Francisco Javier Andrés Santos, Granada, Comares, 2004, pp.7273;80;89-90, que o ius naturale é um "fator constitutivo de normas" e, ao mesmo tempo, um "motivo para a construção do Direito", que se fundamenta tanto no direito escrito quanto no não-escrito (costumes). Porém, não é possível, na opinião do autor, neste trecho, supervalorizar a expressão ius quod natura omnia animalia docuit, pois os juristas romanos não conheceram um "Direito para os animais", nem tiveram qualquer pretensão sistematizadora do ius naturale. Não é um sistema de conceitos jurídicos, pois não se fundamenta em nenhum critério dogmático-jurídico. É o mero instinto natural que induz determinados animais (e não todos!) a um comportamento semelhante à família humana, à procriação, a união entre homem e mulher e à educação e cuidado com a prole. É possível, porém, que este paralelismo indique que o matrimônio e a
} 
filiação devam ser regulados segundo as exigências e de acordo com a Natureza. Porém, sua principal finalidade, neste caso, seria servir de ilustração, uma simples lição elementar de Direito e não o indício de um "direito para os animais".

Ao tratar da "comunidade de natureza" defendida pelos estóicos e a influência desta escola filosófica no conceito ulpianeu de ius naturale, A. CORREIA, O conceito de 'ius naturale', 'gentium et civile' no Direito Romano, São Paulo, Odeon, 1934, pp.9-11, exemplifica a procriação como instinto comum à reprodução e à conservação tanto dos homens quanto dos animais: "Mas nas relações naturais universais, donde depende a procriação e a subsistência da humanidade, a matéria é comum aos homens e aos animais". Porém, conclui (p.10) como "infeliz" a expressão e o conceito de ius naturale utilizado por Ulpiano em D.1,1,1,3, pois fundamenta-se nas categorizações e interpretações propostas por SAVIGNY em relação ao ius naturale, ao subdividi-lo em sentido amplo e estrito. Na verdade, A. CORREA seguiu a opinião de P.BONFANTE sobre o trecho de Ulpiano. Segundo P. BonfANTE, Istituzioni di diritto romano, Firenze, G. Barbèra, 1896, p.18, o conceito ulpianeo ius naturale est quod animalia docuit é "abbastanza infelice", pois não é possível a existência de normas jurídicas comuns a homens e animais, mas apenas relações comuns. E conclui: (...) la congiunzione del maschio e della femmina, ricordata dal giuresconsulto, non è matrimonio, come del resto non è nemeno matrimonio ogni unione tra uomo e donna. Também segue a opinião de BONFANTE, J.C. Matos PeiXoto, Curso de Direito Romano cit. (nota 5 supra), p.248: "Quanto ao ius naturale em sentido lato, é inegável que Ulpiano e as Institutas que o repetem, se exprimem de forma manifestamente infeliz (...)"; R. Porchat, Curso Elementar de Direito Romano, 2aed., v.1, São Paulo, Melhoramentos, 1937, pp.153-156, que qualifica a definição de Ulpiano, "defeituosa", além de afirmar que Ulpiano errou ao "rebaixar o homem à escala dos animais inferiores, e de reconhecer entre estes o uso do direito, quando é certo que o direito se funda na razão, faculdade de que exclusivamente é dotado o gênero humano"; E.H.J. Petit, Traité Élémentaire de Droit Romain, 9aed., Paris, Rousseau, 1925, trad. port. de Jorge Luís Custódio Porto, Tratado Elementar de Direito Romano, Campinas, Russell, 2003, p.24: “Apenas o homem tem direitos e deveres, porque somente ele está dotado de razão e de consciência da moralidade de seus atos".

Para E. Volterra, Istituzioni di Diritto Privato Romano, Roma, La Sapienza, “s.d.”, pp.38-39, o conceito de ius naturale tem importância meramente filosófica: Il termine non ha un significato preciso e nelle fonti lo troviamo usato in affermazioni che rispondono a speculazioni meramente filosofiche. (...) Queste idee espresse nelle fonti (...) non risultano avere mai avuto elaborazione dottrinale od avere esercitato influenza nel campo giuridico. Na opinião de M. TALAMANCA, Istituzioni di diritto romano, Milano, Giuffrè, 1990, p.51: (...) l'esemplificazione che ne fa il giurista (il rapporto fra maschio e femmina per la procreazione, la procreazione stessa, l'educazione dei piccoli) mostra che siamo in um campo che - inglobando anche gli esseri animati irrazionali - rileva più dall'etologia, si direbbe adesso, che dal diritto. De acordo com A. BURDESE, Il concetto di 'ius naturale' nel pensiero della giurisprudenza clássica, in RISG 90 (1954), p.418, o conceito de ius naturale do trecho de Ulpiano apresenta um valor meramente teórico. Também suprime o caráter jurídico do conceito ulpianeo, A. GUARINO, Diritto privato romano cit. (nota 1 supra), pp.130-131, pois, ao falar sobre a "tricotomia ulpiano-jutinianea", sustenta a existência de um ius naturale em sentido estrito e que este conceito tem importância apenas social, de mero fato: Per effetto di che svaní il presupposto che di diritto si potesse parlare solo relativamente alle società politiche e tesero ad essere qualificati come istituti giuridici (di 'ius naturale') anche gli istituti cui precedentemente fosse stata riconosciuta una rilevanza puramente sociale, di mero fatto (cioè 'naturaliter'). Na opinião de L.R. ARGÜELLO, Manual de Derecho Romano - Historia e instituciones, $3^{\mathrm{a}} \mathrm{ed}$., Buenos Aires, Astrea, 1993, p.12, no es admisible la concepción de Ulpiano porque se confunden funciones o necesidades biológicas comunes al hombre y al animal, con normas jurídicas que, por estar dirigidas a regular la conducta nacida de una voluntad libre, solo pueden tener referencia al ser humano. P. VocI, Istituzioni di diritto romano, $6^{\mathrm{a}} \mathrm{ed}$., Milano, Giuffrè, 2004, p.59, ressalta a origem pitagórica da noção e conclui que secondo Ulpiano, il diritto naturale è la legge primordiale comune a tutti gli esseri viventi, siano uomini o animali: una legge intuita e praticata dagli uomini allo stato di natura, ma poi dimenticata e sostituita dalle leggi degli Stati.

Faz uma crítica à communis opinio, P.P. ONIDA, Studi sulla condizione degli animali non umani nel sistema giuridico romano, Torino, Giappichelli, 2002, p.116: La dottrina romanistica ha spesso mostrato un certo scetticismo in merito alla rilevancia giuridica della nozione di 'ius naturale', in particolare di quella ulpianea, riconducendo il valore di essa nell'ambito della sociologia o della etologia. "A doutrina romanística frequentemente mostrou um certo ceticismo em relação à importância jurídica da noção de ius naturale, em particular da ulpianea, relacionando o significado dela ao âmbito da sociologia ou da etologia". $\mathrm{O}$ autor (pp.125-126;145-146;158) conclui que Ulpiano ao empregar a fórmula quod natura animalia docuit reconhece a todos os animais, racionais e irracionais, uma peritia, uma capacidade para aprender 
generis proprium, sed omnium animalium, quae in terra, quae in mari nascuntur, avium quoque commune est. Hinc descendit maris atque feminae coniunctio, quam nos matrimonium ${ }^{13}$ appellamus, hinc liberorum procreatio, hinc educatio: videmus etenim cetera quoque animalia, feras etiam istius iuris peritia censeri.

"O direito natural é o que a natureza ensinou a todos os animais. Pois este direito não é próprio do gênero humano, mas de todos os animais que nascem na terra ou no mar, comum também das aves. Daí deriva a união do macho e da fêmea, a qual denominamos matrimônio; daí a procriação dos filhos, daí a educação. Percebemos, pois, que também os outros animais, mesmo as feras, são guiados pela experiência deste direito". ${ }^{14}$

Esta menção ulpianéia ao instinto da procriação como elemento comum aos homens e aos animais, em virtude de sua própria natureza, já havia sido destacada por Cícero em de off., 1,4,11-12:

11. Principio generi animantium omni est a natura tributum, ut se, vitam corpusque tueatur, declinet ea, quae nocitura videantur, omniaque, quae sint ad vivendum necessaria, anquirat et paret, ut pastum, ut latibula, ut alia generis eiusdem; commune autem animantium omnium est coniunctionis appetitus procreandi causa et cura quaedam eorum, quae procreata sint. (...) 12. Eademque natura vi rationis

\footnotetext{
naturalmente determinados comportamentos (natura animalium). E considera a noção de ius naturale como uma conquista da ciência jurídico-religiosa romana, pois, em seu âmbito, todos os seres vivos são destinatários do ius. Também apresenta opinião semelhante, M. BRETONE, Storia del diritto romano, trad. port. de Isabel Teresa Santos e Hossein Seddighzadeh Shooja, História do Direito Romano, Lisboa, Estampa, 1998, p.254, quando ressalta que “(...)o homem é, ao mesmo tempo, um ser moral e um indivíduo biológico. A reflexão de Ulpiano não separa um aspecto do outro(...) só o respeito devido à espécie como espécie, e, portanto, devido à todas as espécies, está em condições de fundar, definitivamente, os direitos que, no que diz respeito à nossa, qualquer indivíduo pode pretender como indivíduo: ao mesmo título de uma espécie qualquer, mas não mais além". Na p.244, BRETONE fala da importância e da prioridade do direito natural em relação às fontes do direito romano: "(...)o direito natural inclui em si(...)defender os "costumes" e as "leis", a pertença dos bens e as distinções sociais, numa palavra, a ordem constituída da "república". Também sobre o ius naturale como uma fonte rica de soluções jurídicas para o Direito Romano está a opinião de M. VILLEY, Le Droit Romain, Paris, Universitaires de France, trad. port. de Fernando Couto, Porto, Resjuridica, 1991, pp.80-81, "Espontaneamente, naturalmente (o homem é naturalmente sociável segundo a doutrina de Aristóteles), formam-se justas relações sociais, das famílias, dos grupos de vizinhos ou de comerciantes, das cidades bem organizadas. (...) Por esta via, ele [o jurista] descobrirá não somente modelos de direito apropriados às condições da vida romana, mas outros que podem ser observados e são válidos para todos os homens (...) e mesmo (...) tipos de relações sociais, como a união dos sexos, as relações dos pais com os seus filhos, que pode existir também entre os animais".

${ }^{13}$ Segundo A. ERnOUt - A. MeILlet, Dictionnaire Etymologique cit. (nota 4 supra), p.693, a palavra matrimonium tem sua origem em mater (mãe) e pode ser utilizada em Roma tanto para os animais quanto para as plantas, indicando, neste último caso, o tronco principal. Tem sua formação semelhante à palavra patrimonium, porém sem o sentido de propriedade ou direito sobre as coisas, pois indica a maternidade, o casamento.

${ }^{14}$ Veja-se também Inst.1,2pr.
} 
hominem conciliat homini et ad orationis et ad vitae societatem ingeneratque in primis praecipuum quendam amorem in eos, qui procreati sunt, impellitque ut hominum coetus et celebrationes et esset et a se obiri velit ob easque causas studeat parare ea, quae suppeditent ad cultum et ad victum, nec sibi soli, sed coniugi, liberis, ceterisque quos caros habeat tuerique debeat.(...).

"11. Antes de tudo, a todos os seres vivos a natureza concedeu o instinto de conservar a si próprio, a vida e o corpo, de evitar tudo aquilo que pode prejudicar, e de buscar e procurar obter as coisas necessárias para o sustento da vida, como o alimento, os covis e outras coisas do mesmo gênero. Igualmente comum a todos é o desejo de procriar e o cuidado com a prole.(..) 12. A própria natureza, mediante a força da razão, une o homem aos outros animais, cria uma semelhança que se manifesta na linguagem e na relação de vida, inspira, principalmente, um amor extraordinário para com a prole, impele-o a desejar os agrupamentos e reuniões: por estes mesmos motivos o homem esforça-se em procurar as coisas que são necessárias ao culto e à sua subsistência, e não apenas para si mesmo, mas para a esposa, para os filhos, para os outros que ele tenha por queridos e deva proteger. (...)".

O matrimônio fundamentado na expressão coniunctio maris et feminae, segundo afirma Ulpiano, influenciado pela doutrina estoica ${ }^{15}$, tem o seu preceito no ius naturale e sua finalidade principal na procriação (procreatio) e na educação da prole (educatio). ${ }^{16}$

\footnotetext{
${ }^{15}$ Para R. Astolfi, La Lex Iulia et Papia, 4aed., Padova, CEDAM, 1996, pp.352;362, as concepções estoicas de matrimônio e de procriação, consideradas como "deveres públicos do cidadão", influenciaram diretamente na elaboração e promulgação das Leis Matrimoniais de Augusto. Na opinião do autor, La concezione che il matrimonio e la procreazione sono doveri pubblici del cittadino è conforme (...) alla tradizione romana e all'etica stoica. La giurisprudenza sente l'influenza e li attua nell'interpretazione e nell'applicazione della legge. Para R. BeSNIER, L'application des lois caducaires d'Auguste cit. (nota 10 supra), p.97: La vieille doctrine stoïcienne du Portique fait également prevaloir l'interêt de l'Etat, elle considere le mariage comme une loi naturelle, l'homme a le devoir de perpétuer la race, dans ce but il doit se marier et procréer. Também alguns filósofos pitagóricos, principalmente Ocellus Lucanus, declaravam, já no século I a.C., que a finalidade do matrimônio é a procriação e não o mero prazer entre os cônjuges.

${ }^{16}$ M.P. BACCARI, Persona e famiglia: concetti e principi giuridici contra le astrazioni e l'individualismo in, Revista Brasileira de Direito Comparado 27 (2005), p.34; M. KASER, Ius gentium cit. (nota 12 supra), pp.8687. No trecho de Ulpiano, D.1,1,1,3, a sequência dos advérbios hinc...hinc...hinc indica atos concatenados. O termo "natureza" também é utilizado em outro trecho por Ulpiano ao falar sobre a condição dos filhos: Ulp. 27 ad Sab. D.1,5,24: Lex naturae haec est, ut qui nascitur sine legitimo matrimonio matrem sequatur, nisi lex specialis aliud inducit. "A lei da natureza é esta: que aquele que nasce sem um matrimônio legítimo siga a mãe, a não ser que uma lei especial o induza a coisa diversa". Segundo G. LONGO, Per la interpretazione del fr. 24 D.1,5, in IURA 18.1 (1967), pp.20-27, o fragmento D.1,5,24 é interpolado e os compiladores pósclássicos elaboraram um princípio genérico e abstrato em seu conteúdo. Termos como legitimum matrimonium e lex naturae não eram empregados pelos juristas clássicos, que preferiram, v.g., o termo iustae nuptiae para designar o matrimônio. O termo natura está presente em outros textos de Ulpiano: Ulp. 26 ad Sab. D.1,7,17,1; Ulp. 24 ad ed. D.10,4,3,15; Ulp. 26 ad ed. D.12,6,26,12; Ulp. 69 ad ed. D.43,16,1,9; Ulp. 6 ad ed. D.50,16,10.
} 
A definição ulpianea de direito natural descreve um verdadeiro ius commune entre o homem e os outros animais (quae in terra, quae in mari nascuntur, avium quoque commune est), vincula o conceito jurídico ${ }^{17}$ de homem à toda a Natureza: a união do macho e da fêmea ${ }^{18}$, a procriação, a alimentação, a educação da prole. ${ }^{19}$

Neste sentido, também a doutrina da Igreja Católica, em 1962, com a Constituição Pastoral Gaudium et Spes do Concílio Vaticano II, fundamentou a finalidade do matrimônio cristão na finalidade do matrimônio romano (procreatio et educatio filiorum) ao afirmar que o matrimônio é uma societas lícita para a procriação e a educação da prole, para a propagação do gênero humano (n.48: "Por sua própria natureza, a instituição matrimonial e o amor conjugal estão ordenados para a procriação e a educação da prole, que constituem a sua coroa"). A carta encíclica Humanae Vitae, de Paulo VI, de 25 de julho de 1968, sobre "a regulação da natalidade", reforçou o princípio do ius naturale, fundamental ao matrimônio, de que a união e a procriação sejam aspectos inseparáveis: n.12: “(...) Na verdade pela sua estrutura íntima, o ato conjugal, ao mesmo tempo que une profundamente os esposos, torna-os aptos para a geração de novas vidas, segundo leis inscritas no próprio ser do homem e da mulher. Salvaguardando estes dois aspectos essenciais, unitivo e procriador, o ato conjugal conserva integralmente o sentido de amor mútuo e verdadeiro e a sua ordenação para a altíssima vocação do homem para a paternidade". Traça as características comuns entre o trecho de Cícero (de off. 1,4,11-12) e a definição de ius naturale de Ulpiano, P.P. ONIDA, Studi sulla condizione cit. (nota 12 supra), pp.153-154: La considerazione dell'istinto alla procreazione come fattore propulsivo di società, non solo di uomini: da quella fondata sul 'coniugium', a quella dei 'liberi', e quindi a quella della 'domus' e delle altre 'res communes', costituisce le premesse perché il legame fra gli esseri animati trovi espressione nel sistema giuridico. La riflessione ciceroniana, attraverso il riferimento al tema del 'coniugium' e dalla 'societas liberorum', si pone in evidente rapporto con le problematiche relative alla 'coniunctio', alla 'procreatio' e alla 'educatio liberorum', richiamate nella concezione ulpianea del 'ius naturale', come 'ius' comune a uomini e animali non umani. "A consideração do instinto à procriação como fator propulsor da sociedade, não apenas dos homens: daquela fundada no coniugium, dos liberi, e portanto, da domus e das demais res communes, constituía a premissa para que o vínculo entre os seres vivos encontrasse expressão no sistema jurídico. A reflexão ciceroniana, em relação ao tema do coniugium e da societas liberorum, coloca-se em vínculo nítido com as questões relativas à coniunctio, à procreatio e à educatio liberorum, referidas na concepção ulpianea de ius naturale, como ius comum aos homens e aos animais "não humanos".

${ }^{17}$ Vejam-se M.P. BACCARI, Persona e famiglia cit. (nota 16 supra), p.34; O. RoBLEDA, Intorno alla nozione di matrimonio nel diritto romano e nel diritto canonico, in Apollinaris 50 (1977), p.183. P.P. ONIDA, Studi sulla condizione cit. (nota 12 supra), pp.95-96. Nesta obra de ONIDA, pp.104-106, o autor estabelece uma interessante analogia entre o trecho de Ulpiano (D.1,1,1,3) e um trecho de Filostrato sobre a "Vida de Apolônio de Tiana" (Philostr. Vita Apoll. 2,14). Apolônio observa o comportamento de trinta elefantes que atravessam o Rio Indo. Depois analisa diversos comportamentos comuns a todos os animais (Apolônio descreve a Damis, seu discípulo, situações análogas com as baleias, as focas, os golfinhos, os peixes, os leões, os leopardos, os tigres, as panteras, as águias, as cegonhas): o auxílio mútuo quando se encontram em situações difíceis (no caso, a travessia do Indo), o modo como eles protegem suas crias, a educação da prole, a procriação. Na opinião de M. KASER, Ius gentium cit. (nota 12 supra), pp.86-88, estes fenômenos comuns à vida tanto dos homens quanto dos animais (e principalmente, o paralelo realizado entre as relações do macho e da fêmea, a procriação e o matrimônio liberorum procreandorum causa) são na verdade fruto de um instinto inato, um impulso natural, destinado à reprodução da espécie mediante a procriação e a educação dos filhos. A poesia e a filosofia grega deduziram regras de comportamento comuns aos homens e animais, porém falta aos últimos a compreensão "intelectual” destes fenômenos. A idéia de relações jurídicas comuns aos homens e animais e a idéia da existência de "leis naturais" parecem ter se baseado na compreensão das

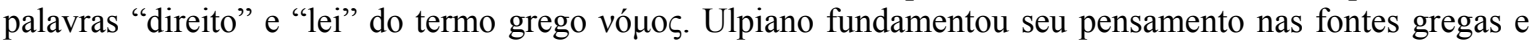
em Cic. de rep. 3,11,19: Pythagoras et Empedocles unam omnium animantium condicionem iuris esse denuntiant.

${ }^{18}$ Caius Musonius Rufus, filósofo estóico do período neroniano (30?-101?), escritor de 700 livros segundo Prisciano, fez várias referências à "virtude própria" das relações sexuais entre os animais, que tem como finalidade a procriação e a manutenção da espécie e não os meros "prazeres". O filósofo ressalta que nada era mais belo que a união entre o homem e a mulher, nada mais forte do que esta união para constituir uma cidade e que estas uniões agradavam as divindades como Eros e Afrodite. $\mathrm{O}$ criador do homem distinguiu dois órgãos reprodutores, um na fêmea e outro no macho e infundiu em ambos um forte e intenso desejo 
Entre homens e animais podem estabelecer-se relações com relevância jurídica, principalmente o dever do homem de proteger a vida destes animais. ${ }^{20}$

Ao realizar sua síntese sobre a estrutura familiar romana, o jurista Calístrato ressalta que a finalidade principal da vontade entre os cônjuges é o animus e o votum liberorum procreandorum. Do mesmo modo que Ulpiano, este jurista reforça as estreitas ligações entre matrimônio, procriação e o ius naturale, nos respectivos termos utilizados

recíproco de viverem em união. Quanto ao ius commune entre homens e animais, a opinião de Musonius Rufus em relação ao aborto é muito significativa. Em suas assertivas éticas ele condena abertamente tal prática, ainda que a família com prole numerosa tivesse poucos recursos econômicos. O filósofo narra a situação de um homem pobre com muitos filhos e sem condições de mantê-los e que questiona como poderá alimentar todos eles. Musonius dá o exemplo dos passarinhos, andorinhas, rouxinóis, cotovias e melros que alimentam suas ninhadas mesmo sendo muito mais frágeis e pobres que qualquer homem.

R. LAURenTI, Musonio, maestro di Epitteto, in ANRW II.36 (1989), p.2141; p.2142, nota 151; M.P. BACCARI, Persona e famiglia cit. (nota 16 supra), p.35; P.P. ONIDA, Studi sulla condizione cit. (nota 12 supra), pp.95-96;151-152 defendem a existência de um ius commune entre homens e animais, pois a união do macho e da fêmea, a procriação, o aleitamento, a alimentação e a educação da prole são, igualmente, relações do ius naturale também presentes nos animais. Sêneca faz referência a este ius commune a todos os seres vivos em Sen., Clem. 1,18,2 ao falar dos escravos que se refugiavam nos templos e junto às estátuas dos imperadores por sofrerem maus tratos de seus donos: Servis ad statuam licet confugere! Cum in servum omnia liceant, est aliquid, quod in hominem licere commune ius animantium vetet. "Mesmo aos escravos é permitido refugiarem-se junto a uma estátua! Embora tudo seja lícito contra os escravos, existe algo que o direito comum aos seres vivos impede utilizar contra um ser humano". Vejam-se também Gai.1,53; Ulp. 8 de off. procons. D.1,6,2; Ulp. l.s. de off. praef. urb. D.1,12,1,1; Ulp. 1 ad ed. Aedil. Curul. D.21,1,17,12; Ulp. 5 de off. procons. D.47,11,5; Inst. 1,8,2; Coll. 3,3,1-3; 3,3,5-6.

${ }^{19}$ Nas palavras de Ulpiano em D.1,1,1,3, (...) quod natura omnia animalia docuit (...). Segundo R. LAURENTI, Musonio cit. (nota 18 supra), pp.2.131; 2141, o termo grego бvveĩvaı utilizado por Musonius Rufus em diatribe XIV indica a vontade de viver junto do casal, de um cuidar do outro e de priorizar a procriação e a educação dos filhos.

Em relação à educação, Musonius defendia sua aplicação, tanto para os meninos quanto para as meninas, baseada na $\dot{\alpha} \pi$ ó $\varepsilon 1 \xi 1 \zeta$. Desde pequena, a criança já deveria aprender a discernir aquilo que é bom daquilo que é mau, o útil do prejudicial, aquilo que é permitido daquilo que é proibido, para que, por meio do costume, tenha seus atos dirigidos pela justiça e pela verdade quando tornar-se adulto. Afirma P. VEYNE, L'Empire Romain. Histoire de la vie privée. I. De l'Empire Romain à l'an mil, Paris, Du Seuil, 1985, trad. it. de Maria Garin, La vita privata nell'impero romano, Roma-Bari, Laterza, 1992, pp.11-16, a finalidade da educação era fortalecer o caráter do cidadão desde criança, a transmissão dos hábitos dos antepassados pelo paterfamilias. Era justificável este cuidado com a prole por ela constituir a continuação e a manutenção do nome e da condição social desta família. A educação nos primeiros anos de vida ficava a encargo da mãe; nas famílias nobres e mais ricas, além da mãe, da nutriz (ama-de-leite); e, sob influência grega, de um pedagogo (paedagogium), geralmente um escravo ou liberto, que era encarregado de ensinar a criança a ler e a ter boas maneiras. Aos sete anos a criança passava a ser um infans maior e ingressava na escola primária (ludus litterarius) sob a autoridade do magister. De acordo com A. CALDERINI, Antichità private, in Vicenzo USSANI e Francesco ARNALDI (org.), Guida allo studio della civiltà romana antica, vol.2, Napoli, Istituto Editoriale del Mezzogiorno, 1954, p.23, o cuidado e a responsabilidade pela educação da criança romana era uma tarefa da família. O menino romano, para uma austera disciplina do seu corpo e do seu caráter, acompanhava seu pai em várias atividades sociais e religiosas. Se nas famílias mais ricas e nobres existia a figura do pedagogo, geralmente era tarefa do pai ensinar a criança a ler, escrever, fazer cálculos, decorar as leis e guardá-las na memória. Vejam-se M.C. Giondani, História de Roma, 16aed., Petrópolis, Vozes, 2005, pp. 166-177; G. CIPRIANI - P. FEDELI, Vivere a Roma antica cit. (nota 4 supra), pp.75-76; H. BORNECQUE D. Mornet, Rome et les Romains, Paris, Delagrave, s.d., trad. port. de Alceu Dias Lima, Roma e os Romanos - Literatura, História, Antigüidades, São Paulo, EPU, 1977, pp.155-157.

${ }^{20}$ Veja-se P.P. ONIDA, Studi sulla condizione cit. (nota 11 supra), p.115. Veja-se Verg. Georg. 3,295-310 ; 3,394-408. 
"uxores ducunt", "liberorum procreandorum animo" e "natura":

Callist. 2 quaest. D.50,16,220,3: Praeter haec omnia natura nos quoque docet, parentes pios, qui liberorum procreandorum animo et voto uxores ducunt, filiorum appellatione omnes, qui ex nobis descendunt, contineri; nec enim dulciore nomine possumus nepotes nostros, quam filii appellare. Etenim idcirco filios filiasve concipimus atque edimus, ut ex prole eorum earumve diuturnitatis nobis memoriam in aevum relinquamus.

"Além de tudo isto, a Natureza também ensina a nós, os pais pios, que tomam uma esposa com a intenção e o desejo de procriar filhos, que todos os que descendem de nós estão contidos na denominação de filhos; de fato não podemos chamar os nossos netos por um nome mais doce do que filhos. Por esta razão, concebemos e damos à luz filhos e filhas, para que deixemos para os tempos vindouros a nossa memória permanente por meio da prole deles ou delas".

O ideal familiar nestas fontes jurídicas analisadas é o de um casamento monogâmico e com prole numerosa, em que o cidadão romano cumpre tanto as regras da Natureza como as suas obrigações em relação à res publica. ${ }^{21}$

\subsection{FAMILIA}

A família, originada pela procriação de seus membros, interessa ao "Estado" romano por estar na base de sua organização política e garantir novos cidadãos à res publica.

Nas palavras de B. BIONDI ${ }^{22}$, "a família é, talvez, o instituto mais antigo e universal. É a organização humana primordial, originada pela própria ocorrência da procriação".

Em Roma, havia duas concepções de família: a familia proprio iure, composta por

${ }^{21}$ O.M. PETER, Liberorum quaerendorum causa - L'image idéale du mariage et la filiation à Rome, in RIDA 3 (1991) p.294.

22 Istituzioni di diritto romano, Milano, Giuffrè, 1946, p.417, "La famiglia è forse l'istituto più antico ed universal. È la primordiale organizzazione umana, originata dal fatto stesso della procreazione". Nas palavras de B. BIONDI, op. cit., p.420: La famiglia fondata sul rapporto di matrimonio e di procreazione, un tempo assorbita nella cerchia della 'familia' basata sulla 'patria postestas', da prima nel costume, poi nello stesso ordinamento giuridico, gradatamente viene ad emergere col riconoscimento del vincolo di sangue, al di sopra di quello giuridico risultante della soggezione alla 'patria potestas'. "A família baseada sob a relação de matrimônio e de procriação, num momento assimilada no âmbito da familia baseada na patria potestas, primeiramente no costume, depois no próprio ordenamento jurídico, foi gradativamente manifestada com o reconhecimento do vínculo de sangue, além daquele [vínculo] jurídico resultante da submissão à 
todas as pessoas submetidas à potestas de um paterfamilias e a familia communi iure, que compreendia os agnados submetidos a um paterfamilias comum, pertencente a uma mesma gens, um antepassado longínquo, às vezes lendário.

No fragmento Ulp. 46 ad ed. D.50,16,195,2, Ulpiano, ao realizar um comentário do Edito Perpétuo concernente à bonorum possessio unde familia patroni, determina a existência de dois órgãos familiares distintos fundamentados na agnatio e na cognatio e na sua relação com a res publica. Gera inúmeras influências jurídicas: (a) no matrimônio; (b) na condição do nascido e; (c) na potestas, que define a família romana "aut natura aut iure". 23

Familiae appellatio refertur et ad corporis ${ }^{24}$ cuiusdam significationem, quod aut iure propio ipsorum aut communi universae cognationis continetur. Iure propio familiam dicimus plures personas, quae sunt sub unius potestate aut natura aut iure subiectae, ut puta patrem familias, matrem familias, filium familias, filiam familias quique deinceps vicem eorum sequuntur, ut puta nepotes et neptes et deinceps. Pater autem familias appellatur, qui in domo dominium habet, recteque hoc nomine appellatur, quamvis filium non habeat: non enim solam personam eius, sed et ius demonstramus: denique et pupillum patrem familias appellamus. Et cum pater familias morietur, quotquot capita et subiecta fuerint, singulas familias incipiunt habere: singuli enim patrum familiarum nomen subeunt. Idemque eveniet et in eo qui emancipatus est: nam et hic sui iuris effectus propriam familiam habet. Communi iure familiam dicimus omnium adgnatorum: nam etsi patre familias mortuo singuli singulas familias habent, tamen omnes, qui sub unius potestate fuerunt, recte eiusdem familiae appellabuntur, qui ex eadem domo et gente proditi sunt.

“A palavra família refere-se também ao significado de qualquer grupo que está unido por direito próprio das mesmas ou pelo [direito] comum do parentesco. Chamamos família iure proprio um conjunto de pessoas que estão sob o poder de uma única, a ela submetidas ou pela natureza ou pelo direito, como por exemplo, o pater familias, a mater familias, o filho

\footnotetext{
patria potestas".

${ }^{23}$ P. Bonfante, Corso di diritto romano - Diritto di Famiglia, vol.1, Milano, Giuffrè, 1963, pp.7, nota 1; 8, nota $1 ; 12$, nota 4. Sobre a afinidade, veja-se M.C. GIORDANI, O Código Civil à luz do Direito Romano. Parte Especial. Livro I. Do Direito de Família, Rio de Janeiro, Lumen Juris, 1996, pp. 11-14; 203.

${ }^{24}$ A communio dos cônjuges faz nascer um corpus familiae. Vejam-se P. CATALANO, 'La famiglia sorgente della storia', secondo Giorgio La Pira, in INDEX 23 (1995), p.27; M.P. BACCARI, Persona e famiglia cit.
} 
e a filha de família e seus descendentes, como os netos, as netas e descendentes. Chama-se paterfamilias aquele que tem dominium na casa, e chama-se corretamente com este nome ainda que não tenha filho; com efeito, não designamos apenas sua pessoa, mas também o seu direito. Finalmente, chamamos paterfamilias ao pupilo. ${ }^{25}$ E quando morre o paterfamilias, todos os que estavam submetidos a ele, começavam a constituir famílias diferentes, pois todos adquirem o nome de paterfamilias. E o mesmo também ocorre com aquele que é emancipado, pois este também, ao tornar-se independente, tem sua própria família. Chamamos família communi iure a de todos os agnados, pois mesmo que morto o paterfamilias, todos têm suas próprias famílias, embora, todos os que estiveram sob o mesmo poder poderão ser chamados propriamente de mesma família, porque procedem da mesma casa e da mesma gens". ${ }^{26}$

(nota 10 supra), p.38; B. BIONDI, Istituzioni di diritto romano cit. (nota 15 supra), p.419.

${ }^{25}$ Portanto, paterfamilias não quer dizer "pai" no sentido de "gerador de filhos", mas sim "chefe de família". Vejam-se B. BIONDI, Istituzioni cit. (nota 22 supra), p.419; P. BonfANTE, Corso di diritto romano cit. (nota 23 supra), pp.11-12;

${ }^{26}$ Vejam-se B. BIONDI, Istituzioni cit. (nota 22 supra), p.420; J.C. MoReIRA ALVES, Direito Romano cit. (nota 9 supra), p.603; E. BETTI, Istituzioni di diritto romano, 2aed., vol.1, Padova, CEDAM, 1947, pp.48-49; G. FranciosI, Famiglia e persone in Roma antica. Dall'età arcaica al principato, $3^{\mathrm{a}} \mathrm{ed}$., Torino, Giappichelli, 1995, pp.8-10. De acordo com P. GIUNTI, 'Mores' e 'Interpretatio prudentium' nella definizione di 'materfamilias' (una qualifica fra 'conventio in manum' $e$ 'status' di 'sui iuris'), in Nozione formazione ed interpretazione del diritto. Dall'Età romana alle esperienze moderne - Ricerche dedicate al professor Filippo Gallo, vol.1, Napoli, Jovene, 1997, pp.329, nota 59;332, materfamilias identificava-se, neste fragmento de Ulpiano, como a uxor legítima, geradora de prole. Portanto, é um termo ligado aos elementos do matrimônio e da procriação. Conclui P. GIUNTI, op.cit., pp.306;310;316-317;328-332;334, que materfamilias indicava um modelo teórico estruturado sobre um pressuposto principal: uma uxor que tivesse um matrimônio fecundo com o paterfamilias (uxor legittima generatrice di prole). Apenas no período clássico esse modelo de esposa legítima e prolífica de um paterfamilias, responsável pela educação da prole, passou a exprimir, por antonomásia, a "mulher de moralidade exemplar", que respeitava os boni mores. Vejase também A. RomANo, Matrimonium iustum - Valori economici e valori culturali nella storia giuridica del matrimonio, Napoli, Jovene, 1996, pp. 80-84.

Para S. PerozzI, Istituzioni di diritto romano, 2aed., vol.1, Roma, Athenaeum, 1928, p.327, a mulher que estivesse submetida à manus (poder marital), ou seja, que se uniu em matrimônio e efetuou a conventio in manu, recebia o título de materfamilias. Caso contrário, ela recebia o nome de uxor. Ulp. 59 ad ed. D.50,16,46,1: Matrem familias accipere debemus eam, quae non inhoneste vixit: matrem enim familias a ceteris feminis mores discernunt atque separant. Proinde nihil intererit, nupta sit an vidua, ingenua sit an libertina: nam neque nuptiae neque natales faciunt matrem familias, sed boni mores. "Devemos entender por materfamilias a que não viveu desonrosamente, pois os costumes distinguem e separam uma materfamilias das demais mulheres. Assim, nada interessará se é casada ou não, nascida livre ou liberta, pois nem as núpcias nem o nascimento fazem a [mulher] uma materfamilias, mas os bons costumes". No século II d.C., Aulo Gélio indicou o significado de materfamilias como uxor in manu mancipioque. Gell. 18,6,8-9: Enim vero illud impendio probabilius est quod idonei vocum antiquarum enarratores tradiderunt matronam dictam esse proprie quae in matrimonium cum viro convenisset, quod in eo matrimonio maneret, etiamsi liberi nondum nati forent, dictamque ita esse a matris nomine, non adepto iam, sed cum spe et omine mox adpiscendi, unde ipsum quaoque 'matrimonium' dicitur. Mater autem familias appellatam esse eam solam, quae in mariti manu mancipioque, aut in eius, in cuius maritus, manu mancipioque esset, quoniam non in matrimonium tantum, sed in familiam quoque mariti et in sui heredis locum venisset. "Parece, pois, que os idôneos intérpretes dos antigos termos deixaram escrito, que matrona se denomina aquela que se unisse em matrimônio com um varão, até quando nesse matrimônio permanecesse, embora ainda não fossem nascidos filhos e ter sido assim chamada pelo nome de mãe, não pelo já obtido, mas com esperança e voto de em breve 
A família proprio iure é um conjunto de pessoas, de bens e valores ético-culturais (mores) que estão submetidos à patria potestas do paterfamilias, vínculo que se inicia por meio da conventio in manum, da adoção ou da adrogação. ${ }^{27}$

Com a expressão aut natura aut iure ${ }^{28}$ o jurista reconheceu a família como um

adquirir; matrimonium tem a mesma origem. Materfamilias foi denominada aquela que unicamente estivesse sob a manus e in mancipio do marido ou sob a manus e in mancipio daquele em cuja manus e in mancipio o marido estivesse, depois que surgisse a sua posição de sui heredis não apenas para o matrimônio, mas também para a família do marido". Também neste sentido, Cic. Top. 3,14: (...) genus enim est uxor; eius duae formae: una matrumfamilias, eae sunt, quae in manum convenerunt; altera earum, quae tantummodo uxores habentur. "Há um único gênero de esposa, do qual existem duas formas: uma, de materfamiliae, que são aquelas que realizaram a conventio in manum, a outra, daquelas que são apenas consideradas esposas". $\mathrm{Na}$ opinião de T. Spagnuolo Vigorita, Casta Domus - Un seminario sulla legislazione matrimoniale

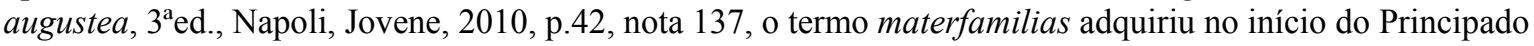
o significado de "mulher de bons costumes", submetida às sanções da Lex Iulia de adulteriis, compreendendo não apenas as mulheres casadas, mas as mulheres núbeis e as viúvas. Contrária à opinião de PEROZZI, P. GIUNTI, op.cit., pp.301-302; Idem, Consors vitae - Matrimonio e ripudio in Roma antica, Milano, Giuffrè, 2004, pp.304-305, afirma que o termo materfamilias envolve valores éticos e técnico-jurídicos. Pode indicar a procriação dentro de um matrimonium iustum. Vejam-se Fest. s.v. Materfamiliae, 112: Materfamiliae non ante dicebatur, quam vir eius paterfamiliae dictus esset; nec possunt hoc nomine pluras in una familia praeter unam appellari. Sed nec vidua hoc nomine, nec, quae sine filius est, vocari potest. "Não era chamada materfamilias antes que seu marido fosse paterfamilias; nem podem ser chamadas mais de uma, com este nome, na própria família. Mas nem com esse nome pode ser chamada a viúva, nem a mulher sem filhos. Também indica a esposa legítima que tenha gerado tanto um único filho quanto aquela que tenha gerado dois filhos"; Isid. Etym. 9,5,8: (...) ita materfamilias illa est quae plures enixa est. Nam familia ex duobus esse incipit; Etym. 9,7,3: Distinguitur autem inter matronam et matrem, et matrem et materfamilias. Nam matronae, quia iam in matrimonium convenerunt: matres, quia genuerunt: matres familias, quia per quandam iuris solemnitatem in familiam mariti transierunt. "Distingue-se entre matrona e mãe e entre mãe e materfamilias. De fato, matronas, porque agora estão casadas; mães, porque geraram; materfamilias, porque entraram na família do marido mediante alguma cerimônia jurídica solene"; Serv. ad Aen. 11,476: Matrem vero familias eam esse, quae in mariti manu mancipioque, aut in cuius maritus manu mancipioque esset, quoniam in familiam quoque mariti et sui heredis locum venisset. "Materfamilias é aquela que está na manus e in mancipio do marido ou na manus e in mancipio de alguém sob a manus e in mancipium do qual está o marido, uma vez que entrou na família do marido e na posição de herdeira sua".

${ }^{27}$ E. Volterra, Famiglia (diritto romano), in ED 16 (1967), p.737; A. RoMANO, Matrimonium iustum cit. (nota 26 supra), p.91.

${ }^{28}$ Para salientar este caráter naturalístico da família romana, que Modestino denomina "parentesco natural", veja-se Mod. 12 pand. D.38,10,4,2: Cognationis substantia bifariam apud Romanos intelligitur, nam quaedam cognationes iure civili, quaedam naturali connectentur; nonnunquam utroque iure concurrente, et naturali et civili, copulatur cognatio. Et quidem naturalis cognatio per se sine civili cognatione intelligitur, quae per feminam descendit, quae vulgo liberos peperit; civilis autem per se, quae etiam legitima dicitur, sine iure naturali cognatio consistit per adoptionem. Utroque iure consistit cognatio, quum iustis nuptiis contractis copulatur. Sed naturalis quidem cognatio hoc ipso nomine appellatur; civilis autem cognatio licet ipsa quoque per se plenissime hoc nomine vocetur, proprie tamen agnatio vocatur, videlicet quae per mares contingit. "O parentesco entre os Romanos divide-se em duas espécies. Porque há um parentesco civil e um parentesco natural e existe ainda um parentesco misto, quando os laços de sangue e os da lei concorrem conjuntamente. Pode-se perceber o parentesco natural por si mesmo, abstraindo-se o parentesco civil; isto tem lugar tratando-se de filhos concebidos vulgarmente. O parentesco civil considerado por si mesmo, abstraindo-se os laços de sangue, é aquele que se contrai por adoção. O parentesco é misto e pleno quando é constituído pelas justas núpcias. O parentesco natural conserva o nome de cognação; mas o parentesco civil, conquanto possa ser chamado com o mesmo nome, tem mais particularmente, entretanto, a designação de agnação. Esta palavra designa o parentesco vindo dos varões". Também neste sentido, Gai.1,156 e Paul. 35 ad ed. D.23,2,14,2. Vejam-se M.C. Giordani, O Código Civil à luz do Direito Romano. Parte Especial. Livro I. Do Direito de Família cit. (nota 23 supra), p.203; A. BURDESE, Il concetto di 'ius naturale' cit. (nota 12 supra), pp.414-415. 
fenômeno tanto de ordem natural quanto jurídica. ${ }^{29}$

Estes grupos familiares já existiam antes da civitas romana, como entidades autônomas, "Estados rudimentares" que eram organizados pelo paterfamilias, chefe soberano, protetor de todos os interesses daqueles que a ele estavam submetidos. Esta soberania, que assume as relações com outros grupos familiares, era regulada e limitada pelos mores $^{30}$ e normas religiosas comuns a todas as gentes. ${ }^{31}$

A noção de "Estado"32 para os romanos indicava a coletividade dos cidadãos, com

${ }^{29}$ E. VOlterra, Famiglia cit. (nota 27 supra), pp.728-729; G. PACChIOnI, Corso di diritto romano, vol.3, Roma-Torino-Napoli, UTET, 1922, p.327.

${ }^{30}$ Para F. De MARTINo, Individualismo e Diritto Romano Privato, in Annuario di Diritto Comparato e di Studi Legislativi, vol. 16, fasc. $1^{\circ}$, Roma, Istituto Italiano di Grazia e Giustizia, 1941, trad. esp. de Fernando Hinestrosa, Individualismo y Derecho Romano Privado, Bogotá, Universidad Externado de Colombia, 1991, pp.13;20;23, apesar da grande liberdade e autonomia do paterfamilias, nas relações entre famílias ou gentes, os costumes (mores maiorum) se sobrepõem à vontade dos particulares. $\mathrm{O}$ formalismo para a realização de determinados "atos jurídicos" no período arcaico constitui a vitória da sociedade sobre o particular, pois limita o poder do paterfamilias, por meio dos mores e dos sacra. Contra esta opinião, E. VolterRA, Famiglia cit. (nota 27 supra), pp.728-731; 738-739. VOLTERRA sustenta que não está confirmada nas fontes a hipótese de que o núcleo familiar fosse orientado juridicamente pelos mores maiorum e nem há indícios de punições ainda que estritamente de caráter religioso, aos membros do grupo familiar que violassem estes mores. A família, após a desagregação das gentes e das tribus, foi o único grupo que permaneceu como núcleo original da civitas. Para E. VOLTERRA, op. cit. (nota 27 supra), p.735, a origem etimológica da palavra "família" viria do termo famulus que significava "aquele que pertence à casa". Seria aquele membro que participava do fas (direito divino) deste grupo, submetido ao paterfamilias. Veja-se Fest. s.v. famuli 77: famuli origo ab Oscis dependit, apud quos servus famel nominabatur, unde et familia vocata. "A origem do termo famuli deriva dos Oscos, junto aos quais o escravo era denominado famel, donde também chamada familia".

A família tem seu próprio culto (sacra privata), e o paterfamilias exerce a justiça no âmbito doméstico (iudicia domestica) para julgar seus membros e até puní-los com a morte (ius vitae ac necis - direito de vida e de morte). As uniões de famílias em grupos maiores distintos (familiae - gens - tribus) tinham uma finalidade política de organização e de defesa dos indivíduos que as constituíam, superiores aos laços de consanguinidade (cognatio) e originaram uma organização superior, que foi denominada civitas. Vejam-se neste sentido, E. VolTerRa, Ancora sul problema della 'familia' romana, in Scritti Giuridici II. Famiglia e Sucessioni, Napoli, Jovene, 1991, p.411; Idem, La conception du Mariage d'après les juristes romains, in Scritti Giuridici II. Famiglia e Sucessioni, Napoli, Jovene, 1991, pp.30-34; Idem, Sui 'mores' della 'familia' romana, in Scritti Giuridici II. Famiglia e Sucessioni, Napoli, Jovene, 1991, pp.180-181; Idem, La conception du Mariage à Rome, in Scritti Giuridici II. Famiglia e Sucessioni, Napoli, Jovene, 1991, pp.354355; Idem, Les formes du Mariage chez les Romains, in Scritti Giuridici II. Famiglia e Sucessioni, Napoli, Jovene, 1991, p.279; A. RomANO, Matrimonium iustum cit. (nota 26 supra), pp.23;84.

${ }^{31}$ F. DE MARTINO, Individualismo e Diritto Romano Privato cit. (nota 30 supra), pp.20-21. O "Estado" e a "família" arcaicas não se fundamentam sobre o conceito de poder, mas sobre o comando do pater, uma espécie de proteção dos membros do grupo e de administração. Na opinião de T. SPAGNUOLO VIGORITA, Casta Domus cit. (nota 26 supra), p.70, as núpcias e a procriação permitiram o crescimento da cidade e a concentração dos poderes políticos às gens mais ilustres (Marcii, Fabii, Valerii, Iulii). Veja-se Dio Cass.

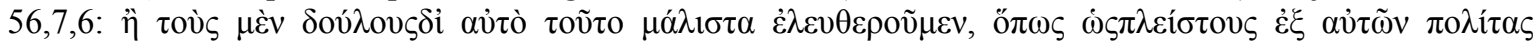

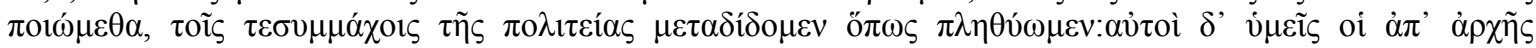

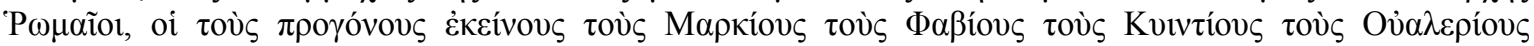

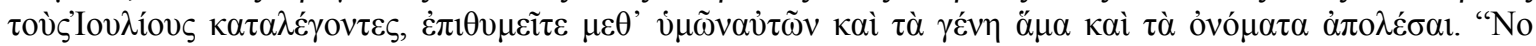
mais, o escopo principal pelo qual libertamos os escravos é exatamente o de retirar dentre eles o máximo possível de cidadãos; e para aumentar o número, concedemos aos aliados a cidadania. E vós, que sois Romanos desde as origens, que enumerastes antepassados famosos - os Marcii, os Fabii, os Valerii, os Iulli exatamente vós desejais que as suas famílias e os seus nomes morram com vós?".

${ }^{32}$ Status é o particípio do verbo stare e os romanos o utilizaram em diversas situações, geralmente seguido pelo genitivo de um substantivo: típica a expressão status rei Romanae ou rei publicae indicando o "modo de 
suas raízes na família, a primeira célula da coletividade organizada. Res publica ${ }^{33}$ indica o que é comum a todos (os interesses comuns do povo) e as denominadas "coisas públicas" (res publicae). ${ }^{34}$

Nas origens de Roma, a família tem uma autonomia relativa em relação à res publica. Nestes primórdios, a civitas raramente interferia nas relações familiares, pois qualquer ato contrário aos mores maiorum praticado por um dos membros da família, era

ser" da organização do povo romano. Apenas no século XV a palavra "Estado" assumiu o significado que hoje lhe é atribuída. A História, portanto, não conhece um "Estado Antigo", apenas o "Estado Moderno". Veja-se Ulp. 1 inst. D.1,1,1,2: Huius studii duae sunt positiones, publicum et privatum. Publicum ius est quod ad statum rei Romanae spectat, privatum quod ad singulorum utilitatem: sunt enim quaedam publice utilia, quaedam privatim. Publicum ius in sacris, in sacerdotibus, in magistratibus consistit. Privatum ius tripertitum est: collectum etenim est ex naturalibus praeceptis aut gentium aut civilibus. "São duas as posições deste estudo: o público e o privado. Direito público é o que se volta ao estado da res Romana [da coisa pública romana; do "Estado" romano], privado o que se volta à utilidade de cada um dos indivíduos, enquanto tais. Pois alguns são úteis publicamente, outros particularmente. O direito público se constitui nos sacra, sacerdotes e magistrados. O direito privado é tripartido: foi, pois, coligido ou de preceitos naturais, ou civis, ou das gentes”. Na opinião de V. GIUFFRÈ, Il 'Diritto pubblico' nell'esperienza romana, $2^{\mathrm{a}} \mathrm{ed}$. , Napoli, Jovene, 1989, pp.93-95, a noção ulpianéia reflete o "ponto de chegada" de um processo dirigido a incluir na concepção de ordenamento jurídico (Ius Romanum), as normas relativas à organização do "Estado", que anteriormente, por sua natureza política, foram consideradas pela communis opinio dos jurisconsultos como extrajurídicas. As reformas do Principado, com a criação de novos cargos, fez com que a concepção metajurídica do "Estado" não se identificasse diretamente com os cidadãos que participavam de sua vida política. Ulpiano identifica duas positiones de atuação, duas áreas do conhecimento jurídico às quais o jurisconsulto pode se dedicar. GIUFFRĖ critica esta sistematização do Direito Público Romano elaborada por Ulpiano, denominando-a "ambígua" e "imperfeita". Ambígua, por oscilar da busca pela utilitas (pública ou privada) à distinção de determinadas áreas (sacra, sacerdotes e magistraturas). Imperfeita pela omissão tanto do poder supremo do período em que foi escrita (o princeps), quanto de outros setores como o ordenamento militar (res militaris).

${ }^{33}$ Segundo o filósofo estóico Panécio de Rodes (185-110 a.C.), a res publica é um conjunto de homens que vivem no mesmo território e são governados por uma lei. Para Panécio, o "Estado" seria uma sociedade baseada na igualdade de direitos e tendo como principal objetivo a utilidade comum fundamentada no valor vinculante da lei. Este pensamento é elemento essencial da definição de res publica de Cipião Africano (Emiliano) em Cic. de rep. 1,25,39: Est igitur, inquit Africanus, res publica res populi, populus autem non omnis hominum coetus quoquomodo congregatus, sed coetus multidudinis iuris consensu et utilitatis communione sociatus. Eius autem prima causa coeundi est non tam imbecillitas quam naturalis quaedam hominum quasi congregatio (...) "A res publica - afirma Africano - é a res populi. E o povo é, não uma reunião de homens agrupados de qualquer maneira, mas a reunião de uma multidão associada pela sua adesão a uma lei e pela comunhão de interesses. A causa primeira que impele os homens a reunir-se é tanto a necessidade de auxílio recíproco, quanto uma inclinação natural de viver em conjunto (....." Esta referência de Cícero salienta a noção "constitucional" de populus que é construída na idéia de lei baseada no conceito de pacto. Vejam-se O. SACCHI, Le nozioni di stato e di proprietà in Panezio e l'influenza della dottrina stoica sulla giurisprudenza romana dell'epoca scipionico-cesariana, in RIDA 52 (2005), pp.335-337; A.A. CASTRo CoRrÊA, O Estoicismo no Direito Romano, Dissertação (Livre Docência) - Faculdade de Direito da USP, São Paulo, 1950, pp.18-19. Portanto, pela definição de Cícero, deduz-se que o populus Romanus não é uma raça, nem uma etnia, nem uma nação, mas uma multidão de homens unida pelo consensus iuris e pela communio utilitatis. Na concepção estoica, a virtus do vir bonus é aquela que atende ao bem comum, concebível a serviço da res publica. O cidadão romano virtuoso é aquele que sacrifica seus interesses individuais em prol do interesse coletivo.

${ }^{34}$ Veja-se Gai. 2 inst. D.1,8,1pr.: (...) Hae autem res, quae humani iuris sunt, aut publicae aut privatae. Quae publicae sunt, nullius in bonis esse creduntur, ipsius enim universitatis esse creduntur: privatae autem sunt, quae singulorum sunt. “(...) Por outro lado, estas coisas que são do direito humano ou são públicas ou são privadas. Considera-se que as coisas públicas não estão entre os bens de ninguém, pois são reputadas como sendo da própria coletividade; são privadas, porém, as que são de cada um particularmente". É preciso salientar que o ius Romanum constitui um sistema em que religio, mos e ius estão profundamente compenetrados. 
julgado pelo paterfamilias, ou, em determinados casos, pelo conselho familiar.

Durante o período republicano, com o desenvolvimento econômico e político, os mores populi Romani baseados no tacitus consensus, influenciaram diretamente a organização familiar. Algumas relações familiares como o matrimônio e a procriação passaram a ser de interesse não apenas do paterfamilias, mas de toda a civitas. ${ }^{35}$

O dever de um Romano ter filhos consiste num princípio de conduta do cidadão, que se desenvolve na comunidade jurídica da civitas. Os mores que regulam a procriação nas famílias não surgem no âmbito familiar, mas da consciência e do consenso dos cives como um princípio destinado a assegurar a existência e o futuro da própria civitas. ${ }^{36}$

Como será analisado na segunda parte desta pesquisa, este dever do cidadão em relação à procriação tornar-se-á mais importante no início do Império, com a promulgação das leis matrimoniais que identificavam o modelo ideal de cidadão romano com o pater que tem uma descendência numerosa. ${ }^{37}$

Cícero em sua obra De officiis $(1,17,53-54)$, analisa o vínculo existente entre os cidadãos dentro de uma determinada sociedade e salienta o papel da procriação, fundamentado nos mores maiorum:

\section{Gradus autem plures sunt societatis hominum. Ut enim ab illa infinita}

\footnotetext{
${ }^{35} \mathrm{Na}$ opinião de E. BETTI, Istituzioni di diritto romano cit. (nota 26 supra), p.49, tali comunità familiari o gentilizie vaste e potenti dovevano perdere loro ragion d'essere quando la civitas assunse le funzioni politica di ordine e di difesa. Vejam-se também J.C. MoreIRA Alves, Direito Romano cit. (nota 9 supra), p.604; E. VOLTERRA, La conception du Mariage à Rome cit. (nota 30 supra), pp.354-355; Idem, Les formes du Mariage chez les Romains cit. (nota 30 supra), p.279; Idem, Sui 'mores' della 'familia' romana cit. (nota 30 supra), p.188.

Em relação à família patriarcal no direito pré-clássico, Sen. Epistolae ad Lucilium, 5,47,14: (...) maioris nostri domum pusillam rem publicam esse iudicaverunt. “(...) os nossos antepassados julgaram que o lar doméstico era uma pequena república”. Para V. GIUfFrè, Il 'Diritto pubblico’ cit. (nota 32 supra), pp.54-55, o pater representava todos os membros, os nascidos de sua união esogâmica estável com a esposa (cognati) e aqueles que se agregavam para integrar a força de trabalho e receber proteção (clientes).

${ }^{36}$ Vejam-se E. VolterRA, Sui 'mores' della 'familia' romana cit. (nota 30 supra), pp192;195; R. BESNIER, L'application des lois caducaires cit. (nota 10 supra), p.96; R. AsTOLFI, Note per una valutazione storica della 'Lex Iulia et Papia', in SDHI 39 (1973), p.210; A. RoMANO, Matrimonium iustum cit. (nota 26 supra), p.23. Na opinião de R. Astolfi, La Lex Iulia et Papia cit. (nota 15 supra), p.346, probabilmente ha ragione chi pensa che la procreazione fosse il contenuto di un obbligo imposto dai 'mores'. Nas palavras de E. CANTARELla, Matrimonio e sessualità nella Roma republicana: una storia romana di amore coniugale, in Diritto e sessualità in Grecia e a Roma, Milano, CUEM, 2003, p.118, la riproduzione (...) era percepita (e imposta) come un dovere civico. I romani, certamente, procreavano anche perché volevano avere una discendenza legittima, onde evitare l'estinzione della famiglia: ma non solo per questo, e soprattutto non in primo luogo per questo. La ragione principale e prima del matrimonio era la necessità (e il dovere civico) di generare cittadini. De acordo com A. BOUCHÉ-LECLERCQ, Les lois démographiques d'Auguste, in RH 57 (1895), p.255, (...) on peut dire que les Romains comme les Grecs ont toujours associé au mariage l'idée un peu austère de devoir, devoir envers les ancêtres, devoir envers la cité. Segundo T. SPAGNUOLO VIGORITA, Casta Domus cit. (nota 26 supra), p.57, para realizar a sua reforma moral, Augusto percebeu que não poderia basear-se apenas na coerção de sua legislação, mas que deveria utilizar-se também dos mores maiorum.

${ }^{37}$ Conforme O.M. PÉTER, Liberorum quaerendorum causa cit. (nota 21 supra), pp.301, nota 22 e 325.
} 
discedatur, proprior est eiusdem gentis, nationis, linguae, qua maxime homines coniunguntur; interius etiam est eiusdem esse civitatis; multa enim sunt civibus inter se communia, forum, fana, porticus, viae, leges, iura, iudicia, suffragia, consuetudines praeterea et familiaritates multisque cum multis res rationesque contractae. Artior vero colligatio est societatis propinquorum; ab illa enim immensa societate humani generis in exiguum augustumque concluditur. 54. Nam cum sit hoc natura commune animantium, ut habeant libidinem procreandi, prima societas in ipso coniugio est, proxima in liberis, deinde una domus, communia omnia; id autem est principium urbis et quasi seminarium rei publicae.

“53. Há vários graus de sociedade humana. Para não falar, de fato, da sociedade muito numerosa que une todos os homens, considera-se mais próxima aquela constituída entre os homens do mesmo povo, nação e língua, que são os vínculos mais importantes. Ainda mais íntima é aquela entre os homens da mesma civitas; uma vez que muitas coisas são comuns aos cidadãos, a praça principal (forum), os templos, o pórtico, as estradas, as leis, os direitos, os tribunais, os sufrágios, além disso, os costumes (consuetudines), os laços de parentesco, os numerosos negócios e relações contraídos. Sociedade mais restrita, é pois, o vínculo da própria família: de fato, da imensa sociedade do gênero humano encerra-se a um círculo muito pequeno. 54. E, uma vez que em todos os animais é natural o desejo da procriação, a sociedade é constituída primeiro no próprio casamento [união conjugal], depois nos filhos; em seguida numa única casa e nas coisas comuns. Isto é o princípio da cidade e como que a origem [sementeira] da res publica".

A procriação era, no sistema jurídico-religioso romano, o fundamento do matrimônio, pois criava uma nova família, uma nova unidade (ontológica) social, que Cícero denominou "seminarium rei publicae", "principium urbis", "pusilla res publica", a pedra angular da civitas. ${ }^{38}$

${ }^{38}$ P. CATALANO, 'La famiglia sorgente della storia' cit. (nota 24 supra), p.27; B. BIONDI, Istituzioni cit. (nota
22 supra), p.440; P. VOCI, Istituzioni di diritto romano cit. (nota 12 supra), p.515; R. BESNIER, L'application
des lois caducaires cit. (nota 10 supra), p.97; R. AsTOLFI, Note per una valutazione storica della 'Lex Iulia et
Papia' cit. (nota 36 supra), p.194. Deste trecho de Cícero, conclui P.P. ONIDA, Studi sulla condizione cit.
(nota 12 supra), pp.110-111: La prospettiva della riflessione ciceroniana non è dunque dissimile da quella
adottata da Ulpiano nella definizione del 'ius naturale' come diritto comune a uomini e ad altri esseri
animati, ove è evidente, per quel riferimento alla 'coniunctio', alla 'procreatio' e alla 'educatio liberorum',
il paralelismo com la riflessione di Cicerone, in tema di 'coniugium' e di 'societas liberorum'. Tradução
deste trecho: "A perspectiva da reflexão ciceroniana não é, portanto, diferente da adotada por Ulpiano na
definição de ius naturale como direito comum aos homens e aos outros seres vivos, onde é evidente, pela
referência à coniunctio, à procreatio e à educatio liberorum, o paralelismo com a reflexão de Cícero, no
assunto de coniugium e de societas liberorum". FRANCIOSI recorda que a Roma la famiglia è appunto 
Para bem entender este trecho de Cícero, é preciso considerar que o termo gradus significa os graus, os passos (conforme o verbo gradior, "caminhar"), pois Cícero faz uma analogia entre o desenvolvimento da sociedade humana com uma estrada que o homem percorre em fases sucessivas. A primeira fase é a sociedade universal, que reúne todos os homens, de todas as línguas e nações. ${ }^{39}$

Além disso, Cícero ressalta no trecho final citado (principium urbis et quasi seminarium reipublicae) a importante função social e o interesse público que está no fundamento do matrimônio (coniugium). ${ }^{40}$

Nesta passagem, Cícero indica que a civitas é formada por um conjunto de elementos jurídicos (iura, iudicia, suffragia, consuetudines) e arquitetônicos (forum, fana, porticus, viae) que possibilita aos cidadãos unirem-se harmonicamente em sociedade. ${ }^{41}$

Um dos elementos jurídicos citados por Cícero são as consuetudines, costumes, também denominados mores, ou seja, normas não-escritas válidas para uma população

considerata 'quasi seminarium rei publicae' e il matrimonio è preordinato 'liberorum quaerendorum causa'. Veja-se G. FrancIOSI, Famiglia e persone in Roma antica cit. (nota 26 supra), pp.34;131; Idem, Corso istituzionale di diritto romano, $2^{\mathrm{a}} \mathrm{ed}$., Torino, Giappichelli, 1997, p.154: Il matrimonio è infatti preordinato al fine della procreazione della prole, liberorum quaerendorum causa: esso è, secondo la nota definizione di Cicerone, quasi seminarium rei publicae. Na opinião de R. Astolfi, La Lex Iulia et Papia cit. (nota 15 supra), p.352, a mesma concepção ciceroniana de família encontra-se numa passagem do Digesto do jurista Terêncio Clemente. Ter. Clem. 5 ad l. Iul. et Pap. D.35,1,64,1: “(...)legem enim utilem rei publicae, subolis scilicet procreandae causa latam, adiuvandam interpretatione”. "(...) porque deve-se favorecer com a interpretação uma lei útil à res publica, certamente promulgada para a procriação da prole”.

Sêneca, o Retor, em sua obra Controversiae, afirma que o matrimônio deve ser contraído de acordo com o interesse da res publica e exorta os cidadãos a não ficarem satisfeitos com um único filho. Veja-se Sen. Contr. 1,83;2,5,13. De acordo com P. GIUNTI, Consors vitae cit. (nota 26 supra), pp.4;6, a expressão principium urbis et quasi seminarium reipublicae indica o papel do matrimonium iustum na organização sócio-política da civitas. Por meio da procriação, a família garante a permanência e a existência da própria civitas. No matrimônio originam-se diversos institutos jurídicos, v.g., a familia proprio iure, a patria potestas, as relações de agnação e cognação. Além disso, o matrimônio iustum e a família modelaram as situações subjetivas que articulavam a vida dos cidadãos.

${ }^{39}$ Vejam-se P. CATALANO, 'La famiglia sorgente della storia' cit. (nota 24 supra), pp.25-28; G. CIPRIANI - P. FEDELI, Vivere a Roma antica cit. (nota 4 supra), p.279.

${ }^{40}$ Quanto à etimologia, é interessante verificar-se que algumas palavras presentes no texto fazem referência ao principio urbis e ao importante papel da procriação, como gens (de gignere, gerar); natio, nationis que deriva do verbo nasci (nascer) e indica o conjunto de indivíduos reunidos pelo nascimento num determinado local; a sociedade mais restrita é a família fundada no matrimônio e que constitui a "sementeira" de semen (semente, origem, princípio); a libido procreandi de libet, "ter vontade de", indica particularmente neste trecho o "desejo sexual". Vejam-se, G. CIPRIANI - P. FEDELI, Vivere a Roma antica cit. (nota 4 supra), p.279; B. BIONDI, Istituzioni cit. (nota 22 supra), p.440; P. CATALANO, 'La famiglia sorgente della storia' cit. (nota 24 supra), p.26; R. BESNIER, L'application des lois caducaires cit. (nota 10 supra), p.97; D. DALLA - R. LAMBERTINI, Istituzioni di diritto romano cit. (nota 10 supra), p.103; P. GIUNTI, Consors vitae cit. (nota 26 supra), p.4. Contra essas opiniões, A. LóPEz PEDrEIRA, Limitaciones a la 'libertas nuptialis' en la legislación Augustea in El Derecho de Familia: De Roma al Derecho Actual, Huelva, Universidad de Huelva, 2004, p.397, defende que o termo principio urbis et quasi seminarium rei publicae do trecho de Cícero é uma mera "recomendação moral".

${ }^{41}$ P.P. ONIDA, Studi sulla condizione cit. (nota 12 supra), pp.109-110. 


\section{organizada em uma civitas. ${ }^{42} \mathrm{Na}$ Realeza e na República, o "Estado" utiliza poucas vezes}

leis escritas para ajustar as relações familiares, que eram reguladas pela autoridade do paterfamilias e pelos mores maiorum (hábitos dos antepassados). ${ }^{43}$

${ }^{42}$ Cic. de leg. 2,10,23: (...) et si quae forte a me hodie rogabuntur, quae non sint in nostra re publica nec fuerit, tamen fuerunt fere in more maiorum, qui tum ut lex valebat. "(...) e se hoje eu propuser algumas [leis], que não estão nem estiveram na nossa res publica, estão contudo próximas ao mos maiorum [hábitos dos antepassados], que então valia como lei”.

${ }^{43}$ A base do matrimônio romano estava nos mores maiorum. Os mores se baseiam em uma série de atos voluntários, semelhantes e inveterados, atos que se tornam fonte do direito fundamentados não na vontade dos membros da família, mas de toda a sociedade, manifestado como consentimento. São comportamentos contínuos e constantes que espontaneamente se mantêm em uma sociedade organizada e que, pela longa e voluntária observância por parte de todos, são considerados como necessários, obrigatórios e vinculantes. Veja-se UE 1,4: Mores sunt tacitus consensus populi, longa consuetudine inveteratus. "Os costumes são o tácito consentimento do povo inveterado pela longa repetição". Acerca de definições na literatura romana do termo "costume", vejam-se: Cic. De inv. 2,22,67: (...) Consuetudine autem ius esse putatur id, quod voluntate omnium sine lege vetustas comprobarit, in ea autem quaedam sunt iura ipsa iam certa propter vetustatem. Quo in genere et alia sunt multa et eorum multo maxima pars, quae praetores edicere consuerunt. Quaedam autem genera iuris iam certa consuetudine facta sunt; quod genus pactum, par, iudicatum. "Denomina-se direito baseado no costume aquilo que a antiguidade comprovou, sem lei, por vontade de todos. Nele se encontram alguns direitos que, por eles próprios, receberam da antiguidade uma força incontestável. Pelo que, por outro lado, os mais numerosos encontram-se habitualmente nos editos dos pretores. Algumas espécies de direitos são, por isso, fundados num costume bem estabelecido, por exemplo, um pacto, a igualdade, a coisa julgada"; Rhet. Her. 2,19: Natura ius est, quod cognationis aut pietatis causa observatur, quo iure parentes a liberis, et a parentibus liberi coluntur. Lege ius est id, quod populi iussu sanctum est quod genus: ut in ius eas, cum voceris. Consuetudine ius est id, quod sine lege aeque, ac si legitimum sit, usitatum est quod genus id quod argentario tuleris expensum, ab socio eius recte petere possis. "Direito natural é o que se observa em razão da cognação ou da piedade filial. Por esse direito, os pais são cultuados pelos filhos e os filhos pelos pais. Direito fundado na lei é aquele sancionado por decreto do povo, por exemplo: o dever de comparecer perante a Justiça quando se é chamado. Direito consuetudinário é aquele que, mesmo não havendo lei, é admitido pelo uso com força de lei. Por exemplo, a soma que entregamos a um banqueiro, temos o direito de exigir de seu sócio". Vejam-se M.H. RochA PEREIRA, Estudos de História da Cultura Clássica - Cultura Romana, v.2, Lisboa, Fundação Calouste Gulbenkian, 1984, pp.357-361; A. LÓPEZ PEDREIRA, Limitaciones a la 'libertas nuptialis' en la legislación Augustea cit. (nota 40 supra), p.391; E. Volterra, Sui 'mores' della 'familia' romana cit. (nota 30 supra), pp.186, nota 186;193, notas 2 a 4;195.

Na opinião de E. VOLTERRA, Istituzioni di Diritto Privato Romano cit. (nota 12 supra), p.27: I giuristi romani attribuiscono alla consuetudine la creazione delle più antiche norme (mores, instituta maiorum). Nel periodo classico la consuetudine non viene neppure elencata fra le fonti del diritto ed il binomio 'mores et leges' viene usato ad indicare le antiche e le più recenti norme giuridiche. Il fatto che in questo periodo non si hanno più norme e istituti creati della consuetudine può spiegarsi con la considerazione che non appena nella società romana cominciava ad affermarsi una consuetudine, questa trovava facile accoglimento nell'editto del pretore, in guisa da apparire come creazione del 'ius honorarium'. "Os juristas romanos atribuem ao costume a criação das normas mais antigas (mores, instituta maiorum). No período clássico, o costume não está sequer elencado entre as fontes do Direito e o binômio mores et leges é usado para indicar as antigas e as mais recentes normas jurídicas. O fato de que neste período não há normas e institutos criados pelo costume, pode explicar-se considerando que, apenas começava a confirmar-se um costume na sociedade romana, este encontrava uma fácil recepção no edito do pretor, de forma que se manifestava como criação do ius honorarium". VOLTERRA neste trecho refere-se, principalmente, a Gai. 1,2:. Constant autem iura populi romani ex legibus, plebiscitis, senatusconsultis, constitutionibus principum, edictis eorum qui ius edicendi habent, responsis prudentium. "Os direitos do povo romano constam de leis, plebiscitos, senatusconsultos, constituições imperiais, editos dos que têm o direito de expedi-los, respostas dos prudentes" e a Pap. 2 def. D.1,1,7pr.: Ius autem civile est, quod ex legibus, plebis scitis, senatus consultis, decretis principum, auctoritate prudentium venit. "Ius civile é o que advém das leis, plebiscitos, senatus-consultos, decretos dos príncipes e da autoridade dos prudentes". Para F. ScHUlz, Prinzipien des römischen Rechts, MünchenLeipzig, trad. esp. de Manuel Abellán Velasco, Princípios del Derecho Romano, Madrid, Civitas, 1990, pp.35-36, Gaio ao dispor sobre as fontes do direito romano, não mencionou o costume propositalmente, pois enumerou apenas as fontes provenientes dos órgãos "estatais" romanos e os responsa prudentium, ou seja, as 
Nos capítulos posteriores, veremos que no início do Império o "Estado" protegeu o interesse comum da res publica, de acordo com uma utilitas publica ${ }^{44}$ e realizou uma série de intervenções legislativas nas relações matrimoniais. ${ }^{45}$

As fontes literárias demonstram inúmeros modelos de famílias romanas com prole numerosa, garantia de uma vida feliz e próspera.

Plínio, o Jovem, menciona como "modelo" um de seus amigos, Asinius Rufus, que tinha uma família numerosa e que cumpria suas obrigações de bom cidadão romano.

Plin. Iun. Ep. 4,15,1-3. Si quid omnino, hoc certe ex iudicio facio, quod Asinium Rufum singulariter amo(...) Sunt ei liberi plures. Nam in hoc quoque functus est optimi civis officio, quod fecunditate uxoris large frui voluit eo saeculo, quo plerisque etiam singulos filios orbitatis praemia graves faciunt; quibus ille despectis, avi quoque nomem adsumpsit.

"Se eu não estou absolutamente desprovido de todo o juízo, amava particularmente a Asinius Rufus (...) Ele tem vários filhos. Pois ele ainda cumpriu seu dever de ótimo cidadão desejando que sua família fosse tão grande quanto permitisse a fecundidade de sua esposa, e isso numa época onde tantos outros, pensando nas vantagens que garantiam a ausência de filhos, consideravam que um filho único era um fardo. Desdenhando destas vantagens, ele mesmo desejou ter o nome de avô".

Em suma, os vínculos familiares sempre representaram um papel importante na vida social e política em Roma, pois garantiram a perpetuidade da sociedade pela procriação de grande quantidade de filhos legítimos. ${ }^{46}$

sentenças e as opiniões daqueles que tinham permissão do imperador para emitirem pareceres com força de lei. Os costumes diferem destas normas jurídicas formuladas pelo "Estado", pois estas últimas exigem uma "observância incondicionada". O mais provável, no entanto, é que Gaio e Papiniano enumeraram as fontes do chamado "direito escrito" e o costume era denominado como ius non scriptum. Ulp. 1 inst. D.1,1,6,1: Hoc

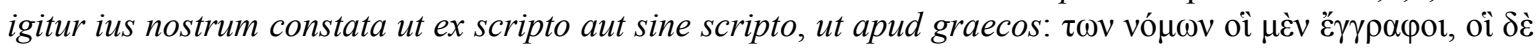

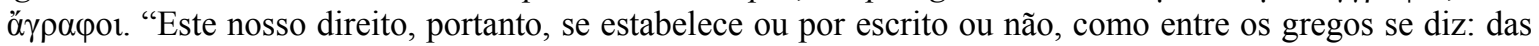
normas, umas são escritas outras não escritas". Vejam-se Inst. 1,2,3; Gell. 12,10,9; Macr. Sat. 3,8,8; Quint. Inst. Orat. 5,10,13.

${ }^{44}$ Vejam-se G. LONGO, Utilitas publica, in LABEO 18.1 (1972), pp.7-71; J. GAUdEMET, Utilitas Publica, in Études de droit romain. II. Institutions et doctrines politiques, Napoli, Jovene, 1979, pp.163-197.

${ }^{45}$ B. BIONDI, Istituzioni cit. (nota 22 supra), p.440. Esta intervenção do "Estado" no Mundo Antigo foi maior ou menor dependendo das necessidades e dos próprios costumes de cada povo. Por exemplo, em Esparta, a intervenção do "Estado" nas relações familiares para atender aos interesses públicos era muito nítida. Veja-se Aelian. Varia Historia 6,6: Lex est Spartanis, ut qui tres filios exhiberet reipublicae, is ab excubiis haberet immunitatem: qui vero quinque, ab omnibus publicis muneribus literaretur.

${ }^{46}$ B. BIONDI, Istituzioni cit. (nota 22 supra), p.420. 
E para a constituição de uma família e a procriação de uma prole legítima eram necessários alguns requisitos que perfaziam as justas núpcias, das quais passamos a tratar.

\subsection{MATRIMONIUM LEGITIMUM - IUSTAE NUPTIAE}

\subsubsection{Aspectos conceituais}

O casamento romano era um estado de fato contínuo, consistente na convivência de duas pessoas de sexo diferente, com a intenção de serem marido e mulher. ${ }^{47}$

O consentimento entre os cônjuges para a formação do matrimônio não é instantâneo, porém contínuo, não é um mero acordo inicial de comunhão de vida entre os nubentes, não se forma num momento determinado, como um contrato. ${ }^{48}$ Sua conclusão

${ }^{47}$ J.C. MAtos PeIXOTO, Convivência no matrimônio romano, in Romanitas - Revista de Cultura Romana (Língua, Instituições e Direito) 1, Rio de Janeiro, 1958, p.19; A. BuRDESE, Manuale di diritto privato romano, Torino, UTET, 1964, p.265; J.M. ОтноN Sidou, Matrimonium I. in, Enciclopédia Saraiva do Direito 52 (1977), p.67; F. DELla CORTE, Le 'leges Iuliae' e l'elegia romana, in ANRW II.30 (1981), p.553; O. RoBlEDA, Intorno alla nozione di matrimonio cit. (nota 17 supra), p.176; S. PEROZZI, Istituzioni cit. (nota 26 supra), p.325; C. PUjal, La concepción jurídica del matrimonio romano clásico in El Derecho de Familia: De Roma al Derecho Actual, Huelva, Universidad de Huelva, 2004, pp.605;611-612.

R. ORESTANO, La struttura giuridica del matrimonio romano cit. (nota 1 supra), p.205, critica as definições modernas de matrimônio e qualifica como "incompletas" e "inexatas" aquelas que, elaboradas com base apenas na convivência e na intenção (affectio maritalis), geralmente atribuem uma função essencial à convivência que não existiu no matrimônio do período clássico: (...) la mera convivenza non era sufficiente da sola a qualificare come matrimonio il rapporto. “(...) a mera convivência não era suficiente para qualificar a relação como matrimônio". Veja-se também M.J. GARCIA GARRIDO, Minor annis XII nupta, in LABEO 3 (1957), pp.86, nota $23 ; 87$.

${ }^{48}$ Três fragmentos de Ulpiano informam que o casamento romano não exigia a conjunção carnal para a sua formação. A procriação é o escopo principal do matrimônio romano, não um elemento essencial desta formação: Ulp. 36 ad Sab. D.50,17,30: Nuptias non concubitus, sed consensus facit. "Não é o concúbito, mas o consentimento que faz as núpcias"; Ulp. 33 ad Sab. D.24,1,32,13: Si mulier et maritus diu seorsum quidem habitaverint, sed honorem invicem matrimonii habebant, quod scimus interdum et inter Consulares personas subsecutum, puto, donationes non valere, quasi duraverint nuptiae, non enim coitus matrimonium facit, sed maritalis affectio; si tamen donator prior decesserit, tunc donatio valebit. "Se a mulher e o marido tivessem, na verdade, morado longo tempo separadamente, porém conservassem reciprocamente a dignidade do matrimônio, o que sabemos ocorreu às vezes entre consulares, considero que não são válidas as doações, como se subsistissem as núpcias, porque não é a união sexual [coito] que faz o matrimônio, mas a affectio maritalis; porém, se o doador falecesse primeiro, então será válida a doação"; Ulp. 35 ad Sab. D.35,1,15: Cui fuerit sub hac conditione legatum: si in familia nupsisset, videtur impleta conditio statim atque ducta est uxor, quamvis nondum in cubiculum mariti venerit; nuptias enim non concubitus, sed consensus facit. "Deixando-se legado a uma mulher sob condição de casar na família, considera-se verificada a condição, desde que é introduzida na casa do marido, ainda que não tenha entrado no quarto do marido, pois não é a relação sexual [a cópula], mas o consenso que faz o matrimônio". Sobre este último fragmento, D.35,1,15, D. DALLA - R. LAMBERTINI, Istituzioni di diritto romano cit. (nota 10 supra), p.104, observam que la speranza della procreazione viene potenzialmente realizzata nel momento in cui un uomo e una donna si uniscono in matrimonio. Non si richiede la consumazione o la capacità di procreare. Il matrimonio esiste ed è valido anche se poi non segua l'unione sessuale. 
não necessita de nenhuma solenidade nem de formas pré-estabelecidas. ${ }^{49}$

Este consentimento, em alguns casos, sofria algumas restrições. Para os alieni iuris, era necessário o consentimento dos respectivos patresfamilias, a interposição de sua auctoritas $^{50}$, manifestação da patria potestas que integrava a vontade do filho ou da filha.

Sobre a vontade contínua e recíproca dos cônjuges, vejam-se Quint. Declam. 306: Vis scire quid sint nuptiae? - : aspice illam virginem, quam pater tradidit, euntem die celebri, comitante populo. Non potest quisquam dare, quod constat duorum voluntate. "Por que saber o sentido das núpcias? Observe aquela jovem, a qual o pai a entregou [em casamento], dirigindo-se para o dia célebre, acompanhada pelo povo. Não pode alguém conceder, aquilo que permanece pela vontade de dois"; Quint. Inst. Orat. 5,11,32: (...) nihil obstat quo minus iustum matrimonium sit mente coeuntium, etiam si tabulae signatae non fuerint; nihil enim proderit signasse tabulas si mentem matrimonii non fuisse constabit. “(...) nada se opõe ao fato que um matrimônio seja justo, quando há o acordo[de vontades entre os contraentes], mesmo se não tenham sido firmadas as tábuas; nada, de fato, servirá ter firmado as tábuas, se constar que não houve o acordo de vontade em relação ao matrimônio". Vejam-se J.C. MOREIRA ALVES, J.E. Labbé e a natureza jurídica do casamento romano in Revista da Faculdade de Direito da USP 74 (1979), p.113; A. BuRdESE, Manuale cit. (nota 47 supra), pp.274-275, nota 2; M. MARrone, Istituzioni di diritto romano, $3^{\mathrm{a} e d ., ~ P a l e r m o, ~ P a l u m b o, ~ 2006, ~ p .218 ; ~ A . ~}$ LÓPEZ PEDREIRA, Limitaciones a la 'libertas nuptialis' cit. (nota 40 supra), p.395; J. DAZA MARTíNEZ, La influencia cristiana en la concepción postclásica y justinianea del matrimonio romano, in El Derecho de Familia: De Roma al Derecho actual, Huelva, Universidad de Huelva, 2004, p.116; G. LongO, Riflessioni critiche in tema di matrimonio, in Sodalitas - Scritti in onore di Antonio Guarino, vol.5, Napoli, Jovene, 1984, pp.2364;2367; E. VOlterrA, La conception du Mariage d'après les juristes romains cit. (nota 30 supra), p.45.

Sobre a etimologia de coeundi, segundo A. ERNOUT - A. MEILlET, Dictionnaire Etymologique de la Langue Latine cit. (nota 4 supra), p.353, coire, de coeo, no caso entre os animais , "acasalar-se", com o significado de "unir-se carnalmente", que originou a palavra coitus.

${ }^{49}$ R. ORESTANO, Alcune considerazioni sui rapporti fra matrimonio cristiano e matrimonio romano nell'età postclassica, in Scritti di diritto romano in onore di Contardo Ferrini, Milano, Ulrico Hoepli, 1946, pp.357358; M. DURRY, Le mariage des filles impubères dans la Rome Antique, in RIDA 2 (1955), p.271; L.F. Raditsa, Augustus Legislation Concerning Marriage, Procreation, Love, Affairs and Adultery, in ANRW II.13 (1980), p.307; E. VOLTERRA, La conception du Mariage à Rome cit. (nota 30 supra), pp.350;352;356; Idem, La conception du Mariage d'après les juristes romains cit. (nota 30 supra), p.36; M. MARRONE, Istituzioni cit. (nota 48 supra), p.216; A. BURDESE, Manuale cit. (nota 47 supra), p.274; B. BIONDI, Istituzioni cit. (nota 22 supra), p.438.

Contra a tese do consentimento contínuo no matrimônio romano sustentada principalmente por VOLTERRA e Orestano, veja-se J.C. MoreIRA Alves, A natureza jurídica do casamento romano no Direito Clássico, in Estudos de Direito Romano, Brasil, Senado Federal, 2009, pp.229; 240-241. Segundo o autor, "o matrimônio no direito romano, foi sempre um ato jurídico, surgindo, assim, do consentimento inicial que gera um vinculum iuris, e prescindindo da vontade contínua que dá vida a um estado de fato". O casamento romano no Direito Clássico surgia de um ato jurídico independente de forma e exigia, para a sua dissolução, outro ato jurídico contrário a ele (divórcio também aformal). Segundo MoreIRA ALVES, inúmeros textos, literários e jurídicos demonstram, v.g., que o segundo casamento não dissolvia o primeiro, o que é incompatível com a tese do consentimento contínuo: Cic. De orat. 1,40,183 e 1,56,238; Gai. 1,63; Iul. 1 ad ed. D.3,2,1; Ulp. 6 ad ed. D.3,2,13,1-4; Paul 35 ad ed. D.24,2,1; Pap. l.s. de adult. D.48,5,11,12; Valer. et Gall. C. 5,3,5 (258) e Valer. et Gall. C.9,9,18pr. (258). Na verdade, encontramos nas fontes juridicas romanas dois tipos de matrimônio: o do direito clássico, mero fato na vida social romana que se constitui sem qualquer formalidade e o matrimônio cristão, introduzido gradualmente pelas constituições imperiais a partir dos séculos IV e V d.C. e que diferia profundamente do antigo matrimônio quanto à sua formação, concepção religiosa e configuração jurídica, pois dependia da vontade inicial dos cônjuges. Vejam-se neste sentido J. DAZA MARTÍNEZ, La influencia cristiana cit. (nota 48 supra), pp.109-110;120; D. DALlA - R. LAMBERTINI, Istituzioni di diritto romano cit. (nota 10 supra), p.104; E. VOLTERRA, La conception du Mariage à Rome cit. (nota 30 supra), pp.360; Idem, La conception du Mariage d'après les juristes romains cit. (nota 30 supra), p.20.

${ }^{50} \mathrm{Na}$ opinião de V.C. CORTES, Alcance del 'consensus' del 'paterfamilias' en el matrimonio de su filia in potestate, in El Derecho de Familia: De Roma al Derecho actual, Huelva, Universidad de Huelva, 2004, 
Segundo o jurisconsulto Paulo, não pode haver casamento sem o consentimento de todos, dos que se casam e dos que têm a 'potestas' sobre eles. ${ }^{51}$

Outra situação semelhante ocorria com as mulheres sui iuris, que precisavam do consentimento de seu pater ou, quando ela não tinha mais pater, de seu tutor. ${ }^{52}$

Todo este interesse da família e a intervenção do pater, ao permitir ou proibir um matrimônio, justificavam-se pela entrada de novos elementos no grupo: tanto a esposa que ingressava pela conventio in manum, quanto os filhos procriados nesta relação, ficavam

pp.95-97, o consentimento principal e anterior para a formação do matrimônio era aquele dos cônjuges, ou seja, neste caso, o consentimento do filius e da filia é anterior ao consentimento do pater. Portanto, a auctoritas era um consentimento complementar que o paterfamilias outorgava aos atos realizados pelas pessoas que estivessem sob a sua potestas, podendo até dissolver o matrimônio dos filiifamilias. Este poder sofreu restrições da jurisprudência e das constituições imperiais para impedir a intervenção injusta do pater no matrimônio da filha, principalmente no bene concordans matrimonium: Clem. 3 ad l. Iul. et Pap. D.23,2,21; Ulp. 33 ad Sab. D.24,1,32,19; Ulp. 71 ad ed. D.43,30,1,5; PS 5,6,15 e Diocl. et Max. C.5,17,5pr. (294). Veja-se Inst.1,10pr. que afirma que o consentimento dos pais deve preceder o casamento, segundo o direito natural.

51 Paul. 35 ad Sab. D.23,2,2: Nuptias consistere non possunt, nisi consentiant omnes, id est, vi coeunt, quorumque in potestate sunt. "As núpcias não podem subsistir se todos não consentissem, isto é, os que se unem e aqueles sob cuja potestas estão". O silêncio do pater ou daquele que estivesse sob a sua potestas, indicava tacimente o seu consentimento em relação ao matrimônio. Vejam-se Paul. 35 ad ed. D.23,1,7,1: In sponsalibus etiam consensus eorum exigendus est, quorum in nuptiis desideratur; intelligi tamen semper filiae patrem consentire, nisi evidenter dissentiat, Iulianus scribit: "Nos esponsais se exigirá também o consentimento daqueles dos quais se requer as núpcias; mas escreve Juliano, que se entende que o pai sempre dá o seu consentimento à filha, se não demonstrasse, evidentemente, seu dissenso"; Ulp. l. s. de spon. D.23,1,12pr.: Sed quae patris voluntati non repugnat, consentire intelligitur. "Porém, entende-se que consente aquela que não se opõe à vontade de seu pai”.

No trecho a seguir, Juliano apresenta alguns casos, de ausência ou de cativeiro do pater, nos quais se prescinde da auctoritas no consentimento inicial. Iul. 62 dig. D.23,2,11: Si filius eius, qui apud hostes est, vel absit, ante triennium captivitatis vel absentiae patris uxorem duxit, vel si filia nupserit, puto, recte matrimonium vel nuptias contrahi, dummodo eam filius ducat uxorem, vel filia tali nubat, cuius conditionem certum sit patrem non repudiaturum. "Se o filho daquele que está em poder dos inimigos, ou ausente, casou antes dos três anos do cativeiro ou da ausência do pai, ou se a filha deste se casar, opino que se contrai o matrimônio legitimamente ou as núpcias, contanto que o filho se case, ou a filha se case com tal [indivíduo], cuja condição seja certo que o pater não está para o repudiar". Vejam-se, F. SCHULZ, Classical Roman Law, Oxford, 1951, trad. esp. de José Santa Cruz Teigeiro, Derecho Romano Clásico, Barcelona, Bosch, 1960, p.128; J. GAUDEMET, Justum matrimonium, in Études de droit romain - III. Vie familiale et vie sociale, Napoli, Jovene, 1979, p.115; J. IGLESIAS, Derecho Romano, 13ªed., Madrid, Ariel, 2001, p.341; M.B. Fumagalli, Sponsali (Diritto romano), in ED 43 (1990), p.505; O. RoBledA, Il divorzio in Roma prima di Costantino, in ANRW II.14 (1981), pp.369-370, notas 114 e 117; A. BURDESE, Manuale cit. (nota 47 supra), pp.265;270;275;; L.F. RADITSA, Augustus Legislation cit. (nota 49 supra), p.308; A. LÓPEZ PEDREIRA, Limitaciones a la 'libertas nuptialis' cit. (nota 40 supra), p.395, nota 19; V.C. CORTES, Alcance del 'consensus' del 'paterfamilias' cit. (nota 50 supra), p.95; B. BIONDI, Istituzioni cit. (nota 22 supra), p.442; F. SCHUlZ, Classical Roman Law cit. (nota 28 supra), p.128.

${ }^{52} \mathrm{O}$ tutor, ao contrário do paterfamilias, não tinha a auctoritas para dissolver o matrimônio. Ele podia limitar a liberdade matrimonial das nubentes, assim como o paterfamilias, tanto diretamente, ao recusar o consentimento às núpcias, quanto indiretamente, ao não constituir o dote. Ulp. $36 a d$ Sab. D.23,1,6: $S i$ puellae tutores ad finienda sponsalia nuntium miserunt, non putarem suffecturum ad dissolvendam nuptiarum spem hunc nuntium, non magis, quam sponsalia posse eos solos constituere, nisi forte omnia ista ex voluntate puellae facta sint. "Se os tutores da moça enviaram um núncio para extinguir os esponsais, eu não acreditaria que bastaria este núncio para dissolver a esperança das núpcias, assim como estes, sozinhos, não podem constituir os esponsais, salvo se tudo isto tenha sido feito por vontade da moça". Vejam-se J. IGLESIAS, Derecho Romano cit. (nota 51 supra), p.342; V.C. CORTES, Alcance del 'consensus' del 'paterfamilias' cit. (nota 50 supra), pp.91 e 95; R. ASTOLFI, La Lex Iulia et Papia cit. (nota 15 supra), p.149. 
sob a patria potestas. ${ }^{53}$

As Leis Matrimoniais de Augusto enfraqueceram a patria potestas do paterfamilias em prol da promoção do matrimônio legítimo e do estímulo à procriação entre os cidadãos romanos, interesses defendidos pela res publica no início do Principado. ${ }^{54}$

A lex Iulia de maritandis ordinibus proibiu a oposição do pater no matrimônio de seus filhos sem uma causa justificada. Se o paterfamilias negasse o consentimento, seria possível recorrer ao pretor urbano, ao praefectus urbi ou aos governadores de província, para obrigá-lo a consentir as núpcias e a constituir o dote. ${ }^{55}$

Havia, nesta situação, uma restrição do "Estado" à intervenção do paterfamilias na formação do consentimento, para incentivar a procriação e atender a utilitas publica ${ }^{56} \mathrm{O}$

${ }^{53}$ V.C. CORTES, Alcance del 'consensus' del 'paterfamilias' cit. (nota 50 supra), p.92, conclui que para o matrimônio da filha, o consentimento tinha um papel inferior em relação ao matrimônio do filho, pois neste último caso, ingressavam na família a esposa e os filhos da relação, que se tornavam herdeiros do paterfamilias. Por isso, no trecho do Digesto Paul. 35 ad ed. D.23,2,16pr., verifica-se uma diferença quanto à expressão do consentimento. Informa-se que era exigido, no matrimônio do neto, não apenas o consentimento do paterfamilias, mas também o do filho, o pai do noivo: Nepote uxorem ducente et filius consentire debet, neptis vero si nubat, voluntas et auctoritas avi sufficiet. "Ao se casar o neto, deve consentir também o filho, porém se a neta se casasse, bastarão a vontade e a autoridade do avô". Vejam-se R. ASTOLFI, Il matrimonio nel diritto romano preclassico cit. (nota 1 supra), p.101; F. SERAFINI, Istituzioni di diritto romano comparato col diritto civile patrio, $10^{\mathrm{a}} \mathrm{ed}$., vol.1, Roma, Athenaeum, 1920, p.247; V. ARANGIO-RUIZ, Istituzioni di diritto romano, 14a ed., Napoli, Jovene, 2006, p.442. Na opinião de G. LONGO, Sullo scioglimento del matrimonio per volontà del 'paterfamilias', in BIDR 40 (1932), p.206, a impossibilidade de manter a convivência entre os cônjuges era a causa que gerava a dissolução do matrimônio, pois o pater não podia interromper a affectio maritalis: (...) la volontà paterna, per dispotica che sia, non può mettere termine al requisito subbiettivo che lo caratterizza: l'affectio maritalis. Questo perdura indipendentemente da ogni volere paterno; può, il 'pater', agire sull'altro elemento, sul sostrato di fatto su cui il matrimonio - con analogia caratteristica col possesso - si fonda: la convivenza.

${ }^{54}$ L.F. RADITSA, Augustus Legislation Concerning Marriage cit. (nota 49 supra), p.320; D. NöRR, The matrimonial Legislation of Augustus: An early instance of social engineering, in The Irish Jurist 16.1 (1981), p.355.

${ }^{55}$ A lex Iulia de maritandis ordinibus permitia a nomeação de um tutor ou curador dotis constituendae causa (Gai.1,178; Ter. Clem. 3 ad l. Iul. et Pap. D.23,3,61,1). Vejam-se R. Astolfi, La Lex Iulia et Papia cit. (nota 15 supra), p.149; Idem, Note per una valutazione storica della 'Lex Iulia et Papia' cit. (nota 36 supra), p.194; 226; G. CoRnIL, Droit Romain, Bruxelles, Medicale et Scientifique, 1921, pp.128-129. Na opinião de O. RoBleDA, Il divorzio in Roma prima di Costantino cit. (nota 51 supra), p.373, é provável que somente a partir do governo de Antonino Pio o paterfamilias não possa mais dissolver o matrimônio da filiafamilias. Veja-se PS 5,6,15: Bene concordans matrimonium separari a patre divus Pius prohibuit itemque a patrono libertum, a parentibus filium filiamque, nisi forte quaeratur, ubi utilius morari debeat. Na opinião de $\mathrm{F}$. ScHulz, Classical Roman Law cit. (nota 51 supra), p.128, apesar deste "princípio" patriarcal estar em conflito com a humanitas, os juristas clássicos sempre respeitaram o direito dos pais em dissolver o matrimônio dos filhos, inclusive o bene concordans matrimonium. Para E. CANTARELLA, Famiglia romana e demografia sociale - Spunti di riflessione critica e metodológica, in IURA 43 (1992), p.106, nota 26, ainda no século III d.C., era concedido ao pai utilizar o interdictum de liberis ducendis para interromper o matrimônio dos filhos, independentemente da vontade destes. R. ASTOLFI, Il matrimonio nel diritto romano classico cit. (nota 10 supra), pp.8;339-340, defende que a partir do século II d.C., os pais poderiam dissolver o matrimônio dos filhos apenas com o consentimento deles. É socialmente importante a manutenção do bene concordans matrimonium. Mas o autor não menciona qualquer alteração realizada pela Lex Iulia et Papia neste sentido.

56 Vejam-se B. BIONDI, La legislazione di Augusto. Leggi matrimoniali, in Scritti Giuridici II - Diritto romano, Milano, Giuffré, 1965, pp.132;133, nota 1; Idem, Istituzioni cit. (nota 22 supra), pp.452-453; R. Astolfi, La Lex Iulia et Papia cit. (nota 15 supra), pp.149-150, nota 1;326;363;364; D. NöRR, The 
capítulo 35 da lex Iulia de maritandis ordinibus dispôs sobre a concessão da auctoritas pelos patresfamilias quando o filho ou a filha estivessem submetidos à sua patria potestas. $^{57}$

Marcian. 16 inst. D.23,2,19: Capite trigesimoquinto legis Iuliae, qui liberos, quos habent in potestate, iniuria prohibuerint ducere uxores, vel nubere, vel qui dotem dare non volunt, ex Constitutione Divorum Severi et Antonini per Proconsules Praesidesque provinciarum coguntur in matrimonium collocare, et dotare; prohibere autem videtur, et qui conditionem non quaerit.

Matrimonial Legislation of Augustus cit. (nota 54 supra), p.355; F. SCHUlZ, Classical Roman Law cit. (nota 51 supra), p.117; J.M. OTHON SIDOU, Matrimonium I. cit. (nota 47 supra), pp.64 e 73; G. PACCHIONI, Corso di diritto romano cit. (nota 29 supra), p.323; A. LÓPEZ PEDREIRA, Limitaciones a la 'libertas nuptialis' cit. (nota 40 supra), p.404; V.C. CoRTES, Alcance del 'consensus' del 'paterfamilias' cit. (nota 50 supra), pp.91 e 97; J. ARIAS RAmos, Derecho Romano - Obligaciones (fuentes, garantia, cesion y extinción), Derecho de Familia, Derecho de Sucesiones, vol.2, 4ª ed., Madrid, Revista de Derecho Privado, 1940, p.214; V. ARANGIO-RUIZ, Istituzioni cit. (nota 53 supra), p.442; D. DALlA - R. LAMBERTINI, Istituzioni cit. (nota 10 supra), p.108; C. ACCARIAS, Précis de droit romain cit. (nota 9 supra), p.207; A.A. CASTRO CorrêA, $O$ Estoicismo no Direito Romano cit. (nota 33 supra), p.91; L.F. RADITSA, Augustus Legislation cit. (nota 49 supra), p.320.

${ }^{57} \mathrm{O}$ princípio disposto neste trecho é semelhante àquele do Código Civil Brasileiro, no art.1519, em relação à capacidade para o casamento e a denegação injustificada dos pais, tutores ou curadores quando o casamento exigir a autorização destes: “A denegação do consentimento, quando injusta, pode ser suprida pelo juiz”.

Na opinião de G. LONGO, Sullo scioglimento del matrimonio cit. (nota 53 supra), pp.208-210;214-217;219220, o trecho PS 2,19,2 não tem lógica alguma e não pode ser considerada fonte fidedigna. Não é possível afirmar que o matrimônio daqueles que estão submetidos à potestas do pater não se dissolve, apesar da falta do consentimento paterno quando foi contraído. Conclui o autor que, o consenso do pater é uma das condições essenciais para a existência do matrimônio romano. Quanto à validade, a interrupção do consentimento paterno não dissolve o matrimônio, não é requisito a vontade permanente do pater. Para o autor, o pretor concedia interditos e outros remédios processuais (exceptiones) contra o titular da potestas, com base na aequitas e com o escopo de proteger o bene concordans matrimonium. Complementa G. LONGO que, apesar desta intensa atividade administrativa do pretor, não foi extinto por completo o princípio que determinava que o paterfamilias poderia dissolver o matrimônio daqueles que estivessem submetidos ao seu pátrio poder. Vejam-se Ulp. 71 ad Ed. D.43,30,1,5; Diocl. et Max. C.5,17,5pr. (294-305).

Em razão desta publica nuptiarum utilitas promovida pela legislação matrimonial de Augusto, o filho do cativo de guerra, pode casar-se sem o consentimento paterno. Veja-se Tryph. 4 disp. D.49,15,12,3: Medio tempore filius, quem habuit in potestate captivus, uxorem ducere potest, quamvis consentire nuptiis pater eius non posset, nam utique nec dissentire; susceptus ergo nepos in reversi captivi potestate, ut redierit, erit, suusque heres in quodammodo invito, quam nuptiis non consenserit; non mirum, quia illius temporis conditio necessitasque faciebat, et publica nuptiarum utilitas exigebat. "O filho, que o cativo teve sob sua potestas, pode casar-se no intervalo de tempo [que o pai estivesse no cativeiro], ainda que seu pai não pudesse dar seu consentimento para as núpcias, porque certamente tampouco pode manifestar seu dissentimento; logo, o neto gerado estará sob a potestas do cativo que regressou, assim que tiver regressado e será heres suus [do cativo] de certa forma contra a sua vontade, não tendo prestado seu consentimento para as núpcias; e não é de se estranhar, porque o admitia a condição e a necessidade daquela época e o exigia a utilidade pública das núpcias". Outras fontes confirmam a possibilidade do casamento dos filhos do prisioneiro de guerra: Ulp. 26 ad Sab. D.23,2,9,1; Iul. 62 dig. D.23,2,11; Paul. ad Sab. D.23,4,8; Iul. 69 dig. D.49,15,23. Vejam-se U. RATTI, Studi sulla 'captivitas' e alcune repliche in tema di 'postliminio', Napoli, Jovene, 1980, pp.39-41; 59, nota 2;60-62; G. LONGO, Utilitas publica cit. (nota 44 supra), p.33. 
"Pelo capítulo trigésimo quinto da lex Iulia aqueles que contra o direito proibirem que os descendentes que têm em seu poder, levem uma mulher para casa ou se casem, ou aqueles que não querem dar-lhes dote, são obrigados, em virtude de Constituição dos Divinos Severo e Antonino, pelos Procônsules e os Presidentes das Províncias, a uni-los em matrimônio e a dotá-los; porém, considera-se que proíbe também aquele que não busca um acordo [de casamento]".

O verbo prohibere indica a proibição, ou seja, tanto um comportamento ativo (proibir as núpcias) quanto um comportamento passivo (não constituir o dote para a filha). ${ }^{58}$

O sogro poderia mover contra o genro um interdictum de liberis exhibendis et ducendis. O pretor poderia denegar o interdito do pater caso ele o considerasse iníquo e injusto. Neste caso, o pretor concedia ao marido um interdictum de uxore exhibenda vel ducenda contra o sogro que pretendesse desfazer o seu matrimônio, sem um motivo justificado. ${ }^{59}$

Nas Sentenças de Paulo, na interpretatio do fragmento 2,19,2, observa-se a supressão da auctoritas do paterfamilias e a dispensa do consentimento paterno. $\mathrm{O}$ matrimônio dos filhos não pode ser dissolvido em conformidade com a utilitas publica (interesse do "Estado e do Povo Romano") ${ }^{60}$, se o casamento foi realizado para procriar

\footnotetext{
${ }^{58}$ R. Astolfi, La Lex Iulia et Papia cit. (nota 15 supra), pp.150-153; Idem, Note per una valutazione storica della 'Lex Iulia et Papia' cit. (nota 36 supra), pp.188;226; G. CoRNIL, Droit Romain cit. (nota 55 supra), pp.128-129. Na opinião de B. BIONDI, Istituzioni cit. (nota 22 supra), pp.452, nota 68;453, com a Lex Iulia et Papia a constituição do dote, de mera obrigação moral, torna-se obrigação jurídica. Os imperadores Severo e Caracala seguiram, neste caso, a Legislação matrimonial de Augusto e obrigaram o paterfamilias a constituir um dote para a filha, caso contrário, considerava-se tacitamente uma oposição do pater ao matrimônio.

${ }^{59}$ Conforme J. GAUDEMET, L'Apport du Droit Romain, in Claude BonTEMS (org.), Mariage-Mariages, Paris, Presses Universitaires de France, 2001, p.35; Idem, Utilitas Publica cit. (nota 44 supra), pp.186-187; Idem, Justum matrimonium cit. (nota 51 supra), p.116; V. ARANGIO-RUIZ, Istituzioni cit. (nota 53 supra), p.438; B. BIONDI, Istituzioni di diritto romano cit. (nota 22 supra), pp.442, nota 17;447;452-453; G. CoRNIL, Droit Romain cit. (nota 55 supra), pp.128-129; A. BOUCHÉ-LECLERCQ, Les lois démographiques d'Auguste cit. (nota 36 supra), p.261; R. Astolfi, Note per una valutazione storica della 'Lex Iulia et Papia' cit. (nota 36 supra), p.188. Neste sentido, veja-se também Vat. Frag. 116.

${ }^{60}$ De acordo com G. LoNGO, Utilitas publica cit. (nota 44 supra), pp.8-10;12-13;17;34-36;63;71, no principado de Augusto, a utilitas publica não é um poder exclusivo e autoritário do "Estado Romano" ou do imperador, mas identifica-se com a utilitas omnium civium, ou seja, é a vontade de todo o Povo Romano. A utilitas publica dependia da utilitas omnium. Nas palavras de LONGO, l'utilitas publica è coincidente con l'utilitas omnium. E na p.71, conclui que 'Publica utilitas' è nozione che si collega, indissolubilmente, in ciascuna epoca storica, con la nozione di 'res publica', di atteggiamenti del potere statale di fronte ai 'cives', di nozione dei poteri di questi ultimi, in sé e per sé considerati di fronte allo Stato. De acordo com Cícero, a utilitas coletiva não pode ser contrária à utilitas do particular.Veja-se Cic. de off. 1,7,22;3,11-12;2021;27. A utilitas publica é o escopo de todos os atos legítimos da res publica e o interesse público é fundamento de justiça (de off. 1,10). Para Cícero, não há contraposição entre os termos publicus e communis. Utilitas publica e res publica derivam de uma Lex naturae, ou seja, o fundamento da organização "estatal" e a convivência social são provenientes do ius naturale. Augusto adota em sua política legislativa este conceito
} 
filhos (favor matrimonii).

PS 2,19,2: Eorum qui in potestate patris sunt sine voluntate eius matrimonia iure non contrahuntur, sed contracta non solvuntur: contemplatio enim publicae utilitatis privatorum commodis praefertur. IP: Viventibus patribus inter filiosfamilias sine voluntate patrum matrimonia non legitime copulantur; sed si coniuncta fuerint, non solvuntur, quia ad publicam utilitatem antiquitas pertinere decrevit, ut procreandorum liberorum causa coniunctio facta non debeat separari.

“Os matrimônios daqueles que estão sob o poder do pai não se contraem legitimamente sem a vontade dele, porém uma vez contraídos não se dissolvem, pois se prefere a consideração da utilidade pública aos interesses dos particulares". IP: "Estando vivos os pais, os matrimônios entre filiosfamilias não se realizam legitimamente sem a vontade daqueles. Porém se tiverem se unido, não se dissolvem, porque a antiguidade decretou que corresponde à utilidade pública que uma união realizada para procriar filhos não se deva separar".

Neste ponto da pesquisa, salienta-se um outro aspecto importante: a procriação de filhos legítimos como um dos elementos ético-sociais que contribuía para que uma relação fosse considerada um matrimônio liberorum procreandorum causa. Ou seja, a procriação como um dos vários elementos caracterizadores do honor matrimonii.

A procriação salienta o importante papel social da mulher romana na geração de muitos filhos e pode ser adotada pelo Direito, em algumas situações, para indicar a natureza jurídica de uma determinada relação, se é realmente um matrimônio.

O matrimônio romano apresentava dois elementos constitutivos essenciais: a affectio maritalis ${ }^{61}$ (elemento subjetivo) e o honor matrimonii (elemento objetivo).

ciceroniano de utilitas publica. Sintetiza G. LONGO, op.cit., pp.14-15, 'Respublica' è un'associazione basata sull'ordine giuridico e per l'utilità comune. (...) Conclui-se, portanto, que não existia contradição entre as liberdades individuais dos cidadãos e o bem comum da res publica. Veja-se também, M. HUMBERT, L'individu, l'État: quelle stratégie pour le mariage classique?, in Parenté et stratégies familiales dans l'Antiquité romaine. Actes de la table ronde (Paris, 2-4 octobre 1986), Rome, École Française de Rome, 1990, pp.178;197.

${ }^{61}$ De acordo com R. Astolfi, Il matrimonio nel diritto romano classico cit. (nota 10 supra), p.10, l'affectio maritalis e la procreazione qualificano come matrimonio il rapporto fra un uomo e una donna. A affectio maritalis era a intenção de ser marido e mulher, a repetição da vontade manifestada pessoalmente por ambos os cônjuges, se fossem sui iuris. A simples interrupção da intenção (affectio maritalis), deste consenso de estar casado, dissolvia o vínculo conjugal. Affectio não significa apenas "afeto", mas uma "vontade duradoura, contínua", "um estado volitivo permanente", com a intenção de estabelecer relações morais e 
Devido a esses elementos ${ }^{62}$ constitutivos, o matrimônio era análogo à posse, esta última iniciada pela apreensão (corpus - elemento objetivo) e que gera uma situação de fato que perdura enquanto uma vontade (animus - elemento subjetivo) não o faça cessar. ${ }^{63}$

sociais (manifestadas pelo termo Honor matrimonii), de procriar e educar os filhos. Portanto, o animus difere da voluntas que é uma manifestação de vontade instantânea. Conforme E.C.S. MARCHI, Matrimônio moderno e matrimônio clássico - divórcio e "Soneto de Fidelidade", in Direito de Família no Novo Milênio, Estudos em homenagem ao Professor Álvaro Villaça Azevedo, São Paulo, Atlas, 2010, pp.58-59: “(...) a palavra affectio, ao invés de significar 'afeição', corresponderia mais propriamente, em comparação com as atuais línguas neolatinas, como o português, a 'afecção', vocábulo hoje a indicar 'estado de enfermidade' ou 'processo constante de uma doença', vale dizer, uma situação que perdura”. Vejam-se A. VILLAÇA AZEVEDO, Dever de Coabitação - Inadimplemento, São Paulo, José Bushatsky, 1976, p.49; O. RoBLEDA, Intorno alla nozione di matrimonio cit. (nota 17 supra), p.177; E. VOLTERRA, Matrimonio (diritto romano), in ED 25 (1975), pp.738;744-745;785-786; Idem, Les formes du Mariage chez les Romains cit. (nota 30 supra), pp.278-282; Idem, La conception du Mariage d'après les juristes romains cit. (nota 30 supra), pp.40;60-63; E. Albertario, Honor matrimonii e affectio maritalis, in Studi di diritto romano, vol.1, Milano, Giuffrè, 1933, pp.197-210; Idem, Matrimonio (Roma), in Enciclopedia Italiana 12 (1934), p.581; J.C. MorEIRA Alves, J.E. Labbé cit. (nota 48 supra), pp.109-110; P. LAMBRINI, L'elemento soggetivo nelle situazioni possessorie nel diritto romano classico, Padova, CEDAM, 1998, pp.28-29; C. PUJAL, La concepción jurídica cit. (nota 47 supra), pp.606;615; V.C.CORTES, Alcance del 'consensus' del 'paterfamilias' cit. (nota 50 supra), p.90; M.J. GARCIA GARRIDO, Minor annis XII nupta cit. (nota 47 supra), p.87; G. LONGO, Riflessioni critiche cit. (nota 48 supra), pp.2364;2368; Idem, Affectio maritalis, in BIDR 46 (1939), pp.119-141; V. ARANGIO-RUIZ, Istituzioni cit. (nota 53 supra), p.450; A. BURDESE, Manuale cit. (nota 47 supra), pp.274;280; B. BIONDI, Istituzioni cit. (nota 22 supra), p.438; G. D'ERCOLE, Il consenso degli sposi e la perpetuità del matrimonio nel diritto romano e nei padri della Chiesa, Roma, Appollinaris, 1939, pp.6-7.

Para C. PUJAL, La concepción jurídica cit. (nota 47 supra), p.615; J. DAZA MARTÍNEZ, La influencia cristiana cit. (nota 48 supra), pp.118-119;123; J.C. MoREIRA ALVES, A natureza jurídica cit. (nota 49 supra), pp.229, a partir de Constantino, o casamento era um vinculum contratual decorrente do consentimento inicial dos nubentes e não mais uma relação de fato que se mantinha enquanto persistisse a affectio maritalis. Veja-se Theod. C.5,17,8 (449).

${ }^{62}$ É importante ressaltar que a distinção entre elemento subjetivo e elemento objetivo, não é romana. $\mathrm{O}$ elemento subjetivo deveria manifestar-se por qualquer ato exterior. Veja-se E. VOLTERRA, La conception du Mariage d'après les juristes romains cit. (nota 30 supra), p.52.

${ }^{63}$ Consideram análogos a posse e o matrimônio, J. ARIAS RAMOs, Derecho Romano cit. (nota 56 supra), pp.212-213; J.C. MAtos PeiXoto, Convivência no matrimônio romano cit. (nota 47 supra), p.19; E. Albertario, Matrimonio (Roma) cit. (nota 61 supra), p.581; J.C. MoreIRA AlveS, J.E. Labbé cit. (nota 48 supra), pp.109-110; J. GAUdemet, L'Apport du Droit Romain cit. (nota 59 supra), p.31; R. Astolfi, Il matrimonio nel diritto romano classico cit. (nota 10 supra), pp.7-8; V. ARANGIO-RUIZ, Istituzioni cit. (nota 53 supra), pp.436-437; M. MARrone, Istituzioni cit. (nota 48 supra), p.220; A. LÓPEZ PEDREIRA, Limitaciones a la 'libertas nuptialis' cit. (nota 40 supra), pp.391-392; P. BONFANTE, Corso di diritto romano - Diritto di Famiglia cit. (nota 23 supra), p. 256; M.J. GARCIA GARRIDO, Minor annis XII nupta cit. (nota 47 supra), p.86, nota 23; G. LONGO, Sullo scioglimento del matrimonio cit. (nota 53 supra), p.206; B. BIONDI, Istituzioni cit. (nota 22 supra), p.438; A. RoMANO, Matrimonium iustum cit. (nota 26 supra), pp.14-16. Contrários à opinião sobre uma possível analogia entre os institutos da posse e do matrimônio, O. ROBLEDA, Il divorzio in Roma cit. (nota 51 supra), pp.387-388; E. VOLTERRA, La conception du Mariage d'après les juristes romains cit. (nota 30 supra), p.41; P. VOCI, Istituzioni cit. (nota 12 supra), p.526; G. FRANCIOSI, Famiglia e persone in Roma antica cit. (nota 26 supra), p.133.

O ius postliminium (literalmente "direito depois dos limites") prova que tanto a posse quanto o matrimônio eram situções de fato em Roma. O Postliminium era uma ficção jurídica criada pelos jurisconsultos determinando que o cativo cidadão romano permanecera sempre em território romano, e, ao retornar à Roma de modo definitivo, ele recuperava retroativamente todos os direitos que tinha antes do momento de sua captura pelo inimigo. A captura na guerra dissolvia o matrimônio, pois o captivus sofria uma capitis deminutio maxima (tornando-se escravo do inimigo, servus hostium), situação que tornava sua vontade juridicamente irrelevante. O postliminium não renovava o matrimônio, não operava a reaquisição do estado matrimonial quando o cativo retornava à Roma, visto que, em decorrência da natureza jurídica do matrimônio romano, fundamentado no consentimento contínuo entre os cônjuges, não poderia entrar numa 


\section{A manifestação social da convivência conjugal e da affectio maritalis prova-se} mediante a sua manifestação exterior, o honor matrimonii ${ }^{64}$, a efetiva subsistência das

situação de pendência (Gai. 1,129). O cativeiro de um dos cônjuges dissolvia o matrimônio ipso iure. Mesmo se os dois cônjuges estivessem juntos no cativeiro, o casamento não poderia manter-se e os filhos nascidos desta relação eram considerados espúrios. Seria necessário que o casal contraísse um novo matrimônio ao retornar para o território romano (consensus redintegratur matrimonio): Pomp. 3 ad Sab. D.49,15,14,1: Non ut pater filium, ita uxorem maritus iure postliminii recipit, sed consensu redintegratur matrimonium. "O marido não recupera iure postliminii à esposa, como o pai ao seu filho, porém o matrimônio é restabelecido pelo consentimento"; Tryph. 4 disp. D.49,15,12,4: Sed captivi uxor, tametsi maxime velit, et in domo eius sit, non tamen in matrimonio est. "Porém a mulher do cativo, ainda que o desejasse muito, e estivesse na casa dele, não está, contudo, em matrimônio". Vejam-se M.C. GIORDANI, O Novo Código Civil à luz do Direito Romano - Parte Geral, Rio de Janeiro, Lumen Juris, 2005, pp.25,43-44; Idem, O Código Civil à luz do Direito Romano. Parte Especial. Livro I. Do Direito de Família cit. (nota 23 supra), p. 185; R. VILLERS, Le mariage envisagé comme institution d'État dans le droit classique de Rome, in ANRW II.14 (1981), p.290; C. PUJAL, La concepción jurídica cit. (nota 47 supra), pp.619-620; J. DAZA MARTÍNEZ, La influencia cristiana cit. (nota 48 supra), pp.114-115;127-128, nota73; D. DALLA - R. LAMBERTINI, Istituzioni di diritto romano cit. (nota 10 supra), p.110; H. ANKUM, La 'captiva adultera'. Problèmes concernant l'accusatio adulterii en droit romain classique, in RIDA 32 (1985), pp.191-193;199; U. RATTI, Studi sulla 'captivitas' cit. (nota 57 supra), pp.84; 85, nota 1;86;216-217; L. D'AMATI, Matrimonium e Postliminium: brevi considerazioni, in Revista da Faculdade de Direito da USP 98 (2003), p.44, nota 6; G. LONGO, Riflessioni critiche cit. (nota 48 supra), p.2370; E. VOLTERRA, La conception du Mariage d'après les juristes romains cit. (nota 30 supra), pp.46;66; V. ARANGIO-RUIZ, op.cit., p.438; A. BuRDESE, Manuale cit. (nota 47 supra), pp.270, nota 11;279; B. BIONDI, Istituzioni cit. (nota 22 supra), p.446.

Para G. Pugliese - F. Sitzia - L. VACCA Istituzioni di Diritto Romano, $2^{\mathrm{a} e d ., ~ T o r i n o, ~ G . G i a p p i c h e l l i, ~}$ 1990, pp.392-393, não era a falta de convivência que dissolvia o matrimônio dos captivi, mas a falta do elemento subjetivo, da affectio maritalis. Contra esta opinião de PUGLIESE, A. VILlAÇA AZEVEDO, Dever de Coabitação cit. (nota 61 supra), pp.63-64, sustenta que a falta de convivência era um dos motivos da dissolução do matrimônio dos captivi: “(...) vemos que o inadimplemento do dever de coabitação é causa do rompimento do vínculo conjugal, sem que exista culpa por parte do inadimplente, cativo". Sustenta L. D'AMATI, op.cit., pp.45;52-55, ao analisar Iul. 62 dig. D.24,2,6, que a mulher mantém a condição de uxor, apesar da dissolução do matrimônio em função do cativeiro do marido. Ao analisarem o mesmo texto, J. DAZA MARTíneZ, La influencia cristiana cit. (nota 48 supra), p.128, nota 74 e J. GAUDEMET, Justum matrimonium cit. (nota 51 supra), p.161, afirmam que apenas no direito justinianeu é possível admitir que a captivitas não dissolva ipso iure o matrimônio e consideram essa passagem uma interpolação. Na opinião de U. RATTI, Studi sulla 'captivitas' cit. (nota 57 supra), p.88, há interpolação em Ulp. 2 de adult. D.48,5,13,7, pois considera como adúltera a uxor que fosse infiel durante o cativeiro do marido. Para G. RIzZELLI, Alcuni aspetti dell'accusa privilegiata in materia di adulterio, in BIDR 89 (1986), pp.438-439, não há possibilidade de configurar neste caso nem adultério nem stuprum, porque a mulher sofre a capitis deminutio maxima e torna-se escrava.Vejam-se Paul. 3 ad l. Iul. et Pap. D.49,15,8; Paul. 16 ad Sab. D.49,15,19; Iul. 62 dig. D.49,15,22,1; Tryph. 4 disp. D.49,15,12,4. Sobre a relação entre postliminium e posse, vejam-se Pap. 3 quaest. D.4,6,19 e Iav. 1 epist. D.41,2,23,1.

${ }^{64}$ Nas opiniões de E. VOLTERRA, Istituzioni cit. (nota 12 supra), p.649; Idem, La conception du Mariage d'après les juristes romains cit. (nota 30 supra), pp.41;52; Idem, La conception du Mariage à Rome cit. (nota 30 supra), p.357; Idem, Les formes du Mariage chez les Romains cit. (nota 30 supra), p.281 e A. BURDESE, Manuale cit. (nota 47 supra), p.274, a convivência liberorum quaerendorum causa, o honor matrimonii e a cerimônia da deductio in domum mariti não constituem elementos essenciais para a existência do matrimônio em Roma, mas são meros fatos que servem para demonstrar a existência da vontade recíproca dos cônjuges em manter o matrimônio (affectio maritalis). Neste sentido C. PUJAL, La concepción jurídica cit. (nota 47 supra), pp.606;613; J. DAZA MARTíNEZ, La influencia cristiana cit. (nota 48 supra), p.117. Também D. DALla - R. LAMBertini, Istituzioni di diritto romano cit. (nota 10 supra), p.104, neste caso, parecem estabelecer uma divisão entre costumes e direito. Os ritos, cerimônias e a deductio in domum mariti seriam costumes, porém excluídos dos demais elementos essenciais da constituição do matrimônio, considerando apenas que eles serviam para tornar pública a convivência e identificar o momento inicial das núpcias. Porém, se são costumes, não podem ser tratados como meros "fatos jurídicos", pois os costumes são fontes do Direito em Roma. Para A. VIllaça AZEVEDo, Dever de Coabitação cit. (nota 61 supra), p.61, "A vida em comum, a habitação sob o mesmo teto, a guarda da fidelidade conjugal, dentre outras situações, são traços que demonstram a existência entre os romanos do dever de coabitação representado pelo elemento objetivo 
relações recíprocas e morais, que se concretizava em uma série de fatos inequívocos que serviam como meios de prova da existência do matrimônio: os testemunhos de afeição, as cerimônias e os cultos religiosos comuns aos cônjuges (nos quais eles pediam a proteção, a felicidade e a fecundidade para o novo lar à deusa Juno pro-nuba), a preexistência de esponsais entre os cônjuges, a coabitação para ter filhos (liberorum quaerundorum causa), a constituição de dote, os juramentos, a dextratum iunctio, ${ }^{65}$ a deductio mulieris in domum

(...)". Neste sentido, M. MARRONE, Istituzioni cit. (nota 48 supra), p.220: Quanto alla convivenza quale requisito per l'esistenza del matrimonio giova puntualizzare che il suo inizio, quando era accompagnato da 'affectio maritalis', segnava il momento a partire dal quale il matrimonio si costituiva. Per il mantenimento, la convivenza doveva perdurare, e non essere interrotta. Vejam-se também, G. LONGO, Sullo scioglimento del matrimonio cit. (nota 53 supra), p.206; Idem, Riflessioni critiche in tema di matrimonio cit. (nota 48 supra), pp.2367;2370-2371.

Concluem J. Gaudemet, L'Apport du Droit Romain cit. (nota 59 supra), pp.35;37; C. ACCARIAS, Précis de droit romain cit. (nota 9 supra), p.194; G. PACCHIONI, Corso di diritto romano cit. (nota 29 supra), p.323; O. RoBleda, Il divorzio in Roma cit. (nota 51 supra), p.371; A. CALDERINI, Antichità private cit. (nota 19 supra), pp.25-26; L. D’AMATI, Matrimonium e Postliminium cit. (nota 63 supra), p.52, que desde o período clássico, a coabitação não era um elemento essencial para a existência do matrimônio romano. Apesar da impossibilidade de alguns casais co-habitarem, seus matrimônios não sofriam qualquer alteração. Vejam-se Ulp.33 ad Sab. D.24,1,32,13;Ulp. 34 ad ed D.25,2,15pr.; Vat. Frag. 104.

O honor matrimonii é a expressão do consortium omnis vitae e poderia verificar-se inter absentes, na ausência do homem. Se a mulher se ausenta, não se realiza o matrimônio, pois ela deve ser conduzida ao domicílio do marido, conforme verificamos nestes dois fragmentos: Pomp. 4 ad Sab. D.23,2,5: Mulierem absenti per literas eius, vel per nuntium posse nubere placet, si in domum eius deduceretur; eam vero, quae abesset, ex literis vel nuntio suo duci a marito non posse, deductione enim opus esse in mariti, non in uxoris domum, quase in domicilium matrimonii. "É permitido que uma mulher possa casar-se com um ausente por carta deste, ou por núncio, se fosse conduzida à casa do mesmo; porém, aquela que estivesse ausente não pode ser tomada como esposa pelo marido por carta, ou pelo seu núncio, porque é necessário que a condução seja à casa do marido, não à casa da esposa, como no domicílio do matrimônio"; PS 2,19,8: Vir absens uxorem ducere potest: femina absens nubere non posse. "O homem ausente pode casar-se com uma mulher: a mulher ausente não pode casar-se". Vejam-se O. ROBLEDA, Intorno alla nozione di matrimonio cit. (nota 17 supra), p.180; E. VOLTERRA, Matrimonio cit. (nota 61 supra), pp.741-742; Idem, La conception du Mariage d'après les juristes romains cit. (nota 30 supra), pp.48-49;51; A. BURDESE, op.cit., p.274; E. AlBERTARIO, Honor matrimonii cit. (nota 61 supra), pp.197-198; Idem, Matrimonio (Roma) cit. (nota 61 supra), p.580; P. GIUNTI, Consors vitae cit. (nota 26 supra), p.299; A. LÓPEZ PEDREIRA, Limitaciones a la 'libertas nuptialis' cit. (nota 40 supra), p.395; A. VILlaÇA AZEVEDo, Deductio mulieris in domum mariti (Direito Romano), in Enciclipédia Saraiva do Direito 23 (1977), pp.15-17; E.C.S. MARCHI, Matrimônio moderno cit. (nota 61 supra), p.60; A.A. CASTRo CorrêA, O Estoicismo no Direito Romano cit. (nota 33 supra), p.91. Nesta situação do casamento inter absentes, a deductio in domum era a única prova que demonstrava socialmente a persistência da affectio maritalis.

Para R. ORESTANO, La struttura giuridica del matrimonio romano cit. (nota 1 supra), pp.206-208, a convivência era um dos escopos matrimoniais, porém, se ela fosse considerada isoladamente, não era suficiente para demonstrar que uma relação fosse um matrimônio ou não. Na conclusão de M.J. GARCIA GARRIDO, Minor annis XII nupta cit. (nota 47 supra), p.86, a convivência tem um duplo sentido: o ínicio da relação matrimonial, com a deductio in domo mariti e uma das diversas situações que exteriorizam a affectio maritalis, ou seja, o honor matrimonii.

${ }^{65}$ J. GAUDEMET, Droit privé romain, $2^{\mathrm{a}} \mathrm{ed}$., Paris, Montchrestien, 2000, p.8, explica que a dextratum iunctio era a união da mão direita dos cônjuges, realizada por uma matrona univira, denominada pronuba, seguida pelo sacrifício de um animal. Esta formalidade exteriorizava o consenso e vontade de viver em comum. Vejam-se O.M. PÉTER, Liberorum quaerendorum causa cit. (nota 21 supra), p.313; U.E. PAOLI, Matrimonio (Roma), in Enciclopedia Italiana 12 (1934), p.581; A. RoMANO, Matrimonium iustum cit. (nota 26 supra), p.10. Neste sentido, Fest. s.v. pronubae 282. 
mariti. $^{66}$

É importante diferenciar, quanto aos escopos e a natureza jurídica, o matrimônio da conventio in manum.

A conventio in manum era o "ato jurídico" cuja função era subordinar a mulher ao poder (manus) do marido.

E. VOlterra, ${ }^{67}$ defende que o exame direto das fontes permite constatar que os juristas romanos nunca conheceram dois tipos de matrimônio, cum manu e sine manu,

${ }^{66}$ A deductio in domum mariti (condução da mulher recém-casada à casa do marido), era um "rito de passagem" que marcava o início da vida em comum dos cônjuges com a entrada da mulher na casa do marido e sua associação ao culto das divindades de sua nova família. Caracteriza-se por uma série de ritos tradicionais, com o objetivo de ser a mulher conduzida à casa do marido por uma comitiva de amigos. Feitos os auspícios e servido um banquete (cena nuptialis) na casa da noiva, realizava-se uma procissão à noite, à luz de tochas (acesas no fogo da casa da esposa), entoando-se em coro cantos fesceninos, de conteúdo erótico (canções que exaltavam a virilidade do marido) e os amigos lançavam nozes sobre os nubentes, como expressão do desejo de fecundidade (sem dúvida este simbolismo reforça a importância da procriação como principal finalidade no matrimônio romano). Na entrada da casa do marido, simulava-se um rapto, no qual se pode verificar um resquício remoto da lenda do "Rapto das Sabinas". O esposo recebe-a, oferece-lhe água e fogo, para significar que a admite na comunidade dos seus deuses domésticos (lares). A esposa ornava a soleira da porta com faixas de lã e a ungia com gordura de porco. Antes de entrar, o marido perguntava-lhe o nome e a esposa pronunciava a fórmula: Ubi tu Gaius ego Gaia "Onde quer que tu sejas Gaio, eu serei Gaia". Então, em seguida, ela era erguida pelo marido e eles atravessavam o limen, evidentemente pela superstição de que um tropeço da esposa, logo na entrada da casa, seria um péssimo augúrio. O marido realizava o accipere aqua et igni. Realizada a deductio in domum, a habitação comum entre os cônjuges naquele momento, a mulher inicia a participação na vida comum (convivência) e na condição social do marido. No dia seguinte às núpcias, os cônjuges recebiam os parentes para um banquete (repotia), no qual a esposa fazia suas primeiras ofertas aos deuses da sua nova família (Lares e Penates). Sobre o momento da realização da deductio, veja-se Scaev. 9 dig. D.24,1,66pr; -1. Vejam-se A. SURGIK, Deductio mulieris in Enciclopédia Saraiva do Direito 23 (1977), pp.14-15; Idem, A 'Manus' e o 'Consensus' no Casamento Romano, in El Derecho de Familia: De Roma al Derecho Actual, Huelva, Universidad de Huelva, 2004, p.733; J.C. MATOS PeIXoto, Convivência no matrimônio romano cit. (nota 47 supra), p.23; P. Bonfante, Istituzioni cit. (nota 12 supra), pp.139-140; E. VOLTERRA, Matrimonio cit. (nota 61 supra), pp.741-742; 743, nota 34; Idem, La conception du Mariage d'après les juristes romains cit. (nota 30 supra), pp.46;58; B. BIONDI, Istituzioni cit. (nota 22 supra), p.438; G. CoRnIL, Droit Romain cit. (nota 55 supra), p.33; E. AlberTARIO, Matrimonio (Roma) cit. (nota 61 supra), p.580; U.E. PAOLI, Matrimonio (Roma) cit. (nota 65 supra), pp.581-582; A. VillaÇa AZevedo, Dever de Coabitação cit. (nota 61 supra), p.52; J. Gaudemet, L'Apport du Droit Romain cit. (nota 59 supra), pp.36-37 e 39; A. CALDERINI, Antichità private cit. (nota 19 supra), p.26; M.J. GARCIA GARRIDO, Minor annis XII nupta cit. (nota 43 supra), p.79; C. ACCARIAS, Précis de droit romain cit. (nota 9 supra), p.193, nota 1; M. MARRONE, Istituzioni cit. (nota 48 supra), p.221; G. LONGO, Riflessioni critiche cit. (nota 48 supra), pp.2364-2366; E.C.S. MARCHI, Matrimônio moderno cit. (nota 61 supra), p.60.

${ }^{67}$ Istituzioni di diritto privato romano cit. (nota 12 supra), p.646; Idem, Matrimonio cit. (nota 61 supra), pp.760-761. Com o mesmo entendimento de Volterra, F. Schulz, Classical Roman Law cit. (nota 51 supra), p.111; D.R.M. RoDRIGUES, Aspectos de interesse atual do matrimônio romano, in Revista da Faculdade de Direito da USP 93 (1998), pp.89-90; B. BIONDI, Istituzioni di diritto romano cit. (nota 22 supra), p.437; E. Albertario, Matrimonio (Roma) cit. (nota 61 supra), p.580; A. Romano, Matrimonium iustum cit. (nota 26 supra), p.18.

E. CANTARELla, Sui rapporti fra matrimonio e 'conventio in manum', in RISG 93 (1963), pp.181-228; A. BURDESE, Manuale cit. (nota 47 supra), p.262 e R. ASTOLFI, Il matrimonio nel diritto romano preclassico cit. (nota 1 supra), p.98, declaram-se favoráveis à tese de VOLTERRA sobre a distinção dos dois institutos, matrimônio e conventio in manum, apenas em relação à coemptio e ao usus. Para estes autores, a confarreatio identificava-se como matrimônio cum manu nos primórdios de Roma. Também R. VILLERS, Le mariage envisagé cit. (nota 63 supra), p.292, sustenta que a manus e o matrimônio eram indissolúveis antes das XII Tábuas. 
constituindo tal distinção fruto da romanística moderna.

\author{
Portanto, é imprópria a distinção entre casamento cum manu e sine manu, pois \\ "casamento" e "manus"
}

${ }^{68}$ Quando os cônjuges não realizassem a conventio in manum, a mulher continuava em sua família de origem. Três são os modos de constituição da conventio in manum: a confarreatio, a coemptio e o usus. Não são formas de matrimônio, pois não se extinguem pela simples vontade dos cônjuges, como o matrimônio, mas por atos formais destinados a extinguir a manus, como a diffarreatio e a remancipatio.

${ }^{69}$ Muitos autores adotaram, alguns até por questões didáticas, a distinção entre os dois tipos de matrimônio (cum manu e sine manu), fundamentados principalmente em um trecho de Quintiliano, Inst. Orat. 5,10,62: Cicero genus et speciem, quam eamdem formam vocat, a finitione diducit, et iis, quae ad aliquid sunt, subiicit; ut, si is, cui argentum omne legatum est, petat signatum quoque, utatur genere: at, si quis, cum legatum sit ei, quae viro materfamilias esset, neget deberi ei, quae in manum non convenerit, specie quoniam duae formae sint matrimoniorum. Vejam-se E. CUQ, Les Institutions juridiques des romans, 2ªed., t.1, Paris, Plon-Nourrit,1904, pp.61-63; G. BRINI, Matrimonio e divorzio nel diritto romano, vol.1, Bologna. Nicola Zanichelli, 1887, pp.35;37 e 58; A. SURGIK, A 'Manus' e o 'Consensus' cit. (nota 66 supra), p.729; O.M. PÉTER, Liberorum quaerendorum causa cit. (nota 21 supra), pp.285-331; F. Della CORTE, Le 'leges Iuliae' e l'elegia romana cit. (nota 47 supra), p.549; A. VILLAÇA AZEVEDO, Dever de Coabitação cit. (nota 61 supra), p.54; G. PUGLIESE - F. SITZIA - L. VACCA, Istituzioni cit. (nota 63 supra), p.391; P. VocI, Istituzioni cit. (nota 12 supra), p.515; V. ARANGIO-RUIZ, Istituzioni cit. (nota 53 supra), p.436;449; G. CoRNIL, Droit Romain cit. (nota 55 supra), p.32; J. IGLESIAS, Derecho Romano cit. (nota 51 supra), p.340; B. BIONDI, Istituzioni cit. (nota 22 supra), p.426; P. BONFANTE, Istituzioni cit. (nota 12 supra), p.138; F. SERAFINI, Istituzioni cit. (nota 53 supra), pp.200-201; A.A. CASTRO CORRÊA, O Estoicismo no Direito Romano (nota 33 supra), pp.89-94.

${ }^{70}$ A confarreatio era um ritual religioso solene que recebia a sua denominação de um pão de cereais (espelta), chamado Panis farreus (libum farreum), que os nubentes repartiam como símbolo de sua vida em comum e ofereciam como sacrifício a Júpiter Fárreo. Este ato era realizado com os noivos sentados em cadeiras recobertas com a pele de um animal sacrificado para a cerimônia, na presença de 10 (dez) testemunhas e deveriam pronunciar palavras solenes diante do flamen dialis ou do próprio pontifex maximus, ambos sentados em duas cadeiras unidas pelo couro de um carneiro sacrificado. A esposa, a partir da realização deste ritual, submetia-se à manus do marido ou do paterfamilias deste e passava a cultuar, por meio dos sacra, os deuses familiares (manes) do marido. A confarreatio foi utilizada exclusivamente pelos patrícios. No Principado, por volta do século II d.C., a confarreatio caiu em desuso e era realizada apenas pelos flâmines de Júpiter como ato meramente simbólico. Os flâmines maiores (Dialis, Martiales e Quirinalis), os reges sacrorum e seus ancestrais deveriam realizar obrigatoriamente a confarreatio para ingressarem nas funções mais importantes da religião romana.Cf. Gai.1,112; 1,136; UE 9,1; Dio. Hal. 2,25,2; Plin. Nat. Hist. 8,48;74;194;18,3,10; Tac. Ann. 4,16,2-3; Plut. Romulus 22; Plut. Quaest. Rom. 30; Serv. Ad Aen. 4,29;4,103; 9,374; Serv. Ad Georg. 1,31; Macr. Sat. 1,15,19. Sobre a indissolubilidade do matrimônio do flamen dialis durante o seu officio, veja-se Gell. 10,15,22. Quando a flaminica ou a regina sacrorum morria, o flamen ou rex sacrorum perdia a sua dignidade, ou seja, eram destituídos do seu cargo pontifício. Portanto, deduz-se que o divórcio entre o flamen dialis e a flaminica era proibido. Neste caso, percebe-se a intenção da res publica em manter os matrimônios destas pessoas que ocupassem as posições mais importantes da religião romana. Segundo a narrativa em Macr. Sat. 1,16,30, a flaminica sacrificava um carneiro macho de nove em nove dias, nos nundinae, como oferenda em honra à fertilidade. Sobre a confarreatio, vejam-se E. VOLTERRA, Matrimonio cit. (nota 61 supra), pp.675-675, nota 83; 763-765; Idem, La conception du Mariage d'après les juristes romains cit. (nota 30 supra), pp.10-11;18-19;26-27; Idem, La conception du Mariage à Rome cit. (nota 30 supra), pp.351-353; Idem, Nuove osservazioni sulla 'conventio in manum', in Scritti Giuridici II, Napoli, Jovene, 1991, pp.199-200;215; Idem, Les formes du Mariage chez les Romains cit. (nota 30 supra), pp.278-279; Idem, Divorzio (Diritto romano), in NNDI 6 (1960), p.63; S.PEROZZI, Istituzioni cit. (nota 26 supra), pp.328-330; F. SCHULZ, Classical Roman Law cit. (nota 51 supra), p.111; A. Burdese, Manuale cit. (nota 47 supra), pp.262-263; G. Pugliese - F. SitziA - L. VACCA, Istituzioni cit. (nota 63 supra), p.388; B. BIONDI, Istituzioni cit. (nota 22 supra), p.426; G. PACCHIONI, Corso di diritto romano cit. (nota 29 supra), pp.328-329; F. SERAFINI, Istituzioni cit. (nota 53 supra), pp.200-201; L. PEPPE, Recenzione a Patrizia Giunti, 'Consors vitae' - Matrimonio e ripudio in Roma antica, in IURA 55 (2004-2005), pp.244-245, nota 20; O. RoBleDA, Il divorzio in Roma cit. (nota 51 supra), pp.360-362; A. BOUCHÉ-LECLERCQ, Les lois démographiques d'Auguste cit. (nota 36 supra), p.255; A. RomANO, Matrimonium iustum cit. (nota 26 supra), pp.74-76. 
coemptio $^{71}$ e o usus $^{72}$ são formas de conventio in manum.

\begin{abstract}
${ }^{71}$ A coemptio era realizada pela mancipatio, um negócio per aes et libram, com a pronúncia de fórmulas verbais essenciais para a realização e a validade do ato, diante de cinco testemunhas (homens, púberes e cidadãos romanos), de um libripens (porta balança que também servia de testemunha) e da mulher que seria submetida à manus. L. PePPE, Recenzione a Patrizia Giunti, 'Consors vitae'cit. (nota 70 supra), p.247, menciona em relação a coemptio, o denominado "rito dos três asses", pois a entrega de cada um deles tinha um significado: o primeiro, estabelecia a passagem da mulher para uma nova familia; o segundo, indicava a entrada na domus mariti; o terceiro, fazia referencia ao compitum vicinale, quando nasce o primeiro filho e a nupta torna-se mater. Esta forma de conventio in manum era utilizada pelos plebeus, pois a confarreatio eralhes proibida. Verifica-se nas Institutas de Gaio (Gai. 1,113-115-b;1,123;1,136; 1,137a;1,166a;1,195a) que a coemptio era realizada para diversas finalidades, v.g., fiduciae causa ou a tutelae evitandae causa. Estas fontes reforçam a tese de VOLTERRA, ou seja, que a coemptio, sendo uma forma de conventio in manum, não constituía o matrimônio, não tornava a mulher esposa do marido. Submetida à manus, ela passa a ter a condição jurídica de filha do próprio marido (loco filiae) e de irmã dos filhos. Portanto, a coemptio poderia ter uma funcionalidade de procriação ao gerar uma relação de filiação [fictícia] entre os cônjuges (Gai. 1,114; $1,118 ; 1,136)$. A partir do século II d.C., a conventio in manum é equiparada ao termo coemptio pela jurisprudência. Sobre a coemptio, vejam-se S.PerozzI, Istituzioni cit. (nota 26 supra), p.330; V. ARANGIORuIZ, Istituzioni cit. (nota 53 supra), p.436; E. VOLTERRA, Matrimonio cit. (nota 61 supra), p.766; Idem, La conception du Mariage d'après les juristes romains cit. (nota 30 supra), pp.23-27; Idem, La conception du Mariage à Rome cit. (nota 30 supra), p.350; Idem, Nuove osservazioni sulla 'conventio in manum' cit. (nota 70 supra), pp.32-33, nota 10; Idem, Les formes du Mariage chez les Romains cit. (nota 30 supra), pp.278279; F. SchUlZ, Classical Roman Law (nota 51 supra), p.111; A. BuRdeSE, Manuale cit. (nota 47 supra), p.263; B. BIONDI, Istituzioni cit. (nota 22 supra), p.426; G. PACCHIONI, Corso di diritto romano cit. (nota 29 supra), p.329; P. GiUnTI, 'Mores' e 'Interpretatio prudentium' cit. (nota 26 supra), pp.320-329; A. ROMANO, Matrimonium iustum cit. (nota 26 supra), pp.76-80.
\end{abstract}

Quanto às fórmulas verbais utilizadas na coemptio, segundo G. PUGLIESE - F. SITZIA - L. VACCA, Istituzioni cit. (nota 63 supra), pp.386-387, a mulher pronunciava a seguinte fórmula: an sibi mulier materfamilias esse vellet. O homem, por sua vez, an vir sibi paterfamilias esse vellet. Algumas contribuições importantes das fontes literárias sobre o assunto encontram-se nos seguintes trechos: Cic. Mur.12,27; Cic. Top. 3,14; Serv. Ad Aen. 2,476; 4,103;11,476; Serv. Ad Georg. 1,31; Boeth. Ad Cic. Top. 3,14.

${ }^{72} \mathrm{O}$ usus constituía a aplicação da posse prolongada para a aquisição da manus. Após um ano de convivência, sem a realização da confarreatio ou da coemptio, ou se houve algum vício de forma ou de fundo na realização destes atos, o marido ou o seu paterfamilias adquiria a manus sobre a mulher (Gai.1,111). Esta aquisição da manus por transcurso ininterrupto de tempo poderia ser evitado pela mulher por meio da trinoctium usurpatio, ou seja, ela se afastava da casa do marido durante três noites consecutivas. O usus foi abolido, provavelmente, na época da promulgação das Leis Matrimoniais de Augusto, não se sabe ao certo se pela própria legislação ou pelo desuso (desuetudine). Sobre o usus vejam-se J.C. MoREIRA AlveS, Direito Romano cit. (nota 9 supra), p.628; J. CARCOPINO, La vie quotidienne à Rome à l'apogée de l'Empire, 1937, trad. port. de António José Saraiva, A vida quotidiana em Roma no apogeu do Império, Lisboa, Livros do Brasil, s.d., p.106; F. SCHULZ, Classical Roman Law cit. (nota 51 supra), p.112; E. VOLTERRA, La conception du Mariage d'après les juristes romains cit. (nota 30 supra), pp.4-8; Idem, Nuove osservazioni sulla 'conventio in manum' cit. (nota 70 supra), pp.200-201; Idem, Les formes du Mariage chez les Romains cit. (nota 30 supra), p.279; G. PUGLIESE - F. SITZIA - L. VACCA, Istituzioni cit. (nota 63 supra), p.387; B. BIONDI, Istituzioni cit. (nota 22 supra), p.426; G. PACCHIONI, Corso di diritto romano cit. (nota 29 supra), pp.329330; V. ARANGIO-RUIZ, Istituzioni cit. (nota 53 supra), p.434-437; A. BURDESE, Manuale cit. (nota 47 supra), pp.263-264. Segundo a Lei das XII Tábuas, L. XII Tab. VI,6: Mulieris quae annum matrimonii ergo apud virum mansit, ni trinoctium ab eo usurpandi ergo abescit, usus esto (...). "A mulher que residiu durante um ano em casa de um homem, como se fora sua esposa, é adquirida por esse homem e cai sob o seu poder, salvo se se ausentar da casa por três noites" - Tradução de S.A.B. MeIRA, Curso de Direito Romano História e Fontes, São Paulo, Saraiva, 1975, p.86; Idem, A Lei das XII Tábuas - Fonte do Direito Público e Privado, $3^{\mathrm{a} e d .,}$ Rio de Janeiro, Forense, 1972, p. 149. Conforme R. VILLERS, Le mariage envisagé cit. (nota 63 supra), p.293, é muito provável que a usurpatio trinoctium tinha importância no direito de sucessão, com a possibilidade da mulher, pela actio familiae erciscundae, recolher sua parte na herança familiar. Vejam-se Gell. 3,2,12-13; Macr. Sat. 1,3,9.

Nas palavras de L. PEPPE, Storie delle parole, storie di istituti sul diritto matrimoniale romano arcaico, in SDHI 63 (1997), pp.176-177, a procriação era uma das finalidades do usus: l'usus di una donna da parte di 
A diferença fundamental entre os dois institutos está na finalidade: para o casamento, o escopo seria a união liberorum quaerundorum causa (a finalidade de ter filhos); para a conventio in manum, a incorporação da mulher num grupo familiar, submetida ao seu respectivo paterfamilias, independente do matrimônio, levando-se em consideração se a mulher fosse ou não uxor in manum conventione mater. ${ }^{73}$

As Leis Matrimoniais de Augusto não faziam referências à conventio in manum, o que reforça a tese de VOLTERRA sobre a separação entre este instituto e o matrimônio.

No final da República, houve um enfraquecimento do instituto jurídico da manus, o que reforçou a diminuição das diferenças entre marido e mulher especialmente em relação ao direito sucessório. As disposições sucessórias na família dos Cipiões demonstram que, por volta de 150 a.C., as mulheres eram, em sua maioria, casadas sob o regime da conventio in manum. Com a liberdade dos divórcios e o acúmulo de riquezas pelas famílias senatoriais e equestres, as mulheres adquiriram uma maior independência. Na época de Augusto, raramente se realizava a conventio in manum após o matrimônio. A manus, na verdade, nesta época, perdeu o seu caráter de proteção do grupo familiar. ${ }^{74}$

Os jurisconsultos romanos, influenciados pela Estoicismo, enfatizaram em suas obras o importante papel da procriação no matrimônio romano.

Nas duas principais definições de matrimônio ${ }^{75}$ presentes nas fontes jurídicas

un uomo individua in primo luogo una relazione sessuale, nella quale è possibile cogliere fondamentalmente due finalità: una consistente nella relazione in se stessa, l'altra la procreazione. Tra le due finalità, non è necessario dimostrare che nel mondo romano la procreazione è prioritária o è comunque il risultato che giustifica e rende necessaria la relazione sessuale stabile. In questa propettiva l'usus della donna non legata all'uomo da vincoli di sangue è prima di tutto l'utilizzazione sessuale a fini di procreazione e la sua manifestazione massima è il figlio nato della coppia.

${ }^{73}$ Veja-se Gai. 1,55-95; 1,114. De acordo com S. PEROZZI, Istituzioni di diritto romano cit. (nota 26 supra), p.322, nota 2, no período arcaico, o escopo da vida conjugal era ter fillhos para dar continuidade à família e este objetivo serviu para distinguir o matrimônio das demais relações entre homem e mulher. Vejam-se E. VOLTERRA, Matrimonio cit. (nota 61 supra), p. 754, nota 62; Idem, La conception du Mariage d'après les juristes romains cit. (nota 30 supra), p.10; La conception du Mariage à Rome cit. (nota 30 supra), p.352; O. RoBleDA, Intorno alla nozione di matrimonio cit. (nota 17 supra), p.181; Idem, El Matrimonio en Derecho Romano cit. (nota 10 supra), pp.61-66; R. BESNIER, L'application des lois caducaires d'Auguste cit. (nota 10 supra), p.97. P. GIUNTI, Consors vitae cit. (nota 26 supra), pp.226-234, afasta a possibilidade de atribuir-se à trinoctium usurpatio do usus, um meio de dispensar a esposa que não tivesse condições de ter filhos e que não pudesse alcançar o principal escopo do matrimônio romano.

${ }^{74}$ Vejam-se E. VOLTERRA, Matrimonio cit. (nota 61 supra), p.762; R. VILLERS, Le mariage envisagé cit. (nota 63 supra), pp.293 e 300.

${ }^{75} \mathrm{O}$ termo nuptiae indicava as cerimônias celebradas, os ritos, enquanto matrimonium indicava um status, uma causa ou um escopo. Na opinião de P. GIUNTI, Consors vitae cit. (nota 26 supra), pp.298-307, matrimonium indica a condição legal de mater. A autora descarta a etimologia que vincula a origem da palavra nuptiae de nubo (obnubo) ao "véu" que cobria a cabeça da esposa no dia da cerimônia do matrimônio. De acordo com C. ACCARIAS, Précis de droit romain cit. (nota 9 supra), p.190, nota 1, os termos já eram sinônimos no Direito Romano clássico. De acordo com L. PEPPE, Storie delle parole cit. (nota 72 supra), p.175, as nuptiae eram não apenas o conjunto de ritos pertencentes à deductio da uxor na casa do marido, mas principalmente, incluíam o nascimento do primeiro filho. Salienta J. GAUDEMET, Justum matrimonium cit. (nota 51 supra), p.105, que são poucas as obras de jurisconsultos romanos que tratam 
romanas, uma atribuída a Modestino e a outra provavelmente elaborada por Ulpiano, salienta-se a importância da procriação para este instituto.

Segundo Modestino,

\author{
Mod. 1 reg. D.23,2,1: Nuptiae sunt coniunctio maris et feminae et consortium \\ omnis vitae, divini et humani iuris communicatio.
}

\begin{abstract}
"As núpcias são a união do homem e da mulher, o consórcio de toda a vida, a comunicação do direito divino e humano".
\end{abstract}

A definição de Modestino, por ser o matrimônio um instituto prolis creande causa ao utilizar a expressão coniunctio maris et feminis, fazia alusão à sua finalidade procriativa. $^{76}$

exclusivamente sobre o matrimônio: uma obra chamada de nuptis de Nerácio Prisco, cujo texto não chegou até nós (Gell.4,4), um liber singularis de ritu nuptiarum de Modestino e um de sponsalibus liber singularis de Ulpiano. As núpcias fariam referência à mulher apta à procriação e ao casamento (nubilis, nupta), enquanto matrimônio (a raiz matr- acompanhada do sufixo - monium), indicaria que o marido se casa com a mater, aquela que ele conduzirá até a sua domus (ducit uxorem) e que futuramente procriará seus filhos. Vejam-se A. LóPEZ PEDREIRA, Limitaciones a la 'libertas nuptialis' en la legislación Augustea cit. (nota 40 supra), p.393, nota 10; F. BETANCOURT, Derecho Romano Clásico, Sevilla, Universidad de Sevilla, 2001, p.401, nota 3. Para A. RoMANo, Matrimonium iustum cit. (nota 26 supra), pp.6;9;84, a palavra nuptiae era derivada do verbo nubere que significa "velar"; "cobrir com um véu". De acordo com Festo, Festus. s.v.

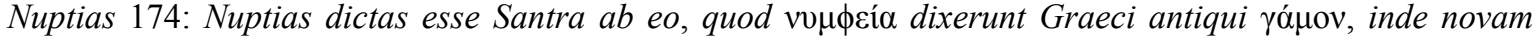
nuptam véav vó $\emptyset_{\eta}$ (...) Aelius et Cincius, quia flammeo caput nubentis obvolvatur, quod antiqui obnubere vocarint. "Sustenta Santra que as nuptiae são assim chamadas pelo fato que os antigos gregos chamaram o matrimônio de $v v \mu \phi \varepsilon i ́ \alpha$ e portanto, a nova esposa véav vó $\mu \phi \eta v$ (...) Élio e Cíncio pelo fato que envolvia-se com um véu vermelho a cabeça da mulher que se casava, o que os antigos chamavam envolver com um véu". ${ }^{76}$ A legislação matrimonial de Augusto ressalta que o escopo principal e caracterizador do matrimônio romano é a procriação e a educação de filhos legítimos. Eram exigências morais já acentuadas pelo ius sacrum no período pré-clássico. Vejam-se O. RoBledA, El Matrimonio en Derecho Romano cit. (nota 10 supra), p.66; R. AstOLFI, Il matrimonio nel diritto romano preclassico cit. (nota 1 supra), pp.99-100; Idem, Il matrimonio nel diritto romano classico cit. (nota 10 supra), pp.3-4; F. SERAFINI, Istituzioni cit. (nota 53 supra), pp.199, nota 3; 200, nota 1; G. FRANCIOSI, Famiglia e persone in Roma antica cit. (nota 26 supra), p.131. Na opinião de R. ASTOLFI, Il matrimonio nel diritto romano preclassico cit. (nota 1 supra), p.371, este escopo, dos primórdios da civitas, foi mantido por Modestino no conceito de matrimônio: In èta arcaica il 'ius sacrum' concepisce il matrimonio quale unione di un uomo con una donna, contratta allo scopo di procreare figli legittimi. Segundo G. MAY, Éléments de Droit Romain a l'usage des étudiants des Facultés de Droit, 17aed., Paris, Recueil Sirey, 1927, pp.111-112, nota 3: Le mariage du droit primitif peut se définir, l'union légitime de l'homme et de la femme, 'iustae nuptiae', 'iustum matrimonium', en vue de la procréation d'enfants légitimes qui assureront la durée de la famille et la perpétuité des sacrifices domestiques. Contra esta opinião, argumenta sobre a expressão coniunctio maris et feminae, G. LONGO, Riflessioni critiche, cit. (nota 48 supra), p.2358, que (...) è arbitrario ritenere - a mio modo di vedere - che essa alluda al fatto naturale che il matrimonio origina la procreazione. “(...) é arbitrário considerar - em minha opinião - que ela se refira ao fato natural que o matrimônio origina a procriação". Na mesma obra, na p.2359, G. LONGO defende que a intenção de procriar (quaerere liberos) não estabelece nenhum elemento jurídico para o matrimônio romano e não pode ser associado ao termo coniunctio: Ecco che la frase 'coniunctio maris et feminae' non dice nulla per essenza definitoria del matrimonio romano. E conclui, nas pp.2361-2362, que os termos coniunctio, consortium vitae, individua consuetudo vitae são expressões que, se interpretadas isoladamente, são incompletas, não definem de modo exauriente a essência do matrimônio. Uma relação omnis vitae, uma consuetudo vitae obrigatória não são conceitos romanos do período clássico. Também neste sentido, P. Bonfante, Corso di diritto romano - Diritto di Famiglia cit. (nota 23 supra), p. 263, afirma que 
O termo coniunctio reforça a idéia de que, para a realização das nuptiae, é essencial a diferença de sexo entre os cônjuges. A palavra coniunctio também servia para indicar as uniões entre os animais da mesma espécie para a sua procriação. ${ }^{77}$

O sentido da expressão coniunctio maris et feminae tem caráter naturalístico (ius naturale), pois é possível utilizá-la tanto para os animais (coniunctio animalium) quanto para os homens, livres ou escravos. ${ }^{78}$

o escopo de procriar filhos não está indicado nas definições de Modestino e Ulpiano, pois a procriação não era um dos elementos jurídicos da essência do matrimônio.

${ }^{77}$ Veja-se M.P. BACCARI, Persona e famiglia cit. (nota 16 supra), p.38; C. PUJAL, La concepción jurídica cit. (nota 47 supra), p.607. Segundo GAUDEMET, L'Apport du Droit Romain cit. (nota 59 supra), p.32: "Le mariage consiste donc en une union des corps entre un homme et une femme". "O matrimônio consiste, pois, numa união de corpos entre um homem e uma mulher". Afirma A. VILLAÇA AZEvEDo, Dever de Coabitação cit. (nota 61 supra), p.48, que "a coniunctio significa, dentre outras coisas, união, convivência, casamento, comunhão de vida, cópula, coito, do verbo latino coniungo, is, xi, ctum, ere, com o sentido de juntar, jungir, atar, unir, pegar, ligar, unir em matrimônio, casar, sendo certo que os romanos se referiam à coniunctio sexualis maris atque feminae (...)".

${ }^{78}$ E. Albertario, La definizione del matrimonio secondo Modestino, in Studi di diritto romano, vol.1, Milano, Giuffrè, 1933, p.182. Para o autor a coniunctio maris et feminae não representa um elemento necessário juridicamente, mas um elemento relevante para a principal finalidade ético-social do matrimônio, a procriação dos filhos. Muitos autores consideram que o conceito de matrimônio de Modestino não é propriamente jurídico, porém de caráter ético-social, moral e religioso; vejam-se D.R.M. RoDRIGUES, Aspectos de interesse atual do matrimônio romano cit. (nota 67 supra), p.89; E.C.S. MARCHI, Matrimônio moderno cit. (nota 61 supra), pp.57;59; A. SURGIK, A 'Manus' e o 'Consensus' cit. (nota 66 supra), p.726; M. MARRONE, Istituzioni cit. (nota 48 supra), p.216; J. IGLESIAS, Derecho Romano cit. (nota 51 supra), p.340; C. PuJAL, La concepción jurídica cit. (nota 47 supra), p.607; J. DAZA MARTínez, La influencia cristiana cit. (nota 48 supra), p.111; G. LONGO, Riflessioni critiche cit. (nota 48 supra), pp.2357;2361; A. BURDESE, Manuale cit. (nota 47 supra), p.261. Na opinião de M. TALAMANCA, Istituzioni di diritto romano cit. (nota 12 supra), p.131, para o qual a definição de Modestino, “(...) enfatizza momenti a carattere etico-religioso, non immediatamente rilevanti ai fini della disciplina giuridica del matrimonio romano". Tradução: “(...) enfatiza importantes elementos de caráter ético-religioso, não imediatamente relevantes às finalidades da disciplina jurídica do matrimônio romano". F. LANFRANCHI, Le definizioni e il concetto del matrimonio nei retori romani, in SDHI 2 (1936), pp.149-150, nota 17; Idem, Il diritto nei retori romani - Contributo alla storia dello sviluppo del diritto romano, Milano, Giuffrè, 1938, pp.215-216, confirma a tese dominante de que a definição não indica os elementos jurídicos essenciais à formação do matrimônio, mas os elementos éticos do instituto. Coniunctio maris et feminae, segundo LANFRANCHI, faz alusão à importância meramente social da procriação. Para G. PUGLIESE - F. SiTZIA - L. VACCA, Istituzioni cit. (nota 63 supra), p.393, este conceito de caráter retórico salienta aspectos corporais, espirituais e ético-sociais do matrimônio. De acordo com G. FRANCIOSI, Famiglia e persone in Roma antica cit. (nota 26 supra), p.130, esta definição de Modestino é "muito genérica" (troppo generica) e seus elementos também poderiam compreender outras relações de fato como o concubinato e o contubérnio. Segundo J. GAUDEMET, Justum matrimonium cit. (nota 51 supra), pp.106-107, o matrimônio romano é sobretudo um fato social, muito mais influenciado pelos mores maiorum e pelas prescrições religiosas. Para GAUDEMET, a coniunctio maris et feminae não era um elemento essencial na formação do matrimônio.

Deve-se salientar, porém, que este pode ser mais um caso em que os romanistas, ao elaborarem estas conclusões, utilizando uma expressão de P. CATALANo, Diritto, soggetti, oggetti cit. (nota 11 supra), p.112, nota 54, sono scientificamente mal poste, pois analisam as definições romanas de matrimônio fundamentando-se na Isolierung do direito, nas "autoprojeções" (autoproiezioni) subjetivas e abstratas, ou seja, em definições e conceitos modernos que atribuem ao matrimônio romano um caráter estritamente éticosocial e, portanto, extra-jurídico. Faz esta mesma advertência, E Volterra, Sui 'mores' della 'familia' romana cit. (nota 30 supra), p.181, nota 1, pois na opinião do autor, os juristas romanos faziam claramente a distinção entre os elementos jurídicos e os elementos sociais ao elaborarem seus conceitos. Muitas teorias modernas que procuram explicar algumas normas romanas por meio de elementos não-jurídicos, distorcem o pensamento dos juristas romanos. 
A noção de matrimônio de Caius Musonius Rufus presente em seus tratados moraisfilosóficos, muito semelhante à de Aristóteles, parece ter tido grande influência na jurisprudência romana para a elaboração do conceito de matrimônio em D.23,2,1. ${ }^{79}$

No diatribe XII, intitulado "Dos prazeres sexuais", Musonius condena todas as uniões contrárias à Natureza: “Aqueles que não vivem na preguiça e que não são viciados devem considerar que os prazeres sexuais permitidos são aqueles que se encontram no

79 O. SACCHI, Le nozioni di stato cit. (nota 33 supra), p.334; O.M. PÉTER, Liberorum quaerendorum causa cit. (nota 21 supra), pp.311-312; P. VEYNE, L'Empire Romain cit. (nota 19 supra), pp.41-42 ; M. MARRONE, Istituzioni cit. (nota 48 supra), p.266, nota 185. Afirma F. SCHULZ, Prinzipien des römischen Rechts cit. (nota 43 supra), p.68, que a definição de matrimônio de Modestino foi elaborada tendo como influência o pensamento filosófico grego. Esta inspiração de Modestino na filosofia grega, principalmente na ética estoica, também é salientada por F. LANFRANCHI, Le definizioni e il concetto del matrimonio cit. (nota 78 supra), pp.149-150, nota 17; Idem, Il diritto nei retori romani cit. (nota 78 supra), pp.215-216, nota 3; R. ASTOLFI, Note per una valutazione storica della 'Lex Iulia et Papia' cit. (nota 36 supra), p.228. Segundo R. LAURENTI, Musonio cit. (nota 18 supra), pp.2115; 2137; 2.142, a doutrina do estoicismo influenciou o instituto do matrimônio romano em dois pontos principais: 1) exigirá o controle dos desejos e dos gestos entre os cônjuges, condenando tanto o adultério do marido quanto o da mulher, as uniões "contra a Natureza" e aquelas uniões formadas sob qualquer forma de violência; 2) defenderá que o fundamento e a finalidade principal do matrimônio é a procriação e a multiplicação da espécie humana (Antipatro de Tarso e Musônio Rufo). Além disso, é importante salientar que Musonius Rufus foi um dos primeiros filósofos a defender a igualdade intelectual e psíquica entre homens e mulheres. Suas idéias contribuíram, mesmo que de forma modesta no período clássico, para uma reavaliação do papel da mulher na sociedade romana, visto que, em suas obras, ele defendia que elas não deveriam ser tratadas como res ou simples instrumentos de prazer. Musonius, no diatribe VIII, defendia uma espécie de "onipresença" da Filosofia em todos os campos do conhecimento e da vida e sua aplicação na solução dos mais variados problemas (instauratio philosophiae in omnibus). No matrimônio, a Filosofia e os seus preceitos eram importantes para a manutenção da vida conjugal comum, fundamentada no auto-controle, no amor e no bem. No diatribe XIV, que tinha como título "Se o casamento constitui um obstáculo à filosofia", reforçou que qualquer limite imposto aos nascimentos no matrimônio era um crime, contrário à prosperidade e ao poder da cidade: "Como alguém afirmou que o casamento e a vida com uma mulher eram um obstáculo à Filosofia, Musonius respondeu que isto não havia nem para Pitágoras, nem para Sócrates, nem para Crates, que todos, viviam com uma mulher. (...) E nós que temos o lar de onde nós podemos sair e que às vezes, temos os empregados ao nosso serviço, nós ousamos, no entanto, afirmar que o casamento é um obstáculo à Filosofia! A Filosofia é verdadeiramente a senhora e a comandante dos homens em todas as coisas que são corretas ao homem conforme a Natureza. Logo, se existe uma coisa conforme à Natureza, o casamento é manifestamente uma. Para qual finalidade, com efeito, o criador do homem dividiu primeiro nossa raça em duas partes, porque ele lhe concedeu em seguida dois sexos, um para ser o macho, o outro a fêmea, porque ele colocou em cada um deles um forte desejo de se unir e de se associar ao outro e porque lhe inspirou uma forte paixão um pelo outro, do macho pela fêmea e da fêmea pelo macho? Não é evidente que desejava que eles estivessem unidos, que eles vivessem juntos e que eles unissem seus esforços para levar uma vida em comum, para gerar filhos e alimentá-los, a fim de que nossa raça se perpetue? (...) Por isso, aquele que suprime o casamento entre os homens, suprime a casa, suprime a cidade, suprime a raça humana inteira. Com efeito, para subsistir, ela tem necessidade que nasçam crianças, há necessidade do casamento, deseja-se, pelo menos, que estes nascimentos sejam justos e legais. É evidente que uma casa ou uma cidade não é constituída de mulheres solitárias ou de homens solitários, mas na sua união". Todos os fragmentos dos tratados de Musonius Rufus citados no trabalho são provenientes da compilação elaborada por A. JAGU, Musonius Rufus - Entretiens et fragments. Introducion, traduction et comentaire, New York, Georg Olms, 1979, pp.13, notas 48 e 49;18; 67-70. Na opinião de A.A. CASTRO CORRÊA, O Estoicismo no Direito Romano cit. (nota 33 supra), p.93, "não é possível determinar com precisão geométrica a contribuição do Estoicismo ao desenvolvimento das idéias jurídicas em Roma; como em todos os fenômenos culturais, as influências ideológicas nunca operam isoladamente, mas em concurso com inúmeras outras causas que no conjunto, formam a atmosfera espiritual duma época. Sabemos, com certeza, que o ideal estoico da igualdade humana, sua consideração moral das relações sociais (...) atuaram intensamente na vida Romana. É, por conseguinte, sob o influxo parcial do Estoicismo, que o direito clássico opera as reformas que tão altamente beneficiaram a mulher". 
casamento e que têm por finalidade a procriação dos filhos, porque eles são conformes à lei. ${ }^{80}$ Quanto àqueles que estão à procura da volúpia, eles são injustos e contrários à lei, mesmo no casamento". 81

Sobre a "finalidade principal do casamento", disposta no diatribe XIII A, Musonius salienta: "Viver em união e cooperar com a procriação dos filhos, eis a finalidade principal

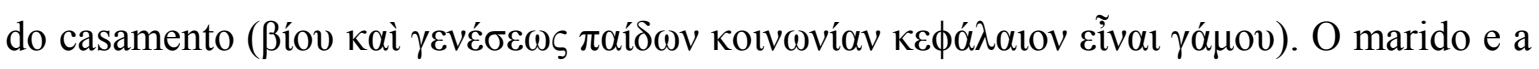
mulher (...) devem se unir ao mesmo tempo para levar uma vida em comum e para procriar os filhos, para pensar que tudo é comum entre eles e que não há nada pessoal, nem sequer seus corpos. É um grande acontecimento, com efeito, o nascimento de um ser humano, finalidade desta união". 82

Segundo Musonius Rufus e a filosofia estoica, no matrimônio os prazeres sexuais

${ }^{80}$ Exemplo da influência do Estoicismo sobre a jurisprudência romana manifesta-se na definição de lei do filósofo Crisipo, mencionada por Marciano e posteriormente incluída no Digesto de Justiniano. Nesta definição, o fílósofo indica como elementos fundamentais da lei, o ius naturale (ducem et magistram animalium, quae natura civilia esse voluit), a equidade e a justiça (esse iusti et iniusti). $\mathrm{O}$ ius naturale, na concepção de Crisipo, poderia ampliar e derrogar o ius civile: Marc. 1 inst. D. 1,3,2: Nam et Demosthenes orator sic definit: Haec lex est, cui omnes homines convenit obtemperare cum propter alia pleraque tum maxime, quod omnis lex inventum est et donum dei, placitum vero sapientium hominum coercitioque peccatorum tam voluntariorum quam non voluntariorum, civitatis autem pactum commune, secundum quod convenit vivere quicunque in ea sunt. Sed et philosophus summae stoicae sapientiae Chrysippus sic incipit libro, quem fecit $\pi \varepsilon \rho i$ vó $\mu$ ov: Lex est omnium regina rerum divinarum humanarumque, oportet autem praeesse eam tam bonis quam malis, et ducem et magistrum esse animalium quae natura civilia esse voluit, indeque normam esse iusti et iniusti, quae iubeat fieri facienda, vetet fieri non facienda. "Pois também o orador Demóstenes assim define: "lei é aquilo a que convém a todos os homens obedecer, se por causa de várias outras coisas, então principalmente porque toda lei é uma descoberta e um dom de Deus, a resolução dos homens sábios e a repreensão das faltas, tanto das voluntárias quanto das não voluntárias; um pacto, pois, comum da polis, conforme o que convém a todos que nela vivam”. Mas também um filósofo da grande sabedoria estoica, Crisipo, assim começa no livro que fez "sobre as normas": "a lei é a rainha de todas as coisas divinas e humanas. É preciso, pois, que seja superior tanto aos bons quanto aos maus e que seja condutora e mestra dos animais que a natureza quis que convivessem civilmente, daí então que seja a norma do justo e do injusto, que obriga serem feitas as coisas que devem ser feitas, que proíba as que não devem ser feitas". Veja-se A.A. CAStro CORRÊA, O Estoicismo no Direito Romano cit. (nota 33 supra), pp.64-65.

${ }^{81}$ A. JAGU, Musonius Rufus cit. (nota 79 supra), p.62.

${ }^{82}$ A. JAGU, Musonius Rufus cit. (nota 79 supra), pp.65-66. No diatribe XIII B, o filósofo complementa que “os pretendentes ao casamento não devem, pois, levar em consideração nem a nobreza da família, nem a importância dos bens, nem a beleza física. Com efeito, nem a riqueza, nem a beleza, nem a nobreza do nascimento ajudam a melhorar a comunhão de vida mais do que o consenso dos sentimentos, nem contribuem mais para aumentar a procrição de filhos. É suficiente, para o casamento, que os corpos tenham boa saúde, com uma aparência exterior normal e que estejam aptos para o trabalho, qualidades que tornamlhes menos vulneráveis às armadilhas de pessoas intemperadas, melhor adaptadas à realização de trabalhos corporais e totalmente adaptadas à procriação de filhos". No diatribe XV A "Se é necessário erguer todos os filhos que nasceram", conforme A. JAGU, Musonius Rufus cit. (nota 79 supra), pp.71-72, Musonius reforça a importância da procriação no matrimônio ao descrever a cena de um pai e uma mãe passeando com seus filhos, afirma que ela é mais bela que qualquer cerimônia religiosa: "Que o fato de erguer numerosos filhos seja uma coisa bela e útil, podemos saber refletindo que o homem que tem filhos numerosos é honrado na cidade, que ele goza da estima de seus vizinhos, que ele tem mais influência que todos os seus semelhantes, se eles não têm tantos filhos. Com efeito, mesmo que um homem que tem numerosos amigos é, penso, mais influente que um homem sem amigos, o mesmo um homem que têm numerosos filhos é mais que aquele que não tem ou tem poucos (...) Podemos compreender que belo espetáculo é ver um homem e uma mulher cuidando de seus filhos. Com efeito, o espetáculo de uma procissão organizada em honra dos deuses não poderia ser tão bela". 
têm um sentido e uma justificação. Fora dele, conduzem à falta de moderação, às paixões desordenadas, à inveja e ao ciúme, contrários às virtudes, à prudência, à coragem, à temperança. ${ }^{83}$

Apesar da semelhança destes princípios éticos do estoicismo com as concepções cristãs referentes a uma vida pura e casta, a definição de Modestino é clássica, pois o jurista utiliza expressões recorrentes nas fontes jurídicas e literárias do período. ${ }^{84}$

A expressão consortium omnis vitae deve ser interpretada no sentido de que os cônjuges concordam em permanecer unidos enquanto dure a affectio maritalis, sendo essa união duradoura, uma comunhão absoluta de existência, física (coabitação), religiosa, patrimonial e social, que não pode ser temporária, nem estar submetida a condição resolutiva ou a termo. ${ }^{85}$

${ }^{83}$ As paixões e os únicos prazeres sexuais "justos" são aqueles que buscam a "procriação" e são inspirados pelo "logos" e conformes à "Lei”" (vónos) da Natureza"; são injustos e contra a "Lei da Natureza", os meros prazeres, mesmo se ocorrem dentro do matrimônio. Vejam-se O.M. PÉTER, Liberorum quaerendorum causa cit. (nota 21 supra), pp.311-312; R. LAURENTI, Musonio cit. (nota 18 supra), pp.2140-2141. Conclui LAURENTI na p.2143, (...) l'uomo di Musonio vive alla luce del logo: le sue parole, $i$ suoi atti sono ispirati dal logo e nel logo trovano conferma e verità, soprattutto quelli sui quali l'abitudine e l'opinione comune, rifiutato il logo, avevano avanzato concezioni differenti. Tradução: "(...) o homem de Musonio vive à luz do "logos": as suas palavras, os seus atos inspirados pelo "logos" e no "logos" encontram confirmação e verdade, sobretudo aqueles sobre os quais o costume e a opinião comum, rejeitado o "logos", propuseram diferentes concepções".

${ }^{84}$ Defendem a atribuição do trecho ao período clássico, E. AlBerTario, La definizione del matrimonio cit. (nota 78 supra), pp.185 e 193; M.P. BACCARI, Persona e famiglia cit. (nota 16 supra), p.36; E. VolterRA, Matrimonio cit. (nota 61 supra), p.754; G. PUGLIESE - F. SITZIA - L. VACCA, Istituzioni cit. (nota 63 supra), p.393; R. ORESTANO, La struttura giuridica del matrimonio romano cit. (nota 1 supra), pp.167 e 220; O.M. PÉTER, Liberorum quaerendorum causa cit. (nota 21 supra), pp.311-312; C. PUJAL, La concepción jurídica cit. (nota 47 supra), pp.609-610.

Segundo J. Gaudemet, L'Apport du Droit Romain cit. (nota 59 supra), p.31 e P. Bonfante, Corso di diritto romano - Diritto di Famiglia cit. (nota 23 supra), p. 263, os romanos no período clássico não aplicaram nem impuseram o princípio da indissolubilidade ao matrimônio, descartando, portanto, o significado "comunhão durante toda a vida". Eles, porém, elogiavam os matrimônios duradouros, principalmente aqueles que durassem até a morte de um dos cônjuges. O Direito Romano sempre possibilitou a dissolução matrimonial, especialmente no período clássico. Portanto, descarta-se qualquer interpretação desta expressão como "indissolubilidade da união" com uma eventual influência cristã pós-clássica. No Direito pós-clássico, apesar da influência do Cristianismo e do dogma da indissolubilidade, a legislação romana adotou uma postura de permitir o divórcio por determinadas causas justificadas: esterilidade durante três anos consecutivos; ausência do marido por cinco anos, como prisioneiro ou desaparecido em guerra; doença mental ou voto de castidade de algum dos cônjuges. Símbolo do pensamento cristão, os preceitos do apóstolo Paulo de Tarso sobre casamento e virgindade podem ser constatados na sua primeira epístola aos Coríntios (1Cor. 7). É inegável a verificação de "pontos comuns" entre a definição de Modestino (principalmente do consortium omnis vitae) e a definição do matrimônio cristão do período pós-clássico. O Código de Direito Canônico de 1983, cânon 1055 §1, retomou a importância da procriação e da educação da prole para o totius vitae consortium: Matrimoniale foedus, quo vir et mulier inter se totius vitae consortium constituunt, indole sua naturali ad bonum coniugum atque ad prolis generationem et educationem ordinatum, a Christo Domino ad sacramenti dignitatem inter baptizatos evectum est. "O pacto matrimonial, pelo qual o homem e a mulher constituem entre si o consórcio de toda a vida, por sua índole natural ordenado ao bem dos cônjuges e à geração e educação da prole, entre batizados foi por Cristo Senhor elevado à dignidade de sacramento".

${ }^{85}$ Nas palavras de R. Astolfi, Il matrimonio nel diritto romano classico cit. (nota 10 supra), p.5, la procreazione e la cura dei figli è quindi per il diritto lo scopo per il quale i coniugi instaurano fra loro una comunanza di vita, cioè il 'consortium omnis vitae'. Para D.R.M. RODRIGUES, Aspectos de interesse atual do 
A respeito da comunicação entre o direito divino e humano (divini et humanis iuris communicatio) esta expressão indica que o consortium omnis vitae contém elementos sacros e laicos. ${ }^{86}$ A uxor participa do culto doméstico (sacra privata; sacra familiaria) ${ }^{87}$ da família do marido, passa a ser membro desta por meio da conventio in manum. ${ }^{88}$

matrimônio romano cit. (nota 67 supra), p.94, omnes vitae "não deve ser entendido como para toda a vida e sim em todas as coisas da vida". Na opinião de E.C.S. MARCHI, Matrimônio moderno (nota 61 supra), p.64, nota 39: "Predomina hoje a idéia (...) que o enunciado de Modestino se referisse, originalmente, não à duração do matrimônio, mas sim à vontade dos cônjuges: mesmo podendo o casamento se extinguir pelo divórcio, exigia-se que a vontade recíproca do homem e da mulher, enquanto estivessem unidos, fosse destinada a constituir uma comunhão perpétua". E. ALBERTARIO, La definizione del matrimonio cit. (nota 78 supra), p.184, afirma que consortium tem o sentido de indicar que os cônjuges compartilham todas as coisas da vida, felizes ou tristes. O termo consortium omnis vitae muito se assemelha à expressão, provavelmente de Ulpiano, individua consuetudo vitae. Na opinião de B. BIONDI, Istituzioni di diritto romano cit. (nota 22 supra), pp.444-445, la società coniugale che si instaura col matrimonio presenta una disciplina giuridica che riflette tutto il campo del diritto, sia pubblico che privato; tale disciplina si fonda, mira anzi a rafforzarlo, su quel 'consortium omnis vitae' e quella 'individuae vitae consuetudo' che per i romani costituisce l'essenza del matrimonio.

Vejam-se A. VillaçA AzeVedo, Dever de Coabitação cit. (nota 61 supra), pp.48 e 59; C. PuJAL, La concepción jurídica cit. (nota 47 supra), pp.605-606;609; P. BONFANTE, Corso di diritto romano - Diritto di Famiglia cit. (nota 23 supra), p. 263; R. AstOLFI, Il matrimonio nel diritto romano preclassico cit. (nota 1 supra), pp.100-101; E. VOLTERRA, La conception du Mariage d'après les juristes romains cit. (nota 30 supra), p.37; Idem, La conception du Mariage à Rome cit. (nota 30 supra), p.356; Idem, Les formes du Mariage chez les Romains cit. (nota 30 supra), p.281. A idéia de Modestino também se encontra em Quint. Decl. 376: Matrimonium vero tum perpetuum est, si mutua voluntate iuguntur. Cum ergo quaeratur mihi uxor, socia tori, vitae consors, in omne saeculum mihi eligenda est. "O matrimônio é, verdadeiramente, perpétuo, se estão unidos [os cônjuges] pela vontade mútua. Portanto, no momento em que a esposa é obtida por mim, para mim é escolhida a companheira do leito, a consorte da vida, para todo tempo em que se vive"; Quint. Decl. 368: Matrimonia sunt ab ipsa rerum natura inventa. Sic mares feminis iuguntur, ut imbecillior sexus praesidium ex mutua societate sumat. "Os matrimônios foram criados pela própria natureza das coisas. De tal modo estão unidos os homens e as mulheres, que o sexo fraco tomou para si a proteção na sociedade mútua". Para R. ORESTANO, La struttura giuridica del matrimonio romano cit. (nota 1 supra), pp.167 e 220 , as expressões consortium omnis vitae e individua consuetudo vitae não estavam de acordo com a possibilidade da dissolução matrimonial pelo divórcio. Na opinião de G. LONGO, Riflessioni critiche cit. (nota 48 supra), p.2360, na interpretação do termo perpetuum na declamação retórica de Quintiliano (Decl. 376), não é possível supor que o consenso inicial do matrimônio origine uma perpetuidade indissolúvel da sociedade conjugal.

${ }^{86}$ R. ASTOLFI, Il matrimonio nel diritto romano classico cit. (nota 10 supra), p.5.

87 D.R.M. Rodrigues, Aspectos de interesse atual do matrimônio romano cit. (nota 67 supra), p.93; R. ASTOLFI, Il matrimonio nel diritto romano preclassico cit. (nota 1 supra), p.95; E. AlBERTARIO, Matrimonio (Roma) cit. (nota 61 supra), p.580; C. ACCARIAS, Précis de droit romain cit. (nota 9 supra), pp.192-193; G. LONGO, Riflessioni critiche cit. (nota 48 supra), p.2363; G. CoRnIL, Droit Romain cit. (nota 55 supra), p.30. Em relação ao vínculo entre a religião e a procriação, no diatribe XIV, Musonius Rufus, ao fazer referência aos deuses Eros e Afrodite, o filósofo afirma que "Nós acreditamos, com efeito, que todos esses deuses trabalham para unir o homem e a mulher um ao outro para a procriação de filhos. Em qual circunstância, com efeito, Eros prestaria mais justamente seu auxílio, que pela união legítima do homem e da mulher?”.

${ }^{88}$ E. AlBERTARIO, La definizione del matrimonio cit. (nota 78 supra), p.186. Caso após o casamento a mulher não se submetesse à manus do marido, ela permanecia vinculada ao culto dos sacra de sua família e mantinha a sua condição de herdeira. Para ALBERTARIO a expressão communicatio iuris humani et divini seria juridicamente possível apenas no casamento acompanhado da conventio in manum, enquanto no casamento sem a constituição da manus, a expressão teria uma importância mais ético-social que jurídica. Na verdade, divini iuris communicatio adapta-se e assume diferentes significados para qualquer legislação ou religião, a expressão apresenta uma espécie de perpetuidade. Vejam-se G. FrANCIOSI, Famiglia e persone in Roma antica cit. (nota 26 supra), p.130; G. BRINI, Matrimonio e divorzio cit. (nota 69 supra), p.35. Na opinião de R. ASTOLFI, Il matrimonio nel diritto romano preclassico cit. (nota 1 supra), p.100: La definizione di Modestino riguarda il matrimonio 'cum manu', ma coglie e rispetta l'essenza del matrimonio religioso 
Muitas obras literárias e jurídicas, influenciadas pelo Estoicismo, apresentam conceitos e noções com as expressões divini et humani rerum e divini et humani iuris. Cícero, v.g., menciona na obra De amicitia 6,20, ao definir a amizade, omnium divinarum humanarumque rerum consensio. ${ }^{89}$

Outra passagem nas fontes que faz referência à expressão divini et humani iuris é um rescrito do imperador Gordiano de 242 d.C. (C.9,32,4pr.). Ali se afirma que a mulher casada é socia rei humanae atque divini domus, revelando uma espécie de caráter societário ao casamento, de verdadeira comunhão de vida entre os cônjuges (societas vitae). ${ }^{90}$

arcaico in quanto tale.

${ }^{89}$ Cic. De amic. 6,20: Est enim amicitia nihil aliud nisi omnium divinarum humanarumque rerum cum benevolentia et caritate consensio, qua quidem haud scio an, excepta sapientia, nihil melius homini sit a dis immortalibus datum. "A amizade, de fato, nada mais é senão um acordo perfeito nas coisas divinas e humanas, unido a um sentimento de benevolência e de amor; e dela certamente não sei se, excetuada a sabedoria, nada de melhor tenha sido dado aos homens pelos deuses imortais". O conceito de amizade de Sêneca é muit semelhante: Sen., Epist. 48: Consortium rerum omnium inter nos facit amicitia. "A amizade faz entre nós o consórcio de todas as coisas". Veja-se também, ao falar sobre a sabedoria, Cic. de off., 1,43,153: (...) illa autem sapientia, quam principem dixi, rerum est divinarum et humanarum scientia, in qua continetur deorum et hominum communitas et societas inter ipsos; ea si maxima est, ut est, certe necesse est, quod a communitate ducatur officium, id esse maximum. Etenim cognitio contemplatioque [naturae] manca quodam modo atque inchoata sit, si nulla actio rerum consequatur. Ea autem actio in hominum commodis tuendis maxime cernitur; pertinet igitur ad societatem generis humani; ergo haec cognitioni anteponenda est. “(...) esta sabedoria, portanto, que eu denominava a maior das virtudes, é a ciência das coisas divinas e humanas, e abrange as relações mútuas dos deuses com os homens e a sociedade entre os próprios. Se, portanto, ela é a maior das virtudes, importantíssimos devem ser os deveres que dizem respeito à comunidade humana. E, de fato, o estudo e a contemplação da natureza seriam falhos e imperfeitos, se não houvesse esta ação. E ela se manifesta, sobretudo, na defesa do que é útil ao homem; tem por finalidade principal a sociedade humana, portanto deve ser anteposta ao conhecimento".

${ }^{90}$ A comunhão de vida indica a igualdade de domicílio, de condição social e de nome entre os cônjuges. Gord. C. 9,32,4pr. (de 242 d.C.): Adversus uxorem, quae socia rei humanae atque divinae domus suscipitur, mariti diem suum functi successores expilatae hereditatis crimen intendere non possunt. (...) "Os sucessores do marido falecido não podem intentar a acusação de herança roubada contra a mulher, que é admitida na casa como sócia das coisas divinas e humanas" (...). Quanto ao termo societas para designar o matrimônio, Paulo utiliza a expressão societas vitae quodammodo dominam eam faceret para reforçar a proibição de mover uma actio furti contra a própria esposa. Era permitida apenas uma actio rerum amotarum, de natureza reipersecutória. Paul. 7 ad Sab. D.25,2,1: Rerum amotarum iudicium singulare introductum est adversus eam, quae uxor fuit, quia non placuit, cum ea furti agere posse, quibusdam existimantibus, ne quidem furtum eam facere, ut Nerva, Cassio, quia societas vitae quodammodo dominam eam faceret, aliis, ut Sabino et Proculo, furto quidem eam facere, sicuti filia patri faciat, sed furti non esse actionem constituto iure(...). "A ação singular de coisas subtraídas foi introduzida contra aquela, que foi esposa, porque não pareceu agradável que contra ela, pudesse se exercer a ação de furto, opinando alguns, como Nerva e Cássio, que ela certamente não comete furto, porque a sociedade da vida a torna, de certo modo, dona [proprietária dos bens], e outros, como Sabino e Próculo, que verdadeiramente comete furto, como a filha comete em relação ao pai, mas não é a ação de furto a estabelecida pelo direito(...)". Vejam-se E. VOLTERRA, Matrimonio cit. (nota 61 supra), p.754, nota 62; O. RoBLEDA, Intorno alla nozione di matrimonio cit. (nota 17 supra), pp.175; 181; E. AlBerTARIO, La definizione del matrimonio cit. (nota 78 supra), p.188; G. BRINI, Matrimonio e divorzio cit. (nota 69 supra), p.33; A. LÓPEZ PEDREIRA, Limitaciones a la 'libertas nuptialis' cit. (nota 40 supra), p.393; R. ASTOLFI, Il matrimonio nel diritto romano preclassico cit. (nota 1 supra), pp.96-97; Idem, Il matrimonio nel diritto romano classico cit. (nota 10 supra), p.6; C. ACCARIAS, Précis de droit romain cit. (nota 9 supra), p.191; V. ARANGIO-RUIZ, Istituzioni cit. (nota 53 supra), p.446; M. MARRONE, Istituzioni cit. (nota 48 supra), p.222. 
A expressão divini et humani iuris comunicatio indica que as noções de ius e mos atuam dentro de uma concepção unitária no Ius Romanum e também envolve elementos religiosos $($ fas $) .^{91}$

Outra definição importante, provavelmente de Ulpiano, está disposta nas Institutas de Justiniano (533 d.C.) 1,9,1:

Nuptiae autem sive matrimonium est viri et mulieris coniunctio, individuam consuetudinem vitae continens.

"Núpcias ${ }^{92}$, ou matrimônio, são a união do homem e da mulher, compreendendo comunhão

BONFANTE ao interpretar a constituição de Gordiano, levanta a hipótese de que exista uma interpolação da expressão divini et humani iuris communicatio em D.23,2,1, pois ela indicaria uma exigência cristã de igualdade de religião entre os cônjuges. P. BonfANTE, Corso di diritto romano - Diritto di Famiglia cit. (nota 23 supra), p. 263: La definizione di Modestino e la costituzione di Gordiano si stimano ispirate, nel rilievo dato alla comunanza del diritto divino ed umano, all'antico matrimonio accompagnato dalla 'manus': ma forse una simile allusione non è che un'interpolazione in senso cristiano. Conclui C. PUJAL, La concepción jurídica cit. (nota 47 supra), p.610: Pensamos que las palabras de la definición: 'divini et humani iuris communicatio' son clásicas, porque la 'manus' nada tenía que ver con el concepto del matrimonio y porque seria un anacronismo el que Modestino se refiriese a la 'manus', cuando en su tiempo sería rarísimo el matrimonio 'cum manu'.

91 Modestino utiliza esta expressão provavelmente influenciado pela doutrina estoica, que considera a Humanidade como a união entre homens e deuses. Sobre os escritos estóicos, M.H. RocHA PEREIRA, Estudos de História da Cultura Clássica - Cultura Grega, vol.1, 7ªed., Lisboa, Fundação Calouste Gulbenkian, 1993, p.530, afirma que "embora derivados dos Cínicos, distinguem-se deles pela importância que deram à investigação científica, pois a verdadeira moralidade assenta no saber. Ser virtuoso identifica-se com ser sábio, e a filosofia é o saber do humano e do divino. Tudo no mundo é obra da razão, e a razão absoluta é a base do mundo" (grifos nossos). Veja-se Cic. De finibus bonorum et malorum 3,19,62-64.

Ulpiano, em seu conceito de jurisprudência, refere-se à divisão das res em divinas e humanas (Ulp. 1 reg. D.1,1,10pr.: Iuris prudentia est divinarum atque humanarum rerum notitia, iusti atque iniusti scientia "Jurisprudência é o conhecimento das coisas divinas e humanas, a ciência do justo e do injusto"). Segundo S. CRUZ, Direito Romano (Ius Romanum) - Introdução. Fontes, 4aed., v.1, Coimbra, Coimbra, 1984, p.286, em relação ao conceito de jurisprudência de Ulpiano, "o Direito (ciência e técnica) para conseguir o seu fim (a realização da utilitas de cada um na convivência social) parte de certos pressupostos metajurídicos indiscutíveis (pelo menos para determinada época e para determinado grau de civilização): uns de ordem teológica (as res divinae), outros de ordem filosófica (res humanae), os quais (uns e outros) informam a ordem social dum povo". Para Gaio (Gai. 2 inst. D.1,8,1pr.), Summa rerum divisio in duos articulos deducitur: nam aliae sunt divini iuris, aliae humani. "A suma divisão das coisas se reduz a dois artigos, pois são umas do direito divino, outras do direito humano". O referido texto de Ulpiano significa que o direito, abrange princípios que governam os homens entre si, as relações do homem com a divindade, a organização do culto e dos sacerdócios. O vocábulo res deve ser interpretado num sentido lato, pois a jurisprudência se ocupa, tanto das coisas divinas (templos, túmulos, cerimônias religiosas, nomeação dos pontífices, das instituições religiosas na sociedade romana) quanto das coisas humanas (de propriedade e da persona e seus direitos e deveres na vida pública e privada). Vejam-se R. PORCHAT, Curso Elementar de Direito Romano cit. (nota 12 supra), pp.138-139; J. GAUDEMET, L'Apport du Droit Romain cit. (nota 59 supra), pp.31 e 34; A.A. CAStro CorrÊA, O Estoicismo no Direito Romano cit. (nota 33 supra), pp.37;65; E. AlBERTARIO, La definizione del matrimonio cit. (nota 78 supra), p.182.

92 De acordo com P. GIUNTI, Consors vitae cit. (nota 26 supra), pp.302-303, em alguns trechos da literatura romana e do Digesto, a palavra nuptiae tinha um significado diferente de matrimonium, como se indicasse a origem da cerimônia que iniciava a relação entre os cônjuges, ou seja, um momento no qual a relação ainda não tinha os requisitos sócio-jurídicos do matrimônio. Outras vezes, o termo nupta indicava a menina menor de 12 anos (ante aetatem). Vejam-se Cic. Pro Cluent. 12,35; Macr. Sat. 1,15,22; Ulp. 35 ad ed. D.23,1,9; 
indivisível de vida". 93

Esta definição é semelhante à de Modestino, visto que não dispõe sobre os requisitos exigidos para a formação do matrimônio, mas prioriza a íntima comunhão entre os cônjuges e a recíproca participação deles na vida comum. ${ }^{94}$

A exigência da diversidade de sexo constitui uma condição natural no Direito Romano, sendo impossível imaginar o casamento ou o concubinato entre dois homens ou entre duas mulheres. ${ }^{95}$

Isso não impediu, todavia, que os romanos admitissem socialmente, sem ilicitude, a união homossexual, que apenas em um caso parece ter sido punida como crime: o da pederastia em relação ao cidadão romano livre e sui iuris. ${ }^{96}$

Scaev. 9 dig. D.24,1,66,1; Lab. 3 post. D.36,2,30.

${ }_{93}$ E. VOLTERRA, Matrimonio cit. (nota 61 supra), p. 754, afirma que este conceito de matrimônio das Institutas de Justiniano provavelmente é de autoria de Ulpiano ou de Florentino. Veja-se O. RoBLEDA, El matrimonio en Derecho Romano cit. (nota 10 supra), p.60, nota 2. Na opinião de A. LóPEZ PEDREIRA, Limitaciones a la 'libertas nuptialis' cit. (nota 40 supra), p.393, nota 10, pela semelhança de alguns termos entre Inst.1,9,1 e D.1,1,1,3, a definição é de Ulpiano, mestre de Modestino. Para C. PUJAL, La concepción jurídica cit. (nota 47 supra), p.607 e J. DAZA MARTíNEZ, La influencia cristiana cit. (nota 48 supra), p.111, nota 5, o trecho das Institutas é de Ulpiano, pois este jurista empregou palavras semelhantes em D.1,1,1,3: (...) hinc descendi maris atque feminae coniunctio. (vide pp.4-5, notas 8 e 9 supra).

94 O. RoBledA, Intorno alla nozione di matrimonio cit. (nota 17 supra), p.172 considera Inst.1,9,1 interpolado. Contra a interpolação neste trecho e em D.23,2,1, vejam-se E. ALBERTARIO, La definizione del matrimonio cit. (nota 78 supra), p.183; E. VOLTERRA, Matrimonio cit. (nota 61 supra), p.754, nota 62; C. PUJAL, La concepción jurídica cit. (nota 47 supra), p.609; J. DAZA MARTínEZ, La influencia cristiana cit. (nota 48 supra), p.111; C. ACCARIAS, Précis de droit romain cit. (nota 9 supra), p.190. AlBERTARIO sustenta a diferença da terminologia utilizada para indicar a coniunctio entre o homem e a mulher e confirma que os dois trechos são do período clássico: Modestino utiliza a expressão, maris et feminae; Ulpiano (ou Florentino), viri et mulieris. As duas definições mais importantes do matrimônio romano são de juristas clássicos. Sintetiza a idéia central dos dois conceitos, A. VILlaÇA AZEVEDo, Dever de Coabitação cit. (nota 61 supra), p.47: "Poder-se-ia, então, dizer, em fusão desses conceitos, que o casamento romano, além de ser a conjunção carnal do marido com sua mulher, é, também, o pleno consórcio de ambos, sua estreita comunhão de vida. Dois elementos, assim, destacam-se neste conceito: um de natureza material, que é a união sexual dos cônjuges, sua íntima convivência; outro de ordem imaterial ou espiritual, que é a comunhão assistencial, enquanto durar a sociedade matrimonial". Veja-se também A. VILlAÇA AZEVEDO, Deductio mulieris cit. (nota 64 supra), p.15.

${ }^{95}$ Quanto à união de pessoas do mesmo sexo em Roma, Ovídio ao falar sobre a "elegância" (ars 1,503-522) salienta que agem contra a natureza os homens que procuram o amor de outros homens (521-522: Cetera lascivae faciant, concede, puellae / Et siquis male vir quaerit habere virum: "Quanto ao mais, abandone-o, tanto às jovens lascivas quanto aos homens que, de modo contrário [à natureza], procuram ter um homem". Indica ampla bibliografia sobre o assunto A. ROMANO, Omosessualità, amore e potere nella società romana, in LABEO 36.2 (1990), pp. 301-306. Veja-se D. DALLA - R. LAMBERTINI, Istituzioni di diritto romano cit. (nota 10 supra), p.103.

${ }_{96}$ Antes do século III a.C., não era penalizado o stuprum de inimigos vencidos em guerra, escravos e até mesmo libertos. Houve uma Lei Scantinia de nefanda Venere de 149 a.C., que procurou reprimir a pederastia nas classes romanas mais importantes, principalmente o stuprum cum puero. Na República, o crime daqueles que desonrassem um homem ingênuo era punido com uma multa de 10.000 (dez mil) sestércios. As leis matrimoniais de Augusto não apresentaram qualquer disposição contrária à pederastia. Manteve-se esta pena pecuniária da Lex Scantinia durante o Principado e apenas no período pós-clássico, com a influência do Cristianismo, a pena foi agravada, com a morte e a deportação. Vejam-se Quint. Inst. Orat. 4,2,69: Ingenuum stupravit et stupratus se suspendit; non tamen ideo suprator capite ut causa mortis punietur, sed decem milia, quae poena stupratori constituta est, dabit. "Aquele que tinha ou teria cometido stuprum em ingênuo 
seja pendurado; isto não é causa para que o stuprator fosse punido com a morte, mas ele pagará dez mil sestércios, multa que é estabelecida aos stupratori."; Quint. Inst. Orat. 7,4,42; PS 5,4,14. Verifica-se a retomada da Lei Scantinia na época do imperador Domiciano (81-96 d.C.), juntamente com inúmeros dispositivos da Lex Iulia et Papia e da Lex Iulia de Adulteriis, dentre os quais aquele que determinava a incapacidade das feminae probrosae de capere heranças e legados. Provavelmente o termo feminae probrosae para indicar as mulheres de "conduta sexual vergonhosa" tenha surgido neste trecho de Suetônio. Veja-se Suet. Domitianus 8,4: Suscepta correctione morum licentiam theatralem promiscue in equite spectandi inhibuit; scripta famosa vulgoque edita, quibus primores viri ac feminae notabantur, abolevit non sine auctorem ignomina; quaestorium virum, quod gesticulandi saltandique studio teneretur, movit senatu; probrosis feminis lecticae usum ademit iusque capiendi legata hereditatesque; equitem $R$. ob reductam in matrimonium uxorem cui dimissae adulterii crimen intenderat, erasit iudicum albo; quosdam ex utroque ordine lege Scantinia condemnavit; incesta vestalium virginum, a patre quoque suo et fratre neglecta, varie ac severe coercuit, priora capitali supplicio, posteriora more veteri. "Pôs-se a reformar os costumes, ele não tolerou mais que qualquer espectador ocupasse um lugar no teatro entre os cavaleiros; ele destruiu as cartas difamatórias que se espalharam publicamente contra homens e mulheres, a maioria intencionalmente, não sem abolir a ignomínia dos autores; ele excluiu do senado um questor por causa de sua paixão pela pantomima e pela dança; ele proibiu às mulheres probrosae o direito ao uso de liteira e de receber legados e heranças: um cavaleiro Romano retomou como esposa uma mulher que ele havia repudiado após acusá-la de adultério; ele riscou seu nome da lista dos juízes [album iudicum]; ele condenou alguns membros das duas ordens em virtude da Lei Escantinia; os incestos das virgens vestais, dos quais seu pai ou seu irmão fecharam seus próprios olhos, ele puniu-os com severidade, de diferentes modos, primeiro pela pena capital, em seguida conforme os costumes dos antepassados".

Vejam-se R. AStOLFI, La Lex Iulia et Papia cit. (nota 15 supra), p.49; Idem, Femina probrosa, concubina, mater solitaria, in SDHI 31 (1965), pp.15;18-19;47;54; G. CASTELLI, Il concubinato e la legislazione augustea, in BIDR 27 (1915), pp.58;63; D. NÖRR, The matrimonial Legislation of Augustus, cit. (nota 54 supra), p.358; H. ANKUM, La 'captiva adultera' cit. (nota 63 supra), p.154, nota 4; M. MolÈ, Stuprum, in NNDI 18 (1957), p.587; A. RoMANO, Omosessualità, amore e potere cit. (nota 95 supra), pp.302-304; T. Mommsen, Römisches Strafrecht, Leipzig, 1899, trad. esp. de P. Dorado, Derecho Penal Romano, Santa Fé de Bogotá, Temis, 1999, pp.439-440; E. NARDI, La 'incapacitas' delle 'feminae probrosae', in SSA 17 (1939), pp.151-153;155-156. Juvenal também faz menção à Lei Escantínia, nas palavras de Laronia, considerada uma mulher infame pela sociedade da época e que fez uma menção sobre a pederastia no exército romano. Iuv. Sat. 2,43-47: Quod si vexantur leges ac iura, citari / ante omnes debet Scantinia; respice primum / et scrutare viros, faciunt qui plura; sed illos / defendit numeros iunctaeque umbone phalanges. / Magna inter molles concordia. / Non erit ullum exemplum in nostro tam detestabile sexu. "Não se envergonhe. Tu queres provocar as leis e os editos? Comecemos, no entanto, pela Lei Escantinia. Observa primeiro os homens, examina-os bem, o que muitos fazem; mas são tantos a fazê-lo que a própria ordem defende-os e estão bem protegidos na falange pelos escudos. Como é grande a concórdia entre estes efeminados! Nunca entre nosso sexo [feminino] se encontrará exemplo tão deplorável”.

Observa-se, ao menos no período pós-clássico, a aplicação da pena capital (decapitação) à pederastia (stuprum ao homem livre contra a sua vontade), conforme as Sentenças de Paulo, PS 2,26,12: Qui masculum liberum invitum stupraverit, capite punitur. "Quem comete stuprum com um homem livre, sem o seu consentimento, será punido com a pena capital" e também nas Institutas de Justiniano (Inst. 4,18,4), que afirma ser esta pena prevista já na Lex Iulia de Adulteriis coercendis: Item lex Iulia de adulteriis coercendis, quae non solum temeratores alienarum nuptiarum gladio punit, sed etiam eos, qui cum masculis infandam libidinem exercere audent. Sed eadem lege Iulia etiam stupri flagitium punitur, cum quis sine vi vel virginem vel viduam honeste viventem stupraverit. Poenam autem eadem lex irrogat peccatoribus, si honesti sunt, publicationem partis dimidiae bonorum, si humiles, corporis coercitionem cum relegatione. "Ainda, a lex Iulia de Adulteriis coercendis [Lei Júlia coercitiva dos adultérios], que não somente pune com a decapitação os conspurcadores do leito conjugal alheio, mas também os que se atrevem a exercer a nefanda libidinagem com os do mesmo sexo. Mas a mesma lex Iulia também castiga o escândalo do stuprum, quando alguém o tiver cometido, sem violência, contra uma virgem ou viúva de vida honesta. E ainda a mesma lei irroga aos criminosos, se de posição honorável, o confisco da metade dos bens; se são pessoas vis, açoites e o degredo". Para as Institutas, portanto, o stuprum também abrange as relações sexuais (cópula) que não apresentavam violência em seus atos, desde que praticadas com virgem ou viúva honesta.

Na coleção pós-clássica de Direito Romano e Mosaico denominada Mosaicarum et Romanarum Legum Collatio, o seu desconhecido autor realiza inúmeras comparações entre as leis do Pentateuco e a Legislação 


\subsubsection{Capacidade de procriação}

Um dos requisitos essenciais do iustum matrimonium e do conubium romano era a puberdade $^{97}$ (masculus pubes e femina viripotens), ou seja, os cônjuges, deveriam ter a capacidade de procriação (14 anos para os homens e 12 para as mulheres). ${ }^{98}$ O matrimônio

Romana. O stuprum em homem livre, contra a vontade deste (homossexualidade passiva), está disposto no Título V (De Stupratoribus) e foi comparado ao trecho 20,13 do livro do Levítico, no qual está disposto: “O homem que se deita com outro homem como se fosse uma mulher, ambos cometeram uma abominação, deverão morrer, e o seu sangue cairá sobre eles". Coll. 5,1,1: Moyses dicit: Qui manserit cum masculo mansione muliebri, aspernamentum est: ambo moriantur, rei sunt. "Moisés disse: É desprezível aquele que permaneceu com um homem em co-habitação mulheril. Ambos morram: são réus"; Coll. 5,2,1-2 [Paulus libro sententiarum II sub titulo de adulteris] (= PS 2,26,12-13): Qui masculum liberum invitum stupraverit, capite punietur, qui voluntate sua stuprum flagitiumque inpurum patitur, dimidia parte bonorum suorum multatur nec testamentum ei ex maiore parte facere licet. "Aquele que tenha cometido stuprum com um homem livre contra a sua vontade, será castigado com a pena capital. Aquele que por sua própria vontade sofre stuprum e desonra impura, é castigado com o confisco da metade de seus bens e não é lícito fazer testamento pela parte maior". Em Coll. 5,3,1, está disciplinada a condenação "do pudor efeminado no varão": (...)effeminati in viro pudoris contaminatione(...). Neste sentido, C.Th. 9,7,3 (342); C.Th. 9,7,6; Nov.77 e 141. Em relação à PS.2,26,12 e 2,26,13, K.C. CANELA, O 'stuprum per vim' no direito romano, Tese (Doutorado) - Faculdade de Direito da USP, São Paulo, 2009, p.85, nota 344, conclui que o "elemento caracterizador de um stuprum violento era justamente a ausência de consentimento do sujeito passivo da relação sexual". E complementa na p.86: "O fragmento contido em PS 2,26,12 referir-se-ia, não apenas ao estupro violento, mas também de prática sexual com uma pessoa livre sem pleno discernimento, isto é, incapaz de manifestar por si só a sua vontade" e que esses crimes "eram punidos com a pena capital já no final do período clássico".

${ }^{97}$ Segundo D. DALLA - R. LAMBERTINI, Istituzioni di diritto romano cit. (nota 10 supra), p.105, il requisito della pubertà discende dalla almeno potenziale funzione delle nozze quale 'seminarium' dello Stato e dalla conseguente necessità che le parti dispongano della maturità fisiologica. Segundo C. ACCARIAS, Précis de droit romain cit. (nota 9 supra), pp.203-204; A. RoMANO, Matrimonium iustum cit. (nota 26 supra), p.103; A. CALDERINI, Antichità private cit. (nota 19 supra), p.23 e G. CoRnIL, Droit Romain cit. (nota 55 supra), pp.3031, conjectura-se que uma lei régia promulgada por Sérvio Túlio no período da Realeza considerava os homens púberes aos dezessete anos, quando adquiriam o status civitatis, com a inscrição de seu nome na lista dos cidadãos (censo) e os direitos e deveres relativos à cidadania romana (iuniores). Como exteriorização desta nova condição jurídica, eles trocavam a toga pretexta (toga praetexta) pela toga viril (toga virilis) nos Liberalia, festa em honra ao deus Baco, que realizava-se em 17 de março e depositavam a bulla (bolinha de ouro, couro ou de outro metal que traziam ao pescoço) diante do altar dos Lares domésticos. Com esta idade, os jovens também estavam aptos a exercer o serviço militar. Vejam-se Ovid. Fast. 3,771-788; Catull. Carm. 68,15; Cic. Phil. 2,18. No Império, a troca da toga nos Liberalia não tem mais qualquer valor ou importância para se estabelecer o início da puberdade. Na opinião de M. DURRY, Sur le mariage romain - Autocritique et mise au point, in RIDA 3.3, pp.228;241-243, era prática comum em Roma a realização de esponsais e até mesmo de casamentos com meninas impúberes, menores de 12 anos. Vejam-se Dio Cass. 48,5; Suet. Claudius 26.

${ }^{98}$ É interessante analisar a opinião de Macróbio sobre o início da puberdade. Em um primeiro momento, ele parece seguir a opinião dos Sabinianos, estabelecendo o início da puberdade, tanto para os homens quanto para as mulheres, aos 14 anos, porém salienta que os juristas e os legisladores da época entenderam que as mulheres podiam casar-se dois anos mais cedo, em razão da festinatio votorum. Macr. Somnium Scipionis 1,6,71: Post annos autem bis septem ipsa aetatis necessitate pubescit; tunc enim moveri incipit vis generationis in masculis et purgatio feminarum. Ideo et tutela puerili quasi virile iam robur absolvitur, de qua tamen feminae propter votorum festinationem maturius biennio legibus liberantur. "Após duas vezes sete anos [14 anos], a vida atinge a puberdade pela própria idade; então, pois, inicia nos homens o poder de reprodução e nas mulheres a menstruação. Por esta razão, os meninos que daí em diante são homens, estão liberados da tutela pueril, da qual as meninas, por outro lado, são liberadas pelas leis dois anos mais cedo, por causa da pressa dos votos [nupciais]." Contra a communis opinio, M. DuRRY, Le mariage des filles impubères cit. (nota 49 supra), p.271, considera que a expressão maturius biennio do trecho de Macróbio, indica os doze anos de idade. 
do impúbere é inexistente (iniustum matrimonium), pois impossibilita a procriação entre os nubentes. ${ }^{99}$

Em outro trecho, porém, Macróbio seguiu a mesma opinião dos Proculianos, Macr. Sat. 7,7,6: (...) cum calor semper generationis causa fit, feminae ideo celerius quam pueri fiunt idoneae ad generandum quia calent amplius. Nam et secundum iura publica duodecimus annus in femina et quartus decimus in puero definit pubertatis aetatem. "(...) como a procriação é sempre realizada com calor, as mulheres se tornam aptas à procriação mais rapidamente que os homens, por que elas são mais quentes [ardentes]. Pois, e conforme os direitos públicos, delimita-se a idade da puberdade para a menina [mulher] no décimo segundo ano e para o menino [homem] no décimo quarto". Sobre o início da nubilidade, o Manual de Ginecologia de Soranos de Éfeso, o Gynaecia, também estabelece os 14 anos. Nesta obra, Soranos descrevia uma lista completa de critérios morfológicos para identificar uma mulher fecunda. A mulher, segundo este manual, tem capacidade de procriação dos 14 aos 40 anos. Uma Novela do imperador Leão (457-474) confirma a manutenção destes limites de idade no período pós-clássico. Nov. Leon. 109: (...) ne quo ante septimum aetatis annum sponsalia constituantur neque matrimonium sponsa duodecim, sponso vero quattuordecim annis minore confirmetur. “(...) não são constituídos os esponsais antes do sétimo ano de idade nem é confirmado o matrimônio antes dos doze anos para a sponsa e também para o sponsus menor de 14 anos". Veja-se D. Gourevitch, Se marier pour avoir des enfants: Le point de vue du médecin, in Parenté et stratégies familiales dans l'Antiquité romaine. Actes de la table ronde. (Paris, 2-4 octobre 1986), Rome, École Française de Rome, 1990, p.142.

${ }^{99}$ Vejam-se R. AsTOLFI, Il matrimonio nel diritto romano classico cit. (nota 10 supra), p.10; O. ROBLEDA, El Matrimonio en Derecho Romano cit. (nota 10 supra), pp.145-149; J.C. MoReIRA Alves, Direito Romano cit. (nota 9 supra), pp.131-132; E. NARDI, La reciproca posizione successoria dei coniugi privi di conubium, Milano, Giuffrè, 1938, p.4; E. VolTerRA, Matrimonio cit. (nota 61 supra), p.748; Idem, La conception du Mariage d'après les juristes romains cit. (nota 30 supra), p.46; D. DALLA - R. LAMBERTINI, Istituzioni di diritto romano cit. (nota 10 supra), pp.105-106; J. GAUDEMET, Justum matrimonium cit. (nota 51 supra), pp.112-113. Quanto ao interesse público sobre a capacidade de procriação dos nubentes, veja-se Ulp. 63 ad ed. D.42,5,17,1; Paul. 60 ad ed. D.42,5,18. Não era matrimônio a união com mulheres menores de 12 anos, nem gerava qualquer efeito jurídico, pela falta de dois requisitos essenciais para a sua existência: a idade e o consentimento. Porém, não sofria impedimento se, mesmo antes de completar a idade núbil, a mulher fosse conduzida (deducta sit) à casa do marido, tornando-se matrimônio, ipso iure, quando a mulher completasse os 12 anos. De acordo com E. VOLTERRA, La conception du Mariage d'après les juristes romains cit. (nota 30 supra), p.46, a simples vontade do homem é interpretada como uma prova da existência de vontade entre os cônjuges. M.J. GARCIA GARRIDO, Minor annis XII nupta cit. (nota 47 supra), pp.79-81;85-88, opina que a jurisprudência frequentemente recorreu a uma ficção jurídica para expressar a entrada da mulher inmatura na casa do homem por meio de cerimônias nupciais antecipadas e a sua coabitação. A convivência, neste caso, teria um aspecto meramente social, excluída, portanto, qualquer relação sexual entre a minor nupta e o futuro marido. Veja-se Pomp. 3 ad Sab. D.23,2,4: Minorem annis duodecim nuptam tunc legitimam uxore fore, quum apud virum explesset duodecim annos. "A casada menor de doze anos será mulher legítima quando tenha completado os doze anos [de idade] junto ao homem". De acordo com P. GIUNTI, Consors vitae cit. (nota 38 supra), pp.299-300, a mulher só se tornava legitima uxor ao completar 12 anos, pois falta-lhe a capacidade física para a procriação. GIUNTI defende nas pp.307-308, que neste caso narrado em D.23,2,4, há uma evolução gradual entre dois status distintos da mulher: primeiro, a condição de nupta, originada da celebração do rito e destinada a permanecer no tempo e, posteriormente, ao atingir a puberdade (12 anos), a condição de uxor, ou seja, quando pode alcançar a função reprodutiva do matrimonium.

Neste sentido, Ulp. 35 ad ed. D.23,1,9: Quaesitum est apud Iulianum, an sponsalia sint ante duodecimum annum, si fuerint nuptiae collatae. Et semper Labeonis sententiam probavi existimantis, si quidem praecesserint sponsalia, durare ea, quamvis in domo loco nuptae esse coeperit: si vero non praecesserint, hoc ipso quod in domum deducta est non videri sponsalia facta, quam sententiam Papinianus quoque probat. "Perguntou-se a Juliano se há esponsais antes do décimo segundo ano, se as núpcias foram ajustadas. E sempre aprovei a opinião de Labeão, que acredito, que se verdadeiramente precedessem os esponsais, estes subsistem, ainda que a mulher começou a estar na casa na qualidade de esposa: porém, se não tivessem precedido, por isto mesmo, porque foi conduzida à casa, não se consideram realizados os esponsais; cuja opinião Papiniano também aprova."

Nas opiniões de Papiniano e Labeão, não há iustum matrimonium com uma menor de 12 anos, pois o matrimônio é nulo. Pap. 10 quaest. D.23,3,68: (...) Nam et si minor annis duodecim ut maior deducta sit, tunc primum petetur, quum maior annis apud eundem esse coeperit (...) “(...) Porque também se a menor de doze 
No período clássico, para as mulheres, estabeleceu-se que a idade de procriação se iniciava aos 12 anos. Para os homens, os Sabinianos defendiam a exigência do exame corpóreo (habitus corporis, inspectio). Por outro lado, os Proculeianos defendiam a fixação da idade em 14 anos para que o homem se tornasse púbere. ${ }^{100}$

Gai. 1,196: Masculi autem cum puberes esse coeperint, tutela liberantur. Puberem autem Sabinus quidem et Cassius ceterique nostri praeceptores eum esse putant, qui habitu corporis pubertatem ostendit, is este eum qui generare potest; sed in his qui pubescere non possunt, quales sunt spadones, eam aetatem esse spectandam, cuius aetatis puberes fiunt. Sed diversae scholae auctores annis putant pubertatem aestimandam, id est eum puberem esse existimant qui XIV annos explevit.

\begin{abstract}
“Os varões, atingindo a puberdade, libertam-se da tutela. E Sabino e Cássio, assim como nossos outros mestres, consideram púbere quem manifesta a puberdade pela compleição do corpo, isto é, quem pode gerar; mas relativamente aos que se não podem desenvolver, como os eunucos, deve-se levar em conta a idade em que os outros se tornam púberes; mas os autores da outra escola entendem deva a puberdade ser estimada pela idade, isto é, consideram púbere quem completou catorze anos".
\end{abstract}

anos for conduzida à casa do homem [maior], será reclamada tão logo como se em poder do mesmo, começasse a ser maior com estes anos (...)"; Labeo 6 post.a Iav. Epit. D.24,1,65: Quod vir ei, quae nondum viripotens nupserit, donaverit, ratum futurum existimo. "Aquilo que o marido tiver doado à que se casou viripotens opinio que deverá ser válido"; Quint. Declam. Min. 12,22: Nuptiae in aliis sint sane necessariae, quamquam ne id quidem utique ius exigit, causam tamen nuptiae in domo hanc habent ostedendae voluntatis (...). Vejam-se também Pap. 8 resp. D.35,1,101pr.; Labeo 3 post. a Iavol. epit. D.36,2,30.

Contrário à communis opinio, M. DURRY, Sur le mariage romain cit. (nota 97 supra), pp.233-234; 240-241; Idem, Le mariage des filles impubères dans la Rome Antique cit. (nota 49 supra), pp.267-269, admite a possibilidade da ocorrência de relações sexuais no casamento com meninas impúberes. Ao fazer a exegese dos textos Pomp. 3 ad Sab. D.23,2,4; Labeo 6 post.a Iav. Epit. D.24,1,65 e Ulp. 2 de adult. D.48,5,13,8, DURRY defende que era costume que as mulheres se casassem em Roma antes dos 12 anos.

100 A determinação do início da puberdade feminina aos doze anos, já no período clássico, pode ser comprovada nos seguintes trechos: Ulp. 35 ad ed. D.23,1,9; Mod. 4 dif. D.23,1,14; Pap. 10 quaest. D.23,3,68; Hermog. 5 epist. D.23,3,74; Ulp. 33 ad sab. D.24,1,32,27; Lab. 6 post. a Iav. epit. D.24,1,65; Ulp. 2 ad l. Iul. et Pap. D.25,7,1,4; Labeo 3 post. a Iav. epist. D.36,2,30; Ulp. 83 ad ed. D.42,5,17,1; Ulp. 2 de adult. D.48,5,13,8. Vejam-se E. VOlTERRA, Matrimonio cit. (nota 61 supra), pp.736;746; S. PEROZZI, Istituzioni cit. (nota 26 supra), p.323; V. ARANGIO-RUIZ, Istituzioni cit. (nota 53 supra), p.439; A. LÓPEZ PEDREIRA, Limitaciones a la 'libertas nuptialis'cit. (nota 40 supra), pp.396-397; C. ACCARIAS, Précis de droit romain cit. (nota 9 supra), p.203, nota 1; G. CORNIL, Droit Romain cit. (nota 55 supra), pp.30-31; M.J. GARCIA GARRIDO, Minor annis XII nupta cit. (nota 47 supra), pp.83-85, nota 15; M. DURRY, Sur le mariage romain cit. (nota 97 supra), pp.235;236, nota 32; 237-239; Idem, Le mariage des filles impubères dans la Rome Antique cit. (nota 49 supra), pp.266-267;270; L.F. RADITSA, Augustus Legislation cit. (nota 49 supra), p.317; M. MARrone, Istituzioni cit. (nota 48 supra), p.218; M.B. FuMAGALLI, Sponsali cit. (nota 51 supra), p.506; J. GAUDEMET, Justum matrimonium cit. (nota 51 supra), pp.112-113. 
O jurisconsulto Javoleno Prisco, sabiniano, era ainda mais exigente, considerando que o homem era púbere apenas quando atingisse os catorze anos e após a realização do exame para averiguar a compleição corpórea.

UE 11,28: Liberantur tutela masculi quidem pubertate: puberem autem Cassiani quidem eum esse dicunt, qui habitu corporis pubes apparet, id est qui generare possit; Proculeiani autem eum, qui quattuordecim annos explevit; verum Priscus eum puberem esse, in quem utrumque concurrit, et habitus corporis, et numeros annorum.(...).

"Os homens saem da tutela pela puberdade. Os Cassianos consideram púbere quem mostra ser tal pela compleição física, isto é, quem pode gerar; os Proculianos, quem completou quatorze anos; mas Prisco julgou púbere quem tem os dois requisitos, o do físico e o da idade. (...)".

Esta controvérsia entre Sabinianos e Proculeianos foi resolvida definitivamente por Justiniano [Iust. C. 5,60,3 (529); Inst.1,22pr.]: prevaleceu neste caso a opinião dos Proculianos, o critério da fixação do início da puberdade aos doze anos para as mulheres e aos catorze para os homens (numerus annorum).

Não existe para a jurisprudência romana qualquer diferença entre a idade para a mulher se casar e a idade para tornar-se fisicamente apta à procriação, ou seja, ser "apta à relação sexual com o marido" (viripotens = quae virum pati potest $)^{101}$ : aos doze anos a mulher está formada fisiologicamente.

No início do Principado, a lex Iulia de maritandis ordinibus considerou a presunção da capacidade de procriação como critério para exigir que os homens entre os 25 e 60 anos e as mulheres entre 20 e 50 anos, se casassem. ${ }^{102}$

\footnotetext{
${ }^{101}$ Na opinião de M. DURRY, Le mariage des filles impubères cit. (nota 49 supra), pp.269;272-273, o termo viripotens não indicava "aquela que tem as suas primeiras menstruações", mas sobretudo, "aquela que pode, antes mesmo de sua formação, ter relações sexuais". Portanto, para DURRY, não há relação entre a idade núbil e a idade de formação corpórea. As mulheres eram núbeis (aptas ao casamento) antes de se tornarem púberes. O termo viripotens designaria, em suma, tanto as moças púberes quanto as impúberes, desde que elas pudessem suportar fisicamente a relação sexual com um homem.

${ }^{102}$ A finalidade do matrimônio levada em consideração é a capacidade do casal para a procriação. Porém, estes limites mínimos de idade, 12 anos para a mulher e 14 para o homem, não os obrigavam a casar-se imediatamente, segundo a Lex Iulia de maritandis ordinibus até porque, na data de sua promulgação, havia controvérsia entre sabinianos e proculianos sobre o início da puberdade. A legislação estabelecia um prazo maior, 25 anos para os homens e 20 para as mulheres, para que eles fossem considerados orbus e sofressem uma diminuição em sua capacitas sucessória. Em relação à tutela perpétua das mulheres (tutela mulierum) era uma restrição ao que denomina-se modernamente "capacidade de agir", visto que elas eram consideradas
} 
Esta lei penalizava o celibato e a falta de prole, com pesadas sanções fiscais e sucessórias. Eram concedidos praemia para os cônjuges com filhos e incentivos para aqueles que se divorciassem e casassem novamente. ${ }^{103}$

UE 16,1: Aliquando vir et uxor inter se solidum capere possunt, velut si uterque vel alteruter eorum nondum eius aetatis sunt, a qua lex liberos exigit, id est si vir minor annorum $X X V$ sit, aut uxor annorum $X X$ minor; item si utrique lege Papia finitos annos in matrimonio excesserint, id est vir LX annos, uxor L; item si cognati inter se coierint usque ad sextum gradum, aut si vir absit et donec abesset intra annum, postquam abesse desierit.

“Às vezes, os cônjuges podem reciprocamente tomar a totalidade dos bens: por exemplo, se ambos ou um deles não tiverem a idade a partir da qual a lei exige filhos, i.e., o marido

“relativamente capazes", sendo necessária a intervenção (assistência) de um tutor mulierum para a realização de determinados negócios: UE 11,27: Tutoris auctoritas necessaria est mulieribus quidem in his rebus: si lege aut legitimo iudicio agant, si se obligent, si civile negotium gerant, si libertae suae permittant in contubernio alieni servi morari, si rem mancipi alienent. Pupillis autem hoc amplius etiam in rerum nec mancipi alienatione tutoris auctoritate opus est. "A assistência do tutor é necessária às mulheres nos casos seguintes: se propuserem uma ação de lei ou pleitearem num juízo legítimo; se se obrigarem; se gerirem um negócio civil; se permitirem à sua liberta viver em contubérnio com escravo alheio; se alienarem coisa mancipi. Aos pupilos, além disso, é necessária a assistência do tutor também no caso de alienação de coisas nec mancipi". Segundo o trecho das Institutas de Gaio, Gai.1,190, já no século II d.C., a tutela mulierum estava em decadência e existia apenas formalmente: (...) mulieris enim, quae perfectae aetatis sunt, ipsae sibi negotia tractant et in quibusdam causis dicis gratia tutor interponit auctoritatem suam, saepe etiam invitus autor fieri a praetore cogitur. “(...) com efeito, as mulheres de idade perfeita cuidam, elas mesmas, dos próprios negócios e em certos casos o tutor interpõe sua autoridade por mera formalidade; muitas vezes é até obrigado a interpô-la, ainda contra sua vontade, pelo pretor". A tutela mulierum desapareceu formalmente no início do período pós-clássico (séculos III-IV). Vejam-se M.J. GARCIA GARRIDO, Minor annis XII nupta cit. (nota 47 supra), pp.84-85;87; D. DALlA - R. LAMBERTINI, Istituzioni di diritto romano cit. (nota 10 supra), pp.105;133; M. DURRY, Sur le mariage romain cit. (nota 49 supra), p.241; Idem, Le mariage des filles impúberes cit. (nota 49 supra), pp.267;269; K. GALINSKY, Augustan Culture, New Jersey, Princeton University, 1996, p.130.

${ }^{103}$ Eram considerados solidi capaces marido e mulher menores de 25 e 20 anos, respectivamente, mesmo que não tivessem filhos. Essa limitação de idade aos homens púberes menores de 25 anos coincide com a estabelecida pela Lex Laetoria ou Plaetoria do ano 191 a.C. Esta lei foi promulgada para a proteção dos filhos sui iuris (talvez em decorrência do grande número de mortes de patres na Segunda Guerra Púnica) na realização de "negócios jurídicos". Vejam-se S. RicCOBONO, La politica demografica di Augusto, in Capitolium 12 (1937), p.576; M. ZABŁOCKA, Il 'ius trium liberorum' nel diritto romano, in BIDR 91 (1988), p.362; Idem, Le modifiche introdotte nelle leggi matrimoniale Augustee sotto la dinastia Giulio-Claudia, in BIDR 89 (1986), p.384, nota 28; G. LoNGO, Lex Iulia de maritandis ordinibus e Lex Papia Poppaea, in NNDI 9, p.811; R. BESNIER, L'application des lois caducaires cit. (nota 10 supra), p.113; A. GUARINO, Storia del diritto romano, 12a ed., Napoli, Jovene, 1998, p.450; F. Della CorTe, Le 'leges Iuliae' e l'elegia romana cit. (nota 47 supra), p.544; L.R. ARGÜELlO, Manual cit. (nota 12 supra), p.435; M. TALAMANCA, Istituzioni cit. (nota 12 supra), p.137; R. Astolfi, La Lex Iulia et Papia cit. (nota 15 supra), pp.1; 2, nota 8; 24;210; B. BIONDI, La legislazione di Augusto cit. (nota 56 supra), pp.135-136; L. PEPPE, Storie delle parole cit. (nota 72 supra), pp.125-127, nota 7. Sobre a questão do lapso temporal entre a idade exigida para contrair núpcias (12-14 anos) e aquela exigida pela legislação matrimonial para ter filhos (20-25 anos), C. ORTíN GarCíA, Edad, Matrimonio y Lex Iulia et Papia Poppaea, in El Derecho de Familia: De Roma al Derecho Actual, Huelva, Universidad de Huelva, 2004, p.511, nota 11, considera esta diferença desproporcional e 
for menor de 25 anos ou a mulher de 20; igualmente, se ambos, segundo as normas da Lei Papia, ultrapassassem a idade para o casamento, i.e., o varão 60 anos e a mulher 50; o mesmo se os cônjuges forem parentes até o sexto grau; ou também se o marido for ausente, durante a ausência e dentro do ano posterior àquele em que acabou sua ausência”.

Os limites máximos de idade, presunções simples da incapacidade de procriação ${ }^{104}$, eram os 60 (sessenta) anos para os homens e os 50 (cinquenta) anos para as mulheres. Quando completassem estes limites máximos de idade previstos na legislação matrimonial de Augusto, os caelibes deixavam de sofrer as restrições legais e readquiriam a capacidade completa anterior. ${ }^{105}$

Este regime das leis matrimoniais, principalmente no campo sucessório, foi modificado na época de Tibério, pelo senatusconsultum Persicianum (ou Pernicianum) de 34 d.C, ano do consulado de Paulo Fábio Pérsico e de Lúcio Vitélio. Este senatusconsulto

excessiva.

${ }^{104}$ E. Domínguez LóPeZ, La impotencia en las 'Leges Iulia et Papia Poppaea', in El Derecho de Familia: De Roma al Derecho Actual, Huelva, Universidad de Huelva, 2004, pp.174-175.

105 E. Domínguez LóPEZ, La impotencia en las 'Leges Iulia et Papia' cit. (nota 104 supra), p.168; F. SAMPER, Sobre el destino del 'ius liberorum' en el tardo Derecho Romano Occidental, Santiago de Compostela, Universidad de Santiago de Compostela, 1972, p.10; D. DALLA, La vecchiaia nelle fonti giuridiche romane, in Ricerche di diritto delle persone, Torino, G. Giappichelli, p.81; Idem - R. LAMBERTINI, Istituzioni di diritto romano cit. (nota 10 supra), p.108; R. Astolfi, La Lex Iulia et Papia cit. (nota 15 supra), p.2, notas 8 e 10;41; C. ORTín GARCÍA, Edad, Matrimonio cit. (nota 103 supra), p.513, nota 15; M. ZABŁOCKA, Le modifiche cit. (nota 103 supra), pp.385;388; A. BOUCHÉ-LECLERCQ, Les lois démographiques d'Auguste cit. (nota 36 supra), p.262.

Plínio indica uma diferença de critérios para a avaliação da esterilidade entre homem e mulher. Parece indicar a certeza de esterilidade da mulher a partir dos cinquenta anos e a presunção do homem a partir dos 60 anos. Plin. Nat. Hist. 7,14,61-62: Mulier post quinquagensimum annum non gignit, maiorque pars XL profluuium genitale sistiti. Nam in viris Masinissam regem post LXXXVI annum generasse filium, quem Methimannum appellaverit, clarum est, Catonem censorium octogensimo exacto e filia Salonis clientis sui. Qua de causa aliorum eius liberum propago Liciniani sunt cognominati, hi Saloniani, ex quis Uticensis fuit. Nuper etiam L. Volusium Saturnino in urbis praefectura extincto notum est $<e>$ Cornelia Scipionum gentis Volusium Saturninum, qui fuit consul, genitum post LXII annum. Et usque ad LXXV apud ignobiles vulgaris reperitur generatio. "Passados os cinquenta anos, a mulher não tem mais filho; geralmente, ela vê cessar, aos quarenta anos, o fluxo menstrual. Quanto aos homens, é notório que o rei Masinissa gerou, completados oitenta e seis anos, um filho, que ele tinha chamado Methimanus, e que Catão, o censor, teve um [filho] da filha de Salonis, seu cliente, aos oitenta anos completos. Por esta razão, os filhos da primeira geração tiveram seus cognomes Licinianos, os outros, Salonianos - àqueles se vincula Catão de Útica. É de notoriedade pública que, ainda recentemente, como praefectus urbi, teve, com mais de sessenta e dois anos, de Cornélia, da família dos Cipiões, Volusius Saturninus o qual tornou-se cônsul. Aliás, até os setenta e cinco anos, as pessoas comuns frequentemente descobrem sua capacidade de geração"; Lac. Divin. Inst. 1,16,10: Non illepide Seneca in libris 'moralis philosophiae': 'Quid ergo est, inquit, quare apud poetas salacissimus Iuppiter desierit liberos tollere? Ultrum sexagenarius factus est et illi lex Papia fibulam impossuit?'. 'Não sem graça, Sêneca, em seus livros de filosofia moral, disse isto: 'Qual é a causa pela qual, segundo os poetas, o muito lascivo Júpiter deixou de ter filhos? Acaso porque tornou-se sexagenário e a Lex Papia impôs-lhe um cinto de castidade?". Paul. 33 ad ed. D.19,1,21 pr.: Si sterilis ancilla sit, cuius partus venit, vel maior annis quinquaginta, quum id emptor ignoraverit, ex empto tenetur venditor. "Se a escrava, cujo parto se vende, fosse estéril ou maior de cinquenta anos, o comprador ignorando isto, obriga-se o vendedor pela ação de compra". Sobre os direitos sucessórios dos filhos nascidos de mulher com mais de cinquenta anos no direito 
estendeu as sanções aos que não pudessem mais procriar em razão da idade, tanto os caelibes quanto os orbi, e portanto, aumentou o rigor das leis matrimoniais. ${ }^{106}$

O senatusconsultum Calvisianum de 61 d.C. ${ }^{107}$ também estabeleceu medidas que

justinianeu, veja-se Iust. C.6,58,12pr. (532).

${ }^{106}$ Vejam-se F. SAMPER, Sobre el destino del 'ius liberorum' cit. (nota 105 supra), p.10; E. VerA-CruZ, Senatus-Consulta, in Estudos de Direito Romano, vol.2, Lisboa, Associação Académica da Faculdade de Direito de Lisboa, 1991, p.187; C. ORTín GarCíA, Edad, Matrimonio cit. (nota 103 supra), p.514; L.F. RADITSA, Augustus Legislation cit. (nota 49 supra), pp.323-324; D. NÖRR, The Matrimonial Legislation of Augustus cit. (nota 54 supra), p.357; M. ZABŁOCKA, Le modifiche cit. (nota 103 supra), pp.385-386;388389;392-393; A. BOUCHÉ-LECLERCQ, Les lois démographiques d'Auguste cit. (nota 36 supra), p.278. Na opinião de E. Domínguez LóPEZ, La impotencia en las 'Leges Iulia et Papia Poppaea' cit. (nota 104 supra), p.172, o senatusconsulto Persiciano não estabeleceu limitações em relação à idade, mas aplicou simplesmente sanções de caráter sucessório. Este senatusconsulto teria corrigido uma incoerência apresentada pela legislação matrimonial de Augusto, ou seja, premiar aqueles que, apenas para escapar das sanções desta legislação, casaram-se em idade avançada, pois presumia-se a incapacidade para a procriação dos homens com mais de 60 anos e das mulheres com mais de 50 anos que não cumprissem seu dever público de ter filhos. A correção desta "incoerência", realizada pelo Senatusconsulto Persicianum, na opinião de R. BESNIER, L'application des lois caducaires cit. (nota 10 supra), p.103, estava em total contradição com a Legislação matrimonial de Augusto, pois pretendia apenas aumentar o seu rigor e atingir os sexagenários com incapacidades e sanções caducárias, além da idade limite prevista anteriormente. Para R. Astolfi, La Lex Iulia et Papia cit. (nota 15 supra), pp.41;353; Idem, Note per una valutazione storica della 'Lex Iulia et Papia' cit. (nota 36 supra), pp.214-215 e M. ZABŁOCKA, Le modifiche cit. (nota 103 supra), pp.388-389;392393, o principal objetivo deste senatusconsulto foi fiscal e buscava aumentar as rendas do "Estado" em virtude de uma crise econômica no governo de Tibério, em 33 d.C. Portanto, o senatusconsulto Persiciano teve pouco em comum com a legislação matrimonial de Augusto, pois a questão da procriação e o aumento dos cives romanos ficou em segundo plano. Tácito em Ann. 6,16-20, recorda que em 33 d.C., por causa da grave crise, Tibério estabeleceu um fundo de empréstimo aos bancos de cem milhões de sestércios, por três anos sem usura. Além disso, houve neste período um incentivo à atividade dos delatores. Salienta $\mathrm{R}$. Astolfi, Note per una valutazione storica della 'Lex Iulia et Papia' cit. (nota 36 supra), p.210, que no principado de Tibério, o aumento da população constituiria uma forma de impedir os interesses políticos da nobilitas. Portanto, havia uma política demográfica também neste período.

Segundo R. Astolfi, La Lex Iulia et Papia cit. (nota 15 supra), pp.13;354-355, na época de Vespasiano (6979 d.C.), provavelmente em 73 d.C., o Senatusconsulto Pegasiano estendeu as normas da Lex Iulia et Papia aos fideicomissos, também com o escopo de gerar um aumento nas rendas do "Estado", sem preocupações maiores com o problema demográfico. Gai.2,286-a: (...) Sed postea senatusconsulto Pegasiano proinde fideicommissa quoque ac legata hereditatesque capere prohibiti sunt; eaque translata sunt ad eos, qui in eo testamento liberos habebunt, ad populum, sicut iuris est in legatis et in hereditatibus, quae eadem aut simili ex causa caduca fiunt. “(...) Depois, pelo senatusconsulto Pegasiano foram igualmente proibidos [os orbi] de tomar, tanto fideicomissos como legados e heranças; e os fideicomissos se transferem aos herdeiros testamentários com filhos ou, se nenhum deles os tiver, ao povo, como é do direito nos legados e heranças caducos, por esta ou por causa semelhante". De acordo com R. BESNIER, L'extension des lois caducaires aux fidéicommis d'après Gaius - Institutes, II, 286 et 286a, in Mélanges Henri Lévy-Bruhl, Paris, Sirey, 1959, pp.27-28, a finalidade do Senatusconsulto Pegasiano era tornar caducos os fideicomissos destinados aos caelibes e aos orbi, para serem destinados ao Aerarium. Só seriam entregues estes bens se o fideicomissário estivesse de acordo com a legislação matrimonial, ou seja, casado e com filhos. Justiniano em Inst.2,23,5, confirma a promulgação deste Senatusconsulto no principado de Vespasiano (69-79 d.C.). Nota-se claramente que o escopo principal desta medida não é demográfica, mas fiscal. Vejam-se também A. BOUCHÉ-LeCLERCQ, Les lois démographiques d'Auguste cit. (nota 36 supra), p.281; R. Astolfi, Note per una valutazione storica della 'Lex Iulia et Papia' cit. (nota 36 supra), p.216.

${ }^{107}$ Segundo M. ZABŁOCKA, Le modifiche cit. (nota 103 supra), p.393, promulgado no principado de Nero, o senatusconsultum Calvisianum, parece ter um escopo mais fiscal e econômico que demográfico. A situação econômica do Império era de crise, devido principalmente aos gastos excessivos do poder público e às despesas nas Guerras da Armênia e da Bretanha, fatos que contribuíram para uma grave desvalorização da moeda em 64 d.C. De acordo com R. Astolfi, Note per una valutazione storica della 'Lex Iulia et Papia' cit. (nota 36 supra), p.215, este senatusconsulto confirma uma política de privilégios para a oligarquia senatorial-equestre. 
alteraram o conteúdo das Leis Matrimoniais e abrandou as severas disposições do senatusconsultum Persicianum. Ele apresentou disposições contra legem Iuliam et Papiam ao estabelecer válida a união conjugal entre uma mulher dentro dos limites de idade para se casar (ou seja, com menos de 50 anos) e um homem além desses limites (com mais de 60 anos). ${ }^{108}$

UE 16,4: Quod si maior quinquagenaria minori sexagenario nupserit, 'impar matrimonium' appellatur et senatus consulto Calvisiano iubetur non proficere ad capiendas hereditates et legata dotes, itaque mortua muliere dos caduca erit.

"Se a mulher maior de cinquenta anos se casar com menor de sessenta, o matrimônio se
chama impar, e pelo senatus-consulto Calvisiano, não aproveita para que se tomem as

${ }^{108}$ Vejam-se F. SAMPER, Sobre el destino del 'ius liberorum' cit. (nota 105 supra), p.10; E. VOLTERRA, Matrimonio cit. (nota 61 supra), pp.737, nota 28;772, nota 106; M. ZABŁOCKA, Le modifiche cit. (nota 103 supra), p.385-387;393; R. AstOLFI, La Lex Iulia et Papia cit. (nota 15 supra), pp.32;41-42, nota 3;353; A. GUARINO, Storia del diritto romano cit. (nota 103 supra), p.451; E. VERA-CRUZ, Senatus-Consulta cit. (nota 106 supra), p.187; C. ACCARIAS, Précis de droit romain cit. (nota 9 supra), p.203, nota 3; C. ORTín GARCÍA, Edad, Matrimonio cit. (nota 103 supra), p.515; E. DoMíngUEZ LóPEZ, La impotencia en las 'Leges Iulia et Papia' cit. (nota 104 supra), p.171; R. BESNIER, L'application des lois caducaires cit. (nota 10 supra), pp.102-104;115-116; L.F. RADITSA, Augustus Legislation cit. (nota 49 supra), p.324; V. ARANGIO-RUIZ, Istituzioni cit. (nota 53 supra), p.444.

Segundo R. Astolfi, Le exceptae personae nella lex Iulia et Papia, in BIDR 67 (1964), p.225; Idem, La Lex Iulia et Papia cit. (nota 15 supra), pp.43-44;145-146; M. ZABŁOCKA, Le modifiche cit. (nota 103 supra), p.387 e R. BESNIER, L'application des lois caducaires cit. (nota 10 supra), pp.115-117, o Senatusconsulto Calvisianum considerou irrelevante (impar) para o escopo da Lex Iulia et Papia o matrimônio de uma mulher maior de cinquenta anos com um homem menor de sessenta, ou seja, ambos são considerados caelibes (non proficere ad capiendas hereditates et legata), além de estabelecer o confisco do dote ou do legado pelo Erário, pois tornavam-se caducos. Portanto, o matrimônio da mulher com mais de cinquenta anos não era proibido, porém não produzia nenhum efeito no campo sucessório.

Contrário à disposição de UE 16,3, o Gnomon do Idiólogo, que fornece importantes informações sobre a aplicação das leis caducárias no Egito e seu regime fiscal, em seu §25, desconsiderava a presunção de que o homem com mais de sessenta anos ainda estava apto à procriação e determinava o confisco do dote da

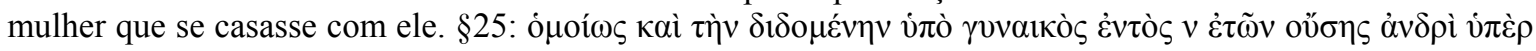

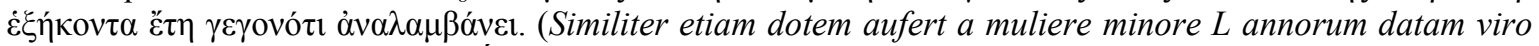
maiori sexaginta annos nato): "É igualmente confiscado o dote trazido por uma mulher com menos de cinquenta anos à um homem com mais de sessenta". Em relação ao dote de uma liberta latina, veja-se

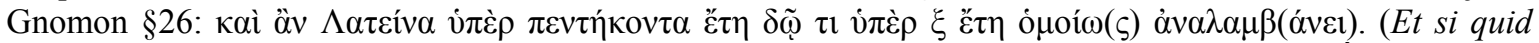
Latina maior quinquaginta annorum det [viro] maiori LX annorum, similiter aufert):"É igualmente confiscado o dote trazido pela liberta latina que tivesse mais de cinquenta anos à um homem com mais de

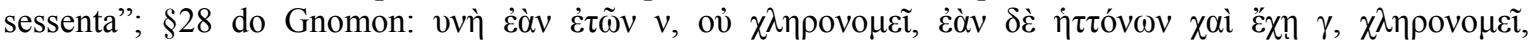

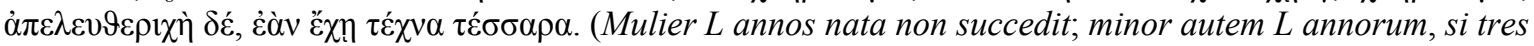
liberos habet, succedit, liberta autem si quattuor): "Uma mulher de cinquenta anos de idade não pode herdar. Se ela tem menos de cinquenta anos ela herda, desde que tenha três filhos ou se é liberta, quatro"; Gnomon

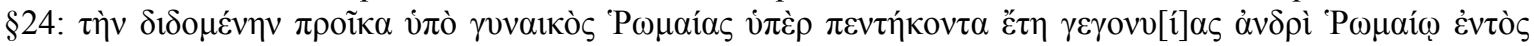

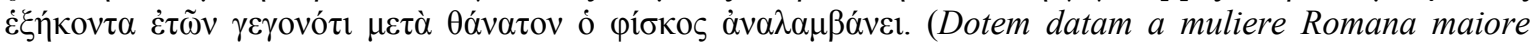
quinquaginta annos nata viro Romano minori sexaginta annos nato post mortem fiscus aufert): " $\mathrm{O}$ dote trazido por uma mulher romana, com mais de cinquenta anos, a um romano com menos de sessenta, é apreendido após a morte [da mulher] pelo Fisco". Veja-se também, Pap. 23 Quaest. D.23,2,61. 
heranças, bem como os legados e dotes. Assim, morta a mulher, o dote torna-se caduco”.

Portanto, apesar deste matrimônio impar não ser proibido, os cônjuges ficavam privados da capacitas recíproca, quer a sucessão fosse testamentária, quer fosse $a b$ intestato. $^{109}$

O senatusconsultum Calvisianum estabeleceu que o matrimônio da mulher com cinquenta anos, mesmo não sendo proibido, não produzia nenhum efeito jurídico no campo do direito das sucessões, uma questão que talvez tenha surgido com a promulgação, quase uma década antes, do senatusconsultum Claudianum. ${ }^{110}$

Conjectura-se que este senatusconsultum Claudianum, provavelmente do ano 52 d.C. ${ }^{111}$, já tivesse apresentado esta mesma disposição, ao dispensar das sanções da lex Iulia et Papia o homem com mais de 60 anos que se casasse com uma mulher com menos de 50 anos. Neste caso, ele readquiria a capacitas. ${ }^{112}$

UE 16,3: Qui intra sexagesimum vel quae intra quinquagesimum annum neutri legi paruerit, licet ipsis legibus post hanc aetatem liberatus esset, perpetuis tamen poenis tenebitur ex senatus consulto Perniciano. Sed Claudiano senatus consulto maior sexagenario si minorem quinquagenaria duxerit, perinde habebitur, ac si minor sexaginta annorum duxisset uxorem.

"Quem não obedecer nenhuma das suas leis até os sessenta anos ou cinquenta anos, conforme seja homem ou mulher, embora depois de tal idade se subtraia a estas leis, entretanto, por força do senatusconsulto Persiciano, estará sempre sujeito às penas; mas, pelo senatusconsulto Claudiano, o maior de sessenta anos que se casar com uma menor de cinquenta, se considera como se se casasse tendo menos de sessenta anos".

$\mathrm{Na}$ primeira parte do passo ulpianeo, o trecho perpetuis tamen poenis tenebitur indicava uma situação injusta, pois estabelecia que as pessoas mencionadas pelo

\footnotetext{
109 De acordo com J. GAUDEMET, Justum matrimonium cit. (nota 51 supra), p.129, a expressão impar matrimonium tinha um valor técnico, pois foi retomada em C.6,58,12,2. E. NARDI, Sui divieti matrimoniali delle leggi augustee, in SDHI 7 (1941), pp.133-134, nota 60, defende que o matrimônio impar era nulo e os cônjuges eram penalizados por não estarem de acordo com o escopo demográfico das Leis Matrimoniais.

110 A. BOUCHÉ-LECLERCQ, Les lois démographiques d'Auguste cit. (nota 36 supra), pp.279-280.

111 Para M. ZABŁOCKA, Le modifiche cit. (nota 103 supra), pp.392-393, o Senatusconsulto Claudiano foi votado entre o final de 48 d.C. e o início de 49 d.C., pois em 49 d.C., Cláudio casa-se com a sobrinha Agripina. Veja-se A. BouchÉ-LECLERCQ, Les lois démographiques d'Auguste cit. (nota 36 supra), p.278.

${ }^{112}$ F. SAMPER, Sobre el destino del 'ius liberorum' cit. (nota 105 supra), p.10; E. VOLTERRA, Matrimonio cit.
} 
senatusconsultum Persicianum estariam privadas perpetuamente de qualquer capacidade sucessória, mesmo quando contraíssem um matrimônio posterior de acordo com as determinações da lex Iulia et Papia. ${ }^{113}$

Para a aplicação da penalidade da lei (capacidade recíproca entre os cônjuges), não era essencial que ambos superassem a idade limite, bastando que um dos cônjuges superasse os 60 ou 50 anos como caelebs ou orbus.

Vale a pena ressaltar que o texto de Ulpiano não esclarece, em relação às sanções do senatusconsultum Persicianum, qual era a situação daqueles que, pouco antes de atingir os 60 e os 50 anos, tivessem contraído esponsais para casar-se menos de dois anos depois. É provável que esta situação não excluía o sponsus e a sponsa do âmbito dos caelibes.

Em relação à incapacidade de procriação dos homens com mais de 60 anos, Suetônio narra que o imperador Cláudio derrogou o senatusconsultum Persicianum, promulgado por Tibério e o sexagenário readquiriu a capacitas:

Suet. Claudius, 23,3: Capiti Papiae Poppaeae legis a Tiberio Caesare, quasi sexagenarii generare non possent, addito obrogavit.

"Ele [Cláudio] derrogou um capítulo que Tibério César tinha acrescentado à Lei Papia Poppaea como se os sexagenários fossem incapazes de gerar".

A parte final de UE 16,3 e o trecho de Suetônio indicam a alteração e a diminuição dos rigores impostos pelo senatusconsultum Persicianum com a inserção de um capítulo na lex Papia Poppaea que dispunha sobre a incapacidade de procriação dos homens com mais de 60 anos. O homem era beneficiado com uma "ficção favorável" pela qual se admitia estar ele de acordo com as leis caducárias. Note-se que Suetônio fez referência neste trecho apenas à lex Papia Poppaea. ${ }^{114}$

Portanto, conclui-se que tanto o senatusconsultum Calvisianum, quanto o

(nota 61 supra), p.737, nota 28; M. ZABŁOCKA, Le modifiche cit. (nota 103 supra), pp.385-387;393.

${ }_{113}$ M. ZABŁOCKA, Le modifiche cit. (nota 103 supra), pp.386-387.

${ }^{114}$ M. ZABŁoCKA, Le modifiche cit. (nota 103 supra), p.387; 392-393. A promulgação do Senatusconsulto Claudiano vincula-se mais às finalidades da legislação matrimonial de Augusto, considerando a hipótese que o homem com mais de 60 anos ainda estivesse em condições de procriar. Parece, porém, que a promulgação deste senatusconsulto beneficiava o próprio Cláudio. Após a morte de Messalina em 48 d.C., Cláudio temia incorrer nas sanções do Senatusconsulto Persiciano, pois estava próximo de completar os sessenta anos nesta época. Portanto, ele ab-rogou parcialmente o Senatusconsulto Persiciano, pois alterou apenas a condição dos homens para também beneficar-se. Cláudio, portanto, modificou as normas da Lex Iulia et Papia, porém, na opinião de M. ZABŁOCKA, op.cit., pp.392-393, sem a intenção de incentivar a procriação, mas, antes, para resolver uma situação jurídica pessoal que poderia prejudicá-lo, ou seja, perder a capacitas plena. 
senatusconsultum Persicianum alteraram e estabeleceram medidas mais rígidas às leis matrimonais de Augusto. ${ }^{115}$

Apenas no século VI, uma constituição de Justiniano (C.5,4,27) derrogou as disposições da lex Iulia et Papia e permitiu o matrimônio independente da idade dos cônjuges.

Iust. C.5,4,27: Sancimus, nuptias, quae inter masculos et feminas maiores vel minores sexagenariis lege Iulia vel Papia prohibitae sunt, homines volentes contrahere, et ex nullo modo vel ex nulla parte tales nuptias impediri.

"Ordenamos que as núpcias que foram proibidas pela lex Iulia et Papia entre homens e mulheres maiores ou menores de sessenta ou cinquenta anos não se impeçam de nenhum modo ou por nenhuma parte, desejando os homens contrair tais núpcias". ${ }^{116}$

\subsubsection{Impedimentos}

Os romanos estabeleceram alguns impedimentos ${ }^{117}$ matrimonais para aqueles que apresentassem algum tipo de incapacidade para a procriação, geralmente indicados nas fontes com os termos spado, castratus, eunuchus.

Por spadones ${ }^{118}$ os romanos indicavam os homens que não possuíam a capacidade de procriar desde o nascimento ou por fato posterior, originado voluntária ou involuntariamente por ação humana. ${ }^{119}$

\footnotetext{
${ }^{115}$ De acordo com M. ZABŁOCKA, Le modifiche cit. (nota 103 supra), pp.409-410, na época de Tibério, a lex Papia Poppaea tornou-se mais branda, enquanto a aplicação da lex Iulia de adulteriis tornou-se mais rígida. ${ }^{116}$ Veja-se neste sentido, Iust. C.6,58,12pr. (532).

117 De acordo com J. GAUDEMET, Justum matrimonium cit. (nota 51 supra), p.109, utiliza-se o termo impedimentum (Gai.1,61; Tryph. 9 disp. D.23,2,67,3; Ulp. 22 ad ed. D.24,1,3,1) e o verbo impedire não no sentido técnico que teria apenas com o direito canônico. Impedimentum nem sempre é utilizado para indicar as proibições matrimoniais.

${ }^{118}$ Ulpiano, para avaliar a capacidade dos spadones, realizou a exegese da Lex Iulia et Papia. Ulp. 1 ad l.Iul. et Pap. D.50,16,128: Spadonum generalis appellatio est: quo nomine tam hi, qui natura spadones sunt, item thlibiae thlasiae, sed et si quod aliud genus spadonum est, continentur. "A palavra spado é geral: denominação que inclue tanto aqueles que são spadones por natureza, assim como os castrados por corte ou esmagamento, como também qualquer outro gênero de spado". Para o jurista, o termo spadonum indica os impotentes por natureza (qui natura spadones sunt), os castrados (item thlibiae thlasiae) e qualquer tipo de impotentes para procriar (aliud genus spadonum). Vejam-se D. DALlA, L'incapacità di procreare nell'adozione e nella tutela in Ricerche di diritto delle persone, Torino, G. Giappichelli, 1995, p.112; E. Domínguez LóPeZ, La impotencia en las 'Leges Iulia et Papia Poppaea' cit. (nota 104 supra), pp.169-170; 175; R. ASTOLFI, La Lex Iulia et Papia cit. (nota 15 supra), p.2.

119 G. Sciascia, Eunucos, Castrados e Spadones no Direito Romano, in Varietà Giuridiche - Scritti brasiliani di diritto romano e moderno, Milano, Giuffrè, 1956, p.112.
} 
Nada impedia o casamento com o spado, pois apesar de sua esterilidade, esta poderia constituir uma falha orgânica temporária e este homem poderia tornar-se viável à procriação futuramente. A impotência relativa, portanto, não impedia a realização do matrimônio. $^{120}$

Por sua vez os castrati (castrados) ${ }^{121}$ são absolutamente incapazes para contrair casamento, por sua incapacidade de procriação (impotência para a realização do ato sexual). Este fato reforça a prova da importância da procriação como principal finalidade do matrimônio romano. ${ }^{122}$

\footnotetext{
${ }^{120}$ Segundo E. Domínguez LóPeZ, La impotencia en las 'Leges Iulia et Papia Poppaea' cit. (nota 104 supra), pp.171-175, nada indica se as leis de Augusto determinassem a proibição do matrimônio em relação aos spadones. Na opinião de R. Astolfi, La Lex Iulia et Papia cit. (nota 15 supra), p.3, não é possível estabelecer se foi a lei ou a jurisprudência que estabeceu a incapacidade de procriar por razões fisiológicas. Em D.50,16,128, segundo o autor, não é possível conjecturar se Ulpiano referia-se ao problema da validade do matrimônio ou das isenções em relação às obrigações matrimoniais. Além disso, o autor questiona se o termo spadones era utilizado juridicamente no período clássico. Veja-se C. ACCARIAS, Précis de droit romain cit. (nota 9 supra), p.203. De acordo com F. Schulz, Classical Roman Law cit. (nota 51 supra), pp.127-128, no período do Principado já é possível notar que a mentalidade dos romanos, fundamentada na gravitas, era contrária ao divórcio mesmo no caso de esterilidade de um dos cônjuges. Veja-se o exemplo de Trimalcião em Petron. Satiricon, 74,16.

${ }^{121}$ Castratus termo originado do verbo castro, -are que significa "cortar, podar, amputar, castrar" seria o homem, geralmente escravo, que se tornou impotente por meio de alguma intervenção, uma ação de castração. E. Domínguez LóPeZ, La impotencia en las 'Leges Iulia et Papia Poppaea' cit. (nota 104 supra), p.172.

${ }^{122}$ Conclui S. Perozzi, Istituzioni cit. (nota 26 supra), pp.322-323: Sono quindi incapaci di matrimonio $i$ castrati. Chi non sai castrato, ma solo impotente (frigidus, spado), è capace, perché non può constatarsi sicuramente la sua insufficienza al coito. L'impotenza è per questo motivo di divorcio. Tradução: "São, portanto, incapazes de contrair matrimônio os castrados. Aquele que não seja castrado, mas impotente (frigidus, spado), é capaz, uma vez que não se pode constatar seguramente a sua insuficiência ao coito. A impotência é, por isso, motivo de divórcio". No período justinianeu, conforme uma constituição promulgada por Justiniano Iust. C.5,17,10 (528) a impotência do marido, motivada por causas naturais, servia como iusta causa para a realização do divórcio. Nesta passagem, porém, não é considerada a impotência da uxor como justa causa para o divórcio: In causis iamdudum specialiter definitis, ex quibus recte mittuntur repudia, illud addimus, ut si maritus, uxori ab initio matrimonii usque ad duos annos continuos computandos coire minime propter naturalem imbecillitatem valeat: possit mulier, vel eius parentes, sine periculo dotis amittendae repudium marito mittere, ita tamen, ut ante nuptias donatio eidem marito servetur. "Às causas já especialmente definidas pelas quais legalmente são enviados os libelos de repúdio, acrescentamos a seguinte: se o marido, durante dois anos contínuos a contar do início do matrimônio, não puder, em virtude de impotência natural, coabitar, ordenamos que a mulher ou os seus pais possam, sem risco de perder o dote, enviar ao marido o libelo de repúdio, de modo que a doação ante nuptias seja conservada pelo marido". Vejase também Nov.22,6. Conforme V. ARANGIO-RuIZ, Istituzioni cit. (nota 53 supra), p.451 e E. VolTERRA, Divorzio cit. (nota 70 supra), p.63, a impotência do marido constituía, no período pós-clássico, uma das razões admitidas pelas constituições imperiais para a realização do divórcio bona gratia e ex iusta causa. Manifestada a impossibilidade do marido em manter relações sexuais com a sua esposa, contavam-se três anos a partir da data do casamento para que fosse possível o divórcio. De acordo com a Nov. 117, eram proibidas as segundas núpcias de cônjuges que tivessem dissolvido seu matrimônio por voto de continência. Na opinião de E. ALBERTARIO, Matrimonio (Roma) cit. (nota 61 supra), p.581, a proibição matrimonial aos castrados ocorreu apenas no período justinianeu.
}

Ulpiano estabelece uma distinção entre os impotentes por causas naturais, ou seja, que sofrem de alguma enfermidade ou causas congênitas de origem orgânica ou psíquica (spadones em sentido estrito) e os impotentes por causas acidentais (castrati, thlibiae, thlasiae): para os spadones há possibilidade de matrimônio. Ulp. 33 ad ed. D.23,3,39,1: Si spadoni mulier nupserit, distinguendum arbitror, castratus fuerit, necne, ut in castrato dicas dotem non esse; in eo, qui castratus non est, quia est matrimonium, et dos, et dotis 


\section{A função substitutiva da adoção em relação à filiação natural e seu caráter}

subsidiário em relação à procriação contribuíram às exigências demográficas da lex Iulia et

Papia. ${ }^{123}$ A adoção deve seguir o modelo da procriação (adoptio imitatur naturam). ${ }^{124}$

actio est. "Se a mulher tiver se casado com um spado, opino que se deve distinguir, se fora ou não castrado, de maneira que em relação ao castrado digas que não há dote; e em relação ao que não está castrado, que tenha dote e ação de dote, porque há matrimônio". Esta distinção entre os spadones e os castrati também pode ser observada em Ulp. 3 ad Sab. D.28,2,6pr.-1: Sed est quaesitum, an is, qui generare facile non possit, postumum heredem facere possit; et scribit Cassius et Iavolenus posse: nam et uxorem ducere et adoptare potest. Spadonem quoque posse postumum heredem et Labeo et Cassius scribunt: quoniam nec aetas nec esterilitas ei rei impedimento est. 1.Sed si castratus sit, Iulianus Proculi opinionem secutus non putat postumum heredem posse instituere, quo iure utimur. "Porém perguntou-se, se aquele que não possa gerar facilmente poderá instituir herdeiro a um póstumo; e escrevem Cássio e Javoleno que pode; porque pode casar e adotar. Escrevem Labeão e Cássio que também o spado pode instituir a um póstumo herdeiro, porque nem a idade, nem a esterilidade serve de impedimento para isto. 1. Porém se fosse um castrado, seguindo Juliano a opinião de Próculo, não acredita que se possa instituir a um póstumo herdeiro; deste direito usamos" e Marc. 4 regul. D.40,2,14,1: Sunt qui putant etiam feminas posse matrimonii causa manumittere, sed ita, si forte conservus suus in hoc ei legatus est. Et si spado velit matrimonii causa manumittere, potest; non idem est in castrato. "Há quem opine que também as mulheres possam manumitir por causa do matrimônio, mas deste modo, se por acaso à ela foi legado um co-escravo seu. E se o spado desejasse manumitir por causa do matrimônio, pode fazê-lo; o que não é o mesmo para o castratus". Vejam-se E. Domínguez LóPeZ, La impotencia en las 'Leges Iulia et Papia Poppaea' cit. (nota 104 supra), pp.171-173; A. Villaça AzeVEdo, Dever de Coabitação cit. (nota 61 supra), p.55; D. DAlla - R. LAMBERTINI, Istituzioni di diritto romano cit. (nota 10 supra), p.103; C. ACCARIAS, Précis de droit romain cit. (nota 9 supra), p.203, nota 2; R. Astolfi, La Lex Iulia et Papia cit. (nota 15 supra), p.3; E. MALDONADO DE LIZALDE, Lex Iulia de Maritandis Ordinibus. Leyes de familia del emperador César Augusto, in Anuario Mexicano de Historia del Derecho 14 (2002), p.550, nota 71.

${ }^{123}$ Para R. Astolfi, La Lex Iulia et Papia cit. (nota 15 supra), pp.27;361; Idem, Note per una valutazione storica della 'Lex Iulia et Papia' cit. (nota 36 supra), p.223 e A. BouchÉ-LECLERCQ, Les lois démographiques d'Auguste cit. (nota 36 supra), p.280, houve uma equiparação entre os filhos adotivos e os naturales, pois a adoção nunca constituiu qualquer ameaça à política demográfica de Augusto. Se o pai adotivo assume as responsabilidades e encargos relativos ao filho, deve também ter direito às vantagens que este filho adotivo lhe proporcione. Veja-se Paul. 3 ad l. Iul. et Pap. D.1,7,45: Onera eius, qui in adoptionem datus est, ad patrem adoptivum transferuntur. "Os ônus daquele que foi dado em adoção se transferem ao pai adotivo". Neste sentido, D. DALLA - R. LAMBERTINI, Istituzioni di diritto romano cit. (nota 10 supra), p.121: L'adozione crea artificialmente un figlio. Con essa un soggetto estraneo alla famiglia viene aggregato e posto sullo stesso piano dei figli procreati, in eguale sottomissione alla potestà del 'pater'.(...) Identica è la condizione di arrivo di tutti gli adottati: sono figli nella nuova famiglia. Em Gell. 2,15,4, observa-se que no capítulo VII da Lex Iulia, já havia uma equiparação entre os filhos adotivos e os procriados para a obtenção dos fasces, pois eram contados os filhos que estivessem sob a patria potestas do candidato: Sicuti kapite VII legis Iuliae priori ex consulibus fasces sumendi potestas fit, non qui pluris annos natus est, sed qui pluris liberos quam collega aut in sua potestate habet aut bello amisit. “Assim, segundo o capítulo VII da Lei Júlia [de maritandis ordinibus], é dada entre os cônsules a preferência em assumir as honras [fasces] do poder, não a quem tem mais anos, mas a quem tem mais filhos que o colega, quer ainda sob a potestas, quer perdido na guerra". Veja-se Ulp. 21 ad Sab. D.50,4,2: Quod ad honores pertinet, creditur in potestate filium habere etiam is, qui in patris potestate est. "Ao que se refere aos cargos [honras], acredita-se que tem seu filho sob sua potestas também aquele que está sob a potestas de seu pai”.

${ }^{124} \mathrm{O}$ adotante deve ter, pelo menos, 60 anos, pois é preciso dar prioridade à procriação de filhos dentro de um matrimônio legítimo (quia magis liberorum creationi studere debeat: "porque ele deve se dedicar mais à procriação dos filhos"). Ulp. 26 ad Sab. D.1,7,15,2: In adrogationibus cognitio vertitur, num forte minor sexaginta annis sit qui adrogat, quia magis liberorum creationi studere debeat: nisi forte morbus aut valetudo in causa sit aut alia iusta causa adrogandi, veluti si coniunctam sibi personam velit adoptare. "Nas ad-rogações o conhecimento versa sobre isto: se acaso quem ad-roga for menor de sessenta anos, porque ele deve se dedicar mais à procriação dos filhos; a não ser, porventura, que haja em causa uma doença ou um mau estado de saúde, ou alguma outra causa de ad-rogação, como, por exemplo, se se deseja adotar uma pessoa a si unida"; Ulp. 26 ad Sab. D.1,7,17,2: Et primum quidem excutiendum erit, quae facultates pupilli sint et quae eius, qui adoptare eum velit, ut aestimetur ex comparatione earum, an salubris adoptio possit pupillo intellegi: deinde cuius vitae sit is, qui velit pupillum redigere in familiam suam: tertio cuius idem 
Iav. 6 ex Cas. D.1,7,16: Adoptio enim in his personis locum habet, in quibus etiam natura potest habere.

“A adoção, pois, tem lugar naquelas pessoas nas quais também a natureza pode ter". ${ }^{125}$

O princípio de que a adoção imita o modelo da procriação, pode ser observado em um caso narrado por Cícero em 57 a.C., presente na obra De domo sua 14-34;36. Ao

aetatis sit, ut aestimetur, an melius sit de liberis procreandis cogitare eum quam ex aliena familia quemquam redigere in potestatem suam. "E na verdade primeiramente se deve extrair quais são os bens do pupilo e quais os daquele que quer adotá-lo, para que se estime por meio da comparação delas se a adoção pode ser entendida como favorável ao pupilo. Depois, qual é o tipo de vida deste que quer submeter o pupilo à sua família. Em terceiro lugar, qual é a idade dele, para que se estime se é melhor que ele cogite em gerar filhos do que trazer para sua potestas alguém de uma família alheia”. A regra de Ep. Gai. 1,5pr.: Adoptio naturae similitudo est, ut aliquis filium habere possit, quem non generaverit. "A adoção é uma imitação da natureza, a fim de que alguém possa ter como filho aquele que não gerou", foi difundida no período pós-clássico. Vejam-se B. BIONDI, Istituzioni cit. (nota 22 supra), p.422;425, nota 13; G. BRANCA, Adozione (Diritto romano), in ED 1 (1958), p.581; E. VolTERRA, Adozione (Diritto romano), in NNDI $1^{1}$ (1957), p.288; D. DALlA - R. LAMBERTINI, Istituzioni di diritto romano cit. (nota 10 supra), pp.124-127; M. SALVADORE, L'adozione di Clodio, in LABEO 38.3 (1992), p.287, nota 5.

${ }^{125}$ Contra essa opinião de Javoleno, Gai.1,103 (= Gai. 1 inst. D.1,7,2,1) estende a adoção e a adrogação também àqueles que não podem gerar: Illud vero utriusque adoptionis commune est, quod et hi qui generare non possunt, quales sunt spadones, adoptare possunt. "É, porém, comum a ambas as espécies de adoção, que mesmo aqueles que não podem gerar, como os spadones, podem adotar". No trecho gaiano, o termo spadones indica todo o tipo de impotentes, tanto por causas naturais quanto por castração. Neste mesmo sentido estão UE 8,6: Hi qui generare non possunt, velut spado, utroque modo possunt adoptare; idem iuris est in persona caelibis. "Os que não podem gerar, como o impotente, tanto podem adotar como adrogar; o mesmo se dando com relação aos caelibis"; Mod. 1 dif. D.1,7,40,2: Spado adrogando suum heredem sibi adsciere potest nec ei corporale vitium impedimento est. "O spado, por ad-rogação, pode admitir para si um heres suus; e não lhe é impedimento o vício corporal".

Posteriormente, no período pós-clássico, outro foi o critério para estabelecer a proibição da adoção. Em Inst. $1,11,9$, ao fazer-se uma distinção entre spadones e castrati, proíbe-se a adoção ao castrado exatamente por ele não ter qualquer possibilidade de procriar. Inst.1,11,9: Sed et illud utriusque adoptionis commune est, quod et hi, qui generare non possunt, quales sunt spadones, adoptare possunt, castrati autem non possunt. "Mas também é comum a ambas as espécies de adoção, que pode adotar mesmo quem não pode gerar, como os spadones, enquanto os castrados não podem". Vejam-se G. BRANCA, Adozione cit. (nota 124 supra), p.581; D. DAlla - R. LAmBertini, Istituzioni di diritto romano cit. (nota 10 supra), pp.123-124; M. SALVADORE, L'adozione di Clodio cit. (nota 124 supra), p.287.

Na opinião de D. Dalla, D. 50,16,135: Sui perché di uma 'Lex Specialis', in Iuris Vincula - Studi in onore di Mario Talamanca II, Napoli, Jovene, 2001, pp.349, nota 2 e 350, tanto o castrado quanto a mulher estéril não podiam adotar, no período justinianeu, exatamente em razão da grande difusão do princípio adoptio imitatur naturam. A mulher que não teve filhos naturais não podia adotar, mas uma exceção foi concedida, por concessão do príncipe (indulgentia principis) em Inst. 1,11,10 que permitiu à mulher adotar quando perdesse um filho. Verifica-se uma finalidade de reintegrar numericamente a família em que um dos filhos tenha morrido. Segundo C. RUSSO RUGGERI, Ancora sulla donna adottante, in LABEO 36.1 (1990), pp.64;68-70;74-75, ao comentar Marc. 26 dig. D.1,7,38: Adoptio non iure facta a principe confirmare portest. "A adoção que não foi feita conforme o direito pode ser confirmada pelo imperador", desde o início do Império o princeps poderia autorizar a adoção feita por uma mulher. O filho adotado pela mulher era considerado legítimo, equiparado aos filhos naturais. Vejam-se algumas concessões imperiais (ex sua indulgentia) que autorizavam a adoção pela mulher em Suet. Galba 4 (Adoptatus a noverca sua) e num rescrito de Diocleciano, Diocl. C.8,47,5 (291). Contra esta opinião, defende que a adoção por mulheres só ocorreu no período justinianeu, M. SALVADORE, L'adozione di Clodio cit. (nota 92 supra), pp.292, nota $16 ; 294-295$. 
invocar o ius pontificium, ele critica a adrogação de Clódio (patrício da classe senatorial) pelo jovem Fonteio (plebeu, triumvir monetalis em 57 a.C.) e salienta que um dos motivos da adoção em Roma era quod natura iam adsequi non postest ("o que neste momento não pode conseguir pela Natureza", ou seja, a procriação de filhos). ${ }^{126}$

Cic. De domo sua 34;36:

34. Quod est, pontifices, ius adoptionis? Nempe ut is adoptet qui neque procreare iam liberos possit et, cum potuerit, sit expertus (...)

Adoptat annos viginti natus, etiam minor senatorem. Liberorumne causa? At procreare potest, habet uxorem, suscipiet iam liberos; exheredarit igitur pater filium. (...)

36. Dico apud pontifices; nego istam adoptionem iure esse factam, primum quod eae vestrae sunt aetates ut is qui te adoptavit vel filii tibi loco per aetatem esse potuerit vel eo quo fuit, deinde quod causa quaeri solet adoptandi ut et is adoptet qui, quod natura iam adsequi non potest, legitimo et pontificio iure quaerat, et ita adoptet ut nequid aut de dignitate generum aut de sacrorum religione minuatur, illud in primis ne qua calumnia, ne qua fraus, ne qui dolus adhibeatur, ut haec similata adeptio filii quam maxime veritatem illam suscipiendorum liberorum imitata esse videatur.

“O que é, pontífices, o direito de adoção? Evidentemente que esta adoção é possível a quem, agora, não possa procriar filhos, porém tentou tê-los quando podia(...)

\footnotetext{
${ }^{126}$ Neste caso, Clódio tornou-se tribuno da plebe graças a adoção de Fonteio. Cícero estabeleceu como requisito principal para a adoção a impossibilidade de gerar filhos, em razão da idade avançada. A adoção em Roma muitas vezes tinha como principal finalidade a manutenção dos sacra de uma família na qual seus membros não tivessem mais condições de gerar descendentes. Cícero não considerava a adoção de Clódio legítima porque se supõe que Fonteio poderia ter filhos com a própria mulher, tinha capacidade de procriação, por ser jovem e recém-casado. Tecnicamente, ocorreu neste caso uma adrogatio e Cícero fica indignado com a situação, pela importância em relação ao ius publicum e pela omissão dos pontífices. Verificou-se, portanto, a extinção da família patrícia de Clódio e de seus respectivos ritos ao realizar a sua transferência para a família plebeia de Fonteio. É nítido o objetivo de Cícero neste caso: revogar os atos praticados por Clódio enquanto este ocupou o cargo de tribuno e criticar os requisitos que permitiram a sua candidatura. Portanto, no trecho analisado, Cícero considera irregular a adoção de Clódio por Fonteio e enumera no discurso diante dos pontífices os requisitos legais e consuetudinários de uma adoção legítima. Vejam-se D. DALLA, L'incapacità di procreare nell'adozione cit. (nota 118 supra), pp.117-118; Idem - R. LAMBERTINI, Istituzioni di diritto romano cit. (nota 10 supra), p.124; B. BIONDI, Istituzioni cit. (nota 22 supra), p.425, nota 13; M. SALVADORE, L'adozione di Clodio cit. (nota 124 supra), pp.286-290; C. ORTíN GARCÍA, Edad, Matrimonio cit. (nota 103 supra), p.513, nota 15.
} 
Um homem de vinte anos de idade, e além disso, menor, adota um senador. Para ter filhos? Mas, no entanto, pode procriar $^{127}$, tem esposa e agora terá filhos; então o pai deserdará o filho (...).

36. Digo diante dos pontífices; nego que esta adoção se realizou de acordo com o direito [pontifical], primeiro porque vossas idades são tais que quem vos adotou pode, pela sua idade, ou ocupar a posição de teu filho ou a posição que ocupou; além disso, porque se costuma exigir a causa da adoção de modo que adote aquele que, conforme as leis e o direito dos pontífices exija aquilo que agora não pode conseguir pela Natureza e adote de modo que não sofra qualquer diminuição a honra da família ou o culto das coisas sagradas; e sobretudo, que não se utilize nenhuma calúnia, fraude ou dolo, a fim de que esta adoção simulada de um filho pareça ter imitado, o mais possível, o fato real de gerar filhos”.

Estas adoções simuladas, que tinham escopo principalmente a obtenção de direitos sucessórios (capacitas) e de vantagens e privilégios em cargos públicos, além de burlar a lex Iulia et Papia, foram duramente criticadas no ano de 62 d.C. por Tácito ${ }^{128}$, e logo em seguida combatidas pelo poder público por um senatusconsulto denominado Memmiano de 63 d.C., da época de Nero. Geralmente, após alcançada a sua finalidade, as adoções eram dissolvidas pelos próprios adotantes. ${ }^{129}$

Para constituir esta relação análoga à procriação, deve haver entre adotante e adotado uma diferença de idade igual àquela que existe entre o pai e o filho natural. ${ }^{130}$

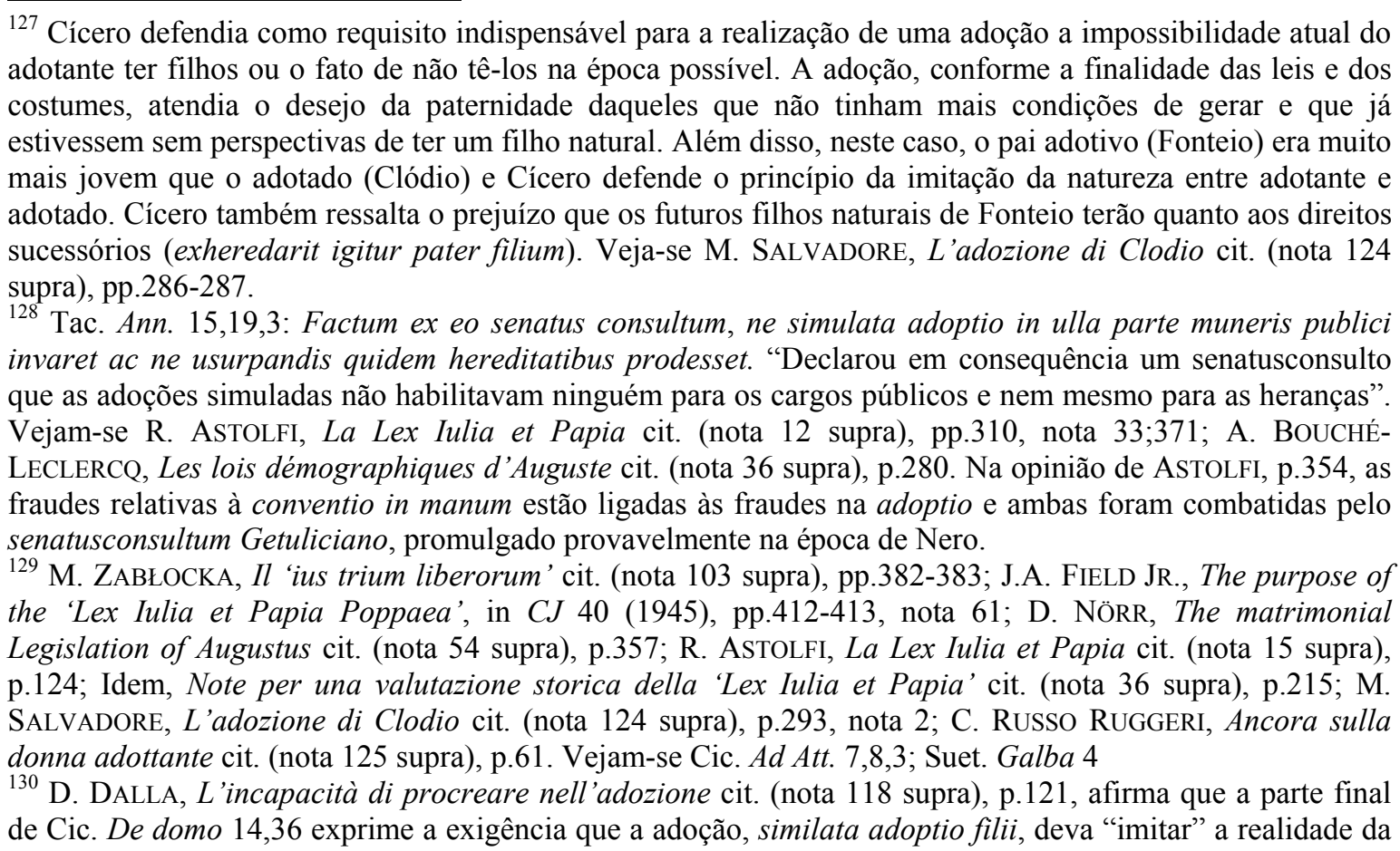


Portanto, a adoção e a ad-rogação em Roma, já no período clássico, reproduzem o evento biológico-jurídico da procriação legítima. ${ }^{131}$

\subsubsection{Finalidade}

\section{O matrimônio romano é a base e o fundamento do grupo designado como "família",} ou seja, a união conjugal que atende aos requisitos da civitas e à qual o próprio

procriação [veritatem illam suscipiendorum liberorum 'imitata' esse videatur]. Seria um primeiro indício do princípio adoptio imitatur naturam já no final da República. Na opinião de D. DALLA - R. LAMBERTINI, Istituzioni di diritto romano cit. (nota 10 supra), p.124, é possível admitir que no período clássico, cominciò a farsi strada l'esigenza, sino allora peraltro non ignota, che l'adozione dovesse in qualche modo seguire la natura, conformarsi alle sue regole e ad avere una funzione sussidiaria rispetto alla filiazione naturale. Modest. 2 reg. D.1,7,1 pr.: Filios familias non solum natura, verum et adoptiones faciunt. "Não só a natureza, mas também as adoções fazem os fillhos de família".

Quanto à diferença de idade entre adotante e adotado, Gaio (Gai.1,106) expressa uma quaestio resolvida definitivamente no período justinianeu, em concordância com o trecho de Cic. De domo sua 14-34,36, pois estabelece que o adotante (adrogante) deve ser, no mínimo, dezoito anos mais velho que o adotado: Sed et illud, de quo quaestio est, an minor natu maiorem natu adoptare possit, utriusque adoptionis communis est. "Mas é dúvida comum a ambas as espécies de adoção saber se o mais moço pode adotar o mais velho". Esta diferença mínima de idade entre adotante e adotado também é confirmada nos seguintes trechos: Mod. 1 dif. D.1,7,40,1: Non tantum cum quis adoptat, sed et cum adrogat, maior esse debet eo, quem sibi per adrogationem vel per adoptionem filium facit, et utique plenae pubertatis: id est decem et octo annis eum praecedere debet. "Não somente quando alguém adota, mas também quando ad-roga, deve ser maior do que aquele a quem fez filho por ad-rogação ou por adoção, e de qualquer maneira deve ser de plena puberdade, isto é, deve precedê-lo em ao menos dezoito anos" e Inst. 1,11,4: Minorem natu non posse maiorem adoptare placet: adoptio enim naturam imitatur et pro monstro est, ut maior sit filius quam pater. Debet itaque is, qui sibi per adrogationem vel adoptionem filium facit, plena pubertate, id est decem et octo aniis praecedere. "Determinamos que o mais jovem não pode adotar o mais velho. Pois, a adoção imita a natureza e é monstruoso seja o pai mais jovem que o filho. Por onde, quem perfilha alguém por adoção ou adrogação deve ser mais velho de plena puberdade, isto é, de dezoito anos". Vejam-se B. BIONDI, Istituzioni cit. (nota 22 supra), pp.422; 425, nota 13; C. RUSSO RUGGERI, Ancora sulla donna adottante cit. (nota 125 supra), p.59.

De acordo com P. GIUNTI, 'Mores' e 'Interpretatio prudentium' cit. (nota 26 supra), pp.307-309, a criação de uma relação "fictícia" de filiação entre adotante e adotado, de uma "procriação simulada" dentro de um matrimonium iustum, era indicado por Aulo Gélio com a expressão quam si ex eo patre matreque familias eius natus esset e por Próculo, quasi ex Lucio puta filio suo et ex matre familias eius natus esset. Nestes trechos, o termo materfamilias indicava o papel biológico da mãe, como artífice de um nascimento "fictício" e o complemento de especificação eius, vinculava a mulher ao pai natural (fictício), ou seja, ao paterfamilias adotante. Vejam-se Gell. 5,19,9: Eius rogationes verba haec sunt: 'Velitis, iubeatis, uti L. Valerius L. Titio tam iure legeque filius siet, quam si ex eo patre matreque familias eius natus esset, utique ei vitae necisque in eum potestas siet, uti patri endo filio est. Haec ita, uti dixit, ita vos, Quirites, rogo. "Dessa rogatio as palavras são essas: 'Queirais e ordenais que Lúcio Valério seja um filho para Lúcio Tício, por direito e por lei como se tivesse nascido deste pater ou desta materfamilias; em todo caso, haja para este [pater] o poder de vida e de morte sobre aquele, como é o do pai para com o filho. Assim, como eu disse, vos proponho estes termos, Quirites"; Procul. 8 epist. D.1,7,44: Si is, qui nepotem ex filio habet, in nepotis loco aliquem adoptavit, non puto mortuo avo iura consanguinitatis inter nepotes futura esse. Sed si sic adoptavit, ut etiam iure legis nepos suus esset, quasi ex Lucio puta filio suo et ex matre familias eius natus esset, contra puto. "Se alguém, que tem um neto do seu filho, adotou outro na qualidade de neto, reputo que não haverá os vínculos de consanguinidade entre os netos. Mas se adotou de tal forma que fosse por direito seu neto, como, por exemplo, tivesse nascido de seu filho Lúcio e da mater familias deste, reputo o contrário".

${ }^{131}$ P. GIUNTI, 'Mores' e 'Interpretatio prudentium' cit. (nota 26 supra), p.309. Vejam-se Gai.1,99; Gai. 1 inst. D.1,7,2pr. 
ordenamento relaciona determinados efeitos jurídicos. ${ }^{132}$

A afirmação sobre a procriação ser a principal finalidade do matrimônio romano, pode ser sustentada em diversas fontes jurídicas que apresentam determinadas expressões, v.g., "liberorum quaeredorum causa uxorem duxerit" nas Regras de Ulpiano 3,3; "liberorum procreandorum causa” em C.5,4,9 (do imperador Probo); “...qui liberorum procreandorum animo ex voto uxores ducunt...) em Call. 2 quaest. D.50,16,220,3 ${ }^{133}$.

\subsubsection{Fontes literárias e jurídicas}

Situado nos domínios do direito público e do direito de família e condicionado por conceitos antigos, cujo desenvolvimento foi frontalmente tolhido, o estudo da procriação humana sob o foco do interesse republicano em Roma exige aquela força extra, já recomendada metodologicamente, do estudo das fontes jurídicas e literárias da época. Retornar às fontes é importante para a compreensão de alguns conceitos antigos do sistema jurídico-religioso romano. ${ }^{134}$

Sem dúvida, a fórmula mais utilizada e que expressava a vontade de uma coabitação marital era aquela liberorum quaerundorum causa e parecia constituir, nas primeiras fontes literárias, uma condição jurídica necessária para a validade de um

\footnotetext{
${ }^{132}$ E. VOLTERRA, Famiglia cit. (nota 27 supra), p.741; O. RoBlEDA, Intorno alla nozione di matrimonio cit. (nota 17 supra), pp.175; 181; Idem, Sobre el Matrimonio en Derecho Romano, in SDHI 37 (1971), p.340; P. VEYNE, L'Empire Romain cit. (nota 19 supra), p.33.

${ }^{133}$ Vejam-se F. LANFRANCHI, Le definizioni e il concetto cit. (nota 78 supra), p.155; Idem, Il diritto nei retori romani cit. (nota 78 supra), p.223; O.M. PÉTER, Liberorum quaerendorum causa cit. (nota 21 supra), pp.285 e 305; L. D'AMATI, Matrimonium e Postliminium cit. (nota 63 supra), na p.44, nota 6, ao realizar a exegese do trecho de Tryph. 4 disp. D.49,15,12,4, afirma que o termo uxor indica a mulher casada com o marido liberorum sibi quaesendum gratia; uxor liberorum procreandorum causa. A qualidade de uxor já estabelecia, pelos menos no período arcaico e clássico, que a mulher convivesse liberorum procreandorum causa. Vejase R. ORESTANO, La struttura giuridica del matrimonio romano cit. (nota 1 supra), p.208, que afirma: Dal ponto de vista giuridico infatti l'espressione 'uxor liberorum procreandorum causa' non aveva un valore maggiore o diverso da quello che poteva avere l'indicazione fatta col solo termine di 'uxor'. Quintiliano indica que o simples desejo de procriar filhos não estabelecia os vínculos matrimoniais entre os cônjuges, pois não pode ser considerada uxor a mulher que não está casada legitimamente. Quint. Declam. 247: Uxor est quae femina viro nuptiis collocata in societatem vitae venit (...). Fingamus enim nuptias quidem fecisse nullas, coisse autem liberorum creandorum gratia: non tamen uxor non erit, quamvis nuptiis non sit collocata. "A esposa é aquela mulher que é unida ao marido pelas núpcias em sociedade na vida (...). Imaginamos, de fato, que as núpcias tivessem sido nulas, apesar de [a esposa] estar unida por causa da procriação dos filhos: não terá sido esposa, entretanto, posto que não estava unida pelas núpcias". Para A. ERNOUT - A. MeILlet, Dictionnaire Etymologique de la Langue Latine cit. (nota 4 supra), p.1341, uxor, oris designa a mulher unida ao homem liberorum quaesendum gratia e completam os autores que a palavra opõe-se a vir nos textos das leis. O termo coniux e mulier também podem representar a mulher casada, porém eram mais utilizados no âmbito familiar.

${ }^{134}$ M.P. BACCARI, Persona e famiglia cit. (nota 16 supra), pp.21-22; P. CATAlANO, Religione morale diritto nella prospettiva dello 'Ius Romanum' cit. (nota 3 supra), p.394. CATALANO, em seu artigo Diritto, soggetti, oggetti cit. (nota 11 supra), p.102, afirma que o principale obiettivo moderno dei romanisti deve essere quello di ricostruire la memoria storica dei giuristi tornando alle fonti(...). Tradução: "Principal objetivo moderno dos romanistas deve ser o de reconstruir a memória histórica dos juristas retornando às fontes(...)".
} 
casamento romano. $^{135}$

Esta fórmula apareceu pela primeira vez nas fontes literárias no século III a.C, em uma obra de Plauto. ${ }^{136}$ Posteriormente, no século II d.C., Festo e Aulo Gélio citam duas fórmulas semelhantes, utilizadas por Ênio (liberorum quaesendum gratia e liberorum quaesendum causa). ${ }^{137}$

Suetônio menciona a fórmula liberorum quaerundorum causa ao narrar a história escandalosa de Júlio César (Suet. Iulius Caesar 52, 5-6) sobre a sua intenção de legalizar a poligamia em Roma, conforme a acusação do Tribuno da Plebe Helvius Cinna:

Helvius Cinna TR. PL. plerisque confessus est habuisse se scriptam paratamque legem, quam Caesar ferre iussisset cum ipse abesset, ut ei uxores liberorum quaerundorum causa quas et quot vellet ducere liceret; at ne cui dubium omnino sit et impudicitiae et adulteriorum flagrasse infamia, Curio pater quadam eum oratione "omnium mulierum virum et omnium virorum mulierem" appellat. ${ }^{138}$

“Helvius Cinna, tribuno da plebe, confessou a um grande número de pessoas que tivera em mãos um texto totalmente pronto de uma lei redigida apressadamente por ordem de César a

135 O.M. PÉTER, Liberorum quaerendorum causa cit. (nota 21 supra), p.307. Nas palavras de P. GIUNTI, 'Mores' e 'Interpretatio prudentium' cit. (nota 26 supra), pp.305-306, alla donna viene positivamente richiesto soltanto di attualizare, con la nascita del figli, il senso di quella unione costituita 'liberorum quaerendorum causa'.

${ }^{136}$ Plaut. Capitivi 4,2,109: Liberorum quaerundorum causa ei, credo, uxor datast. "A esposa foi dada à ele, creio, para ter filhos". Veja-se também Plaut. Aul. 2,1,25: (...) Salutare sit, liberis procreandis... - ita di faxint - volo te uxorem domum ducere (...) “(...) Te saúdo [faço votos], para que procries filhos... - Assim seja feito pelos deuses - Desejo que tu te cases (...)".

${ }^{137}$ Fest. s.v. Quaeso: Quaeso, ut significat idem quod rogo, ita quaesere ponitur ab antiquis pro quaerere, ut est apud Ennium (...) in Cresphonte: ducit me uxorem liberorum sibi quaesendum gratia; et in Andromeda: liberorum quaesendum causa familiae matrem tuae. "Quaeso [pedir, suplicar]. Se esta palavra significa o mesmo que rogo [pedir, solicitar, rogar], os antigos utilizaram quaesere por quaerere [obter, procurar obter, exigir], como está em Ênio (...), em Oresfonte: Ele me pediu para casar a fim de obter filhos; e em Andrômeda: Por causa de ter filhos, para dar uma mãe à tua família". Aulo Gélio utiliza a expressão liberorum quaesendorum gratia em Gell. 17,21,44. Macróbio menciona que tem origem e é consagrada pela religião romana a finalidade do casamento para ter filhos. Ao mencionar neste trecho a fórmula liberorum quaerendorum causa, ele salienta a utilidade pública da procriação para fornecer mais soldados à respublica e ao exército romano. Veja-se, Macr. Sat. 1,16,18: Mundus cum patet, deorum tristium atque inferum quasi ianua patet: propter ea non modo praelium committi, verum etiam dilectum rei militaris causa habere, ac militem profisci, navem solvere, uxorem liberorum quaerendorum causa ducere, religiosum est. "Quando o mundus abriu, a porta das divindades da adversidade e do inferno também pôde ser considerada como aberta: isto porque é religioso, além disso, não só começar um combate, mas na verdade também erguer os soldados, partir para a guerra, levantar a âncora, casar-se para ter filhos". Vejam-se também, F. LANFRANCHI, Il diritto nei retori romani cit. (nota 78 supra), p.223, nota 6; O.M. PÉTER, Liberorum quaerendorum causa cit. (nota 21 supra), p.313; R. ORESTANO, La struttura giuridica del matrimonio romano cit. (nota 1 supra), pp.206207, nota 857; E. VolterRA, La conception du Mariage d'après les juristes romains cit. (nota 30 supra), p.44, nota 70; R. ASTOLFI, Il matrimonio nel diritto romano classico cit. (nota 10 supra), p.4, nota 7.

${ }^{138}$ Conforme O.M. PÉTER, Liberorum quaerendorum causa (nota 21 supra), p.310, esta acusação de Helvius Cinna não tem fundamento algum, trata-se apenas de uma tentativa de denegrir a imagem de César, seu adversário político. 
fim de que fosse proposta na sua ausência, permitindo-lhe casar-se, à vontade, com tantas mulheres que ele quisesse para ter filhos. Mas, para que não houvesse qualquer dúvida de que ele fosse flagrado na infâmia de impudicícia e de adultérios, Curião, o pai, chamou-lhe num de seus discursos "o homem de todas as mulheres e a mulher de todos os homens".

Valério Máximo na obra Facta et dicta memorabilia 7,7,4 narra a história de uma mulher idosa que, para vingar-se da ingratidão dos filhos e deserdá-los, casou-se com um homem também idoso e não mencionou-os em seu testamento.

Val. Max. 7,7,4: Septicia quoque mater Trachalorum Ariminensium irata filiis in contumeliam eorum, cum iam parere non posset, Publicio seni admodum nupsit, testamento etiam utroque praeterito; a quibus aditus divus Augustus et nuptias mulieris et suprema iudicia improbavit: nam hereditatem maternam filios habere iussit, dotem, quia non creandorum liberorum causa coniugium intercesserat, virum retinere vetuit; si ipsa aequitas hac de re cognosceret, potuitne iustius aut gravius pronuntiare? Spernis quos genuisti, nubis effeta, testamenti ordinem violento animo confundis neque erubescis ei totum patrimonium addicere, cuius pollincto iam corpori marcidam senectutem tuam substravisti; ergo dum sic te geris, ad inferos usque caelesti fulmine adflata es.

“Septícia, mãe dos Trachales de Ariminum, irada com os filhos, para prejuízo deles, quando ela não podia mais dar à luz, decidiu casar-se com Publício, um homem bastante idoso e, além disso, silenciou para ambos os lados em seu testamento; os quais [os filhos] se dirigiram ao divino Augusto e a sentença suprema que desaprovou o casamento da mulher: de fato, ele ordenou ter os filhos direito à herança materna e, porque o casamento não era para ter filhos, ele proibiu o marido reter o dote; se a própria equidade julgou este litígio, acaso ela podia declarar-se mais justa ou mais séria? Tu rejeitas aqueles que geraste; tu te casas estando já esgotada [para a procriação]; confundes, com violenta vontade, a ordem do testamento e nem te envergonhas em entregar todo o teu patrimônio a este idoso já prestes a se preparar para o enterro, ao qual submetes a velhice de teu corpo estragado; portanto, enquanto procedeu desta maneira, foi fulminada por um raio celeste e precipitada no inferno".

Ao apreciar o caso, Augusto declarou inválido tanto o casamento (et nuptias 
mulieris et suprema iudicia improbavit) quanto o testamento (nam hereditatem maternam filios habere iussit), para proteger o patrimônio dos filhos e utilizou para isso a fórmula creandorum liberorum causa. Restituiu a herança e o dote aos filhos alegando que a finalidade do casamento legítimo dos romanos é ter filhos, o que não poderia mais ocorrer com o casamento destes idosos, sem capacidade de procriação. ${ }^{139}$

Tácito utiliza a fórmula liberorum causa ao narrar a celebração das núpcias entre Messalina $^{140}$, então esposa do imperador Cláudio ${ }^{141}$, e seu amante Sílio.

\footnotetext{
${ }^{139}$ Neste caso, os bens destinados aos terceiros no testamento cabiam, por sucessão pretoriana (ab intestato) aos filhos do primeiro casamento. Além disso, a constituição do dote era inválida, pois os bens dotais deveriam ser destinados aos filhos, não ao viúvo. Os filhos nascidos no primeiro matrimônio são herdeiros legítimos da mãe e podiam impugnar a constituição do dote, se este superasse os três quartos da herança. Vejam-se T. Spagnuolo Vigorita, Casta Domus cit. (nota 26 supra), p.59; R. Astolfi, La Lex Iulia et Papia cit. (nota 15 supra), pp.45-46;118; J.M. RIBAS-AlBA, La desheredación injustificada em Derecho Romano - Querella inofficiosi testamenti: Fundamentos y régimen clásico, Granada, Comares, 1998, pp.167, nota 262; 247, nota 270. Segundo A.A. CASTRO CoRRÊA, O Estoicismo no Direito Romano cit. (nota 33 supra), pp.85-86, houve no final da República, sob a influência do Estoicismo, uma orientação humanizadora do direito e o pretor instituiu a querela inofficiosi testamenti para a proteção do parentesco e do respeito que deve existir entre os membros de uma família. Aplicava-se quando o testador omitia injustamente os parentes próximos e dava preferência a terceiros em suas disposições testamentárias. Na opinião de R. AstolfI, op.cit., p.46, esta decisão de Augusto foi o modelo para a promulgação do senatusconsultum Persicianum, em 34 d.C., que invalidava o matrimônio entre idosos, além de tutelar os interesses dos filhos nascidos nas primeras núpcias.

${ }^{140}$ No caso de Messalina, apenas uma dissolução prévia, expressa ou tácita, do matrimônio com o imperador Cláudio permitiria a validade das núpcias com Sílio. A celebração de um segundo matrimônio não produzia, ipso iure, a dissolução do matrimônio anterior. Vejam-se O. ROBLEDA, Cic. de Orat. 1,40,183;56,283, y el divorcio de Mesalina, in SDHI 42 (1976), pp.429-430; Idem, Il divorzio in Roma cit. (nota 51 supra), pp.386;376-377, nota 151; E. VOLTERRA, La conception du Mariage à Rome cit. (nota 30 supra), p.350; Idem, Les formes du Mariage chez les Romains cit. (nota 30 supra), p.277-278. Sobre a degradação dos costumes de Messalina, afirma V. VANOYEKE, La prostitution em Grèce et à Rome, Paris, Les Belles Lettres, 1990, pp.126-129 que a lista de amantes de Messalina é impressionante, membros do exército e das classes senatorial e equestre, além de seu meio-irmão Vinícius.

${ }^{141}$ Nas opiniões de C. PUJAL, La concepción jurídica cit. (nota 47 supra), pp.606;618-619; J. DAZA MARTíneZ, La influencia cristiana cit. (nota 48 supra), 2004, pp.134-135; D. DALLA - R. LAMBERTINI, Istituzioni di diritto romano cit. (nota 10 supra), p.105; M. MARRONE, Istituzioni cit. (nota 48 supra), p.220; E. VOLterRA, Les formes du Mariage chez les Romains cit. (nota 30 supra), p.282; Idem, La conception du Mariage d'après les juristes romains cit. (nota 30 supra), pp.59;64-65; Idem, Divorzio cit. (nota 70 supra), p.63; A. BuRdeSe, Manuale cit. (nota 47 supra), p.270; O. RoBledA, Cic. de Orat. 1,40 cit. (nota 140 supra), pp.429, nota 10;430, Idem, Il divorzio in Roma cit. (nota 51 supra), pp.385-386, J. GAUDEMET, Justum matrimonium cit. (nota 51 supra), p.151; não existia o crime de bigamia no direito romano pré-clássico e clássico, pois não era possível existir a affectio maritalis em relação à duas ou mais pessoas diferentes ao mesmo tempo. A affectio, neste caso, cessaria em relação ao primeiro matrimônio e a nova relação seria considerada um stuprum ou um concubinato. Um matrimônio com outra pessoa dissolve automaticamente o matrimônio precedente. Este trecho do Digesto atribuído ao jurista Marcelo confirma a opinião dos jurisconsultos do período clássico (plerique opinatur) sobre a impossibilidade do crime de bigamia nesta época, pois o segundo matrimônio dissolveria ipso iure o primeiro. Marcell. 3 ad l. Iul. et Pap. D.23,2,33: Plerique opinantur, quum eadem mulier ad eundem virum revertatur, id matrimonium idem esse; quibus assentior, si non multo tempore interposito reconciliati fuerint, nec inter moras aut illa alii nupserit, aut hic aliam duxerit, maxime si nec dotem vir reddiderit. "Muitos opinam que, quando a mesma mulher volta ao mesmo marido, este matrimônio é o mesmo; e confirmo a opinião deles, se se reconciliarem não tendo muito tempo intercalado e se, no espaço de tempo, ou ela não casasse com outro ou ele não se casasse e, sobretudo, se o marido não devolvesse o dote”. G. LONGO, Riflessioni critiche cit. (nota 48 supra), pp.2381-2382, defende que um segundo matrimônio seria apenas um "indício probatório" do divórcio. A dissolução do primeiro matrimônio não pode ser declarada implicitamente.
} 
Tac. Ann. 11,27: Haud sum ignarus fabulosum visum iri tantum ullis mortalium securitatis fuisse in civitate omnium gnara et nihil reticente, nedum consulem designatum cum uxore principis, praedicta die, adhibitis qui obsignarent, velut suscipiendorum liberorum causa, convenisse, atque illam audisse auspicum verba, $<$ vota $>$ subisse, sacrificasse apud deos; dicutibum inter convivas, oscula, complexus, noctem denique actam licentia coniugali. Sed nihil compositum miraculi causa, verum audita scriptaque senioribus trado.

“Confesso, que parecerá um conto fabuloso, que existiram pessoas de um tal atrevimento no meio de uma grande cidade que tudo via e nada calava; e que houvesse um homem, e ainda mais um cônsul eleito, que chegasse a ter a impudência de casar com a mulher do seu príncipe em um dia antecipadamente estabelecido, e diante de testemunhas que confirmaram o ato, como para uma união destinada à gerar filhos, e que a mulher (Messalina) ouvisse as palavras dos áugures; fizesse promessas solenes; sacrificasse aos deuses; assistisse às bodas entre os convidados; recebesse ósculos e abraços; e, por fim, por passar depois a noite em liberdade conjugal. Contudo, não tenho inventado nada para fazer deste fato coisa extraordinária: refiro fielmente o que eu mesmo tenho ouvido e o que escreveram os mais velhos". 142

Um dos trechos mais conhecidos em que a fórmula liberorum quaerendorum causa é mencionada está na epítome denominada "Regras de Ulpiano" (Ulpiani liber singularis regularum).

Neste trecho, se o latino juniano, apesar de não ter o conúbio, provasse que coabitava com uma mulher para ter filhos e tivesse por escopo constituir uma família, ele poderia obter como prêmio o direito à cidadania romana, de acordo com a lex Iunia

Sobre o matrimônio romano monogâmico e a impossibilidade de um "repúdio tácito" por meio de um segundo matrimônio, vejam-se Cic. De orat. 1,40,183; 1,56,238; Gai.1,63. A bigamia só foi constituída como crime, distinta do adulterium e do stuprum, no período pós-clássico: Valent., Theod. et Arcad. C.1,9,7 (393); Diocl. et Maxim. C.5,5,2 (285); Valer. et Gallien. C.9,9,18pr. (258); Honor. et Theod. C.9,9,34 (421).

${ }^{142}$ Vejam-se Suet. Claudius 26 e 29; Tac. Ann. 11,30;37. Sobre este episódio de Messalina, O. RoBLEDA, Cic. de Orat. 1,40 cit. (nota 140 supra), p.428, acredita que parece mais uma "aventura escandalizadora" de uma adúltera do que a realização de um segundo matrimônio. Neste caso, também é importante lembrar as palavras de E.C.S. MARCHI, Matrimônio moderno cit. (nota 61 supra), pp.62-63: "Os relatos e testemunhos das fontes acerca de casos de imoralidade e falta de pudor na sociedade romana do final da República e do período do Principado ou Alto Império - temas frequentes, aliás, nos romances e no cinema -constituem, como reconhece a doutrina, fenômenos claramente isolados na história de Roma" (...) "No mais das vezes, tais escândalos atingiam, no espectro da sociedade romana, um grupo bastante restrito de pessoas, quase sempre pertencentes às classes mais elevadas, como, aliás, ainda hoje costuma-se verificar”. 
Norbana de 19 d.C. ${ }^{143}$

UE 3,3: Liberis ius Quiritium consequitur Latinus, qui minor triginta annorum manumissionis tempore fuit: nam lege Iunia cautum est, ut, si civem Romanam vel Latinam uxorem duxerit, testatione interposita, quod liberorum quaerendorum causa uxorem duxerit, postea filio filiave nato natave et anniculo facto, possit apud praetorem vel praesidem provinciae causam probare et fieri civis Romanus, tam ipse quam filius filiave eius et uxor; scilicet si et ipsa Latina sit; nam si uxor civis Romana sit, partus quoque civis Romanus est ex senatus consulto, quod auctore divo Hadriano factum est.

"Pelos filhos consegue a cidadania o latino que tiver menos de trinta anos no momento da alforria. Pois a Lei Júnia dispôs que, tendo-se casado com romana ou latina, provando que se casou para ter filhos, e tendo nascido depois um filho ou filha que atingiu a idade de um ano, o latino pode provar a causa perante o pretor ou o governador da província e tornar-se cidadão, obtendo igualmente a cidadania o filho ou a filha e a mulher, naturalmente se for latina; pois, se for romana, o filho também é romano, por um senatusconsulto de iniciativa do divino Adriano".

A lex Iunia Norbana fundamenta-se nas determinações da lex Aelia Sentia (de 4 d.C.), pois de acordo com Gai. 1,29, a procriação já era utilizada como meio de prova, com o auxílio de testemunhas, para o reconhecimento do matrimônio legítimo ${ }^{144}$ e a obtenção da cidadania romana. A expressão liberorum quaerendorum causa uxorem duxerit das Regras de Ulpiano equivale ao uxorem ducere do parágrafo das Institutas de Gaio. ${ }^{145}$

\footnotetext{
${ }^{143}$ R. Astolfi, La Lex Iulia et Papia cit. (nota 15 supra), p.72; E. Volterra, La conception du Mariage d'après les juristes romains cit. (nota 30 supra), pp.42-43. Segundo ASTOLFI, era concedido ao latino o ius liberorum. Veja-se G. IMPALLOMENI, In tema di vitalità e forma umana come requisiti essenziali alla personalità, in Scritti di diritto romano e tradizione romanistica, Padova, CEDAM, 1996, p.282.

${ }^{144} \mathrm{Na}$ opinião de E. VOLTERRA, La conception du Mariage d'après les juristes romains cit. (nota 30 supra), p.44, nota 70, mais do que demonstrar o desejo de procriar filhos, a expressão liberorum quaerendorum causa uxorem ducere indica a intenção dos cônjuges em constituir uma união conjugal estável, um legitimum matrimonium. Veja-se PSI 730,48. Neste sentido, A. BouCHÉ-LECLERCQ, Les lois démographiques d'Auguste cit. (nota 36 supra), p.271.

${ }^{145}$ A Lex Aelia Sentia (Gai. 1,13-31;37) restringia o número de manumissões previstas pelo ius civile (vindicta, censo ou testamento) que tornavam o manumitido cidadão romano e exigia que o manumissor tivesse pelo menos 20 anos de idade e o manumitido 30 anos. Para uma interpretação do termo anniculus, ou seja, que um filho de um ano que permitia aos latinos solicitarem ao pretor a concessão da cidadania romana, veja-se Paul. 2 ad l. Iul.et Pap. D.50,16,134: 'Anniculus' non statim ut natus est, sed trecentesimo sexagesimo quinto die dicitur, incipiente plane, non exacto die, quia annum civiliter, non ad momenta temporum, sed ad dies numeramus. "Chama-se [filho] de um ano não desde o momento em que nasceu, mas a partir do exato tricentésimo sexagésimo quinto dia, quando começa o dia, não quando terminou, porque contamos o ano civil não por momentos, mas por dias". L. PEPPE, Storie delle parole cit. (nota 72 supra),
} 
Gai.1,29: Statim enim ex lege Aelia Sentia [cautum est ut] minores triginta annorum manumissi et Latini facti si uxores duxerint vel cives Romanas vel Latinas coloniarias vel eiusdem condicionis, cuius et ipsi essent, idque testati fuerint adhibitis non minus quam septem testibus civibus Romanis puberibus, et filium procreaverint, cum is filius anniculus esse coeperit, datur eis potestas per eam legem adire praetorem vel in provinciis praesidem provinciae, et adprobare se ex lege Aelia Sentia uxorem duxisse et ex ea filium anniculum habere; et si is, apud quem causa probata, est id ita esse pronuntiaverit, tunc et ipse Latinus et uxor eius, si et ipsa iusdem conditionis sit, et filius, si et ipse eiusdem condicionis sit, cives Romani esse iubentur.

"Pois, a lei Élia Sência determinou que os menores de trinta anos alforriados e tornados latinos, se se casarem com cidadãs romanas ou latinas coloniárias, ou da mesma condição que eles; e o provarem na presença de não menos de sete testemunhas, cidadãos romanos púberes; e se procriarem um filho, dando-lhe então a referida lei o poder de, quando esse filho entrar na idade de um ano, apresentar-se ao pretor ou, nas províncias, ao presidente da província, e provar que casou, nos termos da lei Élia Sência, e tem da sua mulher um filho com a idade de um ano; e se o magistrado, perante o qual a causa foi provada, assim o declarar; então que esse latino e a sua mulher fiquem cidadãos romanos, contanto que a mulher e o filho sejam da mesma condição que ele".

A formalização apresentada em UE 3,3 para que o latino pudesse provar que se casava para ter filhos, de acordo com a lex Aelia Sentia, poderia ser realizada pela interposição da testatio, ou seja, por uma declaração redigida na presença de testemunhas e que dava a publicidade necessária para provar que o homem coabitava com uma mulher liberorum quaerendorum causa, ou seja, com a intenção de procriar filhos legítimos e ter um matrimônio estável, baseado na affectio maritalis e não numa mera união

p.127, nota 10 , considera rígido este critério para a concessão da cidadania romana, pois nesta época, cerca de $30 \%$ dos recém-nascidos morriam antes de completar um ano, ou seja, era alta a taxa de mortalidade infantil. Vejam-se E. VolTERRA, Matrimonio cit. (nota 61 supra), p.740, nota 30; Idem, La conception du Mariage d'après les juristes romains cit. (nota 30 supra), pp.44, nota 70;45; M. ZABŁOCKA, Il 'ius trium liberorum' cit. (nota 103 supra), p.375; R. AstOLFI, La Lex Iulia et Papia cit. (nota 15 supra), pp.314-316; V. ARANGIO-RUIZ, Istituzioni cit. (nota 53 supra), p.441, nota 1; E. CUQ, Les lois d'Auguste sur les déclarations de naissance, in Mélanges Fournier, Paris, Sirey, 1929, pp.123;125; A. BouCHÉ-LECLERCQ, Les lois démographiques d'Auguste cit. (nota 36 supra), p.271. 
temporária. $^{146}$

De acordo com a lex Papia e a lex Aelia Sentia, os filhos espúrios (ilegítimos) não podiam ter seu nascimento declarado oficialmente, por meio de uma certidão, uma anotação efetuada no registro público (professio in albo). ${ }^{147}$ A professio era permitida

${ }^{146}$ E. CUQ, Les lois d'Auguste sur les déclarations de naissance cit. (nota 145 supra), pp.119-121;124; E. VOLTERRA, Matrimonio cit. (nota 61 supra), p.740, nota 30; Idem, La conception du Mariage d'après les juristes romains cit. (nota 30 supra), pp.42-43. VOLTERRA afirma que, nas palavras de Ulpiano, (...) testatione interposita, quod liberorum quaerundorum causa uxorem duxerint, o latino precisava provar que realizara um matrimônio válido juridicamente (iustum matrimonium), baseado na affectio maritalis e na procriação. Nas palavras de M.C. GIORDANI, O Novo Código Civil à Luz do Direito Romano cit. (nota 63 supra), pp.32-33: "As partes interessadas podem obter declarações da inscrição (testationes), nas quais consta o nome do filho, dos pais, a data de nascimento e a indicação sobre a cidadania do filho". Também poderia ser expressa a intenção de que os cônjuges se casavam para ter filhos durante a redação das tabulae nuptiales. Vejam-se J. GAUDEMET, L'Apport du Droit Romain cit. (nota 59 supra), p.37; V. CÉSAR DA SILVEIRA, v. Testatio, in Dicionário de Direito Romano cit. (nota 9 supra), p.699; R. MONIER, Manuel élémentaire de droit romain, 6aed., t.1, Paris, Domat Montchrestien, 1947, pp.287-288. Em relação à legislação éticomatrimonial de Augusto, afirma R. Astolfi, La Lex Iulia et Papia cit. (nota 15 supra), pp.316;341 que as testationes já serviam como prova de filiação para a Lex Iulia de Maritandis Ordinibus. Segundo M. ZABŁOCKA, Il 'ius trium liberorum' cit. (nota 103 supra), p.375, a Lex Papia determinava, para que os cônjuges pudessem receber os privilégios da filiação, que esta declaração do nascimento de um filho (testatio) fosse realizada diante do praefectus aerarii em Roma e do governador, nas províncias. Salienta T. SPAGNUOlO VigORITA, Casta Domus cit. (nota 26 supra), pp.74-75, que a declaração de nascimento tornouse importante, após a promulgação das Leis matrimoniais de Augusto, para que os cônjuges pudessem beneficar-se do ius liberorum. O funcionário inseria o nome em um ou dois registros em papiros redigidos em ordem cronológica (Kalendarium). Estes registros também eram realizados nas províncias e transmitidos periodicamente a Roma, para a atualização de uma lista central com o nome de todos os cidadãos, chamada Tabularium.

${ }^{147}$ Esta distinção entre o registro dos filhos legítimos e dos filhos naturais pode ser verificada em algumas fontes papirológicas (Díptico de Karanis), denominadas Michigan Papyri [Pap. Mich. 3,169 (de 145 d.C.); Pap. Mich. 7,436 (de 138 d.C.)] descobertas em Fayoum no Egito e publicadas em 1937 no Jornal Americano de Arqueologia. As fontes papirológicas reforçam a importância dos aspectos demográfico e moral das Leis Matrimoniais. O Díptico contém alguns casos de proibição da realização da professio in albo. Esta distinção auxiliava a identificar se os filhos eram provenientes de matrimônios legítimos, de concubinatos ou de alguma união ilícita; também para provar a idade dos filhos. No primeiro caso, uma mulher chamada Semprônia Gemella, mãe de dois filhos ilegítimos (spurii, vulgo concepti), devia declará-los publicamente pela testatio em Alexandria, de acordo com a leis Aelia Sentia e Papia Poppaea. O ato público da declaração de nascimento dos gêmeos spurii teria sido feito por meio de um tutor dativo chamado Sempronius C. Iunius Saturninus. Os gêmeos nascidos em 21 de março foram declarados em 29 de abril pelo tabularius publicus. Em Alexandria a tabula albi ficava afixada tanto no Atrium Magnum quanto no Forum de Augusto.

Pap. Mich. 3,169: (...) [s]e has testationes interposuisse dixit quia lex [Ae]lia Sentia et Papia Poppaea $[$ spu $]$ rio $[s]$ spuriasve in albo pr[ofiteri vet]at(...): “(...)declarou ter recorrido (Semprônia Gemella) a estas disposições feitas na presença de testemunhas, porque a lex Aelia Sentia e a Papia Poppaea proíbe declarar (o nascimento de) filhos e filhas ilegítimos no registro(...)".

Esta anotação oficial no registro (album), realizada pela autoridade pública competente, servia para provar o nascimento do filho (professio in actis). Augusto próibe a professio in albo aos filhos ilegítimos, pois seu objetivo não era apenas o de aumentar o número de cidadãos, mas aumentar o número de matrimônios legítimos. Portanto, no caso da filiação ilegítima, declarava-se o nascimento pela testatio.

No outro caso, Pap.Mich. 7,436, as referidas leis também proibiam a professio in album aos soldados peregrinos em campanha: (...)Camerino et] Nigro co(n)s(ulibus) loco Pselchi a]d hib(erna) coh(ortis) s(upra) s(criptae) anno XXII I]mp(eratoris) Caesaris Traiani Hadriani A]ug(usti) et vocari eum Numissium at]que se testari ex lege A(elia) ] S(entia) et Papia $\{e\}]$ Poppaea $\{e\}$ quae de filis procreandi]s latae sunt nec potuisse se profiteri propt]er distri\{n\}ctionem militiae. “(...)do ano em que eram cônsules Camerino e Nigro, na localidade de Pselkis, junto ao campo invernal da supra citada corte, no ano XXII do imperador Trajano 
apenas para os filhos legítimos e a testatio era realizada para o registro dos filhos espúrios (ilegítimos).

Tal situação só foi alterada pelo imperador Marco Aurélio (161-180 d.C.), que tornou obrigatória a declaração de nascimento para todos os cidadãos. ${ }^{148}$

No próximo texto, verifica-se que a fórmula liberorum quaerundorum causa foi mantida, como símbolo de um casamento romano legítimo, no século III d.C.

No Código de Justiniano (C.5,4,9), o imperador Probus (276-282 d.C.) escreveu a um certo Fortunato que, se faltassem os documentos escritos probatórios da existência de um casamento, mas fosse possível que os cônjuges demonstrassem a intenção liberorum quaerundorum causa com o auxílio de testemunhas, isto seria suficiente para provar a legitimidade da prole.

Si vicinis vel aliis scientibus uxorem liberorum procreandorum causa domi habuisti et ex eo matrimonio filia suscepta est, quamvis neque nuptiales tabulae neque ad natam filiam pertinentes factae sunt, non ideo minus veritas matrimonii aut susceptae filiae suam habet potestatem.

"Se sabendo os vizinhos ou outras pessoas que tiveste em tua casa uma esposa para procriar filhos, e deste matrimônio nasceu uma filha, ainda que não se tenham feito nem os instrumentos nupciais, nem os concernentes à filha nascida, nem por isto tem menos força a verdade do matrimônio ou do nascimento da filha".

Portanto, o imperador Probus levou em consideração para dar sua decisão a intenção liberorum procreandorum causa e o comportamento dos cônjuges diante de

Adriano augusto; e que o filho se chama Numíssio, e que o seu pai cumpria a declaração diante de testemunhas por força da lex Aelia Sentia e Papia Poppaea, leis que foram propostas para favorecer a procriação dos filhos, e que não podia efetuar a professio pelo vínculo da milícia(...)". Vejam-se R. ASTOLFI, La Lex Iulia et Papia cit. (nota 15 supra), pp.313-314;329;337; Idem, Note per una valutazione storica della 'Lex Iulia et Papia' cit. (nota 36 supra), pp.190;198;202;224; T. Spagnuolo Vigorita, Casta Domus cit. (nota 26 supra), pp.74-75;170-172, nota 280; B. BIONDI, La legislazione di Augusto cit. (nota 56 supra), p.149, nota 1; L.F. RADITSA, Augustus Legislation cit. (nota 49 supra), p.320; E. CUQ, Les lois d'Auguste cit. (nota 145 supra), pp.120-122;128-129;132.

148 R. Astolfi, La Lex Iulia et Papia cit. (nota 15 supra), pp.314-315;341;357; Idem, Note per una valutazione storica della 'Lex Iulia et Papia' cit. (nota 36 supra), p.218; A. CALDERINI, Antichità private cit. (nota 19 supra), pp.22-23; E. CUQ, Les lois d'Auguste cit. (nota 145 supra), p.130. Não eram obrigatórias as declarações oficiais de nascimento até a época de Marco Aurélio, bastava muitas vezes o reconhecimento dos filhos pelo pai no dies lustricus, o nono dia de vida para os meninos e o oitavo para as meninas, momento em que recebiam o nome e geralmente eram apresentadas em diversos templos da cidade. A partir de Marco Aurélio, o pai tinha até 30 dias, contados a partir do nascimento da criança, para declará-la junto ao praefectus aerarii em Roma e aos publici tabularii fora de Roma. De acordo com E. CUQ, op.cit., p.123, tanto a testatio quanto a professio não eram atos oficiais conservados em arquivos públicos, mas lembranças que a familia conservava para mostrar aos amigos e parentes. 
terceiros, no caso os vizinhos, o que substitui as provas escritas do casamento para o reconhecimento jurídico da legitimidade da filha. Esta intenção, que demonstra ser recíproca e duradoura, serve para diferenciar o matrimônio das demais uniões estáveis ou temporárias. $^{149}$

\subsubsection{Doutrina}

Muitas definições de matrimônio romano elaboradas pelos romanistas modernos indicam a procriação não apenas como a sua finalidade principal, mas como um dos principais elementos da exteriorização da affectio maritalis, o honor matrimonii.

Conforme a definição de P. BONFANTE, ${ }^{150}$ "o matrimônio romano é a convivência do homem e da mulher com a intenção de ser marido e mulher, ou seja, de procriar e educar os filhos e de constituir ainda uma sociedade perpétua e íntima em todas as relações. Tal intenção é chamada pelos romanos affectio maritalis".

Segundo M. KASER, ${ }^{151}$ para a existência do matrimônio: “(...) têm de dar-se certos pressupostos: a consciência matrimonial tem de se propor uma união vitalícia, monogâmica, realizada em comunidade de vida e associação doméstica, cujo fim mais nobre é conseguir descendentes de pleno direito".

Para L.R. ARGÜELLO ${ }^{152}$, “o matrimônio, no conceito romano, pode definir-se como a coabitação de duas pessoas de sexo diferente, com a intenção de ser marido e mulher, de procriar e educar seus filhos e constituir entre elas uma comunhão absoluta de vida".

Na opinião de R. MONIER ${ }^{153}$, “o elemento essencial e indispensável exigido para a formação do matrimônio, é o acordo dos dois cônjuges, a vontade recíproca de ocupar a mesma classe social (honorem matrimonii invicem habere), de procriar e de educar os filhos".

\footnotetext{
${ }^{149}$ E. VOLTERRA, Matrimonio cit. (nota 61 supra), p.739-740, nota 30; R. ORESTANO, La struttura giuridica del matrimonio romano cit. (nota 1 supra), p.206; P. GIUNTI, Consors vitae cit. (nota 26 supra), p.442, nota 55.

${ }_{150}$ Istituzioni cit. (nota 12 supra), p.137: Il matrimonio romano è la convivenza dell'uomo e della donna con l'intenzione di essere marito e moglie, cioè di procreare ed allevare figliuoli e di costituire altresì tra $i$ coniugi una società perpetua ed intima sotto tutti i rapporti. Tale intenzione è detta dai romani affectio maritalis'. No dizer de A. GuARINo, Profilo del diritto romano, $8^{\mathrm{a}}$ ed., Napoli, Jovene, 1994, p.134, o matrimônio romano é "l'unione intesa alla procreazione".

${ }^{151}$ Römisches Privatrecht cit. (nota 12 supra), p.318.

${ }_{152}$ Manual cit. (nota 12 supra), p.421: El matrimonio, en el concepto romano, puede definirse como la cohabitación de dos personas de distinto sexo, con la intención de ser marido y mujer, de procrear y educar a sus hijos y constituir entre ellos una comunidad absoluta de vida.

${ }^{153}$ Manuel cit. (nota 146 supra), p.286: L'élément essentiel et indispensable requis pour la formation du mariage, c'est l'accord des deux époux, la volonté réciproque d'occuper le même rang social (honorem matrimonii invicem habere), de procréer et d'élever des enfants.
} 
A noção de matrimônio romano de E. CUQ ${ }^{154}$ também enfatiza o elemento da procriação dos filhos e sua importância para a família: "o matrimônio é o fundamento da família: ele tem por objetivo assegurar a sua perpetuidade e aumentar o seu poder pela procriação dos filhos".

De acordo com G. CORNIL ${ }^{155}$, “o matrimônio é o fundamento da família romana: sua finalidade é a de assegurar, pela perpetuação da família, o exercício ininterrupto do culto aos antepassados. Em consequência, os Romanos consideram como matrimônio legítimo, não toda união sexual monogâmica formada liberorum quaerendorum causa, mas somente a união formada em condições tais que, os filhos que nasceram podem ser associados ao culto da família".

Conforme V. ARANGIO-RUIZ ${ }^{156}$, “o matrimônio do direito romano mais antigo é um ato ou fato jurídico, por força do qual uma mulher, sui ou alieni iuris, sai da família de origem e entra em uma nova família, em condição de subordinada e com a particular função de procriar (...) uma descendência legítima".

Ao falar dos principais escopos do matrimônio romano, S. PEROZZI ${ }^{157}$, explica que “a própria finalidade importa dois requisitos do matrimônio. Um é aquele que nenhum dos dois cônjuges viva em um outro matrimônio. Tanto a poligamia quanto a poliandria são incompatíveis com a plenitude de união entre homem e mulher. O outro, que os cônjuges tenham um hábito de corpo tal para torná-los aptos à procriação".

VOLTERRA $^{158}$, ao falar sobre o consentimento entre os cônjuges, explica que "nas

\footnotetext{
${ }^{154}$ Les Institutions cit. (nota 69 supra), p. 57: Le mariage est le fondement de la famille: il a pour but d'en assurer la perpétuité et d'en accrô̂te la puissance par la procréation des enfants.

${ }^{155}$ Droit Romain cit. (nota 55 supra), p.30: Le mariage est le fondement de la famille romaine: son but est d'assurer, par la perpétuation de la famille, l'exercice ininterrompu du culte des ancêtres. En consequence les Romains tiennent pour marriage légitime, non pas toute union sexuelle monogamique formée 'liberorum quaerendorum causa', mais seulement l'union formée dans des conditions telles que les enfants qui en sont issus peuvent être associés au culte de la famille.

${ }^{156}$ Istituzioni cit. (nota 53 supra), p.434: Il matrimonio del più antico diritto romano è um atto o fatto giuridico, in forza del quale una donna, 'sui' od 'alieni iuris', esce dalla famiglia d'origine ed entra in una famiglia nuova, in condizione di sottoposta e con la particolare funzione di procreare (...) una discendenza legittima.

${ }^{157}$ Istituzioni cit. (nota 26 supra), pp.322-323: Il fine stesso importa altri due requisiti del matrimonio. L'uno si è che nessuno dei due coniugi viva in un altro matrimonio. La poligamia come la poliandria sono incompatibili colla pienezza di unione tra uomo e donna. L'altro che i coniugi abbiano um abito del corpo tale da renderli atti alla procreazione.

${ }^{158}$ Matrimonio cit. (nota 61 supra), p.738: Nelle fonti questa reciproca volontà viene designata con $i$ termini di 'consensus', 'affectio maritalis', 'mens coeuntium'. L'oggetto di questa deve essere la costituzione di un'unione monogamica per la durata della vita dei coniugi avente lo scopo di far sorgere una società domestica fondata sulla comunanza di vita dell'uomo e della donna con la partecipazione di questa al rango sociale del marito, su rapporti reciproci di protezione ed assistenza e diretta alla procreazione $e$ all'educazione dei figli. L'elemento infatti che in vari testi giuridici e letterari viene assunto come criterio per caratterizzare il matrimonio legittimo e pertanto la volontà di costituirlo e differenziarlo da altre unioni temporanee o occasionali fra um uomo e una donna è precisamente la 'procreandorum liberorum causa'.
} 
fontes, esta vontade recíproca é designada com os termos consensus, affectio matitalis, mens coeuntium. O objeto desta deve ser a constituição de uma união monogâmica para a duração da vida dos cônjuges, tendo o escopo de fazer surgir uma sociedade doméstica fundada sobre a comunhão de vida do homem e da mulher com a participação desta na condição social do marido, sob as relações recíprocas de proteção e assistência, destinada à procriação e à educação dos filhos. O elemento que, de fato, em vários textos jurídicos e literários aparece como critério para caracterizar o matrimônio legítimo e, portanto, a vontade de constituí-lo e diferenciá-lo das outras uniões temporárias ou ocasionais entre um homem e uma mulher é exatamente a procreandorum liberorum causa".

\subsection{ORDINES}

No início do Principado, a população da cidade de Roma crescia e a dos campos itálicos e das províncias tendia a uma diminuição.

As guerras civis entre Mário e Sila, entre Pompeu e César, entre Marco Antônio e Otaviano, haviam diminuído a população em todo o Império, observando-se uma queda na natalidade, especialmente das classes dirigentes e mais ricas (senatorial e equestre). ${ }^{159}$

Esta queda demográfica abalou a estrutura político-administrativa do Império. $\mathrm{O}$ censo dos cidadãos romanos, ocorrido em 28 a.C., foi o ponto de partida para as reformas jurídicas que incentivavam a procriação. ${ }^{160}$

A base desta estrutura encontrava-se, sobretudo, nas famílias romanas mais ricas e

Vejam-se também E. VolterRA, La conception du Mariage d'après les juristes romains cit. (nota 30 supra), pp.36-37; Idem, La conception du Mariage à Rome cit. (nota 30 supra), p.356; Idem, Les formes du Mariage chez les Romains cit. (nota 30 supra), p.280; C. PUJAL, La concepción jurídica cit. (nota 47 supra), p.605; J. DAZA MARTínEZ, La influencia cristiana cit. (nota 48 supra), p.110; E.C.S. MARCHI, Matrimônio moderno e matrimônio romano clássico (nota 61 supra), p.58.

${ }^{159}$ S. RiccoBono, La politica demografica cit. (nota 103 supra), p.574, ressalta que a migração de romanos da Itália para as colônias localizadas no norte da África, na Hispânia, em Corinto e que totalizavam o número de 100 (cem) colônias em 28 a.C., foi um dos fatores que contribuiu para o despovoamento da cidade. Vejam-se também R. BESNIER, L'application des lois caducaires cit. (nota 10 supra), pp.93-94; D. DALLA R. LAMBERTINI, Istituzioni di diritto romano cit. (nota 10 supra), p.108. Conforme R. VILlERS, Le mariage envisagé cit. (nota 63 supra), p.293, as classes senatoriais, importantes na sociedade e na política romana, foram dizimadas pelas guerras civis e pelas proscrições. Os nobres que sobreviveram a estes acontecimentos consideravam um mau exemplo uma pessoa solteira ou viúva que não se casava e se entregava à libertinagem e devassidão. Vejam-se F. DElla CORTE, Le 'leges Iuliae' e l'elegia romana cit. (nota 47 supra), p.557; D. NÖRR, The matrimonial Legislation of Augustus cit. (nota 54 supra), p.350; J. GAUDEMET, Justum matrimonium cit. (nota 51 supra), p.328; A. BOUCHÉ-LECLERCQ, Les lois démographiques d'Auguste cit. (nota 36 supra), p.244.

${ }_{160}$ Segundo B. BIONDI, Istituzioni di diritto romano cit. (nota 22 supra), p.440, o censo de 28 a.C. demonstrou um total de quatro milhões de cives (Aug. Res Gestae 2,8), um número consideravelmente baixo e que preocupou as autoridades romanas. Vejam-se, R. VILLERS, Le mariage envisagé cit. (nota 63 supra), pp.293-294; L.F. RADITSA, Augustus Legislation cit. (nota 49 supra), pp.284-285; D. NÖRR, The matrimonial Legislation of Augustus cit. (nota 54 supra), p.350. 
influentes politicamente e Augusto buscava com a sua legislação manter "pura" "161 a "estirpe itálica", ou seja, aumentar o número de cidadãos principalmente nas classes senatorial e equestre para garantir o seu poder e reformar os quadros da nova administração imperial (os altos cargos das magistraturas eletivas, da administração e do exército). ${ }^{162}$

${ }^{161}$ Para F. Della CORTE, Le 'leges Iuliae' e l'elegia romana cit. (nota 45 supra), p.545, no período final da República, houve um aumento no número de matrimônios entre ingênuos e libertos. Esta "ameaça" do aumento dos "novos cidadãos" em relação às famílias gentílicas tradicionais, devia-se, dentre inúmeros fatores, segundo J.C. TELlO, La concesión discrecional por 'princeps' del 'ius trium liberorum' y su reflejo en Marcial, in El Derecho de Familia: De Roma al Derecho Actual, Huelva, Universidad de Huelva, 2004, p.769, nota 2, ao caos econômico que propiciou o aumento no número de manumissões segundo as formalidades do direito quiritário (ius civile), que concediam ao escravo, além da liberdade, a cidadania romana; ao surgimento de novos estratos sociais; ao aumento das migrações de peregrinos para os grandes centros urbanos do Império; ao choque de costumes e valores morais dos peregrinos com os valores e os mores maiorum dos cives romanos das classes elevadas. Sobre a intenção de Augusto conservar a "pureza racial" do povo romano, veja-se Suet. Augustus 40,3: Magni praeterea existimans sincerum atque ab omni colluvione peregrini ac servilis sanguinis incorruptum servare populum, et civitates Romanas parcissime dedit et manumittendi modum terminavit. "Além disso, considerando uma coisa muito importante conservar o povo romano puro e não contaminado com a mistura de sangue servil ou peregrino, [Augusto] foi muito parco em conceder o direito de cidadania romana e impôs muitos limites às manumissões".

${ }^{162} \mathrm{Na}$ opinião de A. Daviault, Le 'mos maiorum', in J. GAillard (org.), Rome Ier siècle av. J.-C. - Ainsi périt la République des vertus..., Paris, Autrement, 2001, p.67, ao término das Guerras Púnicas, muitos romanos, especialmente a nobilitas, não seguiam mais os mores maiorum como nos períodos anteriores, pois estavam dominados pela ambição (ambitio) desmedida e, graças à hegemonia do poder no Mediterrâneo e a grande circulação de riquezas, muitos se preocupavam apenas com seus interesses pessoais, substituindo os interesses e ideais da res publica por um "individualismo" perigoso que deveria ser combatido. Quanto às famílias mais influentes, U. VINCENTI, Categorie del diritto romano, Napoli, Jovene, 2007, defende a opinião de que era uma prática frequente em Roma, no século II a.C., uma mulher gerar filhos para famílias diferentes. Tal situação, porém, não pode ser adjetivada como "frequente", apesar de socialmente aceitável. O caso mais conhecido é aquele do grande orador Quinto Hortênsio Hortalo (114-50 a.C.), narrado por Appian. Bell. Civ. 2,99 e Plut. Cato Minor 25,3-12. Conforme a narração de Plutarco, o orador "com o desejo de não ser apenas amigo e íntimo de Catão (...) tenta persuadi-lo em conceder para si mesmo, sua filha Pórcia, casada com Bíbulus, a quem ela tinha gerado dois filhos, como um campo fértil para lá novamente semear uma descendência". Porém Catão, não desejando dissolver o matrimônio de sua filha Pórcia, pois Bíbulus também era influente politicamente (cônsul em 59 d.C.), ofereceu a própria esposa Márcia (grávida dele naquele momento), que casou-se com Hortênsio e deu-lhe dois descendentes. Após a morte de Hortênsio, Márcia casou-se novamente com Catão. Apesar de ser um caso excepcional na sociedade romana, ele reforça a importância, principalmente para a aristocracia militar e senatorial, do dever cívico da procriação de filhos e da manutenção do nome familiar. Vejam-se O.M. PÉTER, Liberorum quaerendorum causa cit. (nota 21 supra), p.294; E. CANTARELLA, Matrimonio e sessualità cit. (nota 36 supra), pp.109113;119-130; E.M. AgAti MAdEIRA, Advogadas Romanas Republicanas, in Revista da Faculdade de Direito da USP 101 (2006), p.88, nota 2; M. ZABŁOCKA, Il 'ius trium liberorum' cit. (nota 103 supra), p.361; Idem, Le modifiche cit. (nota 103 supra), p.379; R. AstOLFI, La Lex Iulia et Papia cit. (nota 15 supra), pp.325;333334;347; R. BESNIER, L'application des lois caducaires cit. (nota 10 supra), pp.96; 108; A. BouCHÉLECLERCQ, Les lois démographiques d'Auguste cit. (nota 36 supra), p.245; P. GIUNTI, Consors vitae cit. (nota 26 supra), pp.440-441, nota 50; E. MALDONADO DE LiZALDE, Lex Iulia de Maritandis Ordinibus cit. (nota 122 supra), p.540.

Essa preocupação com a procriação nas famílias mais influentes politicamente pode ser verificada em Cic. Ad. Att. 14,20,2 que reprova o aborto de Tertula (meia-irmã de M.Bruto, mulher de E.Cassius), porque tanto Cassius quanto Bruto precisavam de descendentes: Primum, quae de re mea gesta et in solutione et in Albiano negotio, grata. De tuo autem Buthroto, cum in Pompeiano essem Misenum venit Antonius. Inde ante discessit, quam illum venisse audissem. A quo in Samnium. Vide quid speres. Romae igitur de Buthroto. L. Antoni horribilis contio, Dolabellae praeclara. Iam vel sibi habeat nummos, modo numeret idibus. Tertullae nollem abortum. Tam enim Cassii sunt iam quam Bruti serendi. De regina velim atque etiam de Caesare filio.(...) "Em primeiro lugar obrigado por ter gerido meus interesses, tanto pelo pagamento do meu crédito quanto pelo negócio com Albus. Quanto ao teu Butroto, Antônio chegou a Miseno enquanto eu estava em 
Nitidamente, esta "estirpe itálica" (senadores, equestres, decuriões) teve uma posição privilegiada em relação aos cidadãos das províncias, devido à sua grande influência no âmbito político-econômico do Império. ${ }^{163}$

Augusto, com a promulgação das leis matrimoniais, procurou conciliar o aumento demográfico com o aumento da dignidade social das famílias com maior prestígio e importância política. Não foram apenas critérios de caráter ético-demográfico que serviram de fundamento para a divisão dos cidadãos romanos em diversas classes, mas também aqueles de ordem econômica. ${ }^{164}$

A população masculina foi dividida em senadores, cavaleiros (equites), ingênuos e libertos; a população feminina em ingênuas, libertas (libertinae) e feminae probrosae. ${ }^{165}$ Havia um incentivo para que se casassem as pessoas da mesma classe e foram estabelecidos impedimentos matrimoniais fundamentados em motivos sociais. ${ }^{166}$

Pompéia. Ele partiu antes que eu soubesse de sua chegada e se dirigiu a Sâmnio. Observo aquilo que tu podes esperar: por isso, é em Roma que ele nos falará de Butroto. O discurso de L. Antônio é de temer, aquele de Dolabela é notável. Que ele receba, se for necessário, seu dinheiro; que ele me pague nos idos. Eu não sou favorável ao aborto de Tertula. Pois ele importa tanto à descendência de Cassius quanto de Brutus. Eu adoraria ser informado sobre a rainha e também sobre o famoso filho de César. (...)".

${ }^{163} \mathrm{Na}$ opinião de R. ASTOLfI, La Lex Iulia et Papia cit. (nota 15 supra), p.347, a política demográfica de Augusto e as reformas dos costumes sociais têm como uma de suas finalidades assegurar às classes ricas da sociedade romano-itálica a supremacia sobre os habitantes das províncias. Por isso, a proteção da família está vinculada à valores ético-morais. Consequentemente, aos pertencentes à classe senatorial, em razão de seu grande poder político e econômico, a legislação matrimonial estabeleceu um número maior de impedimentos matrimoniais em relação às outras ordines. Na época de Augusto, o patrimônio mínimo declarado ao censo, de um senador, era de um milhão de sestércios, enquanto que de um membro da classe equestre, era de quatrocentos mil sestércios. Isso não quer dizer que na Lex Iulia et Papia não existiram normas aplicadas a todos os cidadãos, indistintamente, v.g., o ius trium liberorum, o dever do pai em consentir no matrimônio dos filhos, o favor dotis, a proibição determinada pela Lex Iulia de maritandis ordinibus, dos caelibes assistirem espetáculos públicos (vide nota 314, infra, CIL VI,32323). Vejam-se R. Astolfi, La Lex Iulia et Papia cit. (nota 15 supra), pp.326;333-336;349; Idem, Note per una valutazione storica della 'Lex Iulia et Papia' cit. (nota 36 supra), p.196; T. Spagnuolo Vigorita, Casta Domus cit. (nota 26 supra), pp.57-58;79; R. BESNIER, L'application des lois caducaires cit. (nota 10 supra), p.95; J.A. FIELD JR., The purpose cit. (nota 129 supra), p.399; G. PIERI, L'Histoire du cens cit. (nota 221 supra), pp.199-201. Nas palavras de A. BOUCHÉ-LECLERCQ, Les lois démographiques d'Auguste cit. (nota 36 supra), p.246, Auguste comptait sur cette hiérarchie sociale pour donner au grand corps de l'empire une ossature solide, pour associer au gouvernement et intéresser au maintien du noveau régime le vrai peuple romain, concentré presque tout entier dans les deux ordres.

${ }^{164} \mathrm{Na}$ opinião de L.F. RADITSA, Augustus Legislation cit. (nota 49 supra), p.335, essa divisão discriminatória dos cidadãos romanos em diversas categorias era um efeito da guerra civil do final da República. Discriminatória, pois parece encorajar a sexualidade com um classe de mulheres (feminae probrosae) e o casamento com outras, v.g., as ingênuas. Veja-se R. ASTOLFI, Note per una valutazione storica della 'Lex Iulia et Papia' cit. (nota 36 supra), p.191.

165 Quanto ao termo probrum ele significa neste contexto, "vergonha" ou "torpeza". Probrosae corresponderia a "moralmente torpe" em relação à vida sexual. Veja-se E. NARDI, La 'incapacitas' delle 'feminae probrosae' cit. (nota 96 supra), pp.154-155. Veja-se, sobre o termo probrum, Ulp. 56 ad ed. D.50,16,42.

${ }^{166}$ Nas opiniões de E. VOlTERrA, Concubinato (Diritto romano), in NNDI 3 (1957), pp.1052 e A. LÓPEZ PEDREIRA, Limitaciones a la 'libertas nuptialis' cit. (nota 27 supra), p.403, esta classificação das mulheres em várias ordines foi realizada pela Lex Iulia de Adulteriis para reprimir as relações extra-matrimoniais (adultério, stuprum, incestum). No início do Principado, crescia o número de peregrinos e de libertos, fato que as duas classes, senatorial e equestre, consideraram politicamente perigoso. Para restringir o excesso de 
Em relação às ingênuas era permitido casar-se com homens de qualquer classe social e deviam abster-se de qualquer relação extra-conjugal, mantendo-se castas e fiéis. ${ }^{167}$

A lex Iulia de maritandis ordinibus proibiu o matrimônio entre membros da classe senatorial (senador e seus descendentes agnatícios até o terceiro grau) e as libertas ${ }^{168}$ ou

manumissões, Augusto promulgou duas leis: a lei Fufia Caninia, de 2 a.C., que limitou, de acordo com o total de escravos possuídos pelo dono, o número de manumissões (manumissio testamenta) que o testador poderia fazer, nunca ultrapassando 100 (Gai.1,42-46); e a lei Aelia Sentia de 4 d.C., que condicionava a idade do dono e dos escravos, bem como o modo de realização da manumissão para que esta fosse válida e declarou nulas as manumissões praticadas em fraude aos credores do ex-dono do escravo (Gai.1,18; 36-41; 47). Para L.F. RADITSA, Augustus Legislation Concerning Marriage cit. (nota 49 supra), p.319, essa divisão da sociedade romana em diversas categorias estabelecida pela legislação matrimonial constituiu a origem de outras divisões surgidas no decorrer do Império, como aquela entre os humiliores (pobres, aos quais eram aplicadas penas com maior rigor) e os honestiores (pessoas de classe social elevada, que tinham suas penas abrandadas). Vejam-se T. MARKY, Curso Elementar de Direito Romano, 8 ed., São Paulo, Saraiva, 2007, p.32; J.C. MoReIRA Alves, Direito Romano cit. (nota 9 supra), pp.108-109; B. BIONDI, Istituzioni cit. (nota 22 supra), p.443; F. Della CORTE, Le 'leges Iuliae' e l'elegia romana cit. (nota 47 supra), pp.546 e 553; S. RicCOBONO, La politica demografica cit. (nota 103 supra), p.576; M. ZABŁOCKA, Il 'ius trium liberorum' cit. (nota 72 supra), pp.361; R. ASTOLFI, La Lex Iulia et Papia cit. (nota 15 supra), p.329; K. GALINSKY, Augustan Culture cit. (nota 102 supra), p.137.

${ }^{167}$ G. CASTELli, Il concubinato cit. (nota 96 supra), p.70; T. Spagnuolo Vigorita - V. Marotta, La legislazione imperiale. Forme e orientamenti in Storia di Roma, vol.2, Torino, GiulioEinaudi, 1992, p.88.

${ }^{168} \mathrm{Na}$ época de Augusto, estes impedimentos matrimoniais tornavam o matrimônio irrelevante em relação à Lex Iulia et Papia e os cônjuges, neste caso, eram considerados caelibes. Em relação a este impedimento dos senadores de se casarem com libertas, esta disposição, na opinião de R.Astolfi, La Lex Iulia et Papia cit. (nota 15 supra), pp.100;131, não se estendeu à classe equestre. Conclui-se que, na legislação matrimonial de Augusto, a sanção não era a nulidade do matrimônio. De acordo com R. ASTOLFI, Note per una valutazione storica della 'Lex Iulia et Papia' cit. (nota 36 supra), p.191, la nullità del matrimonio (...) aumenterebbe le occasioni di illegittimità della prole, conseguendo un effeto che Augusto tende a evitare.

O imperador Marco Aurélio (161-180), por meio de um Senatusconsulto (Oratio), não apenas manteve a proibição do matrimônio entre membros da classe senatorial e os libertos, disposta na Lex Iulia de maritandis ordinibus, como determinou a sanção de nulidade absoluta do matrimônio, caso não se observassem as disposições da legislação matrimonial de Augusto. De acordo com S. SOLAZZI, Sui divieti matrimoniali delle leggi augustee, in Scritti di diritto romano (1938-1947), vol.4, Napoli, Jovene, 1963, pp.88;96-97, deduz-se dos textos que as Leis Matrimoniais eram leges minus quam perfectae e que provavelmente não estabeleceram a nulidade aos matrimônios que não estivessem de acordo com as suas disposições. Os impedimentos matrimoniais na Legislação matrimonial de Augusto não eram sancionados com a nulidade. $\mathrm{O}$ matrimônio contrário à legislação não fazia nascer uma questão de validade ou de nulidade, mas uma questão de impunidade. Contra a opinião de SolAzZI, E. NARDI, Sui divieti matrimoniali cit. (nota 109 supra), pp.114, nota 7; 121-126,131, nota 48,136-137, defende que a sanção de nulidade era vigente em todos os impedimentos matrimoniais estabelecidos pela Lex Iulia de maritandis ordinibus e pela Lex Iulia et Papia. O Senatusconsulto promulgado por Marco Aurélio apenas repetiu a norma disposta pela Lex Iulia et Papia, ou seja, todos os matrimônios que não estivessem de acordo com as Leis Matrimoniais eram nulos.

Posteriormente a jurisprudência, ao interpretar o senatusconsulto (Oratio princeps) promulgado por Marco Aurélio e Cômodo estendeu a nulidade absoluta (ipso iure nullius esse momenti) também aos esponsais, conforme Ulp. 3 ad l. Iul. et Pap. D.23,1,16: Oratio Imperatorum Antonini et Commodi, quae quasdam nuptias in personam Senatorum inhibuit, de sponsalibus nihil locuta est; recte tamen dicitur, etiam sponsalia in his casibus ipso iure nullius esse momenti, ut suppleatur, quod Orationi deest. "A Oratio dos imperadores Antonino e Cômodo, que proibiu determinadas núpcias aos Senadores, nada disse sobre os esponsais; porém, com razão se afirma, que nestes casos também os esponsais são nulos pelo próprio direito, para suprir o que falta à Oratio".

Conforme Paul. 35 ad ed. D.23,2,16pr.: Oratione Divi Marci cavetur, ut, si Senatoris filia libertino nupsisset, nec nuptiae essent; quam et senatusconsultum secutum est. "Dispõe-se numa Oratio do Divino Marco, que se a filha de um Senador se casasse com um liberto, não existiam núpcias; cuja disposição também manteve um 
com mulheres infames denominadas feminae probrosae, v.g, prostitutas ${ }^{169}$, atrizes $(\text { scaenicae })^{170}$, alcoviteiras $(\text { lenae })^{171}$, adúlteras colhidas em flagrante (in adulterio

senatusconsulto"; Mod. l. s. de ritu nupt. D.23,2,42,1: Si Senatoris filia, neptis, proneptis libertino vel qui artem ludicram exercuit, cuiusve pater materve id fecerit, nupserit, nuptiae non erunt. "Se a filha, neta ou a bisneta de um Senador se casar com um liberto ou com quem participou dos espetáculos públicos, ou com aquele cujo pai ou cuja mãe tiver feito isto, não haverá núpcias"; Ulp. 3 ad l. Iul. et Pap. D.23,2,27: Si quis in Senatorio ordine agens libertinam habuerit uxorem, quamvis interim uxor non sit, attamen in ea conditione est, ut, si amiserit dignitatem, uxor esse incipiat. "Se alguém pertencendo à ordem Senatorial teve por mulher uma liberta, ainda que, durante este tempo, não seja sua esposa, contudo, encontra-se no caso em que, se ele perdeu a dignidade, ela comece a ser sua esposa". Vejam-se também, sobre os impedimentos matrimoniais entre libertos e membros da classe senatorial, Pap. 4 resp. D.1,9,9; Marcell. 1 ad l. Iul. et Pap. D.23,2,32; Pap. 4 resp. D.23,2,34,3; Paul. 1 ad l. Iul. et Pap. D.23,2,44,1; Ulp. 32 ad Sab. D.24,1,3,1. Apenas com a concessão do imperador (indulgentia principis) é possível o casamento do Senador com uma liberta, conforme Ulp. 4 ad l. Iul. et Pap. D.23,2,31: Si Senatori indulgentia Principis fuerit permissum libertinam iustam uxorem habere, potest iusta uxor esse. "Se ao Senador se permitiu por indulgência do Príncipe ter como legítima esposa uma liberta, pode ser legítima esposa". Nas opiniões de R. ASTOLFI, La Lex Iulia et Papia cit. (nota 15 supra), p.112 e S. SolAzZI, op.cit., pp.85-86, o senatusconsulto de Marco Aurélio determinou a proibição a todos os ingênuos de se casarem com as feminae probrosa, devido aos escândalos sociais que essas uniões criavam. Apenas com Justiniano (Iust. C.5,4,28pr.) foi abolida esta proibição. As leis matrimoniais determinaram a dissolução do matrimônio no caso em que o marido da liberta fosse nomeado senador. Era uma causa posterior que tornava o matrimônio ilegítimo.

Vejam-se E. VOlterRA, Matrimonio cit. (nota 61 supra), p.773; B. Biond, Istituzioni cit. (nota 22 supra), p.447; F. SCHUlZ, Classical Roman Law cit. (nota 51 supra), p.129; V. ARANGIO-RUIZ, Istituzioni cit. (nota 53 supra), p.442; A. BURDESE, Manuale cit. (nota 47 supra), pp.273, nota 26;280; G. CornIL, Droit Romain cit. (nota 55 supra), p.129; R. MonIER, Manuel cit. (nota 146 supra), p.280; A. LÓPEZ PEDREIRA, Limitaciones a la 'libertas nuptialis' cit. (nota 40 supra), p.402; M. ZABŁOCKA, Il 'ius trium liberorum' cit. (nota 103 supra), p.362; G. LONGO, Lex Iulia de maritandis ordinibus e Lex Papia Poppaea cit. (nota 103 supra), p.811; D. DALLA - R. LAMBERTINI, Istituzioni di diritto romano cit. (nota 10 supra), pp.107;110; L.F. RADITSA, Augustus Legislation cit. (nota 49 supra), pp.319;324;327; D. NÖRR, The matrimonial Legislation of Augustus cit. (nota 54 supra), p.351; K. GALINSKY, Augustan Culture cit. (nota 102 supra), p.130; A. BouCHÉ-LECLERCQ, Les lois démographiques d'Auguste cit. (nota 36 supra), p.259; R. ASTOLFI, La Lex Iulia et Papia cit. (nota 15 supra), pp.50;93-94;97;111-112;131;133; Idem, Note per una valutazione storica della 'Lex Iulia et Papia' cit. (nota 36 supra), p.218. Na opinião de T. Spagnuolo Vigorita, Casta Domus cit. (nota 26 supra), p.31, a denominação da lei Iulia de Maritandis ordinibus, era originária das normas sobre a illegittimità della nozze tra i membri dell'ordine senatorio e i libertini, nonché tra gli altri 'ingenui' e le persone di cattiva reputazione, che pare costituissero il primo o i primi due capitoli della leggi. De acordo com J. GAUDEMET, Justum matrimonium cit. (nota 51 supra), p.124, nota 66, dois trechos, um de Celso (Cels. 30 dig. D.23,2,23) e outro do Código de Justiniano (Iust. C.5,4,28) atribuíam os impedimentos matrimoniais entre as ordens à Lex Papia Poppaea. É mais provável tratar-se de uma repetição das normas da Lex Iulia de maritandis ordinibus na Lex Papia Poppaea.

${ }^{169}$ No período clássico, as ex-prostitutas não se reabilitavam socialmente e permaneceu a proibição de seus matrimônios com os Senadores. Isto também se aplicava às ex-atrizes e ex-alcoviteiras. Veja-se Ulp. $1 \mathrm{ad} l$. Iul. et Pap. D.23,2,43,4: Non solum autem ea, quae facit, verum ea quoque, quae fecit, et si facere desiit, lege notatur; neque enim aboletur turpitudo, quae postea intermissa est. "Porém é condenada pela lei não apenas aquela que faz esta vida [prostituição], mas também aquela que fez, ainda que deixou de fazê-la; porque a torpeza não é abolida depois que foi interrompida". Neste sentido, R. Astolfi, La Lex Iulia et Papia cit. (nota 15 supra), p.97; R. Astolfi, Femina probrosa cit. (nota 96 supra), pp.19-22;30-31; S. SOLAZZI, Glossemi nelle fonti giuridiche romane, in BIDR 46 (1939), pp.52-53; J. GAUDEMET, Justum matrimonium cit. (nota 51 supra), p.125; E. NARDI, La 'incapacitas' delle 'feminae probrosae' cit. (nota 96 supra), p.157; Idem, Sui divieti matrimoniali delle leggi augustee cit. (nota 109 supra), pp.132-133, nota 55. Em relação à prostituição, a notoriedade do exercício público da atividade é o elemento que caracteriza a probrositas. Não é fundamental, para caracterizar a prostituição, que a mulher receba pagamento em dinheiro. Conforme Marcell. 26 dig. D.23,2,41pr.; -1; Ulp. 1 ad l. Iul. et Pap. D.23,2,43pr.

${ }^{170}$ De acordo com M. ZABŁOCKA, Le modifiche introdotte nelle leggi matrimoniale Augustee cit. (nota 103 supra), pp.404-407, é provável que Augusto tenha promulgado um senatusconsulto em 22 a.C., anterior à Lex Iulia de maritandis ordinibus, proibindo que qualquer membro das classes senatorial e equestre se apresentasse em exibições públicas, nos teatros e nas arenas dos circos. Vejam-se Suet. Augustus 43;45; Dio 
deprehensa) ${ }^{172}$, mulheres condenadas em juízo público (iudicio publico damnata) ${ }^{173}$, dançarinas e aquelas que exercessem qualquer profissão que fosse realizada em apresentações no palco (scaenicae $)^{174}$, além das mulheres que tivessem "proveniência desconhecida" (obscuro loco natae). ${ }^{175}$

Cass. 54,2,5; Pap. 2 de adult. D.48,5,10,2. Salienta R. Astolfi, Femina probrosa cit. (nota 96 supra), p.23, nota 19, que, as scaenicae eram elencadas entre as probrosae porque, para a sociedade romana do início do Império, tinham uma vida considerada imoral e torpe.

${ }^{171}$ Ulp. 1 ad l. Iul. et Pap. D.23,2,43,6. Vejam-se R. Astolfi, Femina probrosa cit. (nota 96 supra), pp.2223; E. NARDI, La 'incapacitas' delle 'feminae probrosae' cit. (nota 96 supra), p.157.

${ }^{172}$ Pap. 4 resp. D.23,2,34,1.

${ }^{173}$ De acordo com R. Astolfi, La Lex Iulia et Papia cit. (nota 15 supra), pp.96-97;112-113; Idem, Femina probrosa cit. (nota 96 supra), pp.20;23;30;34-36;38-40, este impedimento matrimonial com mulher iudicio publico damnata foi estabelecido a todos os ingênuos por um senatusconsulto de data incerta. Contra esta opinião, S. SoLAzZI, Sui divieti matrimoniali delle leggi augustee cit. (nota 168 supra), p.87, defende que não foi necessário um senatusconsulto para proibir o casamento dos senadores com as mulheres condenadas em juízo, pois a proibição já era determinada pela Lex Iulia de maritandis ordinibus. Ulp. 1 ad l. Iul. et Pap. D.23,2,43,10: Senatus censuit, non conveniens esse ulli Senatori, uxorem ducere aut retinere damnatam publico iudicio; quo iudicio cuilibet ex populo experiri licet, nisi si cui lege aliqua accusandi publico iudicio non est potestas. "O Senado estabeleceu, que não era permitido a nenhum senador casar-se ou continuar a ter como esposa, à condenada em juízo público; cuja ação é lícito exercer qualquer indivíduo do povo, a não ser que alguém não tenha, em virtude de alguma lei, a faculdade para acusar em juízo público". Também faz referência a este impedimento determinado pelo Senado, o jurisconsulto Mauriciano, de acordo com UE 13,2: Ceteri autem ingenui prohibentur ducere lenam, et a lenone lenave manumissam, et in adulterio deprehensam, et quae artem ludicram fecerit: adicit Mauricianus et a senatu damnatam. "Aos outros ingênuos é proibido casarem-se com a alcoviteira ou com a alforriada por rufião ou por alcoviteira, com a adúltera e a condenada criminalmente, e com a atriz; Mauriciano acrescenta o mesmo com relação à condenada pelo Senado". Veja-se J. GAUDEMET, Justum matrimonium cit. (nota 51 supra), p.133.

${ }^{174}$ No caso de um dos pais dos cônjuges faça atuação em espetáculos e jogos públicos (arte ludicram), isto não é causa para que ocorra a dissolução deste matrimônio, principalmente se o casal já tivesse filhos. Vejase Paul. 1 ad l. Iul. et Pap. D.23,2,44,6: Si postea ingenuae uxoris pater materve artem ludicram facere coeperit, iniquissimum est, dimittere eam debere, quum nuptiae honestae contracta sint, et fortasse iam liberi procreati sint. "Porém, se o pai ou a mãe de uma mulher ingênua tiver começado depois a representar em diversões públicas [espetáculos e jogos públicos], é muito injusto que o marido deva repudiá-la, celebrandose honestas núpcias, e tendo, talvez, procriado filhos". Mas, se ela começasse a exercer a artem ludicram, deveria ser repudiada, o marido não pode mais tratá-la como uxor. Paul. 1 ad l. Iul. et Pap. D.23,2,44,7: Plane si ipsa artem ludicram facere coeperit, utique dimittenda erit. "Porém, se a mesma começar a representar nos espetáculos públicos, de qualquer maneira será repudiada". De acordo com R. AsTOLFI, Femina probrosa cit. (nota 96 supra), pp.31; 34, nota 47, pode-se afirmar que era previsto pela Lex Iulia et Papia a proibição do matrimônio entre os membros da classe senatorial com os filhos de atores e ex-atores, ou seja, a atividade infamante dos pais influenciava nos impedimentos matrimoniais dos filhos. O exercício da ars ludicra por parte da mãe prejudica o filhos, mesmo se vulgo conceptus. Não tem importância o momento em que os pais exerceram a ars ludicra. Não prejudica, se os pais cessaram de exercê-la antes da concepção ou da adoção.

R. Astolfi, La Lex Iulia et Papia cit. (nota 15 supra), pp.100;113-114; Idem, Femina probrosa cit. (nota 96 supra), p.38, indica que há divergências entre a Epítome de Ulpiano (Regras de Ulpiano) UE 13,1-2 e os passos do Digesto, em relação aos impedimentos matrimoniais entre os ingênuos e membros da classe senatorial, previstos na Lex Iulia et Papia, ou seja, as atrizes, ex-atrizes, prostitutas e mulheres iudicio publico damnata (feminae probrosae). Na opinião do autor, a Epítome de Ulpiano não reproduz o direito do período clássico. Nos trechos da Epítome, os ingênuos não poderiam casar-se com a mulheres iudicio publico damnatae, com as atrizes e ex-atrizes; apenas a classe senatorial era proibida de casar-se com as prostitutas. Segundo o Digesto, o matrimônio com as prostitutas era proibido a todos os ingenui.

${ }^{175}$ Ulp. 1 ad l. Iul. et Pap. D.23,2,43pr.;6-9;12 e 13; Paul. 2 ad l. Iulia et Papia D.23,2,47; Ulp. 2 ad l. Iul. et Pap. D.25,7,1,2; Marcian. 12 inst. D.25,7,3pr.; Pap. 2 de adult. D.48,5,10,2; Pap. l. s. de adult. D.48,5,12,13; Ulp. 2 de adult. D.48,5,13,2; Suet. Domitianus 8,4 (vide nota 96 supra). Afirma G. CASTELLI, Il concubinato cit. (nota 96 supra), p.59, que as mulheres obscuro loco natae eram aquelas cujo pai ou mãe tivessem 
Paul. 1 ad l. Iul. et Pap. D.23,2,44pr.: Lege Iulia ita cavetur: Qui senator est, quive filius, neposve ex filio, proneposve ex filio nato cuius eorum est, erit, ne quis eorum sponsam uxoremve sciens dolo malo habeto libertinam, aut eam, quae ipsa, cuiusve pater materve artem ludicram facit, fecerit; neve senatoris filia, neptisve ex filio, proneptisve ex nepote filio nato, nata, libertino eive, qui ipse cuiusve pater materve artem ludicram facit, fecerit, sponsa nuptave sciens dolo malo esto; neve quis eorum dolo malo sciens sponsam uxoremve eam habeto.

“Dispõe-se na lex Iulia deste modo: 'Ninguém que é Senador, ou que é ou foi filho, ou neto nascido de um filho, ou bisneto nascido de um filho nascido de qualquer deles, tenha intencionalmente e com dolo mau, por sponsa [noiva] ou esposa uma liberta, ou aquela que, ela mesma, ou seu pai ou mãe, representa, ou representou, nos espetáculos públicos; nem a filha de um Senador, ou a neta nascida de um filho, ou a bisneta nascida de um neto nascido de um filho, se considere sponsa ou casada intencionalmente e com dolo mau, com um liberto, ou com aquele que, ele mesmo, ou seu pai ou mãe, representa, ou representou nos espetáculos públicos; e nenhum destes tenha-lhe por sponsa ou esposa, com dolo mau e intencionalmente". 176

exercido a ars ludicra. Este autor, na p.70, dividiu as feminae probrosae em duas categorias, tendo como critério a possibilidade de casamento com os ingênuos. As alcoviteiras, atrizes e adúlteras não podiam casarse com ingênuos. Estes podiam casar-se com as prostitutas e as mulheres obscuro loco natae, equiparadas às libertas. As relações sexuais com todas essas mulheres mencionadas não eram consideradas stuprum e, portanto, elas não estavam submetidas às sanções das leis matrimoniais de Augusto. Na opinião de E. NARDI, La 'incapacitas' delle 'feminae probrosae' cit. (nota 96 supra), pp.156-158, nota 27;159, eram feminae probrosae somente as prostitutas, alcoviteiras e atrizes, pois faziam da "vergonha"(probrum) o objetivo de sua vida, numa profissão reiterada e obscena, obtendo lucros torpes. E conclui que, feminae probrosae eram le professioniste del 'probrum'. Para E. VOLTERRA, Concubinato (Diritto romano) cit. (nota 166 supra), pp.1052, as relações com prostitutas, atrizes, alcoviteiras, condenadas em juízo público por adultério, obscuro loco natae, foram consideradas, provavelmente, como concubinato (in quas stuprum non committitur). Salienta R. Astolfi, La Lex Iulia et Papia cit. (nota 15 supra), p.49; Idem, Femina probrosa cit. (nota 96 supra), p.20, que a probrositas não é necessariamente uma imoralidade sexual, mas uma degradação moral e social, um ato contrário ao pudor e à decência pública. Na opinião de T. MOMMSEN, Römisches Strafrecht cit. (nota 96 supra), p.438, a legislação de Augusto puniu, com a perda da testamenti factio, os cônjuges que, conscientemente, se casassem com uma mulher que não fosse materfamilias e tivessem um comportamento desonroso ou não observassem os impedimentos matrimoniais entre as ordens, v.g., o matrimônio entre o senador e a liberta.

Vejam-se T. Spagnuolo Vigorita, Casta Domus cit. (nota 26 supra), p.42; R. Astolfi, La Lex Iulia et Papia cit. (nota 15 supra), pp.49-50;96-98;133-134;330; D. DALLA - R. LAMBERTINI, Istituzioni di diritto romano cit. (nota 10 supra), p.108; L.F. RADITSA, Augustus Legislation cit. (nota 49 supra), p.314; J.A. FIELD JR., The purpose cit. (nota 129 supra), p.402; D. NÖRR, The matrimonial Legislation of Augustus, cit. (nota 54 supra), p.360; M. MoLÈ, Stuprum cit. (nota 96 supra), p.585; M. ZABŁOCKA, Le modifiche introdotte nelle leggi matrimoniale Augustee cit. (nota 103 supra), p.397; J. GAUDEMET, Justum matrimonium cit. (nota 51 supra), pp.124-132.

176 D. NÖRR, The matrimonial Legislation of Augustus, cit. (nota 54 supra), p.360, ao realizar alguns 
O caput da lex Iulia de maritandis ordinibus que estabelecia os impedimentos matrimoniais aos ingênuos (ceteri ingenui) ${ }^{177}$ provavelmente estava disposto logo após as proibições relativas à ordem senatorial. Os ingênuos podiam casar-se com as libertas, mas não com as feminae probrosae, visto que, se casassem com estas últimas, apesar de seu matrimônio não ser nulo, não estariam de acordo com a legislação matrimonial. ${ }^{178}$

comentários sobre D.23,2,44pr., considera que a Lex Papia Poppaea, neste caso, não obteve êxito ao tentar realizar este planejamento social. Além disso, NÖRR critica a linguagem e a técnica interpretativa utilizada pelo jurista Paulo, por ser muito casuística, privada de conceitos e com um texto repleto de omissões e falhas. Veja-se R. Astolfi, La Lex Iulia et Papia cit. (nota 13 supra), pp.93-94;98;337. Segundo S. SolAzZI, Sui divieti matrimoniali delle leggi augustee cit. (nota 168 supra), p.81, permanece a dúvida se o impedimento das núpcias era dirimente neste trecho de Paulo.

${ }_{177}$ Paul. 1 ad l. Iul. et Pap. D.23,2,44,8: Eas, quas ingenui ceteri prohibentur ducere uxores, senatores non ducent. "Os Senadores não se casarão com aquelas que aos demais ingênuos é proibido se casar". Os impedimentos matrimoniais relativos aos ceteri ingenui também eram aplicados à ordem senatorial. Vejamse R. Astolfi, La Lex Iulia et Papia cit. (nota 15 supra), pp.98-99; Idem, Femina probrosa cit. (nota 96 supra), pp.34-35; J. GAUDEMET, Justum matrimonium cit. (nota 51 supra), p.126.

${ }^{178}$ Contra a opinião de que todas as feminae probrosae eram proibidas de casar-se com os ingênuos, veja-se G. CASTELLI, Il concubinatocit. (nota 96 supra), p.70; S. SOLAZZI, Glossemi nelle fonti giuridiche romane cit. (nota 169 supra), pp.51, nota 5;52-53; R. AstolfI, La Lex Iulia et Papia cit. (nota 15 supra), pp.138-140; Idem, Femina probrosa cit. (nota 96 supra), pp.40-41. AsTOLFI defende que o ingênuo, de acordo com a Lex Iulia de maritandis ordinibus não poderia casar-se com a prostituta, com a alcoviteira e com a ré de adultério, mas poderia casar-se com a atriz, ex-atriz, a profissional de teatro e com as mulheres iudicio publico damnatae, conforme UE 13,1-2; Ulp. 1 ad l. Iul. et Pap. D.23,2,43pr.,5-9; Pap. l. s. de adult. D.48,5,11,13; Ulp. 2 de adult. D.48,5,13,2. Algumas disposições da Lex Iulia et Papia excluíam o elemento objetivo do matrimônio romano, o honor matrimonii, principalmente nas relações em que existissem grandes diferenças sociais entre homem e mulher ou quando um dos cônjuges exercesse profissão considerada infame. Estas normas buscavam impedir o ingresso na cidadania romana de indivíduos considerados inferiores pela sociedade da época. A união estável com estas mulheres infames foi denominada concubinato.

Segundo Modestino, há no direito romano um princípio, inconcebível no direito moderno, de que toda união entre homem e mulher livres é presumida ser um matrimônio. Augusto parece ter seguido este princípio e estabeleceu que todas as outras uniões que não fossem presumidas como um matrimônio fossem atingidas com penas severas. Vejam-se Mod. 1 reg. D.23,2,24: In liberae mulieris consuetudine non concubinatus, sed nuptiae intelligendae sunt, si non corpore quaestum fecerit. "A convivência com uma mulher livre deve ser interpretada como matrimônio e não como concubinato, se não tivesse feito comércio com seu corpo"; UE 13,1: Lege Iulia prohibentur uxores ducere senatores quidem liberique eorum libertinas et quae ipsae quarumque pater materve artem ludicram fecerit, item corpore quaestum facientem. "Pela Lei Júlia é proibido aos senadores e seus filhos casarem-se com libertas, atrizes e suas filhas, assim como com as que mercadejam com o próprio corpo".

O matrimônio ilícito em relação à Lex Iulia et Papia era irrelevante, os cônjuges eram considerados caelibes mesmo tendo filhos. Por isso, o matrimônio deveria ser válido para o ius civile (iustum secundum ius civile) e lícito, de acordo com a Lex Iulia et Papia. Conforme UE 16,2: Aliquando nihil inter se capiunt: id est, si contra legem Iuliam Papiamque Poppaeam contraxerint matrimonium, verbi gratia si famosam quis uxorem duxerit, aut libertinam senator. "Às vezes não tomam nada reciprocamente, como quando contraírem casamento contra as Leis Júlia e Papia Poppaea; por exemplo, se alguém se casar com mulher de má reputação ou se um senador se casar com liberta". Surge portanto a noção de um casamento válido, mas privado de certos efeitos jurídicos, v.g., os cônjuges considerados caelibes eram privados do ius capiendi. Contra esta opinião E. NARDI, Sui divieti matrimoniali cit. (nota 109 supra), pp.136-138, afirma que estes matrimônios contrários ao Ius civile e à Lex Iulia et Papia eram nulos.

Era proibido que o Senador casasse com uma mulher in adulterio deprehensa (a mulher apanhada em flagrante de adultério, conforme Ulp. 1 ad l. Iul. et Pap. D.23,2,43,12), ou uma mulher quae quaestum vel artem ludicram fecerit (Paul. 1 ad l. Iul. Et Pap. D.23,2,44,1). Paulo afirma que era impune o matrimônio 
É considerado filho de senador não apenas o natural, mas também o adotivo. ${ }^{179}$

Em relação à liberta, conforme a lex Iulia de maritandis ordinibus, se fosse casada

com o seu patrono, não podia repudiá-lo e, caso isso ocorresse, só poderia casar-se

novamente ou tornar-se concubina de outro homem com o consentimento dele. ${ }^{180}$

entre o liberto e a filha do senador que foi atriz ou foi condenada em juízo público, conforme Paul. $2 \mathrm{ad} l$. Iulia et Papia D.23,2,47: Senatoris filia, quae corpore quaestum vel artem ludicram fecerit, aut iudicio publico damnata fuerit, impune libertino nubit; nec enim honos ei servatur, quae se in tantum foedus deduxit. "A filha de um Senador, que tivesse realizado lucro com o seu corpo ou representado nos espetáculos públicos, ou que tivesse sido condenada em juízo público, casa-se impunemente com um liberto; porque não se conserva a honra daquela que se rebaixou a tanta torpeza". Celso confirma que os ingênuos podem casarse com as libertas, uma vez que elas não eram consideradas feminae probrosae. Cels. 30 dig. D.23,2,23: Lege Papia cavetur omnibus ingenuis, praeter senatores eorumque liberos, libertinam uxorem habere licere. "Dispõe a Lei Papia que é permitido a todos os ingênuos, exceto aos Senadores e aos seus descendentes, casar-se com uma liberta". Vejam-se também Iust. C.5,4,28pr. (531-532); UE 16,2; Dio Cass. 54,16,2; $56,7,2$. Os ingênuos não podiam casar-se com prostitutas, nem com mulheres que foram prostitutas em algum período de suas vidas (Ulp. 1 ad l. Iul et Papia D.23,2,43,4), nem alcoviteiras (Ulp. 1 ad l. Iul. et Papia D.23,2,43,6-9), nem com aquelas que foram condenadas por adultério (Ulp. 1 ad $l$. Iul. et Papia D.23,2,43,12-13). No trecho de Paulo, D.23,2,44pr., este impedimento é indicado pelo verbo fecerit.

Na opinião de F. Della CORTE, Le 'leges Iuliae' e l'elegia romana cit. (nota 47 supra), pp.546 e 553, em suma, na época de Augusto havia duas concepções de mulher: uma mulher casta, de bons costumes, personificada na mãe-esposa (materfamilias), na viúva ou na filha; outra uma mulher sensual, a meretrix, a liberta e a puella dos elegíacos. Também neste sentido Paul. 1 ad Iul. et Pap. D.23,2,44pr.; Marcell. ad l. Iul. et Pap. D.23,2,49.

Vejam-se A. GuARINO, Storia del diritto romano cit. (nota 103 supra), p.446; E. VolTERRA, Matrimonio cit. (nota 61 supra), pp.770-771; 743-744; Idem, La conception du Mariage d'après les juristes romains cit. (nota 30 supra), pp.37-38; Idem, Les formes du Mariage chez les Romains cit. (nota 30 supra), p.281; Idem, La conception du Mariage d'après les juristes romains cit. (nota 30 supra), p.54; E. AlBERTARIO, Honor matrimonii cit. (nota 61 supra), p.200; L.F. RADITSA, Augustus Legislation cit. (nota 49 supra), pp.290;326; R. Astolfi, La Lex Iulia et Papia cit. (nota 15 supra), pp.49-51;115;129-130;330-331;337;340;363; Idem, Femina probrosa cit. (nota 96 supra), pp.31-32;36; Idem, Note per una valutazione storica della 'Lex Iulia et Papia' cit. (nota 36 supra), p.191; G. PUGLIESE - F. SiTZIA - L. VACCA, Istituzioni cit. (nota 63 supra), p.401; A. LóPez PEDREIRA, Limitaciones a la 'libertas nuptialis' cit. (nota 40 supra), p.402; C. PUJAL, La concepción jurídica cit. (nota 47 supra), p.616; E. MALDONADO DE LIZALDE, Lex Iulia de Maritandis Ordinibus cit. (nota 122 supra), p.547-548; M. ZABŁOCKA, Il 'ius trium liberorum' cit. (nota 103 supra), p.362; T. Spagnuolo Vigorita, Casta Domus cit. (nota 26 supra), pp.23;30;42, nota 137; B. BiONDI, La legislazione di Augusto cit. (nota 56 supra), pp.132;156; V. ARANGIO-RUIZ, Istituzioni cit. (nota 53 supra), p.443; M. MARRONE, Istituzioni cit. (nota 48 supra), p.218, nota 56; E.C.S. MARCHI, Matrimônio moderno cit. (nota 61 supra), p.60; H. ANKUM, La 'captiva adultera' cit. (nota 63 supra), p.156; G. LONGO, Riflessioni critiche cit. (nota 48 supra), pp.2374-2375; S. SolAZZI, Sui divieti matrimoniali delle leggi augustee cit. (nota 168 supra), pp.82-83;97; J. GAUDEMET, Justum matrimonium cit. (nota 51 supra), pp.127-128;130;159; A. BouchÉ-LEClERCQ, Les lois démographiques d'Auguste cit. (nota 36 supra), p.259; E. NARDI, La 'incapacitas' delle 'feminae probrosae' cit. (nota 96 supra), pp.164, nota 46;172-173; Idem, Sui divieti matrimoniali cit. (nota 109 supra), pp.115-118;124-125;128-129, nota 39; E. MALDONADO DE LIZALDE, Lex Iulia de Maritandis Ordinibus cit. (nota 122 supra), pp.556-557.

${ }^{179}$ R. AstOLFI, Femina probrosa cit. (nota 96 supra), p.38, nota 47. Veja-se Ulp. 34 ad ed. D.1,9,10: Liberos senatorum accipere debemus non tantum senatorum filios, verum omnes, qui geniti ex ipsis exve liberis eorum dicantur, sive naturales sive adoptivi sint liberi senatorum, ex quibus nati dicuntur. Sed si ex filia senatoris natus sit, spectare debemus patris eius condicionem. "Devemos tomar como descendentes dos senadores não somente os filhos dos senadores, mas todos os que se digam por eles gerados ou pelos filhos deles; quer naturais, quer adotivos, sejam eles filhos de senadores dos quais se dizem nascidos. Mas se for um nascido da filha de senador, devemos aguardar a condição do pai dele".

180 Portanto, de acordo com a Lex Iulia de maritandis ordinibus, sem o consentimento do patrono o matrimônio entre ele e a liberta continua a existir, por força do ius civile. A affectio maritalis do patrono mantinha o matrimônio válido e existente. A liberta não podia se divorciar e o segundo matrimônio era nulo. 
Contra esta opinião, S. SolAzZI, Sui divieti matrimoniali delle leggi augustee cit. (nota 168 supra), pp.86-87; Idem, La legge augustea sul divorzio della liberta e il diritto civile, in BIDR 51-52 (1948), pp.327-331;336. Vejam-se, Marc. 10 inst. D.23,2,28; Ulp. 3 ad leg. Iul. et Pap. D.23,2,29; Ulp. 3 ad leg. Iul. et Pap. D.23,2,45pr.,-2,-4,-5; Gai. 8 ad l. Iul. et Pap. D.23,2,46; Ter. Clem. 8 ad l. Iul. et Pap. D.23,2,48pr.,-1; Marc. 3 ad l. Iul. et Pap. D.23,2,50; Herm. 2 iur. ep. D.24,1,62,1; Mod. 1 reg. D.24,2,10; Ulp. 3 ad l. Iul. et Pap. D.24,2,11pr.,-2 ; Ulp. 3 ad l. Iul. et Pap. D.24,3,11,1; Marc. 10 inst. D.24,3,35; Ulp. 47 ad Ed. D.38,11,1,1; Ulp. L.s. de off. Proc. D.40,2,13; Mod. 1 pand. D.40,9,21; Alex. C.5,5,1; 6,3,9 (225). O dote permanecia com o patrono (Ulp. 3 ad leg. Iul. et Pap. D.24,2,11pr; Marc. 10 inst. D.24,3,35). Ulpiano defende como lícito e honroso o concubinato entre a liberta e o patrono (Ulp. 2 ad leg. Iul. et Pap. D.25,7,1pr.; Ulp. 2 de adult. D.48,5,13pr.). Se o matrimônio entre o patrono e a liberta não estivesse de acordo com a Lex Iulia de maritandis ordinibus, ela tinha plena liberdade para divorciar-se e casar-se com outro. Por exemplo, se o patrono contra os impedimentos matrimoniais da Lex Iulia de maritandis ordinibus, casou-se com uma liberta prostituta (ignominiosa) ele não poderia gozar do "benefício da lei”. Conforme, Ter. Clem. 8 ad l. Iul. et Pap. D.23,2,48,1: Si ignominiosam libertam suam patronus uxorem duxerit, placet, quia contra legem maritus sit, non habere eum hoc legis beneficium. "Se o patrono casou com uma liberta sua ignominiosa, está estabelecido, por que se casou contra a lei, que ele não tenha este benefício da lei”. Na relação de concubinato, a liberta tinha a possibilidade de abandonar o patrono quando desejasse. Ulp. 2 ad leg. Iul. et Pap. D.25,7,1pr.: Quae in concubinato est, ab invito patrono poterit discedere, et alteri se aut in matrimonium, aut concubinatum dare. "Aquela que está em concubinato poderá separar-se de seu patrono contra a vontade do mesmo e dar-se a outro em matrimônio ou em concubinato".

Caso o patrono fosse capturado pelos inimigos, o matrimônio é mantido por causa da reverência a ele devida pela liberta e só pode ser dissolvido pela morte de um dos cônjuges, conforme Ulp. 3 ad Iul et Pap. D.23,2,45,6, uma exceção à regra do ius postliminii, em que o casamento é dissolvido pelo cativeiro de um dos cônjuges: Si ab hostibus patronus captus esse proponatur, vereor, ne possit ista connubium habere nubendo, quemadmodum haberet, si mortuus esset; et qui Iuliani sententiam probant, dicerent, non habituram connubium; putat enim Iulianus, durare eius libertate matrimonium etiam in captivitate propter patroni reverentiam. Certe, si in aliam servitutem patronus sit deductus, proculdubio dissolutum esset matrimonium. "Se se dissesse que o patrono foi capturado pelos inimigos, temo que não possa ter esta [a liberta] o direito de matrimônio ao casar-se, como o teria, se ele tivesse morrido; e aqueles que aprovam a opinião de Juliano, diriam que ela não terá o direito de matrimônio; porque opina Juliano, que subsiste o matrimônio desta liberta mesmo durante o cativeiro em razão da reverência ao patrono. Porém, na verdade, se o patrono fosse reduzido à outra escravidão, sem dúvida nenhuma se dissolveria o matrimônio". Portanto, dissolve-se o matrimônio entre a liberta e o patrono reduzido à escravidão, de captivus tornou-se servus hostium e não pode mais manifestar vontade juridicamente relevante. U. RATTI, Studi sulla 'captivitas' cit. (nota 57 supra), pp.87-88, nota 1, considera interpolado o passo D.23,2,45,6, pois defende que no direito clássico o cativeiro dissolvia ipso iure o matrimônio e as mulheres, tanto ingênuas quanto libertas, estavam livres para contrair um novo vínculo matrimonial.

Em outra situação análoga, caso o patrono torne-se louco (demens ou furiosus), o matrimônio só poderia ser dissolvido pela morte de um dos cônjuges, conforme Ulp. 3 ad l. Iul. et Pap. D.23,2,45,5: Deinde ait lex: 'invito patrono'; invitum accipere debemus eum, qui non consentit ad divortium; idcirco nec a furioso divertendo solvit se huius legis necessitate, nec si ab ignorante divorterit; rectius enim hic invitus dicitur, quam qui dissensit. "Depois diz a lei: 'contra a vontade do patrono': e devemos entender que é contra a vontade daquele que não consente no divórcio; pelo qual, nem se divorciando de um louco [furioso], nem se se divorciar daquele que o ignorasse, se exime da obrigação desta lei; na verdade, com certeza se diz que tanto este age contra a vontade, quanto aquele que discordou".

Vejam-se V. ARANGIO-RuIZ, Istituzioni di diritto romano cit. (nota 53 supra), pp.442;463; A. BURDESE, Manuale cit. (nota 47 supra), p.281; E. VOLTERRA, La nozione giuridica del 'conubium', in Scritti Giuridici II. Famiglia e Sucessioni, Napoli, Jovene, 1991, pp.301-302; J. IGLESIAS, Derecho Romano cit. (nota 51 supra), p.345; L. D’AMATI, Matrimonium e Postliminium cit. (nota 63 supra), p.48, nota 18; G. CASTELLI, Il concubinato cit. (nota 96 supra), p.57; R. AstolfI, La Lex Iulia et Papia cit. (nota 15 supra),pp.103;109;173175;177;179-183;187-189;191-194;197-198;209-210;327;333;336; Idem, Note per una valutazione storica della 'Lex Iulia et Papia' cit. (nota 36 supra), p.188; T. Spagnulo VigoritA, Casta Domus cit. (nota 26 supra), pp.34-35; B. BIONDI, La legislazione di Augusto cit. (nota 56 supra), p.151; Idem, Istituzioni cit. (nota 22 supra), p.448, nota 48; L.F. RADITSA, Augustus Legislation cit. (nota 49 supra), pp.328-329; H. ANKUM, La 'captiva adultera'cit. (nota 63 supra), pp.201-202; J. GAUDEMET, Justum matrimonium cit. (nota 51 supra), pp.114;130;152. 
Se o patrono negasse tal consentimento (invito patrono) ${ }^{181}$, ficava a mulher liberta, embora separada de fato, impedida de contrair novo matrimônio, pois a lex Iulia de maritandis ordinibus retirava-lhe o conubium. Apenas no momento em que o patrono consentisse, o matrimônio se dissolvia e então a mulher poderia casar-se. ${ }^{182}$

A lex Iulia et Papia estabelecia que a liberta, entre os 20 e os 50 anos de idade, que tivesse a permissão do patrono e se casasse com um terceiro, estava liberada da prestação das operae officiales. Este benefício era um incentivo para que as libertas se casassem. Por isso, quando a liberta completasse 50 anos, ela era dispensada de realizar as operae, pois a partir desta idade ela não era mais obrigada a casar-se, de acordo com a lex Iulia.

Paul. 2 ad l. Iul. et Pap. D.38,1,35: Liberta maior quinquaginta annis operas

\begin{abstract}
${ }^{181}$ Neste caso, a palavra invitus indicava tanto a falta de consentimento voluntária do patrono quanto o caso da impossibilidade de seu consentimento. Vejam-se R. Astolfi, La Lex Iulia et Papia cit. (nota 15 supra), pp.173-188;193-194; B. BIONDI, La legislazione di Augusto cit. (nota 56 supra), p.151. Conclui R. AsTOLFI, Note per una valutazione storica della 'Lex Iulia et Papia' cit. (nota 36 supra), p.194, que mesmo sendo nulas as segundas núpcias da liberta, o divórcio dissolvia o matrimônio entre ela e o patrono. Esta situação não está de acordo com a política de Augusto, ou seja, fortalecer o matrimônio e o direito de patronato, pois parece que o patrono fica na dependência da vontade da liberta para poder gozar dos prêmios e vantagens da legislação matrimonial. Contra esta opinião, S. SOLAZZI, La legge augustea sul divorzio cit. (nota 180 supra), pp.329-331;336;341;350, as segundas núpcias da liberta não eram nulas, mas plenamente válidas em relação ao ius civile, que determinava a plena liberdade dos cônjuges se divorciarem. Este novo matrimônio era contrário à Lex Iulia et Papia e os cônjuges sofreriam as sanções previstas em relação aos caelebs e não poderiam gozar dos prêmios desta legislação. A liberta não poderia mover a actio rei uxorie, porque o ius honorarium subordinava-se às leis matrimoniais e o pretor negava a ação de restituição de dote. A proibição das segundas núpcias contrasta com o escopo demográfico das leis matrimoniais de Augusto. Conclui SolAZZI na p.336 de seu trabalho: per la 'lex Iulia et Papia' il matrimonio della liberta, che divorziava contro la volontà del patrono, non era sciolto ed ella non poteva passare a nuove nozze; per il 'ius civile' ogni divorzio scioglieva il matrimonio e dava la facoltà di contrarne un altro.

${ }^{182}$ A liberta que se separou não pode exigir a sucessão ab intestato do patrono, mesmo com a permanência de seu matrimônio. Vejam-se R. Astolfi, La Lex Iulia et Papia cit. (nota 15 supra), pp.173-175;179;182188;191-194;333;363; Idem, Note per una valutazione storica della 'Lex Iulia et Papia' cit. (nota 36 supra), pp.194;225, nota 171; E. VOLTERRA, Matrimonio cit. (nota 61 supra), p.734, nota 15; A. SURGIK, A 'Manus' e o 'Consensus' cit. (nota 66 supra), p.738; F. SCHULz, Classical Roman Law cit. (nota 51 supra), p.128. Neste sentido, Ulp. 3 ad l. Iul. et Pap. D.23,2,45pr., -6; Ulp. 3 ad l. Iul. et Pap. D.24,2,11pr.; Ulp. 3 ad l. Iul. et Pap. D.24,3,11,1 e 2. Esta impossibilidade da liberta divorciar-se do patrono foi estendida a um outro caso: o da liberta manumitida matrimonii causa, que era obrigada a se casar com o patrono, independente de sua vontade. De acordo com E. VolterRA, Divorzio cit. (nota 70 supra), p.63, deve-se interpretar que a proibição da liberta separar-se do patrono fazia referência à manumitida matrimonii causa, e caso o matrimônio dela se dissolvesse, ela retonaria à condição de escrava e não poderia ter o conubium com um homem livre.
\end{abstract}

Um senatusconsulto determinou que, caso ela não se casasse dentro de seis meses, tornar-se-ia escrava novamente. Além deste poder do patrono se casar com a liberta por ele manumitida mesmo contra a vontade dela, também deveria ser comprovado, segundo a Lex Iulia de maritandis ordinibus, o sacrifício econômico e a perda patrimonial do patrono com esta manumissão matrimonii causa. Vejam-se Marcian. 10 inst. D.23,2,28; Ulp. 3 ad l. Iul. et Pap. D.23,2,29; Licin. 1 reg. D.23,2,51 pr.; Marcian. l. de off. Proc. D.40,2,13; Mod. 1 pand. D.40,9,21. Se a liberta fosse apenas sponsa do patrono, podia dissolver unilateralmente os esponsais. Conforme Ulp. 3 ad l. Iul. et Pap. D.23,2,45pr.,-4. No final do século II d.C., constituições imperiais e a jurisprudência proibiram o matrimônio entre patrona e liberto, considerando estas núpcias odiosas. Veja-se Pap. 4 resp. D.23,2,62,1: Mulier liberto viri ac patroni sui mala ratione coniungitur. "De maneira injusta une-se a mulher com o liberto de seu marido e de seu patrono". 
praestare patrono non cogitur.

"A liberta maior de cinquenta anos não é obrigada a prestar as operae ao patrono".

A lex Iulia de maritandis ordinibus punia o patrono que, por juramento (iusiurandum) ou pela stipulatio no ato da manumissão, obrigasse o liberto (ou a liberta) a não ter filhos ou a não se casar. ${ }^{183}$

Paul. 2 ad l. Ael. Sent. D.37,14,6,4: Lege Iulia de maritandis ordinibus remittitur iusiurandum, quod liberto in hoc impositum est, ne uxorem duceret, libertae, ne nuberet, si modo nuptias contrahere recte velint.

"Por força da lex Iulia de maritandis ordinibus, é rejeitado o juramento que foi imposto ao liberto de não se casar, à liberta de não se casar, apenas se desejassem honestamente contrair as núpcias".

Clem. 8 ad l. Iul. et Pap. D.40,9,32pr.: Si non voluntate patroni is, qui in eius potestate sit, iusiurandum adegerit vel stipulatus fuerit, ne nubat, nisi id patronus remittat aut liberabit libertam, incidet in legem: videbitur enim id ipsum dolo malo facere.

"Se, sem a vontade do patrono, aquele que estava sob sua potestas impusesse juramento ou estipulasse, para que a liberta não se casasse, se o patrono não o rejeitasse ou não desobrigasse a liberta, incide na lei: porque se considerará que o mesmo fez isso com dolo mau".

A união com a liberta, a mater solitaria, a femina probrosa ou a ingênua de baixa condição social, principalmente em virtude das penas rigorosas das Leis Matrimoniais de Augusto, não se caracterizava como matrimônio e sim como concubinato. Os casais recorriam ao concubinato quando suas relações fossem proibidas pela legislação

\footnotetext{
${ }^{183}$ R. Astolfi, La Lex Iulia et Papia cit. (nota 15 supra), pp.205-208;326;340-341; Idem, Note per una valutazione storica della 'Lex Iulia et Papia' cit. (nota 36 supra), p.201; A. BOUCHÉ-LeCLERCQ, Les lois démographiques d'Auguste cit. (nota 36 supra), p.271. Veja-se também Clem. 5 ad l. Iul. et Pap. D.40,9,31. Além disso, a Lex Aelia Sentia aumentava a punição ao patrono, com a perda do patronato caso ele obrigasse a liberta a não se casar ou o liberto a não ter filhos no momento da manumissão. Vejam-se Paul. 8 ad l. Iul. et
} 
matrimonial de Augusto. Nesta relação a mulher era geralmente denominada nas fontes como concubina, amica ou pellex. ${ }^{184}$

Ocorria o concubinato nas situações de convivência estável entre homem e mulher em que faltasse a affectio maritalis ${ }^{185}$, seja porque que eles não desejassem contrair matrimônio, seja porque eles pertencessem a classes sociais diferentes, existindo um impedimento legal para a caracterização das justas núpcias. ${ }^{186}$

Pap. D.37,4,15; Clem. 8 ad l. Iul. et Pap. D.40,9,32pr.

${ }^{184}$ Veja-se R. Astolfi, Femina probrosa cit. (nota 96 supra), pp.54;59. Nas palavras de J.C. MoReiRA ALves, Direito Romano cit. (nota 9 supra), p.672: "Foi em virtude das leis matrimoniais do tempo de Augusto (...) que o concubinato passou a ser levado em consideração pelo direito, ainda que de maneira indireta". Também considera que as reformas da legislação matrimonial de Augusto, mesmo que indiretamente, deram origem ao instituto do concubinato, E. VOLTERRA, Concubinato (Diritto romano) cit. (nota 166 supra), p.1052; Idem, La conception du Mariage d'après les juristes romains cit. (nota 30 supra), p.36. Acredita que a Lex Iulia et Papia fazia menção ao concubinato, apesar de não proibí-lo, A. BouCHÉLECLERCQ, Les lois démographiques d'Auguste cit. (nota 36 supra), p.260, e a concubina recebeu diversas denominações: amica, uxor gratuita, convictrix. Vejam-se Ulp. 2 ad l. Iul. et Pap. D.25,7,1,1: Cum Atilicino sentido, et puto, solas eas in concubinatu habere posse sine metu criminis, in quas stuprum non comittitur. "Opino com Atilicino, e acredito, que alguém pode ter em concubinato, sem temor de delito, somente aquelas [mulheres] com as quais não se comete stuprum"; Marcian. 12 inst. D.25,7,3,1: Nec adulterium per concubinatum ab ipso committitur; nam quia concubinatum per leges nomen assumsit, extra legis poenam est, ut et Marcellus libro septimo Digestorum scripsit. "E, não se comete adultério, pelo mesmo, com o concubinato porque como o concubinato recebeu seu nome das leis [Lex Iulia et Papia?], está fora da pena da lei, assim como escreveu Marcelo no livro sétimo do Digesto". Informa M. HUMBERT, L'individu, l'État cit. (nota 60 supra), p.191, nota 34, que a grande maioria dos casos de concubinato presentes no Digesto eran uniões entre o patrono e a liberta.

${ }^{185}$ Conforme E. Albertario, Honor matrimonii cit. (nota 61 supra), pp.200 e 209 e G. D’ERCole, Il consenso degli sposi cit. (nota 61 supra), p.7, para identificar se a relação estável entre um homem e uma mulher era matrimônio ou concubinato, os juristas afirmavam que a concubina não tinha a dignitas da uxor (esposa). Veja-se Ulp. 22 ad Sab. D.32,49,4: Parvi autem refert, uxori, an concubinae quis leget, quae eius causa empta parata sunt; sane enim, nisi dignitate, nihil interest. "Porém, pouco importa que alguém legue à sua mulher ou à sua concubina, as coisas que por causa dela foram compradas ou adquiridas; porque, na verdade, a não ser na dignidade, não há nenhuma diferença". O termo dignitas, neste caso, significa a honra, a consideração social: a uxor tem a dignitas do marido, ou seja, se ele é consularis ou clarissimus ela também compartilha destes títulos (consularis e clarissima). Dignitas tem, conforme Cícero, o sentido de mérito. Conforme Cic. Rhet. Her. 3,3: Iustitia est aequitas ius uni cuique rei tribuens pro dignitate cuiusque. "A justiça é a equidade que atribui direito a cada coisa conforme seus méritos". Vejam-se Frag. Vat. 104; Ulp. 62 ad ed. D.1,9,1pr.; Ulp. 6 fidei. D.1,9,8; Ulp. 2 de cens. D.1,9,12pr. No período pós-clássico, veja-se Valent., Theod. et Arcad. C.12,1,13(392). Também deveria ser considerado o elemento objetivo da relação (honor matrimonii).

ALBERTARIO, op.cit., p.204, sustenta que houve uma mudança entre os períodos clássico e pós-clássico, para a identificação do concubinato, em relação a ausência de um dos dois elementos necessários para a existência do matrimônio romano (affectio maritalis e honor matrimonii): Se nell'età clássica il concubinato è la relazione stabile dell'uomo con la donna senza 'honor matrimonii', nell'età postclassica giustinianea esso è la relazione stabile dell'uomo e della donna senza 'affectio maritalis'. Tradução: "Se no período clássico o concubinato é a relação estável do homem com a mulher sem honor matrimonii, no período pós-clássico justinianeu ele é a relação estável do homem e da mulher sem affectio maritalis". Vejam-se E. VOLTERRA, La conception du Mariage d'après les juristes romains cit. (nota 30 supra), pp.28-29;52-53; A. LÓPEZ PEDREIRA, Limitaciones a la 'libertas nuptialis' cit. (nota 40 supra), p.395; C. PUJAL, La concepción jurídica cit. (nota 47 supra), p.613; J. DAZA MARTíneZ, La influencia cristiana cit. (nota 48 supra), pp.115-116. Contra a tese de ALBERTARIO, de que existiu uma mudança nos períodos clássico e pós-clássico em relação à ausência de um dos elementos do matrimônio romano, veja-se G. LONGO, Riflessioni critiche cit. (nota 48 supra), p.2367, nota 29; Idem, Affectio maritalis cit. (nota 61 supra), pp.125-127.

186 Vejam-se E. Volterra, Concubinato (Diritto romano) cit. (nota 166 supra), pp.1052-1053; M. MARRONE, Istituzioni cit. (nota 48 supra), pp.219-220; R. MONIER, Manuel cit. (nota 146 supra), p.308; R. 
Apesar de não ter reconhecido formalmente a sua licitude, Augusto não combateu o concubinato, pois este era amplamente difundido na sociedade romana, determinado e sancionado pelos costumes. ${ }^{187}$

As Leis Matrimoniais provavelmente não estabeleciam qualquer disposição que fizesse referência direta ${ }^{188}$ a esta relação estável que não poderia ser considerada nem matrimônio, nem adulterium, nem stuprum. ${ }^{189}$

Astolfi, La Lex Iulia et Papia cit. (nota 15 supra), p.50; B. BIONDI, Istituzioni cit. (nota 22 supra), pp.450451; V. ARANGIO-RUIZ, Istituzioni cit. (nota 53 supra), pp.439;462-464; A. BURDESE, Manuale cit. (nota 47 supra), p.283; G. CoRNIL, Droit Romain cit. (nota 55 supra), pp.130-131; F. SCHULZ, Classical Roman Law cit. (nota 51 supra), pp.131-133; A. ROMANO, Matrimonium iustum cit. (nota 26 supra), p.99, nota 104;100, nota 106. Paul. 10 ad l. Iul. et Pap. D.50,16,144: Libro memorialium Massurius scribit "pellicem" apud antiquos eam habitam, quae, cum uxor non esset, cum aliquo tamen vivebat: quam nunc vero nomine amicam, paulo honestiore concubinam appellari. Granius Flaccus in libro de iure Papiriano scribit pellicem nunc volgo vocari, quae cum eo, cui uxor sit, corpus misceat: quosdam eam, quae uxoris loco sine nuptiis in

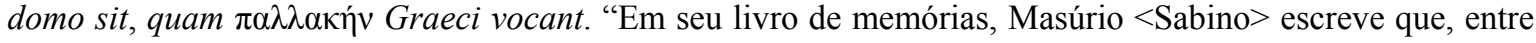
os antigos, chamava-se "pellex" àquela que, ainda que não fosse a esposa legítima, contudo, vivia com um homem: à qual, agora, chama-se com o nome de "amiga" e com outro um pouco mais discreto, "concubina". Granio Flaco, no livro sobre o direito Papiriano, escreve que na atualidade chamava-se vulgarmente "pellex" aquela que envolve seu corpo com o $<$ homem $>$ que tem esposa legítima e alguns assim denominam àquela que está na casa no lugar da esposa sem ter matrimônio, à qual os gregos denominam 'pállake'”. Havia outras denominações para a concubina: hospita (CIL VI, 8972) e focaria (CIL V,4923). As focaria e as hospita eram as concubinas dos soldados em campanha, impedidos de contrair iustum matrimonium. Os nascidos destas uniões eram filhos espúrios e não estavam submetidos à potestas do pai.Para G. CASTELLI, Il concubinato cit. (nota 96 supra), p.70, nota 2, se o concubinato estivesse presente nas leis matrimoniais de Augusto, Masúrio Sabino no trecho supracitado não teria escrito paulo honestiore, mas ex lege Iulia et Papia Poppaea.

Veja-se Gell. 4,3,3: Pellicem autem appellatam probrosamque habitam, quae iuncta consuetaque esset cum eo, in cuius manu mancipioque alia matrimonii causa foret, hac antiquissima lege ostenditur, quam Numae regis fuisse accepimus: pellex aedem iunonis ne tangito; si tanget, iunoni crinibus demissis agnum feminam caedito. Pellex autem quasi $\pi \alpha \dot{\lambda} \lambda \alpha \xi_{\xi}$, id est quase $\pi \alpha \lambda \lambda \alpha \chi i$ s. Ut pleraque alia, ita hoc quoque vocabulum de Graeco flexum est. "Chamamos de pellex e consideramos como infame, aquela que vivia com um homem que já tinha sob a sua manus [poder marital] uma outra mulher. Aceitamos por uma lei antiquíssima que a tradição atribui ao rei Numa: 'Que a concubina, pellex, não toque o templo de Juno; se ela o tocar, que, com os cabelos desfeitos, ela imole uma ovelha fêmea à deusa'. A palavra pellex é aproxidamente a palavra $\pi \dot{\alpha} \lambda \lambda \alpha \xi$ [menina], que se parece, ela mesma, muito à $\pi \alpha \lambda \lambda \alpha \alpha i$ [ [concubina]. Como a maior parte das outras, ela é uma palavra derivada do grego"; Ulp. 32 ad Sab. D.24,1,3,1; Marcian. 12 inst. D.25,7,3pr.; Paul. 19 resp. D.25,7,4; PS 2,20,1. Segundo D. DALLA - R. LAMBERTINI, Istituzioni di diritto romano cit. (nota 10 supra), pp.117-118, a palavra concubinato tem raiz etimológica em cum + cubare, que significa "ir para a cama junto". De acordo com R. Astolfi, Note per una valutazione storica della 'Lex Iulia et Papia' cit. (nota 36 supra), p.192, o concubino era considerado caelebs e totalmente incapaz de receber heranças e legados (capacitas).

${ }^{187}$ B. BIONDI, La legislazione di Augusto cit. (nota 56 supra), pt.156;159-160; D. DALLA - R. LAMBERTINI, Istituzioni di diritto romano cit. (nota 10 supra), p.118; G. LONGO, Riflessioni critiche cit. (nota 48 supra), pp.2375-2376; G. CORNIL, Droit Romain cit. (nota 55 supra), pp.130-131; M. MoLĖ, Stuprum cit. (nota 96 supra), p.584, nota 10.

${ }^{188}$ G. CoRNIL, Droit Romain cit. (nota 57 supra), p.131; F. SCHulz, Classical Roman Law cit. (nota 28 supra), p.131. Apesar do concubinato não estar confirmado expressamente na Lex Iulia et Papia, segundo R. Astolfi, La Lex Iulia et Papia cit. (nota 12 supra), pp.56;365, a figura da concubina poderia estar inserida num destes casos de incapacitas: (a) na femina probrosa, se tivesse maus costumes; (b) na mater solitaria se tivesse bons costumes e pelo menos um filho; (c) na mulher caelebs, se não fosse probrosae e não tivesse filhos. Se a relação entre homem e mulher tivesse algum impedimento legal que não pudesse tornar-se um matrimônio legítimo romano, geralmente o casal continuava a viver more uxorio e, no caso das mulheres consideradas probrosae, havia concubinato.

${ }^{189} \mathrm{Na}$ opinião de B. BIONDI, La legislazione di Augusto cit. (nota 56 supra), p.159, parrebbe che le leges 
Com a promulgação da legislação demográfica e o incentivo da procriação no âmbito do matrimônio legítimo, os filhos nascidos de uma relação de concubinato não poderiam ser considerados relevantes para que os pais pudessem gozar dos prêmios e vantagens destas leis. ${ }^{190}$

Na prática, porém, em virtude dos rigorosos impedimentos matrimoniais impostos pela legislação, houve um aumento no número de relações extra-conjugais que caracterizavam o concubinato, um fato que contrariava a política ético-matrimonial do

\begin{abstract}
'Iulia et Papia', ammettendo talune incapacita al matrimonio per ragioni sociale, avrebbero dato luogo al sorgere di unioni permanenti diverse dal matrimonio, e non considerate come adulterio. Para T. MOMMSEN, Römisches Strafrecht cit. (nota 96 supra), p.434, a própria legislação matrimonial reconheceu o concubinato como forma legítima de união. Vejam-se D. DALLA - R. LAMBERTINI, Istituzioni di diritto romano cit. (nota 10 supra), p.118; G. PACChIONI, Corso di diritto romano cit. (nota 29 supra), p.345; F. SCHUlz, Classical Roman Law cit. (nota 51 supra), p.131; A. BURDESE, Manuale cit. (nota 47 supra), p.274-275;283.
\end{abstract}

Para L.F. RADITSA, Augustus Legislation cit. (nota 49 supra), pp.308-309, a procriação e o desejo de ter filhos não eram critérios para distinguir o matrimônio do concubinato. Vejam-se G. CASTELLI, Il concubinato cit. (nota 96 supra), p.56. É importante ressaltar, de acordo com R. Astolfi, La Lex Iulia et Papia cit. (nota 12 supra), pp.103-104;114-115;330-331 e A. LÓPEZ PEDREIRA, Limitaciones a la 'libertas nuptialis' (nota 40 supra), p.402, nota 63, conforme o entendimento do jurista Ulpiano, os matrimônios que não se ajustassem às determinações das leis matrimoniais eram válidos iure civile, não eram nulos: a prole destes matrimônios era legítima, não poderia haver distinção entre fillhos iusti e iniusti secundum legem Iuliam et Papiam (Vat. Frag. 168 e 194; PS 4,8,4; Coll. 16,3,4). Para V. ARANGio-RuiZ, Istituzioni cit. (nota 53 supra), p.463, o filho nascido da concubina permanecia vulgo conceptus. De acordo com S. SolAzZI, Sui divieti matrimoniali delle leggi augustee cit. (nota 168 supra), pp.82-83, os filhos nascidos de matrimônio nulo são iniusti de modo absoluto, ou seja, como não eram reconhecidos pelo ius civile, também não eram pela Lex Iulia et Papia. $\mathrm{O}$ ius civile somente reconhecia os filhos nascidos de um matrimonium legitimum. Neste caso, aqueles que contraíram matrimônio contrário às disposições da Lex Iulia et Papia não podem nem ser considerados marido e mulher (uxor). Na opinião de E. NARDI, Sui divieti matrimoniali cit. (nota 109 supra), pp.118-119, todos os matrimônios que não estivessem de acordo com a Legislação Matrimonial eram nulos e os filhos nascidos destas relações eram considerados iniusti, tanto para o Ius civile quanto para a Lex Iulia et Papia. O Ius civile só considerava iusti os filhos nascidos de matrimônios válidos.

${ }^{190}$ Contra esta opinião, veja-se R. AstoLfi, La Lex Iulia et Papia cit. (nota 15 supra), p.56. Em relação ao concubinato, ele não era uma união transitória, nem acarretava infâmia para a concubina, porém os filhos desta união eram ilegítimos, pois não havia qualquer vínculo jurídico entre pai e filho. Quanto aos filhos spurii (filhos ilegítimos), eles não tinham qualquer relação de parentesco com o pai e a sua condição era de sui iuris. Gai. 1,64: Ergo si quis nefarias atque incestas nuptias contraxerit, neque liberos: itaque si qui ex eo coitu nascuntur matrem quidem habere videntur, patrem vero non utique: nec ob id in potestate eius sunt sed tales sunt quales sunt hi, quos mater vulgo concepit; nam et hi patrem habere non intelleguntur, cum is etiam

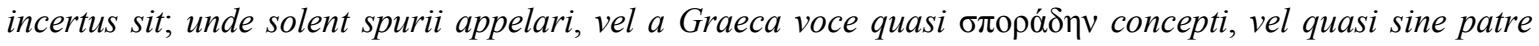
filii. "Logo, quem contrair núpcias nefárias e incestuosas não se considera como tendo mulher nem filhos. Por onde, os nascidos desse coito consideram-se como tendo mãe, mas de nenhum modo pai. Nem, por isso, lhe caem sob o poder, mas são tais como os nascidos de coito vulgar, porque também esses entendem-se não terem pai, por ser este incerto; donde vem que sóem chamar-se filhos espúrios, ou com a palavra grega, concebidos $\sigma \pi \mathrm{o} \alpha \dot{\delta} \delta \eta v$, isto é, filhos sem pai"; Mod. 1 pand. D.1,5,23: Volgo concepti dicuntur qui patrem demonstrare non possunt, vel qui possunt quidem, sed eum habent, quem habere non licet. Qui et spurii

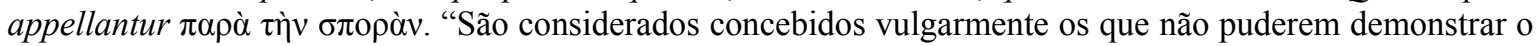
pai, ou os que, na verdade, puderem, mas tiverem aquele que não é lícito ter. Os quais são chamados espúrios, de 'spora' [sêmen]"; Ulp. 27 ad Sab. D.1,5,24. Vejam-se J.M. Othon Sidou, Matrimonium I cit. (nota 47 supra), pp.71-72; E. VOLTERRA, Matrimonio cit. (nota 61 supra), p.776; Idem, La nozione giuridica del 'conubium' cit. (nota 180 supra), pp.295-296; Idem, La conception du Mariage à Rome cit. (nota 30 supra), pp.358-359; B. BIONDI, La legislazione di Augusto cit. (nota 56 supra), p.149; Idem, Istituzioni cit. (nota 22 supra), pp.460-461; S. SolAzZI, La legge augustea sul divorzio cit. (nota 180 supra), pp.350-351. 
princeps. $^{191}$

\subsection{CIVITAS}

Como visto anteriormente, desde a Realeza por meio de tratados (foedera) intergentilícios ${ }^{192}$, os costumes comuns às diversas gentes constituiram a estrutura organizadora e os primeiros institutos jurídicos da civitas. ${ }^{193}$

O matrimônio constituiu em Roma uma importante fonte de cidadania, uma vez que apenas o matrimonium legitimum ou iustae nuptiae ${ }^{194}$ garantia novos cidadãos para a civitas e produzia todos os efeitos jurídicos. ${ }^{195}$

A prole seguia a situação jurídica do pai no momento da concepção e mantinha sua estirpe familiar (nomen familiae) com os filhos submetidos à patria potestas. ${ }^{196}$

${ }^{191}$ Vejam-se M. ZABŁOCKA, Le modifiche introdotte nelle leggi matrimoniale Augustee cit. (nota 103 supra), p.397; R. Astolfi, La Lex Iulia et Papia cit. (nota 15 supra), pp.56;331; G. SCIASCIA, A Concubina no Direito Romano Cristão, in Varietà Giuridiche - Scritti brasiliani di diritto romano e moderno, Milano, Giuffrè, 1956, p.37; D. DALlA - R. LAMBERTINI, Istituzioni di diritto romano cit. (nota 10 supra), p.118; A. Burdese, Manuale cit. (nota 47 supra), p.283; M. MARrone, Istituzioni cit. (nota 48 supra), p.220; B. BIONDI, La legislazione di Augusto cit. (nota 56 supra), pp.159-160. Na opinião de F. SCHUlZ, Classical Roman Law cit. (nota 51 supra), p.131, o concubinato tornou-se mais frequente e obteve grande importância social no Principado, contrário ao escopo de Augusto de aumentar o número dos casamentos legítimos.

192 V. GIUfFrè, Il 'Diritto pubblico' cit. (nota 32 supra), pp.55-56, afirma que a convivência entre as famílias, a tutela dos bens conquistados e o regime de trocas eram confiados aos antigos mores maiorum. Alguns mores eram limitados a determinadas gentes (ius gentilicium). Outros, fundamentais, constituíam o Ius Quiritium, cuja coerção, antes de ser protegida de eventuais transgressões pelas reações de toda a sociedade ou de seus grupos hegemônicos, repousava sobre o fas (conjunto de normas religiosas). Era nefas (o ilícito, o proibido pelos numina) a violação dos antigos costumes, que refletiam exigências de ordem sócio-econômica. O poder dos mores maiorum estava, inicialmente, fundamentado numa qualidade, que era aquela do respeito, o pudor, sentimento de obediência aos hábitos dos antepassados e que abrangia um conjunto de comportamentos que influenciava todas as atividades da sociedade romana: militares, técnicas, intelectuais ou religiosas. Veja-se A. DAVIAUlt, Le 'mos maiorum' cit. (nota 162 supra), p.59.

${ }^{193}$ Veja-se M.C. Giordani, Iniciação ao Direito Romano, 5aed., Rio de Janeiro, Lumen Juris, 2003, p.162. P. CERAMI, Breviter su Iul. D.1,3,32 (Riflessioni sul trinomio 'Lex', 'Mos', 'Consuetudo'), in Nozione formazione ed interpretazione del diritto. Dall'Età romana alle esperienze moderne - Ricerche dedicate al professor Filippo Gallo, vol.1, Napoli, Jovene, 1997, pp.124-126; A. RoMANO, Matrimonium iustum cit. (nota 26 supra), pp.23-24.

${ }^{194}$ Defendem a existência das expressões iustae nuptiae e legitimum matrimonium já no período clássico, F. LANFRANCHI, Le definizioni e il concetto cit. (nota 78 supra), p.156; Idem, Il diritto nei retori romani cit. (nota 78 supra), p.225; E. Volterra, Istituzioni cit. (nota 12 supra), p.643; A. RomANO, Matrimonium iustum cit. (nota 26 supra), pp.22-23. Defende que a terminologia legitimum matrimonium é pós-clássica, E. AlBertario, Conceptus pro iam nato habetur, in Studi di diritto romano, vol.1, Milano, Giuffrè, 1933, p.8.

195 Em relação à Legislação Matrimonial de Augusto, eram relevantes apenas os filhos nascidos de um matrimônio iustum secundum ius civile. Por isso, afirmam M. MARRONE, Istituzioni cit. (nota 48 supra), p.215 e E. Volterra, La conception du Mariage d'après les juristes romains cit. (nota 30 supra), p.33, que o termo iustae significava, neste caso, secundum ius. Vejam-se também R. ORESTANO, Alcune considerazioni sui rapporti fra matrimonio cristiano e matrimonio romano cit. (nota 49 supra), p.365; R. ASTOLFI, La Lex Iulia et Papia cit. (nota 15 supra), pp.27;115.

${ }^{196}$ Vejam-se UE 5,1: In potestate sunt liberi parentum ex iusto matrimonio nati. "Estão sob o pátrio poder os filhos nascidos de justas núpcias"; Gai. 1 inst. D.1,6,3: Item in potestate nostra sunt liberi nostri, quos ex 
Algumas disposições das Regras de Ulpiano ${ }^{197}$ esclarecem que, além da diversidade de sexo, puberdade e consentimento, as justas núpcias apresentam como pressuposto o conubium $^{198}$, pois ele era necessário para que o matrimônio produzisse efeitos reconhecidos pelo ius civile. Quando faltasse qualquer destes elementos, o matrimônio era contrário ao direito (iniustum). ${ }^{199}$

iustis nuptiis procreaverimus: quod ius proprium civium Romanorum est. "Igualmente estão em nossa potestas os nossos filhos os quais tivermos procriado em justas núpcias, direito este que é próprio dos cidadãos romanos"; Gai. 1,55: Item in potestate nostra sunt liberi nostri, quos iustis nuptiis procreavimus. Quod ius proprium civium Romanorum est: fere enim nulli alii sunt homines, qui talem in filios suos habent potestatem, qualem nos habemus. Idque divus Hadrianus edicto, quod proposuit de his, qui sibi liberisque suis ab eo civitatem Romanam petebant, significat. Nec me praeterit Galatarum gentem credere in potestate parentum liberos esse. "Igualmente sob o nosso poder estão os nossos filhos, que procreamos por justas núpcias, direito próprio aos cidadãos romanos; pois quase não há nenhum outro tipo de homem que tenha sobre os filhos um poder tal como o que temos. E isto significou o divino Adriano pelo edito que fez para os que lhe pediam para si e para seus filhos a cidadania romana. Nem ignoro que a nação dos Gálatas crê tenham os pais poder sobre os filhos". Vejam-se G. MANCINI, Cives romani municipes latini, vol.1, Milano, Giuffrè, 1997, p.7; E. VOLTERRA, La nozione giuridica del 'conubium' cit. (nota 180 supra), pp.293;298;305;317; Idem, La conception du Mariage à Rome cit. (nota 30 supra), p.357; Idem, La conception du Mariage d'après les juristes romains cit. (nota 30 supra), pp.35-36.

${ }^{197}$ UE 5,2: Iustum matrimonium est, si inter eos, qui nuptias contrahunt, conubium sit, et tam masculus pubes quam feminas potens sit, et utrique consentiant, si sui iuris sunt, aut etiam parentes eorum, si in potestate sunt. "Há justas núpcias se os que contraem casamento têm conúbio, atingiram a puberdade e desde que sui iuris, consentem; é necessário também o consentimento dos pais, se os contraentes estiverem sob o seu poder". UE 5,3: Conubium est uxoris ducendis facultas. "O conúbio é a faculdade de se casar segundo o direito". Os juristas clássicos utilizavam as expressões iustae ou legitimae nuptiae; iustum ou legitimum matrimonium para designar a união conjugal duradoura entre um homem e uma mulher púbere, ambos livres e com conúbio. De acordo com o comentarista da Eneida, Sérvio, "o conúbio é o direito do matrimônio legítimo". Serv. In Verg. Aen. 1,73: Conubium est ius legitimi matrimonii. Isidoro, bispo de Sevilha no século VI d.C., assim definia o conubium: Conubium (...) a nubendo formatum. Dicitur autem conubium cum aequales in nuptiae coeunt. "Conubium (...) formado por nubendo. Diz-se, de fato, conubium quando pessoas de igual capacidade unem-se em núpcias". Vejam-se E. VolterRA, Les formes du Mariage chez les Romains cit. (nota 30 supra), pp.279-280, nota 138; Idem, La nozione giuridica del 'conubium' cit. (nota 180 supra), pp.296;298; Idem, Nuove osservazioni sulla 'conventio in manum' cit. (nota 70 supra), pp.206-207. De acordo com a opinião de R. Astolfi, Il matrimonio nel diritto romano classico cit. (nota 10 supra), p.7, Il 'conubium', inteso quale capacità giuridica di contrarre matrimonio, è concetto risalente e appare dommaticamente corretto il suo accostamento alla pubertà, intesa quale capacità naturale a contrarre matrimonio, certamente pretesa anche in età classica, se lo scopo del matrimonio continua a essere la procreazione. Tem opinião semelhante A. RomAno, Matrimonium iustum cit. (nota 26 supra), p.4, ao fazer a exegese de UE 5,2: Spunto della ricerca è stato il sospeto che l'apparente contrapposizione semantica tra 'contrahere nuptiae' e 'matrimonium' rifletesse la sequenza storica tra fasi diverse di un unico fenomeno: la risposta formale della comunità alle unione sessuali a scopo riproduttivo. Critica profundamente os trechos das Regras de Ulpiano relativos aos requisitos do matrimônio, J. GAUDEMET, Justum matrimonium cit. (nota 51 supra), p.117: Le groupement des conditions qu'opèrent les Reg. Ulp. ne constitue pas un argument serieux. On ne peut demander à ce résumé tardif une grand rigueur dogmatique. Il est d'ailleurs tout aussi criticable lorsqu'il fait de la puberté, comme du 'conubium', une condition du 'justum matrimonium'.

${ }^{198}$ Veja-se Inst. 1,10pr. Quanto à etimologia de conubium e coniugium em relação ao matrimônio, explicam G. CIPRIANI - P. FEDELI, Vivere a Roma antica cit. (nota 4 supra), p.280, que conubium (cum + nubere) remete ao aspecto político do matrimônio, enquanto coniugium (cum + iungere) designa-o como fato natural, como a união de duas pessoas. E. VolterRA, Matrimonio cit. (nota 61 supra), p.733; Idem, Nuove osservazioni sulla 'conventio in manum' cit. (nota 70 supra), p.206; Idem, La nozione giuridica del 'conubium' cit. (nota 180 supra), pp.296;305-312;360; A. RomANo, Matrimonium iustum cit. (nota 26 supra), pp.4-6;26; A. BURDESE, Manuale cit. (nota 47 supra), pp.268-269; C. ACCARIAS, Précis de droit romain cit. (nota 9 supra), p.209, nota 2; afirmam que existia uma palavra grega correspondente ao termo

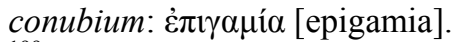

${ }^{199}$ Quando uma determinada situação jurídica impedisse o matrimônio entre duas pessoas, os juristas 
De acordo com a utilidade pública e a própria evolução social romana, determinavam-se os impedimentos matrimoniais de acordo com a existência ou não do conubium entre os cônjuges (patrícios e plebeus ${ }^{200}$; ingênuos e libertos; senadores e libertas ou feminae probrosae; cidadãos romanos e peregrinos). ${ }^{201}$

O conubium exigia alguns requisitos: a cidadania romana ${ }^{202}$, a liberdade e a ausência de parentesco entre os cônjuges em linha ascendente ao infinito ou colateral até o sexto grau (primos). ${ }^{203}$

Nos casos de ausência do conubium entre os cônjuges, a prole seguia a condição da mãe no momento do nascimento, conforme um princípio do ius gentium. ${ }^{204}$

romanos nunca utilizaram a expressão "impedimento matrimonial", mas preferiam indicar simplesmente a falta do conubium. Vejam-se J. GAUDEMET, L'Apport du Droit Romain cit. (nota 59 supra), p.37; E. VolterRa, Matrimonio cit. (nota 61 supra), p.732; Idem, La conception du Mariage à Rome cit. (nota 30 supra), p.360; Idem, La nozione giuridica del 'conubium' cit. (nota 180 supra), p.294; G. PACCHIONI, Corso di diritto romano cit. (nota 29 supra), p.321; D. DALLA - R. LAMBERTINI, Istituzioni di diritto romano cit. (nota 10 supra), pp.105-106. Na lição de T. MOMMSEN, Römisches Strafrecht cit. (nota 96 supra), p.434, o matrimônio iniustum nunca foi um ato punível pelo direito. A. ROMANO, Matrimonium iustum cit. (nota 26 supra), pp.24-25, defende que o conubium é preexistente à formação do ius civile: l'elaborazione del diritto arcaico, nella sua dialettica tra momento di selezione e momento interpretativo dei 'mores', si è trovata certamente a fare $i$ conti con $i$ rituali di fertilità legati alla produzione e alla riproduzione, espressi dai diversi contesti socio economici confluiti nel tessuto della città.

${ }^{200}$ No início da República em 450 a.C., a Lei das XII Tábuas estabeleceu a proibição do casamento entre patrícios e plebeus, disposição que foi suprimida pela Lex Canuleia de conubio patrum et plebis de 445 a.C. Conforme Cic. de rep. 2,36-37;61;63; Dio Cass. 10,60; Liv. 4,1,1;4,2,6;4,3,4;4,4,5. Vejam-se E. VolTERRA, Nuove osservazioni sulla 'conventio in manum' cit. (nota 70 supra), pp.209-211; 213; A. BURDESE, Manuale cit. (nota 47 supra), p.269; V. ARANGIO-RUIZ, Istituzioni cit. (nota 53 supra), p.440.

${ }^{201}$ Vejam-se, F. DELla CORTE, Le 'leges Iuliae' e l'elegia romana cit. (nota 47 supra), p.545; G. SCIASCIA, O Senatoconsulto das Bacanais, in Varietà Giuridiche - Scritti brasiliani di diritto romano e moderno, Milano, Giuffrè, 1956, p.81; A. LÓPEZ PedreIRA, Limitaciones a la 'libertas nuptialis' cit. (nota 40 supra), p.396.

${ }^{202}$ UE 5,4: Conubium habent cives Romani cum civibus Romanis; cum Latinis autem et peregrinis ita, si concessum sit. "Há conúbio entre cidadãos romanos e romanas; estes o têm com latinos e peregrinos só por concessão especial". UE 5,5: Cum servis nullum est conubium. "Não há conúbio com os escravos"; UE 5,9: Ex cive Romano et Latina Latinus nascitur, et ex libero et ancilla servus; quoniam, cum his casibus conubia non sint, partus sequitur matrem. "O filho de cidadão romano e latina é latino; o de homem livre e escrava é escravo; pois, nestes casos, não havendo conúbio, o parto segue a condição da mãe". A união conjugal entre estrangeiros em Roma era denominada "matrimônio peregrino" e a ela não se aplicava as leis matrimoniais romanas, nem gerava efeitos jurídicos de matrimônio legítimo e seguia as leis e os costumes do povo estrangeiro. Cf. Gai.1,92. Vejam-se E. VOLTERRA, Matrimonio cit. (nota 61 supra), pp.751; 773; Idem, Nuove osservazioni sulla 'conventio in manum' cit. (nota 70 supra), pp.205-206, nota 136; E. BETTI, Istituzioni di diritto romano cit. (nota 26 supra), pp.44-45; A. BURDESE, Manuale cit. (nota 47 supra), p.269.

${ }^{203}$ J. GAUDEMET, L'Apport du Droit Romain cit. (nota 59 supra), p.38; E. VolterRA, Matrimonio cit. (nota 61 supra), p.734; Idem, Les formes du Mariage chez les Romains cit. (nota 30 supra), p.280; M. MARRONE, Istituzioni cit. (nota 48 supra), pp.217-218; E. BETTI, Istituzioni di diritto romano cit. (nota 26 supra), p.47. Neste sentido, UE 5,6-8; Gai.1,59; 1,64; 1,78; 1,82 .

${ }^{204}$ Gai. 1,56; 1,67; 1,76; 1,78; 1,80; Cic. Top. 4,20. De acordo com E. VolTERRA, La nozione giuridica del 'conubium' cit. (nota 180 supra), p.298; Idem, Les formes du Mariage chez les Romains cit. (nota 30 supra), p.281, Idem, La conception du Mariage à Rome cit. (nota 30 supra), p.359 o conubium não era um instituto exclusivamente romano, mas comum às populações latinas, itálicas e às cidades gregas. $\mathrm{O}$ jurisconsulto Gaio em Gai.1,80, determina que o princípio semper conubium efficit, ut qui nascitur patris condicioni accedat (pelo conúbio, sempre o nascido segue a condição do pai), pertencia ao ius gentium. Se o pai fosse peregrino ou latino sem o Ius Latii maioris, os filhos seguiam a condição do pai e eram peregrinos e latinos e, neste caso, não estavam submetidos à patria potestas. 
Gai. 1,89: Quod autem placuit, si ancilla ex cive Romano conceperit, deinde manumissa pepererit, qui nascitur liberum nasci, naturali ratione fit; nam hi, qui illegitime concipiuntur, statum sumunt ex eo tempore quo nascuntur; itaque si ex libera nascuntur, liberi fiunt, nec interest, ex quo mater eos conceperit, cum ancilla fuerit; at hi, qui legitime concipiuntur, ex conceptionis tempore statum sumunt.

"E quanto à norma recebida pela qual, se uma escrava conceber de um cidadão romano e, depois de alforriada, parir, o nascido nasce livre, isso o é pela razão natural. Pois, os concebidos ilegitimamente ficam no estado que têm ao tempo do nascimento; portanto, os nascidos de mulher livre nascem livres, nem importa de quem a mãe os concebeu, enquanto era escrava; mas os concebidos legitimamente, ficam no estado do tempo da concepção".

Este ius conubii constituía um dos elementos políticos fundamentais da civitas, pois reconhecia aos filhos de certas uniões a qualidade de cidadãos romanos e de filhos legítimos. $^{205}$

Este direito poderia ser concedido como prêmio à uma pessoa determinada ou até mesmo a toda uma população estrangeira. Esta concessão permitia que o matrimônio entre romanos e peregrinos fosse considerado legítimo (iustae nuptiae) e certamente contribuiu

Este princípio do ius gentium de que o filho seguia a condição da mãe no momento do nasimento, sofreu uma alteração com a promulgação da Lex Minicia de liberis no início do século I a.C., de cerca de 90 a.C., (Gai.1,75; 1,78; UE 5,8) ao estabelecer-se que, mesmo que a mãe fosse cidadã romana, se o pai fosse peregrino sem conubium, o filho seguia a condição de peregrino. Vejam-se M. TALAMANCA, Istituzioni cit. (nota 12 supra), p.105; A. Burdese, Manuale cit. (nota 47 supra), p.269; V. ArANGIO-RuIZ, Istituzioni cit. (nota 53 supra), pp.440-441; A. GUARINO, Diritto privato romano cit. (nota 1 supra), pp.277-278; E. VOLTERRA, Matrimonio cit. (nota 61 supra), pp.733-734;774; Idem, Istituzioni cit. (nota 12 supra), p.66; Idem, Nuove osservazioni sulla 'conventio in manum' cit. (nota 70 supra), pp.213-214; Idem, La nozione giuridica del 'conubium' cit. (nota 180 supra), pp.297-298; J. IGLESIAS, Derecho Romano cit. (nota 51 supra), p.341; G. LongO, Per la interpretazione del fr. 24 D.1,5 cit. (nota 16 supra), pp.22-23; G. MANCINI, Cives romani municipes latini cit. (nota 196 supra), p.18, nota 31; A. RoMANO, Matrimonium iustum cit. (nota 26 supra), p.45.

${ }^{205}$ Veja-se F. DE VISSCHER, « Conubium » et « Civitas », in IURA 2 (1951), pp140-144. Para DE VISSCHER, nas origens de Roma, o conubium indicava um direito que permitia o casamento entre os romanos e os latinos antigos (latini prisci). Era um direito estabelecido pelas classes nobres da aristocracia romana para impedir o matrimônio entre plebeus e patrícios, além de constituir um instrumento essencial da política romana para efetuar diversas alianças com os povos vizinhos do Latium e desta forma garantir seu domínio sobre esta região. Com as conquistas territoriais e o aumento das relações com outros povos do Mediterrâneo no período republicano, medidas legislativas estabeleceram a inclusão, principalmente dos povos itálicos, na cidadania romana. Por exemplo, no início do Principado, a Lex Aelia Sentia de 4 d.C., reforçou a tendência de igualar as condições, em relação à cidadania, das latinas (junianas, coloniárias) com as cidadãs romanas (eiusdem condicionis), desde que procriassem filhos para a res publica. Veja-se Gai.1,29. 
para o aumento da população romana. ${ }^{206}$

A legislação matrimonial de Augusto, objeto da nossa pesquisa, exigia uma prole legítima, procriada em iustae nuptae. Interessava a esta legislação a procriação de cidadãos romanos livres, que poderiam receber os prêmios por ela estabelecidos. ${ }^{207}$

Afirma B.BIONDI ${ }^{208}$ que "o problema demográfico é problema também de raça" ( $\mathrm{il}$ problema demografico è problema anche di razza).

Porém, o aumento no número dos peregrini é irrelevante para o império. As leis matrimoniais não tiveram um caráter racista, a procriação não foi utilizada para promover a “pureza da raça romana” ou afastar os peregrinos e os libertos da cidadania. Não é uma questão eugênica, fiscal, religiosa ou cultural, mas uma questão de poder político das classes dominantes, senatorial e equestre. ${ }^{209}$

A procriação de filhos e a concessão da cidadania eram fundamentais para a utilitas publica, pois auxiliavam na solução do problema da acelerada queda demográfica no Império.

No decorrer do Principado, de acordo com as necessidades econômicas e sociais, esta cidadania romana foi "ampliada" (civitas augescens) para as latinas que tivessem, pelo menos, três filhos. ${ }^{210}$

\footnotetext{
${ }^{206}$ E. VOLTERRA, Nuove osservazioni sulla 'conventio in manum' cit. (nota 70 supra), pp.205-206; Idem, La nozione giuridica del 'conubium' cit. (nota 180 supra), pp.296-297.

${ }^{207}$ B. BIONDI, La legislazione di Augusto cit. (nota 56 supra), pp.149-150;160-161.

${ }^{208}$ B. BIONDI, La legislazione di Augusto cit. (nota 56 supra), p.160: Augusto concepisce i 'cives' come uma razza eletta, a cui il fato ha assegnato il compito di guidare i destini del mondo. Non oppressione degli altri popoli, ma precisa coscienza della superiorità della razza latina.

${ }^{209}$ R. AstOLFI, Note per una valutazione storica della 'Lex Iulia et Papia' cit. (nota 36 supra), p.201. Contra esta opinião, J.A. FIELD JR., The purpose cit. (nota 129 supra), pp.398-399;403 e E. MALDONADO DE LizALDE, Lex Iulia de Maritandis Ordinibus cit. (nota 122 supra), pp.543;559, acreditam que a legislação matrimonial de Augusto foi concebida de acordo com uma forte política eugênica e demográfica, principalmente em razão da divisão das classes sociais estabelecida para manter uma "pureza racial" na classe senatorial (caráter claramente oligocrático da legislação). J.A. FIELD JR. defende que o número de peregrini na península itálica e principalmente no exército romano, aumentou significativamente no final da República, tornando-se uma ameaça ao poder político central. Também neste sentido, A. BoUCHÉLECLERCQ, Les lois démographiques d'Auguste cit. (nota 36 supra), p.259 ao afirmar que Auguste voulait avant tout, c'était conserver les hautes classes, perpétuer la descendande legitime du vrai peuple romain.(...) Les membres de l'ordre majeur devaient rester les Romains authentiques (...).

${ }^{210}$ Ulpiano lista em UE 3,1, uma série de situações nas quais se concedia a cidadania romana aos Latini. Neste trecho, as latinas obtinham a cidadania se tivessem, pelo menos, três filhos: Latini ius Quiritium consequuntur his modis: beneficio principali, liberis, iteratione, militia, nave, aedificio, pistrino; praetera et senatus consulto mulier, quae sit ter enixa. "Os latinos obtêm a cidadania dos seguintes modos: por concessão do imperador, pelos filhos, pela iteração, pelo serviço militar, pelo navio, pelo edifício, pela padaria; além disso, em virtude de um senatusconsulto, obtém a cidadania aquela que teve três partos, embora ilegítimos". Este senatusconsulto, mencionado por Ulpiano é, provavelmente, o Tertuliano, da época da Adriano. Ao comentar este mesmo senatusconsulto, Paulo indica que há diferença na quantidade de filhos exigida pela disposição normativa, de uma latina ingênua e de uma latina liberta. PS 4,9,7: Latina libertina ut ius liberorum consequi possit, quater eam sufficit peperisse; "À latina liberta, para que possa obter o ius liberorum, é suficiente ter dado à luz quatro vezes"; PS 4,9,8: Latina ingenua ius Quiritium consecuta si ter peperit, ad legitimam filii hereditatem admittitur: non est enim manumissa. "A latina ingênua que obtém o
} 


\section{PARTE II - A PROCREATIO E A RES PUBLICA:}

\section{PERÍODOS}

\section{PERIODIZAÇÃO}

\subsection{JUSTIFICATIVA}

A definição de casamento como relação entre um homem e uma mulher para procriar filhos não é uma idéia exclusivamente romana, pois os fenômenos mais elementares da natureza humana, a vida familiar, o desejo de ter filhos, têm, com efeito, raízes tão profundas quanto a História da Humanidade.

O controle populacional sempre foi uma preocupação dos governantes, em todos os tempos e em todos os povos, em virtude de períodos de fome, pestes, migrações e as guerras constantes. $^{211}$

No decorrer da História romana, o matrimônio e a procriação foram, senão impostos coativamente pela res publica, pelo menos incentivados e estimulados por meio de muitas medidas legislativas. ${ }^{212}$

Para aumentar a população, ou seja, para fins de procriação, os primeiros romanos não hesitaram em raptar as mulheres das cidades vizinhas. É conhecido o episódio do

ius Quiritium por ter dado à luz três filhos, é admitida na herança legitima dos filhos: uma vez que ela não é manumitida". M. ZABŁOCKA, Il 'ius trium liberorum' cit. (nota 103 supra), p.377, defende que UE 3,1 referese às latinas coloniárias, as quais obtinham a cidadania após ter dado à luz três filhos. Com a promulgação do Edito de Caracala (Constitutio Antoniniana), em 242 d.C., o conubium perdeu totalmente sua justificação como requisito do matrimonium legitimum. Além disso, cessam os privilégios jurídicos e políticos para a "estirpe itálica" e para as classes mais ricas. Vejam-se D. DALLA - R. LAMBERTINI, Istituzioni di diritto romano cit. (nota 10 supra), pp.106-107;117; M. MARRONE, Istituzioni cit. (nota 48 supra), p.217; R. AStOLfi, La Lex Iulia et Papia cit. (nota 15 supra), pp.357-358;367; Idem, Note per una valutazione storica della 'Lex Iulia et Papia' cit. (nota 15 supra), pp.214;228-229.

${ }^{211}$ D. NÖRR, The matrimonial Legislation of Augustus cit. (nota 54 supra), p.350; A. BouCHÉ-LECLERCQ, Les lois démographiques d'Auguste cit. (nota 36 supra), p.248. Narra Tito Lívio que Filipe V da Macedônia tentou remediar a situação da baixa natalidade e o alto número de derrotas de seu exército, obrigando todos os cidadãos a procriar e a educar filhos. Liv. 39,24: (...) non subolem tantum stirpis parabat cogendis omnibus procreare atque educare liberos. “(...) não somente assegurou o nascimento de uma geração, obrigando os súditos a procriar e a educar os filhos." Políbio confirma a baixa taxa de natalidade grega e a utilização de leis para obrigarem os homens a terem muitos filhos, em Polyb. Hist. 37,4,6. 
"Rapto ${ }^{213}$ das Sabinas". 214

Ocorreu logo após a fundação de Roma, com o rapto das Sabinas e de mulheres de outros povos limítrofes, durante a festa dos Consualia, após muitas tentativas de tratados amigáveis com estes povos. Após um sinal combinado, a juventude romana rapta as mulheres das cidades vizinhas e as mais bonitas são entregues aos mais ricos e poderosos. Rômulo justifica a sua ação exatamente pelo matrimônio, caracterizado pela comunhão de bens e pela certeza da prole. ${ }^{215}$

Realizavam-se, por volta do V século a.C., ritos de passagem para os jovens de ambos os sexos, o que demonstra como a religião e os mores maiorum familiares e gentilícios estabeleciam o papel de cada cidadão dentro da sociedade: os homens, para

${ }^{212}$ T. Spagnuolo Vigorita, Casta Domus cit. (nota 26 supra), p.70.

${ }^{213}$ Sobre o termo "rapto" vejam-se Fest. s.v. Rapi 364: Rapi simulator virgo ex gremio matris, aut, si ea non est, ex proxima necessitudine, cum ad virum traditur. "Quando a moça era conduzida junto ao marido, fingiase levá-la à força dos braços da mãe ou, se esta não existisse, do parente mais íntimo"; Serv. ad aen. 8,635: Raptas sine more sabinas raptas spectaculo sine ullo exemplo, aut sine ullo bono more: vel 'raptas' stupratas, id est per vim. "Raptadas sine more as Sabinas, levadas de uma forma nunca vista, ou sem nenhum bom costume: ou sofreram o stuprum, ou seja, tomadas pela força". Veja-se L. PEPPE, Storie delle parole cit. (nota 72 supra), pp.171-175. Dentre as mulheres raptadas, as mais bonitas eram conduzidas aos mais poderosos da cidade. O rapto indica o vínculo entre matrimônio, procriação e exército. No lapis Satricanus é notável este vínculo, com a relação entre os deuses Marte e Mater Matuta. Nesta época, a principal função da mulher romana era, do ponto de vista religioso, a de uxor que procriava muitos filhos. Sobre o culto da Mater Matuta, eram celebradas festas denominadas Matralia, no dia 11 de junho, no templo da deusa provavelmente construído na época de Sérvio Túlio. Veja-se G. Franciosi, Clan gentilizio e strutture monogamiche - Contributo alla storia della famiglia romana. (Corso di diritto romano II), Napoli, Jovene, 1976, p.76.

${ }^{214}$ Dio Cássio relembra o lendário episódio e ressalta que, em meio às inúmeras dificuldades e batalhas que se seguiram após a fundação de Roma, os seus antepassados priorizaram tanto o matrimônio quanto a procriação. Vejam-se A. RoMANo, Matrimonium iustum cit. (nota 26 supra), pp.20;30-33; L. PePPE, Storie delle parole cit. (nota 72 supra), pp.171-175. De acordo com T. SPAGNUOLO VigORITA, Casta Domus cit. (nota 26 supra), pp.166-167, nota 264, uma das tradições sobre este episódio narra exatamente que Hersília, a única casada dentre as Sabinas raptadas, teria se casado com Rômulo e ensinado aos Romanos os costumes

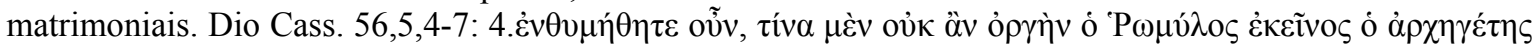

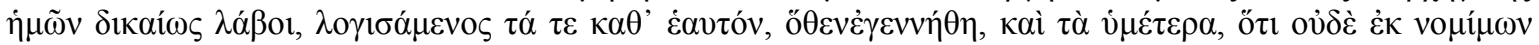

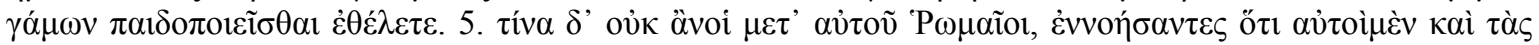

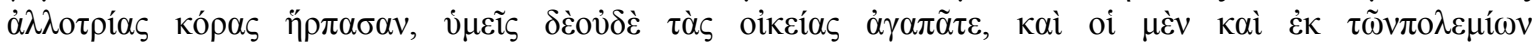

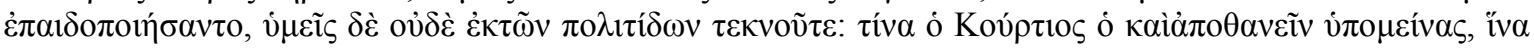

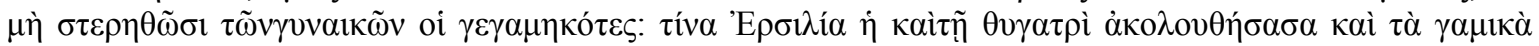

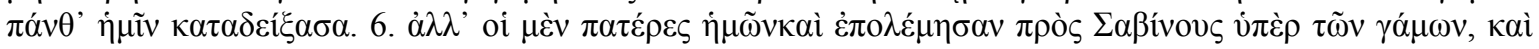

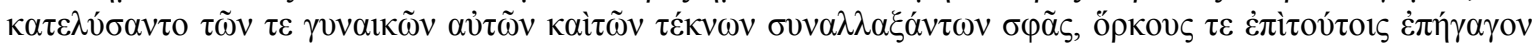

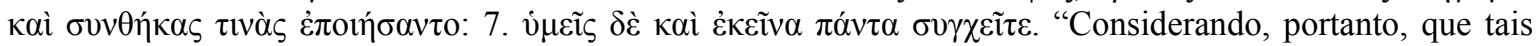
indignações nunca se compreenderiam, e justamente, como Rômulo que é o nosso fundador, se pudesse refletir por um lado sobre os acontecimentos que a ele se referem, como aqueles que levaram ao seu nascimento, de outro sobre aqueles que se referem a vós, que nem por um matrimônio legítimo estais dispostos a gerar filhos. 5. O compreenderiam os Romanos que ele teve como companheiros, se verificassem que, enquanto eles raptaram até mesmo as meninas estrangeiras, vós não sois atraídos nem pelas nativas, enquanto eles geraram filhos até com mulheres inimigas, vós não procriais nem com as vossas co-cidadãs. $\mathrm{Ou}$, ainda, Curtius, que preferiu enfrentar a morte a fim de que os homens casados não fossem afastados das suas esposas. Ou Hersília, que seguiu a filha e nos ensinou os costumes nupciais. 6. Na verdade, exatamente para garantir as núpcias, os nossos pais enfrentaram os Sabinos, estabelecendo a paz somente depois que as suas esposas e os seus filhos tivessem se reconciliado; e exatamente por este escopo, prestaram juramentos e concluíram vários tratados: 7. Mas vós tornastes vãos todos os seus esforços". Veja-se também Liv. 1,9,11. 
dedicarem-se ao exército e à política; as mulheres, à procriação e à maternidade, atributos de Athena Ilias (Minerva). A virgo deveria tornar-se uxor e mater. ${ }^{216}$

De acordo com Dio Cassio, 56,2,2 e 56,6,4, nas origens da cidade houve o incentivo ao aumento dos matrimônios e da procriação por meio de inúmeras medidas legislativas, promulgadas pelo Senado e pelo Povo.

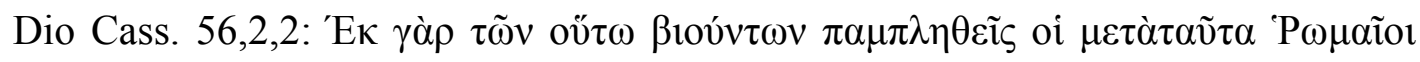

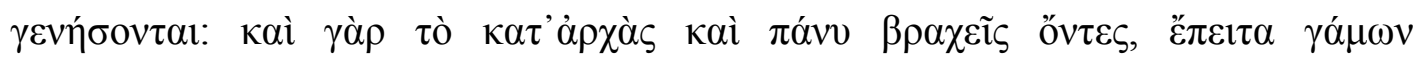

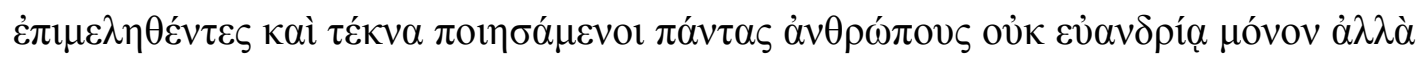

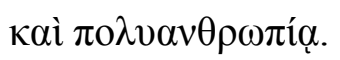

"Por mérito de quem vive assim, os Romanos do futuro poderão tornar-se mais numerosos: na origem, de fato, nós eramos muito poucos, depois, praticando o matrimônio e gerando filhos, superamos todos os homens não apenas pelo valor de nossos cidadãos, mas também pela grande quantidade da população".

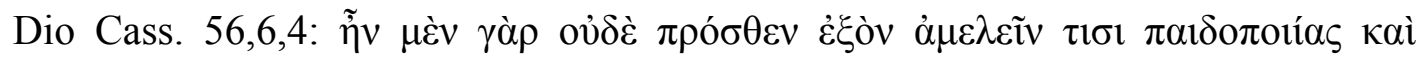

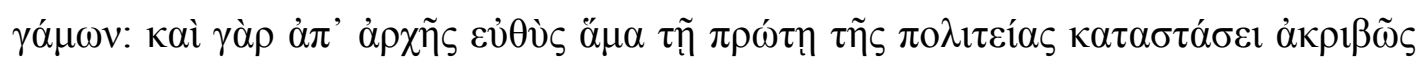

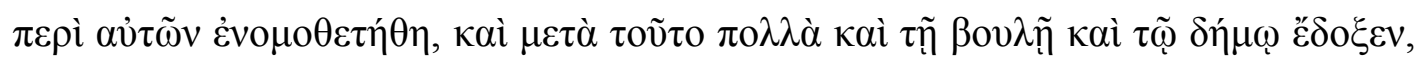

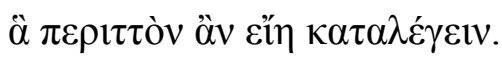

"No mais, nem no passado permitiu-se a alguém esquecer-se da filiação e das núpcias; antes, sobre elas, legislou-se com rigor desde as origens, com o constituir-se da própria res publica; e, em seguida, tantas normas foram estabelecidas pelo povo e pelo Senado, que seria supérfluo enumerar".

A seguir, propomos uma periodização de acordo com alguns fatos históricos que julgamos mais importantes, a fim de descrever a evolução da procriação especialmente do período da Realeza ao início do Principado, o seu escopo principal e as principais consequências jurídicas geradas por algumas medidas legislativas.

Esta periodização varia de acordo com o interesse da res publica romana na

215 A. Romano, Matrimonium iustum cit. (nota 26 supra), p.32. Vejam-se Liv. 1,9; Dio. Hal. 2,35,1-6.

216 A. Romano, Matrimonium iustum cit. (nota 26 supra), pp.33-35. A figura da deusa Minerva Capta era associada à juventude, ao matrimônio e à maternidade. 
procriação, principalmente em razão da queda populacional nas classes dirigentes decorrente de inúmeras guerras e de sua importância como escopo principal do matrimônio.

Divide-se o estudo em dois períodos principais: um, anterior à promulgação das leis matrimoniais ou demográficas de Augusto; e um outro período posterior denominado "Período da unidade conceitual das Leis Matrimoniais de Augusto", quando a res publica interveio de forma mais incisiva e intensa no incentivo à procriação e ao matrimônio.

Subdivide-se o primeiro período em três partes: militar, censória e o período da nequitia e dos mali mores (termos utilizados para indicar o período de degradação dos costumes entre o final da República e o início do Principado). Esta periodização indica que não apenas no início do Principado, mas desde a fundação de Roma, a família e o matrimônio tiveram um papel social, estratégico-militar e político muito importante, especialmente na procriação de novos cidadãos.

\subsection{PERÍODO ANTERIOR ÀS LEIS MATRIMONIAIS DE}

\section{AUGUSTO}

\subsubsection{PERÍODO MILITAR}

$\mathrm{Na}$ época da fundação de Roma, as guerras entre as diversas cidades itálicas eram constantes e isto criava a necessidade de um exército cada vez mais numeroso e jovem. ${ }^{217}$

A procriação, na Realeza e na República era estabelecida pelos mores maiorum, o costume dos antepassados. Estes costumes foram complementados por muitas leis, que, de acordo com a época e a necessidade, estabeleceram incentivos e prêmios às famílias com

\footnotetext{
${ }^{217}$ Sobre os primórdios da família romana e a importância da procriação para a composição de um exército jovem e para o trabalho agrícola, afirma P. CoGLIOLO, Storia del diritto privato romano (Dalle origini all'Impero), vol.2, Firenze, G. Barbèra, 1889, p.63, que: (...) essendo ancora picoli i poteri dello stato ogni famiglia è uno stato com funzione sacre economiche civili giurisdizionali e persino militari e politiche. Suo scopo massimo rispondente alle exigenze demografiche di un popolo giovani è la procreazione numerosa di figli, cioè di persone forti che combattano i nemici e lavorino i campi. “(...) sendo ainda pequenos os poderes do 'Estado', cada família é um 'Estado' com funções sagradas, econômicas, civis, jurisdicionais e até mesmo políticas. Seu escopo máximo corresponde às exigências demográficas de um povo jovem é a procriação numerosa de filhos, isto é, de pessoas fortes que combatam os inimigos e trabalhem os campos".
} 
prole numerosa e sanções àqueles que não tivessem filhos. ${ }^{218}$

Na Realeza, no reinado de Tulo Hostílio (639-616 a.C.) já é possível identificar uma preocupação de auxílio do "Estado" Romano às famílias com prole numerosa. Foi promulgada uma lei régia, de acordo com uma narrativa sobre os Horácios e Curiácios de Dionísio de Halicarnasso $(3,22,10)$, em que o "Estado" romano deveria contribuir com as despesas alimentares das famílias que tivessem trigêmeos até que eles atingissem a puberdade. $^{219}$

O rei etrusco Sérvio Túlio, que governou Roma entre 578 e 535 a.C., instituiu as assembleias centuriatas, com funções legislativas e militares. Estas Centúrias foram os primeiros censos realizados no Campo de Marte com finalidades militares (exercitus centuriatus), pois o povo apresentava-se armado e era repartido de acordo com a idade ${ }^{220}$ (a aptidão para o combate) e o patrimônio: de um lado, os cavaleiros e os patrícios mais ricos, que tinham maior poder político; de outro, os infra classim, ou seja, aqueles que não possuíam patrimônio suficiente para pagar os impostos e sustentar as despesas do serviço militar. $^{221}$

Sérvio realizou pela primeira vez o censo (foram contados oitenta e três mil cidadãos) e a divisão do populus Romanus em classes, pelo critério econômico-social, tendo como escopo principal reformar o exército romano. ${ }^{222}$

${ }^{218}$ R. AstOLFI, Note per una valutazione storica della 'Lex Iulia et Papia' cit. (nota 36 supra), p.210.

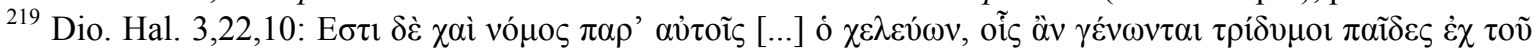

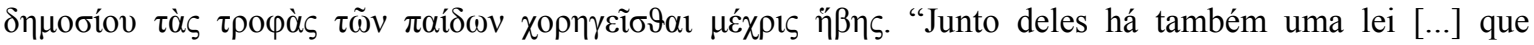
estabelece que àqueles pais, aos quais nasceram trigêmeos, forneçam-se os alimentos, às custas do 'Estado', para criarem os filhos até a puberdade".

${ }_{220}$ Iuniores eram os cidadãos entre 17 e 45 anos; Seniores eram os cidadãos acima dos 46 anos e que poderiam ser convocados para o exército até os 66 anos. Veja-se Gell.10,28,1.

${ }^{221}$ M.C. GIORDANI, Iniciação ao Direito Romano cit. (nota 193 supra), pp.140-142; J.C. MoreIRA Alves, Direito Romano cit. (nota 9 supra), pp.19-20; L. AMIRANTE, Una storia giuridica di Roma - Dai re a Cesare, Napoli, Jovene, 1987, pp.19-27; G. PIERI, L'Histoire du cens jusqu'a la fin de la République Romaine, Paris, Sirey, 1968, pp.9-11;131;183-184. De acordo com S.A.B. MEIRA, Curso de Direito Romano cit. (nota 72 supra), pp.34-35;43, o povo foi dividido em cinco classes, num total de 193 Centúrias: 80 Centúrias de cidadãos que possuíssem 20 jeiras de terra ou 100.000 asses; 20 Centúrias dos que possuíssem 15 jeiras de terra ou 75.000 asses; 20 Centúrias dos que possuíssem 10 jeiras de terra ou 50.000; 20 Centúrias dos que possuíssem 5 jeiras de terra ou 25.000 asses; 30 Centúrias dos que possuíssem 2 jeiras de terra ou 11.000 asses; 18 Centúrias de cavaleiros; 5 Centúrias de músicos e operários. O indivíduo excluído das Centúrias perdia tanto o ius suffragii (direito de voto) quanto o ius honorum (direito de ser votado para as magistraturas). Vejam-se Dio. Hal. 4,16,2-5;4,17,1-4;4,18,1-3;4,19,1-2;4,20,3-5; Liv. 1,43,1-10; Cic. de rep. $2,22,39-40$.

${ }^{222} \mathrm{Na}$ época de Sérvio Túlio, Roma foi dividida em quatro tribos territoriais urbanas: Suburana, Palatina, Esquilina e Colina. Nas palavras de L. AMIRANTE, Una storia giuridica di Roma cit. (nota 221 supra), p.24, con l'introduzione del censo e la sostituzione di tribù legate al territorio, anziché alla discendenza familiare, Servio ha posto tutte le premesse per la nascita dello 'status' di citadino legandolo alla stabile presenza sul territorio e obbligando quanti resiedono a farsi censire. Veja-se Dio. Hal. 4,14,1-2. Segundo a narração de Eutrópio, Sérvio Túlio teria feito não apenas o primeiro censo romano, mas realizado esse censo de uma maneira desconhecida em todos os povos do Mundo Antigo. Eutrop. 1,4,7: Primus omnium censum ordinavit, qui adhuc per orbem terrarum incognatus erat; sub eo Roma, omnibus in censum delatis, habuit 
A partir da instauração da República em 510 a.C., o censo passou a ser realizado pelos cônsules. $^{223}$

Em 443 a.C., criou-se em Roma a censura, uma magistratura colegiada. Os censores eram magistrados eleitos nos comícios por centúrias, em número de dois e confirmados mediante uma lex de potestate censoria. Era uma magistratura desprovida de imperium, mas que apresentava a auctoritas. ${ }^{224}$

Por meio do censo, os censores avaliavam as eventuais mudanças que se verificassem na situação patrimonial de um cidadão e que modificariam a sua posição tanto no exército quanto nas assembleias políticas. ${ }^{225}$

Os censores promulgavam as normas relativas ao alistamento e ao serviço militar, determinando a posição do cidadão no exército e na assembléia não por seu nascimento, mas pelo seu patrimônio pessoal. ${ }^{226}$

Plutarco (Camillus 2,3-4) ${ }^{227}$ e Valério Máximo $(2,9,1)$ narram a história de Camilo e Postúmio, célebres magistrados do V século a.C. ${ }^{228}$

Em 403 a.C., sendo censores Marco Furio Camilo e Marco Postúmio Albino, eles obrigaram os solteiros a se casarem com as "viúvas de guerra", ameaçando-os com uma multa pecuniária (aes uxorium). ${ }^{229}$

capita LXXXIII milia civium Romanorum cum his, qui in agris erant. "Pela primeira vez ordenou o censo, que até então era desconhecido em todo o mundo; em Roma, depois que todos tinham sido submetidos ao censo, havia oitenta e três mil cidadãos romanos, compreendidos aqueles que habitavam os campos".

${ }^{223}$ E.M. Agati Madeira, A Censura na Antiga Roma, in Revista da Faculdade de Direito de São Bernardo do Campo 14 (2008), pp.151;153-154. Vejam-se Liv. 4,8,2-3; Pomp. l. s. ench. D.1,2,2,14 e 17.

224 A. Fernandez de Bujan, Derecho Publico Romano, $2^{\mathrm{a}}$ ed., Madrid, Civitas, 1997, pp.98-101; S.A.B. MeIrA, Curso de Direito Romano cit. (nota 72 supra), pp.42-43; E.M. Agati MAdEIRA, A Censura na Antiga Roma cit. (nota 223 supra), pp.153-154;158. Veja-se Liv. 4,8,2-3.

${ }_{225}$ M.V.G. PESSI, Brevi riflessioni sul ruolo della censura nella dialettica costituzionale della prima repubblica, in Societas - Ius, Munuscula di allievi a Feliciano Serrao, Napoli, Jovene, 1999, p.163; M.C. GIORDANI, Iniciação ao Direito Romano cit. (nota 193 supra), pp.135-136. De acordo com A. BOUCHÉLECLERCQ, Les lois démographiques d'Auguste cit. (nota 36 supra), p.249, desde o final do século V a.C. é possível perceber a idéia de que a res publica poderia intervir na questão do aumento do número de filhos para atender ao bem comum e ao interesse geral.

${ }_{226}$ M.V.G. PESSI, Brevi riflessioni sul ruolo della censura cit. (nota 225 supra), p.166; E.M. AGATI MADEIRA, A Censura na Antiga Roma cit. (nota 223 supra), p.158. De acordo com A. FERNANDEZ DE BUJAN, Derecho Publico Romano cit. (nota 224 supra), p.100 e L. AMIRANTE, Una storia giuridica di Roma cit. (nota 221 supra), p.23, ao finalizar o censo, realizava-se a cerimônia do Suovetaurilia, ou seja, o sacrifício de um porco (sus), de uma ovelha (ovis) e de um touro (taurus), para a lustratio (lustrum condere), a purificação dos campos. Portanto, o Suovetaurilia, rito originado na antiga economia pastoril e agrícola, foi adotado nos censos para purificar a força de todos os cidadãos aptos a portar armas, na ocasião em que era realizada a sua contagem.

${ }^{227}$ Camilo estabelece algumas medidas necessárias para o auxílio ao cerco da cidade de Veios, que tinha uma população tão numerosa quanto a romana.

${ }^{228}$ R. Astolfi, Note per una valutazione storica della 'Lex Iulia et Papia' cit. (nota 36 supra), p.210, já indicava um enfraquecimento, na "consciência pública" (mores) sobre a importância das famílias numerosas e da procriação.

${ }^{229}$ Relembra M.V.G. PESSI, Brevi riflessioni sul ruolo della censura cit. (nota 225 supra), p.166, que uma das tarefas dos censores era a imposição dos tributos. A cobrança deste tributo perdurou por cerca de dois séculos 


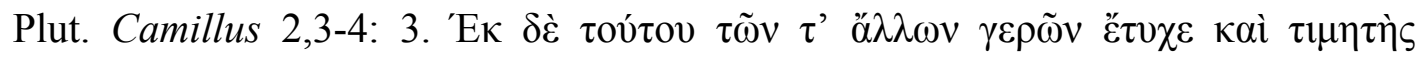

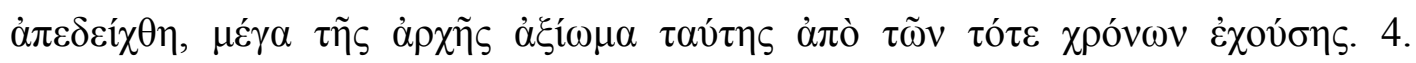

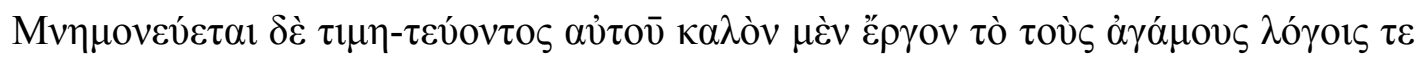

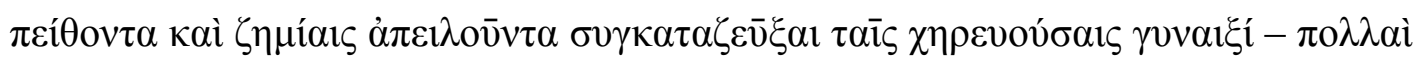

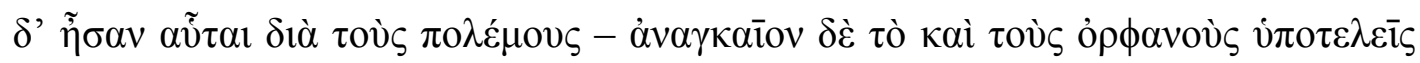

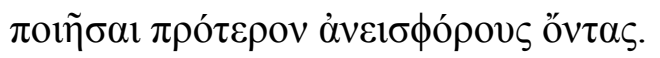

“3. Esta façanha valeu a ele [Camilo], além das responsabilidades ordinárias, ser nomeado censor, cargo que, desde aquela época, atribuía uma grande consideração. 4. Uma bela medida que tomou durante a sua censura foi, dissemos, a de obrigar os celibatários, às vezes persuadindo-lhes pelas suas palavras e ameaçando-lhes com multas, a casar com as mulheres viúvas [e havia muitas por causa das guerras]. Ele tomou uma outra decisão que a necessidade exigiu: submeteu ao imposto até os órfãos, que anteriomente eram isentos".

Segundo Valério Máximo, Camilo e Postúmio censuraram os homens idosos solteiros por não terem cumprido seu dever mais importante e condena-os a uma multa destinada às gerações futuras, por terem violado uma lei natural: a procriação de filhos no matrimônio. O celibato representava um comportamento socialmente inadequado, que prejudicava a coletividade. $^{230}$

durante a República e provavelmente, apenas sobre os homens. Segundo T. Spagnuolo Vigorita, Casta Domus cit. (nota 26 supra), p.8, somente em 167 a.C., suspendeu-se o recebimento do aes uxorium. Veja-se R. BESNIER, L'application des lois caducaires cit. (nota 10 supra), p.108. Este autor defende que um eventual imposto (aes horrearium) que teria incidido sobre as viúvas de guerra e as mulheres sui iuris, elaborado já na época de Sérvio Túlio (616-578 a.C.), é sem dúvida "lendário". Este caso prova que não tem fundamento a opinião de L. PEPPE, Recenzione a Patrizia Giunti, 'Consors vitae 'cit. (nota 70 supra), p.248, segundo o qual após a promulgação da Lei das XII Tábuas em 450 a.C., o matrimônio torna-se instrumento de estratégias políticas e financeiras, no qual a procriação perde a importância. Vejam-se também A. BOUCHÉ-LECLERCQ, Les lois démographiques d'Auguste cit. (nota 36 supra), p.249; P. GIUNTI, Consors vitae cit. (nota 26 supra), p.117. L. PEPPE, Storie delle parole cit. (nota 72 supra), p.138, acredita que a partir do século IV a.C., já eram elaboradas listas censórias com os nomes das mulheres não-casadas (viúvas e solteiras) e dos órfãos.

${ }^{230}$ Sobre a origem da res publica romana nas famílias numerosas, veja-se Cic. de off. 1,17,54: (...) Sequuntur fratrum coniunctiones, post consobrinorum sobrinorunque, qui cum una domo iam capi non possint, in alias domos tamquam in colonias exeunt. Sequuntur connubia et affinitates, ex quibus etiam plures propinqui; quae propagatio et suboles origo est rerum publicarum. “(...) Seguem, pois, os laços com os irmãos, com os primos de primeiro e segundo graus, os quais, não podendo coabitar todos na mesma casa, retiram-se em outras casas, como em colônias. Seguem-se os matrimônios e os parentescos adquiridos, dos quais os parentes tornam-se mais numerosos; e esta propagação e descendência é a origem da res publica". Vejam-se E. Volterra, Matrimonio cit. (nota 61 supra), p.772, nota 108; S. RicCOBONO, La politica demografica di Augusto cit. (nota 103 supra), p.576; R. Astolfi, La Lex Iulia et Papia cit. (nota 15 supra), p.346; R. BESNIER, L'application des lois caducaires cit. (nota 10 supra), pp.96-97; P. GIUNTI, Consors vitae cit. (nota 26 supra), pp.104-107. 
Val. Max. 2,9,1: Camillus et Postumius censores aera poenae nomine eos, qui ad senectutem caelibes pervenerant, in aerarium deferre iusserunt, iterum puniri dignos, si quo modo de tam iusta constitutione queri sunt ausi, cum in hunc modum increparentur: "Natura vobis, quemadmodum nascendi, ita gignendi legem scribit parentesque vos alendo nepotum nutriendorum debito, si quis est pudor, alligaverunt; accedit his quod etiam fortuna longam praestandi huiusce muneris advocationem estis adsecuti, cum interim consumpti sunt anni vestri et mariti et patris nomine vacui. Ite igitur et nodosam exsolvite stipem, utilem posteritati numerosae".

"Camilo e Postúmio, durante sua censura, puniram aqueles que, até sua velhice, permaneceram solteiros, fazendo-lhes pagar uma multa ao erário; e eles pensavam que mereciam ser punidos uma segunda vez se, de um jeito ou de outro, ousassem queixar-se de uma medida tão justa, visto que lhes repreendiam nestes termos: "Se a natureza vos fez nascer, ela também vos prescreveu procriar e vossos pais vos educaram impondo a obrigação de fazer crescer para eles os netos, se vós tendes algum senso de honra. Acrescente-se a isso o fato que vós tivestes a chance de dispor de um longo período para livrar-vos deste encargo, ao longo dos anos de vossas vidas que vós desperdiçastes sem ter o título de marido ou de pai. Ides, por isso, pagar integralmente, de uma mão nodosa, o pequeno tributo que será útil a uma família numerosa".

Os censores punem os solteiros que evitam a vida matrimonial (pois são contrários aos sacra coniugalia) e que não contribuem para o crescimento de uma legítima descendência na civitas e para a própria perpetuação da espécie. ${ }^{231}$

No final deste período, a partir do século III a.C., após a invasão gaulesa, Roma precisou contar, para ter um exército numeroso, com soldados de outras regiões da Itália, que antes eram agricultores e camponeses. Esta mudança alterou a organização citadina e agrícola no mundo romano, com o afluxo maior de cidadãos do campo para a cidade e

\footnotetext{
${ }^{231}$ Salienta P. GIUNTI, Consors vitae cit. (nota 26 supra), p.105, nota 49, que a experiência da procriação está presente nos sacra pro singulis hominibus, cerimônias que ritualizam as diversas fases do desenvolvimento humano: os Liberalia simbolizam a potência da função reprodutiva; as Nuptiae e os Repotia simbolizam uma solenidade sagrada que tem como escopo principal a capacidade de procriação dos cônjuges; os Natalia e os Nominalia comemoram o nascimento e o dia em que os pais dão o nome ao filho. Também o culto aos antepassados está vinculado, de certa forma, à exaltação da importância social da procriação. Nos Parentalia (celebrado em fevereiro) e nos Lemuria (comemorados em maio) os fantasmas daqueles que não tiveram filhos (caelibes) eram considerados espíritos vagantes, pois não tinham descendentes para render-lhes culto.
} 
ocasionou a crise da propriedade rural. ${ }^{232}$

Para aumentar o exército romano em 217 a.C., durante a Segunda Guerra Púnica, os libertos que tivessem filhos foram admitidos pelos censores nas legiões. Além disso, os mesmos libertos garantiram acesso às tribos rústicas e tiveram o direito de voto (ius suffragii) nas assembleias populares. ${ }^{233}$

\subsubsection{PERÍODO CENSÓRIO}

A administração do ager publicus (incluindo os edifícios e as vias públicas), a escolha dos senadores (lectio senatus) e a vigilância dos costumes (regimen morum) eram exercidas pelos censores (sanctissimi magistrati). Tal era a sua importância na República, que a censura foi considerada a dignidade mais elevada que um cidadão romano poderia alcançar, geralmente exercida por um ex-senador.

Em períodos de crise, o regimen morum adquiria uma utilitas publica: com efeito, para usarmos um termo moderno, quando houvesse uma queda acentuada da "taxa de natalidade", isto era uma grave ameaça à segurança do Estado e os meios de controle (sanções e privilégios legais) tornavam-se mais importantes para o incentivo à procriação. $^{234}$

A função do censor estava intimamente vinculada à família e às gentes. A penalidade da exclusão de um cidadão (da tribo, do senado, da ordem equestre) que praticasse alguma ação vergonhosa ou imoral e até alguma atitude econômica irregular já pertencia à antiga tradição e costume das gentes. O censor intervinha, por meio da nota censoria, exatamente quando o cidadão romano não fizesse um uso digno da liberdade, por meio do regimen morum (poder de controle dos comportamentos públicos e privados, civis

\footnotetext{
${ }^{232}$ P. GiunTI, Consors vitae cit. (nota 26 supra), pp.443-444; G. PIERI, L'Histoire du cens cit. (nota 221 supra), pp.160-163. O censo de 208 a.C. indicou uma enorme queda na população em decorrência das derrotas sofridas pelos romanos diante do exército de Aníbal. Foram contados 137.108 censa civium capita, quantia que subiu para 214.000 no censo seguinte de 204 a.C., graças, principalmente, à concessão da cidadania romana a muitos povos itálicos. A Terceira Guerra Púnica e a Guerra Macedônica também diminuíram a população, de acordo com os censos de 154 a.C. (324.000) e de 136 a.C. (317.933). Em relação a estes censos realizados no período da República, veja-se G. PIERI, L'Histoire du cens cit. (nota 221 supra), pp.173-175.

233 A. BouchÉ-LeClerCQ, Les lois démographiques d'Auguste cit. (nota 36 supra), p.249. Veja-se Liv. 22,$11 ; 45,15$.

${ }^{234}$ O.M. PÉTER, Liberorum quaerendorum causa cit. (nota 21 supra), p.322; E. RUIZ FERNÁNDEZ, El divorcio en Roma, Madrid, Universidad Complutense, 1988, p.27; R. Astolfi, Il matrimonio nel diritto romano preclassico cit. (nota 1 supra), p.139; M.C. GIORDANI, Iniciação ao Direito Romano cit. (nota 193 supra), pp.135-136.
} 
e morais). ${ }^{235}$

Os censores faziam a cada cinco anos o recenseamento dos cidadãos e a avaliação de seus bens, a idade, o domicílio, a situação militar dos componentes da família e perguntavam aos patresfamilias se eles viviam em casamento legítimo, confirmando a existência da vontade de procriar filhos. ${ }^{236}$

Esta questão (uma fórmula estável e permanente, como é típico no direito romano) era, muito provavelmente, realizada desta forma: "Vós declarais ter uma esposa segundo vosso desejo, para procriar filhos?"237

${ }^{235}$ R.V. JHERING, Der Geist des römischen Rechts cit. (nota 9 supra), p.144; A. FERNANDEZ DE BUJAN, Derecho Publico Romano cit. (nota 224 supra), pp.99-100; E.M. AgATI MADEIRA, A Censura na Antiga Roma cit. (nota 223 supra), p.159. Em relação ao uso digno da liberdade pelo cidadão romano, vejam-se, Flor. 9 inst. D.1,5,4pr.: Libertas est naturalis facultas eius quod cuique facere libet, nisi si quid vi aut iure prohibetur. "A liberdade é a faculdade natural de fazer o que a cada um apraz, a não ser que isto seja proibido pela força ou pelo direito"; Cic. de rep. 1,31,47: (...) et talis est quaeque res publica, qualis eius aut natura aut voluntas, qui illam regit. Itaque nulla alia in civitate, nisi in qua populi potestas summa est, ullum domicilium libertas habet; qua quidem certe nihil potest esse dulcius, et quae, si aequa non est, ne libertas quidem est. "A qualidade de cada res publica depende da natureza e da vontade de quem o governa. Eis porque em nenhuma outra cidade, senão naquela em que o soberano poder pertence ao povo, a libertas pode ter o seu domicílio. Não há nada que seja mais doce do que ela, e, se não for igual para todos, já não é libertas". Vejam-se L.GIL, Censura en el mundo antiguo, 2ªed., Madrid, Alianza, 1985, pp.132-141; M.V.G. PESSI, Brevi riflessioni sul ruolo della censura cit. (nota 225 supra), pp.167-170. Segundo M.H. RoCHA PEREIRA, Estudos de História da Cultura Clássica - Cultura Romana, cit. (nota 43 supra), p.381, "Libertas é um conceito vago e negativo - liberdade do governo de um tirano ou de uma facção. Segue-se que libertas, tal como regnum ou dominatio, é um termo conveniente para a fraude política. Libertas era invocada com muita frequência na defesa de uma ordem existente por indivíduos ou classes que gozavam de poder e riquezas". De acordo com S.A.B. MEIRA, Curso de Direito Romano cit. (nota 72 supra), pp.42-43, a "nota censória" (penalidade) era transcrita à margem do Registro do Censo (onde as informações dos cidadãos eram incluídas), no caput. Provavelmente a expressão capitis deminutio tenha surgido desta averbação na margem do Registro, pois os censores tinham a competência de reduzir um cidadão à escravidão e também de exclui-lo do exército e do Senado.

${ }^{236}$ Sobre a descrição do cargo dos censores, veja-se Plut. Cato Maior 16. A partir da promulgação da Lex Aemilia de censura minuenda, em 434 a.C., os censores eram eleitos a cada cinco anos, para um período de magistratura de dezoito meses. O controle do respeito aos princípios tradicionais da res publica era realizado por estes magistrados, que exerciam o regimen morum, isto é, a manutenção dos costumes, um cargo tão importante que poderia destituir até um senador. Este respeito aos costumes estava presente em vários compromissos assumidos pelo cidadão romano e considerados valores fundamentais que compunham a "ética" do mos maiorum: a fidelidade à palavra dada, a fides, a perseverança (constantia), a seriedade (gravitas), o mérito (virtus), o sentido de dever para com os deuses, para com os antepassados e para com a pátria (pietas), a nobreza moral (magnitudo animi) e a exaltação de suas virtudes (gloria). Vejam-se A. DAVIAUlt, Le 'mos maiorum' cit. (nota 162 supra), p.60; E. VolTERRA, Matrimonio cit. (nota 61 supra), pp.739-740, nota 30; A. FERnANDEZ DE BujAn, Derecho Publico Romano cit. (nota 224 supra), pp.98-99; S.A.B. MEIRA, Curso de Direito Romano cit. (nota 72 supra), pp.42-43; E.M. AgATI MADEIRA, A Censura na Antiga Roma cit. (nota 223 supra), p.155; A. RoMANo, Matrimonium iustum cit. (nota 26 supra), p.93.

237 Aulo Gélio reforça a noção de gravitas romana quando narra a rígida condenação de um cidadão, num episódio de 184 a.C., que faz uma simples brincadeira após a pergunta do censor.

Gell. 4,20,1-6: Inter censorum severitates tria haec exempla in litteris sunt castigatissimae disciplinae. Censor agebat de uxoribus solemne iusiurandum. Verba erant ita concepta: "Ut tu ex animi tui sententia, uxorem habes?" Qui iurabat cavillator quidam et canalicola et nimis ridicularius fuit. Is, locum esse sibi ioci dicendi ratus, quum ita uti mos erat censor dixisset, "Ut tu ex animi tui sententia uxorem habes?" "Habeo equidem", inquit, "uxorem, sed non hercle ex animi mei sententia". Tum censor eum, quod intempestive lascivisset, in aerarias retulit, causamque hanc ioci scurrilis apud se dicti subscripsit. "Entre as severidades dos censores, estes três exemplos na literatura são de uma disciplina muito rigorosa. Eis o primeiro: o censor 
A pergunta do censor e o juramento perante ele de que a união era liberorum procreandorum causa sem dúvida fixava suas raízes nos mores maiorum. ${ }^{238}$

Vejamos, a seguir, um caso que demonstra essa importância do papel dos censores na "polícia dos costumes". 239

O episódio de Spurius Carvilius Ruga teve grande repercussão na sociedade romana e uma participação importante dos censores. Spurius Carvilius Ruga teria sido o primeiro $^{240}$ cidadão romano a repudiar sua mulher, em 231 a.C., por motivo de

ocupava-se do juramento solene sobre as esposas; as palavras eram assim concebidas: 'Tu pessoalmente, segundo a sinceridade de tua alma, tens esposa?' Quem jurava era um zombeteiro, um morador da região do Canal e foi excessivamente jocoso. Ele achou haver para si a ocasião de fazer um gracejo, visto que assim, conforme era o costume, o censor tivesse dito: 'Tu pessoalmente, segundo a sinceridade de tua alma, tens esposa?' - 'Tenho esposa certamente', ele disse, 'mas não, por Hércules, segundo a sinceridade de minha alma'. Então a este, porque fora de propósito tivesse gracejado, o censor o incluiu entre os aerarii [classe dos cidadãos privados do direito de sufrágio] e registrou como motivo este bobo gracejo pronunciado diante de si". Traduzimos animi como "alma" no sentido de sede da coragem, do desejo, das inclinações e das paixões.

Cícero descreve a insolência de um cidadão diante do censor (De orat. 2,64,260): Ridicule etiam illud L. [Porcius] Nasica censori Catoni, cum ille: "Ex tui animi sententia tu uxorem habes?" "Non hercule", inquit, "ex mei animi sententia". Haec aut frigida sunt aut tum salsa, quom aliud est expectatum. Natura enim nos, ut ante dixi, noster delectat error; ex quo, quom quase decepti sumus expectatione, ridemus. "Também engraçada é a palavra de L. Nasica à Catão, o Censor, que lhe havia feito a pergunta: 'Em tua alma e consciência, tu tens esposa?' - 'Não por Hércules', ele disse, 'de modo algum pela vontade de minha alma'. Estes tipos de respostas não evitaram a frieza [do censor] e não têm graça, sob a condição de não serem entendidas. Nosso desprezo, como já afirmei mais acima, torna-nos, então, um sujeito de espanto espontâneo: vendo nossa esperada decepção, nós rimos". Sobre estes trechos de Aulo Gélio e de Cícero, observa P. GIUNTI, Consors vitae cit. (nota 26 supra), pp.122-125, que a expressão liberorum quaerendorum causa não é mencionada em nenhuma das duas perguntas dos censores, pois era irrelevante em relação às declarações de paternidade. Conclui, portanto, que a pergunta do censor não era utilizada com uma finalidade de verificação ou incentivo à procriação, mas de acordo com exigências político-administrativas, era destinada a definir a situação familiar e patrimonial de cada cidadão, além de avaliar, de acordo com a resposta do declarante sob juramento, a real existência dos filii in potestate na família. Geralmente o paterfamilias limitava-se a declarar na resposta ao censor, o nome de cada um dos membros da família e a sua relação de parentesco com cada um deles. A finalidade procriativa do matrimônio romano já estaria implícita na expressão ex tui anima sententia tu uxorem habes. Esta resposta do cidadão era absolutamente livre, não estava vinculada a nenhuma expressão ou cláusula solene pré-estabelecida.

${ }^{238}$ Nas fontes jurídicas, este juramento perante a autoridade também era exigido pela Lex Iulia Miscella (uma outra denominação da lex Iulia et Papia dada por Justiniano) para as viúvas, às quais se deixasse um legado sob condição de não se casarem novamente após a morte do marido. Elas poderiam contrair segundas núpcias desde que jurassem casar liberorum procreandorum causa. Justiniano ab-rogou esta lei em 531: Iust. C.6,40,2;-3(531); Nov.22,43 (536). Vejam-se A. GuARINO, Diritto privato romano cit. (nota 1 supra), pp.566-567, nota 41.7; E. VOLTERRA, Matrimonio cit. (nota 61 supra), p.740, nota 30.

${ }^{239}$ F. DE MARTINO, Individualismo e Diritto Romano Privato cit. (nota 30 supra), pp.23-24.

${ }^{240}$ Nas opiniões de A. CALDERINI, Antichità private cit. (nota 19 supra), pp.26-27; E. RUIZ FERNÁNDEZ, El divorcio en Roma cit. (nota 234 supra), pp.28-29 e de P. VocI, Istituzioni di diritto romano cit. (nota 12 supra), p.517, nota 17, o caso de Carvilio Ruga não foi o primeiro repúdio em Roma. De acordo com P. GIUNTI, Consors vitae cit. (nota 26 supra), pp.98-107;448-453, antes do caso de Carvílio Ruga, ocorreu o divórcio de Lúcio Ânio, entre 307 e 306 a.C., contrário ao direito, pois ofendia o dever fundamental da procriação na sociedade romana, já estabelecido em 403 a.C. por Camilo e Postúmio, conforme Val. Max. 2,9,2: Horum severitatem M. Valerius Maximus et C. Iunius Brutus Bubulcus censores consimili genere animadversionis imitati sunt: L. enim Annium senatu moverunt, quod quam virginem in matrimonium duxerat repudiasset nullo amicorum consilio adhibito. "Sua severidade encontra em Marco Valério Máximo e Caio Junio Bruto Bubulco os imitadores que, no decorrer de sua censura, aplicaram o mesmo gênero de sanção. Com efeito, eles afastaram Lúcio Ânio do Senado, porque ele repudiou a moça com a qual se casou, sem recorrer ao conselho dos amigos". Neste caso, o repúdio não parece estar ligado a um comportamento 
esterilidade. ${ }^{241}$ Ele jurou diante dos censores que se casava uxorem si liberum quaerundum gratia habiturum.

Gell. 4,3,2: Servius quoque Sulpicius, in libro quem composuit 'de Dotibus', tum primum cautiones rei uxoriae necessarias esse visas scripsit, quum Spurius Carvilius, cui Ruga cognomentum fuit, vir nobilis, divortium cum uxore fecit, quia liberi ex ea, corporis vitio, non gignerentur, anno Urbis conditae quingentesimo vigesimo tertio, M. Attilio, P. Valerio coss. Atque is Carvilius traditur uxorem, quam dimisit, egregie dilexisse carissimamque morum eius gratia habuisse, sed iurisiurandi religionem animo atque amori praevertisse, quod iurare censoribus

feminino culpável. Lúcio Ânio foi removido do Senado pelos censores, pois punia-se rigorosamente o celibato e a violação dos sacra coniugalia. Ao repudiar a esposa (ambos os cônjuges tinham a capacidade de ter filhos) ele comete uma falta gravíssima ao abdicar de seu dever de procriação no matrimônio. Na opinião de G. BRINI, Matrimonio e divorzio, vol.2, cit. (nota 69 supra), pp.106-107, o caso de Carvílio Ruga não foi o primeiro a verificar-se em Roma, mas teria feito surgir o divórcio (divertere) diante e pela intervenção da autoridade pública da época (os censores). Antes de Carvílio, o direito romano apenas conhecia a figura do repúdio. De acordo com E. VolterRA, Divorzio cit. (nota 70 supra), p.63, o episódio de Carvílio Ruga deve ser interpretado não como o primeiro divórcio, mas como o primeiro caso em que, não tendo ocorrido a restituição do dote à esposa, sentiu-se a necessidade de garantir esta restituição por meio das cautiones rei uxorie. Para O. RoBlEDA, Il divorzio in Roma cit. (nota 51 supra), pp.357-359, nota 71;363, o divórcio de Carvílio Ruga foi o primeiro realizado fora das três causas estabelecidas por Plutarco em Romulus 29. Não é possível, segundo ROBLEDA, que antes do divórcio de Carvilius Ruga, nenhuma mulher tenha cometido um dos delitos previstos nas fontes ou que nenhum homem tenha repudiado sua esposa. Quanto ao divórcio de Ânio, ROBLEDA acredita ter ocorrido no ano 300 a.C. e, segundo o autor, não se sabe o motivo.

${ }^{241}$ A questão é saber se este divórcio foi o primeiro na História Romana, se ele foi o primeiro fora das leis de Rômulo ou mesmo se ele foi o primeiro não motivado por culpa da mulher. Sobre este ponto, as fontes são contraditórias, pois não contêm nem mesmo as regras das "leis de Rômulo". Além disso, há uma diferença entre as datas dos textos de Gélio e Valério Máximo. Gélio narra que o repúdio ocorreu no ano 523 da fundação de Roma ( $a b$ urbe condita), quando eram cônsules Marco Atílio e Públio Valério. Porém, o ano destes cônsules não foi 523 (231 a.C.), mas 527 (227 a.C.). Dionísio de Halicarnasso considera que o divórcio de Carvílio ocorreu em 520 ab Urbe condita (234 a.C.). Valério Máximo estabelece que o fato ocorreu no ano $150 a b$ urbe condita (604 a.C.). Outra referência de data deste acontecimento está em Plut. Romulus 6 e Numa 3, que situa o episódio em 524 a.C. (230 ab Urbe condita). Vejam-se O. RoBledA, Il divorzio in Roma cit. (nota 51 supra), p.355; P. GIUNTI, Consors vitae cit. (nota 26 supra), pp.109-110, nota 55.

As leis de Rômulo não previam o repúdio em caso de esterilidade da mulher. Pemitia-se o repúdio em quatro casos: 1) tentativa de envenenamento do marido (ou envenenamento da prole, tentativa de aborto); 2) utilização de chaves falsas; 3) parto simulado; 4) adultério. Neste sentido Plut. Romulus 29. Segundo J. GAUDEMET, Droit privé romain cit. (nota 65 supra), p.51, Ceres é uma divindade tardia para os primórdios da Realeza, sendo provavelmente desta época a antiga deusa da fecundidade do lar, Tellus Genitrix. Vejam-se M. MARRONE, Istituzioni cit. (nota 48 supra), p.223; L.F. RADITSA, Augustus Legislation cit. (nota 49 supra), p.308; R. ORESTANO, La struttura giuridica del matrimonio romanocit. (nota 1 supra), p.208, nota 866; D. DAlla - R. LAMBerTinI, Istituzioni di diritto romano cit. (nota 10 supra), pp.110-111; A. BURDESE, Manuale cit. (nota 47 supra), p.264, nota 6; L. PEPPE, Storie delle parole cit. (nota 72 supra), p.182, nota 247. Na opinião de E. VolterRA, Divorzio cit. (nota 70 supra), p.62, as afirmações de Plutarco sobre as leis de Rômulo e as proibições em relação ao divórcio e ao repúdio, seriam criações da época das reformas matrimoniais de Augusto. Em relação à legislação sobre o aborto e a sua tentativa, afirma E. NARDI, Aborto e omicidio nella civiltà clássica, in ANRW II.13 (1980), p.377, que apenas no século III d.C. o aborto foi condenado pela primeira vez, por um rescrito promulgado pelos imperadores Septímio Severo e Antonino Caracala. 
coactus erat, uxorem se liberum quaerendum gratia habiturum.

"Sérvio Sulpício, no livro que compôs de dotibus, escreveu que as cláusulas de garantia dos bens da mulher foram pela primeira vez consideradas necessárias, quando Spurius Carvilius, que teve o sobrenome Ruga, varão nobre, divorciou-se, porque sua esposa tinha um defeito no corpo, não podia procriar, no ano quingentésimo vigésimo terceiro [523] Urbis conditae [após a fundação de Roma], sob o consulado de M. Attilius e de P. Valerius. Este Carvilius, afirmava-se, amava muito a esposa que ele abandonou; ela the era caríssima por causa dos costumes dela, mas à alma e ao amor fez ultrapassar o respeito do juramento, pelo fato que ele tinha sido obrigado a jurar, pelos censores, que ele se casava para ter filhos". 242

Carvilius Ruga repudiou ${ }^{243}$ a esposa porque queria, com efeito, obedecer a obrigação moral mais severa, de seu próprio juramento, afirmando que um matrimônio

${ }^{242}$ Também neste sentido, Gell. 17,21,44: Anno deinde post Roman conditam quingentesimo undevicesimo Sp. Carvilius Ruga primus Romae de amicorum sententia divortium cum uxore fecit, quod sterila esset iurassetque apud censores uxorem se liberum quaerundorum causa habere. "Em seguida, no ano quingentésimo décimo primeiro após a fundação de Roma, Spurius Carvilius Ruga foi o primeiro que em Roma moveu divórcio com a esposa, a partir da opinião de amigos, porque ela fosse estéril, e ele tivesse jurado diante dos censores ter esposa por causa de querer filhos". O. RoBledA, Sobre el Matrimonio en Derecho Romano cit. (nota 132 supra), p.340; Idem, Il divorzio in Roma prima di Costantino cit. (nota 51 supra), p.358, afirma que, a narrativa de Aulo Gélio indica que a procriação constituía uma finalidade subjetiva e não tinha escopo objetivo. Além disso, o autor salienta que Carvilius Ruga não foi obrigado pelos censores a fazer o juramento para poder se divorciar, pois realizou o juramento num momento anterior ao divórcio, quando ocorreu a realização do censo. O divórcio não se fazia diante dos censores, nem estes magistrados exigiam qualquer explicação sobre a sua causa. Spurius Carvilius Ruga simplesmente provou a veracidade de seu matrimônio por meio de um juramento. É provável, em relação ao trecho amicorum sententia divortium, que Aulo Gélio estabelecia a necessidade de um consilium dos amigos. Sobre o conselho domesticorum ou amicorum, veja-se também Gell. 23,4. Por fim, RoBLEDA, op.cit., p.387, nota 178, admite que a partir do divórcio de Carvílio Ruga, provavelmente a jurisprudência ou os costumes (e não o pretor) introduziram uma actio rei uxoria, in aequum et bonum conceptae. A fórmula da cautio rei uxoriae, no contexto de Gell. 4,3,2, indicaria esta restituição do dote à esposa repudiada por esterilidade. Neste sentido, vejam-se R. ASTOLFI, Il matrimonio nel diritto romano preclassico cit. (nota 1 supra), p.371; O. ROBLEDA, Il divorzio in Roma cit. (nota 51 supra), pp.386-387; A. BuRdESE, Manuale cit. (nota 47 supra), p.281; A. NicOLETTI, Dote (Diritto romano), in NNDI 6 (1960), p.258. Em relação ao iusiurandum, P. GIUNTI, Consors vitae cit. (nota 26 supra), pp.113-116; 121-122, afirma que há uma antinomia nos dois trechos de Gélio (4,3,2 e $17,21,44)$ no momento da prestação do juramento. O trecho iurassetque apud censores uxorem se liberum quaerundorum causa habere parace estabelecer a iusiurandum após a celebração das núpcias, enquanto quod iurare a censoribus coactus erat uxorem se liberum quaerendum gratia habiturum, indica que Carvílio realizava o juramento para a própria constituição do vínculo conjugal. De acordo com M. HUMBERT, L'individu, l'État cit. (nota 60 supra), p.176, a expressão liberorum procreandorum causa indicava uma das condições de validade do matrimônio romano. Ou seja, se a mulher é estéril e não pode procriar, o censor pressionava o marido a contrair um segundo matrimônio.

${ }^{243}$ De acordo com O. RoBleDA, Il divorzio in Roma cit. (nota 51 supra), pp.352-353, o termo divortium sempre se refere à dissolução matrimonial pela uxor, enquanto repudium (dimittere), referia-se ao marido. Além disso, torna-se frequente o uso de repudium para exprimir ou significar a causa, o ato de produção, enquanto divortium passou a determinar o efeito, a dissolução. Vejam-se Gai. 11 ad ed. prov. D.24,2,2,1; Ulp. 26 ad sab. D.24,2,2,4; Ulp. 33 ad ed. D.24,3,22,7; -9. 
legítimo só existe para a procriação dos filhos legítimos. ${ }^{244}$

Val. Max. 2,1,4: Repudium inter uxorem et virum a condita urbe usque ad centesimum et quinquagesimum annum nullum intercessit. Primus autem Sp. Carvilius uxorem sterelitatis causa dimisit. Qui, quamquam tolerabili ratione motus videbatur, reprehensione tamen non caruit, quia ne cupiditatem quidem liberorum coniugali fidei praeponi debuisse arbitrabantur.

"O repúdio jamais separou uma esposa e um marido, desde a fundação de Roma até o ano cento e cinquenta de sua existência. E Spurius Carvilius foi o primeiro a repudiar a sua esposa, por causa de esterilidade. Porém, ele que parecia inspirado por motivos aceitáveis, no entanto, não escapou das críticas, porque se pensava que o desejo de ter filhos não deveria preponderar sobre a fidelidade conjugal”.

Carvílio cumpriu sua obrigação moral realizada diante dos censores (como Dionísio de Halicarnasso 2,25,7 narra $)^{245}$, e verificou-se a necessidade deste do repúdio por

\footnotetext{
${ }^{244}$ Para F. LANFRANCHI, Il diritto nei retori romani cit. (nota 78 supra), pp.233-234, a esterilidade foi motivo de repúdio para os retóricos romanos, influenciados pelos gregos. E acordo com O. ROBLEDA, Il divorzio in Roma cit. (nota 51 supra), p.364, nota 92, no juramento, apenas o censor poderia inscrever Carvílio como casado. Isto reforça que em Roma, a principal finalidade do matrimônio era a procriação. No caso de Carvílio, admitiu-se que a esterilidade da uxor fosse causa de divórcio. Porém, na opinião de RoBLEDA, não era comum na sociedade romana o divórcio por causa da esterilidade de um dos cônjuges, nem o rompimento do juramento de estar casado de acordo com a fórmula liberorum quaerendorum causa dissolvia o matrimônio. As fontes não indicam se o matrimônio de Carvílio era acompanhado ou não da conventio in manum, nem se houve a possibilidade de um divórcio de comum acordo entre marido e mulher. Para P. GiUnTI, Consors vitae cit. (nota 26 supra), p.454, nota 88, no trecho de Valério Máximo $(2,1,4)$ repudium e divortium eram sinônimos. A autora defende duas hipóteses para esta situação: ou o caso de Carvílio Ruga foi o primeiro repudium mencionado nas fontes (literárias e jurídicas) ou foi um ponto de ruptura na dinâmica das relações conjugais, como o primeiro divortium em contraposição ao precedente repudium. De acordo com A. CALDERINI, Antichità private cit. (nota 19 supra), pp.26-27, a esterilidade da esposa era causa de divórcio, pois o escopo principal do matrimônio romano era a procriação. Duvidosa e muito genérica a opinião do autor quando menciona que lo scopo del matrimonio non è raggiunto (...) se nascono solo femmine, perchè le figlie non assicurano la continuità della stirpe, e non continuano il culto familiare (...).
}

Veja-se Quint. Declam. 251: Intra quinquennium non parientem repudiare liceat. "É permido repudiar [aquela que] não deu à luz no espaço de cinco anos". Conclui LANFRANCHI op.cit, pp.231 e 234, que é possível que este trecho de Quintiliano demonstre um costume romano de repudiar as mulheres que não gerassem no quinquênio. $\mathrm{Na}$ análise de P. GIUNTI, Consors vitae cit. (nota 26 supra), pp.123-127;128129;448; L. PEPPE, Recenzione a Patrizia Giunti, 'Consors vitae 'cit. (nota 70 supra), p.248, o principal valor para o direito no divórcio de Carvílio Ruga foi a dissolução do matrimonium e não a procriação ou a formalização da expressão liberorum quaerendorum causa. Veja-se neste sentido, E. VOLTERRA, La conception du Mariage d'après les juristes romains cit. (nota 30 supra), p.43. A título de exemplo, algumas legislações orientais da Antiguidade, como as leis de Manu na Índia, previam o repúdio da mulher estéril após o decurso de oito anos $(9,81)$.

${ }^{245}$ Em razão da importância da constituição de um matrimônio prolífico, era necessário, para o repúdio da uxor por esterilidade, o máximo de solenidade possível, v.g., com a utilização da expressão liberorum procreandorum causa. O trecho final, que indica que Carvílio Ruga teria sido odiado pelo povo romano pelo 


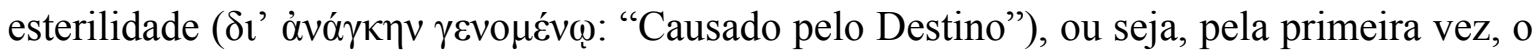
repúdio não foi motivado por nenhuma daquelas situações apresentadas por Rômulo, estabelecidas pelos mores maiorum (tentativa de envenenamento do marido, chaves falsas, adultério, embriaguez, parto simulado). ${ }^{246}$

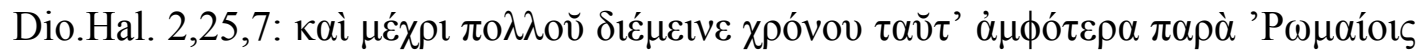

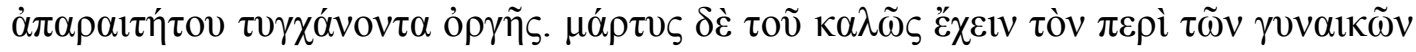

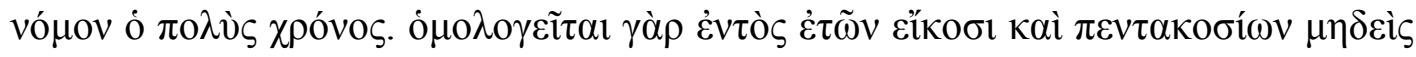

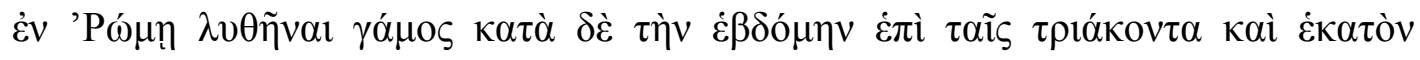

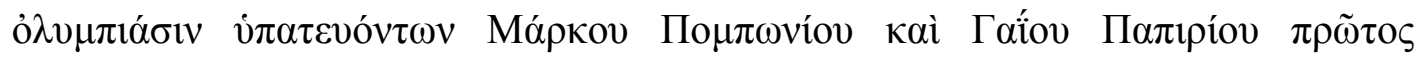

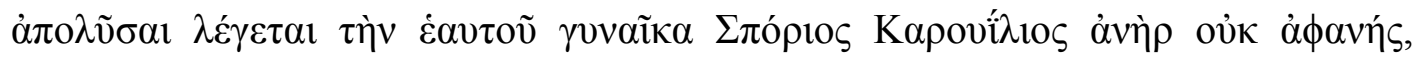

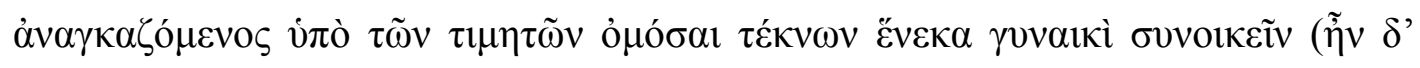

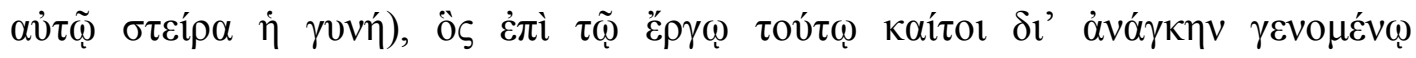

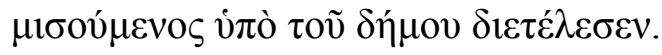

"E durante muito tempo em Roma [as mulheres adúlteras] continuaram recebendo um castigo inflexível. E por longo tempo é testemunho de que esta lei sobre as mulheres era certa, pois se reconhece que durante quinhentos e vinte anos nenhum matrimônio se dissolveu em Roma; contudo, na CXXXVIII Olimpíada [231 a.C.], sob o consulado de Marco Pompônio e de Caio Papírio, afirma-se que Spurius Carvilius, homem ilustre, o primeiro a divorciar-se de sua esposa, foi obrigado pelos censores a jurar que havia se casado com sua mulher para ter filhos e por este fato, causado pelo destino, viveu odiado pelo povo".

resto de sua vida, é ilusório, pois em 228 a.C., ele foi novamente eleito cônsul. Vejam-se P. VeYNE, L'Empire Romain cit. (nota 19 supra), p.38; O. RoBLEDA, Il divorzio in Roma cit. (nota 51 supra), p.357; P. GIUNTI, Consors vitae cit. (nota 26 supra), pp.108-110;126-130.

${ }^{246}$ O. ROBLEDA, Il divorzio in Roma cit. (nota 51 supra), pp.364;386-387, nota 178; O.M. PÉTER, Liberorum quaerendorum causa cit. (nota 21 supra), pp.316-318; A. LóPEZ PEDREIRA, Limitaciones a la 'libertas nuptialis' cit. (nota 40 supra), p.398. A fecundidade era extremamente valorizada na sociedade romana. Ulpiano, v.g., ao analisar os vícios redibitórios de uma escrava, objeto de um contrato de compra e venda, afirma que "a principal função das mulheres é receber e conservar o concebido" e fala da distinção da esterilidade feminina elaborada pelo jurisconsulto Trebácio: Ulp. 1 ad ed. aed. cur. D.21,1,14,1: Si mulier praegnans venierit, inter omnes convenit, sanam eam esse; maximum enim ac praecipuum munus feminarum est accipere ac tueri conceptum. "Se tiver sido vendida uma mulher grávida, ajusta-se entre todos que ela está em bom estado; porque a maior e a principal função das mulheres é receber e proteger o concebido"; D.21,1,14,3: De sterili Caelius distinguere Trebatium dicit, ut, si natura sterilis sit, sana sit, si vitio corporis, contra. "Quanto à estéril, afirma Célio, Trebácio distingue que se for estéril por natureza é considerada que está em bom estado, e contrariamente, se por defeito do corpo". De acordo com P. GIUNTI, Consors vitae cit. (nota 38 supra), pp.114-115;448, o caso de Carvílio Ruga não estabeleceu a esterilidade como causa repudii, mas, em virtude da pressão dos censores pela fecundidade das núpcias, constituiu uma motivação "politically correct". 
No caso de Carvílio, é possível constatar que a procriação era, nesta época, um elemento essencial para o surgimento do próprio matrimonium e a sua dissolução por esterilidade demonstra a finalidade reprodutiva deste instituto. O sintagma liberorum quaerendorum causa não fica mais restrito às formalidades verbais dos censores e começa a ser mencionado, a partir de 230 a.C., em vários documentos literários. ${ }^{247}$

Além disso, a civitas neste período, em plena fase de ascensão militar e crescimento territorial, mantinha como prioridade (já observada, dentro da proposta deste trabalho, no “período militar”) a prole numerosa das famílias dentro de um legítimo matrimônio. ${ }^{248}$

Esta preocupação ético-demográfica perdurou durante toda a República. Por exemplo, em 52-51 a.C., Cícero em De Legibus 3,3,7, ao falar sobre a República ideal, especifica a função dos censores e reforça a importância do combate ao celibato ${ }^{249}$ e do controle dos costumes do povo:

Censoris populi aevitates, suboles, familias pecuniasque censento, urbis templa vias aquas aerarium vectigalia tuento, populique partis in tribus discribunto, exin pecunias aevitates ordines partiunto, equitum peditumque prolem describunto, caelibes esse prohibento, mores populi regunto, probrum in senatu ne relinquonto. Bini sunto, magistratum quinquennium habento; reliqui magistratus annui sunto; eaque potestas semper esto.

\footnotetext{
${ }^{247}$ P. GIUNTI, Consors vitae cit. (nota 26 supra), pp.130;458-459.

${ }^{248}$ Nas palavras de P. GIUNTI, Consors vitae cit. (nota 26 supra), p.118, all'epoca cui il divorzio carviliano è riferito, quando la 'civitas', in piena fase ascensionale, sosteneva il massimo sforzo per la sua crescita, l'istanza populazionista doveva svolgere un ruolo chiave in termini politico-culturali, coinvolgendo immediatamente l'istituto del matrimonio che, con la sua fisiologica connotazione in senso reprodutivo, quell'istanza era chiamato appunto ad assecorare.

${ }^{249}$ Vejam-se T. SPagnuolo VIGORITA, Casta Domus cit. (nota 26 supra), pp.17;95-96; J.A. Field JR., The purpose cit. (nota 129 supra), p.404, notas 20 a 22; A. BOUCHÉ-LECLERCQ, Les lois démographiques d'Auguste cit. (nota 36 supra), p.250, nota 7; E.M. Agati MADEIRA, A Censura na Antiga Roma cit. (nota 223 supra), p.157. Na opinião de D. NÖRR, The matrimonial Legislation of Augustus cit. (nota 54 supra), p.350, o combate ao celibato, o incentivo às famílias numerosas e a pergunta realizada pelos censores se os cônjuges se casavam com o objetivo de ter filhos, teve resultados ínfimos no aumento populacional romano.
}

Apenas como uma breve comparação com outras cidades antigas, em Esparta o combate ao celibato era realizado por meio de leis muito rígidas e até vexatórias. Como podemos comprovar em Plut. Lycurgi 15,2:

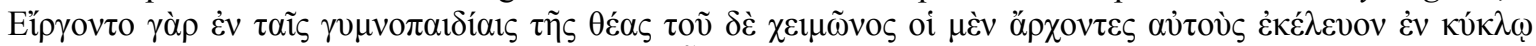

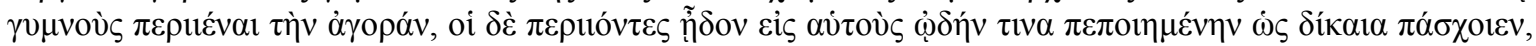

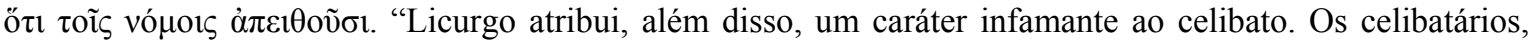
com efeito, não podiam assistir ao espetáculo dos Gymnopédios, e no inverno, os magistrados os obrigavam a fazer a volta na praça pública, completamente nus, e a cantar, enquanto faziam, uma canção composta contra eles, dizendo que eles eram punidos com justiça, porque desobedeceram as leis". Sobre esta intervenção do "Estado" na vida dos cidadãos e o interesse em relação à procriação da autoridade pública em Esparta, Plut. Licurgo 15,12-15. Veja-se também Dio Cass. 43,25,2. 
"Que os censores recenseiem no povo as condições da idade, dos descendentes, do conjunto dos escravos e do patrimônio; a inspeção dos templos, das estradas, das águas, do Erário e do vectigal; que divididam por tribos o povo, depois de distinguir as fortunas, as idades e as ordens; que dividam os jovens em cavaleiros e soldados de infantaria; que impeçam que existam celibatários; que regulem os costumes do povo, não permitindo escândalo no Senado; serão dois e a magistratura durará cinco anos, enquanto que os demais magistrados serão anuais; e que seu poder esteja sempre em vigor".

\subsubsection{PERÍODO DA NEQUITIA E DOS MALI MORES}

Nos dois últimos séculos da República, com a degradação dos costumes das classes dominantes, o aumento dos divórcios e a decadência da manus, os magistrados e os jurisconsultos mais importantes perceberam que o matrimônio deveria ser protegido, visto o baixo crescimento demográfico que colocava em risco o futuro da civitas. ${ }^{250}$

$\mathrm{Na}$ época dos Gracos, num contexto com inúmeros problemas políticos e sociais, inquietava-se o censor Quintus Caecilius Metellus Macedonicus. Num discurso (oratio) que fez ao povo em 131 a.C., ele exortou os seus concidadãos a se casarem legitimamente

${ }^{250}$ É importante salientar aqui que a maioria do povo romano sempre teve grande consideração e respeito pelo matrimônio e pela observância dos mores maiorum e que esta degradação dos costumes, com o aumento do número de divórcios, ocorrida no final da República e início do Principado, verificou-se principalmente nas classes ricas e dominantes. Nas classes mais baixas e nas províncias o divórcio foi menos frequente. Vejam-se M. MARrone, Istituzioni cit. (nota 48 supra), pp.216-217; V. ArANGIO-RuIZ, Istituzioni cit. (nota 53 supra), p.451; B. BIONDI, Istituzioni cit. (nota 22 supra), p.448, nota 49; R. VILLERS, Le mariage envisagé cit. (nota 63 supra), p.293; R. Astolfi, La Lex Iulia et Papia cit. (nota 15 supra), p.346, nota 57. Salienta A.A. CASTRo CorrêA, O Estoicismo no Direito Romano cit. (nota 33 supra), p.89, que a decadência da manus generalizou-se nos fins da República e no Império e corresponde a "uma nova organização da sociedade e da família (...)". Na opinião de F. SchUlz, Classical Roman Law cit. (nota 51 supra), pp.127128, apesar do aumento no número de divórcios ocorrido no último século da República, este fato não implicou necessariamente na decadência da moralidade em todas as classes sociais, mas sobretudo na classe política dominante. Veja-se Sen. De benef. 3,16,2. Nas palavras de E. CANTARELla, Famiglia romana e demografia sociale cit. (nota 55 supra), pp.106-107, anche se la propaganda nazionale esaltava il matrimonio unico, $i$ divorzi erano frequenti, e quantomeno tra le classi abbienti non di rado che una persona, nel corso della vita, contraesse un elevato numero di matrimoni (in alcuni casi sino a cinque o sei?). E questo faceva sì che, quantomeno tra le 'élites', esistessero numerose famiglie “miste”, composte dai coniugi e dai figli nati da successivi matrimoni di questi. De acordo com P. GIUNTI, Consors vitae cit. (nota 26 supra), pp.118;445, o aumento da riqueza, a transformação dos modelos sociais e da ideologia, criaram uma tendência na sociedade romana que tornava a gravidez algo indesejado e muitas mulheres começaram a utilizar-se de técnicas anticoncepcionais e de práticas abortivas para evitar a filiação. Conclui a autora, na p.446, que saranno dunque $i$ nuovi statuti esistenziali, che gradualmente prenderanno corpo durante la media Repubblica per poi divenire costume dominante nel corso degli ultimi due secoli a.C., a determinare questo verosimile "declassamento" della finalità procreativa fra $i$ valori portanti dell'etica familiare: rendendo con ciò inevitabilmente meno cogente, sul piano ideologico e normativo, l'equazione nozze infeconde $=$ nozze risolvibili . Sobre a rejeição da difusão de práticas anticoncepcionais em Roma, veja-se 
e salientou que a salus perpetua era mais importante que uma brevis voluptas.

Aulo Gélio transcreveu este discurso de Quintus Metellus.

Gell. 1,6,1-2: 1. Multis et eruditis viris audientibus legebatur oratio Metelli Numidici, gravis ac diserti viri, quam in censura dixit ad populum de ducendis uxoribus, cum eum ad matrimonia capessenda hortaretur. 2. In ea oratione ita scriptum fuit: "Si sine uxore esse possemus, Quirites, omnes ea molestia careremus; sed quoniam ita natura tradidit, ut nec cum illis satis commode, nec sine illis ullo modo vivi possit, saluti perpetuae potius quam brevi voluptati consulendum est".

"1. Diante de muitas pessoas cultas lia-se o discurso sobre a conveniência de se casar, que Metelo Numídico, homem respeitável e eloquente, dirigiu ao povo como censor quando o exortava a contrair matrimônio. 2. Assim estava escrito naquele discurso: "Se nós pudéssemos viver sem esposas, Quirites, nós nos absteríamos de todo esse desgosto; mas, porque assim a natureza transmitiu, de não poder viver tranquilamente com elas, nem de modo algum viver sem elas, mais vale colocar em primeiro lugar de suas preocupações a saúde perpétua que um breve prazer". ${ }^{251}$

Quintus Metellus ao observar que o número de viúvas e órfãos recenseados era três vezes maior que aquele de cidadãos romanos, proclamou um discurso ut cogerentur omnes ducere uxores liberorum creandorum causa e encorajava os homens solteiros a se casarem com as viúvas. Augusto, cerca de um século depois, para aconselhar o casamento, proclama este mesmo discurso aos senadores. ${ }^{252}$

Plin. Nat. Hist. 25,7,25.

${ }^{251} \mathrm{Na}$ opinião de P. VocI, Istituzioni di diritto romano cit. (nota 12 supra), p.517, nota 20, Quinto Metello Macedônico utilizou palavras "pouco apropriadas" (poco adate) para exortar os cidadãos a ter filhos, pois apresentou o matrimônio mais como um "mal necessário" do que como algo importante para a reforma dos costumes e para a res publica. Opinião semelhante tem T. SPAGnuolo Vigorita, Casta Domus cit. (nota 26 supra), p.16, pois esta oposição aos males da vida conjugal indica uma verdadeira intolerância (insofferenza) de muitos homens em relação ao matrimônio. K. GALINSKY, Augustan Culture cit. (nota 102 supra), p.131, salienta a tradição misógina presente no período republicano. Vejam-se O.M. PÉTER, Liberorum quaerendorum causa cit. (nota 21 supra), p.325, nota 62; E. RUIZ FERNÁNDEZ, El divorcio en Roma cit. (nota 234 supra), p.27; T. Spagnuolo Vigorita - V. Marotta, La legislazione imperiale cit. (nota 167 supra), pp.86-88; S. RicCOBONO, La politica demografica cit. (nota 103 supra), p.576; A. LÓPEZ PEDREIRA, Limitaciones a la 'libertas nuptialis' cit. (nota 40 supra), p.397; R. ASTOLFI, La Lex Iulia et Papia cit. (nota 15 supra), p.346; Idem, Note per una valutazione storica della 'Lex Iulia et Papia' cit. (nota 36 supra), p.210; B. BIONDI, La legislazione di Augusto cit. (nota 56 supra), p.143; J.A. FIELD JR., The purpose cit. (nota 129 supra), p.405, nota 23; A. BouchÉ-LECLERCQ, Les lois démographiques d'Auguste cit. (nota 36 supra), pp.250-251; J.P. NÉRAUdaU, Auguste - La Brique et le Marbre, Paris, Les Belles Lettres, 1996, pp.191-193; P. GIUNTI, Consors vitae cit. (nota 38 supra), pp.117-118; G. PIERI, L'Histoire du cens cit. (nota 221 supra), pp.166-169; D. GouREVITCH, Se marier pour avoir des enfants cit. (nota 98 supra), p.139; M.B. FuMAGALLI, Spes vitae, in SDHI 49 (1983), pp.353-354.

${ }_{252}$ Segundo Gell. 1,6,1 um censor chamado Quinto Metello Numídico também proclamou um discurso de 
Florus, Epit. Liv. 59: Q. Pompeius Q. Metellus, tunc primum uterque ex plebe facti censores, lustrum condiderunt. Censa sunt civium capita CCCXVIII $<$ milia $>$ DCCCXXIII praeter < pupillos> pupillas et viduas. Q. Metellus censor censuit, ut cogerentur omnes ducere uxores liberorum creandorum causa. Extat oratio eius, quam Augustus Caesar, <cum> de maritandis ordinibus ageret, velut in haec tempora scriptam in senatu recitavit.

“Q.Pompeio e Q. Metelo, ambos naquele momento, pela primeira vez, censores da plebe, realizaram o lustrum. Recensearam 318.823 cidadãos, sem contar os pupilos, as pupilas [meninas] e as viúvas. O censor Q. Metelo decidiu que todos os homens seriam obrigados a se casar para ter filhos. Seu discurso subsistiu e César Augusto, quando propôs a lei sobre o matrimônio das ordens, leu-o ao Senado como se ele tivesse sido escrito para aquela época”.

Este censor demonstrou, pela primeira vez, uma preocupação em realizar reformas que retomassem o respeito aos costumes dos antepassados, corrompidos ao longo do tempo. $^{253}$

Cícero e Valério Máximo declaram que o "modelo" da "felicidade romana" é exatamente este censor, Quintus Caecilius Metellus, possuidor de qualidades que serviriam de padrão para todos os cidadãos romanos: uma alma nobre; uma esposa casta e fecunda; uma brilhante carreira política e sacerdotal (cônsul e áugure) ${ }^{254}$; seus três filhos tiveram-no

ducendis uxoribus. Visto que Numídico foi censor no ano 102 a.C. e Macedônico em 131 a.C., é provável que trata-se do mesmo discurso: os dois nomes são praticamente idênticos. No censo seguinte, de 125 a.C. (Florus, Epit. Liv. 60), registraram-se 394.736 cidadãos. Há um aumento de mais de 76.000 cidadãos romanos, provavelmente decorrente de manumissões, concessões da cidadania romana aos povos vencidos e do estímulo à procriação para fins militares.

${ }^{253}$ Foi exatamente esta a política adotada por Augusto, logo após ser-lhe atribuída a tribunicia postestas e como narra em sua obra Res gestae, 8,5. Vejam-se V. ARANGIO-RUIZ, Storia del diritto romano, 5aed., Napoli, Jovene, 1947, pp.236-237; R. VILLERS, Le mariage envisagé cit. (nota 63 supra), p.296. É difícil avaliar os efeitos e resultados imediatos do discurso de Quinto Metello Macedônico na procriação de cidadãos romanos na República. Verifica-se com G. PIERI, L'Histoire du cens cit. (nota 221 supra), pp.165;168-169, um notável aumento populacional no censo de 115 a.C., que registrou 394.336 cidadãos; no censo de 86 a.C., 463.000 ;e no de 57 a.C., 486.000.

${ }^{254}$ Cic. De finibus 5,27,81-82: 81.(...) Immo vero, inquit, ad beatissime vivendum parum est, ad beate vero satis. Animadverti, inquam, te isto modo paulo ante ponere, et scio ab Antiocho nostro dici solere; sed quid minus probandum quam esse aliquem beatum nec satis beatum? Quod autem satis est, eo quicquid accesserit nimium est; et nemo nimium beatus est; ita nemo beato beatior. 82. Ergo, inquit, tibi Q. Metellus, qui tris filios consules vidit, e quibus unum etiam et censorem et triumphantem, quartum autem praetorem, eosque salvos reliquit et tris filias nuptas, cum ipse consul, censor, augur fuisset et triumphasset, ut sapiens fuerit, nonne beatior quam, ut item sapiens fuerit, qui in potestate hostium vigiliis et inedia necatus est, Regulus? "Perdão! Ele completou, para viver a vida mais feliz, sim, é muito pouco; mas para viver uma vida 
como modelo e tornaram-se magistrados (cônsul, pretor e censor); ele encontrou excelentes maridos para as suas três filhas. ${ }^{255}$

A mãe, considerada modelo para as demais, é simbolizada por Cornélia (filha de Cipião, o Africano) a "Mãe dos Gracos": ela deu à luz doze filhos dentre os quais somente três (Tibério, Caio e Semprônia) atingiram a idade adulta. Cornélia, após a morte do marido, decide permanecer viúva para empregar todas as suas forças na educação de seus filhos e apoiar suas carreiras políticas. ${ }^{256}$

Aos cidadãos que tivessem muitos filhos, no final da República, Júlio César fez algumas concessões, como a Lei Agrária (lex agraria) de 59 a.C. (lex Iulia Campana) que estabeleceu a distribuição do campus Stellatis (planície próxima ao monte Callicula e ao território de Falerne) e do ager Campanus, ambos pertencentes à res publica, a cerca de

[simplesmente] feliz, isto é suficiente. Eu observei, disse, que depois, tu enunciaste alguma coisa de análogo e eu sei que nosso amigo Antíoco tem o costume de ter a mesma linguagem. Porém, não é admissível que alguém seja [às vezes] feliz e suficientemente feliz? Alí onde há suficiência, nada podemos acrescentar, sem que haja excesso. Porém, ninguém é excessivamente feliz. Por isso, não há ninguém que seja mais feliz que o homem feliz. 82. Então, segundo você, ele completou, Quinto Metellus, que viu três de seus filhos cônsules e um dos três censor e triunfador, que viu o quarto pretor, que lhes deixou cheios de vida, e suas três irmãs casadas, após ele mesmo ser cônsul, censor, áugure e triunfador; este Metellus, supondo que ele foi sensato, não foi mais feliz que Régulo, supondo que ele foi igualmente sensato, Régulo, aquele que caiu em poder dos inimigos e morreu vítima da privação de sono e de alimentos?".

${ }^{255}$ Val. Max. 7,1,1: Videamus ergo quot gradibus beneficiorum Q. Metellum a primo originis die ad ultimum usque fati tempus nunquam cessante indulgentia ad summum beatae vitae cumulum perduxerit. Nasci eum in urbe terrarum principe voluit, parentes ei nobilissimos dedit, adiecit animi rarissimas dotes et corporis vires, ut sufficere laboribus posset, uxorem pudicitia et fecunditate conspicuam conciliavit, consulatus decus, imperatoriam potestatem, speciosissimi triumphi praetextum largita est; fecit ut eodem tempore tres filios consulares, unum etiam censorium et triumphalem, quartum praetorium videret, utque tres filias nuptum daret earumque subolem sinu suo exciperet. "Vejamos, pois, a sequência de benefícios que levou Quinto Metellus ao cúmulo da felicidade, sem nunca cansar-se de sua bondade desde o primeiro dia de sua vida até sua última hora. Ela [a felicidade] desejou que ele nascesse na principal cidade do mundo; ela lhe fez proceder de uma família ilustre; às suas vantagens ela acrescenta as mais raras qualidades do espírito e as forças físicas que lhe permitiram suportar os trabalhos; ela lhe concede uma esposa tão notável por sua virtude quanto pela sua fecundidade; ela lhe outorga a honra do consulado, o comando dos exércitos, a glória de um triunfo magnífico; ela lhe proporciona a satisfação de ver ao mesmo tempo três de seus filhos, um dos quais tinha sido honrado com a censura e o triunfo, se tornado personagens consulares e um quarto que exerceu a pretura, de casar três filhas e de apertar em seu peito sua descendência".

${ }^{256}$ Sobre Cornélia e seu casamento, cf. Plut. Tiberius Gracchus 1; Gaius Gracchus 19. Seu papel na educação de seus filhos é elogiado por Quint., Inst. Orat., 1,1,6: In parentibus vero quam plurimum esse eruditionis optaverim. Nec de patribus tantum loquor: nam Gracchorum eloquentiae multum contulisse accepimus Corneliam matrem, cuius doctissimus sermo in posteros quoque est epistulis traditus, et Laelia C. filia reddidisse in loquendo paternam elegantiam dicitur, ut Hortensiae $Q$. filiae oratio apud triumviros habita legitur non tantum in sexus honorem. "Desejei que nos pais houvesse o maior nível possível de erudição. E não me refiro apenas aos pais: de fato, sabemos que uma contribuição significativa à eloquência dos Gracos foi transmitida pela mãe Cornélia, cujo discurso elegantíssimo foi transmitido também às gerações futuras graças às suas cartas. E afirma-se que Lélia, a filha de Caio, fez reviver a elegância paterna no falar; ainda se lê o discurso realizado diante dos triúmviros por Hortênsia, filha de Quinto, e não apenas como uma forma de obséquio ao seu sexo". Ao referir-se à Hortênsia, sobre seu famoso discurso diante de Otaviano, Antônio e Lépido, Quintiliano trata do exemplo e dos valores formadores da educação do cidadão romano presentes em Hortênsia, herdadas de seu pai Q. Hortênsio: segurança, liderança, capacidade de comunicação e de persuasão. Para maiores detalhes e fontes literárias e jurídicas sobre o discurso e a atuação de Hortênsia defendendo a isenção das mulheres de um tributo determinado pelos triúnviros em 43 a.C., vejase E.M. AgATI MADEIRA, Advogadas Romanas Republicanas cit. (nota 162 supra), pp.102-105. 
vinte mil cidadãos com pelo menos três filhos (quibus terni pluresve liberi essent). ${ }^{257}$

Em 46 a.C. Cícero exortou a César, naquela época cônsul e praefectus moribus, a reformar os costumes, a reprimir com leis severas os homens lascivos e a incentivar a procriação, naquela sociedade atingida pela queda demográfica e destruída pelas Guerras Civis. $^{258}$

Cic. Pro Marcello 8,23: Omnia sunt excitanda tibi, C. Caesar, uni quae iacere sentis belli ipsius impetu, quod necesse fuit, perculsa atque prostrata: constituenda iudicia, revocanda fides, comprimendae libidines, propaganda suboles, omnia quae dilapsa iam diffluxerunt severis legibus vincenda sunt.

"Cabe a ti, C. César, somente a ti, reanimar tudo aquilo que tu mesmo advertiu estar destruído e arruinado, como era inevitável, pelo próprio ímpeto da guerra: organizar os juízos, restabelecer a boa fé, reprimir as luxúrias, propagar a prole: tudo aquilo que se dissipou e definhou deve ser contido com leis severas".

No mesmo ano, a res publica ofereceu prêmios às famílias com maior número de filhos e proibiu às mulheres que tivessem menos de quarenta e cinco anos e que fossem solteiras e sem prole, o uso da liteira, de jóias que tivessem pérolas e de vestidos tingidos

\footnotetext{
${ }^{257}$ Suet. Iulius Caesar 20,5: Campum Stellatem maioribus consecratum agrumque Campanum ad subsidia rei publicae vectigalem relictum divisit extra sortem ad vigint milibus civium, quibus terni pluresve liberi essent. "A planície de Stella, consagrada à res publica por nossos ancestrais, e o ager Campanus, que permaneceu submetido ao vectigal, pelas necessidades da res publica, foi por eles dividida, sem sorteio, entre aproximadamente, vinte mil cidadãos, que tivessem três filhos ou mais"; Appian. Bell. Civ. 2,10,35: "[César] secretamente preparou um grande exército de soldados e apresentou ao Senado leis em favor dos pobres, com a intenção de distribuir-lhes o campo [ager Campanus] e de mandar conceder a melhor parte dele (sobretudo aquele ao redor de Cápua, que até agora era concedido em empreitada em proveito às caixas públicas) àqueles que eram pais de três filhos, legando à si por este benefício uma grande multidão de homens: de fato,

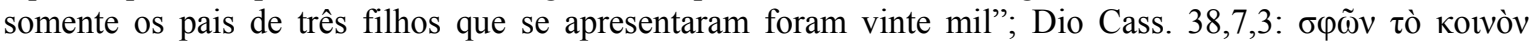

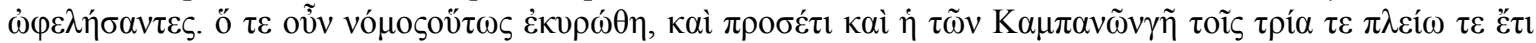

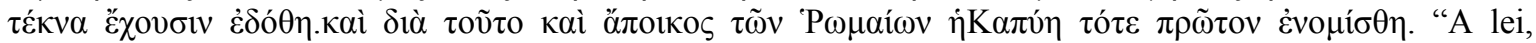
portanto, foi deste modo aprovada e, além disso, a terra dos Campanos foi entregue àqueles que tinham três filhos ou mais. Por isso, então, pela primeira vez, também Cápua foi denominada colônia pelos Romanos." Vejam-se A. LóPez PedreirA, Limitaciones a la 'libertas nuptialis' cit. (nota 40 supra), p.400; T. Spagnuolo Vigorita, Casta Domus cit. (nota 26 supra), pp.57-58; R. Astolfi, La Lex Iulia et Papia cit. (nota 15 supra), pp.346-347; Idem, Note per una valutazione storica della 'Lex Iulia et Papia' cit. (nota 36 supra), p.210; B. BIONDI, La legislazione di Augusto cit. (nota 56 supra), p.143; A. BouCHÉ-LeCLERCQ, Les lois démographiques d'Auguste cit. (nota 36 supra), p.250. Segundo M. ZABŁOCKA, Il 'ius trium liberorum' cit. (nota 103 supra), p.364, nota 18, de acordo com a opinião de A. BOUCHÉ-LECLERCQ, op.cit., p.250, nota 4, a lex Iulia de Agraria de César foi a primeira disposição normativa que exigiu o requisito dos três filhos, prenúncio do ius trium liberorum das Leis matrimoniais de Augusto.

${ }^{258}$ T. SPagnuOlO VIGORITA, Casta Domus cit. (nota 26 supra), p.17; J.A. FiELD JR., The purpose cit. (nota 129 supra), p.400; K. GALINSKY, Augustan Culture cit. (nota 102 supra), p.135; P. JÖRS, Die Ehegesetze des Augustus, Marburg, N.G. Elwert, 1894, p.4, nota 1.
} 
com púrpura, talvez por meio da lex Iulia sumptuaria. ${ }^{259}$

Em 45 a.C., a lex Iulia de provinciis permitiu aos magistrados que tivessem muitos filhos a prioridade de escolherem a província caso fossem nomeados governadores.

$\mathrm{Na}$ passagem do período da República tardia ao novo sistema do Principado (séculos II e I a.C.) observa-se um ideal se manifestar, ideal que permanece estável e que se fundamenta na provável realidade dos "tempos legendários", na vida romana da Realeza e do início da República. ${ }^{260}$

Este ideal familiar é o de um casamento monogâmico estável, graças ao qual o cidadão romano obedece não apenas às regras da Natureza, mas também cumpre, ao mesmo tempo, a disciplina na guerra, o amor à terra, a fecundidade e a estabilidade dos matrimônios, a valorização dos costumes. Em suma, as obrigações fundamentais de um cidadão para com a res publica. ${ }^{261}$

Esta tendência de auxiliar materialmente as famílias com prole numerosa foi mantida por Augusto. Ele adotou a idéia, de Quintus Metellus Macedonicus, que o matrimônio e a procriação não eram questões de caráter privado e familiar, mas de caráter público, social e político. ${ }^{262}$ Esta idéia do matrimônio e da procriação como de utilitas

${ }^{259}$ T. SpagnuOlo VigOrita, Casta Domus cit. (nota 26 supra), p.17; J.A. FiEld JR., The purpose cit. (nota 129 supra), pp.400, nota 10;402, nota 17; 404, nota 22; D. NÖRR, The matrimonial Legislation of Augustus, cit. (nota 54 supra), pp.358;361. Vejam-se, Hor. Carm. 3,6,17-20;33-48;3,24,25-34; Dio Cass. 43,25,2:

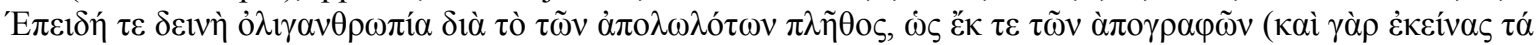

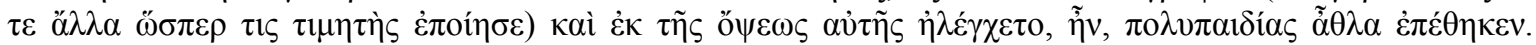
"Uma vez que havia uma terrível escassez de população por causa da grande quantidade de mortos, como era demonstrado tanto pelos censos (e, de fato, ele [César] fez censos e outros atos como se fosse um censor), quanto pela sua própria observação, premiou a grande quantidade de filhos". São Jerônimo (347-420 d.C.) ao narrar os fatos ocorridos em 46 a.C. em sua obra Crônicas (Chronicon) confimou esta proibição da liteira e das pérolas às mulheres sem filhos com mais de quarenta e cinco anos. Hieronymus, Chronicon ad annum 1971 (46 a.C.): Prohibitae lecticis margaritisque uti quae nec viros nec liberos haberent et minores essent annis $X L V$. "Às mulheres que não tivessem nem marido nem filho e tivessem menos de quarenta e cinco anos foi proibido usar liteira e pérolas". Medidas semelhantes contra o luxo das mulheres foram adotadas na República, principalmente por meio de uma lei promulgada em 215 a.C., a denominada Lex Oppia sumptuaria, em razão da profunda crise financeira e política gerada durante a Segunda Guerra Púnica. Vejase E.M. AgAti MADEIRA, A 'Lex Oppia' e a condição jurídica da mulher na Roma republicana, in Revista da Faculdade de Direito de São Bernardo do Campo 12 (2006), pp.161-172.

${ }^{260}$ S. RicCOBONO, La politica demografica cit. (nota 103 supra), p.574.

261 O.M. PÉTER, Liberorum quaerendorum causa cit. (nota 21 supra), p.294; A. RoMANO, Matrimonium iustum cit. (nota 26 supra), p.92.

${ }^{262}$ R. Astolfi, La Lex Iulia et Papia cit. (nota 15 supra), p.352, afirma que as Leis Matrimoniais de Augusto, que influenciaram todas as fontes do Direito no Principado, era conforme alla concezione stoica del matrimonio e della procreazione, considerati dagli esponenti della scuola più attenti alle esigenze ideali del mondo romano doveri pubblici del citadino: la tradizione e l'insegnamento filosofico si avvaloravano a vicenda. Na opinião de T. Spagnuolo Vigorita, Casta Domus cit. (nota 26 supra), p.69, Augusto retoma o discurso de Quinto Metelo Macedônico para salientar que, apesar de alguns aspectos desagradáveis do matrimônio e da filiação, as vantagens são muito maiores. Veja-se o discurso de Augusto em Dio Cass.

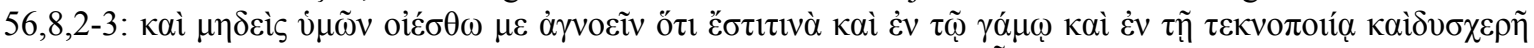

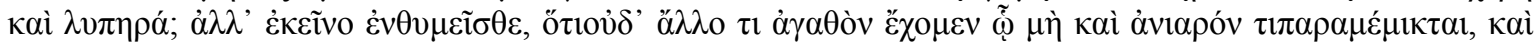

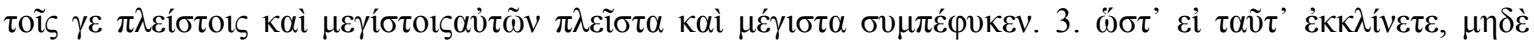

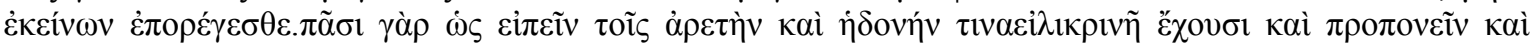


publica ganhará força durante todo o Império. ${ }^{263}$

Nos dias de festa ou no curso de suas viagens, Augusto distribuía dinheiro às famílias numerosas ${ }^{264}$, por meio de bilhetes (tessera), que eram trocados por alimentos (geralmente óleo, pão, sal e vinho) ou dinheiro (congiaria $)^{265}$, prática seguida por Trajano,

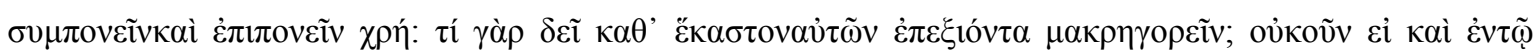

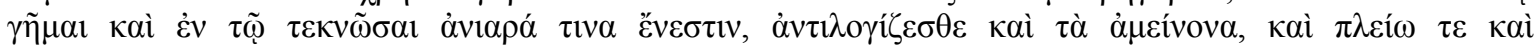

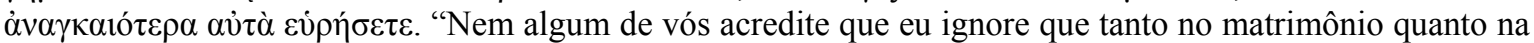
filiação houvesse alguns aspectos desagradáveis e incômodos; mas considerando que não existe nenhum outro bem ao qual não esteja misturado algum incômodo, pelo contrário, em medida mais intensa e maior nos conciliamos com bens mais intensos e maiores. 3. Por isso, nem a estes vós podeis aspirar, se pretendeis afastar-se daqueles. Uma vez que, tudo isto - se poderia dizer - que tem em si alguma virtude genuína ou amável, apenas com esforço poderia ser perseguido, conseguido, conservado. Mas para qual finalidade estender-me, adentrando em cada um destes argumentos? Em suma, quando também o matrimônio e a filiação forem aspectos desagradáveis, avaliareis também os vantajosos, e descobrireis que são mais numerosos e mais impelentes". Veja-se também K. GALINSKY, Augustan Culture cit. (nota 102 supra), pp.131-132.

${ }^{263} \mathrm{Na}$ opinião de G. PUGLIESE, Assistenza all'infanzia nel principato e 'piae causae' del diritto romano cristiano, in Sodalitas - Scritti in onore di Antonio Guarino, vol.7, Napoli, Jovene, 1984, pp.3175-3178, notas 8 e 9, a política demográfica de Augusto previa apenas distribuições públicas esporádicas de alimento e de dinheiro para auxiliar as despesas destas famílias com muitos filhos. Somente no governo de Trajano (98117 d.C.) verificou-se uma mudança no sentido de tornar esse auxílio permanente. De acordo com uma inscrição descoberta em Veleia (no ano de 1747) na Itália foi possível confirmar que Trajano distribuiu um milhão e quarenta e quatro mil sestércios para que vários proprietários de agri vectigales em Veleia, Piacenza, Lucca e Parma, revertessem 5\% dos juros da quantia recebida do imperador para o fornecimento de alimentos às crianças. Segundo esta Tábua Veleiate, a quantia seria utilizada "ut ex indulgentia optimi maximique principis imp. Caes. Nervae Traiani, pueri puellaque alimenta accipiant". Conforme outras informações contidas na Tábua, a quantia de juros total recolhida era de 52.200 sestércios, que foram distribuídos mensalmente da seguinte forma: 16 sestércios para 245 meninos legítimos, 12 para 34 meninas legítimas, 12 para um spurius e 10 para uma spuria. Essa diferença considerável entre o número de meninos e meninas que recebiam o auxílio talvez indique não apenas uma finalidade demográfica ou ética-social nesta política imperial, mas principalmente militar, para aumentar o número de soldados jovens. Para R. ASTOLFI, La Lex Iulia et Papia cit. (nota 15 supra), p.355 e A. BouCHÉ-LeClerCQ, Les lois démographiques d'Auguste cit. (nota 36 supra), pp.254;281, o plano de distribuições de alimentos foi iniciado por Nerva e ampliado por Trajano (instituições alimentares), reforçando o auxílio econômico do "Estado" às famílias pobres mais numerosas. As preocupações de Augusto, segundo A. BOUCHÉ-LECLERCQ, op.cit., p.254, eram muito maiores com a procriação das classes senatorial e equestre (as classes dirigentes) do que com as numerosas famílias dos proletários.

${ }^{264}$ Prática confirmada por Tibério ao fazer o seu elogio fúnebre a Augusto, segundo Dio Cass. 56,41,6: $\pi \tilde{\omega} \varsigma$

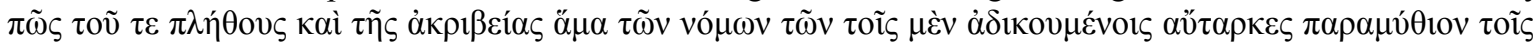

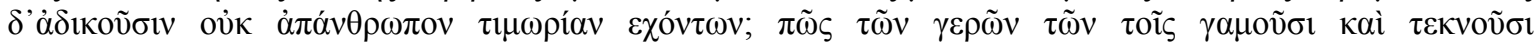
$\pi \rho о \kappa \varepsilon \mu \varepsilon \varepsilon ́ v \omega v$. "Como não recordar a abundância, em conjunto com o cuidado das suas leis, que trazem consolo seguro aos ofendidos, aos culpados um castigo não inumano? Ou os prêmios concedidos àqueles que se casam e geram filhos?".

${ }^{265}$ Cf. Suet. Augustus 41,4-5: Congiaria populo frequenter dedit, sed diversae fere summae: modo quadringenos, modo trecenos, nonnumquam ducenos quinquagenosque nummos; ac ne minores quidem pueros praeteriit, quamvis non nisi ab undecimo aetatis anno accipere consuessent. Frumentum quoque in annonae difficultatibus saepe levissimo, interdum nullo pretio viritim admensus est tesserasque nummarias duplicavit. "Ele frequentemente fazia distribuição de dinheiro ao povo, porém, quase toda vez a quantia variava: ora eram quatrocentos sestércios por cabeça, ora trezentos, às vezes duzentos e cinquenta; ele não excluiu as crianças, mesmo as mais jovens, embora, conforme o costume, fosse preciso ter onze anos para participar. Por isso, geralmente, quando o trigo estava caro, foi distribuído (uma certa quantidade) para cada cidadão por um preço módico, às vezes gratuitamente, e dobrou o valor dos tessera que podiam ser trocados por dinheiro"; 46,2: Ac necubi aut honestorum deficeret copia aut multitudinis suboles, equestrem militiam petentis etiam ex commendatione publica cuiusque oppidi ordinabat, at iis, qui e plebe regiones sibi revisenti filios filiasve approbarent, singula nummorum milia pro singulis dividebat. "Para evitar que faltasse, em todos os sentidos, a honestidade e a descendência das famílias numerosas do povo, ele fez um acordo com as 
Antonino Pio e Marco Aurélio ${ }^{266}$.

classes equestres sobre aquilo que lhes exigia, simplesmente uma recomendação oficial de sua cidade e quando ele visitava as regiões [da Itália], qualquer plebeu que provasse que tinha filhos ou filhas, recebia dele mil sestércios por filho". Não apenas as famílias mais pobres, como também as famílias com prole numerosa das classes senatorial e equestre, recebiam auxílio financeiro de Augusto, segundo Dio Cass.

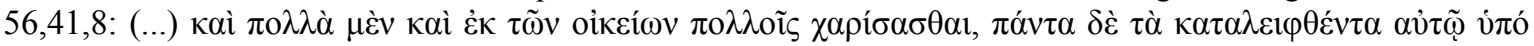

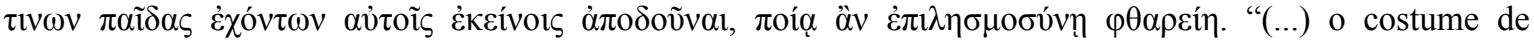
oferecer dádivas a muitos ricos, mesmo com o seu patrimônio particular, ou, quando fosse atribuída a herança para aqueles que tivessem filhos, de restituir tudo a estes últimos: a quem, por acaso, o esquecimento poderia ofuscar tudo isto?".

Tácito em Ann. 2,37-38 narra a história de Hortalus (neto de Hortensius que casou com a esposa de Catão), que foi obrigado pelo divino Augusto, graças a uma doação de um milhão de sestércios, a casar e a ter filhos, para impedir a extinção de família tão ilustre. Este caso também é narrado por Suetônio em Tiberius 47,2-3. Q. Hortalus tinha ancestrais nobres, porém pouco dinheiro. Mesmo nesta situação teve quatro filhos: Paucorum senatorum inopia sustentata, ne pluribus opem ferret, negavit se aliis subventurum, nisi senatui iustas necessitatium causas probassent. Quo pacto plerosque modestia et pudore deterruit, in quibus Hortalum, Quinti Hortensi oratores nepotem, qui permodicare familiari auctore Augusto quattuor liberos tulerat. "Mitigou a miséria de alguns senadores e, para evitar ajudá-los em grande número, declarou que não ajudaria aqueles que não provassem ao Senado a legitimidade de suas necessidades. Assim, a maior parte dos senadores se absteve de pedir auxílio por modéstia e por vergonha: entre estes, Hortalo, neto do orador Quinto Hortênsio, que, com um patrimônio de muito pouca importância, tinha quatro filhos por solicitação de Augusto". Dio Cassio narra em 58,2,3 que Lívia ajudava financeiramente muitos senadores, para que pudessem criar seus filhos e dotar as suas filhas. Por estas liberdalidades ela foi chamada de "mãe da pátria".

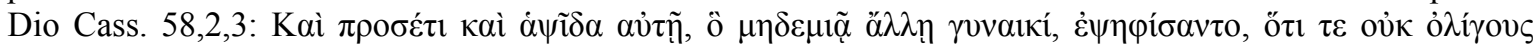

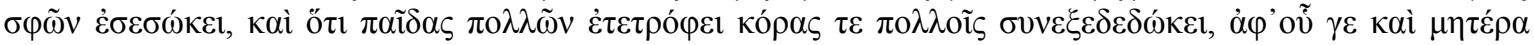

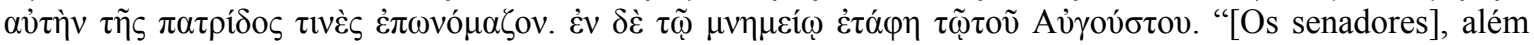
disso, dedicaram um arco em sua honra [Lívia], coisa que não tinha sido concedido a nenhuma outra mulher, seja porque salvou não poucos deles, seja porque, sustentou os filhos de muitos e a muitos ajudou a casar as filhas: virtudes pelas quais alguns a chamavam até de mãe da pátria. Foi sepultada no monumento fúnebre [Mausoleum] de Augusto". Vejam-se T. SPAGnuolo Vigorita, Casta Domus cit. (nota 26 supra), pp.5758;146, nota 199;147-148; B. BIONDI, La legislazione di Augusto cit. (nota 56 supra), p.137.

${ }^{266}$ Plínio, o Jovem em seus "Panegíricos" a Trajano, capítulos 26 a 28, descreve o complemento à legislação matrimonial na época de Trajano, sobre alguns praemia concedidos para o incentivo à procriação e detalha a distribuição de alimentos e de dinheiro (congiarii die). Observa-se na legislação matrimonial o sistema das penas e dos prêmios, conforme Ulp. 1 inst. D.1,1,1,1. Plin. Iun. Paneg. 26,5-6: Locupletes ad tollendos liberos ingentia praemia et pares poenae cohortantur, pauperibus educandi una ratio est bonus princeps. Hic fiducia sui procreatos nisi larga manu fovet, auget, amplecitur, occasum imperii, occasum rei publicae accelerat frustraque proceres plebe neglecta, ut defectum corpore caput nutaturumque instabili pondere, tuetur. "Os ricos são encorajados a gerar filhos pelas recompensas consideráveis e as penas equivalentes; os pobres têm apenas uma razão para educar os filhos, a beneficiência do príncipe. Se de uma mão generosa ele nem protege, nem provêm, nem acolhe do seu procriador aquela confiança, apressa a queda do Império, a queda da res publica; e se isto é em vão, se ele negligencia a plebe, que sustenta os nobres, cabeça com ausência de corpo, fará cair sua situação oscilante e instável"; 27,1: Super omnia est tamen quod talis es ut sub te liberos tollere libeat, expediat. Nemo iam parens filio nisi fragilitatis humanae vices horret, nec inter insanabiles morbos principis ira numeratur. Magnum quidem est educandi incitamentum tollere liberos in spem alimentorum, in spem congiariorum, maius tamen in spem libertatis, in spem securitatis. "Mas o bem que premia todos os outros é que tu sejas aquele em que, sob teu reinado, havia o benefício para gerar filhos. Todos os pais, daqui em diante, não temem mais para os seus filhos as doenças incuráveis da fragilidade humana e nem que seja mais enumerada a cólera do príncipe entre os maus incuráveis. Na verdade, é um grande incentivo para gerar filhos a esperança das distribuições de alimentos, a esperança dos congiaria, mas ainda muito maior a esperança da liberdade, a esperança da segurança"; 28,6-7: Dent tibi, Caesar, aetatem di quam mereris, serventque animum quem dederunt: et quanto maiorem infantium turbam iterum atque iterum iubebis incidi. Augetur enim cotidie et crescit, non quia cariores parentibus liberi, sed quia principi cives. Dabis congiaria, si voles; praestabis alimenta, si voles: illi tamen propter te nascuntur. "Que os deuses, César, te dêem uma vida tão longa que tu a mereças e te conservem os sentimentos que eles te deram; e como se multiplicará esta multidão de crianças que tu farás suceder mais e mais. Ela aumenta cada dia, ela cresce, não porque os pais amem mais os filhos, mas o príncipe mais os cidadãos. Darás os congiaria, se quiseres; as distribuições [de alimento, dinheiro], se quiseres; àqueles, entretanto, [os filhos] que nascem por causa de ti”. 


\subsection{PERÍODO DA UNIDADE CONCEITUAL DAS LEIS}

\section{MATRIMONIAIS DE AUGUSTO}

Passaremos agora a analisar, dentro da periodização proposta, o denominado "período da unidade conceitual" das leis matrimoniais de Augusto. Unidade conceitual, no sentido de que, com Augusto, o incentivo à procriação se tornará um dos elementos principais de sua política e que, na verdade, herda e retoma as finalidades das medidas estudadas nos períodos anteriores.

Ou seja, com a promulgação das Leis Matrimoniais, é nítido o interesse da res publica no aumento da população romana para a garantia de um exército jovem e forte (como no período militar), de um matrimônio legítimito e prolífico (como no período censório) e da reforma dos mores maiorum (como no período da nequitia e dos mali mores).

\section{A REFORMA DE AUGUSTO}

Para restabelecer os fundamentos da res publica e cumprir o seu papel de pater patriae, Augusto deveria resolver alguns problemas decorrentes das inúmeras lutas políticas e guerras civis ${ }^{267}$ no período republicano: a degradação dos costumes, a

Também Dio Cass. 68,5,4, afirma que Trajano realizou a distribuição de grande soma de dinheiro às cidades da Itália para a alimentação dos infantae. Vejam-se G. PUGLIESE, Assistenza all'infanzia nel principato cit. (nota 263 supra), p.3176; D. NöRR, The Matrimonial Legislation of Augustus cit. (nota 54 supra), pp.353;361; A. BouCHÉ-LECLERCQ, Les lois démographiques d'Auguste cit. (nota 36 supra), p.281.

267 O historiador romano Caio Veleio Patérculo narra este início do governo de Augusto e as reformas legislativas que o princeps realizou com o fim das guerras internas e externas. Velleius 2,89,3-4: Finita vicesimo anno bella civilia, sepulta externa, revocata pax, sopitus ubique armorum furor, restituta vis legibus, iudiciis auctoritas, senatui maiestas, imperium magistratuum ad pristinum redactum modum; tantummodo octo praetoribus adlecti duo. Prisca illa et antiqua rei publicae forma revocata, rediit cultus agris, sacris honos, securitas hominibus, certa cuique rerum suarum possessio; leges emendatae utiliter, latae salubriter, senatus sine asperitate nec sine severitate lectus. "Terminadas as guerras civis após vinte anos, sufocados os conflitos externos, restaurada a paz, apaziguada em toda parte a fúria das armas, foi restituída força às leis, autoridade aos julgamentos, majestade ao Senado, o poder dos magistrados foi restabelecido à maneira antiga; somente aos oito pretores foram acrescentados outros dois. A antiga e veneranda ordem da res publica foi restaurada, foi reestabelecido o cultivo aos campos, a honra às coisas sagradas, a segurança aos homens, a cada um foi entregue a posse dos próprios bens; algumas leis foram utilmente reformadas, outras foram propostas em boas condições, a lectio senatus ocorre sem violência, mas não sem severidade". De acordo com T. SPAGnuolo Vigorita, Casta Domus cit. (nota 26 supra), pp.18-19, a reforma dos costumes foi atrelada ao fato do fechamento das portas do Templo de Jano, permitido à Augusto pelo Senado, em três ocasiões: em 11 de janeiro de 29 a.C., em 25 a.C. e provavelmente em 10 a.C. Veja-se Florus, 2,34(4,12,64-65): 64. Sic ubique certa atque continua totius generis humani aut pax fuit aut pactio, aususque tandem Caesar Augustus septingentesimo ab urbe condita anno Ianum geminum cludere, 
decadência do matrimônio, o aumento das práticas abortivas e da exposição de recémnascidos. Era grande o desajuste entre os costumes e as transformações sócio-políticas que o novo Império exigia. ${ }^{268}$

bis ante se clusum sub Numa rege et victa primum Carthagine. 65. Hinc conversus ad pacem pronum in omnia mala et in luxuriam fluens saeculum gravibus severisque legibus multis coercuit, ob haec tot facta ingentia dictator perpetuus et pater patriae. "64. Assim, em todo lugar, a paz e o acordo de todo o gênero humano foram certos e duradouros, e César Augusto, enfim, ousou fechar, setecentos anos após a fundação da cidade, a Porta dupla de Jano, que antes por duas vezes tinha sido fechada, sob o reinado de Numa e após a primeira vitória sobre Cartago. 65. Desde este momento, tendo-se dedicado à paz, corrigiu com numerosas leis graves e severas um século propenso a todos os males e inclinado à luxúria; para estas ações tão numerosas e tão importantes, foi nomeado ditador perpétuo e pai da pátria"; Orosius Hist. 6,22,1-3: 1. Itaque anno ab Urbe condita DCCLII Caesar Augustus ab oriente in occidentem, a septentrione in meridiem ac per totum Oceani circulum cunctis gentibus una pace conpositis, Iani portas tertio ipse tunc clausit. 2. Quas ex eo per duodecim fere annos quietissimo semper obseratas otio ipsa etiam robigo signavit, nec prius umquam nisi sub extrema senectute Augusti pulsatae Atheniensium seditione et Dacorum commotione patuerunt. 3. Clausis igitur Iani portis rempublicam, quam bello quaesiverat, pace enutrire atque amplificare studens leges plurimas statuit, per quas humanum genus libera reverentia disciplinae morem gereret. "E assim, no ano 752 da fundação de Roma [ab Urbe condita], César Augusto, depois de ter unido em uma única paz todos os povos, do oriente ao ocidente, do Norte ao Sul e ao longo de todo o círculo do Oceano, ele mesmo fechou, por três vezes, as portas de Jano; 2. e também a ruína marcou estas portas, sempre fechadas por quase doze anos em uma paz muito tranquila, e antes não foram nunca abertas, senão na velhice extrema de Augusto, impelidas pela revolta dos Atenienses e pela agitação dos Dácios. 3. Uma vez fechadas as portas de Jano, portanto, esforçando-se na paz para nutrir e prosperar a res publica que conquistou com a guerra, estabeleceu muitas leis, por meio das quais o gênero humano aderiu ao costume disciplinado pela livre reverência".

Horácio em 13 a.C., para exaltar a política e a legislação de Augusto, ressaltou em seus poemas os fundamentos do Principado: a organização familiar, a religião, a paz, o prestígio das vitórias do exército e a reforma dos costumes. Hor. Carm. 4,15,1-20;25-32: Phoebus volentem proelia me loqui / victas et urbes increpuit lyra, / ne parva Tyrrhenum per aequor / vela darem. Tua Caesar, aetas / fruges et agris rettulit uberes / et signa nostro restituit Iovi / derepta Parthorum superbis / postibus et vacuum duellis / Ianum Quirini clausit et ordinem / rectum evaganti frena licentiae / iniecit emovitque culpas / et veteres revocavit artis, / per quas Latinum nomen et Italae / crevere vires, famaque et imperi / porrecta maiestas ad ortus / solis ab Hisperio cubili. / Custode rerum Caesare non furor / civilis aut vis exiget otium, / non ira, quae procudit enses / et miseras inimicat urbes (..) Nosque et profestis lucibus et sacris / inter iocosi munera Liberi / cum prole matrimonisque nostris / rite deos prius adprecati / virtute functos more patrum duces / Lydis remixto carmine tibiis / Troiamque et Anchisen et almae / progeniem Veneris canemus. "Febo com a lira incitou-me, desejoso de celebrar as tuas batalhas e as cidades por ti conquistadas, a não estender as minhas pequenas velas pelo mar Tirreno. A tua era, César, restituiu frutos abundantes aos campos, devolveu ao nosso Júpiter as insígnias arrancadas das portes soberbas pelos Partos, fechou o sacelo de Jano Quirino, privado de guerras, colocou os freios à licenciosidade, que transgredia o reto costume, removeu os vícios, revigorou as antigas virtudes, graças aos quais cresceram o nome latino, a potência itálica, a fama e a majestade do império, estendida do leito de Héspero às terras do oriente. Com César protetor das coisas públicas [da res publica] nem o furor civil ou a violência perturbará a tranquilidade, nem a ira que afia a espada e torna inimigas as cidades miseráveis. (...) e nós nos dias não festivos e nos festivos, entre os dons do alegre Líbero, com os vossos filhos e as vossas esposas, tendo antes invocado os deuses, segundo o rito, celebraremos, com o vosso canto unido ao som das flautas lídias, os líderes que cumpriram o seu dever seguindo o exemplo dos pais, depois Tróia e Anquises e dos descendentes da alma de Vênus"; Hor. Epist. 2,1,1-4: Cum tot sustineas et tanta negotia solus, / res Italas armis tuteris, moribus ornes, / legibus emendes, in publica commoda peccem, / si longo sermone morer tua tempora, Caesar. "Visto que sustentas sozinho tantos e tão graves trabalhos, os bens itálicos proteges com as armas, ornas com os costumes, reformas com as leis, cometeria um erro contra o bem público se com um longo discurso, ó César, eu atrasasse o seu tempo".

${ }^{268}$ Sobre a "decadência dos costumes" no final da República, vejam-se A. DAVIAULt, Le 'mos maiorum' cit. (nota 162 supra), p.67; R. LAURENTI, Musonio, maestro di Epitteto cit. (nota 18 supra), p.2138; E. Maldonado De Lizalde, Lex Iulia de Maritandis Ordinibus cit. (nota 122 supra), pp.536;539-540; B. BIONDI, Istituzioni cit. (nota 22 supra), p.440; Idem, La legislazione di Augusto cit. (nota 56 supra), p.129; A. 
Alguns escopos principais estavam incluídos no programa de governo de Augusto para formar uma classe politicamente poderosa, aumentar a quantidade de cidadãos e reformar seus valores morais: a retomada das antigas tradições políticas e sociais, fundamentada nos modelos (exempla) ${ }^{269}$ dos homens de um passado longínquo e glorioso (v.g. Rômulo, Numa Pompílio, Décio, Camilo, os Cipiões); a pacificação das fronteiras; a reconciliação cívica; a transformação (gradual e lenta) dos órgãos políticos da res publica e

LÓPEZ PedReIRA, Limitaciones a la 'libertas nuptialis' cit. (nota 40 supra), p.399; T. SPAGnUOlo Vigorita, Casta Domus cit. (nota 26 supra), p.23. Para K. GALINSKY, Augustan Culture cit. (nota 102 supra), pp.133135 , uma das causas da reforma dos costumes foi o fato de que, grande parte do Senado romano do início do Principado era formado por novi homines, provenientes de outras regiões itálicas. Estes novi homines não entraram choque político, mas ideológico (divergência de costumes) com as classes da nobilitas romana. Além disso, surgiram debates filosóficos sobre a relação entre a conquista de novos territórios e povos e a exigência de que a moral e os bons costumes do povo conquistador fossem superiores aos dos povos conquistados. Ou melhor, procuravam a justificação das conquistas de Roma pela virtus e pela superioridade ética. Contra esta opinião, F. SCHULz, Classical Roman Law cit. (nota 51 supra), p.103, ao afirmar que não foi a degradação dos costumes que provocou a queda numérica da população romana, nem ocasionou a decadência do matrimônio ou a mistura racial ocorrida no momento em que os libertos tornavam-se cidadãos romanos. Para o autor, as verdadeiras causas deste colapso foram principalmente duas: a influência da humanitas no matrimônio e o enfraquecimento da manus (poder marital).

${ }^{269}$ Dio Cássio em várias passagens narra a importância não apenas da retomada dos hábitos dos antepassados, mas ressalta que a família e a procriação eram essenciais tanto ao culto dos deuses familiares (lares) quanto dos deuses do "Estado" romano. O matrimônio e as famílias com prole numerosas estavam de acordo com a vontade destes deuses, pois permitiam a perpetuação da glória romana, conquistada por lutas incessantes dos antepassados. Tanto no âmbito público quanto no privado, verdadeiros homens e verdadeiros

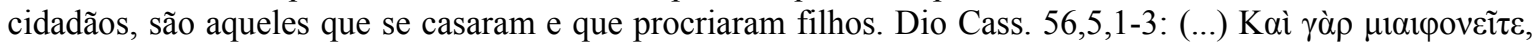

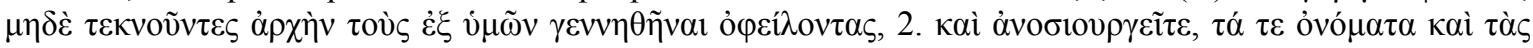

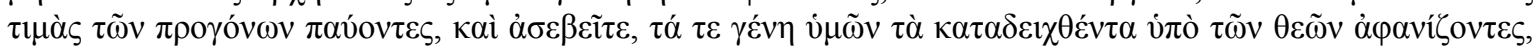

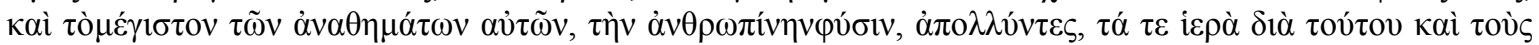

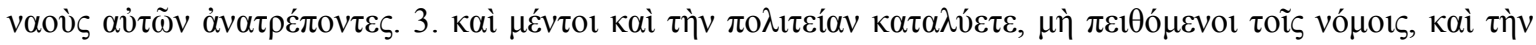

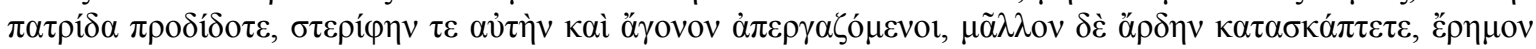

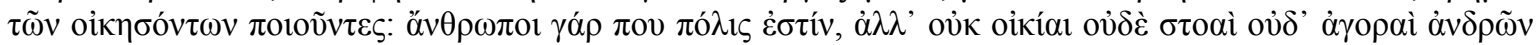

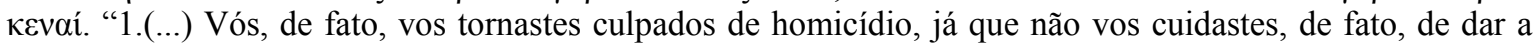
vida àqueles que de vós deveriam ser gerados; 2. cometestes sacrilégio, deixando desaparecer os nomes e as glórias dos antepassados; vos manchastes de impiedade, extinguindo vossas famílias, que foram criadas pelos deuses, destruindo a sua maior oferta, a vida humana, e derrubando, desta forma, os seus cultos e os seus templos. 3. Além disso, dividida também a res publica e não obedecendo as leis, traístes a pátria, tornando-a estéril e sem filhos, antes demoliram-na pelos fundamentos, privando-a dos futuros habitantes: porque a cidade, se não estou errado, é feita de homens, não de casas, de pórticos ou de fóruns vazios de homens";

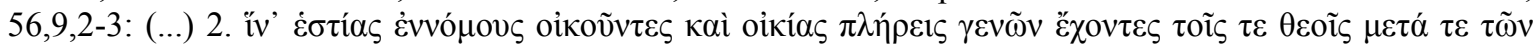

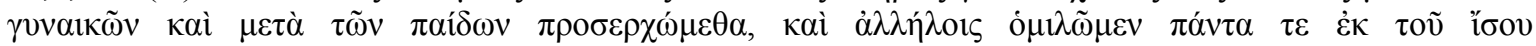

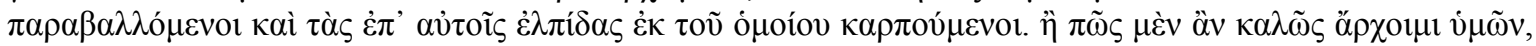

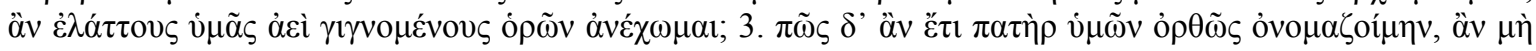

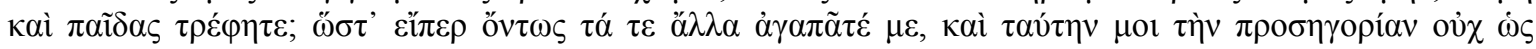

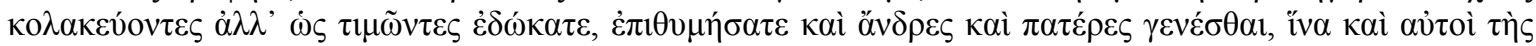

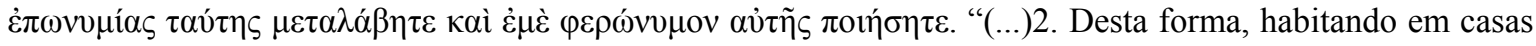
segundo as leis e tendo famílias repletas de descendentes, podemos dirigir-nos aos deuses junto com as nossas esposas e com os nossos filhos, e viver com eles em recíproca familiaridade, partícipes em tudo, em igual medida e da mesma forma prontos para receber as esperanças depositadas nos filhos. Como poderei governar bem se eu permitisse vê-los sempre se tornarem menos numerosos? 3. Como poderia ainda ser chamado justamente vosso pai, se vós não gerastes filhos? E portanto, se vós, de fato, gostais de mim e para honrar-me, não para adular-me, deram-me este título, demonstrais querer tornar-se homens e pais, a fim de que também vós participeis desta denominação e me tornais digno de comandá-la [a cidade]". Vejam-se também Dio Cass. 56,2,3-5;56,3,1-2;56,4,2; 56,7,4-6;56,8,1. Neste sentido, R. AstolfI, Note per una valutazione storica della 'Lex Iulia et Papia' cit. (nota 36 supra), p.194. 
a reforma administrativa e econômica. ${ }^{270}$

Augusto tinha por objetivo que o Senado e o povo romano participassem da reorganização e da reforma de inúmeros institutos jurídicos. ${ }^{271}$

Provavelmente já em 28 a.C., logo após o término das Guerras civis, Augusto elaborou um amplo projeto legislativo, com sanções penais, civis e patrimoniais (sucessão), destinado a aumentar a população ${ }^{272}$ e a proteger a dignidade do matrimônio e

${ }^{270}$ Vejam-se T. SPAGNUOLO VIGORITA, Casta Domus cit. (nota 26 supra), pp.17-19;23;37-38; A. GUARINO,
Storia del diritto romano cit. (nota 103 supra), p.351; A. DAVIAULT, Le 'mos maiorum' cit. (nota 162 supra),
pp.69-70; O.M. PÉTER, Liberorum quaerendorum causa cit. (nota 21 supra), pp.290 e 292; L.F. RADITSA,
Augustus Legislation cit. (nota 49 supra), pp.283-284; S. RICCOBONO, La politica demografica cit. (nota 103
supra), p.575; B. BIONDI, La legislazione di Augusto cit. (nota 56 supra), p.149; A. LÓPEZ PEDREIRA,
Limitaciones a la 'libertas nuptialis' cit. (nota 40 supra), p.399; J.A. FIELD JR., The purpose cit. (nota 129
supra), pp.389-400; D. NÖRR, The matrimonial Legislation of Augustus cit. (nota 54 supra), pp.350-351; R.
AstOLFI, La Lex Iulia et Papia cit. (nota 15 supra), p.347.

Os historiadores do início do Principado, seguindo a política de Augusto, retomam os valores fundamentais dos tempos antigos: a boa fé, a busca pela paz, o sentido da honra, o respeito aos mores maiorum e o mérito pessoal (dignitas). Veja-se Salust. De coniur. cat. 9,1-2: Igitur domi militiaeque boni mores colebantur; concordia maxuma, minima avaritia erat. Ius bonumque apud eos legibus magis quam natura valebat. Iurgia, discordias, simultates cum hostibus exercebant, cives cum civibus de virtude certabant. In supliciis deorum magnifici, domi parci, in amicos fideles erant. Duabos his artibus, audacia in bello, ubi pax evenerat, aequitate, seque remque publicam curabant. "Também, na paz e na guerra cultivavam-se os bons costumes; a concórdia era máxima, e mínima a avareza. O direito e o bem tinham mais força pela Natureza do que pela lei. Litígios, discórdias, inimizades eram exercidas contra os inimigos [estrangeiro]; entre os cidadãos, rivalizavam-se na virtude. Eles eram magníficos nas oferendas aos deuses, econômicos em casa, fiéis com os amigos. Com estas duas qualidades, a audácia na guerra e a equidade, quando a paz acontecia, cuidavam de si e da res publica". Esta política de Augusto foi descrita em suas Res gestae, quando ele efetuou um balanço de suas realizações: a reorganização política do Senado, a nova legislação matrimonial, o fortalecimento dos colégios sacerdotais e das festas religiosas tradicionais, a restauração dos templos e a reafimação do respeito aos mores maiorum. Estas virtudes e qualidades dos antepassados se estendiam não apenas aos cidadãos de Roma, mas a todos os cidadãos romanos da península itálica e das províncias, que teriam, a partir do Principado, a possibilidade de ocupar cargos públicos e políticos de grande importância.

${ }^{271}$ Conforme, H. CuEnCA, Proceso Civil Romano, Buenos Aires, Jurídicas Europa-América, 1957, pp.51-52, a promulgação das Leis Iulia iudiciorum privatorum e publicorum em 17 a.C., constituiu um marco importantíssimo para a História do Processo Civil Romano. Aquela suprimiu as Ações da Lei, permitindo seu uso somente em caso de damnum infectum, para responder aos prejuízos que pudessem ocasionar os edifícios que ameaçavam ruir e nas causas de jurisdição voluntária (graciosa), como na emancipação, adoção, in iure cessio. A Lei Iulia iudiciorum publicorum e as Leis Corneliae no início do Principado, regularam as quaestiones, pelas quais se exteriorizavam os iudicia publica legitima, adequados ao processo dos autores de crimina (portanto, de Direito Penal Público). Vejam-se R. LAURIA TuCCI, Lineamentos do Processo Penal Romano, São Paulo, José Bushatsky, 1976, p.55 e A. D’Ors, Elementos de Derecho Privado Romano, $2^{\mathrm{a} e d .}$., Pamplona, EUNSA, 1975, p.56. Sobre a extraordinaria cognitio, salientam J.R. CRUZ E TUCCI - L.C. AzeVedo, Lições de História do Processo Civil Romano, São Paulo, RT, 2001, pp. 48 e 138: "Além de reorganizar o sistema processual do ordo iudiciorum privatorum, com a promulgação em 17 a.C. da lex Julia Privatorum, Augusto ensejou fosse unificada a instância, ou seja, com a ingerência, em determinadas causas que, em princípio, careciam de tutela jurídica, da cognitio extraordinaria do Princeps ou de seus delegados, o procedimento, até então obrigatoriamente bipartido, passa a desenrolar-se, desde sua instauração, até o final, diante de uma única autoridade estatal (magistrado-funcionário)". Vejam-se P. VocI, Istituzioni di diritto romano cit. (nota 12 supra), p.34; V. ARANGIO-RUIZ, Storia del diritto romano cit. (nota 253 supra), pp.236237.

${ }^{272}$ Um escoliasta de Horácio, provavelmente do sétimo século, ao fazer um comentário do trecho Carmen saeculare 20, atribuiu à Lex Iulia de maritandis ordinibus (lege marita) a tarefa de remediar a perda de muitos jovens nas guerras civis, nas quais teriam morrido cerca de oitenta mil soldados. Pseudo Acron. Expositio in Horatii Carmen saeculare 20: Aut marita dicitur, quae de maritandis ordinibus lata est. Caesar enim post bellum legem tulit, nequis caelebs esset aut vidua, quo posset iuvenum iactura refici, quae bellis 
da família. O projeto serviu para "testar" a opinião pública da época, dividida entre aqueles que defendiam a liberdade dos costumes e outros que acreditavam ser essencial uma reforma. ${ }^{273}$

Com isso, surgiram as primeiras resistências das classes senatorial e equestre em relação à política demográfica de Augusto, após o princeps proclamar o discurso (oratio de prole augenda) de Quinto Metelo Macedônico no Senado Romano. ${ }^{274}$

civilibus contigerat; nam prope octoginta milia perierant armatorum. "É chamada marital [a lei] que foi proposta sobre os matrimônios das ordens. Após a guerra, de fato, César propôs uma lei segundo a qual não deviam mais haver caelibes ou viúvas, a fim de que se pudesse reparar a perda dos jovens que se havia provocado nas guerras civis: foram mortos, de fato, quase oitenta mil soldados". Veja-se T. SPAGNUOLO VIGORITA, Casta Domus cit. (nota 26 supra), p.19.

${ }^{273}$ Uma euforia político-econômica marcou o início do Principado, o que propiciava uma eventual reforma dos costumes. Vejam-se, R. Astolfi, La Lex Iulia et Papia cit. (nota 15 supra), pp.348-349; T. SPAGNuOlo VIGORITA, Casta Domus cit. (nota 26 supra), pp.22-23; P. JÖRS, Die Ehegesetze des Augustus cit. (nota 258 supra), pp.16-17, nota 1.

${ }^{274}$ J.A. FIELD JR., The purpose cit. (nota 129 supra), p.405, nota 25; E. MALDONADO DE LIZALDE, Lex Iulia de Maritandis Ordinibus cit. (nota 122 supra), p.541, nota 26. Para T. SPagnuolo Vigorita, Casta Domus cit. (nota 26 supra), pp.27;32;57, a juventude urbana e itálica, pertencente às classes senatorial e equestre, se opôs fortemente à esta "provável" lei de 28 a.C. e aos deveres políticos e militares. Por outro lado, muitos senadores, de acordo com Hor. Carm. 3,6,17-36;45-48;3,24,17-36 eram favoráveis à promulgação de medidas mais rígidas, principalmente no combate ao adultério. Hor. Carm. 3,6,17-36;45-48: Fecunda culpae saecula nuptias / primum inquinavere et genus et domos: / hoc fonte derivata clades / in patriam populumque fluxit. / Motus doceri gaudet Ionicos / matura virgo et fingitur artibus / iam nunc et incestos amores / de tenero meditatur ungui. / Mox iuniores quaerit adulteros / inter mariti vina, neque eligit, / cui donet inpermissa raptim / gaudia luminibus remotis, / sed iussa coram, non sine conscio / surgit marito, seu vocat institor, / seu navis Hispanae magister, / dedecorum pretiosus emptor. / Non his iuventus orta parentibus / infecit aequor sanguine Punico, / Pyrrhumque et ingentem cecedit / Antiochum Hannibalemque dirum, (...) / Damnosa quid non inminuit dies? / Aetas parentum peior avis tulit / nos nequiores, mox daturos / progeniem vitiosiorem. "Gerações cheias de culpas primeiro corromperam os matrimônios, a estirpe e as casas: a ruína, derivada desta fonte, inundou a pátria e a população. A moça em idade núbil alegra-se ao aprender danças jônicas e se prepara nas artes da sedução e até em tenra idade medita amores incestuosos; e rapidamente procura jovens adúlteros durante os banquetes do marido e não escolhe a quem dar, às escondidas, prazeres ilícitos, às luzes tênues, mas a um sinal levanta-se, diante de todos, com o marido tendo conhecimento, quer chame-a o mercador, quer chame-a o comandante do navio da Hispania, comprador abastado de vergonhas. Não por estes pais nasceu a juventude que manchou o mar de sangue púnico e que matou Pirro, o grande Antíoco e o feroz Aníbal, (...) Mas que coisa a época perniciosa não arruinou? As gerações de nossos pais, pior que aquela dos avós, criou-nos mais dissolutos; nós que daremos vida a uma geração ainda mais corrompida". Em outro trecho, Horácio louva os costumes dos Citas e dos Getas (povos da Ásia na época), pois mesmo estes povos, considerados bárbaros, mantinham os costumes de seus antepassados de maneira mais honrosa que os romanos. Veja-se Hor. Carm. 3,24,17-36: Illic matre carentibus / privignis mulier temperat innocens, / nec dotata regit virum / coniunx, nec nitido fidit adultero; / dos est magna parentium / virtus et metuens alterius viri / certo foedere castitas, / et peccare nefas, aut pretium est mori. / O, quisquis volet impias / caedes et rabiem tollere civicam, / si quaeret pater urbium / subscribi statuis, indomitam audeat / refrenare licentiam, / clarus postgenitis, quatenus, heu nefas, / virtutem incolumem odimus, / sublatam ex oculis quaerimus invidi. / Quid tristes querimoniae, / si non supplicio culpa reciditur, / quid leges sine moribus / vanae proficiunt (...)? "Lá [entre os Citas e os Getas], a mulher irrepreensível cuida dos enteados inocentes; e a mulher não comanda o marido, porque provida de dote, nem se confia a um adúltero sedutor; o dote maior dos pais é a virtude e o pudor de um vínculo estável que rejeita um outro homem; e é contrário às leis da religião cometer um erro ou o seu preço é a morte. Ó, quem quer que seja, desejará estirpar os ímpios estragos e a raiva dos cidadãos, reclamará que seja escrito "pai" nas estátuas a ele dedicadas pelas cidades, ouse colocar freio à licenciosidade indômita e será célebre entre os descendentes , enquanto - ó iniquidade - nós odiamos até a virtude incólume, mas a exigimos, invejosos, quando foi retirada aos nossos olhos. Para que servem tristes queixas, se não se destrói a culpa com o suplício, para que as leis, vãs sem os bons costumes (...)?”. Veja-se, em relação à reforma dos costumes (Sittenbesserung), P. JöRs, Die Ehegesetze des Augustus cit. (nota 258 supra), pp.4-6;11-13, que cita diversos trechos dos Carmina de 
Suet. Augustus 89,5: Etiam libros totos et senatui recitavit et populo notos per edictum saepe fecit, ut orationes $Q$. Metelli 'de prole augenda' et Rutili 'de modo aedificiorum', quo magis persuaderet utramque rem non a se primo animadversam, sed antiquis iam tunc curae fuisse.

"Chegou até a ler livros inteiros ao Senado e outras vezes divulgava-os por meio de um edito, como os discursos de Quinto Metelo Sobre o aumento da prole e os de Rutílio Sobre a maneira de construir. Queria provar deste modo que os dois assuntos interessaram a muitos antes dele, inclusive aos antigos".

Augusto retomou, para a sua propaganda política, o discurso com conselhos e repreensões de Quinto Metello, principalmente em relação a defesa da pátria, exortando os cidadãos a se casarem e a procriar um grande número de filhos. Portanto, observa-se neste caso a preocupação da manutenção de um exército romano forte e jovem. ${ }^{275}$

O princeps, por meio de seus poderes extraordinários, abrandou a severidade de algumas normas diante da oposição social que enfrentou, ao publicar uma lex edicta provavelmente em 28/27 a.C., contentando-se em algumas situações, com medidas de menor alcance. Muitas prescrições minuciosas de sua legislação não tiveram uma boa aceitação na sociedade romana. ${ }^{276}$

Horácio e sua propaganda do regime de Augusto: 4,5,22: Mos et lex maculosum edomuit nefas; 4,25,24: culpam poena premit comes; 4,15,11: emovitque culpas; 4,15,9: ordinem rectum evaganti frena licentiae iniecit.

${ }^{275}$ A. Bouché-LeClercQ, Les lois démographiques d'Auguste cit. (nota 36 supra), p.253; E. MALdonado DE LIZALDE, Lex Iulia de Maritandis Ordinibus cit. (nota 122 supra), p.541.

${ }^{276}$ Vejam-se R. VILLERS, Le mariage envisagé cit. (nota 63 supra), pp.297 e 299; R. AstolFi, La Lex Iulia et Papia cit. (nota 15 supra), p.348, nota 60; J.A. FIELD JR., The purpose cit. (nota 129 supra), pp.401-402; T. Spagnuolo Vigorita, Casta Domus cit. (nota 26 supra), p.27; A. Bouché-LeClerCQ, Les lois démographiques d'Auguste cit. (nota 36 supra), p.253. Desde 28-25 a.C., pode-se perceber a forte resistência ao modelo matrimonial e público proposto por Augusto na obra de Propércio, um jovem rico da classe equestre que narrava o seu desejo de se casar com Cíntia. Porém, Cíntia era liberta e foi manumitida pelas formas pretorianas, que não concediam a cidadania romana, permanecendo como Latina Juniana. Neste caso, não haveria o conubium e consequentemente, as iustae nuptiae. Conforme T. Spagnuolo Vigorita - V. MAROTTA, La legislazione imperiale cit. (nota 167 supra), p.88; Idem, Casta Domus cit. (nota 26 supra), p.7, desde aproximadamente 27 a.C., quando assegurou seu poder, Augusto tinha a intenção de realizar uma reforma radical na ética sexual e matrimonial das classes superiores. Prop. Elegiae 2,7, 1-6: Gavisa est certe sublatam, Cynthia, legem, / qua quodam edicta flesset uterque diu, / ni nos divideret: quamvis diducere amantes / non queat invitos Iuppiter ipse duos. / 'At magnus Caesar': sed magnus in armis; / devictae gentes nil in amore valent. "Tu és verdadeiramente alegre, Cintia, pelo fato que foi atenuada a lei / para cuja futura promulgação deveríamos chorar por muito tempo, / temendo que nos separasse: se bem que dois apaixonados / contra sua vontade nem mesmo Júpiter poderia separá-los / 'Mas César é grande': sim, mas é grande nas armas; / todos os povos vencidos nada valem no amor". Esta situação pode ser considerada como um exemplo de resistência das classes senatorial e equestre em relação à política matrimonial de Augusto, logo 
Augusto adiou o projeto de lei de 28 a.C. e dez anos depois ele promulgou duas leis integradas e coordenadas entre si, a lex Iulia de maritandis ordinibus e a lex Iulia de adulteriis coercendis, que analisaremos com maiores detalhes no Capítulo 4, item 2 do trabalho.

\subsection{O PAPEL DOS COSTUMES E DAS LEIS COMO FONTE DE}

\section{DIREITO NO PRINCIPADO: A “CURA LEGUM ET MORUM”}

\section{DE AUGUSTO}

A cura legum et morum (administração das leis e dos costumes) e a cura et tutela rei publicae universa (organização político administrativa do Império) eram reflexos das mudanças institucionais promovidas por Augusto, detentor da auctoritas principis.

Em 19 a.C., Augusto recebeu do Povo Romano e do Senado a censoria potestas, por cinco anos. ${ }^{277}$ Com este poder, Augusto exerce a mesma função dos censores republicanos na proteção dos costumes e da moralidade pública, além do incentivo à procriação e ao matrimônio dos cidadãos. Por isso investigou a vida particular e puniu

no início do seu governo. Também em outro trecho de Propércio (Prop. Elegiae 2,7,13-14) nota-se a importância da procriação para o aumento do exército romano: Unde mihi patriis gnatos praebere triumphis? / Nullus de nostro sanguine miles erit. "Para que oferecer aos triunfos dos pais, filhos nascidos de mim? / Nenhum soldado nascerá do meu sangue".

Esta lex edicta, depois sublata mencionada por Propércio não se trata, na opinião de T. SPAGNUOLO Vigorita, Casta Domus cit. (nota 26 supra), pp.3-4;9-10;19-22;27, nem de uma lei matrimonial (Lex publica) promulgada e posteriormente retirada pelos protestos das classes senatorial e equestre, nem de uma mero projeto de lei não aceito pelo povo (rogatio), mas de uma lei promulgada por Otaviano antes de 31 a.C. e que exigia aos caelibes e aos orbi o pagamento de um imposto. Esta lei teria sido ab-rogada por um edito em 28 a.C. Na opinião de T. SpagnUOLO VigORITA, op.cit., pp.21, nota 50;23, é pouco provável que o projeto de lei de $28 / 27$ a.C. proibisse as núpcias entre ingênuos e libertas e considera que Cíntia poderia ser uma prostituta e por esta razão estar submetida a um impedimento matrimonial com Propércio. De acordo com E. RUIZ FERNÁNDEZ, El divorcio en Roma cit. (nota 234 supra), p.47, para Propércio, o próprio Augusto, como todos os legisladores da época, estava contrariado com o resultado ínfimo alcançado por esta legislação matrimonial, apesar de todos os esforços.

277 No início do Principado, as antigas magistraturas republicanas são mantidas formalmente, porém, submetidas ao poder do princeps, perdem, gradualmente, sua importância. Vejam-se Dio Cass. 54,2,1; 54,10,5. Neste sentido, F. De MARTINO, Storia della costituzione romana, vol.4.1, Napoli, Jovene, 1974, p.199; L.F. RAdiTSA, Augustus Legislation cit. (nota 49 supra), pp.302-303; T. SPAGNUOLO VigORITA, La data della lex Iulia de Adulteriis, in Iuris Vincula - Studi in onore di Mario Talamanca VIII, Napoli, Jovene, 2001, p.88; T. SPAGNUOlO VigORITA - V. MAROTTA, La legislazione imperiale cit. (nota 167 supra), pp.8688. Contra a opinião de que Augusto recebeu solenemente o título da censoria potestas, G. PIERI, L'Histoire du cens cit. (nota 221 supra), pp.187;195-196. De acordo com o autor, Auguste aurait donc exercé des pouvoirs censoriaux en 29, en 19 et en 12 avant J.-C., sans jamais avoir le titre de 'censor'. 
muitos membros das classes senatorial e equestre que não estivessem de acordo com a sua legislação matrimonial. ${ }^{278}$

Dio Cassio, em 54,10,5-7, narra que Augusto aceitou exercer a cura legum et morum em 19 a.C.

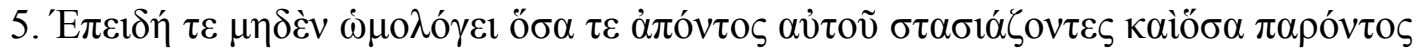


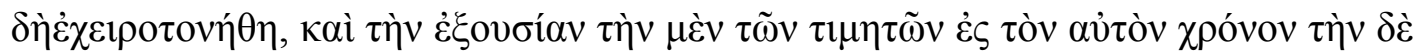

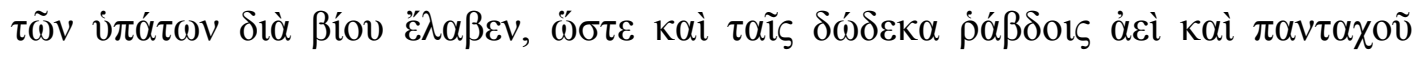

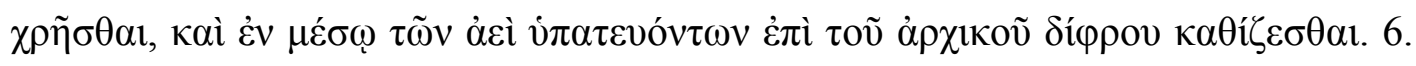

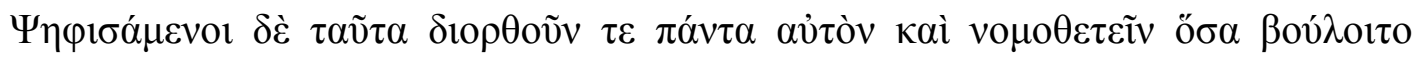

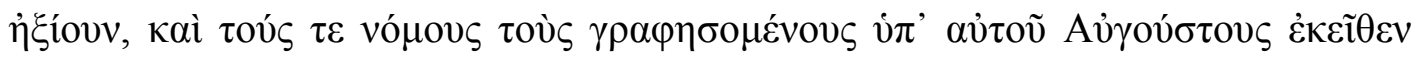

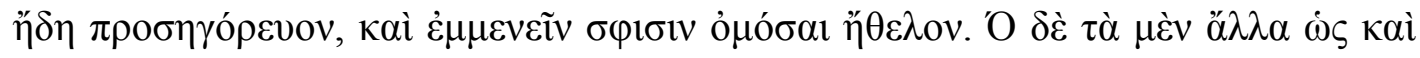

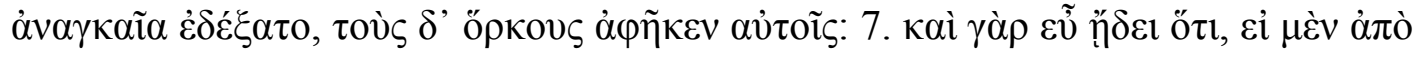

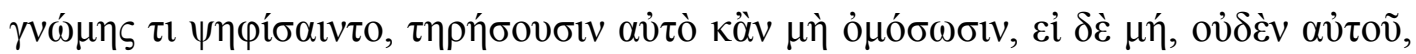

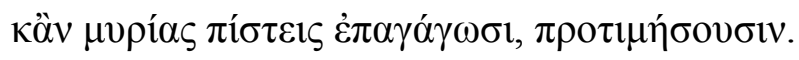

“5. E uma vez que não havia nenhuma coerência entre aquilo que faziam (os senadores) na sua ausência, quando litigavam e aquilo que, atemorizados, faziam quando estava presente, Augusto foi, sob seu convite, eleito curador dos costumes por cinco anos [19 d.C.] e também assumiu o poder de censor ${ }^{279}$ pelo mesmo período, a de cônsul, no entanto, em

278 Veja-se Macr. Sat. 2,4,25: Mira etiam censoris Augusti et laudata patientia. Corripiebatur eques Romanus a principe tamquam minuisset facultates suas. At ille se multiplicasse coram probavit. Mox eidem obiecit quod ad contrahendum matrimonium legibus non paruisset. Ille uxorem sibi tres esse liberos dixit. Tum adiecit: 'posthac, Caesar, cum de honestis hominibus inquiris, honestis mandato'. "Admirável e digna de louvor, foi também a paciência que Augusto demonstrou como censor. Uma vez o príncipe repreendeu um cavaleiro romano por ter reduzido o próprio patrimônio: ele demonstrou publicamente tê-lo multiplicado. Então [Augusto] repreendeu-lhe por não ter observado as leis sobre a obrigação de casar-se: ele disse que tinha esposa e três filhos, e depois acrescentou 'de agora em diante, César, quando investigares seus nobres, encarrega a um nobre [honesto]”. Em 4 d.C., Augusto, ao exercer a sua atividade censória, verificou que muitos jovens das classes senatorial e equestre empobreceram a tal ponto, que não possuíam mais o patrimônio mínimo para pertencerem a estas classes. Então, nesta ocasião, para que estes jovens permanecessem em suas respectivas classes, ele lhes forneceu auxílio financeiro. Conforme Dio Cass.

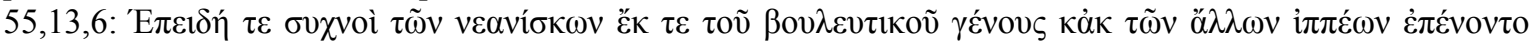

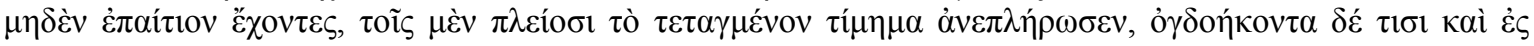

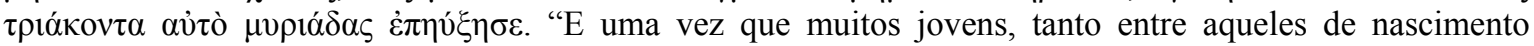
senatorial, quanto entre os outros da classe equestre, estavam na indigência sem ter nenhuma culpa, [Augusto] completou o censo exigido [quatrocentos mil sestércios] à maioria deles, enquanto a cerca de oitenta, acrescentou-lhes até trezentos mil dracmas [um milhão e duzentos mil sestércios]". Vejam-se T. Spagnuolo Vigorita, Casta Domus cit. (nota 26 supra), pp.58;81; A. BouchÉ-LeCLERCQ, Les lois démographiques d'Auguste cit. (nota 36 supra), p.252.

${ }^{279}$ Suetônio confirma esta administração das leis e dos costumes realizada por Augusto, bem como sua tarefa de censor. Suet. Augustus 27,11: Recepti et morum legumque regimen aeque perpetuum, quo iure, 
vida, com a consequência de poder usar também as doze fasces em todo tempo e em todo lugar e poder sentar na cadeira curul entre os dois cônsules no cargo. 6. Após ter tomado estas decisões, julgaram oportuno que reordenasse cada coisa e determinasse com lei tudo aquilo que quisesse; daí em diante denominaram Augustae as leis ditadas por ele e desejavam também comprometer-se com juramento a respeitá-lo. Augusto aceitou como necessárias todas as outras medidas, mas eximiu-os dos juramentos; 7. sabia bem, de fato, que se tivessem tomado uma decisão conforme a sua vontade, a respeitariam mesmo sem prestar juramento; caso contrário, não estariam minimamente protegidos, nem se tivessem feito mil promessas".

Porém, estas curae, na verdade, não são poderes-funções específicos e distintos, mas âmbitos de aplicação de dois poderes fundamentais e vitalícios sobre os quais ele consolidou esse novus status: a tribunicia potestas ${ }^{280}$ (poder tribunício vitalício, direito de

quamquam sine censurae honore, censum tamen populi ter egit, primum ac tertium cum collega, medium solus. "Por isso ele foi encarregado de controlar os costumes e as leis, igualmente à perpetuidade, e, a este título, embora ele não tivesse o cargo de censor, fez três vezes o recenseamento do povo, a primeira e a terceira, com um colega, a segunda sozinho". Esses recenseamentos foram realizados em 28 a.C. (com Agripa), em 8 a.C. e em 14 d.C. (com Tibério). Contra a opinião de Augusto ter assumido esta tarefa de censor, G. PIERI, L'Histoire du cens cit. (nota 221 supra), p.186.

${ }^{280}$ Suet. Augustus 27,10: Tribuniciam potestatem perpetuam recepit, in qua semel atque iterum per singula lustra collegam sibi cooptavit. "Obtém perpetuamente a tribunicia potestas, na qual por duas vezes se associou a um colega para os lustra particulares". Quanto à cura legum et morum, Dio Cássio 54,30,1 narra

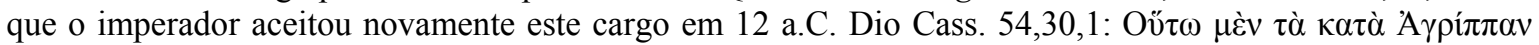

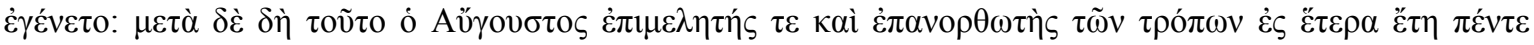

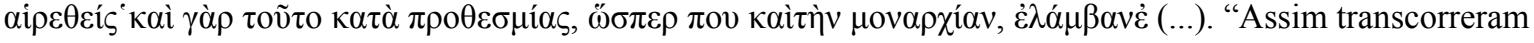
os acontecimentos relativos à morte de Agrippa [12 a.C.]. Em seguida, Augusto, tendo sido eleito curador e restaurador dos costumes por outros cinco anos (também este cargo ele costumava, de fato, assumi-lo por determinados períodos, como fazia nas demais coisas pela monarquia) (...)". Porém, parece que o princeps na verdade recusou a cura legum et morum em três ocasiões, nos anos 19, 18 e 11 a.C. Ao contrário da narração de Dio Cássio, o próprio Augusto confirma que exerceu o controle das leis e dos costumes por meio da tribunicia potestas: Aug. Res gestae 6,1-2: Consulibus M. Vinicio et Q. Lucretio et postea P. Lentulo et Cneo Lentulo et tertium Paullo Fabio Maximo et $Q$. Tuberone senatu populoque Romano consentientibus ut curator legum et morum maxima potestate solus crearer, nullum magistratum contra morem maiorum delatum recepi. Quae tum per me geri senatus voluit, per tribuniciam potestatem perfeci, cuius potestatis collegam et ipse ultro quinquiens a senatu depoposci et accepi. "Sendo cônsules Marco Vinícius e Quinto Lucrécio, e depois Públio Lentulo e Cneo Lentulo e pela terceira vez Paulo Fábio Máximo e Quinto Tuberão, não aceitei magistratura alguma que estivesse contra os costumes dos antepassados, embora o Senado e o Povo Romano concordassem em querer admitir só a mim, com poder enorme, curador [a administração] das leis e dos costumes. E então, estes atos que o Senado desejou fossem por mim realizados, executei-os por força do poder tribunício [tribunicia potestas]; e no exercício desse poder eu mesmo exigi espontaneamente e recebi do Senado um colega, por cinco vezes". De acordo com R. ASTOLFI, La Lex Iulia et Papia cit. (nota 15 supra), p.348, a tribunicia potestas foi o poder que permitiu a Augusto promulgar as leis matrimoniais em 18/17 a.C. Segundo L.F. RADITSA, Augustus Legislation cit. (nota 49 supra), pp.302-303;332, Augusto aceitou este "cargo" de curator legum et morum em 18 a.C. De acordo com C. FAYER, La familia romanaAspetti giuridici ed antiquari. Sponsalia matrimonio dote, vol.2, Roma, L’Erma di Bretschneider, 2005, p.565, Augusto não recusou as funções da cura morum, mas o cargo. Neste sentido, F. DE MARTINO, Storia della costituzione romana cit. (nota 277 supra), pp.201-204. Vejam-se também T. SPAGNUOLO VIGORITA, La data della lex Iulia de Adulteriis cit. (nota 277 supra), p.81; Idem - V. MAROTTA, La legislazione imperiale cit. (nota 167 supra), pp.89-90, Idem, Casta Domus cit. (nota 26 supra), pp.14;29-30;89, nota 15;90; A. 
reunir o Senado, de propor leis, direito de veto e de inviolabilidade) e o imperium proconsulare maius et infinitum (poder ilimitado sobre as províncias e sobre o exército).

O poder imperial também tinha seu fundamento na auctoritas, inicialmente um poder de aspecto moral, metajurídico, de ratificação das decisões jurídicas e políticas. Era um poder de utilitate publica, tendo por escopo os interesses de toda a coletividade dos cives. $^{281}$

Augusto considerava-se o verdadeiro autor de todas as reformas legislativas do período (me auctore) e ao declarar multa exempla maiorum exolescentia, iam nostro saeculo reduxi, demonstra sua intenção de reforma dos costumes ${ }^{282}$ :

BOUCHÉ-LeClerCQ, Les lois démographiques d'Auguste cit. (nota 36 supra), p.244; G. PIERI, L'Histoire du cens cit. (nota 221 supra), pp.194-196.

Em 22 a.C., Augusto recusou o cargo de ditador e o consulado anual e perpétuo que o Senado e o Povo lhe haviam oferecido, pois aceitar estes poderes seria uma atitude contrária à restauração da República. Aug. Res gestae 5,1: Dictaturam et apsenti et praesenti mihi delatam et a populo et a senatu, Marco Marcello et Lucio Arruntio consulibus, non recepi. "Não aceitei a ditadura que, tanto na minha ausência quanto na minha presença, me foi oferecida pelo povo e pelo Senado quando eram cônsules Marco Marcelo e Lúcio Anuncio"; 5,3: Consulatum quoque tum annuum et perpetuum mihi delatum non recepi. "Não aceitei o consulado anual e perpétuo que me foi oferecido".

${ }^{281}$ Veja-se Aug. Res gestae 34,3: Post id tempus auctoritate omnibus praestiti, potestatis autem nihilo amplius habui quam ceteri qui mihi quoque in magistratu colegae fuerunt. "Desde esse momento, superei a todos em auctoritas, porém não tive mais potestas que os demais que foram meus colegas na magistratura". Sobre a auctoritas, vejam-se A. MAGDELAIN, Auctoritas principis, Paris, Les Belles Lettres, 1947, pp.37-56; D.C.A. ShOtTER, Augustus Caesar, London-New York, Routledge-Clays, 1991, pp.32-40; A.V. LimA FiLHO, As constituições imperiais como fonte do Direito Romano, São Paulo, Ícone, 2006, pp.123-124; T. Spagnuolo Vigorita, Casta Domus cit. (nota 26 supra), pp.12;29. Para D.C.A. ShotTer, op.cit., p.29, os poderes da tribunicia potestas eram de grande importância para o governo da res publica exatamente pelo seu forte vínculo com os mores maiorum e por constituir-se como um poder decorrente da auctoritas do princeps. Vejam-se também, G. LONGO, Utilitas publica cit. (nota 44 supra), p.17; L.F. RADITSA, Augustus Legislation cit. (nota 49 supra), pp.303;330; T. SPAGNUOlo VigoRITA, op.cit., p.29. De acordo com M.H. Rocha Pereira, Estudos de História da Cultura Clássica - Cultura Romana, cit. (nota 43 supra), pp.362368 , a palavra auctoritas originou-se do termo augeo (aumentar), bem como as palavras auctor (aquele que aumenta, que está na origem de, que é responsável por), augustus e auxilium. Um escudo votivo encontrado em Arles indica que os fundamentos da auctoritas de Augusto eram a virtus, a iustitia, a clementia e a pietas. A auctoritas foi transmitida à Augusto pelo próprio Senado, pois Cícero afirma, em de rep. 2,33, que a potestas deve residir nos magistrados, a auctoritas no Senado e a libertas no povo: (...) ut et potestatis satis in magistratibus et auctoritatis in principum consilio et libertatis in populo sit (...).

${ }^{282}$ Suet. Augustus 89. Ovídio considera Augusto iustissimus auctor das leis e que ele próprio regia os costumes com os seus exempla. Ovid. Metamoph. 15,832-834: Pace data terris animum ad civilia vertet / iura suum legesque feret iustissimus auctor / exemploque suo mores reget. "Pacificada a terra, voltará o seu pensamento às questões civis; como justíssimo inspirador, proporá leis e com o seu exemplo regerá os costumes". Vejam-se P. Cerami, Il 'Princeps' e la cura 'Legum et morum', in Pietro Cerami, Alessandro Corbino, Antonino Metro, Gianfranco PuRPURA, Ordinamento costituzionale e produzione del diritto in Roma antica - I fondamenti dell'esperienza giuridica occidentale, $2^{\mathrm{a}}$ ed., Napoli, Jovene, 2006, pp.109; 120121; L.F. RADITSA, Augustus Legislation Concerning Marriage cit. (nota 37 supra), pp.304-305; T. Spagnuolo Vigorita, La data della lex Iulia de Adulteriis cit. (nota 277 supra), p.81; Idem, Casta Domus cit. (nota 26 supra), pp.14-15;29; D. NÖRR, The matrimonial Legislation of Augustus cit. (nota 54 supra), pp.351;361-362; A. LóPEZ PEDREIRA, Limitaciones a la 'libertas nuptialis' cit. (nota 40 supra), p.400; A. NicoletTI, Constitutiones principum, in NNDI 4 (1957), p.295; D. DALla, Introduzione a un corso romanistico, $3^{\mathrm{a}}$ ed., Torino, Giappichelli, 1997, p.63; V. CÉSAR DA SILVEIRA, v. Auctoritas e Tribunicia potestas, in Dicionário de Direito Romano, vols.1 e 2 cit. (nota 9 supra), pp.90-91; 707; A. GuARINO, Gli aspetti giuridici del principato, in ANRW II.13 (1980), p.18; M. ZABŁOCKA, Le modifiche introdotte cit. (nota 
Aug. Res gestae 2,8,5: Legibus novis ${ }^{283}$ me auctore latis multa exempla maiorum exolescentia iam ex nostro saeculo reduxi et ipse multarum rerum exempla imitanda posteris tradidi.

"Com novas leis propostas por mim, retomei muitos comportamentos exemplares dos antepassados que, na nossa época, estavam caindo em desuso e eu mesmo transmiti aos pósteros exemplos de muitas coisas a serem imitadas".

Toda esta concentração de poderes delegados ao princeps pelo senatus populusque Romanus, na opinião de A. GUARINO, fez desaparecer, na prática, a República e instaurou uma verdadeira monarquia absoluta. ${ }^{284}$

Mesmo diante deste quadro de concentração de poderes nas mãos do princeps, o importante reordenamento do "direito de família romano" (e de outros campos do direito) foi realizado por meio dos concílios da plebe e dos comícios. O conceito de lex rogata elaborado por Ateio Capitão como generale iussum populi aut plebis rogante magistratu. "A lei é um comando de ordem geral do povo ou da plebe sob a proposta de um magistrado", ilustra de maneira clara esta participação política do Senado e do Populus. ${ }^{285}$

Assim como os mores, a lex estava fundamentada no consenso comum do povo, era o generale iussum populi. A lei surge como um ato bilateral, como o contrato, ajustado

103 supra), p.396; P. JÖRS, Die Ehegesetze des Augustus cit. (nota 258 supra), p.1.

${ }^{283}$ De acordo com K. GALINSKY, Augustan Culture cit. (nota 102 supra), p.129, a expressão leges novae indicava uma verdadeira "reviravolta" e uma profunda mudança nas atitutes, tanto na esfera pública e quanto na privada, em virtude desta nova legislação.

${ }^{284}$ A. GUARINO, Gli aspetti giuridici del principato cit. (nota 282 supra), p.39.

${ }^{285}$ Gell. 10,20,1-3: Quaeri audio quid lex sit, quid plebiscitum, quid rogatio, quid privilegium. Ateius Capito, publici privatique iuris peritissimus, quid lex esset hisce verbis definivit: 'Lex, inquit, est generale iussum populi aut plebis, rogante magistratu'. Ea definitio si probe facta est, neque de imperio Cn. Pompeii neque de reditu M. Ciceronis neque de caede P. Clodii quaestio neque alia id genus populi plebisve iussa leges vocari possunt. "Eu ouço, às vezes, ser questionado o que significa lex, plebiscitum, rogatio, privilegium. Ateio Capitão, grande perito de direito público e privado, definia o termo 'lei' com estas palavras: "A lei é um comando de ordem geral do povo ou da plebe sob a proposta [rogatio] de um magistrado". Se esta definição foi muito bem feita, não podem ser chamadas leges nem o comando relativo aos poderes [extraordinários] de Pompeu, nem ao de reditu de M. Cícero ou ao de caede de P. Clódio, nem outra espécie de ordem do povo ou da plebe". Ateio Capitão eleva a lex publica populi Romani ao parâmetro de fonte primária do direito. A eficácia intrínseca desta fonte (conforme Mod. 1 reg. D.1,3,7: Legis virtus haec est imperare vetare permittere punire. "O mérito da lei é este: mandar, proibir, permitir e punir"), equiparada por Juliano aos costumes, compreendia a manifestação tácita da vontade normativa do povo (Iul. 39 dig. D. $1,3,32,1)$ e posteriormente foi adaptada pelos juristas clássicos à eficácia normativa de outras fontes, principalmente em relação às denominadas contituições imperiais. Vejam-se P. CERAMI, Il 'Princeps' e la cura 'Legum et morum' cit. (nota 282 supra), p.201; V. SCARANO UsSANI, Appunti di storia del diritto romano - Le origini. La monarchia. La repubblica, Torino, Giappichelli, 1996, pp.147-150; B. BIONDI, La legislazione di Augusto cit. (nota 56 supra), p.130. 
entre os cidadãos reunidos nos comícios e o magistrado. No início do Principado, o próprio princeps faz uma proposta (rogatio) e os cives, em pequenas tábuas distribuídas previamente, escreviam se aceitavam (uti rogas, "como pedes") ou negavam (antiquo, rejeito) tal proposta. ${ }^{286}$ Considerando exatamente este aspecto da lei, Papiniano denominaa communis reipublicae sponsio. ${ }^{287}$

Em relação às fontes do direito, a lex Iulia de maritandis ordinibus foi votada pelos concílios da plebe (portanto, formalmente, foi um plebiscito) e a lex Papia Poppaea nuptialis por meio dos comícios centuriatos (comitia). Desde a promulgação da lex Hortensia de plebiscitis em 286 a.C., os plebiscitos, ou seja, as deliberações dos concilia plebis, passaram a ter "força de lei”, válidos para todo o Populus Romanus e denominados como lex. Quando ocorreu a equiparação entre as leis e os plebiscitos, ambos foram compreendidos na categoria das leges publicae (Gai.1,3).

\subsection{AS PRINCIPAIS CARACTERÍSTICAS DAS LEIS}

\section{MATRIMONIAIS DE AUGUSTO}

\subsubsection{ANTECEDENTES HISTÓRICOS}

Após derrotar Marco Antônio em 2 de setembro de 31 a.C., na Batalha de Ácio, Caio Júlio César Otaviano, único sobrevivente do triunvirato, torna-se o detentor do poder, com a tarefa de restaurar a paz, a justiça e os antigos valores e tradições religiosas de Roma. $^{288}$

\footnotetext{
${ }^{286}$ Para F. DE MARTINO, Individualismo e Diritto Romano Privato cit. (nota 30 supra), pp.16-17, os cidadãos, como membros da civitas, corrigem o ius civile pela livre determinação de sua vontade. De acordo com o entendimento de M.V.G. PESSI, Brevi riflessioni sul ruolo della censura cit. (nota 225 supra), p.161, sobre a tensão dialética entre os mores e a lex, os primeiros seriam o elemento de conservação do existente e a segunda, um instrumento de renovação e de modificação. No caso da legislação matrimonial de Augusto, porém, a renovação é exatamente realizada com a retomada dos mores maiorum.

${ }^{287}$ Pap. 1 def. D.1,3,1: Lex est commune praeceptum, virorum prudentium consultum, delictorum quae sponte vel ignorantia contrahuntur coercitio, communis rei publicae sponsio. "A lei é um preceito comum, o ditame dos homens prudentes, a repreensão dos delitos que se cometem voluntariamente ou por ignorância, o compromisso comum de toda a res publica". Segundo R.V. JHERING, Der Geist des römischen Rechts cit. (nota 9 supra), pp.163-164: "A forma primitiva de relação do Estado com o direito privado é, pois, a de um contrato. A comunidade promete a sua proteção e aquele que a pede, submete-se às condições que se lhe impõem. A proteção e o preço pela qual se a dá fundam-se na livre vontade das partes; a relação é, como em todo contrato, o da coordenação. Se o titular do direito não deseja a garantia do povo, este não lhe pode impor restrições: a sua própria vontade limita a esfera do direito particular na ingerência do Estado".

${ }^{288}$ Vejam-se, sobre a transição da República para o Principado, J. IgLeSIAS, Derecho Romano cit. (nota 51 supra), pp.20-22; M.C. GIORDANI, Iniciação ao Direito Romano cit. (nota 193 supra), pp.145-150; D.C.A.
} 
A fundação do Principado está ligada ao estabelecimento em Roma de um novus status rei publicae, ${ }^{289}$ com reformas que trouxeram estabilidade e ordem política.

Suet. Augustus 28,1-4: 1. De reddenda re publica bis cogitavit: primum post oppressum statim Antonium, memor obiectum sibi ab eo saepius, quasi per ipsum staret ne redderetur; ac rursus taedio diuturnae valitudinis, cum etiam, magistratibus ac senatu domum accitis, rationarium imperii tradidit. 2. Sed reputans et se privatum non sine periculo fore et illam plurium arbitrio temere committi, in retinenda perseveravit, dubium eventu meliore an voluntate. 3. Quam voluntatem, cum prae se identidem ferret, quodam etiam edicto his verbis testatus est: "Ita mihi salvam ac sospitem rem publicam sistere in sua sede liceat atque eius rei fructum percipere, quem peto, ut optimi status auctor dicar et moriens ut feram mecum spem, mansura in vestigio suo fundamenta rei publica quae iecero". 4. Fecitque ipse se compotem voti nisus omni modo, ne quem novi status paeniteret.

"Ele pensou, por duas vezes, em restabelecer a res publica: primeiro, logo após ter derrotado Antônio, ao lembrar-se que a este último, muitas vezes acusaram-no que era o único obstáculo ao seu restabelecimento; depois, de novo, no desânimo que lhe lançou uma doença diuturna; estas vezes, ele mesmo fez acompanhar-se dos magistrados e dos senadores, prestando-lhes conta dos negócios do Império. 2. Porém, ao refletir que o retorno à vida privada seria perigosa para ele, e que, por outro lado, ele seria imprudente em restabelecer a res publica nas mãos de muitos, ele manteve o poder, sem que se possa dizer o que foi melhor, o resultado ou a intenção. 3. Esta intenção, insatisfeito de proclamá-la várias vezes, é atestada por ele num edito: 'Queira o céu que a res publica se mantenha sã e salva em seu fundamento e que eu colha os frutos que desejo, de ser denominado como o fundador do ótimo regime e de levar comigo, ao morrer, a esperança de que os fundamentos, que eu lancei, da res publica permaneceram inabaláveis'. 4. Ele mesmo se encarregou de realizar seus votos, fazendo todos os esforços para que ninguém se arrependesse do novo estado de coisas".

ShotTer, Augustus Caesar cit. (nota 281 supra), pp. 24-40; P. BonfAnTE, Storia del diritto romano, $4^{\mathrm{a}} \mathrm{ed}$., vol.1, Milano, Giuffrè, 1958, pp.339-345; A. GUARINO, Storia del diritto romano cit. (nota 103 supra), pp. 347-351; L.F. RADITSA, Augustus Legislation cit. (nota 49 supra), pp.283-284; A. LÓPEZ PEDREIRA, Limitaciones a la 'libertas nuptialis' cit. (nota 40 supra), p.399, nota 43.

${ }^{289}$ Veja-se T. SPagnuolo Vigorita, Casta Domus cit. (nota 26 supra), p.12. 
Em 28 a.C., Otaviano foi inscrito como primeiro na lista dos senadores (princeps senatus). Isto the garantia não apenas exprimir em primeiro lugar a sua opinião nas discussões sobre qualquer assunto que ele considerasse conveniente e oportuno, como também convocar o Senado quando quisesse. Ele tinha o direito de convocar as assembleias populares, iniciar as votações, organizar e até anular as suas deliberações. ${ }^{290}$

Em 13 de janeiro de 27 a.C., Otaviano, diante do Senado, depõe seus poderes extraordinários e declara retornar à condição de simples cidadão romano. O Senado the suplica para que volte atrás nesta resolução e, dias depois, outorga-lhe o título de Imperator Caesar Augustus. ${ }^{291}$

Ainda neste mesmo mês e ano, Otaviano privilegia os senadores casados que tivessem mais filhos ao realizar a divisão do poder nas províncias com o Senado (províncias senatoriais e imperiais), estabelecida pela sortitio, ou seja, um sorteio realizado

\footnotetext{
290 T. Spagnuolo Vigorita, Casta Domus cit. (nota 26 supra), p.29; A. BouchÉ-LeClercQ, Les lois démographiques d'Auguste cit. (nota 36 supra), p.244.

${ }^{291}$ Prevaleceu a proposta de Munácio Planco que sugeria que seu cognome deveria ser "Augusto" e não "Rômulo". Suet. Augustus 7,2: Postea Gai Caesaris et deinde Augusti cognomen assumpsit, alterum testamento maioris avunculi, alterum Munati Planci sententia, cum, quibusdam censentibus Romulum appelari oportere quase et ipsum conditorem urbis, praevaluisset, ut Augustus potius vocaretur, non tantum novo sed etiam ampliore cognomine, quod loca quoque religiosa et in quibus augurato quid consecratur augusta dicantur, ab auctu vel ab avium gestu gustuve, sicut etiam Ennius docet scribens: Augusto augurio postquam inclita condita Roma est. "Em seguida, assumiu o cognome de Gaio César e finalmente o de Augusto, o primeiro em virtude do testamento de seu tio avô materno, o segundo por sugestão de Munácio Planco, pois, na ocasião em que alguns senadores propunham que devia se chamar Rômulo, já que ele também podia ser considerado como fundador de Roma, prevaleceu o critério de que o [cognome] de Augusto seria o mais adequado por ser um cognome novo e mais solene, porque chamam-se augustos ('augustos') aos locais destinados ao culto e nos quais se oferecem sacrifícios aos deuses após tomar-se os augúreos. Esta palavra deriva de 'auctus' [crescimento] assim como na expressão 'avium gestus' ou 'gustus' [movimento ou degustação das aves]. Este é pelo menos o testemunho de Ênio, o qual escreve: 'Depois que a ínclita Roma foi fundada com veneráveis [augustos] augúrios"; Aug. Res Gestae 34,1-2: 1. In consulatu sexto et septimo postquam bella civilia exstinxeram, per consensum universorum potens rerum omnium rem publicam ex mea potestate in senatus populique Romani arbitrium transtuli. 2. Quo pro merito meo senatus consulto Augustus appelatus sum et laureis postes aedium mearum vestiti publice coronaque civica super ianuam meam fixa est, et clupeus aureus in curia Iulia positus, quem mihi senatum populumque Romanum dare virtutis clementiaeque iustitiae et pietatis causa testatum est per eius clupei inscriptionem. "1. Durante meu sexto e sétimo consulados, depois de ter extinguido as guerras civis, eu, que por força do consenso universal dispunha de toda a potestas, transferi a res publica da minha potestas para as mãos do Senado e do povo romano. 2. Por meu mérito fui denominado Augusto com um senatusconsulto, o vestíbulo da minha casa foi ornado com louros por decisão pública, sobre a minha porta foi suspensa a coroa cívica e na Cúria Iulia foi colocado um escudo de ouro que o Senado e o povo romano me concederam por causa do valor, da clemência, da justiça e da piedade, como confirma a inscrição gravada sobre o mesmo escudo". Vejam-se F. SINI, 'Initia Urbis' e sistema giuridico-religioso romano ('ius sacrum' e 'ius publicum' tra terminologia e sistematica), in Roma e America. Diritto romano comune. Rivista di diritto dell'integrazione e unificazione del diritto in Europa e in America Latina 18 (2004), p.207; A. GUARINO, Gli aspetti giuridici del principato cit. (nota 282 supra), p.31; M.H. Rocha Pereira, Estudos de História da Cultura Clássica - Cultura Romana, cit. (nota 43 supra), p.386, nota 171; T. Spagnuolo Vigorita, Casta Domus cit. (nota 26 supra), p.13; A. BouChÉ-LeCLERCQ, Les lois démographiques d'Auguste cit. (nota 36 supra), pp.243-244; E. MALDONADO De LizALDE, Lex Iulia de Maritandis Ordinibus cit. (nota 122 supra), pp.540, nota 17;542, nota 32; F. De MARTINO, Storia della costituzione romana cit. (nota 277 supra), pp.224-227.
} 
para determinar qual província cada proconsul administraria durante um ano. ${ }^{292}$

Em relação às instituições político-administrativas tradicionais da República, a atitude de Augusto foi de prudência, evitando radicais mudanças no início de sua administração. Na verdade, agiu para que tudo permanecesse "formalmente" como na República, para que, depois, tudo mudasse radicalmente. ${ }^{293}$

Em junho de 23 a.C., após descobrir uma conjuração contra sua pessoa organizada por Cipião e Murena, Augusto renuncia ao consulado e recebe, do Senado e dos concilia plebis, a tribunicia potestas e posteriormente, o proconsulado sem as limitações existentes na República e o controle do exército. ${ }^{294}$

Exerceu, em seguida, o proconsulado em toda a extensão do Império Romano e consolidou-se na posição de princeps (primeiro entre todos os cidadãos, donde a denominação "Principado"). ${ }^{295}$

Em 12 a.C. foi eleito pontifex maximus e reorganizou a cidade de Roma em catorze

\footnotetext{
${ }^{292}$ Na opinião de T. Spagnuolo Vigorita, Casta Domus cit. (nota 26 supra), p.23, os senadores casados e com mais filhos não foram totalmente excluídos da sortitio, mas tinham prioridade na escolha da província. Provavelmente este privilégio já estivesse previsto no projeto de lei 28/27 a.C. Veja-se Dio Cass. 53,13,2:

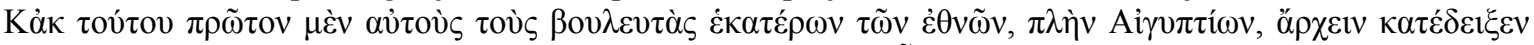

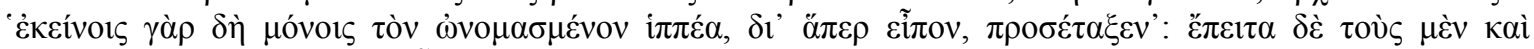

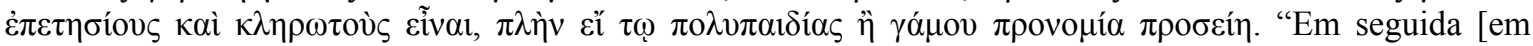
janeiro de 27 a.C., após a divisão das províncias entre Senado e Príncipe], ele [Augusto] para a primeira ação designou os próprios senadores ao governo de ambas as províncias (senatoriais e imperiais) excluídas as Egípcias (apenas para essas, de fato, pelos motivos que disse, nomeou o cavaleiro [Cornellio Gallo] do qual falei); por isso ordenou que alguns [os senadores prepostos das províncias senatorias, os proconsules], durassem um ano no cargo e que fossem escolhidos à sorte, salvo se para algum deles coubesse o privilégio da pluralidade de filhos e do matrimônio". Estes fatos também são confirmados na Chronica de Flávio Magno Aurélio Cassiodoro (485?-580 d.C.). Cass. Chron. 562-563: C.Caesar VI et M. Agrippa III. Caesar leges protulit, iudices ordinavit, provincias disposuit et ideo Augustus cognominatus est. "[Sendo cônsules] C.César [pela sexta vez] e M. Agrippa [pela terceira vez]. César propôs leis, reordenou os juízos, dispôs as províncias e por isto foi denominado Augusto". Nesta mesma época, Augusto estabeleceu que suas funções extraordinárias se limitassem, no tempo, por dez anos. Vejam-se também J.C. MOREIRA ALVES, Direito Romano cit. (nota 9 supra), pp.32-33; P. BONFANTE, Storia del diritto romano cit. (nota 288 supra), p.339; A. GUARINO, Storia del diritto romano cit. (nota 103 supra), pp. 344-348; J.A. FIELD JR., The purpose cit. (nota 129 supra), p.401; A. BOUCHÉ-LECLERCQ, Les lois démographiques d'Auguste cit. (nota 36 supra), pp.254255; E. MALdOnAdo De LizALDE, Lex Iulia de Maritandis Ordinibus cit. (nota 122 supra), p.553.

${ }^{293}$ Veja-se P. Cerami, Il 'Princeps' e la cura 'Legum et morum' cit. (nota 282 supra), p.121. Na obra de Macróbio, Macr. Sat. 2,4,18, Augusto afirma: (...) quisquis praesentem statum civitatis commutari non volet et civis et vir bonus est. "(...) quem não quer mudar a forma de governo vigente é bom cidadão e homem equilibrado".

${ }^{294}$ Augusto já gozava da inviolabilidade tribunícia (sacrosanctitas) desde 36 a.C. e recebeu a tribunicia potestas mesmo sendo patrício e membro da gens Iulia. Veja-se T. Spagnuolo Vigorita, Casta Domus cit. (nota 26 supra), p.29.

${ }^{295}$ Pomp. l.s. enchir. D.1,2,2,11 : Novissime sicut ad pauciores iuris constituendi vias transisse ipsis rebus dictantibus videbatur per partes, evenit, ut necesse esset rei publicae per unum consuli (nam senatus non perinde omnes provincias probe gerere poterat): igitur constitutio principe datum est ei ius, ut quod constituisset, ratum esset. "Por fim, como os meios de constituição do direito tivessem passado a poucos conforme o que os próprios fatos ditaram, ocorreu, por partes, que se fizesse necessário à res publica que ela fosse vigiada por um só (pois o senado não podia de modo absolutamente igual administrar dignamente todas as províncias). Por conseguinte, constituído um príncipe, foi dado a ele o direito, a fim de que o que ele elaborasse fosse confirmado".
} 
regiões e duzentos e sessenta e cinco vici, com o escopo de fazer o censo "de rua em rua", para a aplicação das leis demográficas e para a distribuição de trigo aos cidadãos (frumentum publicum). Nestes vici realizavam-se o culto dos Lares nas encruzilhadas, uma festa denominada Compitalia, que incluía festivais e jogos organizados pelos collegia formados pela plebe urbana, libertos e escravos. ${ }^{296}$

Em 2 a.C. Augusto foi cônsul pela décima terceira vez, inaugurou em primeiro de Agosto (calendis Augustis) o forum Augusti para celebrar as glórias de Roma e recebeu em fevereiro, do Populus e das ordens sentorial e equestre, o titulo de pater patriae, pois o imperador exerce uma espécie de patria potestas sobre todos os cidadãos ${ }^{297}$, a fim de garantir o futuro da civitas a longo prazo. ${ }^{298}$

Após este breve resumo dos primeiros acontecimentos do principado de Augusto, passa-se a analisar, de forma introdutória e brevemente neste capítulo, os escopos da legislação matrimonial de Augusto, visto também pertencerem às primeiras medidas tomadas pelo imperador.

Como já foi salientado, a constituição da família romana tinha uma relação direta com o seu papel de unidade social fundada no matrimônio. O início da educação de um romano era realizado dentro da família, tendo como base os hábitos dos antepassados. Esta unidade familiar foi abalada pelo relaxamento dos costumes observado principalmente após a Segunda Guerra Púnica. ${ }^{299}$

A legislação demográfica e ético-matrimonial de Augusto teve por principais escopos:

(a) facilitar, proteger e estimular o matrimônio;

(b) restaurar os mores maiorum das origens da cidade ${ }^{300}$;

\footnotetext{
${ }^{296}$ K. Galinsky, La ciudad de Roma en la época de Augusto, in Actas del XIII Simposio Nacional de Estudios Clasicos (19-23 setiembre de 1994), vol.1, La Plata, Universidad Nacional de La Plata, 1996, pp.2526; A. Bouché-LeclercQ, Les lois démographiques d'Auguste cit. (nota 36 supra), p.251; G. PIERI, L'Histoire du cens cit. (nota 221 supra), pp.190;193.

${ }^{297}$ Algumas moedas de 19 a.C. já atribuíam o termo parens ao princeps. Vejam-se T. SPAGNUOLO ViGORITA, Casta Domus cit. (nota 26 supra), p.53. L.F. RADITSA, Augustus Legislation cit. (nota 49 supra), p.332; F. DE MARTINO, Storia della costituzione romana cit. (nota 277 supra), pp.227-229. Neste sentido, Hor. Carm. 3,24,25-32.

${ }^{298}$ R. VILLERS, Le mariage envisagé cit. (nota 63 supra), pp.293-294.

${ }^{299}$ Vejam-se R. LAURENTI, Musonio, maestro di Epitteto cit. (nota 18 supra), p.2138; M.H. RoCHA PEREIRA, Estudos de História da Cultura Clássica - Cultura Romana, cit. (nota 43 supra), p.361; E. MALDONADO DE LIZALDE, Lex Iulia de Maritandis Ordinibus cit. (nota 122 supra), p.536; B. BIONDI, Istituzioni cit. (nota 22 supra), p.440; F. Schulz, Classical Roman Law cit. (nota 51 supra), p.103; T. SPAGNuOlo VigoritA, Casta Domus cit. (nota 26 supra), pp.11-12.

${ }^{300}$ A retomada da tradição mítico, religiosa e jurídica dos primórdios de Roma é realçada pelos historiadores e escritores durante a restauração de Augusto. O reino de Saturno (Virg. Aen. 8,314;327), que fundou no antigo Lácio o mos, o cultus, as leges e a pax constitui o ponto de partida da "história romana", que se inicia com o rei Latino e a descendência de Enéias. Augusto, descendente de Enéias dentro desta concepção
} 
(c) estimular a procriação, especialmente dos senadores e da classe equestre ${ }^{301}$, para a glória ${ }^{302}$ e o desenvolvimento político de Roma;

(Troianus Caesar, Virg. Aen. 1,286-290), tinha como objetivo principal estabelecer um novo "século de ouro", semelhante ao antiquíssimo reino de Saturno no Lácio. Vejam-se F. SINI, 'Initia Urbis' cit. (nota 291 supra), pp.221-222; B. Biondi, Istituzioni cit. (nota 22 supra), p.440; T. Spagnuolo Vigorita, Casta Domus cit. (nota 26 supra), pp.37-38; M.H. Rocha PereirA, Estudos de História da Cultura Clássica Cultura Romana, cit. (nota 43 supra), p.361.

No quarto livro de sua obra Elegias, provavelmente em 15 a.C., Propércio, para reforçar a importância da reforma dos costumes, o incentivo à procriação e o orgulho de perpetuar as tradições romanas, narra o exemplo de Cornélia, filha de Cornélio Cipião: elogia seu comportamento e sua reputação no matrimônio, a procriação de três filhos e relembra seus célebres antepassados, orgulhosos de sua conduta. Prop. Eleg. 4,11,33-48;55-70: Mox, ubi iam facibus cessit praetexta maritis, / vinxit et acceptas altera vitta comas, / iungor, Paulle, tuo sic discessura cubili: / in lapide hoc uni nupta fuisse legar. / Testor maiorum cineres tibi, Roma, colendos, I sub quorum titulis, Africa, tunsa iaces, I et Persen proavo stimulantem pectus Achille, I quique tuas proavo fregit Achille domos, / me neque censurae legem mollisse neque ulla / labe mea vestros erubuisse focos. / Non fuit exuviis tantis Cornelia damnum: / quin et erat magnae pars imitanda domus. / Nec mea mutata est aetas, sine crimine tota est: / viximus insignes inter utramque facem. / Mi natura dedit leges a sanguine ductas, / nec $<_{c}>$ possis melior iudicis esse metu(...) / Nec te, dulce caput, mater Scribonia, laesi: / in me mutatum quid nisi fata velis? / Maternis laudor lacrimis urbisque querelis, / defensa et gemitu Caesaris ossa mea. / Ille sua nata dignam vixisse sororem / increpat, et lacrimas vidimus ire deo. / Et tamen emerui generosos vestis honores, / nec mea de sterili facta rapina domo. / Tu, Lepide, et tu, Paulle, meum post fata levamen, / condita sunt vestro lumina nostra sinu. / Vidimus et fratrem sellam geminasse curulem; / consule quo facto tempore rapta soror. I Filia, tu specimen censurae nata paternae, fac teneas unum nos imitata virum. / Et serie fulcite genus: mihi cumba volenti / solvitur aucturis tot mea fata meis. "Bem logo, quando agora a praetexta deu lugar às tochas nupciais e uma segunda fita segurava as minhas cabeleiras presas, unime, Paulo, ao teu leito nupcial, pelo qual, desta forma, agora me destaco: sobre esta lápide leia-se que fui casada com um só. Invoco por testemunhas as cinzas dos meus avós, por ti, Roma, veneranda, sob as glórias das quais tu, África, jaz prostrada, e Perseu, que enchia o seu peito pela descendência de Aquiles, e aquele que viola a tua família, ainda que fosse Aquiles o seu antepassado, que eu não desprezei a disciplina da censura nem por nenhuma mácula minha são envergonhados os vossos lares. Cornélia não provocou descrédito a hábitos tão ricos, era, antes, membro exemplar da grande família. Nem se alterou a minha vida, é toda sem crime: conservei a minha reputação de uma a outra tocha [das núpcias até a morte]. A natureza me deu leis originadas do sangue, nem poderiam ser melhores por medo do juiz (...). Nunca te ofendi, minha doce Escribônia: o que querias mudado em mim, senão o destino? São louvadas pelas tuas lágrimas maternas e pelos lamentos da cidade, os meus ossos também são defendidos pelo gemido de César. Este se lamenta que tenha cessado de viver aquela que foi digna irmã da sua filha, e vemos escorrer lágrimas de um deus. Todavia, mereci a veste que honra a fecundidade [a stola], nem tinha sido retirada de uma casa estéril. Tu, Lépido, e tu, Paulo, meu consolo após a morte, os meus olhos foram fechados sobre os vossos peitos. Eu também vi meu irmão repetir [assumir o cargo por duas vezes] a cadeira curul; na época em que tornou-se cônsul, foi-lhe retirada a irmã. Tu, filha, nascida como modelo da censura paterna, procura ter, imitando-me, um único marido. E com a descendência, mantêm a nossa família: grata por mim, parte na barca [do alémtúmulo], se tão grande número de meus descendentes darão brilho ao meu destino".

${ }^{301}$ Desta forma, o princeps e o Senado procuraram excluir os solteiros e os casados sem prole das classes políticas mais importantes.

${ }^{302}$ A palavra gloria é de etimologia desconhecida, provavelmente originada de gnoria (notícia), de gnosco (conhecer). Para Cícero, o exercício dos cargos públicos, o cursus honorum, é a única fonte da glória romana e esta é a imagem da virtus, de acordo com o interesse da res publica. Cic. Tusc. 3,3: consentiens laus bonorum, incorrupta vox bene iudicantium de excellenti virtute ea virtuti resonat tamquam imago. Outros trechos de Cícero demonstram a estreita relação entre a glória e a res publica e sua característica política e social. Cic. de off. 1,33,121: Optima autem hereditas a patribus traditur liberis omnique patrimonio praestantior gloria virtutis rerumque gestarum. "A melhor herança deixada aos filhos pelos pais, mais útil que o patrimônio, é a glória de sua virtus e dos seus feitos"; Cic. de off. 2,9,31: Summa igitur et perfecta gloria constat ex tribus his: si diligit multitudo, si fidem habet, si cum admiratione quadam honore dignos putat. "Uma glória elevada e perfeita depende de três condições: se a multidão nos quer bem, se tem confiança [fides] em nós e se, com admiração, julga-nos dignos de alguma honra [honor]”. A glória é, sobretudo, o reconhecimento público das qualidades do cidadão, do seu mérito, que atua como estímulo e tem uma função pedagógica para a civitas, conforme Cic. Phil. 1,12,29: Est autem gloria laus recte factorum 
(d) premiar os casais com prole numerosa por meio de inúmeros benefícios sucessórios, fiscais, alimentares e pecuniários, v.g., os congiaria ${ }^{303}$

(e) impor desvantagens e incapacidade aos caelibes e aos orbi. ${ }^{304}$

Em suma, esta política promovida por Augusto, a restitutio reipublicae, desejava promulgar uma reforma em praticamente todos os campos do Direito que proporcionasse estabilidade ao Império, sem realizar profundas transformações, ao menos aparentes, na estrutura dos órgãos políticos republicanos. ${ }^{305}$

A inovação gerada pela legislação matrimonial de Augusto formada pelas leis Iulia de maritandis ordinibus, Papia Poppaea nuptialis (essas duas leis denominadas geralmente nas fontes como lex Iulia et Papia ${ }^{306}$ ) e pela Iulia de adulteriis coercendis, fez

magnorumque in rem publicam meritorum, quae cum optimi cuiusque, tum etiam multitudinis testimonio comprobatur. "A glória é, no entanto, a fama pelos atos bons e grandes serviços para com a res publica, que se comprovam, quer pelo testemunho dos homens notáveis, quer pelo da multidão"; Cic. de leg. Agr. 2,33,91: (...) ubi honos publice non est, ibi gloriae cupiditas esse non potest. “(...)Onde não existe honor publicamente reconhecido, aí não pode haver o desejo de glória”. Vejam-se também Cic. Pro Flaco 13,30; Tusc. 3,2,3. Vejam-se A.A. CASTRo CoRreA, O Estoicismo no Direito Romano cit. (nota 33 supra), p.16; M.H. RoCHA PEREIRA, Estudos de História da Cultura Clássica - Cultura Romana, cit. (nota 43 supra), pp.343-350.

${ }^{303}$ Vejam-se L.F. RADITSA, Augustus Legislation cit. (nota 49 supra), p.301; T. SPAGNUOLO VigORITA, Casta Domus cit. (nota 26 supra), p.10. Desde 22 a.C., após a cidade sofrer com a peste e a fome, Augusto, a pedido do povo, recebeu a cura annonae para cuidar da provisão de cereais da cidade, especialmente de trigo. $\mathrm{O}$ povo acreditou que aquelas catástrofes ocorreram exatamente porque naquele ano Augusto abandonara o consulado. Veja-se Aug. Res gestae 5,2: Non sum deprecatus in summa frumenti penuria curationem annonae, quam ita administravi, ut intra dies paucos metu et periculo praesenti civitatem universam liberarem impensa et cura mea. "Durante a gravíssima falta de trigo não recusei a curae annonae, que exerci de modo a libertar o povo, em poucos dias, com meus cuidados e sacrifícios, do medo ameaçador e do perigo".

${ }_{304}$ B. BIONDI, La legislazione di Augusto cit. (nota 56 supra), p.132.

${ }^{305}$ De acordo com R. Astolfi, La Lex Iulia et Papia cit. (nota 15 supra), p.340, a reforma social de Augusto foi realizada por quatro medidas legislativas principais: a Lex Iulia de maritandis ordinibus, a Lex Iulia de adulteriis coercendis, a Lex Aelia Sentia e a Lex Papia Poppaea. Conclui R. LAURENTI, Musonio, maestro di Epitteto cit. (nota 18 supra), p.2138, ao analisar o diatribe XIV de Musonius Rufus, que reformar a família, principalmente no incentivo à procriação, era o primeiro passo para reformar o Império. Vejam-se B. BIONDI, Istituzioni cit. (nota 22 supra), p.440; J. IGLESIAS, Derecho Romano cit. (nota 51 supra), p.343; V. ARANGIORUIZ, Storia del diritto romano cit. (nota 253 supra), p.236; R. ASTOLFI, La Lex Iulia et Papia cit. (nota 15 supra), pp.325;335-336; L.F. RADITSA, Augustus Legislation cit. (nota 49 supra), pp.285-286; 288; A. JAGU, Musonius Rufus cit. (nota 79 supra), p.18. RADITSA, op.cit., p.290 de sua obra, traça um paralelo entre os Estados Marxistas das décadas de 1970 e 1980 (principalmente a União Soviética) e a política de Augusto ao promulgar a legislação matrimonial, pois, em sua opinião, ambas vinculavam a estrutura social à estrutura familiar. Porém, é importante salientar que estas comparações entre regimes totalitários e o regime de Augusto são totalmente sem sentido e infundadas. De acordo com A. BouchÉ-LECLERCQ, Les lois démographiques d'Auguste cit. (nota 36 supra), p.254, Auguste ne songea pas un instant à résoudre le problème par le procédé cher aux socialistes de tous les temps, par une ingerénce perpétuelle de l'État.

${ }^{306}$ Os romanos designaram o conjunto da legislação demográfica como leges(lex) Iulia et Papia Poppaea, com mais de 70 capita, sem nunca diferenciar o papel respectivo das duas leis, promulgadas entre 18/17 a.C. e 9 d.C. No entanto, é possível em raras passagens do Corpus Iuris Civilis fazer a identificação e a separação para o estudo de algumas normas. Neste sentido, R. VILLERS, Le mariage envisagé cit. (nota 63 supra), p.294; A. BurdeSE, Manuale cit. (nota 47 supra), p.275; V. ARANGIO-RUIZ, Storia del diritto romano cit. (nota 253 supra), pp.236-237; E. VolTERrA, Matrimonio cit. (nota 61 supra), p.768; F. SAMPER, Sobre el destino del 'ius liberorum'cit. (nota 105 supra), pp.7-8; L.R. ARGÜELLO, Manual cit. (nota 12 supra), p.435; G. Pugliese - F. Sitzia - L. VACCA, Istituzioni cit. (nota 63 supra), p.400; C. Ortín GARCÍA, Edad, Matrimonio cit. (nota 103 supra), p.507; M. ZABŁOCKA, Il 'ius trium liberorum' cit. (nota 103 supra), pp.362; 
com que a jurisprudência clássica produzisse diversas obras e comentários a este provável texto unificado, analisando as alterações promovidas principalmente em relação ao ius liberorum, ao dote e aos direitos sucessórios. A natureza das leis, principalmente quanto ao regime caducário e o escopo demográfico, foram os principais motivos para a grande quantidade de interpretações e comentários. ${ }^{307}$

Dentre estas obras de comentários e interpretações dos jurisconsultos Ad legem Iuliam et Papiam, destacam-se a de Gaio (15 livros) ${ }^{308}$, Terêncio Clemente $(20 \text { livros })^{309}$,

Idem, Le modifiche cit. (nota 103 supra), p.380; T. SPAGNUOLO VigORITA, Casta Domus cit. (nota 26 supra), pp.10-11; R. Astolfi, La Lex Iulia et Papia cit. (nota 15 supra), pp.325;335-336; B. BIONDI, La legislazione di Augusto cit. (nota 56 supra), p.130-131; Idem, Istituzioni cit. (nota 22 supra), p.440; J. GAUDEMET, Justum matrimonium cit. (nota 51 supra), p.124; E. MALDONADO DE LIZALDE, Lex Iulia de Maritandis Ordinibus cit. (nota 122 supra), pp.541;544-545.

Para F. Della CORTE, Le 'leges Iuliae' e l'elegia romana cit. (nota 47 supra), p.540: Purtroppo le 'leges Iuliae' ci sono giunte solo in scarsi e dubbi frammenti, attraverso citazioni dei comentari dei giuristi e dei loro trattati monografici sull'argomento, anch'essi del resto frammentari. Neppure è sempre facile distinguere le norme che risalgono alle 'lex Iulia' e quelle che riflettono la 'lex Papia'. Tradução: "Infelizmente, as leges Iuliae chegaram até nós apenas em fragmentos raros e insuficientes, por meio de citações dos comentários dos juristas e de seus tratados monográficos sobre o assunto, também eles, de resto, fragmentados. Nem sempre é fácil distinguir as normas que remontam a lex Iulia e as que refletem a lex Papia". Sustentam D. NöRR, The matrimonial Legislation of Augustus cit. (nota 54 supra), p.351 e E. VOLTERRA, Matrimonio cit. (nota 38 supra), p.769, que é impossível ao estudioso moderno a reconstituição separada da Lex Iulia de Maritandis Ordinibus e da Lex Papia Poppaea. A. LóPEz PeDreIRA, Limitaciones a la 'libertas nuptialis' cit. (nota 40 supra), p.399, nota 43, utiliza o termo moderno "codificação" para ressaltar que a grande maioria dos romanistas estuda as leis matrimoniais de Augusto de forma unitária, como um autêntico "Código Matrimonial”. De acordo com A. BouCHÉ-LECLERCQ, Les lois démographiques d'Auguste cit. (nota 36 supra), pp.268-269, les jurisconsultes citent indifférement, à l'appui d'une même thèse juridique, la loi Julia ou la loi Papia, ou la loi Julia Papia. Pour eux, les deux lois n'en font qu'une, et leur indifférence à l'égard des questions d'origine a rendu le triage des textes à jamais impossible autrement que par voie de présomption. Na opinião de R. AstolfI, Note per una valutazione storica della 'Lex Iulia et Papia' cit. (nota 36 supra), p.196, non è molto agevole distinguere quanto del programma di Augusto è stato realizzato mediante la 'lex Iulia de maritandis ordinibus' e quanto mediante la 'lex Papia Poppaea nuptialis: le notizie sono scarse e talvolta le fonti contraditorie.

${ }^{307}$ V. Arangio-RuIZ, Storia del diritto romano cit. (nota 253 supra), p.273; T. SpagnuOlo Vigorita, Casta Domus cit. (nota 26 supra), p.10; R. Astolfi, Note per una valutazione storica della 'Lex Iulia et Papia' cit. (nota 36 supra), p.221.

308 C. FERrini fez um importante estudo, baseado na Palingenesia iuris civilis de Otto LENEL, sobre os comentários da jurisprudência ad Legem Iuliam et Papiam e procurou reconstituir o conteúdo temático de cada capítulo deste livro. Segundo C. FERrINI, I commentari di Terenzio Clemente e di Gaio 'ad legem Iuliam et Papiam', in Opere di Contardo Ferrini, vol.2, Milano, Ulrico Hoepli, 1929, pp.261-268, a obra do jurisconsulto Gaio apresenta a seguinte subdivisão (apresentam-se aqui os assuntos mais importantes tratados em cada capítulo. Esta divisão, de modo algum, indica o título dos capítulos): capítulo I - sponsalia; II e III celibato e caducorum vindicatio; IV e V - disposições mortis causa; VI - apresenta um único fragmento, Gai. 6 ad l. Iul. et Pap. D.50,15,7, que estabelece aos cidadãos das cidades de Berito, Troas e Dirráquio o Ius Italicum; VII - nenhum fragmento chegou até nós; VIII - Condição especial da liberta casada com patrono, sucessão dos patronos; IX - um único fragmento Gai. 9 ad l. Iul. et Pap. D.50,16,150; X - Gai. 10 ad l. Iul et Pap. D.50,16,152; XI - comentou a Lex Papia (bona caduca); XII - capacitas; XIII - substituição de herdeiro constituído por uma condição; XIV - direito sucessório: caducidade e legados; XV - fideicomissos tácitos; pessoas interpostas in fraudem iuris (Gai. 15 ad l. Iul. et Pap. D.34,9,10) e provavelmente, outros assuntos tratados pela lex Papia, com a delação.

309 De acordo com C. FERrini, I commentari cit. (nota 308 supra), pp.251-261, na obra de Terêncio Clemente, oito capítulos comentavam a Lex Iulia e doze a Lex Papia e poucos fragmentos desta obra chegaram até nós. O livro apresenta uma exposição ampla e minuciosa das Leis matrimoniais, destinada principalmente à prática. Terêncio segue as conclusões de Juliano, citado com frequência em sua obra. 
Ulpiano (20 livros) $)^{310}$, Paulo (10 livros) $)^{311}$, Mauriciano (6 livros) e Marcelo (6 livros). Comentários também foram realizados nos Digesta de Alfeno, Celso, Juliano, Marcelo e Scaevola; nas Quaestiones (Papiniano, Africano, S.Scevola, Tertuliano, Paulo e Calístrato), nos Responsa (Papiniano, Marcelo, S.Scaevola, Ulpiano, Paulo e Modestino), nas Disputationes (Paulo e Ulpiano), nas Institutas (Marciano, Florentino, Ulpiano, Paulo e Calístrato) e na obra De Iure fisci de Calístrato. ${ }^{312}$

\subsubsection{LEX IULIA DE MARITANDIS ORDINIBUS E LEX PAPIA POPPAEA}

\section{NUPTIALIS}

Neste contexto analisado no capítulo anterior, a ampla liberdade individual e espontaneidade que caracterizaram a formação do matrimônio na República, estabelecidos principalmente nos costumes, sofreram uma intervenção e controle maior do poder público por uma série de Leis matrimoniais promulgadas pelo imperador Augusto. ${ }^{313}$

\footnotetext{
${ }^{310}$ Nas palavras de C. FERRINI, I commentari di Ulpiano e di Paolo 'ad legem Iuliam et Papiam', in Opere di Contardo Ferrini, vol.2, Milano, Ulrico Hoepli, 1929, pp.242-249, o ordenamento desta obra era o seguinte: Lex Iulia (livros de I a IX); Lex Papia (livros X a XVIII) e nos dois últimos capítulos (XIX-XX), Ulpiano comenta as normas de direito público estabelecidas pela Lex Iulia.

311 Segundo C. FerRINI, I commentari di Ulpiano e di Paolo cit. (nota 310 supra), pp. 237-242, o jurisconsulto Paulo comentou a Lex Iulia de maritandis ordinibus nos primeiros cinco capítulos (princípios gerais e impedimentos matrimoniais; direitos sucessórios; capacitas e adoção; donatio mortis causa e fideicomisso) e a Lex Papia Poppaea nos últimos cinco (legados pro non scriptis e capacitas; direito das sucessões e a vindicatio caducorum; bona caduca; comentários à Lex Aelia Sentia; ius anulorum; o autor supõe que o título X era intitulado de concubinis). Portanto, FERRINI defendia que a Legislação Matrimonial dispôs diretamente sobre o concubinato.

312 E. VOLTERRA, Famiglia cit. (nota 27 supra), pp.723-724; Idem, Matrimonio cit. (nota 61 supra), pp.741743; T. Spagnuolo Vigorita, Casta Domus cit. (nota 26 supra), p.10; R. Astolfi, La Lex Iulia et Papia cit. (nota 15 supra), pp.121-123;359; Idem, Note per una valutazione storica della 'Lex Iulia et Papia' cit. (nota 36 supra), p.221; M. ZABŁOCKA, Le modifiche cit. (nota 103 supra), p.380. Informa R. BESNIER, L'application des lois caducaires cit. (nota 10 supra), pp.98-99, nota 2, que são aproximadamente 292 fragmentos do Digesto que fazem referência direta às Leis caducárias. Na Palingenésia de Otto Lenel são 190 fragmentos, 4 fragmentos de Mauriciano, 37 de Terêncio Clemente, 28 de Gaio, 6 de Marcelo, 48 de Paulo e 67 de Ulpiano.

${ }^{313}$ G. SCIASCIA, A lei romana sobre os Adultérios, in Varietà Giuridiche, Milano, Giuffrè, 1956, p.29. Conforme A. Guarino, Storia del diritto romano cit. (nota 103 supra), p.450; T. Spagnuolo Vigorita, La data della lex Iulia de Adulteriis cit. (nota 277 supra), p.94, nota 47; Idem, Casta Domus cit. (nota 12 supra), pp.71-74; A. LóPEZ PeDreIRA, Limitaciones a la 'libertas nuptialis' cit. (nota 40 supra), p.401; J.A. FIELD JR., The purpose cit. (nota 129 supra), pp.403;407; R. Astolfi, La Lex Iulia et Papia cit. (nota 15 supra), pp.349-350, conjectura-se que em 28-27 a.C. Augusto tenha promulgado uma medida antecipatória (talvez uma lei, lex edicta) para combater a queda na quantidade de matrimônios e de nascimentos e é provável que uma lei (talvez denominada Lex Iulia caducaria), por volta de 4 d.C., tenha precedido a Lex Papia Poppaea para estimular os cidadãos a se casarem.
}

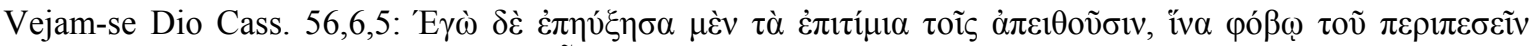

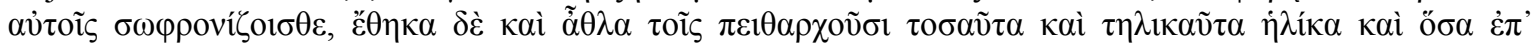

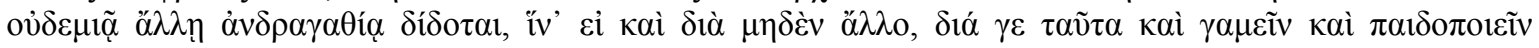
$\dot{\alpha} v \alpha \pi \varepsilon i ́ \theta o ı \sigma \theta \varepsilon$. "Eu, depois, aumentei as penas para os desobedientes, a fim de que o temor de nelas incindir, induza-lhes a se corrigirem; e a quem observa as leis ofereci tais e tantos prêmios, quanto nunca foram concedidos a nenhum outro comportamento virtuoso, de modo que em consideração a eles, salvo por alguma 
A legislação matrimonial (demográfica ou caducária) de Augusto teve duas fases principais: a promulgação da lex Iulia de maritandis ordinibus (17 a.C.) $)^{314}$ e da lex Iulia de

outra razão, a eles persuadi a casar-se e a gerar filhos". Para a Lex Papia Poppaea Augusto concedeu o prazo de um ano de vacatio legis para que principalmente as classes senatorial e equestre pudessem adaptar-se à nova lei. Deve tratar-se de um "Projeto" publicado por Augusto para avaliar a reação da sociedade e aplicar gradualmente estas mudanças. Porém, este "Projeto" foi duramente criticado pela classe equestre. O rigor desta "lei anônima" levou Augusto a suspender a sua aplicação por duas vezes, primeiro por três anos, depois por outros dois.

${ }^{314}$ Informam T. SpagnUOLO VigoritA, La data della lex Iulia de Adulteriis cit. (nota 277 supra), p.81; Idem, Casta Domus cit. (nota 26 supra), pp.31;72 e R. Astolfi, La Lex Iulia et Papia cit. (nota 15 supra), pp.319320;349, a data precisa desta lei em 23 de maio de 17 a.C. Esta data foi confirmada por um senatusconsultum I de ludis saecularibus (Acta ludorum saecularium) e que determinava a suspensão temporária (durante a realização dos jogos seculares) da proibição em relação aos caelibes assistirem os espetáculos públicos. Vejase CIL VI, 32323, linhas 50-57: a.d. X k. Iun. In saepis [Iulis...scribendo adfuerunt] / Quod C. Silanus $[\operatorname{co}(n) s(u l) v($ erba) f(ecit) ludos saecularis post complur[es annos eo qui nunc est facientibus imp(eratore) Caesare...] / August(o) et M. A[grip]pa tribunic(ia) potestate futuros, quos [quod spectare quam plurimos convenit...] / propter rel[igione]m atqu[e] etiam quod tali spectaculo [nemo iterum intererit, permittendo videri...lu] // dorum eo[ru]m [diebu]s qui nondum sunt maritati sin[e fraude sua ut adsint, q(uid) $d(e) e(a)$ $r(e) f($ ieri) $p$ (laceret), $d(e) e(a) r(e) i($ ta $) c$ (ensuerunt), ludi ei] / religio [nis] causa sun[t in] stituti, neque ultra quam semel ulli mo[rtalium eos spectare licet,...ludos] / quos $[$ m] ag(istri) XV vir(orum) s(acris) f(aciundis) [ed]ent s(ine) $f($ raude) $s($ ua $)$ spectare liceat ieis qui lege de marita[ndis ordinibus tenentur...]. "No décimo dia antes das calendas de junho [23 de maio de 17 a.C.] in saepis [...] auxiliaram à redação escrita Emílio Lépido, Lúcio Cestio, Lúcio Petrônio Rufo [...]. Moção oral apresentada pelo cônsul Caio Silano: após muitos anos, naquele atualmente corrente, sob iniciativa do imperador César [...] Augusto e de Marco Agripa, titular do poder tribunício, realizaram-se os jogos seculares; uma vez que é oportuno que a eles auxiliassem o quanto mais possível de pessoas [...] em homenagem à religião e uma vez que, além disso, a este espetáculo ninguém participará uma segunda vez, parece justo permitir [...] que nos dias dos jogos, aqueles que ainda não estão casados estejam presentes sem seu prejuízo. Interrogados sobre o que queriam fazer a este propósito, [os senadores] assim deliberaram: uma vez que os jogos tenham sido instituídos em homenagem à religião e a nenhum mortal é possível assistí-lo mais de uma vez, [...] aos jogos que serão marcados pelos magistri quidecemviri para os sacrifícios, possam assistir aqueles que estão sujeitos à observância da lex Iulia

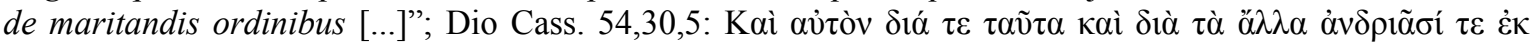

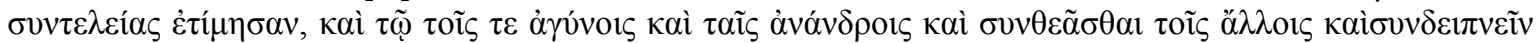

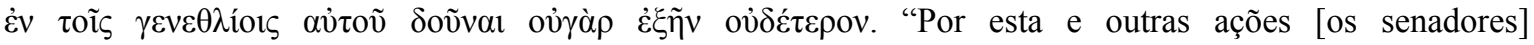
homenageavam-lhe com estátuas erguidas com uma subscrição e também concediam aos solteiros e aos núbeis tanto assistir aos espetáculos quanto participar nos banquetes junto com todos os outros nos seus dias genetlíacos: nenhuma das duas coisas era, de fato, permitida".

Afirma T. Spagnuolo Vigorita, La data della lex Iulia de Adulteriis cit. (nota 277 supra), pp.89-90, que a Lex Iulia de maritandis ordinibus foi anterior à Lex Iulia de adulteriis, fundamentando-se num texto dos Carmen Saeculare de Horácio, escritos pelo poeta para os jogos solenes (ludi saeculares) que ocorreram em meados de 17 a.C. em comemoração a uma nova época de paz e virtude. Os versos faziam menção apenas à Lex Iulia de maritandis ordinibus, o que indicaria que a Lex Iulia de adulteriis não seria de 18 a.C. Horácio denominou a Lex Iulia de maritandis ordinibus como "lei marital fecunda de nova prole" e clama à deusa Ilithyia, divindade protetora das parturientes, que proteja as mães e aumente a descendência. O poeta faz menção aos senadores romanos (patrum), o que indica seu papel importante na aprovação das leis e da promulgação dos decreta patrum (decreta super iugandis feminis) no início do Principado. Estes "decretos sobre o matrimônio (os vínculos) das mulheres" seriam deliberações do Senado romano que incentivavam o matrimônio legítimo e a procriação. Os versos foram cantados no Capitólio, no último dia dos jogos, por dois corais, um com vinte e sete meninos e outro com vinte e sete meninas. Hor. Carm. 4,17,13-20: Rite maturos aperire partus / lenis, Ilithyia, tuere matres, / sive tu Lucina probas vocari / seu Genitalis: / diva, producas subolem, patrumque / prosperes decreta super iugandis / feminis prolisque novae feraci / lege marita (...). " $\mathrm{E}$ tu, Ilithyia, benigna em auxiliar os partos no momento oportuno, quer te agradasse ser chamada Lucínia, quer Genitale [aquela que gera, fecunda] proteja as mães: aumente, ó deusa, a nossa descendência e faça prosperar os decretos senatoriais sobre os vínculos das mulheres e sobre a lei marital [Lex Iulia de maritandis ordinibus], fecunda de nova prole (...)". Veja-se Pseudo Acron. Expositio in Horatii Carmen saeculare 20 (nota 272 supra). 
Adulteriis Coercendis (18-17 a.C.); posteriormente, da lex Papia Poppaea nuptialis (9 d.C.). ${ }^{315}$

As leis matrimoniais incentivaram tanto o matrimônio legítimo quanto a procriação. ${ }^{316}$

O jurista Terêncio Clemente salienta a importância do interesse do "Estado" romano no aumento da população e a utilitas publica em relação à procriação incentivada pela lex Iulia et Papia, ao citar o entendimento de Juliano sobre as condições admissíveis para a instituição de um legado como disposição testamentária: ${ }^{317}$

Vejam-se T. Spagnuolo Vigorita, Casta Domus cit. (nota 26 supra), pp.14-15;31;72;114-115, notas 83 a 89; Idem - V. MARotTA, La legislazione imperiale cit. (nota 167 supra), p.96; A. LÓPEZ PEDREIRA, Limitaciones a la 'libertas nuptialis' cit. (nota 40 supra), p.401, nota 59; R. ASTOLFI, La Lex Iulia et Papia cit. (nota 15 supra), pp.319-320;349-350;349; Idem, Note per una valutazione storica della 'Lex Iulia et Papia' cit. (nota 36 supra), p.197; J.A. FIELD JR., The purpose cit. (nota 129 supra), p.402, nota15; 405, nota 27; D. NÖRR, The matrimonial Legislation of Augustus cit. (nota 54 supra), pp.351;356; M. ZABŁOCKA, Le modifiche cit. (nota 103 supra), p.380; C. FAYER, La familia romana cit. (nota 280 supra), p.573, nota 967; A. BOUCHÉ-LECLERCQ, Les lois démographiques d'Auguste cit. (nota 36 supra), pp.265-266.

${ }^{315}$ Vejam-se G. Rotond, Leges publicae populi romani, Hildesheim, Georg Olms, 1966, pp.443-445;457462; T. MARKY, Curso Elementar de Direito Romano cit. (nota 166 supra), p.18; E. VolTERRA, Istituzioni cit. (nota 12 supra), pp.23 e 564; Idem, Matrimonio cit. (nota 61 supra), pp.769-769; M. TALAMANCA, Istituzioni cit. (nota 12 supra), pp.26 e 137; A. GUARINO, Diritto privato romano cit. (nota 1 supra), p.96, nota 4.3.4; V. SCARANO USSANI, Appunti di storia del diritto romano cit. (nota 285 supra), pp.147-150; B. BIONDI, Istituzioni cit. (nota 22 supra), p.440; Idem, La legislazione di Augusto cit. (nota 56 supra), p.130; A. BURDESE, Manuale cit. (nota 47 supra), pp.275-276; V. ARANGIO-RUIZ, Storia del diritto romano cit. (nota 253 supra), pp.236-237; Idem, Istituzioni cit. (nota 53 supra), p.443; J. GAUDEMET, Utilitas Publica cit. (nota 44 supra), pp.186-187; J. IGLESIAS, Derecho Romano cit. (nota 51 supra), p.341; P. CERAMI, Il 'Princeps' $e$ la cura 'Legum et morum' cit. (nota 282 supra), p.201; T. SPAGNUOlO VigORITA, Casta Domus cit. (nota 26 supra), pp.14-15; Idem - V. MAROTTA, La legislazione imperiale cit. (nota 167 supra), p.91; S. RiCCOBONO, La politica demografica cit. (nota 103 supra), p.575; J.A. FIELD JR., The purpose cit. (nota 129 supra), pp.402-403; E. Domínguez LóPEZ, La impotencia en las 'Leges Iulia et Papia' cit. (nota 104 supra), p.167; M. ZABŁOCKA, Il 'ius trium liberorum' cit. (nota 103 supra), pp.361-362; R. BESNIER, L'application des lois caducaires cit. (nota 10 supra), p.94; F. SERAFINI, Istituzioni cit. (nota 53 supra), p.236; R. AstOLFI, La Lex Iulia et Papia cit. (nota 15 supra), pp.164-165; P. JöRS, Die Ehegesetze des Augustus cit. (nota 258 supra), pp.1-2, nota 1 .

${ }^{316} \mathrm{Na}$ opinião de F. Della CORTE, Le 'leges Iuliae' e l'elegia romana cit. (nota 47 supra), pp.539 e 542, interessava mais a Augusto o aumento da prole, a geração de filhos de acordo com as exigências da Lex Iulia et Pappia, do que o simples aumento no número de matrimônios. Musonius Rufus, no diatribe XV A, salienta a função do legislador em procurar o bem comum e a utilitas publica por meio de uma legislação que incentivasse o matrimônio e a procriação. Na parte final deste diatribe, Musonius claramente faz referência aos prêmios e às penas estabelecidos pela Legislação Matrimonial de Augusto e que permaneceram vigentes durante o Principado: diatribe XV A (Se é necessário erguer todos os filhos que nasceram): "Nisto que os legisladores, aos quais a função é buscar e examinar aquilo que é bom e aquilo que é mal para a cidade, aquilo que serve para o bem comum e aquilo que o impede, nem todos consideraram o aumento das casas dos cidadãos como a coisa mais vantajosa para as cidades e a sua diminuição como a coisa mais prejudicial? Não têm eles [os legisladores] observado como uma desvantagem o fato que os cidadãos tenham poucos filhos ou nenhum e como uma vantagem que eles tenham, melhor ainda, que eles tenham muitos? Eis porque eles proibiram às mulheres de praticar o aborto e inflingir uma pena àquelas que desobedecessem; eis porque eles estabeleceram os prêmios para o homem e a mulher que têm numerosos filhos e estabeleceram penas para as famílias sem filhos". Veja-se A. JAGU, Musonius Rufus cit. (nota 79 supra), p.71.

${ }^{317}$ R. ASTOLFI, La Lex Iulia et Papia cit. (nota 15 supra), pp.164-165;326; J. GAUDEMET, Utilitas Publica cit. (nota 44 supra), pp.186-187; E. MALDONADO DE LIZALDE, Lex Iulia de Maritandis Ordinibus cit. (nota 122 supra), p.542. Afirma A. BouCHÉ-LECLERCQ, Les lois démographiques d'Auguste cit. (nota 36 supra), p.283, que os juristas procuraram adaptar as disposições da Lex Iulia et Papia a diversos casos, sempre preocupados 
Clem. 5 ad l. Iul. et Pap. D.35,1,64,1: Quodsi ita scriptum esset: si Ariciae non nupserit, interesse, an fraus legi facta esset; nam si ea esset, quae aliubi nuptias non facile possit invenire, interpretandum, ipso iure rescindi, quod fraudandae legis gratia esset adscriptum; legem enim utilem Reipublicae, sobolis scilicet procreandae causa latam, adiuvandam interpretatione.

"Porém, se estivesse escrito assim: 'se não se casará em Arícia', importa saber se se fraudasse à lei; porque se se tratasse daquela que não podia encontrar facilmente casamento em outra parte, deve-se interpretar que se rescinde ipso iure aquilo que se escreve para fraudar a lei; porque deve-se favorecer com a interpretação uma lei útil à res publica, certamente promulgada para a procriação da prole".

Juliano considera a finalidade demográfica, de incentivar o aumento dos matrimônios previsto pela lex Iulia et Papia, ao examinar uma disposição condicionada à circunstância de que a mulher não se case na cidade de Arícia. Ele conclui que, se a mulher tiver dificuldade de casar-se em outra cidade, fica evidente se tratar de uma disposição que tinha por escopo impedir o seu matrimônio e fraudar a lex Iulia et Papia. ${ }^{318}$

A lex Iulia de maritandis ordinibus estabelecia a incapacidade absoluta dos caelibes de receber por testamento e inúmeros dispositivos que indicam sanções de natureza sucessória e fiscal. Como indica o próprio nome da lei, ela era uma medida voltada principalmente para incentivar certas classes sociais (senadores e equestres) à procriação e ao matrimônio. ${ }^{319}$

Não há qualquer indício de perturbações sociais ou tumultos decorrentes da promulgação da lex Iulia de maritandis ordinibus pelo menos até 4 d.C., ano em que a reforma da legislação matrimonial sofreu uma forte resistência das classes senatorial e equestre. As reações na sociedade não foram uniformes: parecem indicar uma recepção favorável após a promulgação da legislação e uma forte aversão iniciada no final do

em ampliar a sua aplicação. Segue esta orientação, a intepretação realizada por Marciano em D.35,1,64,1.

${ }^{318}$ R. Astolfi, La Lex Iulia et Papia cit. (nota 15 supra), pp.165-166;360; Idem, Note per una valutazione storica della 'Lex Iulia et Papia' cit. (nota 36 supra), pp.221;222. Deve-se interpretar extensivamente a norma que sanciona a nulidade da condição ou qualquer outro expediente fraudulento que impeça a realização do matrimônio ou a procriação.

${ }^{319}$ R. BESNIER, L'application des lois caducaires cit. (nota 10 supra), p.96; J.A. FIELD JR., The purpose cit. (nota 129 supra), p.402; C. FAYER, La familia romana cit. (nota 280 supra), p.573. 
principado de Augusto. ${ }^{320}$

Suetônio (Augustus 34) fala de um tumultus recusantium no Senado e que a classe equestre exigiu pertinaciter a abolição da lei. Suetônio não menciona uma "lei anônima", porém fala de um "projeto de lei" de 4 d.C. que tinha por objetivo modificar algumas medidas legislativas da lex Iulia de maritandis ordinibus.

Suet. Augustus 34,1-4: Leges retractavit et quasdam ex integro sanxit, ut sumptuariam et de adulteriis et de pudicitia, de ambitu, de maritandis ordinibus. 2. Hanc cum aliquanto severius quam ceteras emendasset, prae tumultu recusantium perferre non potuit nisi adempta demum lenitave parte poenarum et vacatione trienni data auctisque praemiis. 3. Sic quoque abolitionem eius publico spectaculo pertinaciter postulante equite, accitos Germanici liberos receptosque partim ad se partim in patris gremium ostentavit, manu vultuque significans ne graverentur imitari iuvenis exemplum. 4. Cumque etiam inmaturitate sponsarum et matrimoniorum crebra mutatione vim legis eludi sentiret, tempus sponsas habendi coartavit, divortiis modum imposuit.

"Modificou várias leis e renovou algumas inteiramente, por exemplo, a lei sumptuária e aquela sobre os adultérios e a pudicícia, sobre as fraudes eleitorais, sobre o matrimônio das ordens [lex Iulia de maritandis ordinibus]. 2. Esta última, ele tinha emendado de forma tão mais severa que as outras, mas pelo protesto dos opositores não pode fazê-la passar senão após haver suprimido ou mitigado uma parte das penas, concedido uma suspensão de três anos e aumentado os prêmios. 3. Desta maneira, durante um espetáculo público, um cavaleiro pede-lhe obstinadamente a abolição: mas ele apresentou os filhos de Germânico e, trazendo-os uma parte junto a si, uma parte no colo do pai, mostrou-os ao público, demonstrando com a mão e com o semblante que não se recusassem em imitar o exemplo do jovem. 4. Quando, ainda, percebeu que a autoridade da lei era burlada também por esponsais realizados prematuramente com meninas e mudando frequentemente de sponsae, reduziu o período no qual se poderia ter uma sponsa [mulher prometida, noiva] e impôs limites para os divórcios".

\footnotetext{
${ }^{320}$ Segundo R. Astolfi, La Lex Iulia et Papia cit. (nota 15 supra), p.347, as principais fontes literárias que narram as reações que a legislação matrimonial provocou na sociedade romana, são de Dio Cássio e Suetônio, geralmente obscuras e contrastantes.
} 


\section{Para reforçar a sua propaganda ${ }^{321}$ de incentivo ao matrimônio e à procriação,}

Augusto reuniu o povo no Forum em 9 d.C., separando de um lado os casados com filhos e de outro os solteiros. Após ter observado que o número de solteiros era maior, pronunciou um discurso aos casados com filhos, reproduzido em Dio Cass. 56,3,1-9 e outro aos solteiros, em Dio Cass. 56,4,1-6. ${ }^{322}$

${ }^{321}$ A propaganda demográfica de Augusto utilizou inúmeros exemplos de mulheres com prole numerosa, até aquelas que não pertenciam às classes sociais mais elevadas, como as escravas. Aulo Gélio indica como modelo de fecundidade uma escrava de Augusto que deu à luz cinco filhos. A mãe morreu no parto e os filhos sobreviveram poucos dias. Augusto mandou erigir um monumento em homenagem à escrava. Veja-se Gell. 10,2,2: Sed et divo Augusto imperante, qui temporum eius historiam scripserunt, ancillam Caesaris Augusti in agro Laurente peperisse, quinque pueros dicunt eosque pauculos dies vixisse; matrem quoque eorum non multo, quoque eorum non multo, postquam peperit, mortuam, monumentumque ei factum iussu Augusti in via Laurentina, inque eo scriptum esse numerum puerperii eius, de quo diximus. "Mas também, imperando o divino Augusto, os que escreveram a história dessa época afirmam ter uma escrava de César do campo de Laurento, gerado cinco meninos, e esses terem vivido bem poucos dias; a mãe deles também, não muito depois que deu à luz, morreu; e por ordem de Augusto lhe foi feito um monumento na via Laurentina, e neste foi escrito o número daquele parto que falamos". Vejam-se T. Spagnuolo Vigorita, Casta Domus cit. (nota 26 supra), p.57; B. BIONDI, La legislazione di Augusto cit. (nota 56 supra), p.137.

${ }^{322}$ T. Spagnuolo Vigorita, Casta Domus cit. (nota 26 supra), pp.69-71;73-74;164-165; B. BiONDI, La legislazione di Augusto cit. (nota 56 supra), p.144; K. GALINSKY, Augustan Culture cit. (nota 102 supra), p.132. Terminados os discursos, Augusto aumentou o prêmios para aqueles que tinham filhos (preferência nas honras e cargos públicos, direitos sucessórios, vantagens patrimoniais). Vejam-se, Dio Cass. 56,3,1-2:

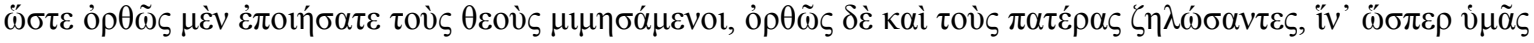

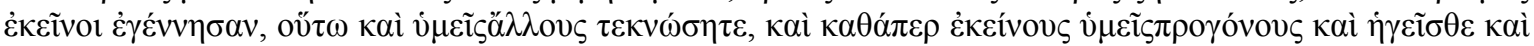

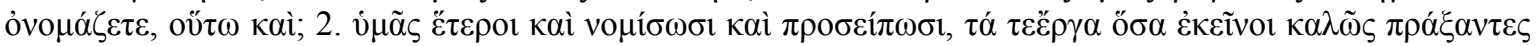

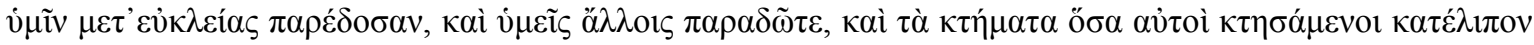

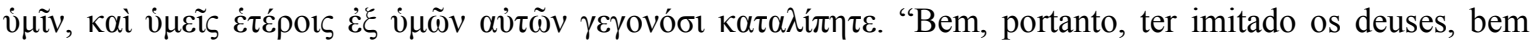
seguir os pais, de maneira que, como aqueles vos geraram, também vós destes a vida a outros; e, como vós estimáveis aqueles que chamastes de antepassados, assim vos consideram e chamam; 2. e as obras, que aqueles realizaram virtuosamente e merecidamente, transmitiram a vós, também vós transmitistes a outros; e os bens que eles adquiriram e vos deixaram, também vós deixastes a outros nascidos de vós mesmos";

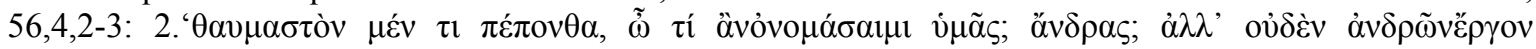

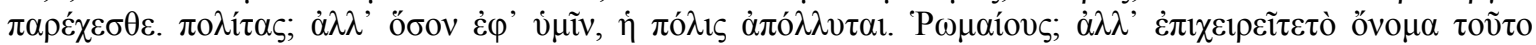

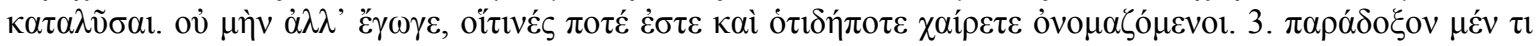

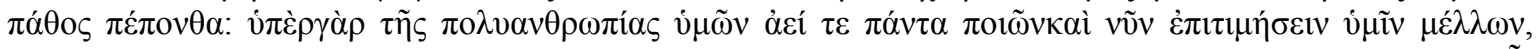

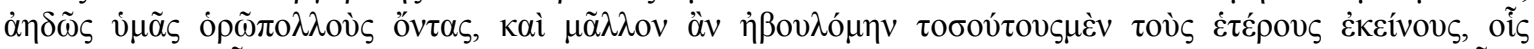

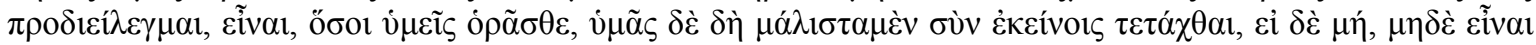
(...). "Fato estranho me interessou, ou - como nunca poderei chamar-vos? Homens? Mas vós não cumpristes nenhum dos deveres próprios dos homens. Cidadãos? Mas no que a cidade depender de vós, pode ir à ruína. Romanos? Mas vós estais se esforçando para apagar este nome. Basta: qualquer de vós que sejais e que vos agrade ser chamados, eu, por minha conta, vivi uma experiência paradoxal. 3. Para aumentar o vosso número faço sempre todo o possível e exatamente agora me preparo para repreender-vos: além de tudo, vejo com desprazer que sois muitos. Antes, desejaria que tão numerosos, quanto vós vos mostrastes, fossem aqueles outros aos quais falei primeiro (...)".

Dio Cassio narra em 56,1,1-2 que em 9 d.C., data da promulgação da Lex Pappia Poppaea, os equites exigiam a abolição da lei matrimonial de 4 d.C. que distinguia os casados com filhos daqueles sem filhos.

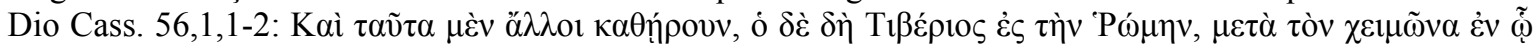

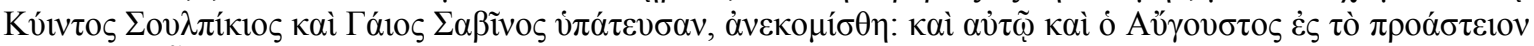

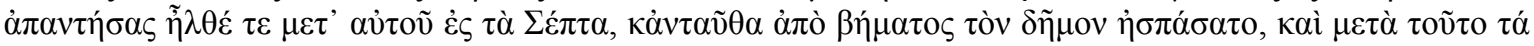

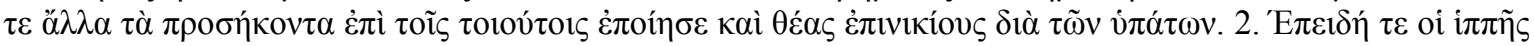

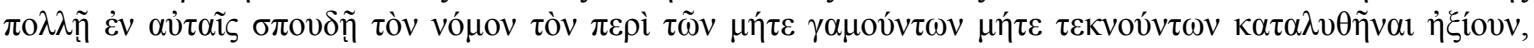

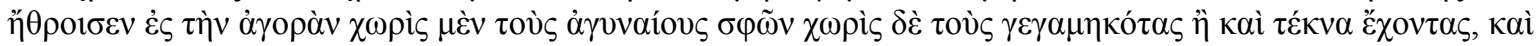

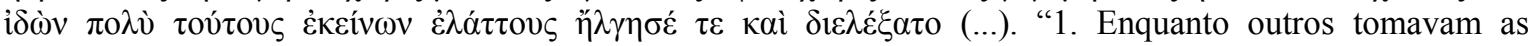
providências para vencê-lo, Tibério retornou a Roma após o fim do inverno, em que eram cônsules Quinto 
Dio Cassio informa, em 56,7,3-4, sobre a promulgação de uma lei anônima ${ }^{323}$, provavelmente em 4 d.C., que ficou suspensa por cinco anos (primeiro por três anos e depois por outros dois), talvez pelo seu rigor. É provável que esta lei anônima de 4 d.C. equiparava os caelibes (termo que, em sentido amplo, indicava os solteiros, os divorciados e os viúvos que não contraíram novas núpcias) aos orbi (cônjuges sem filhos). ${ }^{324}$

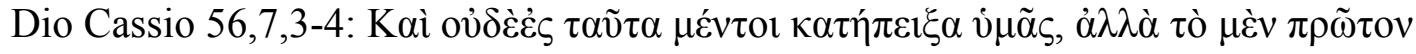 \\ $\tau \rho i ́ \alpha$ ह̌̃

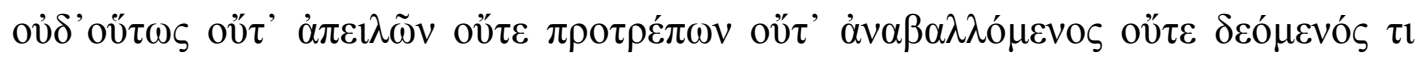

Sulpício e Caio Sabino [início de 9 d.C.]. O próprio Augusto foi ao seu encontro no limite da cidade, reuniuse com ele nos Saepta e alí saudou o povo de uma tribuna; depois cumpriu tudo aquilo que se destinava à estas ocasiões e determinou jogos triunfais para o trâmite dos cônsules. 2. E, uma vez que durantes estes [jogos] os equites exigiam com grande veemência que fosse abrogada a lei sobre aqueles que não eram casados e não tinham filhos, reuniu no Fórum, de um lado, aqueles que não eram casados e de outro, aqueles que tinham filhos; então, percebeu que estes eram muito menos numerosos que os primeiros, e perturbou-se (...)".

${ }^{323}$ T. Spagnuolo Vigorita, Casta Domus cit. (nota 26 supra), pp.74-76, admite a possibilidade de que esta "lei anônima" de 4 d.C. possa ser a Lex Aelia Sentia, proposta pelos cônsules ordinários Sexto Élio Cato e Caio Sêncio Saturnino, com o escopo de diminuir a quantidade de manumissões testamentárias e tornar inválidas as manumissões realizadas para fraudar os credores. Exigia que o manumissor tivesse, pelo menos, 20 anos e o manumitido, 30 anos. Vejam-se Gai.1,29-30;37-38.

${ }^{324}$ Esta lei provavelmente modificou a Lex Iulia de maritandis ordinibus, ao igualar os cônjuges sem prole (orbi) aos caelibes, solteiros sem prole, privando-os totalmente da capacitas, quer sucedessem do próprio cônjuge, quer sucedessem de terceiros. Além disso, supõe-se que esta lei já previa a atribuição dos bona caduca ao Erário e o processo delatório. Augusto ab-rogou esta "lei anônima", porém parte de seu conteúdo foi incluído na Lex Papia Poppaea. O rigor da lei foi abrandado e muitas medidas aumentaram os prêmios para aqueles que tivessem mais filhos. Vejam-se, R. Astolfi, La Lex Iulia et Papia cit. (nota 15 supra), pp.349-350; T. Spagnuolo Vigorita, Casta Domus cit. (nota 26 supra), pp.21;27;71-76; C. FaYer, La familia romana cit. (nota 280 supra), pp.574-575; A. BOUCHÉ-LECLERCQ, Les lois démographiques d'Auguste cit. (nota 36 supra), pp.265-266. Dio Cass. 53,21,3-5, confirma a disponibilidade de Augusto em acolher as sugestões, as correções e as alterações, ao expor publicamente as propostas de leis. Com isso, o princeps incentivava todos os cidadãos a propor emendas, que ele acolhia frequentemente. Neste caso, ouviu

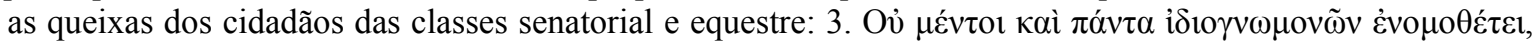

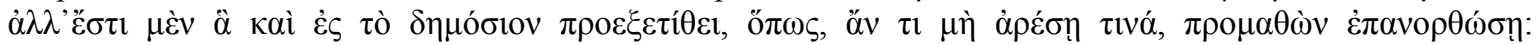

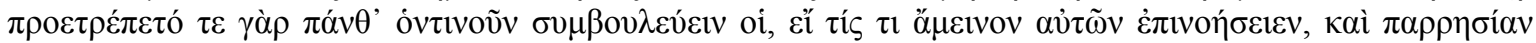

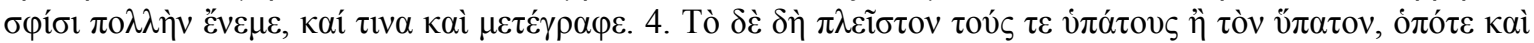

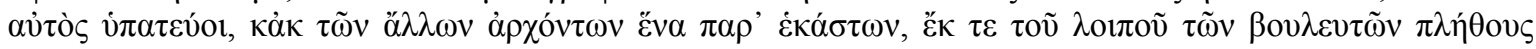

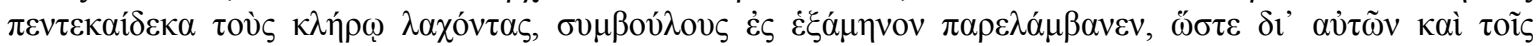

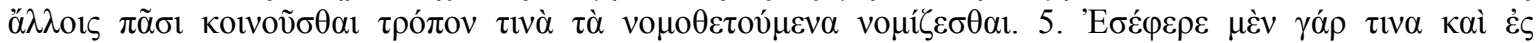

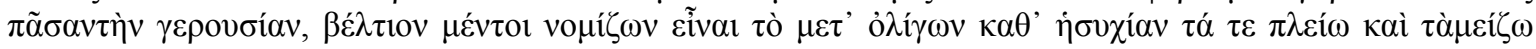

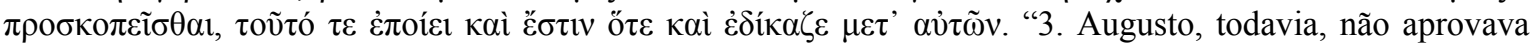
todas as leis seguindo apenas a sua própria opinião: algumas, de fato, expunha antecipadamente em público, de modo que, informado a tempo, pudesse corrigí-las quando algum ponto fosse desagradável a alguém. Antes, exortava todos os cidadãos a dar-lhe conselho, quando alguém cogitasse algo de melhor que as suas propostas, concedendo-lhe a mais ampla liberdade de palavra; e efetivamente modificou, às vezes, alguns pontos. 4. Mas sobretudo, ele tomou como conselheiros, por períodos de seis meses, os cônsules (ou outro cônsul, quando ele mesmo ocupou este cargo), um magistrado para cada uma das outras magistraturas e quinze pessoas sorteadas do resto do corpo senatorial, assim que, por meio dele, fosse hábito que as propostas de lei se tornassem conhecidas, de alguma forma, a todos os outros. 5. E também quando trazia algumas questões diante de todo o Senado, ele seguia, mesmo assim, este procedimento, considerando preferível que grande parte dos problemas, e os mais importantes, fossem examinados tranquilamente entre poucas pessoas; e às vezes também julgava junto com elas". 


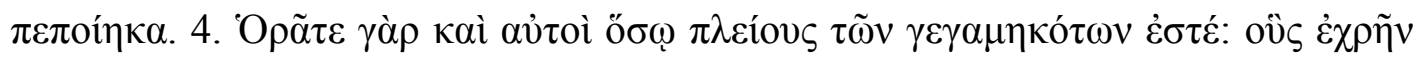

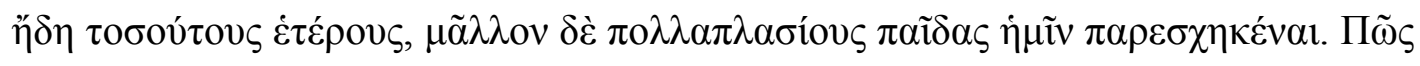

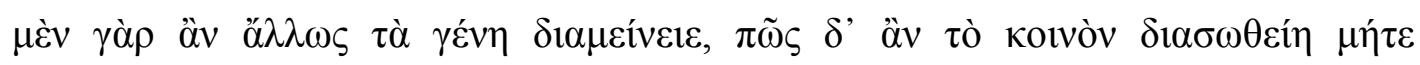

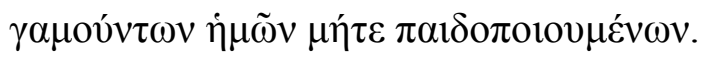

“3. Além disso, certamente não pressionou-lhes a estes comportamentos [de casar-se e de procriar], mas antes concedeu-lhes três anos inteiros para preparar-se, depois outros dois. Mas mesmo assim, nada conseguiu, nem ameaçando, nem exortando, nem adiando, nem suplicando. 4. Podeis bem ver vós mesmos como sois mais numerosos do que os casados, enquanto seria o vosso dever já ter-nos dado tantos filhos para igualar o vosso número, ou melhor, superá-lo em muito. Como, de outro modo, poderiam perdurar as famílias, como conservar-se aquilo que é comum, se nós não nos casássemos e procriássemos?”.

Pela situação conturbada politicamente nesta época e a forte oposição da classe equestre $^{325}$, após um período de três anos, em 7 d.C. Augusto concedeu a vacatio por mais dois anos para que todos os cidadãos se adaptassem à nova lei e abrandou as suas disposições em 9 d.C., ao promulgar a lex Papia Poppea. ${ }^{326}$

Vinte e sete anos após a promulgação da lex Iulia de maritandis ordinibus, os cônsules suffecti (que assumiram este cargo em $1^{\text {o }}$ de julho de 9 d.C.), Marco Pápio Mutilo (Marcus Papius Mutilus) e Quinto Popeu Segundo (Quintus Poppaeus Secundus) convocaram os comícios centuriatos que promulgaram a lex Papia Poppaea (entre 1 de julho e o final de setembro de 9 d.C.). ${ }^{327}$

\footnotetext{
${ }^{325}$ Segundo T. Spagnuolo Vigorita, Casta Domus cit. (nota 26 supra), pp.77-82, no período final do governo de Augusto, intensificaram-se os protestos contra a legislação matrimonial e a classe equestre exigiu a sua ab-rogação. É possível que muitos jovens membros da classe senatorial também fizessem parte da iuventus equestris ordines.

${ }^{326}$ T. Spagnuolo Vigorita, Casta Domus cit. (nota 26 supra), pp.21;61;67-68;72-74; A. Guarino, Storia del diritto romano cit. (nota 103 supra), p.451; F. DELLA CORTE, Le 'leges Iuliae' e l'elegia romana cit. (nota 47 supra), p.540; S. RICCOBONO, La politica demografica cit. (nota 103 supra), p.576; J.A. FIELD JR., The purpose cit. (nota 129 supra), pp.403; 406, nota 31;407; R. Astolfi, La Lex Iulia et Papia cit. (nota 15 supra), pp.349-350, notas 65 e 66;351; D. NÖRR, The Matrimonial Legislation of Augustus cit. (nota 54 supra), p.355. Confundiu-se em relação a estes acontecimentos, A. BouCHÉ-LECLERCQ, Les lois démographiques d'Auguste cit. (nota 36 supra), pp.264, nota 1;266, pois defendeu que a vacatio trienni não teria sido aplicada à Lex Papia Poppaea, mas à Lex Iulia de maritandis ordinibus, lei que teria sido votada pelos comícios.

${ }^{327}$ Segundo a narrativa de Dio Cass. 56,10,3 os dois cônsules, Papius e Poppaeus, eram solteiros, sem filhos:

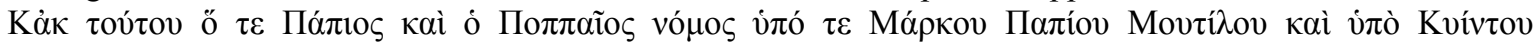

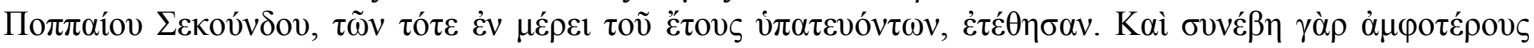

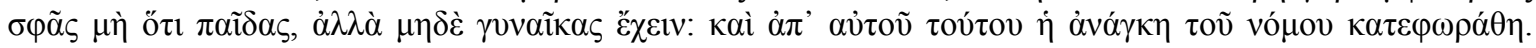
"Portanto a lei Papia Poppaea foi proposta por Marco Papio Mutilo e Quinto Poppeo Segundo, que eram cônsules naquela parte do ano. Acontece que tanto um quanto o outro, não só não tiveram filhos, como nem mesmo esposa: e por isso a necessidade da lei mostrava-se manifesta".
} 
Augusto num primeiro momento, teve que atender às exigências de seus opositores, principalmente de alguns membros da classe equestre e, logo após a aprovação da lex Papia Poppaea, estabeleceu que as suas sanções entrassem em vigor apenas um ano depois. Mesmo após essa vacatio de um ano, os equites, principalmente durante eventos públicos, pediram a ab-rogação da lei. ${ }^{328}$

Esta lei teve dois escopos principais: (a) combater os matrimônios estéreis, tornando os cônjuges sem descendentes (orbi), incapazes de receber a metade da sucessão testamentária; e (b) aumentar o exército romano, devido às dificuldades enfrentadas por Augusto em recrutar soldados para as Guerras da Ilíria (7 d.C.) e da Germânia (9 d.C.). ${ }^{329}$ Sofriam restrições em seus direitos sucessórios os caelibes, os orbi (pais sem prole

Isidoro de Sevilha escreve sobre o cargo ocupado pelos autores desta lei. Isid. etym. 5,15,2-5: Nam [et] sub Octaviano Caesare suffecti consules Papirius et Poppaeus legem tulerunt, quae a nominibus eorum appellatur Papia Poppaea, continens patrum praemia pro suscipiendis liberis. "Pois [e] sob Otaviano César os cônsules suffecti Papius e Poppaeus produziram uma lei, a qual foi denominada com os nomes deles, Papia Poppaea, que contém os prêmios dos pais por gerarem filhos". Vejam-se V. ARANGIO-RUIZ, Storia del diritto romano cit. (nota 253 supra), pp.236-237; F. DELla CORTE, Le 'leges Iuliae' e l'elegia romana cit. (nota 47 supra), p.539; L.F. RADITSA, Augustus Legislation cit. (nota 49 supra), p.297; A. LÓPEZ PEDREIRA, Limitaciones a la 'libertas nuptialis' cit. (nota 40 supra), p.404; T. SPAGNUOLO Vigorita, Casta Domus cit. (nota 26 supra), pp.61;67, nota 291;68;73-74;76-77;83; J.A. FIELD JR., The purpose cit. (nota 129 supra), pp.406-408; D. NÖRR, The matrimonial Legislation of Augustus cit. (nota 54 supra), p.357; C. FAYER, La familia romana cit. (nota 280 supra), pp.574-576; A. BOUCHÉ-LECLERCQ, Les lois démographiques d'Auguste cit. (nota 36 supra), p.267; E. MALDONADO DE LIZALDE, Lex Iulia de Maritandis Ordinibus cit. (nota 122 supra), pp.543.

${ }^{328}$ Em 7 d.C., devido a problemas internos (aumento de impostos, falta de alimentos) e externos (rebeliões na Panônia, revoltas na Ilíria), o princeps concedeu a vacatio legis por mais dois anos e prolongou a sua suspensão. Durante os jogos de 9 d.C., que comemoravam a vitória de Tibério na Guerra Panônica, os membros da classe equestre criaram tumultos e exigiram a ab-rogação da "lei anônima" de 4 d.C. A classe equestre iniciou uma série de reações populares contra a tentativa de Augusto agravar a Lex Iulia de martiandis ordinibus com a promulgação de uma nova lei, a Lex Papia Poppaea. Vejam-se, T. SPAGNUOLO Vigorita, Casta Domus cit. (nota 26 supra), pp.71;73;76-77; J.A. FIELD JR., The purpose cit. (nota 129 supra), p.407; C. FAYER, La familia romana cit. (nota 280 supra), p.575; A. BouCHÉ-LECLERCQ, Les lois

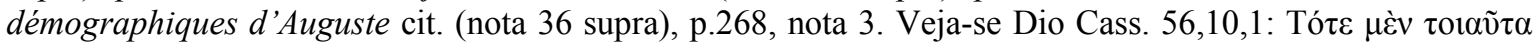

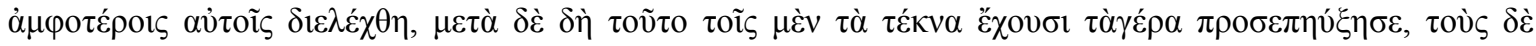

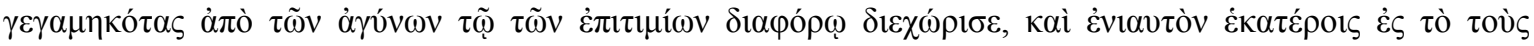

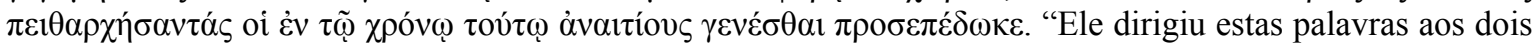
grupos naquela ocasião [discurso de Augusto em 9 d.C.]. Depois disso, de um lado, ainda aumentou os prêmios para aqueles que tinham filhos; de outro, diferenciando as penas, separou os casados dos solteiros [caelebs]: e tanto a uns quanto a outros concedeu também um ano para obedecer-lhe, garantindo-lhes por este período a impunidade". Fica claro que com o termo $\gamma \varepsilon \gamma \alpha \mu \eta \kappa o ́ \tau \varepsilon \varsigma$ Dio Cássio referiu-se aos casados sem filhos (orbi) e exprime a diferença entre a incapacidade total dos caelibes e a incapacidade parcial dos orbi, pois estes poderiam receber a metade da sucessão testamentária.

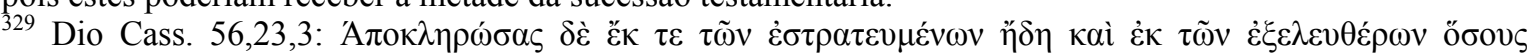

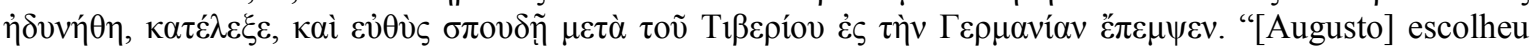
quanto mais homens podia, dentre aqueles que já tinham cumprido a vida militar e dentre os libertos, recrutou-os e enviou-os, às pressas, para a Germânia, junto com Tibério". Vejam-se T. SPAGNUOLO Vigorita, Casta Domus cit. (nota 26 supra), pp.67, nota 291;82-83; R. BESNIER, L'application des lois caducaires cit. (nota 10 supra), pp.94;97; A. BOUCHÉ-LECLERCQ, Les lois démographiques d'Auguste cit. (nota 36 supra), p.263. Augusto teve dificuldades em aumentar o exército romano e aplicou punições (infâmia, confisco de bens, pena de morte) aos homens que procurassem escapar do serviço militar. A grande maioria dos jovens da capital sentiam-se pouco atraídos por uma carreira pública ou militar e preferiam uma 
ou com menos de três filhos) e o pater solitarius (homens que têm menos de três filhos e que não estão casados) ${ }^{330}$, desde que estivessem dentro de uma determinada faixa etária (entre os 25 e os 60 anos para os homens e entre os 20 e os 50 anos para as mulheres). Também as denominadas feminae probrosae, cuja condição já foi estudada no capítulo 2.4, foram atingidas pelas restrições desta lei matrimonial. ${ }^{331}$

A lex Papia Poppaea realizou inúmeras mudanças na legislação matrimonial anterior, principalmente para incentivar a procriação dos cidadãos romanos. Estabeleceu a dispensa da tutela mulierum (tutela das mulheres) em proporção ao número de filhos (ius liberorum), além de determinar que os orbi, ou seja, os casados sem filhos só pudessem

vida mais cômoda e prazerosa.

${ }^{330}$ De acordo com R. Astolfi, La Lex Iulia et Papia cit. (nota 15 supra), p.74, o benefício do ius liberorum ao pater e à mater solitarii já estava previsto na Lex Iulia de maritandis ordinibus. A mater solitaria que tivesse três filhos se ingênua e quatro se liberta, teria a capacitas completa. Veja-se R. Astolfi, Femina probrosa cit. (nota 96 supra), p.58.

${ }^{331}$ Vejam-se V. ARANGIO-RUIZ, Storia del diritto romano cit. (nota 253 supra), pp.236-237; Idem, Istituzioni cit. (nota 53 supra), p.443; B. BIONDI, Istituzioni cit. (nota 22 supra), p.440; R. Astolfi, La Lex Iulia et Papia cit. (nota 15 supra), pp.27;74; F. SAMPER, Sobre el destino del 'ius liberorum' cit. (nota 105 supra), pp.10-12; A. BURDESE, Manuale cit. (nota 47 supra), p.276; G.F. MARGADANT, El Derecho Privado Romano como introducción a la cultura juridica contemporanea, 4aed., México D.F., Esfinge, 1970, p.213; C. ORTíN GARCÍA, Edad, Matrimonio cit. (nota 103 supra), p.508, nota 6; A. LÓPEZ PEDREIRA, Limitaciones a la 'libertas nuptialis' cit. (nota 40 supra), p.404; T. SpAgnuolo VigoritA, Casta Domus cit. (nota 26 supra), p.10; G. LongO, Lex Iulia de maritandis ordinibus e Lex Papia Poppaea cit. (nota 103 supra), p.811; F. SERAFINI, Istituzioni cit. (nota 53 supra), p.236; L.F. RADITSA, Augustus Legislation cit. (nota 49 supra), p.323; D. NÖRR, The matrimonial Legislation of Augustus cit. (nota 54 supra), p.351; H. ANKUM, La 'captiva adultera' cit. (nota 63 supra), p.153; M. ZABŁOCKA, Le modifiche cit. (nota 103 supra), p.382; A. BOUCHÉLECLERCQ, Les lois démographiques d'Auguste cit. (nota 36 supra), p.263; E. MALDONADO DE LIZALDE, Lex Iulia de Maritandis Ordinibus cit. (nota 122 supra), p.549.

Alguns autores cristãos dos séculos V e VI d.C., como Salamanes Herméias Sozomenos e Flávio Magno Aurélio Cassiodoro, fazem referência às sanções patrimoniais promovidas pela Lex Iulia et Papia aos caelibes e aos orbi e indicam que o seu principal escopo foi o de repovoar o Império após as sangrentas

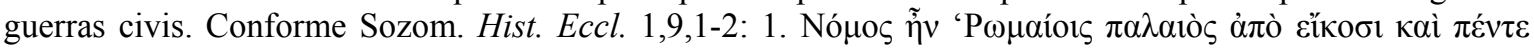

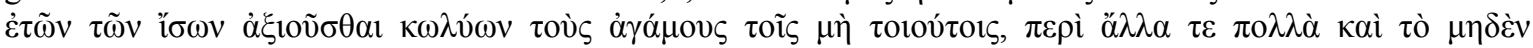

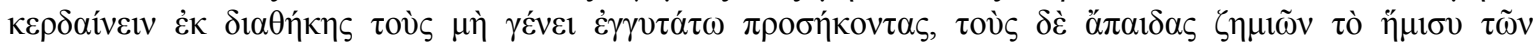

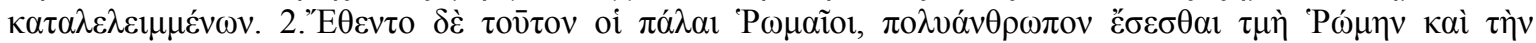
نं "1. Os Romanos tinham uma antiga lei que proibia aos solteiros, a partir dos vinte e cinco anos, de gozar dos mesmos direitos daqueles que não fossem; junto a muitas outras disposições, ela proibia àqueles que, dentre eles, não fossem parentes próximos [do testador] de receber por testamento, enquanto privava a metade da herança aos que não tivessem filhos. 2. Os antigos Romanos estabeleceram isto esperando que Roma e as terras a ela submetidas se tornassem populosas, já que não muito tempo antes da lei, homens morreram nas guerras civis"; Cassiod. Hist. Eccl. 1,9,16: Apud Romanos dudum fuit lex a vicesimo quinto anno non habentes uxores prohibens a privilegiis habentium coniuges, sed et alia multa iubens, ut nihil de testamento lucrarentur, licet generis proximitate consisterent; qui vero filios non habuissent, medietatem relictorum sibimet amittebant. Posuerunt autem has leges antiqui volentes Roman esse populosam omnemque subiectam terram et quia non multum ante has leges plurimos in civilibus bellis amiserant. "Há muito tempo, entre os Romanos, houve uma lei que proibia os privilégios aos homens casados, àqueles que, a partir do vigésimo quinto ano de idade, não tivessem esposa, mas que sancionou muitas outras coisas, a fim de que eles não adquirissem por testamento, mesmo tendo parentesco próximo [com o testador]; ao invés, aqueles que não tivessem tido filhos perdiam a metade do deixado [herança, legado]. Os antigos estabeleceram estas leis desejando que Roma fosse populosa e que lhe fosse submetida toda a Terra, e também porque, não muito tempo antes destas leis, perderam muitos homens nas guerras civis". 
adquirir a metade da herança ou do legado na sua sucessão recíproca.

É possível concluir que, enquanto a lex Iulia de maritandis ordinibus dividiu os homens em casados e caelibes, a lex Papia Poppaea dividia os homens com prole e sem prole e concedia aos primeiros uma série de prêmios e vantagens jurídicas. ${ }^{332}$

Em relação à aplicação espacial desta legislação, ela foi objeto de comentários do jurisconsulto Sálvio Juliano em dois famosos fragmentos do Digesto de Justiniano, Iul. 84 dig. D.1,3,32pr.;-1. ${ }^{333}$ É provável que nestes trechos, que contêm o livro 84 digestorum de Sálvio Juliano, o jurista tenha realizado comentários às leges e aos senatusconsulta

\footnotetext{
${ }^{332} \mathrm{Na}$ opinião de R. Astolfi, La Lex Iulia et Papia cit. (nota 15 supra), pp.23;31-32;74;336, foi provavelmente a Lex Iulia de maritandis ordinibus que introduziu a figura do pater solitarius, para estabelecer uma categoria de homens que tinham prole (menos de três filhos) mas não eram casados (viúvo, solteiro e divorciado com prole) e que teriam suas sanções mitigadas pela lei em relação aos caelibes, os solteiros sem filhos. O mesmo autor, num artigo publicado em 1973, Note per una valutazione storica della 'Lex Iulia et Papia' cit. (nota 36 supra), p.198, parece defender que a Lex Iulia de maritandis ordinibus tenha considerado o pater solitarius como caelebs, privado de capacitas e que sua situação só foi melhorada pela Lex Papia Poppaea. Também a mater solitaria era parcialmente capax, com um número inferior a três fillhos, se ingênua e a quatro, se fosse liberta. Em relação às integrações e modificações na Lex Iulia de maritandis ordinibus realizadas pela Lex Papia Poppaea, o jurista Paulo afirma que as disposições entre elas que não fossem contrárias, permaneciam válidas. Paul. 5 ad l. Iul. et Pap. D.1,3,28: Sed et posteriores leges ad priores pertinent, nisi contrarie sint, idque multis argumentis probatur. "Mas também as leis posteriores se submetem às anteriores, a não ser que sejam contrárias, e isto se prova por muitos argumentos". Sobre a Lex Iulia de maritandis ordinibus estabelecer somente penas para os caelibes e não para os orbi, veja-se Dio.

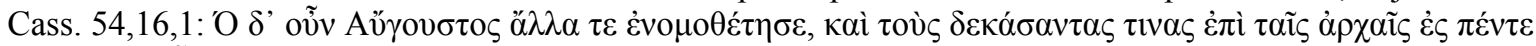

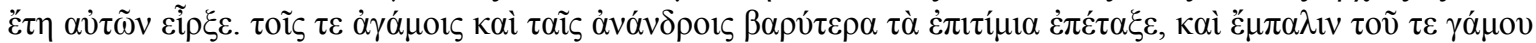

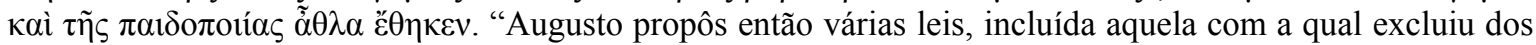
cargos por cinco anos aqueles que tivessem corrompido alguém para obtê-los [Lex Iulia de ambitu]. Aos solteiros [caelebs] e aos núbeis impôs penas muito duras, enquanto ofereceu prêmios a quem se casasse e gerasse filhos".
}

De acordo com R. BESNIER, L'extension des lois caducaires cit. (nota 106 supra), p.28, ao analisar os trechos de Gai. 2,286;286-a, que as disposições que puniam os orbi foram estabelecidas pela Lex Papia Poppaea. Na opinião de A. BouCHÉ-LECLERCQ, Les lois démographiques d'Auguste cit. (nota 36 supra), p.263, nota 1, baseado em Gai. 2,206; Ulp.14,1;18,1, a Lex Iulia de maritandis ordinibus era mais severa que a Lex Papia Poppaea. Veja-se também R. Astolfi, Femina probrosa cit. (nota 96 supra), p.53; Idem, Note per una valutazione storica della 'Lex Iulia et Papia' cit. (nota 36 supra), p.189; E. MALDONADO DE LizALDE, Lex Iulia de Maritandis Ordinibus cit. (nota 122 supra), p.551.

${ }^{333}$ Iul.84 dig. D.1,3,32pr.: De quibus causis scriptis legibus non utimur, id custodiri oportet, quod moribus et consuetudine inductum est: et si qua in re hoc deficeret, tunc quod proximum et consequens ei est: si nec id quidem appareat, tunc ius, quo urbs Roma utitur, servari oportet. "Quanto às causas para as quais não temos leis escritas, é preciso observar o que foi introduzido pelos mores e pela consuetudo. E se em alguma coisa isto for deficiente, então se observe o que lhe for mais próximo e consequente; se na verdade nem isso houver, então se deve observar o direito do qual a cidade de Roma se utiliza"; D.1,3,32,1: Inveterata consuetudo pro lege non immerito custoditur, et hoc est ius quod dicitur moribus constitutum. Nam cum ipsae leges nulla alia ex causa nos teneant, quam quod iudicio populi receptae sunt, merito et ea, quae sine ullo scripto populus probavit, tenebunt omnes: nam quid interest suffragio populus voluntatem suam declaret an rebus ipsis et factis? Quare rectissime etiam illud receptum est, ut leges non solum suffragio legis latoris, sed etiam tacito consensu omnium per desuetudinem abrogentur. "O costume (consuetudo) inveterado não é guardado despropositadamente, e este é o direito que se diz constituído pelos mores. Pois, uma vez que as próprias leis não nos obrigam senão pelo fato de que foram admitidas pelo juízo do povo, com razão também obrigarão a todos estas coisas que o povo aprovou sem sequer um escrito. Pois o que importa ao povo declarar a sua vontade por sufrágio ou por meio dos próprios fatos e feitos? Por isso também foi corretíssimo admitir que as leis sejam ab-rogadas não só pelo sufrágio do legislador, mas também pelo tácito consenso de todos por meio do desuso". 
relacionados com a aplicação da lex Papia Poppaea aos cidadãos romanos das províncias. $^{334}$

Outro ponto importante a ser salientado, de acordo com T. MARKY ${ }^{335}$, é o de que prevaleceu a irretroavidade nos dispositivos desta legislação matrimonial, como geralmente ocorria com as leis votadas nos comícios.

Poucos casos de alterações e inovações apresentadas pela lex Papia Poppaea em relação à lex Iulia de maritandis ordinibus podem ser estudadas isoladamente. Portanto, nos subtítulos seguintes, passaremos a analisar os principais assuntos tratados muitas vezes utilizando a denominação lex Iulia et Papia, modo corrente com o qual a matéria foi designada nos comentários e interpretações dos juristas romanos. ${ }^{336}$

Quando possível, de acordo com as próprias fontes jurídicas e literárias, faremos a divisão dos assuntos tratados, indicando quais matérias foram tratadas exclusivamente pela lex Iulia de maritandis ordinibus ou pela lex Papia Poppaea.

Vejamos a seguir alguns dos temas principais tratados pela legislação éticomatrimonial e demográfica.

${ }^{334}$ Este trecho, de todo o livro 84, foi o único que chegou até nós. Na opinião de P. CERAMI, Breviter su Iul. D.1,3,32 cit. (nota 193 supra), pp.133, 134 e 136, os trechos tinham como principal objetivo estabelecer o ius a ser aplicado nas diferentes partes do Império, em situações não contempladas pelas leges scriptae. Uma espécie de reflexão conclusiva, com o qual o jurista completava o comentário à Lex Iulia et Papia. Na opinião de J. IGLESIAS, Las fuentes del Derecho Romano, Madrid, Civitas, 1989, p.37, nota 5, o famoso texto de Juliano, acolhido em D.1,3,32, pode ser genuíno na essência, mas denuncia, em todo caso, uma justificativa "forçada" e até "distorcida" de seu escopo, ou seja, resolver o problema da aplicação da "Lex Papia Poppaea" nas esferas municipais distantes de Roma. Porém, esta idéia de preencher com a "consuetudo" lacunas legais, não parece sua, mas fruto de uma interpolação pós-clássica, equiparando a consuetudo à lex, pela forma de permitir ao costume ab-rogar a lei. Em relação aos casamentos nas províncias, E. VOLTERRA, Les formes du Mariage chez les Romains cit. (nota 30 supra), p.282, restringe-se a deduzir que, geralmente, nos documentos papirológicos e epigráficos, os Romanos reconheceram um valor jurídico secundum leges moresque peregrinorum às uniões entre peregrinos.

${ }^{335}$ Appunti sul problema della retroattività delle norme giuridiche nel diritto romano, in BIDR 53-54 (1948), pp.245;259. Conclui T. MARKY, op.cit., p. 259, ao realizar um estudo sobre a relação entre as fontes do direito e a retroatividade das "normas jurídicas", que l'editto pretorio era veramente retroativo, mentre nella legislazione comiziale vigeva, se anche non senza eccezioni, il principio della irretroattività.

${ }^{336}$ É muito superficial a divisão proposta por M. ZABLOCKA, Le modifiche cit. (nota 103 supra), p.381, que, ao analisar alguns trechos das Institutas de Gaio $(2,111,2,114,2,286 ; 2,286-a)$, concluiu que o dever de viver em matrimônio legítimo foi introduzido pela Lex Iulia de maritandis ordinibus e o de ter filhos, pela Lex Papia Poppaea. Também pouco coerente e muito genérica, a afirmação de R.ASTOLFI, Note per una valutazione storica della 'Lex Iulia et Papia' cit. (nota 103 supra), pp.197-198, pois, além de distanciar os escopos principais do matrimônio e da procriação, cria a impressão de que, entre 18 a.C. e 9 d.C., a procriação e as famílias numerosas não foram preocupações primordiais do legislador: sommariamente si può affermare che la 'lex Iulia' vuole che i romani si sposino, mentre la 'lex Papia' vuole che dal matrimonio nascano figli. (...) È soltanto con la 'lex Papia' che Augusto mostra di ritenere insufficiente, per l'incremento demografico, il dovere del matrimonio e vi aggiunge espressamente l'onere della procreazione. Quando assim afirma, parece excluir a procriação do conceito de dignitas matrimonial, contradizendo-se, (...) la 'lex Papia' non abbia modificato in alcun ponto la disciplina della 'lex Iulia' sulla dignità del matrimonio: le fonti a proposito dei divieti nuziali, citano, in fatti, la sola 'lex Iulia'. Conclui R. Astolfi, La Lex Iulia et Papia cit. (nota 15 supra), pp.335-336, que tuttavia è abbastanza facile rilevare come nella 'lex Papia' Augusto abbia inteso non solo perfezionare la 'lex Iulia', ma intensificarne gli effetti, aumentando i precetti e 


\section{a) esponsais}

Um dos principais problemas que deveria ser resolvido pela legislação era aquele do número excessivo de divórcios e dos esponsais com crianças impúberes ${ }^{337}$ no início do Principado que colocavam em risco a aplicação da lex Iulia de maritandis ordinibus e da lex Iulia de adulteriis coercendis. ${ }^{338}$

\section{le sanzioni.}

${ }^{337}$ M. DURRY, Sur le mariage romain cit. (nota 97 supra), pp.228;239; Idem, Le mariage des filles impubères cit. (nota 49 supra), pp.265-266;270-273; M.J. GARCIA GARRIDO, Minor annis XII nupta cit. (nota 47 supra), p.78, nota 4; R. AstOLf, La Lex Iulia et Papia cit. (nota 15 supra), p.327; Idem, Note per una valutazione storica della 'Lex Iulia et Papia' cit. (nota 36 supra), p.212; M.B. FUMAGALLI, Sponsali cit. (nota 51 supra), pp.503, nota 24;505. A jurisprudência apenas reconhecia o título de uxor à mulher que completou 12 anos, exatamente para combater esta prática de contrair matrimônio com meninas impúberes. Veja-se Plut. Numa

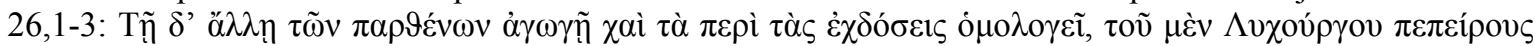

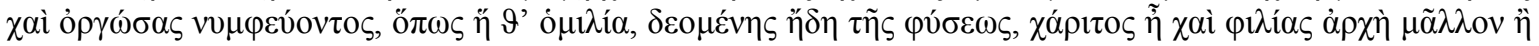

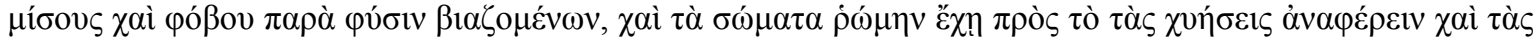

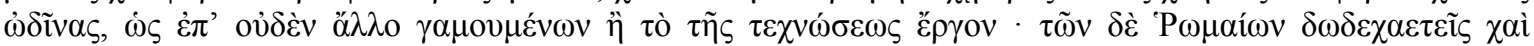

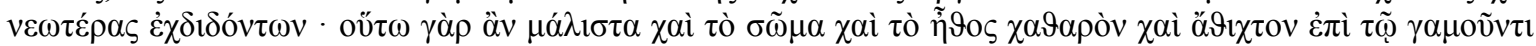

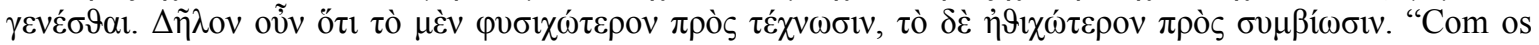
outros modos de tratar as moças, também se concorda com o que diz respeito ao seu casamento. De um lado, Licurgo casa-lhes quando elas estão formadas e sentem desejo, a fim de que as relações, ao apelo da natureza, sejam o início do prazer e da afeição antes do ódio e do medo das moças violentadas contra a natureza e, para que seus corpos tenham a força para suportar a gravidez e as dores da gestação, permitiu-se que elas se casassem apenas para que tivessem fihos. Por outro lado, os Romanos as desposavam aos 12 anos e ainda mais jovens; assim, o marido tem as primícias intactas do corpo e do caráter. De onde é evidente que a primeira solução levou mais em consideração a questão física com a finalidade da procriação e a segunda solução levou mais em consideração o caráter, com a finalidade do bom senso na vida comum". Modestino diferencia os limites de idade para o matrimônio e para os esponsais, apesar de contradizer-se, afirmando primeiramente que não havia limite de idade para realizar-se os esponsais e, na parte final do mesmo trecho, determina a idade mínima de sete anos. Mod. 4 dif. D.23,1,14: In sponsalibus contrahendis aetas contrahentium definita non est, ut in matrimoniis; qua propter et a primordio aetatis sponsalia effici possunt, si modo id fieri ab utraque persona intelligatur, id est, si non sint minores, quam septem annis. "Para contrair esponsais não está definida a idade dos contraentes, como para os matrimônios; pelo qual, podem contrair-se esponsais ainda que desde o primórdio da idade, contanto que se entenda que se faz isto por uma ou outra pessoa, isto é, não sejam menores de sete anos".

${ }^{338}$ A. EsMeIn, Le délit d'adultére a Rome et la loi Julia de adulteriis, in Mélanges d'Histoire du Droit et de critique - Droit Romain, Paris, L. Lorose et Forcel, 1886, p.87; T. SPAGNUOLO VigORITA, La data della lex Iulia de Adulteriis cit. (nota 277 supra), p.96; Idem, Casta Domus cit. (nota 26 supra), p.31; R. ASTOLFI, La Lex Iulia et Papia cit. (nota 15 supra), p.327; J.A. FIELD JR., The purpose cit. (nota 129 supra), p.403, nota 18; M. ZABŁOCKA, Le modifiche cit. (nota 103 supra), pp.382-383. Dio Cass. 54,16,3-4 narra que repercutia

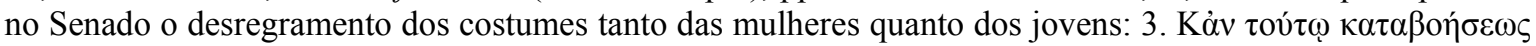

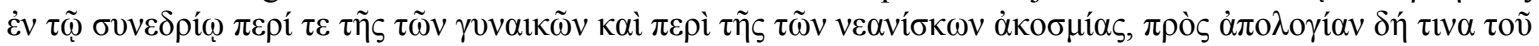

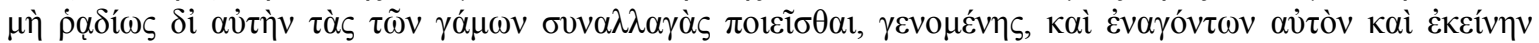

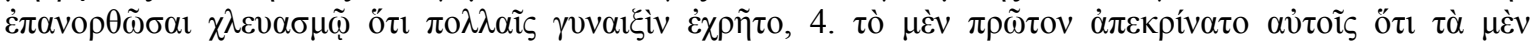

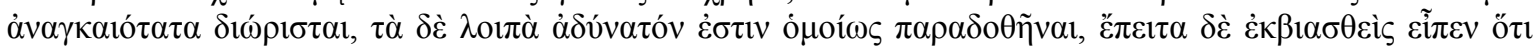

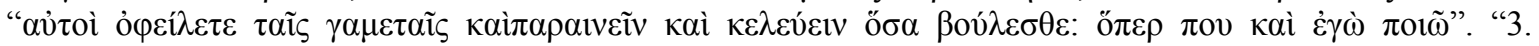
Naquele tempo existiram queixas no Senado sobre o desregramento tanto das mulheres quanto dos jovens, por causa do qual - se sustentava - eles não contraíam facilmente vínculos matrimoniais; e uma vez que os senadores exortavam-no [Augusto] a também corrigir isto, ironizando sobre suas relações com muitas mulheres, 4. ele, no princípio, respondeu-lhes já ter definido as medidas mais necessárias, e que às outras era impossível confiar-lhe a intervenção análoga; depois disse, precipitado: "vós mesmos deveis aconselhar e comandar as vossas esposas naquilo que desejais: é exatamente aquilo que eu também faço"”. 
Para solucionar esta questão dos esponsais com impúberes apenas para gozar das vantagens $^{339}$ da lex Iulia de maritandis ordinibus (principalmente para receber heranças e legados $)^{340}$, a lei Papia Poppaea equiparou, sob determinados aspectos, os esponsais ao matrimônio e limitou a sua duração para dois $\operatorname{anos}^{341}$, a fim de evitar que o noivo utilizasse deste expediente para adiar ou até mesmo não casar, efetuando uma longa série de noivados.

Dio Cassio comenta que os esponsais não deveriam durar mais que dois anos e a sponsa deveria ter pelo menos dez anos, pois o matrimônio legítimo só era admitido quando ela atingisse os doze anos, quando se tornava púbere.

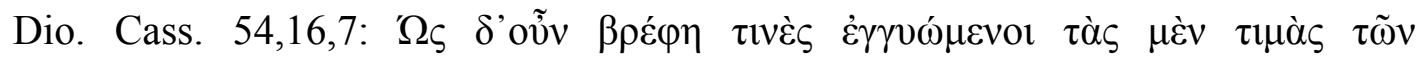

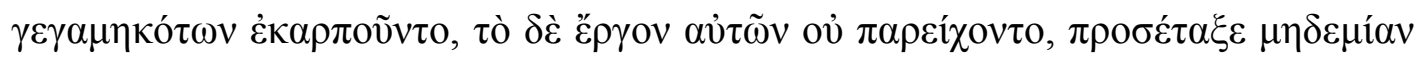

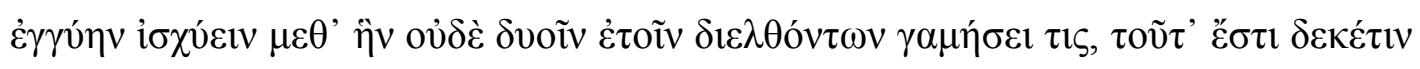

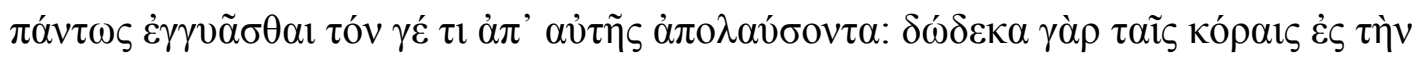

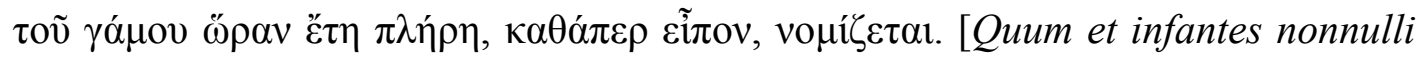
sibi desponsarent, et praemia quidem ferrent maritorum, officium non praestarent; edixit, ne qua pactio nuptialis rata esset, ubi ultra biennium nuptiae differentur: id est, ut omnino ea decem annos nata esset, quam despondere aliquis, et obquam praemia percipere vellet. Puellae enim, ut diximus, post duodecimum annum exactum, nubiles habentur].

"Uma vez que, além disso, alguns, noivando-se com neonatas, gozavam dos prêmios dos casados sem cumprir o ônus que recaía sobre eles, ordenou que não fosse válido nenhum esponsal [noivado] se não se casassem antes que transcorressem dois anos da sua data; ou seja, que quem desejasse levar alguma vantagem disto, devia noivar-se com meninas de pelo menos dez anos, visto que, como afirmei, é costume considerar as meninas maduras para o matrimônio no cumprimento do duodécimo ano de idade". 342

\footnotetext{
339 Tanto o sponsus quanto a sponsa estavam dispensados das normas da lex Iulia et Papia e não eram considerados caelibes. Portanto, os esponsais tornaram-se um meio fraudulento para escapar das determinações da Lex Iulia de maritandis ordinibus. Conforme M. ZABŁOCKA, Le modifiche cit. (nota 103 supra), pp.382-383. Veja-se PS 2,19,1: Sponsalia tam inter puberes quam inter impuberes contrahi possunt. "Os esponsais podem contrair-se tanto entre púberes quanto entre impúberes".

${ }^{340}$ Veja-se Labeo 3 Post. a Iav. Epit. D.36,2,30.

341 Salienta M.B. Fumagalli, Sponsali cit. (nota 51 supra), p.505, que, apesar da legislação, continuou válida a promessa matrimonial feita a uma sponsa menor de 10 anos. De acordo com R. AsTOLFI, Note per una valutazione storica della 'Lex Iulia et Papia' cit. (nota 36 supra), p.188, após o decorrer dos dois anos de esponsais, o sponsus é considerado caelibes.

${ }^{342}$ Eram mais frequentes os casos de esponsais entre homens púberes com meninas impúberes, com idade
} 


\section{b) ius liberorum}

O ius liberorum é um privilégio de natureza pública ou privada que garante aos pais a possibilidade de obterem direitos e vantagens em virtude da quantidade de sua prole ou por concessão graciosa do Senado e posteriormente do imperador. Esta denominação ius liberorum indica o conjunto destes privilégios, principalmente a atribuição da capacitas sucessória. $^{343}$

Dentre estes privilégios, o principal era o direito que a legislação reconhecia às mulheres ingênuas que tivessem três filhos ${ }^{344}$ (ou quatro tratando-se de mulher liberta ${ }^{345}$ )

inferior aos dez anos. Vide Suet. Augustus 34,4 (vide p.143 supra). De acordo com M. ZABŁOCKA, Le modifiche cit. (nota 103 supra), pp.383-384, esta norma descrita por Dio Cassio referia-se à proibição dos esponsais tanto com impúberes do sexo masculino quanto do sexo feminino. O jurisconsulto Gaio, por sua vez, enumera algumas situações eventuais, que ele denomina iustae ac necessariae causae, nas quais este prazo de dois anos dos esponsais poderia ser postergado. Gai. 1 ad l. Iul. et Pap. D.23,1,17: Saepe iustae ac necessariae causae non solum annum vel biennium, sed etiam triennium et quadriennium, et ulterius trahunt sponsalia, veluti valetudo sponsi sponsaeve, vel mortes parentum, aut capitalia crimina, aut longiores peregrinationes, quae ex necessitate fiunt. "Muitas vezes causa justas e necessárias prolongam os esponsais não apenas em um ano, ou dois, mas também em três e quatro, e ainda mais, por exemplo, uma enfermidade do sponsus ou da sponsa ou o falecimento dos pais, ou crimes capitais, ou viagens muito longas, que se fazem por necessidade". Vejam-se A. LÓPEZ PEDREIRA, Limitaciones a la 'libertas nuptialis' cit. (nota 40 supra), p.403; F. Della CORTE, Le 'leges Iuliae' e l'elegia romana cit. (nota 47 supra), p.539; J. CARCopino, La vie quotidienne à Rome cit. (nota 72 supra), p.125; T. Spagnuolo Vigorita, Casta Domus cit. (nota 12 supra), pp.34;36;71, nota 315;105-106; R. AsTOLFI, La Lex Iulia et Papia cit. (nota 12 supra), pp.4-5;326-327;348; Idem, Note per una valutazione storica della 'Lex Iulia et Papia', in SDHI 39 (1973), p.188; M.B. Fumagalli, Sponsali cit. (nota 51 supra), p.505; B. Biondi, La legislazione di Augusto cit. (nota 78 supra), pp.140-141; M. ZABŁOCKA, Le modifiche introdotte nelle leggi matrimoniale Augustee cit. (nota 100 supra), pp.383-384; A. BouCHÉ-LECLERCQ, Les lois démographiques d'Auguste cit. (nota 36 supra), pp.266-267.

${ }^{343}$ Conforme M. ZABŁoCKA, Il 'ius trium liberorum' nel diritto romano cit. (nota 72 supra), p.381, a Legislação matrimonial de Augusto concedia esse privilégio àqueles que pudessem demonstrar a existência da própria prole. Veja-se R. Astolfi, La Lex Iulia et Papia cit. (nota 13 supra), pp.26;72;81. Sobre as referências em Marcial do ius trium liberorum e o destaque que este prêmio teve na vida de cidadãos de todo tipo de classe social, veja-se J.C. TELLO, La concesión discrecional cit. (nota 161 supra), pp.773, nota 37; 774, nota 39; 776. Marcial faz referência ao ius [trium] liberorum utilizando o termo ius [trium] natorum por razões métricas: Mart. Epigr. 2,91-92;3,95;8,31;9,66-67;10,60;11,12. Em 9,66, ressalta que na sua época tornou-se fácil a concessão desse privilégio: Uxor cum tibi sit formosa, pudica, puella / quo tibi natorum iura, Fabulle, trium? / quod petis a nostro supplex dominoque deoque, / tu dabis ipse tibi, si potes arrigere. "Tendo esposa bela, honesta, jovem, / diz-me, Fábulo, que desejo terias / de exigir o direito dos três filhos? [natorum iura...trium] / Aquilo que tu supliques ao imperador / pode facilmente dá-lo por si mesmo, se apenas a ti se destina".

${ }^{344}$ Gai.1,145: Itaque si quis filio filiaque testamento tutorem dederit et ambo ad pubertatem pervenerint, filius quidem desinit habere tutorem, filia vero nihilo minus in tutela permanet; tantum enim ex lege Iulia et Papia Poppaea iure liberorum tutela liberantur feminae. (...) "Portanto, se alguém der em testamento tutor ao filho ou à filha, chegando à puberdade o filho, liberta-se da tutela; mas a filha permanece sob a mesma. Pois, pela lei Iulia et Papia Poppaea as mulheres se libertam da tutela apenas por causa do ius liberorum [direito da prole](...)". Os filhos deviam ser fruto de um iustum matrimonium e estarem submetidos à potestas do pai, de acordo com a Lex Papia Poppaea, caso contrário, não eram levados em consideração para a obtenção do ius liberorum. Coll.16,3,4 (= PS 4,8,4): Sui heredes sunt primo loco filius filia in potestate patris constituti: nec interest, si adoptivi sint an naturales et secundum legem Iuliam Papiamve quaesiti, modo maneant in potestate. "São herdeiros em primeiro lugar o filho e a filha estabelecidos sob a potestas do pai; e não interessa se são adotivos ou naturais, e segundo a Lex Iulia et Papia apenas se permanecem sob a 
em partos diferentes ${ }^{346}$, de serem dispensadas da tutela perpétua (tutela mulierum). ${ }^{347}$

potestas". Independia, na contagem, o sexo das crianças. Gai. 8 ad l. Iul. et Pap. D.50,16,148: Non est sine liberis, cui vel unus filius unave filia est: haec enin enuntiatio 'habet liberos' 'non habet liberos' semper plurativo numero profetur, sicut et pugillares et codicili: "Não é sem filhos, aquele que tem um filho ou uma filha, pois esta expressão 'têm filhos', 'não tem filhos' sempre se expressa no número plural, como as taboinhas e os codicilos:"; Gai. 10 ad Iul. et Pap. D.50,16,149: Nam quem sine liberis esse dicere non possumus, hunc necesse est dicamus liberos habere. "Pois de quem não podemos dizer que está sem filhos, é necessário que digamos que têm filhos". Vejam-se M. MARRONE, Istituzioni cit. (nota 48 supra), p.268; M. ZABŁOCKA, Il 'ius trium liberorum' nel diritto romano cit. (nota 72 supra), pp.372;375; R. AsTOLFI, La Lex Iulia et Papia cit. (nota 12 supra), pp.24;27;328;336-337; Idem, Femina probrosa cit. (nota 96 supra), p.58; Idem, Note per una valutazione storica della 'Lex Iulia et Papia', in SDHI 39 (1973), p.189; G. LONGO, Lex Iulia de maritandis ordinibus e Lex Papia Poppaea cit. (nota 103 supra), p.811; R. BESNIER, L'application des lois caducaires cit. (nota 10 supra), p.105; D. NöRR, The matrimonial Legislation of Augustus cit. (nota 54 supra), p.351; G. IMPALLOMENI, In tema di vitalità e forma umana cit. (nota 143 supra), pp.277-282.

${ }^{345}$ De acordo com T. Spagnuolo Vigorita, Casta Domus cit. (nota 26 supra), p.30, nota 75, somente a Lex Papia Poppaea teria concedido o ius liberorum às libertas com quatro filhos. Veja-se E. CUQ, Les lois d'Auguste cit. (nota 145 supra), p.125.

${ }^{346}$ Segundo M.C. GioRdANI, O Novo Código Civil à Luz do Direito Romano cit. (nota 63 supra), pp.32-33, Augusto instituiu o "registro de nascimento" para possibilitar a aplicação da Lex Aelia Sentia de 4 d.C. Este "registro" facilitava a prova do número de filhos para que os cônjuges gozassem do ius liberorum. De acordo com E. CuQ, Les lois d'Auguste cit. (nota 145 supra), p.125, também os filhos spurii eram contados para a concessão do ius liberorum, pois também eram inscritos no album.

A Lex Iulia et Papia não considerava para efeitos de concessão do ius liberorum a contagem do filho que nasceu morto, situação que foi mantida pelo Senatusconsulto Tertuliano, da época de Adriano (117-138). Neste sentido, Paul. 1 ad l. Iul. et Pap. D.50,16,129: Qui mortui nascuntur, neque nati neque procreati videntur, quia numquam liberi appellari potuerunt. "Os que nascem mortos não são considerados nascidos, nem procriados, porque nunca puderam ser chamados de filhos". O neonato deveria sobreviver, pelo menos, até o nominem dies, ou seja, o nono dia de vida para os meninos e o oitavo para as meninas, quando ocorria a cerimônia da lustratio e os pais davam o nome à criança, conforme UE 15,2 e 16,1-a. Quanto aos denominados ostenta, monstra, prodigia, portenta, a Lex Iulia et Papia contava-os como filhos, situação que foi alterada pelo Senatusconsulto Tertuliano, pois não beneficava à mãe que desse à luz um ser monstruoso ou prodigioso, que não tivesse a forma humana. Vejam-se H.M.F. MADEIRA, O Nascituro no Direito Romano cit. (nota 8 supra), pp.88-89, nota 173; J.C. MoReIRA Alves, A forma humana no Direito Romano, in Estudos de Direito Romano - José Carlos Moreira Alves, Brasília, Senado Federal, 2009, pp.116-118; D. DALlA, Status e rilevanza dell'ostentum, in Ricerche di diritto delle persone, Torino, G. Giappichelli, 1995 , pp.30-31;33;35-37; Idem, D. 50,16,135: Sui perché di uma 'Lex Specialis' cit. (nota 125 supra), pp. 343-352; G. IMPALLOMENI, In tema di vitalità e forma umana cit. (nota 143 supra), p.282.

347 Com a dispensa da tutela pelo ius liberorum, as mulheres, utilizando-se uma linguagem moderna, adquiriam a plena "capacidade de agir". A Lex Papia Poppaea liberou da tutela a liberta que tivesse quatro filhos, e ela teria a capacidade para testar sem a auctoritas do patrono (testamenti factio ativa), podendo até excluí-lo. Sem dúvida, a legislação matrimonial contribuiu para a "emancipação feminina" e na época de Gaio, no século II, a tutela mulierum era mais especiosa que verdadeira. Vejam-se Gai. 1,145;1,190;1,194; 3,42;3,44;3,45;UE26,8;29,3. PS.4,9,1: Matres tam ingenuae quam libertinae cives Romanae, ut ius liberorum consecutae videantur, ter et quater peperisse sufficit, dummodo vivos et pleni temporis pariant. "Às mães cidadãs romanas, tanto as ingênuas quanto as libertas, a fim de que obtenham o ius liberorum, basta ter dado à luz, três e quatro [vezes] respectivamente, contanto que vivos e gerados de pleno tempo" e PS.4,9,2: Quae semel uno partu 'tres' filios edidit, ius liberorum non consequitur: non enim ter peperisse, sed semel partum fudisse videtur, nisi forte per intervalla pariat. "Não é obtido o ius liberorum por aquela que, uma vez, dá à luz três filhos em um único parto: de fato, é considerado não ter dado à luz três [vezes], mas ter dado à luz uma vez, exceto se, porventura, desse à luz durante intervalos [de tempo]'. Este último texto apresenta uma opinião diferente de uma passagem do mesmo jurista. Paul. 2 ad l. Iul. et Pap. D.50,16,137: 'Ter enixa' videtur etiam quae trigeminos pepererit. "Se considera que aquela 'que deu à luz três vezes' é também a que tenha dado à luz trigêmeos". Em relação aos passos PS. 4,9,2 e D.50,16,137, defende M. ZABŁOCKA, Il 'ius trium liberorum' cit. (nota 103 supra), p.370 que o trecho do Digesto foi o entendimento adotado pela Legislação matrimonial de Augusto. Esta divergência entre os textos de um mesmo jurista talvez fosse uma forma de Paulo expressar as diferentes opiniões da jurisprudência. ASTOLFI defende que o passo PS 4,9,2 não é de autoria do jurisconsulto Paulo, mas de origem pós-clássica. Vejam-se também R. AsTOLFI, La Lex Iulia et Papia cit. (nota 15 supra), pp.72-73;219;316, nota 13; Idem, Note per una valutazione storica della 'Lex 
Os homens, ingênuos e libertos, obtinham o ius liberorum quando tivessem, dentro do matrimônio legítimo, três filhos. Em algumas situações excepcionais, previstas na lex Iulia de maritandis ordinibus, o ius liberorum foi concedido, primeiramente pelo Senado e depois pelo imperador, para mulheres sem filhos, ou com menos de três filhos, ou para aquelas que já tivessem perdido os filhos procriados ${ }^{348}$ ou até mesmo para homens solteiros e sem filhos. ${ }^{349}$

Iulia et Papia' cit. (nota 36 supra), p.189; J.C. Matos Peixoto, Curso de Direito Romano cit. (nota 7 supra), p.271; M. MARRONE, Istituzioni cit. (nota 48 supra), p.268; D. NÖRR, The matrimonial Legislation of Augustus cit. (nota 54 supra), pp.351;355; G. IMPALLOMENI, In tema di vitalità e forma umana cit. (nota 143 supra), p.282; A. BOUCHÉ-LECLERCQ, Les lois démographiques d'Auguste cit. (nota 36 supra), p.275, nota 3; E. MALDOnAdo De LizALDE, Lex Iulia de Maritandis Ordinibus cit. (nota 122 supra), p.549.

Gaio observa em suas Institutas, Gai.1,194, que se a tutela da liberta fosse Atiliana ou Fiduciária, era suficiente, para a obtenção do privilégio do ius liberorum, a procriação de três filhos: Tutela autem liberantur ingenuae quidem trium liberorum iure, libertinae vero quattuor, si in patroni liberorumve eius legitima tutela sint; nam ceterae, quae alterius generis tutores habent, veluti Atilianos aut fiduciarios, trium liberorum iure tutela liberantur. "As ingênuas libertam-se também da tutela tendo três filhos e as libertas quatro, desde que se encontrem sob a tutela legítima do patrono ou de seus filhos; pois, as demais, que têm tutores de outra espécie, como os tutores Atilianos ou fiduciários, libertam-se da tutela tendo três filhos".

${ }^{348}$ PS 4,9,9: Ius liberorum mater habet, quae tres filios aut habet aut habuit, aut neque habet neque habuit. Habet, cui supersunt; habuit, quae amisit; neque habet neque habuit, quae beneficio principis ius liberorum consecuta est. "Tem o ius liberorum a mãe que têm ou teve, ou não têm ou não teve, três filhos. Ela têm filhos quando estes sobrevivem; teve se perdeu-lhes; não os têm ou não os teve quando obteve o ius liberorum por benefício do príncipe".

${ }^{349}$ Segundo F. SAMPER, Sobre el destino del 'ius liberorum' cit. (nota 105 supra), pp.8 e 19; M. ZABŁOCKA, Il 'ius trium liberorum' cit. (nota 103 supra), pp.367;378;383; A. BOUCHÉ-LECLERCQ, Les lois démographiques d'Auguste cit. (nota 36 supra), p.270, tanto os homens quanto as mulheres podiam ser beneficiados pelo ius liberorum. No início do Principado, não era fácil obtê-lo. Plínio, o Jovem, solicita e recebe a concessão extraordinária do imperador Trajano (Plin. Iun. Paneg. 2,15) e narra o fato ao seu amigo Crispo; o mesmo autor narra que Calígula também recebeu o ius liberorum, mesmo sendo solteiro (Dio Cass. $59,15,1)$, para ter a capacitas sucessória. Marcial também confirma ter recebido a concessão de Tito e de Domiciano (Mart. Epigr.2,91-92;3,95;8,31;9,97;10,60). Quanto ao procedimento, o imperador concedia o ius liberorum ao solicitante por meio de um rescrito, um dos tipos de constituição imperial. Iniciava-se com um pedido por escrito (libelli, preces, supplicationes). A resposta era escrita logo abaixo da solicitação (subscriptiones). O pedido poderia ser realizado reiteradas vezes. Vejam-se Plin. Iun. Ep. 10,95: (...) cum metiam in senatu adfirmare soleam non excessive me numerum, quem apud amplissimum ordinem suffecturum mihi professus sum. Verbos e expressões utilizados para se fazer este pedido ao imperador podem ser vistos em Martial. Epigr. 2,91 (quod fortuna vetat, fieri permitte videri, natorum genitor credar ut esse trium);2,92 (roganti);8,31 (sed eam supplicibus Dominum lassare libellis desine: et in patriam serus ab urbe redi. Nam dum tu longe, deserta uxore tres quaeris liberos, quattuor inveniens); 9,66 (petis supplicis libellis).

Para E. Vera-CruZ, Senatus-Consulta cit. (nota 106 supra), p.202: "Esta concessão do ius liberorum como graça imperial, em total revelia das condições geralmente exigidas para isso, relaxou a severidade daquela legislação, desvirtuando o seu objetivo de prêmio à maternidade". Sem dúvida, estas concessões imperiais indicam um relaxamento nas leis matrimoniais, sendo que seu próprio mentor, Augusto, recebeu do Senado o ius liberorum sem ter um único filho com Lívia, que também recebeu a concessão em 9 d.C. Outra beneficiada foi Otávia, irmã de Augusto. No decorrer do Principado, as concessões tornam-se mais numerosas à medida que o escopo da legislação matrimonial sofre alterações e fica cada vez mais distante da consciência social. Conforme Dio Cass. 55,2,5-7 e 56,32,1-4. Vejam-se S. RicCOBOnO, La politica demografica cit. (nota 103 supra), p.576; V. ARANGIO-RUIZ, Istituzioni cit. (nota 53 supra), p.444; C. ORTíN GARCÍA, Edad, Matrimonio cit. (nota 103 supra), p.517, nota 28; J.A. FIELD JR., The purpose cit. (nota 129 supra), p.408, nota 37;409; D. NöRR, The Matrimonial Legislation of Augustus cit. (nota 54 supra), p.356; R. Astolfi, La Lex Iulia et Papia (nota 15 supra), pp.63;81; B. BIONDI, La legislazione di Augusto cit. (nota 56 supra), pp.137-138; A. BouChÉ-LeClerCQ, Les lois démographiques d'Auguste cit. (nota 36 supra), p.277; 
A lex Papia Poppaea realizou algumas alterações quanto ao direito das sucessões nas relações de patronato previstas no Edito do pretor, aumentando os direitos do patrono.

De acordo com o Edito do pretor, se o liberto morresse sem testamento ( $a b$ intestato), havia a distinção de três situações: (a) se o liberto teve filhos naturales, ou seja, procriados por ele, estes filhos sucediam ao liberto e excluíam o patrono da sucessão; (b) se o liberto teve filhos adotivos ou pessoas in manu, metade do patrimônio cabia a eles, metade ao patrono; e (c) se o liberto não teve filhos, o patrono o sucedia. ${ }^{350}$

A lex Papia Poppaea apresentou, para estimular a procriação, uma novidade em relação aos direitos sucessórios entre os patronos ingênuos ${ }^{351}$ e os libertos: o ius liberorum igualava a posição sucessória do patrono em relação aos filhos do liberto ou da liberta (portio virilis) e lhe assegurava o direito de suceder tanto se o liberto fizesse testamento quanto se ele morresse sem testamento ${ }^{352}$ : o patrono sucedia mesmo na presença de filhos

E. MaLdonado De LizALDE, Lex Iulia de Maritandis Ordinibus cit. (nota 122 supra), pp.549.

De acordo com J.C. TELlo, La concesión discrecional cit. (nota 161 supra), pp.771-775 e T. SPAGNUOLO Vigorita, Casta Domus cit. (nota 26 supra), pp.10;60;151, nota 214;154, nota 227, no período de Augusto até Calígula, a concessão do ius trium liberorum era realizada pelo Senado. A partir de Cláudio o príncipe outorgava este benefício. Esta concessão, pelo menos até o império de Galba, foi discricionária e realizada de forma seletiva (Suet. Galba 14,3: iura trium liberorum vix uni atque alteri ac ne his quidem nisi ad certum praefinitumque tempus).

A política de concessões e privilégios é comprovada em uma passagem do Digesto, na qual Ulpiano afirma que o princeps não estava submetido às leis matrimoniais, beneficiando igualmente a sua esposa. Ulp. $13 \mathrm{ad}$ l. Iul. et Pap. D.1,3,31: Princeps legibus solutus est: Augusta autem licet legibus soluta non est, principes tamen eadem illi privilegia tribuunt, quae ipsi habent. "O príncipe não está sujeito às leis. Embora sua esposa Augusta não esteja livre das leis, os príncipes, todavia, atribuem a ela os mesmos privilégios que eles próprios possuem". Sobre o ius liberorum defende J.C. TELLO, op.cit., p.777 que este prêmio do imperador era reservado às situações em que não era possível a procriação natural ao solicitante da concessão. Também afirma que a concessão durava até o término do mandato do imperador que a concedia. Veja-se Cels. 33 dig. D. $50,17,191$.

${ }^{350}$ R. Astolfi, La Lex Iulia et Papia cit. (nota 15 supra), pp.214-215; A. BouChÉ-LeCLERCQ, Les lois démographiques d'Auguste cit. (nota 36 supra), p.272. Se o liberto fizesse o testamento, mas os deserdassem ou se eles não quisessem suceder-lhe, o Edito do pretor concedia ao patrono a bonorum possessio contra tabulas e ele poderia receber a metade da herança. O pretor considerava o patrono herdeiro necessário em relação à metade dos bens do liberto.

351 A patrona ingênua que tiver dois filhos ou a liberta, que tiver três, tinham em relação aos bens do liberto os mesmos direitos que o edito concedia ao patrono. Se gozassem do ius liberorum, teriam os mesmos direitos atribuídos ao patrono pela Lex Papia Poppaea. Veja-se R. Astolfi, La Lex Iulia et Papia cit. (nota 15 supra), pp.221-222;365; Idem, Note per una valutazione storica della 'Lex Iulia et Papia' cit. (nota 36 supra), p.189.

${ }^{352}$ R. Astolfi, La Lex Iulia et Papia cit. (nota 15 supra), pp.214-215;218-220;336-337;362-363. Este direito também era estendido aos descendentes masculinos do patrono em linha reta, até o terceiro grau. Se o liberto morresse depois do patrono e sem testamento, mas tivesse tido filhos naturales, os descendentes do patrono não poderiam suceder ao liberto. Se as descendentes femininas do patrono gozassem do ius liberorum, a Lex Papia Poppaea concedia-lhes a ampliação de seus direitos sucessórios, tornando-os iguais aos dos descendentes masculinos. Conforme UE 29,4: Liberi patroni virilis sexus eadem iura in bonis libertorum parentum suorum habent, quae et ipse patronus. "Os filhos varões do patrono têm, quanto aos bens dos libertos de seus pais, o mesmo direito que o patrono"; UE 29,5: Feminae vero ex lege quidem Duodecim Tabularum perinde ius habent, atque masculi patronorum liberi; contra tabulas autem testamenti liberti aut ab intestato contra suos heredes non naturales bonorum possessio eis non competit; sed si ius trium 
naturales.

O patrono se tornava herdeiro em igualdade com os filhos do liberto e recebia uma

parte da quota na sucessão, caso o liberto tivesse o patrimônio igual ou superior a 100.000 (cem mil) sestércios e tivesse menos de 3 (três) filhos. ${ }^{353}$

Se o liberto tem um filho, o patrono obtém a metade do patrimônio; se o liberto têm

liberorum habuerunt, etiam haec iura ex lege Papia Poppaea nanciscuntur. "As mulheres também, pela Lei das XII Tábuas, têm os mesmos direitos que os filhos varões dos patronos. Não lhes cabe, contudo, a posse dos bens contra o testamento do liberto falecido intestado em detrimento dos herdeiros deste, que sejam naturais; mas tendo ela três filhos, obtêm igualmente tal direito pela Lei Papia Poppaea"; Gai. 3,45: Quae diximus de patrono, eadem intellegemus et de filio patroni; item de nepote ex filio et de pronepote ex nepote filio nato prognato. "Aplica-se ao filho do patrono, bem como ao seu neto, nascido de filho, e ao bisneto, nascido do neto pelo filho, o mesmo já dito a respeito do patrono"; Clem. 10 ad l. Iul. et Pap. D.38,2,39: Patroni filia, si in adoptiva familia sit, ad bona libertorum paternorum admittitur. "A filha do patrono, se estivesse em uma família adotiva, é admitida nos bens dos libertos de seu pai”. Vejam-se também Gai. 3,$46 ; 3,47$.

${ }^{353}$ Gai.3,42; Ulp. 10 ad l. Iul. et Pap. D.37,14,16pr.; Inst. 3,7,2; Sever. et Ant. C.6,4,4 (531). Vejam-se J. Ellul, Histoire des Institutiones, Paris, Presses Universitaires de France, 1961-1972, trad. it. de Giovanni Ancarani e Elisa Nicolini, Milano, U.Mursia, 1981, pp.299-300; R. AstolfI, La Lex Iulia et Papia cit. (nota 15 supra), pp.72;82;213-215;310, nota 33;334-335; A. BOUCHÉ-LECLERCQ, Les lois démographiques d'Auguste cit. (nota 36 supra), p.272. As alienações fraudulentas realizadas pelo liberto para diminuir o seu patrimônio para um valor menor que 100.000 sestércios e com isso fraudar a Lex Iulia et Papia, eram nulas. Também aqueles atos que diminuíssem apenas a portio debita ao patrono poderiam ser impugnados por uma actio Calvisiana, no âmbito da bonorum possessio sine tabulis ou com a actio Fabiana no âmbito da bonorum possessio contra tabulas. A quantia de cem mil sestércios coincide com a estabelecida no Gnomon ( $\S 30$ e 32) para a limitação ou exclusão da capacitas testamentária dos homens que não se casam ou não têm filhos (vide nota 402 infra). De acordo com R. ASTOLFI, Note per una valutazione storica della 'Lex Iulia et Papia' cit. (nota 36 supra), pp.195;215, não é fácil estabelecer qual o valor de 100.000 sestércios na época de Augusto. Admite-se que seria possível comprar trinta hectares de terra com essa quantia, o que caracterizaria que a Legislação Matrimonial estabeleceu suas sanções principalmente para a classe rica. No decorrer do Principado, após inúmeras crises econômicas, a desvalorização da moeda fez com que aumentasse a quantidade de homens com um patrimônio superior ao valor estabelecido pela Lex Iulia et Papia.

O Gnomon (norma, forma) do Idiólogo foi um regulamento administrativo elaborado por um funcionário superior fiscal do Egito Romano (o Idiólogo), aos demais funcionários encarregados das finanças imperiais. Foi descoberto em 1912 em Fayûn no Egito e contêm 115 artigos (ou parágrafos) no total. Os mandata de Augusto relativos ao matrimônio estão dispostos nos artigos 23 a 31. De acordo com a sua finalidade e natureza, as normas do Gnomon que fazem referência às Leis Matrimoniais de Augusto podem ser divididas em duas partes principais: uma que tem por escopo o confisco dos bona caduca (parágrafos 27-30;32) e outra que trata do confisco do dote em caso de infração às leis e as alterações quanto a capacitas entre cônjuges (parágrafos 6;24-26;31). Os parágrafos 24 a 26 previam que o marido podia ser privado da retenção do dote caso não tivesse filhos, descumprindo as disposições das Leis matrimoniais. Os parágrafos 27 e 28 descrevem a aplicação dos Senatusconsultos Persicianum e Calvisianum. Portanto, a importância da Lex Iulia et Papia como fonte de rendas fiscais pode ser verificada em inúmeros documentos encontrados no Egito. Esta província, em razão de sua constituição e administração diferenciadas, apresentava uma carga fiscal maior que as demais. Segundo R. Astolfi, La Lex Iulia et Papia cit. (nota 15 supra), p.358, não se deve descartar a hipótese de que algumas leis locais tiveram tanto sucesso e resultados positivos, que posteriormente foram vigentes em todo o Império. Nas palavras de R.ASTOLFI, Note per una valutazione storica della 'Lex Iulia et Papia' cit. (nota 36 supra), p.220, l'Egitto conosce la figura del caelebs, del orbus, del pater e della mater solitarii, la riduzione di capacitas nelle successioni reciproche dei coniugi, il SC Persiciano, il premio ai delatores, l'avocazione dei bona vacantia alla cassa imperiale e il divieto della professio in albo dei figli spuri. Ao estabelecer a política fiscal do Egito, o Gnomon é o principal documento que demonstra a aplicação dos dispositivos da Lex Iulia et Papia nas províncias romanas. Vejam-se R. BESNIER, L'application des lois caducaires cit. (nota 10 supra), pp.100-102;105-106;118; A. GUARINO, Storia del diritto romano cit. (nota 103 supra), p.632; R. ASTOLFI, op.cit., pp.83;358. 
dois filhos, ele recebe um terço. ${ }^{354}$

Gai. 3,42: Postea lege Papia aucta sunt iura patronorum, quod ad locupletiores libertos pertinet. Cautum est enim ea lege, ut ex bonis eius, qui sestertiorum centum milium plurisve patrimonium reliquerit, et pauciores quam tres liberos habebit, sive in testamento facto sive intestato mortuus erit, virilis pars patrono debeatur. Itaque cum unum filium unamve filiam heredem reliquerit libertus, proinde pars demidia patrono debetur, ac si sine filio filiamve moreretur; cum vero duos duasve heredes reliquerit, tertia pars debetur; si tres relinquat, repellitur patronus.

"Mais tarde, pela lex Papia, aumentaram os direitos dos patronos a respeito dos libertos mais ricos. Assim, previu esta lei, que caberia ao patrono um quinhão viril dos bens de quem deixasse um patrimônio de cem mil ou mais de cem mil sestércios, e menos de três

\footnotetext{
${ }^{354}$ Gai. 3,44: Sed postea lex Papia cum quattuor liberorum iure libertinas tutela patronorum liberaret et eo modo concederet eis etiam sine tutoris auctoritate condere testamentum, prospexit, ut pro numero liberorum, quos liberta mortis tempore habuerit, virilis pars patrono debeatur; ergo ex bonis eius quae omnes quattuor incolumes liberos reliquerit, quinta pars patrono debetur; quodsi omnibus liberis superstes fuerit, tota hereditas ad patronum pertinet. "Mas depois, como a lei Pápia libertasse da tutela dos patronos as libertas com quatro filhos, concedendo-lhes assim a faculdade de testar, mesmo sem a assistência do patrono tutor, a mesma lei dispôs coubesse ao patrono uma parte da herança igual à de cada um dos filhos, que tivesse a liberta por ocasião de sua morte. Por conseguinte, deve-se ao patrono uma quinta parte dos bens da liberta, que deixar quatro filhos vivos; mas se ela sobreviveu a todos os filhos, a herança pertence integralmente ao patrono"; UE 29,3: Lex Papia Poppaea postea libertas quattuor liberorum iure tutela patronorum liberavit; et cum intulerit, iam posse eas sine auctoritate patronorum testarit, prospexit, ut pro numero liberorum libertae superstitum virilis pars patrono debeatur. "Posteriormente, em virtude da Lei Pápia Popea, as libertas ficaram livres da tutela dos patronos, por terem quatro filhos; e podendo elas assim testar sem a assistência do tutor, a mesma lei dispôs que o patrono pudesse reclamar uma parte igual à de cada um dos filhos supérstites da liberta"; UE 29,4: Liberi patroni virilis sexus eadem iura in bonis libertorum parentum suorum habent, quae et ipse patronus. "Os filhos varões do patrono têm, quanto aos bens dos libertos de seus pais, o mesmo direito que o patrono".
}

A Lex Papia Poppaea não alterou os direitos da patrona sobre os bens da liberta morta sem testamento: a patrona continua a ser preferida em relação aos filhos da liberta (Gai. 3,51). Se a liberta fez o testamento, há duas situações: ou a liberta tem quatro filhos e exclui a patrona ou a patrona tem direito à metade do patrimônio (pars dimidia), desde que tenha dois filhos se for ingênua e três se for liberta. UE 29,6: Patronae in bonis libertorum illud ius tantum habebant, quod lex Duodecim Tabularum introduxit; sed postea lex Papia patronae ingenuae duobus liberis honoratae, libertinae tribus, id ius dedit, quod patronus habet ex edictio. "As patronas, com relação aos bens de seus libertos, tinham apenas o direito que inicialmente foi conferido pela Lei das XII Tábuas, mas depois, pela Lei Papia, se deram à patrona ingênua com dois filhos ou liberta com três, os mesmos direitos que tem o patrono por força do edito"; UE 29,7: Item ingenuae trium liberorum iure honoratae eadem lex id ius dedit, quod ipsi patrono tribuit. "Ainda, pela mesma lei, à patrona com três filhos foi dado o mesmo direito que se atribuiu ao próprio patrono". Vejam-se também Gai. 3,50-53.

Vejam-se F. SAMPER, Sobre el destino del 'ius liberorum'cit. (nota 105 supra), p.19; M. ZABŁocKA, Il 'ius trium liberorum' cit. (nota 103 supra), p.368; R. Astolfi, La Lex Iulia et Papia cit. (nota 15 supra), pp.72;75;213-215;218;221-222;316, nota 13;328; Idem, Note per una valutazione storica della 'Lex Iulia et Papia' cit. (nota 36 supra), p.189; L.F. RADITSA, Augustus Legislation cit. (nota 49 supra), p.328; D. NÖRR, The matrimonial Legislation of Augustus cit. (nota 54 supra), p.351; A. BOUCHÉ-LECLERCQ, Les lois démographiques d'Auguste cit. (nota 36 supra), pp.273-274; C. FERRINI, I commentari di Terenzio Clemente 
filhos, quer fizesse testamento quer morresse intestado. Portanto, deixando como herdeiro um filho ou uma filha, deve-se ao patrono do liberto a metade do patrimônio, como se morresse sem filho ou filha; se o liberto deixar dois ou duas herdeiras, deve-se a terça parte ao patrono; se deixar três filhos, o patrono é excluído".

O patrono era totalmente excluído tanto na sucessão $a b$ intestato, quanto na sucessão testamentária, se o liberto tivesse três filhos e a liberta quatro. ${ }^{355}$

No decorrer do Principado, a partir da legislação demográfica de Augusto, inúmeros benefícios, direitos e deveres surgiram com a concessão do ius liberorum, tanto em relação ao direito público quanto ao direito privado. Vejamos alguns casos:

(a) As leis matrimoniais de Augusto reconheciam, para a obtenção das vantagens e prêmios do ius liberorum, apenas os filhos legítimos e nascidos de iustae nuptiae. ${ }^{356}$

A partir do Senatusconsulto Tertuliano, promulgado na época do imperador Adriano, ${ }^{357}$ a mulher que tivesse três filhos tinha o direito sucessório ab intestato aos bens

cit. (nota 308 supra), p.259.

355 Vejam-se M. ZABŁOCKA, Il 'ius trium liberorum' cit. (nota 103 supra), pp.369;379; G. LoNGo, Lex Iulia de maritandis ordinibus e Lex Papia Poppaea cit. (nota 103 supra), p.811; L.F. RADITSA, Augustus Legislation cit. (nota 49 supra), p.328; R. ASTOLFI, La Lex Iulia et Papia cit. (nota 15 supra), pp.83;213214;328; A. BouCHÉ-LeCLERCQ, Les lois démographiques d'Auguste cit. (nota 36 supra), p.272. Na opinião de R. BESNIER, L'application des lois caducaires cit. (nota 10 supra), p.110, esta passagem de Gaio indica que a Lex Papia Poppaea era uma "legislação de classe", pois pretendia atingir apenas os cidadãos romanos mais ricos, os denominados centenarii, aqueles que tivessem um patrimônio de cem mil sestércios ou mais. Veja-se Ulp. 10 ad l. Iul. et Pap. D.37,14,16pr.

${ }^{356}$ Ver nota 105, Pap. Mich. 7,436 (a.138) e Pap. Mich. 3,169 (a.145), sobre o impedimento quanto ao registro de nascimento dos filhos ilegítimos (profiteri in albo). Vejam-se R. Astolfi, La Lex Iulia et Papia cit. (nota 15 supra), p.329; Idem, Note per una valutazione storica della 'Lex Iulia et Papia' cit. (nota 36 supra), p.190.

${ }^{357}$ Inst. 3,2,2: Postea autem senatus consulto Tertulliano, quod divi Hadriani temporibus factum est, plenissime de tristi successione matri, non etiam aviae deferenda cautum est: ut mater ingenua trium liberorum ius habens, libertina quattuor ad bona filiorum filiarumve admittatur intestatorum mortuorum, licet in potestate parentis est, ut scilicet, cum alieno iure subiecta est, iussu eius adeat, cuius iuri subiecta est. "Mas posteriormente, pelo senatusconsulto Tertuliano, feito nos tempos do divino Adriano, providenciou-se de modo mais completo sobre deferir-se à mãe, pela sua triste sucessão, mas não à avó. Assim, a mãe ingênua tendo o direito dos três filhos, e a liberta, dos quatro, foram admitidas aos bens dos filhos ou filhas mortos intestados, embora estivessem sob o pátrio poder; de modo a, estando sujeita ao pátrio poder, fazer a adição da herança a mandado daquele a quem está sujeita". Veja-se R. Astolfi, La Lex Iulia et Papia cit. (nota 15 supra), p.72. De acordo com AstolfI, op.cit., p.356, a política de Adriano favorecia os cidadãos das províncias na ascensão aos altos cargos públicos do Império, eliminando os privilégios da "estirpe itálica". De acordo com R. Astolfi, Note per una valutazione storica della 'Lex Iulia et Papia' cit. (nota 36 supra), p.217, o governo de Adriano deu prioridade ao escopo fiscal da legislação caducária, v.g., quando promulgou um senatusconsulto (de data e denominação desconhecidas) que negava o direito dos patres sobre o fideicomisso deixado aos peregrini e o avocou diretamente ao Fisco. Na opinião de A. BOUCHÉ-LECLERCQ, Les lois démographiques d'Auguste cit. (nota 36 supra), p.281, Adriano teve um ideal de generosidade ao promulgar o senatusconsulto Tertuliano e sua política era contrária a qualquer interesse fiscal ou arrecadatório. De acordo com Dio Cass. 69,23, Adriano era indulgente, mesmo na aplicação de penas e condenações, aos pais com grande número de filhos. 
dos filhos falecidos, independentemente se fossem legítimos ou espúrios ${ }^{358}$, desde que ingênuos e sui iuris. ${ }^{359}$

${ }^{358}$ A partir do Senatusconsulto Tertuliano, a mãe que gozasse do ius liberorum podia herdar dos filhos espúrios, também denominados vulgo quaesiti, ou seja, "obtidos vulgarmente". Ulp. 13 ad Sab. D.38,17,2,1: Filium autem vel filiam accipere debemus, sive iuste sint procreati vel vulgo quaesiti; idque in vulgo quaesitis et Iulianus libro quinquagensimo nono Digestorum scripsit. "Mas devemos compreender por filho ou filha, tanto os que tenham sido procriados legitimamente, como os que tenham sido obtidos vulgarmente; e isto escreveu também Juliano no livro quinquagésimo nono do Digesto, a respeito dos filhos obtidos vulgarmente". Vejam-se também Cels. 29 dig. D.1,5,19 e a nota 118 supra. Há possibilidade que desde a época de Cláudio já fosse possível que a mulher com o ius liberorum pudesse suceder aos filhos ab intestato, conforme Inst. 3,3,1: Sed hae iuris angustiae postea emendatae sunt. Et primus quidem divus Claudius matri ad solatium liberorum amissorum legitimam eorum detulit hereditatem. "Mas esses rigores do direito [da mãe não poder receber heranças do filho] foram depois abrandando. O divino Cláudio foi certamente o primeiro que, para consolar uma mãe da perda dos filhos, deferiu-lhe a legítima herança deles". Na opinião de R. Astolfi, La Lex Iulia et Papia cit. (nota 12 supra), p.356, percebe-se neste caso uma ruptura entre o escopo demográfico e a tutela ético-social que Augusto buscava alcançar para aumentar a dignidade da classe dirigente romano itálica. Também a situação das feminae probrosae, no âmbito do direito sucessório, foi melhorada na época de Adriano, pelo senatusconsulto Tertuliano. Esta medida permitiu a capacitas às feminae probrosae em relação ao direito de sucessão dos bens de seus fillhos. Ulpiano salienta a oposição entre o regime da sucessão testamentária e do Senatusconsulto Tertulliano. Ulp. 13 ad Sab. D.38,17,2,4: Si mulier sit famosa, ad legitimam hereditatem liberorum admittetur. "Se a mulher fosse infame, seria admitida à herança legítima de seus filhos". Neste trecho de Ulpiano, o adjetivo famosa pode ser compreendido no sentido amplo de mal-afamada ou no sentido específico de infamis. Ambos os sentidos referiam-se às feminae probrosae. Vejam-se, E. NARDI, La 'incapacitas' delle 'feminae probrosae' cit. (nota 96 supra), pp.169-170; R. AstoLFI, Femina probrosa cit. (nota 96 supra), p.49.

De acordo com R. Astolfi, La Lex Iulia et Papia cit. (nota 15 supra), pp.31;56; Idem, Femina probrosa cit. (nota 96 supra), pp.53-58, Idem, Note per una valutazione storica della 'Lex Iulia et Papia', in SDHI 39 (1973), p.217, num período posterior à legislação matrimonial, o filho vulgo conceptus da mater solitaria poderia ser considerado para que ela obtivesse o ius liberorum, desde que a mesma conservasse a honestas da materfamilias. Conforme Pap. 8 resp. D.34,9,16,1, a mater solitaria que tivesse procriado filhos, ainda que vulgo concepti, durante uma relação de concubinato com um alto funcionário do "Estado" não era considerada femina probrosa, mas ingênua de bons costumes.

${ }^{359}$ UE 26,8: Intestati filii hereditas ad matrem ex lege Duodecim Tabularum non pertinet; sed si ius liberorum habeat, ingenua trium, libertina quattuor, legitima heres fit ex senatus consulto Tertulliano, si tamen ei filio neque suus heres sit quive inter suos heredes ad bonorum possessionem a praetore vocatur, neque pater, ad quem lege hereditas bonorumve possessio cum re pertinet, neque frater consanguineus: quod si soror consanguinea sit, ad utrasque pertinere iubetur hereditas. "Pela Lei das XII Tábuas, a herança do filho falecido sem testamento não pertence à mãe; mas se esta tem o direito da prole [ius liberorum], três filhos sendo ingênua, e quatro sendo liberta, torna-se herdeira legítima pelo senatusconsulto Tertuliano, desde que o filho não tenha um herdeiro seu, nem um herdeiro da classe dos herdeiros seus que o pretor chama à posse dos bens; o mesmo se dá se não tem pai a quem por lei pertença a herança ou a posse dos bens efetiva, ou um irmão consanguíneo; pois tendo o filho uma irmã consanguínea, a herança pertence à mãe e à irmã". Tanto o Senatusconsulto Tertuliano (Inst.3,3; PS 4,9; D.38,17 e C.6,56) quanto o Orficiano (cf. Inst.3,3; PS 4,10; D.38,17; C.6,57) transformaram-se em marcos importantes da História do Direito das Sucessões ao estabelecerem que mãe e filhos podiam suceder-se reciprocamente e ao adotarem como base desta relação a cognatio, a filiação materna natural (princípio da consanguinidade).

No Senatusconsulto Orficiano, de 178 d.C., promulgado na época de Marco Aurélio e Cômodo e sob o consulado de P. Velius Rufus e S. Scipio Orphitus, estabeleceu-se que a patrona ingênua com ius liberorum mantinha os direitos sobre a sucessão da liberta sem ius liberorum. A liberta sem o ius liberorum continua submetida à tutela legítima de seu patrono (Gai. 3,43), porém o Senatusconsulto Orficiano converteu seus filhos em herdeiros necessários. Na prática, se a liberta sem o ius liberorum tem filhos, o patrono não pode pretender mais que uma parte igual à de cada um dos filhos supérstites na sucessão testamentária da liberta. O Senatusconsulto Orficiano apresentou como principal novidade os direitos sucessórios legítimos dos filhos sobre os bens das mães, precedendo aos agnados da mãe no chamamento à herança. Justiniano, nas Institutas e no Código, favoreceu a mãe para que fosse chamada à sucessão legítima, independente do número de filhos [Inst.3,3,4; Iust. C.8,58,2 (528)]. Na opinião de T. MARKY, Appunti sul problema della retroattività cit. (nota 
(b) O liberto que tivesse dois filhos ou um único filho que atingisse a idade de cinco anos, não era mais obrigado a prestar qualquer atividade de trabalho (operae, munera) ou fazer doações para o seu patrono $($ dona $) .{ }^{360}$

(c) O pater que tem três filhos ou mais está liberado do cargo de tutor ou de curador (excusatio muneribus civilibus). ${ }^{361}$ A partir do século II d.C., a quantidade de filhos foi um

335 supra), p.260, fundamentada em Ulp. 12 ad sab. D.38,17,1,2, o Senatusconsulto Orficiano tinha normas retroativas.

Vejam-se F. SAMPER, Sobre el destino del 'ius liberorum'cit. (nota 105 supra), pp.23-25; D. DALla, D. 50,16,135: Sui perché di uma 'Lex Specialis' cit. (nota 125 supra), p.347, nota 15; Idem, Status e rilevanza dell'ostentum cit. (nota 346 supra), p.45, notas 35 e 36; H.M.F. MADEIRA, O Nascituro no Direito Romano cit. (nota 8 supra), p.89, nota 173; M. ZABŁOCKA, Il 'ius trium liberorum' cit. (nota 103 supra), p.372; J.C. MoreIRA Alves, Direito Romano cit. (nota 9 supra), pp.747-748; G. LONGO, Lex Iulia de maritandis ordinibus e Lex Papia Poppaea cit. (nota 103 supra), p.811; A.A. CASTRO CORRÊA, O Estoicismo no Direito Romano cit. (nota 33 supra), pp.60;84-85; B. BIONDI, La legislazione di Augusto cit. (nota 56 supra), p.147; C. RUSSo RUgGerI, Ancora sulla donna adottante cit. (nota 125 supra), pp.72-73, nota 51;84-85; G. IMPALLOMENI, In tema di vitalità e forma umana cit. (nota 143 supra), p.282; A. BouCHÉ-LECLERCQ, Les lois démographiques d'Auguste cit. (nota 36 supra), p.281; R. Astolfi, Femina probrosa cit. (nota 96 supra), p.49, nota 84. Segundo E. Vera-CruZ, Senatus-Consulta cit. (nota 106 supra), p.203: "O Senatusconsulto Tertuliano deu seguimento à lei Papia Poppaea (que já havia modificado e completado a lex Iulia de maritandis ordinibus) que parece ter sido concebida com o espírito de reservar o direito de sucessão testamentária aos cidadãos que tivessem filhos".

${ }^{360}$ Cf. Paul. 2 ad l. Iul. et Pap. D.38,1,37pr.: Qui libertinus duos pleresve a se genitos natasve in sua potestate habebit, praeter eum, qui artem ludicram fecerit, quive operas suas, ut cum bestiis pugnaret, locaverit, ne quis eorum operas doni, muneris, aliudve quicquam libertatis causa patrono, patronae, liberisve eorum, de quibus iuraverit vel promiserit, obligatusve erit, dare, facere, praestare debeto; et si non eodem tempore duo in potestate habuerit, vel unum quinquennem, liberabitur operarum obligatione. "O liberto que tiver sob seu poder dois ou mais filhos ou filhas, exceto o que exercer arte cênica, ou que tiver arrendado seus serviços para lutar com as feras, não deve dar, fazer ou prestar ao patrono, ou à patrona, ou aos filhos destes, serviços, doação, presente, ou qualquer outra coisa a respeito das quais jurasse ou prometesse, ou se obrigasse, por causa da liberdade; e se tivesse sob seu poder os dois filhos não ao mesmo tempo, ou tivesse somente um de cinco anos, se liberará da obrigação dos serviços". Conforme uma constituição do imperador Alexandre Severo, Alex. C.6,3,6,1 (224), era da Lex Iulia de maritandis ordinibus a disposição que dispensava o liberto que tivesse dois filhos das operae: Qui autem duos filios in potestate, vel diversis temporibus, habuit, lege Iulia de maritandis ordinibus obligatione operarum liberatur. "Mas aquele que teve dois filhos sob o seu poder, ainda que em períodos diferentes, livra-se da obrigação das operae pela lex Iulia de maritandis ordinibus". O liberto maior de sessenta anos e a liberta maior de cinquenta também estavam dispensados da prestação das operae ao patrono. Vejam-se D. DALLA, D. 50,16,135: Sui perché di uma 'Lex Specialis' cit. (nota 125 supra), p.348; S. RicCOBONO, La politica demografica cit. (nota 103 supra), p.576; E. VolTERRA, Matrimonio cit. (nota 61 supra), p.772, nota 171; R. Astolfi, La Lex Iulia et Papia cit. (nota 15 supra), pp.205-207; 327-328; 330; Idem, Note per una valutazione storica della 'Lex Iulia et Papia' cit. (nota 36 supra), pp.189;197; J.C. Tello, La concesión discrecional cit. (nota 161 supra), p.770; M. ZABŁOCKA, Il 'ius trium liberorum' cit. (nota 103 supra), p.367; L.F. Raditsa, Augustus Legislation cit. (nota 49 supra), p.328; T. Spagnuolo Vigorita, Casta Domus cit. (nota 26 supra), p.30, nota 76; B. BIONDI, La legislazione di Augusto cit. (nota 56 supra), p.133; A. BoUCHÉLECLERCQ, Les lois démographiques d'Auguste cit. (nota 36 supra), pp.272-273; E. MALDONADO DE LIZALDE, Lex Iulia de Maritandis Ordinibus cit. (nota 122 supra), p.552.

${ }^{361}$ Vejam-se D. DAlla, D. 50,16,135: Sui perché di uma 'Lex Specialis' cit. (nota 125 supra), p.348; J. CARCopino, La vie quotidienne à Rome cit. (nota 72 supra), p.11; B. BIONDI, La legislazione di Augusto cit. (nota 56 supra), p.133; R. Astolfi, La Lex Iulia et Papia cit. (nota 15 supra), p.72; A. BouCHE-LeClerCQ, Les lois démographiques d'Auguste cit. (nota 36 supra), pp.275;283. Ulp. 3 opin. D.50,5,2,1: Numerus liberorum aut, septuaginta annorum ab honoribus aut muneribus bis cohaerentibus excusationem non praestat, sed a muneribus tantum civilibus. "O número de filhos, ou [atingir] setenta anos, não escusa para as honras [magistraturas] ou para os cargos à elas inerentes, mas somente para os cargos civis". Mod. 2 excusat.

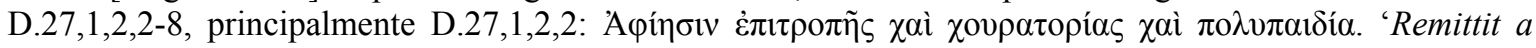


dos motivos de justificação para a dispensa do munus publicum (munera civilia; munera iudicandi) da tutela legítima e Aquiliana. ${ }^{362}$

(d) A filha do pater com mais de três filhos, não poderia ser escolhida como Vestal. $^{363}$

tutela vel curatoria et liberorum multitudo'. "Também o grande número de filhos exime da tutela ou da curatela". Veja-se Inst.1,25pr. Segundo U. RATTI, Studi sulla 'captivitas'cit. (nota 57 supra), pp.65, nota 2;66, o filho que estivesse no cativeiro de guerra não poderia computar-se no número de filhos para a isenção dos ônus públicos. Cf. Ulp. 20 ad Iul. et Pap. D.27,1,18 [20]; Philip. C.10,51,2. Segundo G. Longo, Lex Iulia de maritandis ordinibus e Lex Papia Poppaea cit. (nota 103 supra), p.811; A. BouCHÉ-LeCLERCQ, Les lois démographiques d'Auguste cit. (nota 36 supra), p.283 e A. BURDESE, Manuale cit. (nota 47 supra), p.276, no século III, em 203d.C., estava dispensado do ônus dos munera aquele que tivesse três filhos vivos em Roma, quatro na Itália e cinco nas províncias. Cf. Sever. et Anton. C.5,66,1 (203). Um rescrito de Públio Hélvio Pertinax isentou Silvio Cândido dos munera municipalium, por ele ter dezesseis filhos, cf. Call. 1 de cognit. D.50,6,5,2.

${ }^{362}$ A. Guarino, Profilo del diritto romano cit. (nota 150 supra), p.142; J.C. Tello, La concesión discrecional cit. (nota 161 supra), p.770; M. ZABŁOCKA, Il 'ius trium liberorum' cit. (nota 103 supra), p.380; R. ASTOLFI, La Lex Iulia et Papia cit. (nota 15 supra), pp.317-319; D. DALLA - R. LAMBERTINI, Istituzioni di diritto romano cit. (nota 10 supra), p.130. Na opinião de R. AstolfI, op. cit., pp.114-115, Ulpiano e Papiniano, de acordo com Vat. Frag. 168;169;170;194 e 197, consideraram que os filhos nascidos de um matrimônio ilícito em relação à Lex Iulia et Papia, podiam eximir o pai da gestão da tutela: Vat. Frag. 168: (...) quidam tamen iustos secundum has leges putant dici. Divi quoque Marcus et Lucius Apronio Saturnino ita scripserunt: 'Si instrumentis probas habere te iustos tres liberos, excusationem tuam Manilius Carbo praetor vir clarissimus accipet. Sed iustorum mentio ita accipienda est, ut secundum ius civile quaesiti sint'. “(...) alguns acreditam, entretanto, que se fala dos legítimos segundo estas leis. Também os divinos Marco e Lúcio escreveram a Aprônio Saturnino nos seguintes termos: 'Se demonstras com documentos que tens três filhos legítimos, o pretor Manílio Carbo, homem ilustríssimo, aceitará tua escusa. Porém, a menção de legítimos deve-se tomar no sentido de que estivessem conforme o ius civilee."; Vat. Frag. 169: In adoptionem dati ad hanc causam proderunt. "Aqueles que foram adotados serão úteis para esta causa"; Vat. Frag. 170: Ius liberorum a principe impetratum nec ad hanc causam nec ad munera prodest. "O ius liberorum obtido do príncipe não é vantajoso nem para esta causa nem para os cargos"; Vat. Frag. 194: Iusti autem an iniusti sinti filii, non requiritur; multo minus in potestate necne sint, cum etiam iudicandi onere iniustos filios relevare Papinianus libro V quaestionum scribat. "Não se questiona se os filhos são legítimos ou ilegítimos; e muito menos se estão ou não sob a potestas, visto que Papiniano no livro V quaestionum escreveu que se mitigue aos filhos ilegítimos da obrigação de julgar”.

Os filhos mortos ou desaparecidos na guerra (bello amissi) eram contados com os filhos vivos para a excusatio a muneribus civilibus, como também se procedia para a obtenção dos fasces, prevista no capítulo XXVI da Lex Iulia iudiciorum publicorum e no iudicandi munus, prevista no capítulo XXVII da Lex Iulia iudiciorum privatorum. Vat. Frag. 197: An bello amissi a tutela excusare debeant? Nam et in fascibus sumendis et in iudicandi munere pro superstitibus habentur, ut lege Iulia de maritandis ordinibus de fascibus sumendis et publicorum kapite XXVI, item privarotum kapite vicesimo VII de iudicando cavetur. Et puto constituendum, ut et a tutelis excusent; proinde sive tres bello amiserit sive unum duosve, pro superstitibus cedent. "Os [filhos] desaparecidos na guerra deveriam escusar a tutela? Pois na obtenção dos fasces e na função de julgar [iudicandi munus] são considerados como sobreviventes, tal como se dispõe na Lex Iulia de maritandis ordinibus, sobre a obtenção dos fasces no capítulo XXVI das coisas públicas e também sobre a ação de julgar no capítulo XXVII das privadas. E creio que se estabelecerá uma norma para que também se escusem das tutelas; consequentemente, tanto se perdeu na guerra três como se perdeu um ou dois, todos passarão por sobreviventes". Vejam-se também Ulp. 20 ad Iul. et Pap. D.27,1,18; Inst. 1,25pr.

${ }^{363}$ T. Spagnuolo Vigorita, Casta Domus cit. (nota 26 supra), pp.77; R. Astolfi, La Lex Iulia et Papia cit. (nota 15 supra), p.317, nota 14; B. BIONDI, La legislazione di Augusto cit. (nota 56 supra), p.133-134, nota 3; 143; J.A. FIELD JR., The purpose cit. (nota 129 supra), p.409, nota 44; A. BOUCHÉ-LECLERCQ, Les lois démographiques d'Auguste cit. (nota 36 supra), p.277; E. MALDONADO DE LIZALDE, Lex Iulia de Maritandis Ordinibus cit. (nota 122 supra), p.552, nota 87. Ao descrever os requisitos para a escolha de uma Vestal, Aulo Gélio confirma que a filha dos pais que tivessem o ius liberorum não poderia ser escolhida para esta importante função religiosa (sacra publica). Gell. 1,12,8: Praeterea Capito Ateius scriptum reliquit neque eius legendam filiam, qui domicilium in Italia non haberet, et excusandam eius, qui liberos tres haberet. 
(e) Acelerava-se o cursus honorum do paterfamilias com prole numerosa (contavase, para cada filho, um ano a menos da idade legal para obter uma magistratura). Os candidatos às magistraturas que têm mais filhos são preferidos para assumirem os cargos públicos. ${ }^{364}$ Entre os magistrados eleitos, aquele que tem mais filhos é o mais honrado. ${ }^{365}$

"Além disso, Ateio Capitão deixou escrito que não podia ser escolhida uma filha que não tivesse domicílio na Itália e devia ser escusada a daquele que tivesse três filhos". Sobre este processo de seleção das Vestais disposta na Lex Papia, Aulo Gélio afirma em 1,12,11: Sed Papiam legem invenimus, qua cavetur, ut pontificis maximi arbitratu virgines e populo viginti legantur sortitioque in contione ex eo numero fiat et, cuius virginis ducta erit, ut eam pontifex maximus capiat eaque Vestae fiat. "Mas encontramos na Lei Pápia pela qual se prescreve que, ao arbítrio do pontífice máximo, sejam escolhidas dentre o povo vinte virgens e entre estas seja sorteada uma na assembléia e a designada pela sorte seja 'tomada' [capiat] pelo pontífice máximo e a torne de Vesta". Além disso, as virgens vestais não estavam submetidas à tutela mulierum, conforme Gai.1,145: (...) Loquimur autem exceptis virginibus Vestalibus, quas etiam veteres in honorem sacerdotii liberas esse voluerunt, itaque etiam lege XII Tabularum cautum est. “(...) Do que dizemos [a tutela feminina] porém, se excetuam as virgens vestais, que os antigos quiseram livres em honra do sacerdócio, o que foi, aliás, ordenado pela lei das XII Tábuas". Segundo E.M. AGATI MADEIRA, A condição jurídica das sacerdotisas de Vesta, in Revista da Faculdade de Direito da USP 103 (2008), pp.95;102, Aulo Gélio no trecho 1,12,11 de sua obra Noctes Atticae não fazia referência à Lex Iulia et Papia, mas à Lex Papia de vestalium lectione (de 253 a.C.? ou de 65 a.C.?) que permitiu a participação do povo na escolha das Vestais (sortitio in contione). Eram escolhidas meninas entre seis e dez anos de idade, que apresentassem boa saúde e não podiam ter pais emancipados, libertos ou que tivessem exercido profissão sordida. Para valorizar a castidade das Vestais e a fecundidade das matronas, elas eram dispensadas da tutela mulierum, em razão do ius trium [quattuor] liberorum, o que reflete um grande reconhecimento da res publica em relação a estas mulheres que se colocavam à disposição da utilitas publica. Segundo Dio Cass. 55,22,5, Augusto concedeu

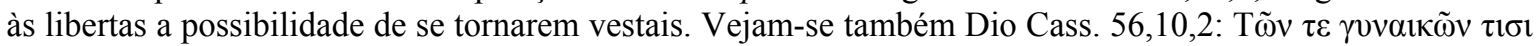

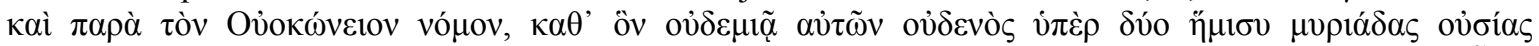

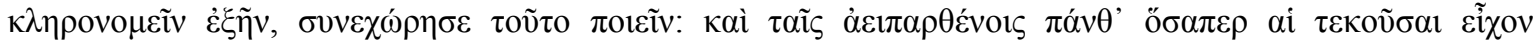

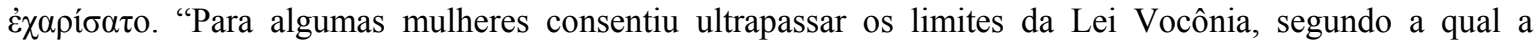
nenhuma delas era lícito herdar de quem tivesse um patrimônio superior a vinte e cinco mil dracmas [cem mil sestércios]; e às virgens Vestais concedeu todos os privilégios dos quais gozavam as mulheres com filhos"; Plut. Numa, 10,5-10.

${ }^{364}$ R. AstOLFI, La Lex Iulia et Papia cit. (nota 15 supra), pp.72;320;326; Idem, Note per una valutazione storica della 'Lex Iulia et Papia' cit. (nota 36 supra), p.197; B. BIONDI, La legislazione di Augusto cit. (nota 56 supra), p.134; L.F. RADITSA, Augustus Legislation cit. (nota 49 supra), p.329; J.A. FIELD JR., The purpose cit. (nota 129 supra), pp.409;412, notas 59 e 60; D. NÖRR, The matrimonial Legislation of Augustus cit. (nota 54 supra), p.352; A. Bouché-LeClerCQ, Les lois démographiques d'Auguste cit. (nota 36 supra), p.284. Conforme Ulp. 19 ad Iul. et Pap. D.4,4,2, os candidatos que pretendessem ocupar cargos públicos e não tivessem atingido a idade prescrita, poderiam somar, para cada filho que tivessem, um ano à sua idade: Nec per liberos suos rem suam maturius a curatoribus recipiat. Quod enim legibus cavetur, ut singuli anni per singulos liberos demittantur, ad honores pertinere divus Severus ait, non ad rem suam recipiendam. "Nem ainda [o menor de vinte e cinco anos], em razão de seus filhos, receba de seus curadores, antes do tempo. Porque o que está previsto nas leis [Iulia et Papia], de que se dispense um ano para cada filho, afirma o Divino Severo, refere-se aos cargos [às honras; ad honores], não à recepção de seus próprios bens"; Tac. Ann. 2,51,1-2: De praetore in locum Vipstani Galli, quem mors abstulerat, subrogando certamen incessit. Germanicus atque Drusus [nam etiam tum Romae erant] Haterium Agrippam propinquum Germanici fovebant: contra plerique nitebantur ut numerus liberorum in candidatis praepolleret, quod lex iubebat. "Seguiram-se depois alguns debates para se nomear um pretor em lugar de Vipsânio Galo, que havia morrido. Germânico e Druso [que então estavam ambos em Roma], protegiam Hatério Agripa, parente de Germânico: contrariamente, o maior número defendia que, para candidato, era superior aquele que tivesse grande número de filhos, segundo estava determinado por lei". Vejam-se, Tac. Ann. 15,19,1; Plin. Iun. Ep. 7,16,2; Lex Malacitana (FIRA I,24 = CIL II, 1964); Suet. Tiberius 35,5. Tinha preferência, para ocupar o cargo de governador de província, aquele que tivesse o número maior de filhos, além de estarem isentos da sortitio. Dio. Cass. 53,13,2. Há um único caso, narrado em Pap. 1 resp. D.50,5,8, em que a grande quantidade de filhos dispensava da ocupação de um cargo público (religioso): a dispensa do sacerdócio da província da Ásia àquele que tivesse cinco filhos.

${ }^{365} \mathrm{Se}$ os dois candidatos tivessem o mesmo número de filhos, a prioridade era daquele que fosse casado. Se 
(f) Alguns grupos profissionais receberam o ius liberorum no decorrer do Principado (principalmente na época de Cláudio), por questões de interesse público, como os militares, os navicularii e todos aqueles que contruíssem navios com a finalidade de transportar trigo e víveres para Roma durante seis anos. ${ }^{366}$

ambos fossem casados e tivessem o mesmo número de filhos, adotava-se o critério anterior da ancianidade e o mais idoso seria o eleito. O capítulo VII da Lex Iulia de Maritandis ordinibus estabelecia os critérios para a escolha dos cônsules e qual deles assumiria o poder em primeiro lugar. Neste caso, aquele que tivesse mais filhos in potestate e procriados (naturales), equiparados aos filhos vivos e aos filhos mortos ou desaparecidos na guerra (Vat. Frag. 197) teria a prioridade para assumir cargos públicos. O mesmo capítulo determinava que o pater solitarius com prole numerosa tinha preferência em relação ao casado sem prole ou com uma prole menos numerosa. Para o cômputo não importava o sexo ou a idade dos filhos. Gell. 2,15,3-8: Sed postquam suboles civitati necessaria visa est et ad prolem populi frequentandam praemiis atque invitamentis usus fuit, tum antelati quibusdam in rebus qui uxorem quique liberos haberent senioribus neque liberos neque uxores habentibus. Sicuti kapite VII. legis Iuliae priori ex consulibus fasces sumendi potestas fit, non qui pluris annos natus est, sed qui pluris liberos quam collega aut in sua potestate habet aut bello amisit. Sed si par utrique numerus liberorum est, maritus aut qui in numero maritorum est, praefertur; si vero ambo et mariti et patres totidem liberorum sunt, tum ille pristinus honos instauratur et qui maior natu est, prior fasces sumit. Super his autem, qui aut caelibes ambo sunt et parem numerum filiorum habent aut mariti sunt et liberos non habent, nihil scriptum in lege de aetate est. Solitos tamen audio, qui lege potiores essent fasces primi mensis collegis concedere aut longe aetate prioribus aut nobilioribus multo aut secundum consulatum ineuntibus. "Mas quando se deu conta que a prole é necessária à cidade e para aumentar a população, se instituíram prêmios e incentivos, então foram preferidos aqueles que tinham esposa e filhos aos anciãos que não tinham nem esposa nem filhos. Assim, segundo o capítulo VII da lei Júlia [de maritandis ordinibus], é dada entre os cônsules a preferência em assumir as honras [fasces] do poder, não a quem tem mais anos, mas a quem tem mais filhos que o colega, quer ainda sob a potestas, quer perdido na guerra. E se o número de filhos é igual, foi preferido aquele que é casado legitimamente e na condição de marido; se ambos são maridos e pais de um número igual de filhos, então retorna-se à antiga honra e aquele de idade mais velha assume primeiro o direito às honras [fasces]. Na lei não se diz nada a propósito da idade quando se trate de dois cônsules, ambos não casados [caelibes] e que têm o mesmo número de filhos ou ambos casados mas sem filhos. Mas ouço dizer que aqueles que têm direito às honras [fasces] em seu primeiro mês, têm costumado conceder a preferência ao colega mais velho, ou de nascimento mais ilustre, ou que inicia um segundo consulado". Vejam-se A. GuARINO, Storia del diritto romano cit. (nota 103 supra), p.450; J. IGLESIAS, Derecho Romano cit. (nota 36 supra), p.344; S. RICCOBONO, La politica demografica cit. (nota 103 supra), p.576; M. ZABŁOCKA, Il 'ius trium liberorum' cit. (nota 103 supra), p.365; T. SPAGNUOlO VIGORITA, Casta Domus cit. (nota 26 supra), p.30, nota 74; R. Astolfi, La Lex Iulia et Papia cit. (nota 15 supra), pp.31-32;317-318, nota 230;326;328; B. BIONDI, La legislazione di Augusto cit. (nota 56 supra), p.134; L.F. RADITSA, Augustus Legislation cit. (nota 49 supra), p.329; A. BOUCHÉ-LECLERCQ, Les lois démographiques d'Auguste cit. (nota 36 supra), p.270; E. MALDONADO DE LizALDE, Lex Iulia de Maritandis Ordinibus cit. (nota 122 supra), p.553.

${ }^{366}$ Se os "construtores de navios", fossem cidadãos romanos e estes navios se destinassem ao comércio marítimo de trigo (annona) para Roma e tivessem uma capacidade de pelo menos 10.000 módios (aproximadamente 70 toneladas), tinham a vacatio das disposições impostas pela Lex Papia Poppaea. Se fossem latinos obtinham a cidadania romana (ius Quiritium). Caso fossem mulheres, tanto ingênuas quanto libertas, recebiam como prêmio o ius [trium] quattuor liberorum. O imperador Cláudio utiliza as disposições das Leis demográficas de Augusto e promulga um edito, provavelmente em 51 d.C., que concedia vantagens e privilégios aos construtores de navios para o transporte de grãos e a todos que participassem economicamente neste ramo de atividade, pois neste ano, segundo relatos de Suetônio (Claudius 18,2) e Tácito (Ann. 12,43,1), Roma passou por um período de grave fome e escassez de alimentos, produtos agrícolas e víveres. Vejam-se Suet. Claudius 18,2: (...) et naves mercaturae causa fabricantibus magna commoda constituit pro condicione cuiusque: civis vacationem legis Papiae Poppaeae, Latino ius Quiritium, feminis ius IIII liberorum; quae constituta hodieque servantur. “ (...) [Cláudio] concedeu grandes benefícios àqueles que construíssem navios de comércio, levando em conta a situação de cada um: excluiu das normas da Lex Papia Poppaea quem fosse cidadão, atribuiu a cidadania a quem fosse latino, concedeu o direito dos quatro filhos [ius liberorum] às mulheres: medidas que ainda hoje estão em vigor”. Gai.1,32-c: Item edicto Claudii Latini ius Quiritium consequuntur, si navem marinam aedificaverint, quae non minus quam decem milia modiorum frumenti capiat, eaque navis vel quae in eius locum substituta sit, sex annis frumentum 


\section{c) dote}

A lex Iulia de maritandis ordinibus tornou o dote juridicamente obrigatório. Com a promulgação desta lei matrimonial, o dote deixou de ser uma obrigação meramente social e tornou-se uma obrigação jurídica.

Para aumentar o número dos matrimônios, Augusto estabeleceu que, caso o paterfamilias impedisse o matrimônio da filha sem uma justa causa, o pretor poderia obrigá-lo a constituir o dote. ${ }^{367}$

$\mathrm{O}$ dote era um complexo de bens, geralmente uma contribuição oferecida pelo paterfamilias da esposa ${ }^{368}$, com o escopo de auxiliar o marido nos encargos iniciais resultantes do matrimônio (ad sustinenda onera matrimonii) e manter a prole numerosa, que a Legislação matrimonial de Augusto estimulava e premiava. ${ }^{369}$

$\mathrm{Na}$ legislação matrimonial, este auxílio material (favor dotis) também foi

Romam portaverit. "Igualmente, pelo edito de Cláudio, os latinos adquirem o direito de cidadãos romanos, se construírem um navio para navegação marítima, capaz de não menos de dez mil módios de trigo, e se nesse navio ou no que o substituir transportarem trigo para Roma durante seis anos"; UE 3,6: Nave Latinus civitatem Romanam accipit, si non minorem quam decem milium modiorum navem fabricaverit, et Romam sex annis frumentum portaverit, ex edicto divi Claudii. "Em virtude do edito de Cláudio, o latino obtém a cidadania se contruir um navio com capacidade para dez mil módios e transportar trigo para Roma durante seis anos". Vejam-se J.C. TELlO, La concesión discrecional cit. (nota 161 supra), p.772; M. ZABŁOCKA, Il 'ius trium liberorum' cit. (nota 103 supra), pp.384;386-387; L. DE SALVO, Sul problema della 'vacatio' dei 'naviculari', in Sodalitas - Scritti in onore di Antonio Guarino, vol.4, Napoli, Jovene, 1984, pp.1653-1654; L.F. RADITSA, Augustus Legislation cit. (nota 49 supra), p.323; J.A. FIELD JR., The purpose cit. (nota 129 supra), p.409; R. AstOlfi, La Lex Iulia et Papia cit. (nota 15 supra), pp.63;86;87, nota 64;88-89; A. BouChÉ-LeClerCQ, Les lois démographiques d'Auguste cit. (nota 36 supra), pp.278, nota 4;279;286; A. Mette-Dittmann, Die Ehegesetze des Augustus - Eine Untersuchung im Rahmen der Gesellshaftspolitik des Princeps, Stuttgart, Franz Steiner, 1991, pp.207-208.

Constantino manteve o privilégio da vacatio legis aos navicularii e a estes não se aplicavam as normas da lex Iulia et Papia. Const. C.Th. 13,5,7 (334): (...) Navicularii (...) vacatione legis Iuliae et Papiae potiantur, ut etiam nullis intervenientibus liberis et viri ex testamento uxorum solidum capiant et uxores integra voluntas perveniat maritorum. “(...) Os navicularii (...) estão isentos da Lex Iulia et Papia, de modo que os homens casados, mesmo sem filhos, podem receber tudo aquilo que seja deixado a eles por testamento pela esposa e para que as esposas obtenham integralmente aquilo que foi disposto pelos maridos".

${ }^{367}$ De acordo com E. CUQ, Les Institutions cit. (nota 69 supra), p.63, a constituição do dote era tão habitual que ela servia para distinguir o matrimônio do concubinato. Vejam-se R. Astolfi, La Lex Iulia et Papia cit. (nota 15 supra), p.153; B. BIONDI, Istituzioni cit. (nota 22 supra), pp.452, nota 68;453; R. MoNIER, Manuel cit. (nota 146 supra), pp.292-293. Neste sentido vide Marcian. 16 inst. D.23,2,19, p.27 supra. Contra a opinião de que o dote tornou-se obrigatório no período clássico, V. ARANGIO-RUIZ, Istituzioni cit. (nota 53 supra), p.453; F. SCHUlZ, Classical Roman Law cit. (nota 51 supra), p.115; A. BuRDESE, Manuale cit. (nota 47 supra), pp.284-285; A. NiCOLETTI, Dote cit. (nota 242 supra), pp.257;259.

${ }^{368}$ Poderia também ser constituído pela própria mulher sui iuris ou por terceiros.

${ }^{369}$ Paul. 6 ad Plaut. D.23,3,56,1: Ibi dos esse debet, ubi onera matrimonii sunt. "O dote deve estar onde estão os ônus do matrimônio". Vejam-se J.M. OTHON SidOU, Matrimonium I. cit. (nota 47 supra), p.70; J. IGLESIAS, Derecho Romano cit. (nota 51 supra), p.351; R. Astolfi, La Lex Iulia et Papia cit. (nota 15 supra), p.326; D. DAlla - R. LAMBERTINI, Istituzioni di diritto romano cit. (nota 10 supra), pp.112-113; A. NiCOLETTI, Dote cit. (nota 242 supra), p.257. Como nos primórdios de Roma geralmente a mulher perdia o vínculo e os direitos sucessórios com a sua antiga família agnatícia, pois realizava um dos atos constitutivos da conventio in manum, ela se tornava alieni iuris na nova família. Para solucionar esta situação, o dote equivalia a uma antecipação do quinhão sucessório da filha. 
demonstrado pelo interesse do "Estado" na conservação e constituição do regime dotal como garantia do matrimônio para as mulheres e manter a estabilidade econômica das famílias recém-formadas. ${ }^{370}$

Isto era imprescindível para que as famílias tivessem um maior número de filhos e fossem protegidas pelo direito público (neste caso, na linguagem moderna, um direito cogente). $\mathrm{O}$ aumento do direito da esposa à restituição do dote garantia uma maior estabilidade familiar. ${ }^{371}$

Com estas medidas a res publica incentivava o matrimônio e assegurava um número maior de cidadãos ${ }^{372}$ :

Pomp. 15 ad Sab. D. 24,3,1:

Dotium causa semper et ubique praecipua est; nam et publice interest, dotes mulieribus conservari, quum dotatas esse feminas ad sobolem procreandam replendamque liberis civitatem maxime sit necessarium.

“A causa do dote é sempre e em todo caso preferencial; porque também é de interesse

\footnotetext{
${ }_{370}$ Paul. 60 ad ed. D.23,3,2: Rei publicae interest mulieres dotes salvas habere, propter quas nubere possunt. "É do interesse da res publica que as mulheres tenham a salvo os dotes em virtude dos quais possam casarse". A Lex Iulia de Maritandis ordinibus previa a nomeação de um tutor dotis constituendae causa pelo pretor urbano, se o tutor legítimo ainda fosse pupilo (impúbere), pois neste caso não poderia prestar a auctoritas ad dotem dicendam, dandam, promittendam. Tanto a sponsa livre quanto a liberta poderiam solicitar ao pretor urbano a nomeação deste tutor. UE 11,20: Ex lege Iulia de maritandis ordinibus tutor datur a praetore urbis ei mulieri virginive, quam ex hac ipsa lege nubere oportet, ad dotem dandam, dicendam promittendamve, si legitimum tutorem pupillum habeat. Sed postea senatus censuit, ut etiam in provinciis quoque similiter a praesidibus earum ex eadem causa tutores dentur. "Por força da Lex Iulia de maritandis ordinibus o pretor urbano, se o tutor legítimo for pupilo, nomeia outro tutor à mulher ou à moça que, segundo a mesma lei, deve se casar, a fim de dar, constituir solenemente ou prometer o dote. Mas depois o senado dispôs que analogamente, também nas províncias, os seus governadores pela mesma razão nomeassem os tutores"; Gai. 1,178: Nam et lege Iulia de maritandis ordinibus ei, quae in legitima tutela pupilli sit, permittitur dotis constituendae gratia a praetore urbano tutorem petere. "Pois pela Lex Iulia de maritandis ordinibus, permitiu-se à que estiver na tutela legítima do pupilo pedir tutor ao pretor urbano, para constituição do dote". Posteriormente, houve uma ampliação da norma da Lex Iulia de maritandis ordinibus por meio de diversos senatusconsultos que permitiram a nomeação dos tutores pelos governadores de províncias $($ Gai.1,183). Surgiram novas formas para a nomeação de um tutor especial: em substituição ao mudo e ao louco (UE 11,21;Gai.1,180); em substituição de tutor absens (UE 11,22). A jurisprudência admitiu que a nomeação de curador ocorresse após a realização do matrimônio com a finalidade de aumentar o dote (Ulp. 1 de omnib. Trib. D.26,5,7). Vejam-se R. Astolfi, La Lex Iulia et Papia cit. (nota 15 supra), pp.155;327;336;362-364; Idem, Note per una valutazione storica della 'Lex Iulia et Papia' cit. (nota 36 supra), p.188; B. BIONDI, Istituzioni cit. (nota 22 supra), pp.453-454; A. NiCOLETTI, Dote cit. (nota 242 supra), p.258.

${ }^{371}$ R. Astolfi, La Lex Iulia et Papia cit. (nota 15 supra), p.327; B. BIONDI, Istituzioni cit. (nota 22 supra), pp.453-454. Vejam-se Cic. Top. 6,17,65: dos licet matrimonio constante in bonis viris sit, est tamen in uxoris iure et post divortium velut res uxoria peti potest; Tryph. 6 disp. D.23,3,75: Quamvis in bonis mariti dos sit, mulieris tamen est. "Ainda que o dote esteja nos bens do marido, é, contudo, da mulher".

372 J. GaUdemet, Utilitas Publica cit. (nota 44 supra), p.187; E. CUQ, Les Institutions cit. (nota 69 supra), p.63; B. BIONDI, Istituzioni cit. (nota 22 supra), pp.453-454.
} 
público que às mulheres se lhe conserve o dote, como é muito necessário que as mulheres sejam dotadas para que procriem descendência e tornem a cidade plena de filhos".

Pomp. 60 ad ed. D.42,5,18:

Interest enim rei publicae et hanc solidum consequi, ut aetate permittente nubere possit.

"Porque interessa à res publica que ela consiga a totalidade [do dote] para que, permitindolhe a idade, possa casar-se".

De acordo com as diretrizes da legislação matrimonial, o regime dotal é qualificado como um ius publicum e torna-se inderrogável. ${ }^{373}$

PS 1,1,6: Functio dotis pacto mutari non potest, quia privata conventio iuri publico nihil derogat.

"A função do dote não pode ser alterada por um pacto, porque uma convenção privada não derroga o direito público". ${ }^{374}$

Ao lado do interesse de assegurar o dote ao matrimônio estava o interesse de retê$10^{375}$, aumentando os direitos da mulher sobre os bens dotais. Isto se manifesta na disposição da lex Iulia de maritandis ordinibus ${ }^{376}$ que, para evitar um prejuízo econômico à esposa, limita os direitos do marido em relação à manumissão do escravo dotal: o marido

373 B. BIONDI, La legislazione di Augusto cit. (nota 56 supra), p.142. Na opinião de E. CANTARELLA, Matrimonio e sessualità cit. (nota 36 supra), pp.124-125, Pompônio fazia alusão, nestes trechos, às viúvas e às divorciadas que, sem dote, tivessem dificuldades de contrair segundas núpcias e não cumprissem o seu dever cívico de procriar muitos filhos.

${ }^{374}$ Esta disposição é retomada na obra Consultatio veteris cuiusdam iurisconsulti 4,3: Paulus sentent. lib. I tit. de pact. et conventionibus vel transactionibus: Functio dotis pacto mutari non potest, quia privata conventio iuri publico nihil derogat.

${ }^{375} \mathrm{Na}$ opinião de R. Astolfi, La Lex Iulia et Papia cit. (nota 15 supra), pp.160;365; Idem, Note per una valutazione storica della 'Lex Iulia et Papia' cit. (nota 36 supra), p.226, não é possível identificar a existência na Lex Iulia et Papia de alguma norma relativa às retentiones propter liberos ou propter mores. Veja-se R. BESNIER, L'application des lois caducaires cit. (nota 10 supra), pp.114-115.

${ }^{376}$ R. Astolfi, La Lex Iulia et Papia cit. (nota 15 supra), pp.157-158;327; Idem, Note per una valutazione storica della 'Lex Iulia et Papia' cit. (nota 36 supra), pp.188;202. A Lex Iulia de maritandis ordinibus estabeleceu que se o marido manumitisse o escravo dotal, deveria entregar à esposa o valor avaliado dos direitos de patronato adquiridos por ele, em dinheiro. Conforme Pap. 1 quaest. D.24,3,61; Scaev. l. s. quaest. Publ. tract. D.24,3,65; Paul. 22 quaest. D.48,10,14,2. Veja-se Ulp. 7 ad l. Iul. et Pap. D.24,3,64pr.: Si vero negotium gerens mulieris non invitae maritus dotalem servum voluntate eius manumiserit, debet uxori restituere quidquid ad eum pervenit. "Mas se o marido, sendo gestor de negócio da mulher, tiver manumitido 
não poderia manumiti-lo sem o consentimento dela, para que não gastasse os bens dotais de forma desenfreada. ${ }^{377}$

Durante o matrimônio, o dote pertence ao marido. Se ele morre, o direito atribui o dote à viúva como aquisição definitiva, mortis causa. A aquisição do dote não decorre da vontade do falecido e, portanto, não pode ser incluído no regime da capacitas. Por isso, é importante salientar que não se exigia um matrimônio com prole para permitir que os viúvos adquirissem definitivamente o dote, nem às viúvas para obterem a restituição do dote. $^{378}$

Em relação às donationes inter virum et uxorem a lex Iulia et Papia manteve, com o escopo de garantir a prosperidade familiar, aquilo que já era estabelecido pelos mores maiorum, ou seja, proibiu-as, para evitar o empobrecimento do cônjuge mais generoso em detrimento do outro e prejudicar a prole. ${ }^{379}$

um escravo do dote pela vontade desta, deve restituir à mulher aquilo que foi ao poder dele".

377 R. Astolfi, La Lex Iulia et Papia cit. (nota 15 supra), pp.157;333;342;364; Idem, Note per una valutazione storica della 'Lex Iulia et Papia' cit. (nota 36 supra), p.225.

${ }^{378}$ R. Astolfi, La Lex Iulia et Papia cit. (nota 15 supra), pp.116-118. Neste sentido, se algum dos cônjuges tentasse fraudar a Lex Iulia et Papia recorrendo ao dote para receber ou transmitir algum bem que não poderia capere por testamento, tal ato seria ilícito e portanto inválido.

${ }^{379}$ Sobre as doações entre marido e mulher, Ulp. 32 ad Sab. D.24,1,1; Ulp.32 ad Sab. D.24,1,3pr.; Pomp. 14 ad Sab. D. 24,1,31,7; Ulp. 32 ad Sab. D.24,1,9; Gai. 2 ad ed. D.24,1,10; Vat. Frag. 262;273;302; UE 7,1. Ulpiano em D.24,1,1, afirma que esta regra tem origem nos costumes (moribus): Moribus apud nos receptum est, ne inter virum et uxorem donationes valerent. (...) "Está admitido entre nós pelo costume, que não sejam válidas as doações entre marido e mulher (...)". Defendem que a fonte da donatio inter virum et uxor são os costumes e que não existe qualquer indício ou referência direta das doações entre cônjuges na Lex Iulia et Papia, E. Volterra, Sui 'mores' della 'familia' romana cit. (nota 30 supra), p.196, nota 2; S. RicCOBOnO, Il diritto romano in America - 'Consuetudo', 'exemplum' nelle fonti giuridiche romane, in BIDR 46 (1939), p.335; A. LóPEZ PeDReira, Limitaciones a la 'libertas nuptialis' cit. (nota 40 supra), p.404, nota 73; R. Astolfi, La Lex Iulia et Papia cit. (nota 15 supra), pp.160;365; Idem, Note per una valutazione storica della 'Lex Iulia et Papia' cit. (nota 36 supra), p.226; T. Spagnuolo Vigorita, Casta Domus cit. (nota 26 supra), p.121, nota 109; M.G. SCACCHETTI, La presunzione muciana, Milano, Giuffrè, 2002, pp.293-307.

Nas opiniões de B. BIONDI, La legislazione di Augusto cit. (nota 56 supra), pp.138-140, F. ScHULZ, Classical Roman Law cit. (nota 51 supra), pp.115-116; A. MANZO, Sull'origine del divieto di donazioni tra coniugi, in LABEO 37.3 (1991), pp.343-350; P. BONFANTE, Corso di diritto romano - Diritto di Famiglia cit. (nota 23 supra), pp.288-290 e A. ROMANO, Matrimonium iustum cit. (nota 26 supra), p.86, a proibição não foi introduzida pelos costumes, mas pela Lex Iulia et Papia, apesar de não existirem evidências nas fontes jurídicas. Permitir essas doações recíprocas seria admitir uma possibilidade para que os orbi pudessem escapar das sanções da lei e assim evitar a sua incapacidade sucessória (metade das heranças e legados). Antes da Legislação matrimonial de Augusto, as doações entre cônjuges foram consideradas lícitas pela Lex Cincia de donationibus et muneribus, plebiscito promulgado em 204 a.C. pelo tribuno M. Cincio Alimento, depois por uma Lex Iulia repetudarum de 59 a.C. promulgada por Júlio César e por Quinto Múcio, que qualificou-as verius et honestius (Pomp. 5 ad Q. Mucium D. 24,1,51). Vejam-se também Iav. 6 ex post. Lab. D.24,1,64; Theod. et Valent. C.Th. 5,1,9 (428); Nov.74,4. Conclui A. MANZO, op.cit., pp.343;349, que a nulidade absoluta em relação ao impedimento destas doações somente poderia ser estabelecida por uma lex perfecta: la esperienza insegna che un attegiamento radicato e diffuso al punto da diventare uso, difficilmente ha un contenuto negativo: la proibizione, in genere, è sancita da un atto d'imperio che s'impone su una prassi di segno contrario. Além disso, doações entre cônjuges eram contrárias à política demográfica de Augusto pois poderiam causar um empobrecimento de um dos cônjuges, o que prejudicaria não apenas os direitos sucessórios da prole, mas a sua criação e educação. 


\section{d) direitos sucessórios}

As Leis Matrimonais também foram denominadas "Leis Caducárias", pois estabeleciam limitações em relação à capacitas dos sucessores testamentários ${ }^{380}$ que eram impedidos de adquirir os bens no momento da morte do testador ou no prazo de cem dias da cretio. ${ }^{381}$

${ }^{380}$ Esclarece R. Astolfi, La Lex Iulia et Papia cit. (nota 15 supra), p.332; Idem, Femina probrosa cit. (nota 96 supra), pp.49-50, que as fontes jurídicas relativas às disposições das leis matrimoniais, apenas fazem referência à capacitas e aos caduca da sucessão testamentária.

${ }^{381}$ Esclarece A.A.L. KLABIN, Estudos sobre as Leis Caducárias, in Revista da Faculdade de Direito da USP 92 (1997), p.26, que o termo "caducar" significa "ficar sem efeito seja porque não se usou o direito que se tinha; seja porque se renunciou a ele; seja porque se deixou de cumprir ato subsequente exigido". Caducum, literalmente era "como se fosse caído do sujeito", segundo UE 17,1: Quod quis sibi testamento relictum, ita ut iure civili capere possit, aliqua ex causa non ceperit, "caducum" appellatur veluti cecidit ab eo: verbi gratia si caelibi vel Latino iuniano legatum fuerit, nec intra dies centum vel caelebs legi paruerit, vel Latinus ius Quiritium consecutus sit; aut si ex parte heres scriptus vel legatarius ante apertas tabulas decesserit vel peregrinus factus sit. "Chama-se caduco, como se caído do sujeito, aquilo que foi deixado a este por testamento, de modo que, segundo o ius civile, o sujeito poderia tomá-lo, mas não o pode por algum motivo; verbigratia: se se deixar um legado a um solteiro ou a um latino juniano e dentro dos cem dias o solteiro não obedecer à lei ou o latino não alcançar a cidadania; ou se o herdeiro de uma parte ou o legatário, antes da abertura do testamento, morrer ou se tornar peregrino". Neste caso a pessoa não tem a capacitas (aliqua ex causa non ceperit), seja porque não é casado (caelebs), seja porque é um latino juniano. O latino juniano tinha o prazo da cretio (geralmente de cem dias) para se tornar cidadão romano e ter a capacidade de herdar (testamenti factio passiva). O caelebs tinha cem dias para casar-se e receber as heranças e legados. Os orbi teriam a possibilidade de beneficiar-se deste prazo, adotando um filho. UE 22,3: Si quidem mortis testatoris tempore vel intra diem cretionis civis Romanus sit, heres esse potest; quodsi Latinus manserit, lege Iunia capere hereditatem prohibetur. Idem iuris est in persona caelibis propter legem Iuliam. "O latino juniano, se no momento da morte do testador ou dentro do prazo da cretio se tornar cidadão romano, poderá ser herdeiro, pois, permanecendo latino, estará proibido de tomar a herança por força da lex Iunia. O mesmo se aplica à pessoa do caelibes, em virtude da Lex Iulia". Portanto, esse prazo de 100 dias era um benefício da Lex Iulia et Papia para incentivar o matrimônio. Dentro dos 100 dias, mesmo o caelebs poderia alcançar a capacitas completa: poderia obter do imperador o privilégio do ius liberorum; ou um cargo público nas províncias; ou alistar-se no exército romano. No caso de heredis institutio, o momento no qual é avaliada a capacitas do herdeiro ou legatário é o da delação (delatio hereditatis). Em relação à aditio hereditatis e ao dies cedens, ou seja, a aceitação da herança e o dia a partir do qual o herdeiro podia adir a sua parte da herança, a Lex Papia Poppaea determinou que o herdeiro aguardasse a abertura formal do testamento, exceto se ele fosse constituído na totalidade da herança. O herdeiro instituído pro parte e não o ex asse deve aguardar a abertura do testamento para adir a herança. O dies cedit era o dia em que nascia o direito sucessório do legatário/herdeiro. Neste sentido, R. Astolfi, Note per una valutazione storica della 'Lex Iulia et Papia' cit. (nota 36 supra), p.200. Veja-se UE 24,31: Legatorum, quae pure vel in diem certum relicta sunt, dies cedit antiquo quidem iure ex mortis testatores tempore; per legem autem Papiam Poppaeam ex apertis tabulis testamenti; eorum vero, quae sub condicione relicta sunt, cum conditio extiterit. "Por direito antigo, o legado deixado pura e simplesmente ou com prazo confere o direito de pedir a coisa legada desde a morte do testador; pela Lex Papia Poppaea, desde a abertura do testamento; mas em se tratando de coisas deixadas sob condição, o legatário tem o direito quando se verifique a condição". Aplicava-se esta regra da procrastinação do dies cedens aos legados no momento da abertura do testamento, desde que estes fossem escritos e que não instituíssem heredes necessarii. Vejam-se Paul. 5 ad l. Iul. et Pap. D.29,2,68; Iul. 31 dig. D.35,1,21; Iust. C.6,51,1,1 (534). Faz uma análise destes trechos das Regras de Ulpiano, P. Voci, Teoria dell'acquisto del legato secondo il diritto romano, Milano, Giuffrè, 1936, pp.13-15;17-18. Ao analisar UE 24,31, VoCI afirma que o dies do legado na morte do testador, não foi modificado pela Lex Papia Poppaea, mas por um sentusconsulto, de acordo com Iust. C.6,51,1,1 (534). Quanto a UE 17,1, o mesmo autor defende que não há coerência entre a definição do termo caducum e os exemplos apresentados. Em relação ao trecho UE 22,3, o prazo para a delação teria início no momento da morte do testador, e não apertis tabulis, ou seja, na abertura formal do testamento. 
O "Estado" priva ou limita a capacidade de receber por testamento daqueles cidadãos, principalmente das classes mais ricas, que não cumprem seu dever público de casar-se, procriar e aumentar a população. ${ }^{382}$

Transfere estes bens, em contrapartida, aos homens com prole numerosa, para assegurar-lhes uma vida melhor e mais proveitosa, associando os interesses do Estado aos interesses de toda a sociedade. Os patresfamilias ${ }^{383}$ com filhos recebiam, por sucessão, a parte que os co-herdeiros sem filhos não podiam mais adquirir. ${ }^{384}$

Institutas de Gaio, apenas em relação a dois institutos: a heredis institutio e o legado. Vejam-se Gai. 2,111;144;150;206;207;208;263-265;286; UE 1,21; 16,4; 17,3; 18,1; 19,17;24,12;28,7; (Iust.) C.6,51,1pr.; 1;-2 (534 d.C.); Tac. Ann. 3,28,3 (nota 318 infra). Vejam-se R. Astolfi, op.cit., pp.10;11;16;34;225229;235-237;251;334;339; L.F. RADITSA, Augustus Legislation cit. (nota 49 supra), pp.321-324; T. Spagnuolo Vigorita, Casta Domus cit. (nota 26 supra), p.30; M. ZABŁocKa, Le modifiche cit. (nota 103 supra), pp.389-390; A. BouCHÉ-LECLERCQ, Les lois démographiques d'Auguste cit. (nota 36 supra), p.269.

${ }^{382}$ V. ARANGIO-RUIZ, Istituzioni cit. (nota 53 supra), pp.443-444; R. AstOLFI, Note per una valutazione storica della 'Lex Iulia et Papia' cit. (nota 36 supra), p.213.

${ }^{383}$ De acordo com R. Astolfi, La Lex Iulia et Papia cit. (nota 15 supra), pp.263;328; Idem, Note per una valutazione storica della 'Lex Iulia et Papia' cit. (nota 36 supra), p.190, é provável que a Lex Papia Poppaea tenha utilizado a palavra patres para indicar os cônjuges que tinham direito aos caduca, vinculado à expressão qui liberos habent. Na palavra pater, também estava incluído o avô. Veja-se Iul. 81 dig. D.50,16,201: Iusta interpretatione recipiendum est, ut appellatione 'filii', sicuti filiam familias contineri saepe respondebimus, ita et nepos videatur comprehendi, et 'patris' nomine avus quoque demonstrari intellegatur. "Segundo uma justa interpretação, deve admitir-se que no nome 'filho', assim como muitas vezes responderemos que se inclui a filiafamilias, parece que também está compreendido o neto, e que com o nome de "pai" também é entendido que se designa o avô". A expressão qui liberos habet indicava tanto a pessoa que gozava da capacitas completa quanto aquela que tivesse direito aos caduca. Vejam-se Gai.1,111;2,206;2,207; 2,286-a; UE 16,1;18,1;25,17; Gnomon § 27.

${ }^{384}$ R. Astolfi, Le exceptae personae cit. (nota 108 supra), p.224; Idem, La Lex Iulia et Papia cit. (nota 15 supra), pp.252-259;268-269;291-296;328-329;332;336-338;355; Idem, Note per una valutazione storica della 'Lex Iulia et Papia' cit. (nota 36 supra), pp.193;199;228; A. LÓPEZ PEDREIRA, Limitaciones a la 'libertas nuptialis' cit. (nota 40 supra), p.404; M. ZABŁOCKA, Il 'ius trium liberorum' cit. (nota 103 supra), pp.365-366; J.A. Field JR., The purpose cit. (nota 129 supra), p.404; T. Spagnuolo Vigorita, Casta Domus cit. (nota 26 supra), pp.24;77. Estes herdeiros preferenciais, com maior número de filhos, podiam exigir sua parte da herança mediante uma ação, a patrum caducorum vindicatio. Também o "Estado", muitas vezes por meio dos delatores, podia exigir o seu direito ao caducum pela vindicatio caducorum. No caso de autodenúncia do incapax, Trajano determinou que ele fosse premiado com a metade dos bona caduca, desde que estivesse na posse dos bens. A outra metade deveria ser entregue ao "Estado". Neste caso, o escopo fiscal é o preponderante. Vejam-se Plin. Iun. Paneg. 42,1; Paul. 7 ad l. Iul. et Pap. D.49,14,13pr. Sobre a vindicatio caducorum, foram estabelecidas disposições, durante o Principado, por diversos senatusconsultos (Iuventianum, Turpillianum). Constantino proibiu o delator mover a vindicatio cadorum. No período pósclassico, a figura do delator é substituída pelo petitor, ou seja, aquele que recebia os bona caduca alienados pelo Fisco. Vejam-se Mauric. 3 ad l. Iul. et Pap. D.49,14,15pr.,-2;-4; D.49,14,22,3.

Gaio nas Institutas $(2,199 ; 2,205)$ referia-se ao caso em que um único legado atribui um único bem a dois ou mais destinatários (legado coniunctio). De acordo com o ius antiquum, o legado per vindicationem permitia o acréscimo da quota caduca aos demais co-legatários (ius accrescendi). No caso do legado per damnationem, a quota daquele que não adquiriu permanecia na herança. A Lex Papia Poppaea atribuía a parte caduca dos legados per damnationem e per vindicationem aos herdeiros testamentários que tivessem o maior número de filhos. Dentre esses co-herdeiros/co-legatários, aqueles com mais filhos tinham a preferência. Gai. 2,206: Quod aut diximus, deficientis portionem in per damnationem quidem legato in hereditate retineri, in per vindicationem vero collegatario adcrescere, admonendi sumus ante legem Papiam hoc iure civili ita fuisse; post legem vero Papiam deficientis portio caduca fit et ad eos pertinet, qui in eo testamento liberos habent. "E quanto ao dito sobre a parte caduca a qual, no legado per damnationem, permanece na herança, e, no legado per vindicationem, é acrescida ao co-legatário, devemos advertir que assim o era pelo ius civile, antes da lex Papia; porém, depois da lex Papia, a parte caduca pertence aos herdeiros testamentários com prole"; 
As leis matrimoniais faziam restrições ao ius capiendi dos caelibes $^{385}$, ou seja, não

Gai. 2,207: Et quamvis prima causa sit in caducis vindicandis heredum liberos habentium, deinde, si heredes liberos non habeant, legatariorum liberos habentium, tamen ipsa lege Papia significatur, ut collegatarius coniunctus, si liberos habeat, potior sit heredibus, etiamsi liberos habebunt. "E muito embora os herdeiros com prole venham em primeiro lugar, na reivindicação dos legados caducos, e depois, se os herdeiros não tiverem filhos, se seguirem os legatários com filhos, a própria Lei Pápia declara que o colegatário conjunto, com filhos, prefira aos herdeiros, mesmo com filhos". Se os herdeiros não tivessem filhos, os legatários com filhos teriam direito ao caducum.

Aos legatarii patres eram equiparados os fideicommissarii patres (UE 25,17). Veja-se, quanto aos legatários conjuntos, Gai. 2,208: Sed plerisque placuit, quantum ad hoc ius, quod lege Papia coniunctis constituitur, nihil interesse, utrum per vindicationem an per damnationem legatum sit. "Mas, segundo a opinião dominante, quanto a este direito constituído pela Lex Papia em favor dos legatários conjuntos, não importa saber se o legado foi per vindicationem ou per damnationem"; Cels. 35 dig. D.32,80: Coniunctim heredes institui aut coniunctim legari hoc est: totam hereditatem et tota legata singulis data esse, partes autem concursu fieri. "Ser instituídos herdeiros conjuntamente ou ser legatários conjuntamente é isto: que a cada um se atribua toda a herança e todos os legados, no entanto, que se constituam quotas para o concurso"; UE 1,21: Inter medias heredum institutiones libertas data utrisque adeuntibus non valet; solo autem priore adeunte iure antiquo valet. Sed post legem Papiam Poppaeam, quae partem non adeuntis caducam facit, si quidem primus heres vel ius antiquum habeat, valere eam posse placuit, quod si non habeat, non valere constat, quod loco non adeuntis legatarii patres heredes fiunt. Sunt tamen, qui et hoc casu valere eam posse dicunt. "Havendo, entre duas nomeações de herdeiros, uma manumissão de escravo, esta não vale se ambos os herdeiros adirem a herança. Pelo ius antiquum, tem valor se somente o primeiro nomeado fizer adição; mas depois da Lex Papia Poppaea, que torna caduca a parte de quem não aceita, julgou-se que a manumissão pudesse valer, desde que o primeiro herdeiro tivesse o direito da prole ou do ius antiquum: é certo que não vale, se não os tiver, pois os com prole tornam-se herdeiros em lugar de quem não aceita. Há, entretanto, alguns que julgam válida a manumissão também neste caso". Vejam-se também Paul. 6 ad l. Iul. et Pap. D.32,89; Paul. 6 ad l. Iul. et Pap. D.50,16,142; Vat. Frag. 195.

${ }^{385}$ Veja-se R. Astolfi, La Lex Iulia et Papia cit. (nota 15 supra), pp.10;13;89-91;326; G. LoNGO, Lex Iulia de maritandis ordinibus e Lex Papia Poppaea cit. (nota 103 supra), p.811. Por outro lado, os caelibes podiam ser fideicomissários, pois não era necessário, neste caso, ter a testamenti factio passiva. Gai. 2,286: Caelibes quoque, qui per legem Iuliam hereditates legataque capere prohibentur, olim fideicommissa videbantur capere posse. "Os caelibes, proibidos pela lex Iulia de tomar heranças e legados, reputavam-se outrora capazes de fideicomissos”. De acordo com R. BESNIER, L'extension des lois caducaires cit. (nota 106 supra), pp.26-28, como os fideicomissos eram simples pedidos endereçados a um parente para que entregassem um determinado objeto ao fideicomissário, não era prevista pelo direito, era uma mera obrigação moral. Por isso, as leis matrimoniais de Augusto não proibiram os fideicomissos. Porém, os fideicomissos tornaram-se um meio para evitar as penas desta legislação e transmitir bens hereditários aos caelibes e aos orbi. Gaio, portanto, demonstrou que as leis caducárias dispunham apenas sobre a instituição de herdeiro (heredis institutio) e sobre os legados (hereditates legataque). De acordo com R. ASTOLFI, Femina probrosa cit. (nota 96 supra), p.47, nota 79, a incapacitas prevista pela Lex Iulia foi ampliada, por interpretação analógica, a todo tipo de mortis causa capio.

Também existia uma exceção quanto a aplicação da Lex Iulia et Papia em relação ao testamento do soldado (testamentum militis). Gaio nas Institutas (2,111), informa que os caelibes e os orbi, chamados à sucessão testamentária pelo militar, podiam capere integralmente. Gai. 2,111: Caelibes quoque, qui lege Iulia hereditatem legataque capere vetantur, item orbi, id est qui liberos non habent, quos lex Papia plus quam dimidias partes hereditatis legatorumque capere vetat, ex militis testamento solidum capiunt (...) “Também os celibatários, impedidos pela lex Iulia de receber herança e legados, e os orbi, isto é, as pessoas sem filhos, proibidas pela lex Papia de receber mais da metade da herança ou dos legados, recebem-na integralmente, por testamento dum militar (...)". Os soldados, empenhados no serviço ao "Estado" (absentes rei publicae causa), não podiam se casar durante o serviço militar, mas recebiam os privilégios previstos na Lex Iulia et Papia para os homens casados e com prole. Aqueles que exerciam funções de interesse público (utilitas publica), estavam isentos das normas que restrigiam a capacitas, não apenas durante a ausência, mas também no ano posterior. O motivo para este benefício era impedir que a ausência por causa do serviço público prejudicasse o cidadão. UE 16,1: Aliquando vir et uxor inter se solidum capere possunt (...) si vir absit et donec abesset intra annum, postquam abesse desierit. "Às vezes, os cônjuges podem reciprocamente tomar a totalidade dos bens (...) durante a ausência e dentro do ano posterior àquele em que acabou a ausência $[$ rei publicae causa]". Em relação à ausência rei publicae causa, vejam-se Ulp. 6 ad l. Iul. et Pap. D.4,6,38,1; 
teriam o direito de entrar na propriedade dos bens que lhes fossem deixados em herança ou legado os homens solteiros e os não-casados (solteiro com prole, viúvo, separado) com idade entre 25 e 60 anos e as mulheres entre 20 e 50 anos. ${ }^{386}$

A lex Papia Poppaea conferia aos ascendentes e descendentes nomeados herdeiros pelo testador, até o terceiro grau, as quotas hereditárias que os orbi e os caelibes não tomaram em virtude de sua incapacitas testamentária. ${ }^{387}$

Ulp. 56 ad ed. D.50,17,140: Absentia eius, qui reipublicae causa abest, neque ei, neque alii, damnosa esse debet. "A ausência daquele que está fora por causa da res publica, nem a si nem a outrem deve ser danosa". Portanto, aqueles chamados a suceder no testamento do absens rei publicae causa gozavam do mesmo privilégio daqueles chamados no testamento militis e tinham a capacitas plena. Uma mulher que contraísse uma relação de contubernium com um militar, mesmo que fosse livre e ingênua, não poderia herdar pelo regime especial do testamentum militis, pois ambos cometiam stuprum. Veja-se Pap. 33 quaest. D.34,9,14.

${ }^{386} \mathrm{Na}$ opinião de R. Astolfi, La Lex Iulia et Papia cit. (nota 15 supra), pp.30-31;109, provavelmente a Lex Iulia de maritandis ordinibus continha uma norma que estabelecia que a prole dos homens dos 25 aos 60 anos e as mulheres dos 20 aos 50 era ilegítima (vulgo concepta), se estes não estivessem casados (iustae nuptiae) ou fossem solteiros com prole (pater solitarius), no momento da abertura da sucessão. Logo, neste caso, seriam parcialmente capazes em relação à sucessão testamentária e aos legados. Veja-se também T. Spagnuolo Vigorita, Casta Domus cit. (nota 26 supra), p.30.

387 Provavelmente, na rubrica de exceptis personis da obra de Ulpiano dedicada à Lex Iulia et Papia, no livro quinto, estavam elencados os parentes agnatícios e cognados do de cuius até o sexto grau e no sétimo o filho do primo ou da prima de sexto grau (sex septimo sobrino sobrinave). Este elenco encontra-se em Vat. Frag. 214-219. Segundo UE 18,1, são chamados à sucessão, para capere "aquilo que outrem não tomou em virtude do testamento", de acordo com a Lex Papia, os ascendentes e descendentes do testador (de cuius) até o terceiro grau em linha reta: Item liberis et parentibus testatoris usque ad tertium gradum lex Papia ius antiquum dedit, ut heredibus illis institutis, quod quis ex eo testamento non capit, ad hos pertineat aut totum aut ex parte, prout pertinere possit. "A Lex Papia confere o direito antigo aos descendentes e ascendentes do testador até o terceiro grau, de forma que, nomeados herdeiros, lhes cabe, na medida do possível, aquilo que outrem não tomou em virtude do testamento". A expressão ius antiquum indica o conjunto de normas que disciplinavam esta matéria antes da promulgação da Lex Iulia et Papia. As normas do ius antiquum são, muitas vezes, indicadas nas fontes como normas do ius civile (UE 17,1; 24,12-13; Vat. Frag. 168). Conforme a opinião de R. Astolfi, Le exceptae personae cit. (nota 108 supra), p.224; Idem, La Lex Iulia et Papia cit. (nota 15 supra), pp.64-67, as personae exceptae, tanto na Lex Iulia quanto na Lex Papia, compreendiam os cognati até o sexto grau. Em UE 16,1 (vide nota 66 supra) ao tratar da sucessão entre cônjuges, insere os cognati na categoria das exceptae personae até o sexto grau: (...) vir et uxor inter se solidum capere possunt (...) si cognati inter se coierint usque ad sextum gradum (...): “(...) o marido e a esposa podem reciprocamente tomar a totalidade dos bens (...) se os cognados estiverem unidos entre si [forem parentes] até o sexto grau (...). Também eram solidi capax marido e mulher menores de 25 e 20 anos, respectivamente, mesmo que não tivessem filhos: (...) si vir minor annorum $X X V$ sit, aut uxor annorum $X X$ minor(...): “(...) se o marido for menor de 25 anos ou a mulher de 20(...)". De acordo com R. Astolfi, op.cit., pp.342-344;347; Idem, Note per una valutazione storica della 'Lex Iulia et Papia' cit. (nota 36 supra), pp.203-207, o elenco das exceptae personae e o conceito de capacitas, distinto da testamentifactio, foram adotados pelo legislador na Lex Iulia et Papia seguindo o modelo elaborado pela Lex Furia testamentaria, um plebiscito de data incerta (promulgado entre 204 e 169 a.C.), que proibia os legados superiores a mil asses, salvo quando fossem dispostos em favor das exceptae personae, ou seja, os parentes até o sexto grau e do sétimo grau o filho do primo. Foi uma tentativa da nobilitas republicana conservar o seu poder em relação aos populares e demais itálicos. Na Lex Furia, considerava-se apenas o valor do legado para que o beneficiado pudesse recebê-lo. Na Lex Iulia et Papia, verificavam-se as condições patrimoniais e pessoais do destinatário. Vejamse UE 1,2; 28,7; Gai.2,225; Inst. 2,22pr.; Vat. Frag. 301. De acordo com a Lex Iulia et Papia, se a femina probrosa fosse chamada a suceder no lugar de uma excepta persona, sua capacitas era total. Os estreitos vínculos de parentesco das exceptae personae garantiam que fosse respeitada a última vontade do de cuius. De acordo com E. NARDI, La 'incapacitas' delle 'feminae probrosae' cit. (nota 96 supra), p.170, possiamo dire che la donna infame (com'è la meretrice) non sia stata ammessa ad altre successioni fuorchè a quella legittima dei figli. 
Quanto aos solidi capaces, pessoas que tinham a capacidade de receber a herança e que estavam isentos das sanções previstas pelas leis matrimoniais referentes à sucessão, elas tinham o direito de suceder ab intestato tanto conforme o ius civile quanto pelo ius honorarium. $^{388}$

Quando o matrimônio não estava de acordo com as disposições da lex Iulia et Papia, os cônjuges não podiam suceder reciprocamente por testamento e, neste caso, o pretor também retirava o direito de suceder $a b$ intestato. O pretor adequou a sucessão $a b$ intestato à sucessão testamentária e concedeu a bonorum possessio denominada unde vir et uxor, sob a condição de que o matrimônio fosse válido segundo o ius civile (matrimonium iustum secundum ius civile) e lícito, de acordo com a lex Iulia et Papia. ${ }^{389}$

del 'ius liberorum' cit. (nota 105 supra), p.9; O.M. PÉTER, Liberorum quaerendorum causa cit. (nota 21 supra), p.330; J. GAUDEMET, L'Apport du Droit Romain cit. (nota 59 supra), p.38; Idem, Utilitas Publica cit. (nota 44 supra), pp.167 e 172; R. AsTOLFI, Le exceptae personae cit. (nota 108 supra), pp.220-226; Idem, La Lex Iulia et Papia cit. (nota 15 supra), pp.64-67;251-252;265;290-294;332;339; Idem, Femina probrosa cit. (nota 96 supra), pp.47-48; Idem, Note per una valutazione storica della 'Lex Iulia et Papia' cit. (nota 36 supra), pp.200;203-205; VOLTERRA, Matrimonio cit. (nota 61 supra), p.772; V. ARANGIO-RUIZ, Istituzioni cit. (nota 53 supra), pp.443-444; J. IGLESIAS, Derecho Romano cit. (nota 51 supra), p.344; E. DOMÍNGUEZ LÓPEZ, La impotencia en las 'Leges Iulia et Papia' cit. (nota 103 supra), pp.167-168; C. ORTín GARCÍA, Edad, Matrimonio cit. (nota 103 supra), pp.510 e 513; L.F. RADITSA, Augustus Legislation cit. (nota 49 supra), pp.322-323; D. NÖRR, The matrimonial Legislation of Augustus cit. (nota 54 supra), pp.351-352;355; T. Spagnuolo Vigorita, Casta Domus cit. (nota 26 supra), p.30; M. ZABŁocKA, Le modifiche cit. (nota 103 supra), p.382; B. BIONDI, La legislazione di Augusto cit. (nota 56 supra), pp.135-136, nota 3; G. IMPALLOMENI, In tema di vitalità e forma umana cit. (nota 143 supra), p.282; A. BOUCHÉ-LECLERCQ, Les lois démographiques d'Auguste cit. (nota 36 supra), pp.262-263.

R. BESNIER, L'application des lois caducaires cit. (nota 10 supra), pp.96;102-104;108;118, afirma que no Gnomon do Idiólogo, o § 27 indicava uma alteração do disposto na Lex Papia Poppaea na província egípcia, pois estabelecia que o caducum era recolhido diretamente pelo Fisco, ao contrário das disposições da Legislação de Augusto [Gai. 2,207;286-a; UE 18,1], que estabeleciam que os co-herdeiros e legatários patres recebiam os bona caduca retiradas dos caelebs e dos orbi. Também foi estabelecida, no Egito, a necessidade da auto-denúncia para que o maior de sessenta anos, desde que orbus, recebesse a metade de sua parte

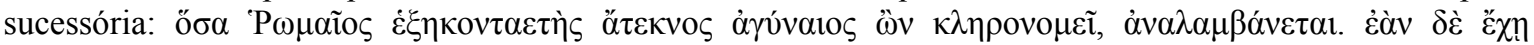

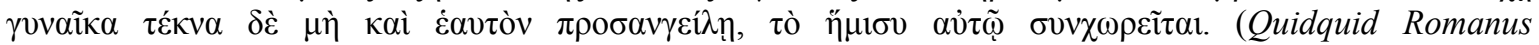
sexagenarius, cui nec liberi nec uxor sunt, hereditario nomine accipit, aufert; quivero uxorem habens liberos non habet, si ipse se defert, ei dimidia pars conceditur): "É confiscada qualquer vantagem sucessória feita a um Romano com sessenta anos de idade, que não tem nem esposa nem filho. Se ele é casado sem filho e se denunciar a si mesmo, ele recolhe a metade da soma".

${ }^{388}$ R. Astolfi, Note per una valutazione storica della 'Lex Iulia et Papia' cit. (nota 36 supra), p.192.

389 As normas limitadoras da capacitas foram estendidas por analogia à bonorum possessio secundum tabulas. Veja-se R. Astolfi, La Lex Iulia et Papia cit. (nota 15 supra), pp.121-123; Idem, Note per una valutazione storica della 'Lex Iulia et Papia' cit. (nota 36 supra), p.221. Paul. 4 ad l. Iul. et Pap. D.50,16,138: 'Hereditatis' appellatione bonorum quoque possessio continetur. "Na palavra 'herança' incluise também a posse dos bens [hereditários]"; Ulp. 47 ad ed. D.38,11,1pr.: Ut bonorum possessio peti possit unde vir et uxor, iustum esse matrimonium oportet. Ceterum si iniustum fuerit matrimonium, nequaquam bonorum possessio peti poterit, quemadmodum nec ex testamento adiri hereditas vel secundum tabulas peti bonorum possessio potest: nihil enim capi propter iniustum matrimonium potest. "Para que se possa exigir a bonorum possessio unde vir et uxor é necessário que o matrimônio seja legítimo. Porém, se o matrimônio fosse ilegítimo, não se poderá exigir nem a bonorum possessio, nem de forma alguma se pode adir a herança por força de testamento ou exigir a bonorum possessio secundum tabulas: por causa da ilegitimidade do matrimônio, não se pode receber nada". Se nem o marido nem a esposa pudessem receber a sucessão, a herança se torna vacante e é destinada ao Fisco. Outro ponto importante a ser destacado: as disposições 
Tendo em vista a importância do aumento da natalidade, os orbi, os casados sem filhos, gozavam do ius capiendi somente a metade da sucessão testamentária. ${ }^{390}$

Os casais que tivessem pelo menos um filho, independente do sexo da criança, adquiriam a capacidade recíproca plena. Neste caso as mulheres, ingênuas ou libertas, não dependiam do ius trium [quattuor] liberorum para ter a capacitas. ${ }^{391}$ As mulheres que

previstas nas leis caducárias não eram aplicadas na herança damnosa, ou seja, na herança em que o passivo superava o ativo. A aquisição de uma herança vacante, por falta de sucessores, ocorria ipso iure, conforme os interesses do "Estado". Veja-se Call. 1 de iure fisci D.49,14,1,1: An bona, quae solvendo non sint, ipso iure ad fiscum pertineant, quaesitum est. Labeo scribit etiam ea, quae solvendo non sint, ipso iure ad fiscum pertinere. Sed contra sententiam eius edictum perpetuum scriptum est, quod ita bona veneunt, si ex his fisco adquiri nihil possit. "É perguntado se o fisco adquire ipso iure um patrimônio passivo. Labeão escreve que também um patrimônio passivo é adquirido ipso iure pelo físco. Mas, contra esta opinião, foi redigido um edito perpétuo, segundo o qual tanto um patrimônio é vendido que dele nada possa ser adquirido pelo fisco".

Neste caso de herança damnosa, prevaleceu a opinião estabelecida pelo pretor no edito perpétuo, pois nem os parentes com prole nem o "Estado" podiam reivindicar os bona vacantia ou os bona caduca. Clem. 4 ad $l$. Iul. et Pap. D.28,5,72: Si quis solidum a lege capere non possit et ex asse sit institutus ab eo qui solvendo non est, Iulianus ex asse eum heredem esse respondit: legi enim locum non esse in ea hereditate quae solvendo non est. "Se alguém não pudesse receber o inteiro por força da lei e foi instuído em toda a herança por quem não é solvente, Juliano respondeu que ele se torna herdeiro no todo: porque a lei não é aplicada na herança que não é solvente". Veja-se R. Astolfi, La Lex Iulia et Papia cit. (nota 15 supra), pp.121-123;268269, nota 43;305-308; Idem, Note per una valutazione storica della 'Lex Iulia et Papia' cit. (nota 36 supra), p.221.

${ }^{390}$ Gai. 2,286-a: Item orbi, qui per legem Papiam [ob id quod liberos non habent] dimidias partes hereditatum legatorumque perdunt, olim solida fideicommissa videbantur capere posse. (...) "Os orbi [os que não tem filhos] que por esta razão perdem, pela lei Pápia, a metade das heranças e legados, reputavam-se outrora capazes de tomar no seu inteiro os fideicomissos.(...)". Na mesma situação do orbus de poder tomar apenas a metade da herança, se encontrava o pater solitarius. Os cônjuges com filhos podiam suceder ilimitadamente um ao outro. A mulher quando o marido tenha morrido rei publicae causa também pode obter toda a herança. Nesta mesma situção estão as mulheres casadas com idade inferior aos vinte ou superior aos cinquenta anos e os homens casados com idade inferior aos vinte e cinco ou superior aos sessenta anos, pois não sofrem restrições sucessórias nas Leis Matrimoniais. Vejam-se V. ARANGIO-RUIZ, Istituzioni cit. (nota 53 supra), pp.443-444; L.R. ARGÜEllo, Manual cit. (nota 12 supra), p.435; E. VolterRA, Matrimonio cit. (nota 61 supra), p.772; D. DALLA - R. LAMBERTINI, Istituzioni di diritto romano cit. (nota 10 supra), p.108; S. Riccobono, La politica demografica di Augusto cit. (nota 103 supra), p.576; E. DOMÍNGUEZ LÓPEZ, La impotencia en las 'Leges Iulia et Papia' cit. (nota 104 supra), p.167; A. LÓPEZ PEDREIRA, Limitaciones a la 'libertas nuptialis' cit. (nota 40 supra), p.404; M. ZABŁOCKA, Il 'ius trium liberorum' cit. (nota 103 supra), pp.363;365-366; D. NÖRR, The matrimonial Legislation of Augustus cit. (nota 54 supra), p.352; R. ASTOLFI, La Lex Iulia et Papia cit. (nota 15 supra), pp.23;327;360; Idem, Note per una valutazione storica della 'Lex Iulia et Papia' cit. (nota 36 supra), p.189; B. BIONDI, La legislazione di Augusto cit. (nota 56 supra), p.136; A. BouchÉ-LeCLERCQ, Les lois démographiques d'Auguste cit. (nota 36 supra), p.263. Veja-se Scaev. 33 dig. D.22,3,27.

${ }^{391}$ Em algumas situações, os filhos mortos (liberi amissi) eram contados e garantiam aos seus pais a solidi capacitas, desde que o neonato atingisse, pelo menos, o nono dia de vida (dies nominum), dia em que recebiam o nome e eram submetidos à cerimônia religiosa da lustratio. Neste caso, de acordo com um trecho das Regras de Ulpiano, UE 16,1-a, o casal que perdesse um filho impúbere teria um ano e seis meses de vacatio em relação à Legislação Matrimonial para procriarem outros filhos e gozavam de uma capacitas completa neste período, no âmbito da sucessão recíproca: Libera inter eos testamenti factio est, si ius liberorum a principe inpetraverint; aut si filium filiamve communem habeant, aut quattuordecim annorum filium vel filiam duodecim amiserint, ut intra annum tamen et sex menses etiam unus cuiuscumque aetatis inpubes amissus solidi capiendi ius praestet. Item si post mortem viri intra decem menses uxor ex eo pepererit, solidum ex bonis eius capit. "Têm capacidade recíproca, se impetrarem o ius liberorum, ou se tiverem filho ou filha em comum, ou se perderem um filho de quatorze anos ou uma filha de doze, ou se perderem dois filhos de três anos ou três de oito dias, mas de forma que, dentro de um ano e seis meses, mesmo um único filho falecido impúbere, com qualquer idade, dá direito de tomar o inteiro. Assim, a mulher 
obtivessem o privilégio do ius liberorum tinham a capacidade plena no âmbito do direito sucessório. $^{392}$

Um capítulo da lex Iulia et Papia, denominado lex decimaria, estabelecia que os cônjuges que não tivessem filhos em comum podiam tomar reciprocamente a décima parte dos bens herdados, aos quais poderiam acrescentar outras tantas décimas quantos fossem os filhos supérstites de casamentos anteriores ou cada filho que tivessem em comum. ${ }^{393}$

Portanto, é suficiente que o casal tenha um filho comum para que possa dispor da décima reciprocamente.

A lex Iulia et Papia também proibiu as disposições de última vontade que limitassem a liberdade matrimonial (in causa caduci, pro non scriptis). A disposição testamentária era ilícita se prometesse vantagens patrimoniais ou impedisse alguém de

toma a totalidade dos bens do marido, se nos dez meses subsequentes à sua morte der à luz uma criança dele". Vejam-se M. ZABŁOCKA, Il 'ius trium liberorum' cit. (nota 103 supra), p.378; R. BESNIER, L'application des lois caducaires cit. (nota 10 supra), pp.112-113; R. AstOLF, La Lex Iulia et Papia cit. (nota 15 supra), pp.24;26;34;74;85-86; V. ARANGIO-RUIZ, Istituzioni cit. (nota 53 supra), p.444; E. CUQ, Les lois d'Auguste cit. (nota 145 supra), p.126. Quanto aos casos em que os cônjuges escapam das restrições da lex decimaria, veja-se UE 16,1. Veja-se também, quanto à disposição deste tema no Egito, Gnomon $\S 6$ :

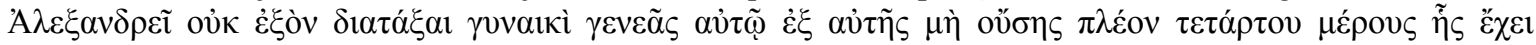

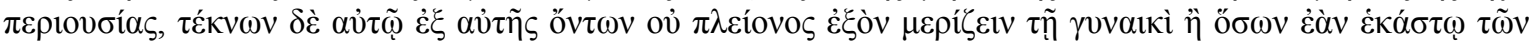

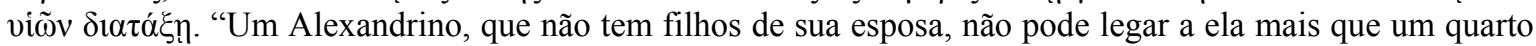
de sua fortuna. Se ele tem filhos, ele não pode legar a ela mais que uma quota viril de filho".

${ }^{392}$ Dio Cass. 56,10,2 (vide nota 363 supra). A Lex Iulia et Papia derrogou, neste caso, a Lex Voconia de 169 a.C. Esta legis minus quam perfectae, da época de Catão, o Antigo, proibia a mulher de ser instituída herdeira por um cidadão que tivesse um patrimônio superior a cem mil asses. Tinha dois escopos principais: evitar que se dispersasse o patrimônio das famílias mais ricas (nobilitas) e evitar a concentração de grandes fortunas nas mãos das mulheres. É provável que a Lex Iulia et Papia, no sistema caducário, tenha mantido em vigor a Lex Voconia para que o "Estado" reivindicasse em favor do Aerarium a parte da herança que as mulheres não podiam receber. Vejam-se M. ZABŁOCKA, Il 'ius trium liberorum' cit. (nota 103 supra), p.376; R. ASTOLFI, La Lex Iulia et Papia cit. (nota 15 supra), pp.344-345; Idem, Note per una valutazione storica della 'Lex Iulia et Papia' cit. (nota 36 supra), pp.207-209; T. SPAGNUOLO Vigorita, Casta Domus cit. (nota 26 supra), p.77; A.A.L. KlabYN, Observações sobre a sanção ('sanctio') das leis em Direito Romano, in Revista de Direito Civil, Imobiliário, Agrário e Empresarial 68 (1994), p.8; E. CUQ, Les lois d'Auguste cit. (nota 145 supra), p.125; A. BOUCHÉ-LECLERCQ, Les lois démographiques d'Auguste cit. (nota 36 supra), pp.273-274. É importante salientar, de acordo com R. ASTOLFI, Femina probrosa cit. (nota 96 supra), pp.48-49, que o ius liberorum não excluía a incapacitas das feminae probrosae. A femina probrosa, ainda que de acordo com as disposições da Lex Iulia et Papia, permanecia incapax, pois, nem o matrimônio e nem a procriação eram critérios que excluíssem a condição de probrosae de uma mulher. Veja-se Ulp. 13 ad Sab. D.38,17,2,4.

${ }^{393}$ UE 15,1: Vir et uxor se matrimonii nomine decimam capere possunt. Quod si ex alio matrimonio liberos superstites habeant, praeter decimam, quam matrimonii nomine capiunt, totidem decimas pro numero liberorum accipiunt. "O marido e a mulher, pelo matrimônio, podem tomar reciprocamente a décima. Tendo filhos supérstites de outro leito, além da décima tomada pelo casamento, recebem outras tantas décimas quanto os filhos"; UE 15,2: Item communis filius filiave post nominum diem amissus amissave unam decimam adicit; duo autem post nominum diem amissi duas decimas adiciunt. "Tanto pelo filho como pela filha comum, mortos depois do dia do nome, acrescenta-se uma décima; por dois mortos, depois de oito dias, duas [décimas]”. Veja-se Gnomon §31. E. DomínGUEZ LóPEZ, La impotencia en las 'Leges Iulia et Papia' cit. (nota 104 supra), p.168, nota 3; C. ORTín GARCÍA, Edad, Matrimonio cit. (nota 103 supra), p.509, nota 9; R. BESNIER, L'application des lois caducaires cit. (nota 10 supra), pp.111-112;118; R. ASTOLFI, La Lex Iulia et Papia cit. (nota 15 supra), pp.34;74; B. BIONDI, La legislazione di Augusto cit. (nota 56 supra), p.136; V. ARANGIO-RUIZ, Istituzioni cit. (nota 53 supra), p.444; A. BOUCHÉ-LECLERCQ, Les lois démographiques d'Auguste cit. (nota 32 supra), p.275; E. MALDONADO DE LIZALDE, Lex Iulia de Maritandis Ordinibus cit. (nota 122 supra), p.551. 
obter estas vantagens, ao induzir a recusa de um determinado matrimônio ou mesmo proibisse contrair um matrimônio ou as segundas núpcias, v.g., "lego a Tícia, se permanecer viúva".394

Os bens deixados por aqueles que não tivessem descendentes (bona vacantia) ${ }^{395} \mathrm{e}$ os não adquiridos por efeito da incapacitas estabelecida pela lex Papia Poppaea (bona

${ }^{394}$ R. Astolfi, La Lex Iulia et Papia cit. (nota 15 supra), pp.121-123;161-164;235-248;298;310, nota 33;326;336;360-361; Idem, Femina probrosa cit. (nota 96 supra), p.48; Vejam-se R. AstolFi, Note per una valutazione storica della 'Lex Iulia et Papia' cit. (nota 36 supra), pp.222-223; E. MALDONADO DE LIZALDE, Lex Iulia de Maritandis Ordinibus cit. (nota 122 supra), p.555. É lícita a disposição (condição ou modo) que incentiva e estimula o seu destinatário a casar-se. Ilícita e privada de efeitos, aquela que impede o destinatário ou um terceiro de contrair matrimônio ou que prive, de qualquer forma, a sua liberdade matrimonial, v.g., o testamento de um paterfamilias que estabeleça a condição do filho permanecer caelebs.

Papianiano afirma que, de acordo com a Lex Iulia et Papia, é nula e ilícita a condição subordinada à vontade de um terceiro (Tício), que limite ou impeça a liberdade matrimonial dos cônjuges. Pap. 18 quaest. D.35,1,72,4: 'Si arbitratu Titii Seia nupserit, heres meus ei fundum dato'. Vivo Titio etiam sine arbitrio Titii eam nubentem legatum accipere respondendum est eamque legis sententiam videri, ne quod omnino nuptiis impedimentum inferatur. Sed si Titius vivo testatore decedat, licet condicio deficit, quia tamen suspensa quoque pro nihilo foret, mulieri succurretur. " 'Se Seia casar-se segundo a vontade de Tício, o meu herdeiro dê-lhe um terreno'. Deve-se responder que, ela casando-se estando Tício vivo, mesmo sem a vontade de Tício, ela pode receber o legado e este parece que é o espírito da lei, para que não se apresente nenhum impedimento às núpcias. Porém, se Tício falecesse quando o testador ainda estivesse vivo, a mulher é socorrida, mesmo se falta a condição, uma vez que ela [a condição], mesmo se permanecesse suspensa, seria considerada nula". Portanto o legado é eficaz, pois a condição é incerta, considerada como não escrita: se Tício sobreviver ao testador, Seia obterá o legado, mesmo se o parecer for contrário ao seu matrimônio. As disposições in causa caduci eram inválidas por não estarem de acordo com as disposições das leis matrimoniais. As disposições caduca e in causa caduci foram limitadas pela jurisprudência, de acordo com a Lex Papia Poppaea, quando: (a) não se realizasse a condição após a conclusão do testamento; (b) pela incapacitas do destinatário; (c) pela falta da testamenti factio; (d) pela perda da cidadania e; (e) pela recusa do herdeiro ou do legatário de aceitar a herança ou legado. Qualquer outra causa de invalidade ou ineficácia posterior à conclusão do testamento, tornava a disposição pro non scripta. Vejam-se, Marcian. 11 inst. D.34,8,3; Gai. 3 ad l. Iul. et Pap. D.35,1,63,1; Pap. 16 quaest. D.35,1,71,1; PS 3,4b,2; Sever. et Ant. C.6,25,1 (199); Ant. C.6,25,2pr. (213).

${ }^{395}$ Caso não houvesse nem herdeiros testamentários, nem herdeiros legítimos, seja porque não podem ou não querem ser herdeiros, a herança é vacante e, de acordo com a Lex Iulia de maritandis ordinibus deveria ser atribuída ao Aerarium Populi Romani. A lei se limita em acrescentar a regra que o "Estado" sucede na ausência de herdeiros determinados pelo ius antiquum. Antonino Pio estabeleceu que o direito do "Estado" sobre os bona vacantia prescrevia em 4 anos, conforme Call. 1 de iure fisci D.49,14,1,2. De acordo com R. Astolfi, La Lex Iulia et Papia cit. (nota 15 supra), pp.301-304, foi a interpretação extensiva da jurisprudência, e não a Lex Iulia, que estabeleceu a exclusão da vacância no caso de haver herdeiros bonorum possessores, previstos pelo ius honorarium. Vejam-se Gai. 2,150: Sane lege Iulia scriptis non aufertur hereditas, si bonorum possessores ex edicto constituti sint. Nam ita demum ea lege bona caduca fiunt et ad populum deferri iubentur, si defuncto nemo heres vel bonorum possessor existat. "Sem dúvida, segundo a Lex Iulia, não se pode privar da herança os herdeiros inscritos, quando o edito thes concede a bonorum possessio. Pois, de acordo com aquela lei, os bens se tornam caducos e se devolvem ao povo, somente não havendo nenhum herdeiro ou bonorum possessor do defunto"; UE 28,7: Intestati datur bonorum possessio per septem gradus (...) et si nemo sit, ad quem bonorum possessio pertinere possit, aut si quidem, sed ius suum omiserit, populo bona deferentur ex lege Iulia caducaria. "A posse dos bens ab intestato concede-se segundo sete graus (...) e não havendo ninguém a quem caiba a posse dos bens, ou, havendo, perdeu seu direito, os bens se devolvem ao povo por força da Lex Iulia caducaria". No Egito e provavelmente em todas as outras províncias imperiais, os bona vacantia e os caduca eram atribuídos ao Fisco. Veja-se Gnomon §4:

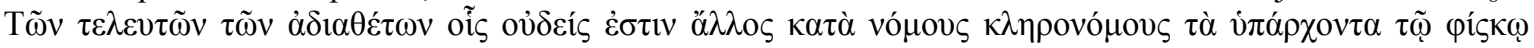
$\pi \rho о \sigma \kappa \rho \varepsilon i ́ v \varepsilon \tau \alpha u$. (Qui intestati decedunt, si nemo alius iis legitimus heres est, eorum bona fisco adiudicatur): "Os bens daqueles que morrem sem testamento, que não têm nenhum herdeiro legítimo, são adjudicados ao Fisco". 
caduca) $)^{396}$ tornaram-se uma fonte de rendas para o "Estado" romano, pois eram recolhidos pelo Aerarium Populi Romani (tesouro do Senado e do povo) e possivelmente a partir da época de Caracala, pelo Fiscus Caesaris (tesouro do imperador). ${ }^{397}$

\begin{abstract}
${ }^{396}$ Na opinião de R. Astolfi, La Lex Iulia et Papia cit. (nota 15 supra), p.328, apenas aquele que tem a solidi capacitas tem direito aos caduca. Para os casados, bastaria um único filho para ter direito aos bona caduca. Gaio em suas Institutas descreveu algumas situações que originavam estes bona caduca. Por exemplo, era uma causa de caducidade o caso em que o segundo testamento provocasse a revogação do primeiro, porém não apresentasse herdeiros com a capacitas para adquirir a herança. Tornavam-se incapaces os caelibes que dentro de 100 dias (cretio) a partir da abertura da sucessão, não atendessem às determinações da Lex Iulia. Neste sentido Gai. 2,144: Posteriore quoque testamento, quod iure factum est, superius rumpitur. Nec interest, an extiterit aliquis ex eo heres, an non extiterit: hoc enim solum spectatur, an existere potuerit. Ideoque si quis ex posteriore testamento quod iure factum est aut noluerit heres esse, aut vivo testatore aut post mortem eius, antequam hereditatem adiret, decesserit, aut per cretionem exclusus fuerit, aut condicione sub qua heres institutus est defectus sit, aut propter caelibatum ex lege Iulia sommotus fuerit ab hereditate: quibus casibus pater familias intestatus moritur, nam et prius testamentum non valet ruptum a posteriore, et posterius aeque nullas vires habet, cum ex eo nemo heres extiterit. "O testamento anterior rompe-se também por outro testamento válido. Pouco importa que neste haja ou não herdeiro instituído; pois só se indaga se poderia existir como tal. Por isso, se alguém não quiser ser herdeiro de testamento posterior feito validamente, ou morrer em vida do testador ou depois dele, antes de adir a herança, ou for excluído por cretio, ou faltou a condição sob a qual foi instituído herdeiro, ou for excluído da herança pela lex Iulia por causa do celibato, o pater familias morre intestado; pois o primeiro testamento, roto pelo posterior, é nulo e este não tem igualmente eficácia alguma, visto não haver nenhum herdeiro". Neste passo de Gaio, deduz-se que a falta de capacitas daquele que fosse chamado à herança impedia a delatio hereditatis. Quanto às causas de caducidade, também Gai. 2,206-208;2,285-286-a; UE 1,21. O "Estado" poderia recusar tanto os bona vacantia quanto os bona caduca se a herança fosse damnosa. Além disso, a abertura da sucessão ab intestato excluía o regime caducário das leis matrimoniais e aplicava-se o ius antiquum. Isso ocorria quando uma única pessoa instituída herdeira (heredis institutio ex asse), não pudesse ou não quisesse suceder. De acordo com o ius antiquum, o testamento caduca e abre-se a sucessão ab intestato.
\end{abstract}

Vejam-se G. Pugliese - F. Sitzia - L. VACCA, Istituzioni cit. (nota 63 supra), p.401; E. Volterra, Matrimonio cit. (nota 61 supra), pp.772-773; L. Bove, Caduca, in NNDI 2 (1964), p.661; S. RicCOBONO, La politica demografica cit. (nota 103 supra), p.576; A. LÓPEZ PEDREIRA, Limitaciones a la 'libertas nuptialis' cit. (nota 40 supra), p.401; T. Spagnuolo Vigorita, Casta Domus cit. (nota 12 supra), pp.4-6;.24;30;77; R. Astolfi, La Lex Iulia et Papia cit. (nota 13 supra), pp.235;270-272;277;285-287;293-294;301;328;332; Idem, Note per una valutazione storica della 'Lex Iulia et Papia', in SDHI 39 (1973), pp.187-188;193;199; L.F. RADITSA, Augustus Legislation Concerning Marriage cit. (nota 37 supra), p.323; D. NÖRR, The matrimonial Legislation of Augustus cit. (nota 54 supra), p.352.

${ }^{397}$ O imperador Antonino Caracala (212-217), demonstrando que o interesse do "Estado" em relação às leis matrimoniais (caducárias) não era o aumento demográfico, mas o recolhimento de mais receitas para o Fisco, alterou algumas disposições sucessórias desta legislação e proibiu os co-herdeiros e legatários com prole a tomar os caduca, que tivessem adquirido dos ascendentes e descendentes até o terceiro grau. Além disso, ao conceder a cidadania romana a todos os habitantes do Império, é provável que nesta época, segundo R. Astolfi, La Lex Iulia et Papia cit. (nota 39 supra), pp.352;354;367; Idem, Femina probrosa cit. (nota 96 supra), p.48, não existisse mais a necessidade de incentivar o aumento demográfico apenas nas classes senatorial e equestre, mas para todos os habitantes. O escopo demográfico é considerado um mero pretexto para providenciar novas receitas para o "Estado". O deslocamento do eixo político do Império para o Oriente, a crise financeira e a concessão da cidadania a todos os habitantes do Império diminuíram a importância da "estirpe itálica". UE 17,2: Hodie ex constitutione imperatoris Antonini omnia caduca fisco vidicantur: sed servato iure antiquo liberis et parentibus. "Hoje, por constituição do imperador Antonino, todas as partes caducas cabem ao fisco, mas se reserva aos descendentes e ascendentes o direito antigo". Em relação aos bona vacantia recolhidos pelo Fisco, veja-se Iul. 39 dig. D.30,96,1. Também os caduca originados da incapacitas das feminae probrosae eram destinados ao Aerarium (depois ao Fisco), na falta de herdeiros que tivessem filhos.

Vejam-se G. PUGLIESE - F. SitZIA - L. VACCA, Istituzioni cit. (nota 63 supra), p.401; A. GuARINO, Storia del diritto romano cit. (nota 103 supra), p.450; L.R. ARGÜELLO, Manual cit. (nota 12 supra), p.435; R. ASTOLFI, Le exceptae personae cit. (nota 108 supra), p.224; Idem, La Lex Iulia et Papia cit. (nota 15 supra), pp.266- 
Durante o Principado, muitos senatusconsultos ${ }^{398}$ alteraram, interpretaram ou confirmaram as disposições das Leis Matrimonais de Augusto, adaptando-as à sociedade da época, e demonstraram as interferências cada vez mais constantes do interesse do "Estado Romano" nas relações familiares e sucessórias, muitas vezes por meio da figura do delator (inditi custodes), introduzida pela lex Iulia de maritandis ordinibus. ${ }^{399}$

268;270-272;276-277;353;357-358;367; Idem, Femina probrosa cit. (nota 96 supra), p.48; Idem, Note per una valutazione storica della 'Lex Iulia et Papia' cit. (nota 36 supra), pp.190;214;219; E. VOLTERRA, Matrimonio cit. (nota 61 supra), pp.772-773; J. IGLESIAS, Derecho Romano cit. (nota 51 supra), p.344; J.C. Tello, La concesión discrecional cit. (nota 161 supra), p.770; A. LÓPEZ PEDREIRA, Limitaciones a la 'libertas nuptialis' cit. (nota 40 supra), p.401; M. ZABŁOCKA, Il 'ius trium liberorum' cit. (nota 103 supra), p.363; Idem, Le modifiche cit. (nota 103 supra), pp.389-392; J. Ellul, Histoire des Institutiones cit. (nota 353 supra), pp.299-300; V. ARANGIO-RuIZ, Storia del diritto romano cit. (nota 253 supra), pp.236-237; F. Della CORTE, Le 'leges Iuliae' e l'elegia romana cit. (nota 47 supra), p.541; R. BESNIER, L'application des lois caducaires cit. (nota 10 supra), pp.96;104-105; B. BIONDI, La legislazione di Augusto cit. (nota 56 supra), p.135; L.F. RADITSA, Augustus Legislation cit. (nota 49 supra), p.324; J.A. FIELD JR., The purpose cit. (nota 129 supra), p.411; D. NÖRR, The Matrimonial Legislation of Augustus cit. (nota 54 supra), pp.354-355; P. VoCI, Teoria dell'acquisto cit. (nota 381 supra), p.17; A. BOUCHÉ-LECLERCQ, Les lois démographiques d'Auguste cit. (nota 36 supra), p.263; E. MALDONADO DE LizALDE, Lex Iulia de Maritandis Ordinibus cit. (nota 122 supra), p.551. Veja-se também UE 18,1 (nota 220 supra).

Os legados caducos seguiam praticamente o mesmo destino dos bens testamentários: tinham prioridade os herdeiros com prole; na ausência deles, eram atribuídos aos legatários com prole; na ausência destes, eram recolhidos pelo Aerarium (posteriormente pelo Fisco). Tinha mais vantagens o herdeiro que tivesse mais filhos. Por exemplo, se os destinatários de dois legados distintos são patres, o caducum seria destinado àquele que tivesse a prole mais numerosa.

${ }^{398}$ É importante destacar o Senatusconsulto Getuliciano, do século I, combateu as fraudes em que os cônjuges utilizavam-se da conventio in manum para obterem vantagens sucessórias. Por exemplo, quando o orbus utiliza-se da conventio in manum e a sua própria esposa tornava-se sua filha (Gai. 1,144; 1,148; 2,139; 2,159; 3,41; Coll. 16,2,3; UE 22,14), loco filiae. Também no caso em que os cônjuges sem filhos, fraudulentamente, realizassem uma conventio in manum para que o marido pudesse receber toda a herança da esposa a título universal, tornando-se proprietário de seus bens, visto que ela se tornava alieni iuris $(G a i .3,83)$. Nos casos em que a mulher não pudesse receber a herança do marido, por meio de uma conventio in manum, ela se tornava heres sua e então recebia a herança na condição de excepta persona. Em todos estes casos, verificada a fraude, o pretor negava a bonorum possessio. A única fonte que menciona o senatusconsultum Getuliciano é um Papiro Berlinense. Pap. Berlin. 11753,3 Paul. 8 ad Plaut. 1150a: Uxor autem, quae in manu <mari>ti erat, olim quidem omnimodo sua heres esset; hodie autem si $f<$ raude in manum venit $>$, non efficitur sua heres propter senatus consultum Gaetulicianum. Veja-se R. AsTOLFI, La Lex Iulia et Papia cit. (nota 15 supra), pp.123-128;338;354.

${ }^{399}$ Vejam-se A. LÓPEZ PEDREIRA, Limitaciones a la 'libertas nuptialis' cit. (nota 47 supra), p.404; C. ORTíN GARCÍA, Edad, Matrimonio cit. (nota 103 supra), pp.516-517; R. Astolfi, La Lex Iulia et Papia cit. (nota 15 supra), pp.293-294;338-339;351; T. SPagnUOlo VIGORITA, Casta Domus cit. (nota 26 supra), pp.4-6; F. SERAFINI, Istituzioni cit. (nota 53 supra), p.236; L.F. RADITSA, Augustus Legislation cit. (nota 49 supra), p.330; D. NÖRR, The matrimonial Legislation of Augustus cit. (nota 54 supra), p.352. De acordo com R. Astolfi, La Lex Iulia et Papia cit. (nota 15 supra), p.354, a resistência das classes senatorial e equestre, a crise econômica (60-70 d.C.) e a tendência a uma política voltada à parte Oriental do Império, a partir de Calígula, foram os principais fatores que influenciaram na promulgação de uma série de senatusconsultos que alteraram e interpretaram as leis matrimoniais de Augusto. Os senatusconsultos Persiciano (34 d.C.), Claudiano (52 d.C.) e Calvisiano (61 d.C.), além de se contituírem importantes complementos à Lex Iulia et Papia, significaram o início de uma reforma que a sociedade romana nunca deixou de exigir. A resistência social que Augusto encontrou ao publicar suas leis, oriunda principalmente das ordens senatorial e equestre, cresceu no decorrer do Principado e se agravou no governo de Tibério. Em relação aos senatusconsultos Persiciano e Claudiano, M. ZABŁOCKA, Le modifiche cit. (nota 103 supra), pp.388;392-395, acredita que tiveram como finalidades principais o aumento das receitas para o Aerarium e não a procriação ou a reforma dos costumes. 
Após fornecer um panorama da degradação dos costumes na transição República-Principado, as discórdias na sociedade romana desde o início das reformas em 28-27 a.C. e sobre o fracasso das leis matrimoniais promulgadas por Augusto, Tácito (Tac. Ann. 3,28,1-4) afirma que Tibério nomeou uma comissão formada por cônsules, pretores e senadores para realizar importantes reformas com a finalidade de abrandar os rigores da legislação matrimonial. Para Tácito, apesar dos nobres propósitos das leis, elas fracassaram devido à cobiça desenfreada dos delatores e de acordo com a impossibilidade de impor a moral aos cidadãos, estas leis muito rígidas deveriam ser ab-rogadas: Tum Cn. Pompeius, tertium consul corrigendis moribus delectus et gravior remediis quam delicta erant suarumque legum auctor idem ac subversor, quae armis tuebatur armis amisit. Exim continua per viginti annos discordia, non mos, non ius; deterrima quaeque impune ac multa honesta exitio fuere. Sexto demum consulatu Caesar Augustus, potentiae securus, quae triumviratu iusserat abolevit deditque iura quis pace et principe uteremur. Acriora ex eo vincla, inditi custodes et lege Papia Poppaea praemiis inducti ut, si a privilegiis parentum cessaretur, velut parens omnium populus vacantia teneret. Sed altius penetrabant urbemque et Italiam et quod usquam civium corripuerant, multorumque excisi status; et terror omnibus intetabatur ni Tiberius statuendo remedio quinque consularium, quinque e praetoriis, totidem e cetero senatu sorte duxisset apud quos exsoluti plerique legis nexus modicum in praesens levamentum fuere. "Sendo, pois, nomeado pela terceira vez cônsul Cneo Pompeu, e propositalmente escolhido para reformar os costumes, ele mesmo foi ainda mais fatal do que foram os males que devia remediar; porque, passando ao mesmo tempo a ser o autor e destruidor das próprias leis que fazia, veio a perder pelas armas o poder que por elas tinha conseguido. Em seguida, a discórdia tinha continuado por vinte anos, sem costumes, sem direito [sem leis]; as piores ações permaneciam impunes e muitas ações honestas tornaram-se causa de morte [exitio]. Finalmente César Augusto no sexto consulado, seguro de seu poder, aboliu as medidas promulgadas no triunvirato e ditou as normas que utilizaríamos na paz e sob um príncipe. Para que fossem mais firmes também criou magistrados que as fizessem executar; porém estes, atraídos pelo prêmio que a Lex Papia Poppaea lhes prometia, converteram-se em delatores dos que evitavam casar-se, para que o povo romano, como pai de todos os povos, entrasse na herança de seus bens. Mas elas [as denúncias] fizeram por fim a desgraça de Roma, da Itália e de todos os cidadãos romanos, a muitos dos quais já se tinha devorado as fortunas; e produziam à todos a consternação e o terror. Tibério, para remediar esta desordem, nomeou à sorte cinco antigos consulares, cinco antigos pretores e outros cinco restantes do senado, os quais, tendo esclarecido muitas dificuldades da lei, ao menos momentaneamente produziram algum bem". $\mathrm{O}$ trecho suarum legum auctor idem ac subversor faz referência a Pompeu, não a Augusto.

Segundo R. Astolfi, La Lex Iulia et Papia cit. (nota 15 supra), p.353, na prática, a atividade dos delatores não foi tão hostilizada pela sociedade na época de Tibério e o autor considera a narrativa de Tácito exagerada neste sentido. ASTOLFI, op.cit., p.354, afirma que é possível identificar a ênfase do escopo fiscal nas leis matrimoniais apenas na época de Nero (54-68 d.C.), vinculada ao enfraquecimento do escopo demográfico em relação às classes senatorial e equestre. Na época de Augusto, portanto, os fins ético-sociais não estão subordinados aos fins fiscais, pelo contrário, o princeps procurou harmonizar os escopos demográfico e fiscal. Posteriormente, no decorrer do Principado, a política dos imperadores tende a salientar o aspecto fiscal e a negar o aspecto "classista" da lei. O interesse das classes privilegiadas é exatamente o oposto. Por isso, a finalidade da lei não era mais a de aumentar a procriação apenas nas classes privilegiadas, mas destinada a todos os cidadãos. A Lex Iulia et Papia torna-se uma forma de "nivelar" vários elementos sociais diante do poder do princeps. Veja-se R. Astolfi, Note per una valutazione storica della 'Lex Iulia et Papia' cit. (nota 36 supra), pp.198-199;200;215. Também com opinião semelhante, acredita B. BIONDI, La legislazione di Augusto cit. (nota 78 supra), p.157, que é um exagero e uma distorção histórica supor que a legislação matrimonial tenha se tornado um instrumento de perseguição política nas mãos do princeps, visto que, se ele quisesse liquidar algum inimigo político, ele disporia de inúmeras outras formas. Para J.A. FIELD JR., The purpose cit. (nota 129 supra), pp.411, nota 55;416, não há qualquer evidência sobre uma priorização do caráter fiscal na legislação de Augusto. No mesmo sentido, afirma D. NöRR, The Matrimonial Legislation of Augustus cit. (nota 54 supra), pp.354-355;363, que não é possível determinar quantitativamente se houve um aumento de bens ou valores confiscados pelo "Estado" romano devido à legislação matrimonial e que, em virtude disto, o interesse fiscal é um efeito colateral e não um dos escopos principais da mesma. Apóia a crítica de Tácito, T. Spagnuolo Vigorita, Casta Domus cit. (nota 26 supra), pp.25;83, ao afirmar que a legislação de Augusto, apesar de seus bons propósitos, agravou a situação social da degeneração moral causada pela cobiça dos delatores e pelos excessos cometidos por eles, motivados pelos prêmios oferecidos pela Lex Papia Poppaea. O autor defende que a possibilidade do Aerarium confiscar os bona vacantia e os bona caduca por meio dos delatores já teria sido prevista por Augusto no seu projeto de lei de 28/27 a.C. E conclui que as leis caducárias revelaram sua maior eficácia exatamente no mecanismo delatório, que contribuiu para aumentar as receitas do Fisco e do Erário. Sobre a proteção de Tibério aos delatores e a defesa dos prêmios como estímulo aos custodes legum, veja-se Tac. Ann. 4,30,2-3. Tem opinião semelhante 


\section{A lex Papia Poppaea ampliou o rigor da lex Iulia de maritandis ordinibus e} estabeleceu prêmios (praemia) para incentivar estes delatores na denúncia daqueles que descumprissem as disposições da legislação matrimonial e não pudessem recolher uma herança, um legado ou um fideicomisso (bona caduca). ${ }^{400}$

Um indício da aplicação da política matrimonial de Augusto nas províncias romanas (neste caso, o Egito), dirigida principalmente às classes mais ricas, pode ser verificado em três trechos presentes no Gnomon do Idiólogo.

O §29 determinava que as mulheres caelibes mais ricas, tanto ingênuas quanto libertas, que tivessem um patrimônio mínimo de 20.000 sestércios eram obrigadas a pagar um imposto anual de um por cento do valor total de seu patrimônio. ${ }^{401}$

M. ZABŁOCKA, Le modifiche cit. (nota 103 supra), pp.394-395, ao salientar que a maioria dos delatores procuravam obter, a todo custo, os prêmios determinados pela Lex Papia Poppaea. O mais provável, segundo a autora, é que a comissão de Tibério tenha sido criada apenas para minimizar o descontentamento crescente do povo em relação aos delatores e não tenha resolvido o problema, visto que Nero também ocupou-se deles. Neste sentido, A. BouchÉ-LECLERCQ, Les lois démographiques d'Auguste cit. (nota 36 supra), pp.263;280, defende que os romanos eram absolutamente contrários à intervenção da res publica em seus negócios particulares.

${ }^{400} \mathrm{Na}$ opinião de R. Astolfi, La Lex Iulia et Papia cit. (nota 15 supra), p.339, com a Lex Papia Poppaea, (...) lo scopo fiscale assume una importanza primaria e in certi casi independente dagli altri fini eticosociale. Salienta ASTOLFI, op. cit., pp.351-352 que o Estado romano já indicava com algumas leis deste período a necessidade de priorizar o escopo fiscal sobre o ético-social, v.g., com a promulgação da Lex Iulia de vicesima hereditatis em 6 d.C., que provocou muitos protestos. No início do Principado, o prêmio estabelecido pela Lex Papia Poppaea aos delatores provavelmente gerou alguns abusos, mas é pouco provável que seja o grande responsável pelos protestos das classes senatorial e equestre, que apesar de suas posições privilegiadas politica e socialmente, eram as mais resistentes às reformas do princeps. No final de seu principado, Augusto parece dar importância a ambos os escopos: seria errado acreditar que Augusto considerasse a legislação matrimonial apenas um meio para aumentar as receitas do "Estado". Todavia, no decorrer do Principado, nota-se uma efetiva e clara subordinação do escopo demográfico ao fiscal. De acordo com T. Spagnuolo Vigorita, Casta Domus cit. (nota 26 supra), p.24, é provável que a atribuição dos bona caduca ao Aerarium já fosse prevista pelo projeto de lei malsucedido de 28/27 a.C. Vejam-se, R. AsTOLFI, Note per una valutazione storica della 'Lex Iulia et Papia' cit. (nota 36 supra), p.214; V. CÉSAR DA SILVEIRA, v. Delator, in Dicionário de Direito Romano cit. (nota 9 supra), pp.193-194; L.F. RADITSA, Augustus Legislation cit. (nota 49 supra), pp.325; J.A. FIELD JR., The purpose cit. (nota 129 supra), p.404; D. NÖRR, The matrimonial Legislation of Augustus cit. (nota 54 supra), pp.352;356-357;359.

No início do Principado, o prêmio estabelecido pela Lex Papia Poppaea aos delatores era, provavelmente, a metade do total dos bona caduca do denunciado. Por volta de 54 d.C., Nero, para refrear a ação dos delatores (ou seria para aumentar os rendas do Aerarium?) reduziu o prêmio para um quarto do valor da herança, legado ou fideicomisso, conforme Suet. Nero 10: Praemia delatorum Papiae legis ad quartas redegit. "Ele [Nero] reduziu a um quarto os prêmios aos delatores pela Lex Papia". Vejam-se também Plin. Nat. Hist. 14,5; Petron. Sat. 116. Não acreditamos, porém, que Nero tenha tomado esta atitude para simplesmente aumentar as rendas do Império.

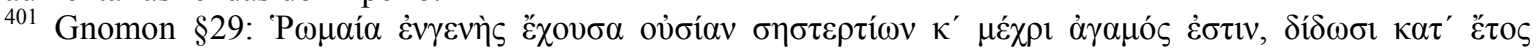

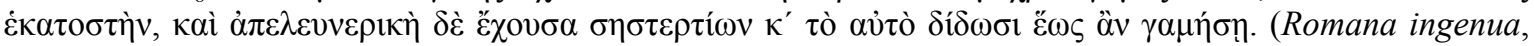
quae sestertium XX milium patrimonium habet, quamdiu caelebs est, in singulos annos centesimam dat, et liberta, quae sestertium XX milium patrimonium habet, idem dat, donec nubat). "Uma Romana de nascimento (ingenua), que tenha um patrimônio de 20.000 sestércios, enquanto é solteira, dá todo ano a centésima parte; também a liberta, que tenha 20.000 sestércios, dá a mesma [quantia], até que se case". Nas opiniões de R. BESNIER, L'application des lois caducaires cit. (nota 10 supra), pp.107;118 e R. ASTOLFI, La Lex Iulia et Papia cit. (nota 15 supra), p.323, é totalmente admissível que esta taxa sobre as solteiras, disposta no Gnomon $\$ 29$, para penalizar as mulheres ricas tanto ingênuas quanto libertas, estivesse de acordo 
Os $\S \S 30$ e 32 estabeleciam a sanção da incapacitas para herdar de acordo com o montante do patrimônio do herdeiro: 100.000 sestércios para os homens e 50.000 sestércios para as mulheres que não se casassem e não tivessem filhos. ${ }^{402}$

\section{e) segundas núpcias}

As Leis Demográficas de Augusto, para estimular a natalidade, favoreciam as segundas núpcias. Estabeleceram um período, denominado vacatio legis Iuliae, para que as mulheres respeitassem o tempus lugendi (literalmente, "tempo de chorar"), ou seja, o período em que a mulher não poderia se casar, após a morte do marido (posteriormente estendido ao divórcio e ao repúdio), para evitar a incerteza da descendência (turbatio sanguinis). ${ }^{403}$

com os objetivos da legislação matrimonial de Augusto. É provável que este imposto tenha sido estabelecido pela Lex Iulia et Papia e cobrado em todo o Império.

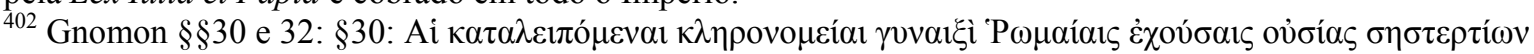

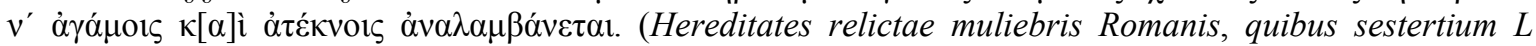
milium patrimonium est, si neque virum neque liberos habent, auferuntur): "As heranças deixadas às mulheres romanas que tiverem um patrimônio de 50.000 sestércios e que não tenham nem marido nem filhos, sejam confiscadas"; §32: 'P

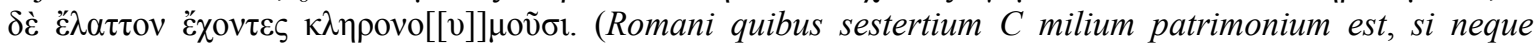
uxorem neque liberos habent, non succedunt; quod si minus habent, succedunt): "Os romanos que tiverem mais de 100.000 sestércios e são solteiros e sem filhos, não herdarão". Vejam-se R. Astolfi, La Lex Iulia et Papia cit. (nota 15 supra), p.82; Idem, Note per una valutazione storica della 'Lex Iulia et Papia' cit. (nota 36 supra), p.195; R. BESNIER, L'application des lois caducaires cit. (nota 10 supra), p.108; B. BIONDI, La legislazione di Augusto cit. (nota 56 supra), p.135; L.F. RADITSA, Augustus Legislation cit. (nota 49 supra), p.322, nota 105; D. NÖRR, The Matrimonial Legislation of Augustus cit. (nota 54 supra), p.352; T. Spagnuolo Vigorita, Casta Domus cit. (nota 26 supra), p.30. Na opinião de A. LóPez Pedreira, Limitaciones a la 'libertas nuptialis'cit. (nota 40 supra), p.401, estas sanções da Legislação matrimonial relativas aos direitos sucessórios indicariam que os interesses do legislador, neste caso, estavam mais voltados à fomentar a existência de uma forte aristocracia (...fomentar la existencia de una fuerte aristocracia que habría de servir a los interesses de Augusto...) que o crescimento demográfico de toda a população. Quanto à diferença entre os valores de homens e mulheres, a política legislativa romana tinha uma forte tendência, desde a Lex Voconia, de impedir as mulheres formarem grandes fortunas.

${ }^{403}$ Vejam-se F. SAMPER, Sobre el destino del 'ius liberorum' cit. (nota 105 supra), p.10; J.M. OTHON Sidou, Matrimonium I. cit. (nota 47 supra), p.75; A. BURDESE, Manuale cit. (nota 47 supra), pp.270-271;276; B. BIONDI, Istituzioni cit. (nota 22 supra), p.444; V. ARANGIO-RUIZ, Istituzioni cit. (nota 53 supra), pp.443-445; O.M. PÉTER, Liberorum quaerendorum causa cit. (nota 21 supra) p.304; R. MONIER, Manuel cit. (nota 146 supra), p.281; J. IGLESIAS, Derecho Romano cit. (nota 51 supra), pp.343-344; E. VOLTERRA, Matrimonio cit. (nota 61 supra), p.771; A. LÓPEZ PEDREIRA, Limitaciones a la 'libertas nuptialis' cit. (nota 40 supra), p.404; M. ZABŁOCKA, Il 'ius trium liberorum' cit. (nota 103 supra), pp.362;387; Idem, Le modifiche cit. (nota 103 supra), pp.380-381; R. AstolfI, La Lex Iulia et Papia cit. (nota 15 supra), pp.63;84-85;166-167;337; M. MARRONE, Istituzioni cit. (nota 48 supra), p.219, nota 59; L.F. RADITSA, Augustus Legislation cit. (nota 49 supra), p.323; F. C. SAVIGNY, System des heutingen römischen Rechts, trad. it. de V. Scialoja, Sistema del diritto romano attuale, vol.2, Torino, UTET, 1888, pp.528-531.

Durante o tempus lugendi, era pemitido à viúva contrair esponsais, conforme M.B. FuMAGALLI, Sponsali cit. (nota 51 supra), p.507; E. AlberTARIO, Matrimonio (Roma) cit. (nota 61 supra), p.587. De acordo com F. Schulz, Classical Roman Law cit. (nota 51 supra), pp.129-130 e A. RoMANo, Matrimonium iustum cit. (nota 26 supra), p.92, a idéia de evitar a turbatio sanguinis foi estabelecida pelo ius pontificium e tinha originariamente o prazo único de dez meses. Veja-se na L. XII Tab. IV,4: Si qui ei in X mensibus proximis 
Para evitar dúvidas sobre a paternidade do concebido, a lex Iulia de maritandis ordinibus, estabelecia um tempus lugendi que variava de acordo com a situação da mulher e a forma de dissolução de seu matrimônio: doze meses para a viúva, seis meses para a divorciada. A lex Papia Poppaea aumentou o período de vacância: dois anos para a viúva e dezoito meses para a divorciada. ${ }^{404}$

UE 14,1: Feminis lex Iulia a morte viri anni tribuit vacationem, a divortio sex mensum, lex autem Papia a morte viri bienni, a repudio anni et sex mensum.

"A Lei Iulia concede às mulheres, para se casarem, o prazo de um ano desde a morte do marido, de seis meses a partir do divórcio; mas a Lei Papia lhe concede o prazo de dois anos, no primeiro caso, e de dezoito meses, a partir do repúdio".

Caso não respeitasse o prazo e se casasse, pela nota pretória ela e o marido tornavam-se infames $(\text { infamia })^{405}$, porém isto não influenciava na validade de seu novo matrimônio. Este aumento do período de vacância ocorreu provavelmente pela valorização social, na época de Augusto, da mulher univira, ou seja, a viúva de um único marido. ${ }^{406}$

posthumus natus escit, justus esto. "Se um filho póstumo nasceu até o décimo mês após a dissolução do matrimônio, que esse filho seja reputado legítimo". Tradução de S.A.B. MEIRA, A Lei das XII Tábuas cit. (nota 72 supra), pp.149;169. De acordo com L. PEPPE, Storie delle parole cit. (nota 72 supra), p.181, é possível estabelecer que a passagem do usus (procriação) para o usus (usucapio) ocorreu quando o rei Numa Pompílio (Plut. Numa 12,3) determinou o tempus lugendi da viúva em dez meses, ou seja, o equivalente a um ano no calendário da época: la temuta procreazione postuma (nello stato vedovile) genera convenzionalmente l'anno liberatorio, la procreazione desiderata (nell'usus) genera altrettanto convenzionalmente l'anno acquisitivo. Sobre o tempus lugendi no período pós-clássico, vejam-se Grat., Valent. et Theod. C.5,9,2 (381); Theod. et Valent. C.5,17,8,4 (449); Anast. C.5,17,9 (497).

${ }^{404}$ Segundo Suetônio (Divus Iulius, 43), César anula o casamento de uma mulher que havia se casado dois dias depois da morte de seu marido. Em outro trecho, Suet. Aug. 34 o historiador indica três anos de espera para a viúva e não dois. V. ARANGIO-RUIZ, Istituzioni cit. (nota 53 supra), p.445, acredita que é pós-clássico o tempus lugendi para a divorciada. Vejam-se B. BIONDI, La legislazione di Augusto cit. (nota 56 supra), pp.136-137; K. GALINSKY, Augustan Culture cit. (nota 102 supra), p.130; A. BouCHÉ-LECLERCQ, Les lois démographiques d'Auguste cit. (nota 36 supra), p.262; R.AsTOLFI, Note per una valutazione storica della 'Lex Iulia et Papia' cit. (nota 36 supra), p.198.

${ }^{405}$ Veja-se Vat. Frag. 320. Veja-se F. C. SAVIGNY, System des heutingen römischen Rechts cit. (nota 403 supra), pp.548-550

${ }^{406}$ Conforme Laudatio Turiae 1,27 (CIL VI, 1527); Prop. Eleg. 4,11,68. Vejam-se Iul. 1 ad ed. D.3,2,1: Praetoris verba dicunt: 'Infamia notatur qui (...) eam, quae in potestate eius esset, genero mortuo, cum eum mortuum esse sciret, intra id tempus, quo elugere virum moris est, antequam virum elugeret, in matrimonium collocaverit (...). "As palavras do pretor dizem: 'É atingido com nota de infâmia quem, (...) morto o genro, tendo o conhecimento de sua morte e estando a viúva sob sua potestas, casou-a durante o tempo em que é costume estar de luto pelo marido, antes que fosse transcorrido este período de luto (...)”. O principal objetivo é evitar a incerteza da descendência, conforme Ulp. 6 ad ed. D.3,2,11,1: Et si talis sit maritus, quem more maiorum lugeri non oportet, non posse eam nuptum intra legitimum tempus collocari: praetor enim ad id tempus se rettulit, quo vir elugetur: qui solet elugeri propter turbationem sanguinis. "E ainda que seja tal o marido, que por ele não deva realizar luto segundo o costume dos antepassados, não pode a mulher ser dada em matrimônio dentro do período legal; pois o Pretor referiu-se ao período em que se guardasse luto pelo 
É importante ressaltar que durante a vacatio Legis Papiae, as mulheres tinham a capacidade plena em relação aos direitos sucessórios. Transcorrido o período da vacatio as mulheres estavam obrigadas às segundas núpcias.

Segundo M. ZABŁOCKA ${ }^{407}$, as mulheres que tivessem adquirido o benefício do ius liberorum não eram obrigadas a casarem-se novamente (vacatio legis Iuliae et Papia).

Quanto aos homens, deveriam eles contrair novas núpcias logo após a dissolução do matrimônio para que tivessem a capacitas plena. ${ }^{408}$

Para incentivar as segundas núpcias, de acordo com UE 15,1, os cônjuges recebiam uma décima (parte dos bens herdados) pelo novo matrimônio e tantas décimas para cada filho procriado. ${ }^{409}$

\subsubsection{LEX IULIA DE ADULTERIIS COERCENDIS}

Na República o adultério não era um crime público, sendo, porém, reprovado pelos costumes (mores) e o pater familias ou o marido (aquele que tivesse a manus sobre a mulher) podia matar a filia familias adúltera em razão de seu ius vitae ac necis, consultando os parentes e vizinhos (iudicium domesticum). O marido, no exercício legítimo de vingança, só poderia matá-la em caso de flagrância. Nesta época anterior à

marido; pelo qual é costume que se guarde luto para evitar a mistura do sangue"; PS 1,21: Parentes et filii maiores sex annis anno lugeri possunt, minores mense: maritus decem mensibus et cognati proximioris gradus octo; qui contra fecerit, infamium numero habetur. "Pode-se estar de luto, durante um ano, pelos pais e pelos filhos maiores de seis anos; pelos menores, durante um mês; pelo marido, durante dez meses e pelos cognados de grau mais próximo, durante oito. Quem fizer contrariamente, é considerado no número dos infames".

${ }^{407}$ Il 'ius trium liberorum' cit. (nota 103 supra), p.376; Idem, Le modifiche cit. (nota 103 supra), pp.380-381; G. Longo, Lex Iulia de maritandis ordinibus e Lex Papia Poppaea cit. (nota 103 supra), p.811; D. DALlA R. LAMBERTINI, Istituzioni di diritto romano cit. (nota 10 supra), pp.108-109; F. SERAFINI, Istituzioni cit. (nota 53 supra), p.235; B. BIONDI, La legislazione di Augusto cit. (nota 56 supra), pp.136-137; R. ASTOLFI, La Lex Iulia et Papia cit. (nota 15 supra), p.71.

${ }^{408}$ A Lex Iulia et Papia estabelecia que os viúvos que se casassem dentro de um ano podiam receber rápida e definitivamente os seus direitos sucessórios. Caso o cônjuge supérstite se casasse novamente dentro de um ano, a Lex Iulia et Papia, para evitar que contraísse matrimônio apenas para receber os direitos sucessórios e não para atender seu escopo principal, ou seja, a procriação, estabelecia que ele fizesse um juramento utilizando a expressão liberorum quaerendorum causa. Este juramento era obrigatório, mesmo se o cônjuge supérstite, tanto para o viúvo quanto para a viúva, tivesse filhos do matrimônio anterior. No trecho Nov. 22,43-44, a Lex Iulia de maritandis ordinibus é denominada Lex Iulia Miscella. Neste caso o adjetivo miscella corresponde ao termo satura, para indicar uma lei que disciplina inúmeros assuntos. Justiniano aboliu este juramento liberorum quaerendorum causa do cônjuge supérstite, por meio de uma constituição imperial de 531 d.C.: Iust. C.6,40,2-3 (531). Se dentro do prazo da vacatio as viúvas ou divorciadas recebessem uma parte da herança, um legado ou um fideicomisso, tinham que prometer casar-se dentro dos prazos estabelecidos pela Legislação matrimonial, por meio de uma cautio. Caso não cumprissem a promessa, deveriam restituir o que receberam. Vejam-se, R. Astolfi, La Lex Iulia et Papia cit. (nota 15 supra), pp.85;166-167;171;336; Idem, Note per una valutazione storica della 'Lex Iulia et Papia' cit. (nota 36 supra), p.197; M. ZABŁOCKA, Il 'ius trium liberorum' cit. (nota 103 supra), p.362; E. AlBERTARIO, Matrimonio (Roma) cit. (nota 61 supra), p.587; E. MALDONADO DE LIZALDE, Lex Iulia de Maritandis Ordinibus cit. (nota 122 supra), pp.545, nota $45 ; 556$. 
Legislação de Augusto, a traição por parte do marido não era considerada nem adultério, nem stuprum. ${ }^{410}$

Nas famílias romanas, homem e mulher desempenhavam papéis bem definidos: os homens protegiam a honra familiar, tendo como obrigação vingar-se de qualquer um que maculasse a castidade de uma das mulheres da família.

A mulher, por sua vez, sofria um forte controle dos demais membros da família quanto às suas relações sexuais. A integridade da família estaria destruída se um membro feminino comprometesse sua honra. ${ }^{411}$

A lex Iulia de adulteriis coercendis (ou de pudicitia) foi uma disposição promulgada em 18/17 a.C. ${ }^{412}$, por iniciativa dos Senadores, com o objetivo de tutelar a

409 A. BOUCHÉ-LECLERCQ, Les lois démographiques d'Auguste cit. (nota 36 supra), p.275.
410 Vejam-se G. BRANCA, Adulterio(Diritto romano), in ED 1 (1958), p.620; H. ANKUM, La 'captiva
adultera'cit. (nota 63 supra), p.154, nota 5; M. ZABEOCKA, Le modifiche cit. (nota 103 supra), p.396; R.
MONIER, Manuel cit. (nota 146 supra), p.289; A. BOUCHÉ-LECLERC, Les lois démographiques d'Auguste
cit. (nota 36 supra), p.258. É provável que antes da legislação de Augusto existiram leis que puniam o
adultério. Segundo este trecho do jurista Paulo (Paulus libro singulari de adulteris sub titulo) presente em
Coll. 4,2,2: (...) et quidem, primum caput legis [Iuliae de adulteriis] prioribus legibus pluribus obrogat: “(...)
e na verdade o primeiro capítulo da lei Iulia de adulteriis derroga numerosas leis anteriores". Para A.
ESMEIN, Le délit d'adultére cit. (nota 338 supra), pp.85-86, quando o homem cometia adultério antes das leis
de Augusto, tornava-se intestabilis. Esta opinãa está fundamentada em Plaut. Curculio, 1,1,29-30. Na
opinião de T. SPAGNUOLO VIGORITA, Casta Domus cit. (nota 26 supra), p.16, L'afermazione del giurista
Paolo, che il primo capitolo della 'lex Iulia de adulteriis' avrebbe abrogato o modificato numerose leggi
precedenti, non doveva dunque riferirsi a specifiche leggi pubbliche sui rapporti sessuali con donne sposate
o nubili; forse rifflete solo una sorta di azzeramento normativo su tutti gli argomenti che erano oggetto della
nuova legge. Na opinião de T. MomMSEN, Römisches Strafrecht cit. (nota 96 supra), pp.431-432, não existiu,
neste período, qualquer punição do adultério pelo direito público, pois era um dever moral controlado
exclusivamente pelo tribunal doméstico. Este "relaxamento" no controle público sobre os costumes gerou
uma degradação moral sem precendentes na sociedade romana.

É provável, como afirma A. BURDESE, Manuale cit. (nota 47 supra), p.277, que a obrigação de fidelidade entre os cônjuges não tenha sido recíproca, pois o adultério da mulher era punido de forma mais severa que o adultério do homem. Veja-se Gell. 10,23,5: In adulterio uxorem tuam si prehendisses, sine iudicio inpune necares; illa te, si adulterares sive tu adulterarere, digito non auderet contingere, neque ius est. "Se tivesses surpreendido tua esposa em adultério, a matarias sem julgamento, impunemente; quanto a ela, se tu cometesses adultério, ou se fores tu que tiveres sido seduzido, ela não ousaria tocar-te com o dedo, nem há direito". Defende a fidelidade recíproca no matrimônio romano, A. ESMEIN, op.cit., pp.85-86. Veja-se também L. ChIAZZESE, Adulterio (Diritto romano), in NNDI $1^{1}$ (1957), p.322, que indica a existência, ainda no período republicano, de uma multae irrogatio à adúltera, determinada por iniciativa dos edis, apesar do adultério não ser ainda considerado um crimen. De acordo com E. CANTARELlA, Famiglia romana e demografia sociale cit. (nota 55 supra), p.104, os limites estabelecidos pela Lex Iulia de adulteriis em relação ao pai matar a filha adúltera confirmam que, até aquele momento, o ius vitae ac necis era frequentemente exercido nestes casos. Matar um filho era, além de um direito, uma obrigação, um dever. Neste sentido, M.G. SCACCHETTI, La presunzione muciana cit. (nota 379 supra), pp.231-235.

${ }^{411}$ G. RizzeLLI, Le donne nell'esperienza giuridica di Roma antica - Il controllo dei comportamenti sessuali. Una raccolta di testi, Lecce, Del Grifo, 2000, p.43. Nas palavras de A.A. CASTRO CORRÊA, O Estoicismo no Direito Romano (nota 33 supra), p.92, “(...) o marido deve à sua mulher, proteção; a mulher deve ao seu marido, respeito".

${ }^{412}$ G. ROTONDI, Leges publicae cit. (nota 315 supra), pp.445-447; A. ESMEIN, Le délit d'adultére cit. (nota 338 supra), p.71, nota 1; G. BRANCA, Adulterio cit. (nota 410 supra), p.620; M. ZABŁOCKA, Le modifiche cit. (nota 103 supra), p.396; L. CHIAZZESE, Adulterio cit. (nota 410 supra), p.322; M. MARRONE, Istituzioni cit. (nota 48 supra), p.221; J. GAUDEMET, Justum matrimonium cit. (nota 51 supra), p.124. Nas fontes a Lex Iulia 
dignidade da família e das iustae nuptiae romanas, reprimir o adultério e o stuprum, além do importante (e difícil) escopo de dificultar o divórcio.

Foi um complemento da lex Iulia de maritandis ordinibus, no âmbito da política de reforma dos costumes promovida por Augusto e que transferiu a repressão do adultério pela vingança privada à res publica, ao torná-lo um crimen publicum. ${ }^{413}$

de adulteriis coercendis recebeu outras duas denominações: uma de Suetônio (Suet. Augustus 34) que denominou-a Lex Iulia de adulteriis et pudicitia; outra do Código de Justiniano (C.9,9), Lex Iulia de adulteriis et stupro. Veja-se nota 332 infra. Na opinião de T. SpAGNUOLO Vigorita, La data della lex Iulia de adulteriis cit. (nota 277 supra), pp.85; 93; 94, nota 46; 95; Idem, Casta Domus cit. (nota 12 supra), pp.10;33-34, a data da promulgação desta lei, votada pelos concílios da plebe (concilia plebis), está entre o início de junho de 17 e o final de junho de 16 a.C. Na verdade, houve, nesta promulgação, uma grande cooperação entre o Senado, o Princeps e os concílios plebeus. O Senado em inúmeros decreta patrum, também exerceu importante influência na propaganda política de Augusto com o escopo de incentivar a realização de matrimônios, o aumento da prole e a repressão aos adultérios. Para sustentar a idéia de que a lex Iulia de Adulteriis não é de 18 a.C., SPagnuolo Vigorita, Casta Domus cit. (nota 26 supra), pp.19;32;34;88, cita o episódio narrado por Dio Cássio $(54,16,6)$ de um jovem acusado de ter se casado com a mesma mulher com a qual cometera o adultério. Augusto, naquele caso, nada pode fazer a não ser advertir o jovem de não reicindir em tal prática contrária aos costumes e considerar as núpcias como ilegítimas. Provavelmente, esta conduta só foi considerada como lenocinium com o advento da lex Iulia de Adulteriis. Neste sentido, M.G. SCACCHETTI, La presunzione muciana cit. (nota 379 supra), pp.235-237. Veja-se Dio

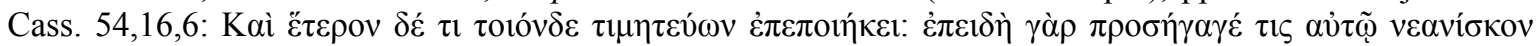

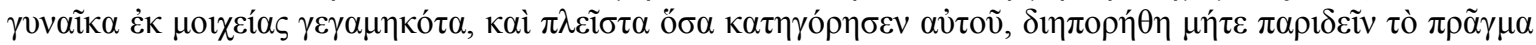

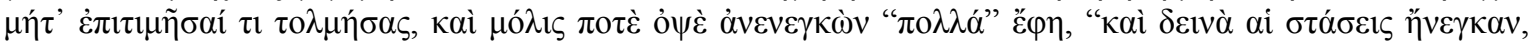

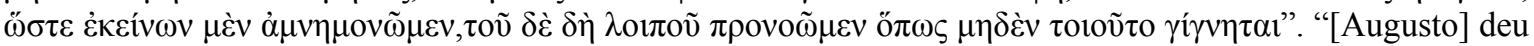
um outro exemplo deste comportamento na atividade censória. Um jovem desposou a mulher com a qual tinha tido uma relação adulterina; quando uma pessoa o denunciou, acusando-lhe pelas culpas mais graves, Augusto foi tomado pelo embaraço, não ousando nem desprezar o fato nem rempreendê-lo; no fim recuperou-se e afirmou: 'As discórdias provocaram muitos e terríveis males: esqueçamo-los e procuremos que no futuro nada de semelhante aconteça".

Em outro trecho, Dio. Cass. 54,16,1-2, salienta que houve um intervalo entre a promulgação da Lex Iulia de maritandis ordinibus e da Lex Iulia de adulteriis. Vejam-se também G. LoNGO, Lex Iulia de maritandis ordinibus e Lex Papia Poppaea cit. (nota 103 supra), p.810; R. Astolfi, La Lex Iulia et Papia cit. (nota 15 supra), p.348; A. LóPEZ PedReIRA, Limitaciones a la 'libertas nuptialis' cit. (nota 40 supra), p.403; L.F. RADITSA, Augustus Legislation cit. (nota 49 supra), p.288; B. BIONDI, La legislazione di Augusto cit. (nota 36 supra), p.157; H. ANKUM, La 'captiva adultera'cit. (nota 63 supra), p.153, nota 3; T. MOMMSEN, Römisches Strafrecht cit. (nota 96 supra), p.433; M.G. SCACCHETTI, La presunzione muciana cit. (nota 379 supra), pp.236-237, nota 374. Na opinião de RADITSA, op.cit., p.297, a data da promulgação da lei é 17 a.C.

${ }^{413}$ Macer 1 de publ. Iud. D.48,1,1: Non omnia iudicia, in quibus crimen vertitur, et publica sunt, sed ea tantum, quae ex legibus iudiciorum publicorum veniunt, ut Iulia maiestatis, Iulia de adulteriis, Cornelia de sicariis et veneficiis, Pompeia parricidii, Iulia peculatus, Cornelia de testamentis, Iulia de vi privata, Iulia de vi publica, Iulia ambitus, Iulia repetundarum, Iulia de annona. "Nem todos os juízos, nos quais o crime é tratado, são públicos, mas apenas os que provém das leis sobre os juízos públicos, como a Iulia maiestatis, Iulia de adulteriis, Cornelia de sicariis et veneficiis, Pompeia parricidii, Iulia peculatus, Cornelia de testamentis, Iulia de vi privata, Iulia de vi publica, Iulia ambitus, Iulia repetundarum, Iulia de annona". Segundo A. Esmein, Le délit d'adultére cit. (nota 338 supra), p.88, a lex Iulia de adulteriis tinha dois tipos de regras: (a) os crimes e as penas estabelecidas, que ele denominou "regras de fundo" e (b) o conjunto de procedimentos a serem aplicados para a condenação dos adúlteros, denominados "regras de forma". Vejamse T. MOMmSEn, Römisches Strafrecht cit. (nota 96 supra), p.433; G. BRINI, Matrimonio e divorzio, vol.2 cit. (nota 69 supra), p.55; G. RIZZELLI, Le donne nell'esperienza cit. (nota 411 supra), p.41; E. MALDONADO DE LIZALDE, Lex Iulia de Maritandis Ordinibus cit. (nota 122 supra), p.544; M. ZABŁOCKA, Le modifiche cit. (nota 103 supra), p.397; J.A. FIELD JR., The purpose cit. (nota 129 supra), p.406; A. ESMEIN, Le délit d'adultére cit. (nota 338 supra), pp.73 e 86; A. BOUCHÉ-LECLERCQ, Les lois démographiques d'Auguste cit. (nota 36 supra), pp.258;266; R. AstolfI, Note per una valutazione storica della 'Lex Iulia et Papia' cit. (nota 36 supra), pp.190;198;202 T. Spagnuolo Vigorita, La data della lex Iulia de Adulteriis cit. (nota 277 
Com a degradação dos costumes observada na sociedade romana e o grande número de divórcios, a lex Iulia de adulteriis tinha por escopos principais: a) reformar moralmente a família e; b) garantir a procriação da prole legítima, com sanções de natureza pública e privada. ${ }^{414}$

Punia principalmente:

(a) o adulterium, ou seja, a relação sexual entre uma mulher livre ${ }^{415}$ casada $^{416} \mathrm{e}$ qualquer homem que não fosse o seu marido, livre ou escravo ${ }^{417}$;

supra), pp.91, nota 41;95; Idem, Casta Domus cit. (nota 26 supra), pp.36-37. SPAGnUOLO VigoritA acredita que esta ode de Horácio foi escrita em 13 a.C.

${ }^{414}$ A certeza da filiação é importantíssima para a formação da família e corresponde às diversas preocupações que Augusto e sua "propaganda oficial" procuravam solucionar. Uma destas exigências é salientada neste trecho de Horácio, que pela aparência do filho seja possível reconhecer o legítimo pai. Hor. Carm. 4,5,20: Nullis polluitur casta domus stupris, / mos et lex maculosum edomuit nefas, / laudantur simili prole puerperae, / culpam poena premit comes. "A casa casta não foi maculada pelo stuprum, o costume e a lei refrearam a torpeza ímpia, as parturientes são louvadas pela prole semelhante [ao pai], a pena sempre acompanha o delito". Vejam-se, R. Astolfi, La Lex Iulia et Papia cit. (nota 15 supra), pp.106;339; Idem, Note per una valutazione storica della 'Lex Iulia et Papia' cit. (nota 36 supra), p.202; L. ChiAzZeSE, Adulterio cit. (nota 410 supra), p.322; K.C. CANELA, $O$ 'stuprum per vim' cit. (nota 96 supra), p.101; O. RoBLEDA, Il divorzio in Roma cit. (nota 51 supra), pp.365-367.

${ }^{415}$ Pap. 1 de adult. D.48,5,6pr.: Inter liberas tantum personas adulterium stuprumve passas lex Iulia locum habet (...) "A lei Iulia [de adulteriis] tem lugar somente em relação às pessoas livres que sofreram adulterium ou stuprum (...)". Veja-se H. ANKUM, La 'captiva adultera'cit. (nota 63 supra), p.193.

${ }^{416}$ De acordo com M. ZABŁOCKA, Le modifiche cit. (nota 103 supra), p.397 e G. RIzZelli, Alcuni aspetti dell'accusa cit. (nota 63 supra), p.426, Augusto apenas reconhecia como união conjugal o matrimonium iustum. Na opinião de E. VOLTERRA, La nozione giuridica del 'conubium' cit. (nota 180 supra), pp.299-300, a Lex Iulia de adulteriis também era aplicada em Roma às mulheres peregrinas que tivessem qualquer relação sexual fora do matrimônio. No caso em que um cidadão romano se unisse com uma mulher peregrina sem o conubium, ele não poderia mover uma accusatio iure mariti de adultério, caso ela tivesse relações sexuais com um terceiro, mas poderia acusá-la de stuprum, por meio da accusatio iure extranei. Também neste sentido, T. MOMMSEn, Römisches Strafrecht cit. (nota 96 supra), p.434, afirma que a Lex Iulia de adulteriis protegia qualquer relação monogâmica tanto de cidadãos romanos quanto de peregrinos, desde que se caracterizasse uma vida matrimonial comum, ainda que não fosse considerada um matrimônio iustum (matrimônio ilegítimo, concubinato). Contra estas opiniões, G. RIzZELLI, op.cit., pp.427-430, afirma que não há qualquer indício de que foi considerado stuprum o caso da infidelidade da peregrina sine conubio casada com um cidadão romano. $\mathrm{O}$ homem não pode acusar de adultério (iure mariti) a mulher se não tiver com ela o conubium. Veja-se Coll. 4,5,1.

Durante o Principado há uma tendência de punir a mulher adúltera, provavelmente já antes do período dos Severos, mesmo quando sua união fosse ilícita, extraconjugal ou não prevista pela Lex Iulia de adulteriis, como o adultério da concubina. Vejam-se Ulp. 2 de adult. D.48,5,13pr.;-1.

${ }^{417}$ Conforme G. SCIASCIA, A lei romana sobre os Adultérios cit. (nota 313 supra), p.30, a palavra adulterium deriva de ad alterum, ou seja, "entregar-se a outrem". Para caracterizar-se o crime de adultério é necessário que o adúltero tenha o sciens dolo malo, ou seja, a "astúcia má", o conhecimento de seu comportamento malicioso. A legislação punia o autor do crime (adultério, stuprum) e também aqueles que auxiliassem o autor em sua execução: Ulp. 1 de Adult. D.48,5,12: Haec verba legis: ne quis posthac stuprum, adulterium facito sciens dolo malo, et ad eum, qui suasit, et ad eum, qui stuprum vel adulterium intulit, pertinent. "Estas palavras da lei: 'De agora em diante, que ninguém faça com pleno conhecimento e com dolo mau, stuprum ou adultério', referem-se, tanto àquele que aconselhou quanto ao que cometeu stuprum ou adultério". Não era possível a tentativa do crime de adultério. A tentativa era considerada apenas iniuria. O novo matrimônio é válido e os cônjuges não cometem nenhum crime. Gai 3 ad l. XII tab. D.48,5,43: Si ex lege repudium missum non sit, et idcirco mulier adhuc nupta esse videatur, tamen si quis eam uxorem duxerit, adulter non erit; idque Salvius Iulianus respondit, quia adulterium, inquit, sine dolo malo non committitur; quamquam dicendum, ne is, qui sciret, eam ex lege repudiatam non esse, dolo malo commitat. "Se não se enviasse o repúdio conforme a lei [Lex Iulia de Adulteriis coercendis], e por isso se considerasse que a mulher ainda 
(b) o stuprum, a prática de relações sexuais entre um homem e uma mulher de bons costumes não casada ou viúva (virgo vel vidua) ${ }^{418}$, ou entre dois homens, sem o consentimento mútuo (stuprum cum masculo) ${ }^{419}$;

estava casada, contudo, se alguém se casasse com ela, não será adúltero; e isto respondeu Salvio Juliano, porque, afirma, não se comete adultério sem dolo mau; ainda que se dirá, que aquele que soubesse que ela não foi repudiada conforme à lei, não o comete com dolo mau". A mulher que, após a longa ausência do marido e que acreditava que ele já estivesse morto, se casa, não comete adultério, conforme o trecho de Pap. 2 de adult. D.48,5,11,12. Vejam-se A. ESMEIN, Le délit d'adultére cit. (nota 338 supra), p.94; K.C. CANELA, O 'stuprum per vim' cit. (nota 96 supra), pp.93;96-97; L.F. RADITSA, Augustus Legislation cit. (nota 49 supra), p.310; H. ANKUM, La 'captiva adultera'cit. (nota 63 supra), p.158; R. Astolfi, La Lex Iulia et Papia cit. (nota 15 supra), p.198; M. MolÈ, Stuprum cit. (nota 96 supra), p.585, notas 15 e 17; T. MOMMSEN, Römisches Strafrecht cit. (nota 96 supra), p.435; S. SolazZI, La legge augustea sul divorzio cit. (nota 180 supra), pp.342-344. Sobre o adultério cometido por escravos, vejam-se Ulp. 3 de adult. D.48,2,5; Ulp. 3 de adult. D.48,5,27,16pr.;-16; Marcian. 1 de publ. Iud. D.48,5,33pr.

${ }_{418}$ Mod. 1 reg. D.48,5,34pr.;-1: Stuprum committit, qui liberam mulierem consuetudinis causa, non matrimonii continet, excepta videlicet concubina. 1. Adulterium in nupta admittitur, stuprum in vidua, vel virgine, vel puero committitur. "Comete stuprum aquele que habitualmente, não por causa de matrimônio, tem uma mulher livre, excetuando-se, sem dúvida, a concubina. 1. Comete-se adultério em mulher casada e comete-se stuprum em viúva, em moça [virgem] ou num menino". Veja-se G. Rizzelli, Alcuni aspetti dell'accusa cit. (nota 63 supra), p.417. De acordo com R. Astolfi, Femina probrosa cit. (nota 96 supra), p.54, o stuprum é uma relação sexual contínua com mulher de baixa condição social ou de maus costumes.

${ }_{419}$ Segundo as opiniões de H. ANKUM, La 'captiva adultera'cit. (nota 63 supra), p.154, nota 4; M. Molè, Stuprum cit. (nota 96 supra), p.587 e de A. RomANo, Omosessualità, amore e potere cit. (nota 95 supra), pp.302-304, nem a Lex Iulia et Papia, nem a Lex Iulia de Adulteriis Coercendis dispunham diretamente ou faziam qualquer previsão legislativa sobre a homossexualidade. Defende Romano, que somente com o advento do Cristianismo e sua influência sobre o Direito Romano Pós-Clássico, a homossexualidade foi combatida abertamente pelos imperadores, por meio de inúmeras leis. E não apenas o relacionamento homoafetivo foi combatido, como qualquer relacionamento sexual que prescindia de uma função procriativa.

Quanto ao stuprum, para V. CÉSAR DA SILveIRA, v. Stuprum, in Dicionário de Direito Romano, vol.2 cit. (nota 9 supra), p.638, conforme a Lex Iulia de adulteriis era o delito público praticado por aquele que realizava relações sexuais com uma mulher ingênua de bons costumes: "os romanos entendiam como stuprum o crime que se comete contra uma jovem ou com viúva, que vivia honestamente. O adultério se comete com a mulher casada e nisso está a diferença do stuprum (...). O stuprum se comete com violência ou sem ela". Para E. VolTERRA, Matrimonio cit. (nota 61 supra), pp.744;769-770; Idem, La nozione giuridica del 'conubium' cit. (nota 180 supra), p.300 e F. Schulz, Classical Roman Law cit. (nota 51 supra), pp.131132, a união conjugal com uma mulher ingênua e de bons costumes era presunção de matrimônio legítimo. Há categorias de mulheres in quas stuprum non committitur, ou seja, o homem pode ter relações sexuais sem sofrer qualquer sanção, pois com elas não havia a possibilidade de iustae nuptiae. Seriam relações de concubinato (vide pp.88-89, notas 184 e 185). O crime pressupõe que a mulher goze de uma boa reputação social. Portanto, as prostitutas e alcoviteiras (lenae) deveriam declarar publicamente a sua condição, pois com elas era possível ter relações sexuais sem cometer adulterium ou stuprum. Conforme Ulp. 2 de adult. D.48,5,14,2. Vejam-se R. ASTOLFI, La Lex Iulia et Papia cit. (nota 15 supra), p.107; Idem, Femina probrosa cit. (nota 96 supra), p.21; G. LoNGO, Riflessioni critiche cit. (nota 48 supra), pp.2372-2373; T. SpAGNUOLO Vigorita, Casta Domus cit. (nota 26 supra), pp.128-129, nota 136; G. RIzZELLI, Alcuni aspetti dell'accusa cit. (nota 63 supra), pp.427;441; T. MOMMSEN, Römisches Strafrecht cit. (nota 96 supra), pp.433;437-438. De acordo com G. RIZZELLI, op.cit., pp.432;436-437, nem a liberta, nem a concubina deveriam ser enumeradas entre as mulheres in quas stuprum non committitur, nem entre as feminae probrosae, pois poderiam ser consideradas como materfamilias. Conforme Ulp. 2 de adult. 48,5,13pr.; Ulp. 59 ad ed. D.50,16,46,1. Conclui G. RIZZELLI, op.cit., p.437 sobre o termo stuprum: Quando è usato in relazione alla 'lex Iulia', descrive o l'adulterium o la condotta illecita della 'virgo', della 'vidua' e del 'puer'.

Também há stuprum, caso ocorressem relações sexuais entre a minor nupta (menor de 12 anos) e o seu futuro marido (sponsa), conforme Ulp. 2 de adult. D.48,5,14,8; Modest. 1 reg. D.48,5,36; Paul. 5 sent. D.48,19,38,3 e PS 5,22,5. Na opinião de A. ESMEIN, Le délit d'adultére cit. (nota 338 supra), p.94, provavelmente a bigamia também era considerada um stuprum. As relações sexuais com a própria escrava (ou alheia) não eram consideradas stuprum (Pap. 1 de adult. D.48,5,6pr.; PS 2,26,16). Vejam-se G. CASTELLI, Il concubinato 
(c) o incestum, a prática de relações sexuais entre parentes ou afins ${ }^{420}$; e

(d) o lenocinium, crime que no direito atual remete à atividade de quem explora a prostituição, mas que em Roma tinha um significado mais amplo. Ocorria, v.g., quando o marido continuava casado com a adúltera que surpreendeu em flagrante adultério ou a esposa recebia recompensa pelo adultério do marido. ${ }^{421}$

cit. (nota 96 supra), p.57, nota 1; 60-61; F. DELLA CORTE, Le 'leges Iuliae' e l'elegia romana cit. (nota 47 supra), pp.547-549; L.F. RADiTSA, Augustus Legislation cit. (nota 49 supra), p.310; T. SpagnUOLO Vigorita, Casta Domus cit. (nota 26 supra), p.33; E.M. Agati Madeira, A condição jurídica das sacerdotisas de Vesta cit. (nota 246 supra), p.103; M.J. GARCIA GARRIDO, Minor annis XII nupta cit. (nota 47 supra), pp.81-82; L. ChiAZZESE, Adulterio cit. (nota 410 supra), p.322; E. VolterRa, Concubinato (Diritto romano) cit. (nota 166 supra), pp.1052; Idem, La nozione giuridica del 'conubium' cit. (nota 180 supra), p.301; C. ACCARIAS, Précis de droit romain cit. (nota 9 supra), p.248, nota 1; R. Astolfi, La Lex Iulia et Papia cit. (nota 15 supra), p.50; M. MoLĖ, Stuprum cit. (nota 96 supra), pp.582-583, notas 5 e 6;584; G. RizZELLI, Alcuni aspetti dell'accusa cit. (nota 63 supra),p.417; V. ARANGIO-RUIZ, Istituzioni cit. (nota 53 supra), p.463, nota 1; F. SCHULZ, Classical Roman Law cit. (nota 51 supra), p.132; T. MOMmSEN, Römisches Strafrecht cit. (nota 96 supra), pp.433-435.

Quanto à Lex Iulia de adulteriis ter previsto o stuprum violento, na opinião de K.C. CANELA, $O$ 'stuprum per vim ' cit. (nota 96 supra), pp.86-91;97;101, a lei não foi um instrumento hábil à sua repressão, pois neste caso a violência suprime a vontade da vítima. Conforme a lei, para que houvesse stuprum ou adulterium era necessário o dolo (a vontade de praticar atos sexuais proibidos pela res publica) e o consenso entre as partes. "Os termos stuprum e adulterium eram utilizados de forma promíscua, pois tais crimes possuíam um conteúdo semelhante, ou seja, referiam-se à prática de atos sexuais ilícitos e consensuais. O estupro violento estava, pois, excluído deste conceito amparado pela lei de adultérios, já que não havia o requisito do consenso". O stuprum violento, no período clássico, era considerado uma iniuria. Vejam-se PS 5,4,1: Iniuriam patimur aut in corpus aut extra corpus: in corpus verberibus et illatione stupri, extra corpus conviciis et famosis libellis, quod ex adfectu uniuscuiusque patientis et facientis aestimatur. "Sofremos iniuria no corpo ou fora do corpo: no corpo, com os golpes e com o stuprum; fora do corpo, com o convicium ou com os libelos que violam a reputação, coisa que se avalia com base do consenso de cada um que sofra ou de quem realiza a iniuria"; 5,4,4: Corpori iniuria infertur, cum quis pulsatur cuive stuprum infertur aut de stupro interpellatur. Quae res extra ordinem vindicatur, ita ut pulsatio pudoris poena capitis vindicetur. "Provoca-se a iniuria no corpo quando alguém é ferido ou é submetido ao stuprum ou recebe propostas para realizar o stuprum. O fato é punido extra ordinem, pela pena capital, assim como o atentado ao pudor".

${ }^{420}$ Gai.1,59;1,64; UE 5,6; Coll. 6,2,4; Marcian. 12 inst. D.25,7,3pr.; Mod. 1 reg. D.48,5,35pr. A palavra incestum qualificava o casamento proibido pelos costumes. Os jurisconsultos estabeleceram diversos impedimentos matrimoniais e sanções penais especialmente quando aqueles que pretendiam casar-se possuíssem laços próximos de parentesco entre si. Vejam-se Paul. 6 ad Plaut. D.23,2,39,1; Paul. 35 ad ed. D.23,2,14,2-4; Mod. 36 quaest. D.48,5,38,1-3; Marc. 2 inst. D.48,18,5. De acordo com Ulp. 2 de adult. D. $48,5,13,4$, o incesto era considerado um stuprum e a mulher poderia ser acusada iure extranei. Veja-se E. VOLTERRA, La conception du Mariage d'après les juristes romains cit. (nota 30 supra), p.57. Segundo J. GAUDEMET, Justum matrimonium cit. (nota 51 supra), pp.118-121, é discutível a existência de repressão penal ao incesto na Lex Iulia de adulteriis, apesar do crime ser punido com a relegatio in insulam, pena prevista na lei de Augusto. O mais provável é que ele tenha sido previsto pelos mores maiorum, por ser reprovado pela opinião comum e pela religião. Veja-se PS 2,26,15: Incesti poenam, quae in viro in insulam deportatio est, mulieri placuit remitti: hactenus tamen, quatenus lege Iulia de adulteriis non apprehenditur. "A pena de incesto, que para o homem é a deportação para uma ilha, agradou condenar a mulher, contudo, visto que, até agora, não está compreendida na Lex Iulia de adulterii". Neste sentido PS 2,19,3;5; Coll. 6,3,1;-3; UE 5,7; Epit. Gai. 1,4,8; Gai. 1,59-61. Na opinião de T. MOMMSEN, Römisches Strafrecht cit. (nota 96 supra), p.428, o incesto era punido desde os primórdios da cidade, pois violava, sobretudo, deveres religiosos.

${ }^{421}$ Ulpiano e Marciano afirmavam que aquele que recebesse recompensa ou facilitasse a aceitação de uma soma de dinheiro para não mover ou desistir da acusação de adultério da esposa, cometia lenocinium. Ulp. 8 disp. D.8,5,2,2: Lenocinii quidem crimen lege Iulia de adulteriis praescriptum est, quum sit in eum maritum poena statuta, qui de adulterio uxoris suae quid ceperit; item in eum, qui in adulterium deprehensam retinuerit. "Pela Lex Iulia de Adulteriis certamente se prescreveu o crime de lenocínio, porque se estabeleceu 
O lenocinium caracterizava-se nas seguintes situações:

(a) caso o marido fosse muito tolerante e continuasse a conviver com a adúltera que supreendeu em flagrante. O imperador Augusto tornou obrigatório o repúdio em caso de adultério comprovado, com a necessidade de punir o marido que fosse muito indulgente com a sua esposa e permitisse que o adúltero fosse embora de sua casa (adulterum in domo deprehensum dimiserit $)^{422}$. Com essa medida, reprimia-se qualquer cumplicidade deste crime entre os cônjuges; ${ }^{423}$

uma pena contra o marido que recebesse algo pelo adultério de sua mulher; e também contra aquele que manteve aquela que apanhou em flagrante adultério"; Marcian. 1 de publ. iud. D.48,5,33,2: Si uxor ex adultério viri pretium acceperit, lege Iulia quasi adultera tenetur. "Se a mulher recebeu quantia pelo adultério do marido, fica sujeita à lex Iulia como adúltera". J. GAUDEMET, L'Apport du Droit Romain cit. (nota 59 supra), p.34; G. RizzelLi, Le donne nell'esperienza cit. (nota 411 supra), p.46; G. SCIASCIA, A lei romana sobre os Adultérios, cit. (nota 313 supra), p.29, defendem que eram extremamente difíceis as acusações de adultério e lenocínio: aquele que acusasse, deveria provar a existência do acordo entre o marido e o amante da esposa, o ganho que aquele obtivesse com a transação e ainda surpreender a adúltera e o seu amante em flagrante durante o ato sexual. Maior dificuldade existiria quando o próprio marido, pela situação vexatória, não desejasse dar publicidade ao caso. Se a acusação de adultério não fosse provada e não se chegasse à conclusão da existência do crime, aquele que acusou poderia seria processado por calúnia. De acordo com R. Astolfi, La Lex Iulia et Papia cit. (nota 15 supra), pp.107-108 e B. BIONDI, Istituzioni cit. (nota 22 supra), p.444, tanto a Lex Iulia de maritandis ordinibus quanto a Lex Iulia de adulteriis proibiram o matrimônio com a adúltera. O matrimônio com a adúltera, comprovada a traição de modo inequívoco, permanecia válido e era necessário o divórcio para dissolvê-lo. Neste sentido, Valer. et Gall. C.9,9,17 (257). Veja-se, T. MOMMSEN, Römisches Strafrecht cit. (nota 96 supra), pp.437-438.

${ }^{422}$ Ulp. 4 de adult. D.48,5,29pr.: Mariti lenocinium lex coercuit, qui deprehensam uxorem in adulterio retinuit adulterumque dimisit. "A lei castigou o lenocínio do marido que manteve a sua esposa surpreendida em adultério e deixou o adúltero escapar".

${ }^{423}$ Vejam-se V. ARANGio-Ruiz, Storia del diritto romano cit. (nota 253 supra), p.260; G. PUGLIESE - F. SITZIA - L. VACCA, Istituzioni cit. (nota 63 supra), p.401; R. MONIER, Manuel cit. (nota 146 supra), p.305; L.F. RADITSA, Augustus Legislation cit. (nota 49 supra), pp.311;313; R. Astolfi, La Lex Iulia et Papia cit. (nota 15 supra), pp.107-108;177-178;200; G. BRANCA, Adulterio cit. (nota 410 supra), p.621; L. CHIAZZESE, Adulterio cit. (nota 410 supra), p.322; B. BIONDI, La legislazione di Augusto cit. (nota 56 supra), p.156; H. ANKUM, La 'captiva adultera'cit. (nota 63 supra), pp.156;164, nota 59; E. VOLTERRA, La conception du Mariage d'après les juristes romains cit. (nota 30 supra), pp.37-38; M. ZABŁOCKA, Le modifiche cit. (nota 103 supra), pp.398;403; M.G. SCACCHETTI, La presunzione muciana cit. (nota 379 supra), pp.246-247. Vejam-se Ulp. 8 disp. D.48,5,2,2: Lenocinii quidem crimen lege Iulia de adulteriis praescriptum est, quum sit in eum maritum poena statuta, qui de adulterio uxoris suae quid ceperit; item in eum, qui in adulterio deprehensam retinuerit. "Pela Lex Iulia de adulteriis certamente estabeleceu-se o delito de lenocínio, porque se fixou a pena contra o marido, que tivesse recebido alguma coisa pelo adultério de sua mulher; e também contra o que manter [a união] com a surpreendida em adultério". Conforme Pap. l. s. de adult. D.48,5,11,13; Scaev. 4 reg. D.48,5,14pr. Segundo A. GUARINO, Storia del diritto romano cit. (nota 103 supra), p.446, uma lex Petronia de adulterii iudicio de 61 d.C. estabeleceu que o marido que se omitisse em acusar a esposa após verificar a veracidade do adultério, perderia o direito à accusatio adulterii, baseado na Lex Iulia de adulteriis. Esta lex Petronia foi proposta, segundo H. ANKUM, op.cit., pp.182-183, pelo cônsul Q. Petronius Turpillianus, que no mesmo ano promulgou um senatusconsultum Turpillianum que combatia o delito da tergiversatio na accusatio adulterii.

Vejamos como exemplo, um discurso de Plínio, o Jovem, de 107 d.C., que narra um processo julgado pelo imperador Trajano e seu conselho, reprovando a atitude de um tribuno militar que continuou casado com sua esposa chamada Gallitta, flagrada em adultério com um centurião. O imperador aplicou ao caso a Lex Iulia de Adulteriis, pois condenou ambos à relegatio: o tribuno, por lenocinium e a sua esposa por adulterium. Plin. Iun. Ep. 6,31,4-6: Sequenti die audita est Gallita adulterii rea. Nupta haec tribuno militum honores petituro et suam et mariti dignitatem centurionis amore maculaverat. Maritus legato consulari, ille Cesari scripserat. Caesar excussis probationibus centurionem exautoravit atque etiam relegavit. Supererat crimini, quod nisi duorum esse non poterat, reliqua pars ultionis; sed maritum non sine aliqua reprehensione 
(b) quando recebeu alguma vantagem econômica pela renúncia em perseguir a mulher infiel ${ }^{424}$;

(c) quando aprovou a infidelidade antes que ela efetivamente ocorresse; e

(d) no caso de alguém casar com uma mulher condenada criminalmente por adultério (in adulterio deprehensam). ${ }^{425}$

patientiae amor uxoris retardabat, quam quidem etiam post delatum adulterium domi habuerat, quasi contentus aemulum removisse. Admonitus, ut perageret accusationem, peregit invitus. Sed illam damnari etiam invito accusatore necesse erat: damnata et Iuliae legis poenis relicta est. Caesar et nomen centurionis et commemorationem disciplinae militaris sententiae adiecit, ne omnis eius modi causas revocare ad se videretur. "No dia seguinte foi ouvida Gallitta, acusada de adultério. Esta, mulher de um tribuno militar de carreira, manchou a própria honra e a do marido com uma paixão por um centurião. $\mathrm{O}$ marido escreveu à um legado consular e este à César. César, apreciadas as provas, destituiu o centurião e, além disso, exilou-o. Permanecia, num crime que não podia ser cometido, a não ser por duas pessoas, a parte restante da punição; mas o marido demorava, não sem alguma repreensão pela tolerância, por amor pela esposa, e, efetivamente, continuava a tê-la na própria casa mesmo após a denúncia de adultério, como se bastasse ter afastado o rival. Advertido a realizar a acusação, realizou-a contra a sua vontade. Mas era necessário que aquela fosse condenada mesmo se o acusador não desejasse: foi condenada e abandonada às penas da Lei Júlia. César acrescentou à sentença o nome do centurião e a menção à disciplina militar, porque não parecia querer chamar para si todas as causas desta maneira".

Vejam-se também PS 2,26,8 (= Coll. 4,12,7): Eum, qui in adulterio deprehensam uxorem non statim dimiserit, reum lenocinii postulari placuit. "Teve-se por bem acusar como réu de lenocínio aquele que não abandonou imediatamente a esposa surpreendida em adultério"; Ulp. 3 disp. D.48,5,26pr.: Constante matrimonio ab eo, qui extra maritum ad accusationem admittitur, accusari mulier adulterii non potest, probatam enim a marito uxorem, et quiescens matrimonium non debet, alius turbare, atque inquietare, nisi prius lenocinii maritum accusaverit. "Durante o matrimônio a mulher não pode ser acusada de adultério por aquele que, além do marido, é admitido à acusação; porque outro não deve perturbar e inquietar à esposa tolerada pelo marido, nem à um matrimônio tranquilo, a não ser que antes acusasse o marido de lenocínio". ${ }^{424}$ Ulp. 4 de adult. D.48,5,29,2.

${ }^{425}$ Vejam-se G. RIZZELLI, Le donne nell'esperienza cit. (nota 411 supra), p.46; R. AstOLFI, La Lex Iulia et Papia cit. (nota 15 supra), p.341; Idem, Femina probrosa cit. (nota 96 supra), p.35; G. BRANCA, Adulterio cit. (nota 410 supra), p.621; B. BIONDI, Istituzioni cit. (nota 22 supra), p.444; J. GAUDEMET, Justum matrimonium cit. (nota 51 supra), pp.132-133; M.G. SCACCHETTI, La presunzione muciana cit. (nota 379 supra), pp.246-247. As núpcias com a mulher condenada por adultério não eram válidas. Ulp. 4 de adult. D.48,5,29,1: Quod ait lex, adulterii damnatam si quis duxerit uxorem, ea lege teneri, an et ad stuprum referatur, videamus; quod magis est. Certe si ob aliam causam ea lege sit condemnata, impune uxor ducetur. "Vejamos se o que diz a lei [Lex Iulia de adulteriis], que se alguém se casar com aquela que foi condenada por adultério fica sujeito a esta lei, se refere também ao stuprum; o que é mais certo. E certamente que se foi condenada por esta lei em virtude de outra causa, se casará impunemente"; Tryph. 3 disp. D.4,4,37,1: Sed et in sexaginta diebus praeteritis, in quibus iure mariti sine calumnia vir acusare potest, denagatur ei in integrum restitutio (...) Sed ut ad leges Iuliae de adulteriis coercendis praecepta veniamus, utique nulla deprecatio adulterii poenae est, si se minor annis adulterum fateatur. Dixi, nec si quid eorum commiserit, quae pro adulterio eadem lex punit, veluti si adulterii damnatam sciens uxorem duxerit, aut in adulterio deprehensam uxorem non dimiserit, quaestumve de adulterio uxoris fecerit, pretiumve pro comperto stupro acceperit, aut domum praebuerit ad stuprum adulteriumve in ea committendum: et non sit aetatis excusatio adversus praecepta legum ei, qui dum leges invocat, contra eas committit. "Mas também por ter transcorrido os sessenta dias nos quais o homem, por força de seu direito de marido, pode acusar a mulher de adultério sem cometer calúnia, a restitutio in integrum lhe é denegada (...) Mas, indo aos preceitos da Lex Iulia de adulteriis coercendis, em todo caso não haverá nenhuma súplica da pena devida aos adúlteros, se o menor de idade confessou o adultério. Disse que tampouco se tivesse cometido algum daqueles atos que a própria lei pune como adultério, como por exemplo, se conscientemente casou-se com uma mulher condenada por adultério, ou não repudiou a esposa surpreendida em adultério, ou obteve um ganho pelo adultério da esposa, ou recebeu um preço por um stuprum manifesto, ou ofereceu o uso da casa para que se cometesse adultério ou stuprum; e não havia escusa pela idade em relação às disposições da lei em favor de quem, enquanto invoca as leis, comete ato contra elas". Ao analisar Pap. l. s. de adult. D.48,5,11,13, S. SolAZZI, Sui divieti 
É importante salientar que a lex Iulia de adulteriis utilizava os termos adulterium e stuprum de forma indistinta para indicar o mesmo crime, apesar dos romanos considerarem o adulterium mais grave, pois a adúltera poderia conceber um filho da relação adulterina e introduzi-lo na família do marido. ${ }^{426}$

Para dar maior publicidade ao repúdio (dissolução unilateral do matrimônio), a fim de reduzir e controlar a sua ocorrência ${ }^{427}$, a lex Iulia de adulteriis exigia, para a sua realização, que estivessem presentes sete testemunhas (cidadãos romanos e púberes) ${ }^{428}$,

matrimoniali delle leggi augustee cit. (nota 168 supra), p.95, conclui que o matrimônio com a adúltera mantinha-se mesmo após a sua condenação. Por isso o marido tinha a obrigação de repudiar a adúltera damnata, pois a condenação não anulava o matrimônio. Contra a opinião de SOLAZZI, E. NARDI, Sui divieti matrimoniali cit. (nota 109 supra), p.132, notas 53 e 54,136, defende que não existia mais o ius connubii entre os cônjuges e o matrimônio era nulo após a condenação da adúltera.

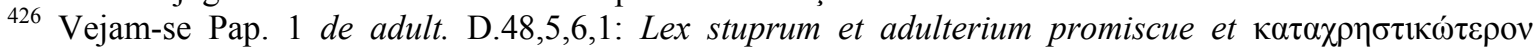
appellat. Sed proprie adulterium in nupta committitur, propter partum ex altero conceptum composito nomine: stuprum vero in virginem viduamve committitur, quod Graeci $\varphi \theta$ opòv appellant. "A lei denomina de modo confuso e muito impróprio stuprum e adultério. Mas, exatamente, o adultério se comete com uma mulher casada; o seu nome deriva do fato que nasce um filho concebido com um homem diferente do marido: o stuprum, ao invés, se comete com uma virgem ou com uma mulher que não tenha mais o marido, ato que os gregos denominam 'corrupção"'; Mod. 9 dif. D.50,16,101pr.: Inter 'stuprum' et 'adulterium' hoc interesse quidam putant, quod adulterium in nuptam, stuprum in viduam committitur. Sed lex Iulia de adulteriis hoc verbo indifferenter utitur. "Alguns consideram que entre 'stuprum' e 'adultério' havia esta diferença, que o adultério se comete com uma mulher casada, o stuprum com aquela que não é casada. Mas a Lex Iulia de adulteriis emprega este termo ('stuprum') indiferentemente". Além disso, o stuprum, como visto na nota 96 supra, também poderia designar o ato sexual realizado num homem livre, à força, contra a sua vontade (stuprum cum masculo). Vejam-se, H. ANKUM, La 'captiva adultera'cit. (nota 63 supra), pp.157158; G. LONGO, Riflessioni critiche cit. (nota 48 supra), pp.2373; G. RizZELli, Alcuni aspetti dell'accusa cit. (nota 63 supra), p.427; T. MOMMSEN, Römisches Strafrecht cit. (nota 96 supra), pp.439-440. Na opinião de K.C. CANELA, $O$ 'stuprum per vim' cit. (nota 96 supra), pp.86-91;97;101: “Os termos stuprum e adulterium eram utilizados de forma promíscua, pois tais crimes possuíam um conteúdo semelhante, ou seja, referiam-se à prática de atos sexuais ilícitos e consensuais".

${ }^{427}$ A Laudatio Turiae redigida em uma lápide entre 8 e 9 d.C., narra em poucas linhas a história de um casal que conviveu por 41 anos e ressalta, no trecho 1,35, que rara sunt tam diuturna matrimonia finita morte, non divortio interrupta: nam contigit nobis ut ad annum XXXXI sine offensa perduceretur. "Raros são os matrimônios tão duradouros acabados com a morte e não interrompidos pelo divórcio: o nosso, de fato, tivemos relações durante quarenta e um anos sem uma ofensa". Esta laudatio, no caso um elogio fúnebre do marido à mulher, também ressalta a procriação como um dever entre os cônjuges e como principal escopo do matrimônio romano. O casal não teve filhos, mas os cônjuges permaneceram unidos até a morte da esposa, apesar desta aconselhar o próprio marido a procurar uma outra mulher que the proporcionasse uma descendência. De acordo com Laudatio Turiae 2, 26-28;31-36 (CIL VI, 1527): Fuerunt optati liberi, quos aliquamdiu sors inviderat. Si fortuna procedere esset passa sollemnis inserviens, quid utrique nostrum defuit? Procedens aetas, spem finiebat(...) Diffidens fecondidati tuae et dolens orbitate mea, ne tenendo in matrimonio te spem abendi liberos deponerem atque eius caussa essem infelix, de divortio elocuta es, vacuamque domum alterius fecunditati te tradituram, non alia mente nisi ut nota concordia nostra tu ipsa mihi dignam condicionem quaereres pararesque, ac futuros liberos te communes proquetuis habituram adfirmares (...) "Desejávamos filhos, que um destino malévolo negou-nos. Se a sorte nos atendesse, que coisa nos teria faltado? Mas com o passar do tempo, as nossas esperanças esvaíram-se.(...) Desconsolada pela tua esterilidade e sofrendo pela minha falta de prole, a fim de que, continuando a tê-la em matrimônio, eu não renunciasse à esperança de ter filhos, falaste em divórcio, oferecendo-se a deixar a casa vazia à fecundidade de outra mulher, sem outra idéia que a de procurar-me e preparar-me, tu mesma, uma esposa digna do nosso afeto recíproco: cujos filhos, tu afirmastes, terias tratado como filhos comuns (...)". Tradução de nossa lavra, baseada na tradução italiana de E. CANTARELla, Matrimonio e sessualità cit. (nota 36 supra), pp.127-128. Vejam-se B. BIONDI, La legislazione di Augusto cit. (nota 56 supra), p.150; Idem, Istituzioni cit. (nota 22 supra), p.448, nota 49; O. ROBLEDA, Il divorzio in Roma cit. (nota 51 supra), p.366.

${ }_{428}$ Também a Lex Aelia Sentia exigia a formalidade da presença de sete testemunhas na aquisição da 
além da redação de um documento, o libellus repudii, que seria entregue à esposa (uxor) pelo liberto do marido que propunha o repúdio. ${ }^{429}$

\author{
Paul. 2 de adult. D.24,2,9: Nullum divortium ratum est, nisi septem civibus \\ Romanis puberibus adhibitis praeter libertum eius qui divortium faciet. Libertum \\ accipiemus etiam eum, qui a patre, avo, proavo, et ceteris susum versum \\ manumissus sit.
}

cidadania romana por um latino. Veja-se Gai.1,29, p.72 supra.

${ }^{429}$ Segundo Suetônio, estas formalidades exigidas para a realização do repúdio eram dispositivos da Lex Iulia de maritandis ordinibus (Suet. Augustus 34,4). Veja-se também Paul. 2 de adult. D.24,2,9; Ulp. 34 ad ed. D.24,1,35; Ulp. 3 ad l. Iul. et Pap. D.24,2,11,2; Ulp. 47 ad ed. D.38,11,1,1. A lei determinava esta solenidade apenas em caso de adultério e de repúdio (um dos cônjuges desejasse dissolver o matrimônio). Vejam-se J. IGLESIAS, Derecho Romano cit. (nota 51 supra), p.345; L.R. ARGÜELlO, Manual cit. (nota 12 supra), pp.433434; V. ARANGIO-RUIZ, Istituzioni cit. (nota 53 supra), p.450; B. BIondI, Istituzioni cit. (nota 22 supra), pp.439;446-448; G. PUGLIESE - F. SitZIA - L. VACCA, Istituzioni cit. (nota 63 supra), p.400; A. BuRDESE, Manuale cit. (nota 47 supra), pp.281-282; E. RUIZ FERNÁNDEZ, El divorcio en Roma cit. (nota 234 supra), pp.63-64; M.KASER, Römisches Privatrecht cit. (nota 12 supra), p.329; R. MONIER, Manuel cit. (nota 146 supra), p.303; S. RicCOBONO, La politica demografica cit. (nota 103 supra), p.577; R. Astolfi, Il matrimonio nel diritto romano preclassico cit. (nota 1 supra), p.108; D. DALLA - R. LAMBERTINI, Istituzioni di diritto romano cit. (nota 10 supra), pp.111; B. BIONDI, La legislazione di Augusto cit. (nota 218 supra), p.153; A.A. CASTRO CORRÊA, O Estoicismo no Direito Romano cit. (nota 33 supra), pp.94-95; L.F. RADITSA, Augustus Legislation cit. (nota 49 supra), p.319; T. Spagnuolo Vigorita, Casta Domus cit. (nota 26 supra), p.35; O. RoBLEDA, Il divorzio in Roma cit. (nota 51 supra), pp.354;378-383.

Para F. LANFRANCHI, Il diritto nei retori romani cit. (nota 78 supra), pp.231, nota 3, nos escritos dos retóricos não existiam indícios da exigência do repúdio per litteras ou per nuntium, nem da intervenção do liberto na presença de sete testemunhas. Vale lembrar que, segundo o ius civile, tanto para o repúdio quanto para o divórcio, era suficiente a simples interrupção da vontade (affectio maritalis) de um dos cônjuges de estar casado. Em suma, as formalidades exigidas pela legislação matrimonial não eram essenciais para que ocorresse o divórcio, mas apenas uma exteriorização da vontade dos cônjuges ou de um deles em dissolver o matrimônio. Neste sentido Diocl. et Maxim. C.5,17,6 (294-305): Licet repudii libellus non fuerit traditus vel cognitus marito, dissolvitur matrimonium. "Ainda que o libelo de repúdio não fosse entregue ao marido, ou não fosse conhecido deste, se dissolve o matrimônio". Portanto, as formalidades exigidas pela Lex Iulia de adulteriis teriam efeitos apenas no âmbito do direito penal. Vejam-se, neste sentido, E. VolTERRA, La conception du Mariage à Rome cit. (nota 30 supra), p.356; Idem, La conception du Mariage d'après les juristes romains cit. (nota 30 supra), p.34; Idem, Les formes du Mariage chez les Romains cit. (nota 30 supra), p.280; Idem, Divorzio cit. (nota 70 supra), p.63; M. MARRONE, Istituzioni cit. (nota 48 supra), p.223; T. Spagnuolo Vigorita, Casta Domus cit. (nota 70 supra), pp.35-36, nota 101; P. Rasi, Consensus facit nuptias, Milano, Giuffrè, 1946, p.134. Contra esta opinião, R. AstolfI, La Lex Iulia et Papia cit. (nota 15 supra), pp194-199;200-202. Sustenta este autor que Paulo em D.24,2,9 afirma que o divórcio (ou o repúdio) era nulo se faltassem as formalidades prescritas na Lex Iulia de adulteriis: as sete testemunhas, o liberto e o libellus repudii. O matrimônio não se dissolvia, permanecia válido não obstante a ausência da affectio maritalis de um dos cônjuges. Portanto, a Lex Iulia de adulteriis criou uma exceção à regra da affectio maritalis. Porém, se o marido repudiou a esposa, não pode alegar adultério se ela se casar com outro, mesmo que não cumpra as formalidades prescritas na Lex Iulia de adulteriis, pois cessou de considerá-la como esposa e não há dolo ou a intenção de trair o marido por parte da mulher. Se não há dolo, também não há adultério (adulterium, inquit, sine dolo malo non committitur). Vejam-se Gai. 3 ad l. XII tab. D.48,5,43: Si ex lege repudium missum non sit, et idcirco mulier adhuc nupta esse videatur, tamen si quis eam uxorem duxerit, adulter non erit (...) "Se não se enviasse o repúdio conforme a lei [Lex Iulia de Adulteriis coercendis], e por isso se considerasse que a mulher ainda estava casada, contudo, se alguém se casasse com ela, não será adúltero (...)."; Ulp. 34 ad ed. D.24,1,35: Si non secundum legitimam observationem divortium factum sit, donationes post tale divortium factae nullius momenti sunt, quum non videatur solutum matrimonium. "Se não se fizesse o divórcio com as formalidades legais, as doações feitas após este divórcio são nulas, como se não parecesse dissolvido o matrimônio". 
"Nenhum divórcio é válido, senão tendo se apresentado sete cidadãos romanos púberes, além do liberto daquele que fizer o divórcio. Mas compreenderemos por liberto também aquele que foi manumitido pelo pai, pelo avô, pelo bisavô e pelos demais ascendentes”.

\section{É provável que este libellus repudii tivesse como finalidade estabelecer o momento} do início do repúdio para ser utilizado pelo marido na accusatio contra a esposa adúltera e para liberá-lo de uma futura acusação pública por lenocinium. ${ }^{430}$

Para julgar o crime de adultério, a lei instituiu uma quaestio perpetua, ou seja, um tribunal permanente. ${ }^{431}$

\footnotetext{
${ }^{430}$ E. VolterRA, La conception du Mariage à Rome cit. (nota 30 supra), p.356; Idem, La conception du Mariage d'après les juristes romains cit. (nota 30 supra), p.34; Idem, Les formes du Mariage chez les Romains cit. (nota 30 supra), p.280; O. RoBLEDA, Il divorzio in Roma cit. (nota 51 supra), pp.376;377, nota 51; 378-383;388. Contra a opinião de que as formalidades do divórcio serviam para determinar o momento da dissolução do matrimônio para a aplicação da pena de adultério, S. SolazzI, La legge augustea sul divorzio cit. (nota 180 supra), pp.344-345. De acordo com F. SCHUlZ, Classical Roman Law cit. (nota 51 supra), p.128, este libellus foi estabelecido para obrigar o divórcio do marido com a esposa adúltera, pois, caso contrário, incorria no crime de lenocinium. No período pós-clássico tornou-se comum na prática a redação de um documento para formalizar o divórcio. Apenas na época de Teodósio II e Valentiniano III o libellus tornou-se uma exigência legal [Theod. et Valent. C.5,17,8(449)]. Justiniano manteve a regra contida na Lex Iulia de adulteriis e a declaração feita diante sete testemunhas. Na opinião de V. ARANGIO-RUIZ, Istituzioni cit. (nota 53 supra), p.450, o libellus repudii e as sete testemunhas eram práticas estabelecidas pelos costumes para documentar o divórcio, com as habituais testationes.

${ }^{431}$ As quaestiones perpetuae eram tribunais permanentes que, subtraindo o julgamento de determinados crimes ou delito públicos às assembléias populares, evitavam que certas decisões sofressem influências políticas, dando-lhes maior autonomia. Nas palavras de M.C. Giordani, Direito Penal Romano, $3^{\mathrm{a} e d .}$, Rio de Janeiro, Lumen Juris, 1997, p.9: "Note-se que a criação de novos tribunais com atribuições definidas em lei tendo em vista novas figuras delituosas sublinha no Direito Penal Romano da época clássica o aspecto nitidamente processual. A lei que criava a quaestio configurava um crimen e fixava a pena; para cada crime instituía-se então uma quaestio. (...) A quaestio se caracterizava pelo sistema acusatório: qualquer cidadão podia intentar e sustentar a acusação". Na opinião de L.F. RADITSA, Augustus Legislation cit. (nota 49 supra), p.310, esta quaestio foi, provavelmente, a última a ser estabelecida na História de Roma: Augustus made love affairs and adultery public crimes, liable to 'accusatio publica'. This entailed the estabilishment of a 'questio', probably the last in Roman history. Vejam-se F. SchUlz, Classical Roman Law cit. (nota 51 supra), p.150; K. Galinsky, Augustan Culture cit. (nota 102 supra), p.130; G. RizZELli, Le donne nell'esperienza cit. (nota 411 supra), p.42; G. SCIASCIA, A lei romana sobre os Adultérios cit. (nota 313 supra), p.33; A. ESMEIN, Le délit d'adultére cit. (nota 338 supra), p.118; L. CHIAZZESE, Adulterio cit. (nota 410 supra), p.322; R. Astolfi, La Lex Iulia et Papia cit. (nota 15 supra), p.105. De acordo com H. ANKUM, La 'captiva adultera'cit. (nota 63 supra), p.155 e T. MommSEN, Römisches Strafrecht cit. (nota 96 supra), p.435, a quaestio de adulteriis existiu até o século III d.C., na época do imperador Alexandre Severo.
}

Uma das inovações introduzidas pela Lex Iulia de Adulteriis foi a possibilidade de admissão do testemunho de escravos que delatassem o adultério cometido pelos próprios senhores. A lei determinou que os escravos do acusador e do acusado, podiam ser torturados para a obtenção do testemunho, pois acreditava-se que o adultério geralmente era cometido com o auxílio dos escravos. Após a tortura e obtido o testemunho, os escravos eram publicati, ou seja, tornavam-se propriedade do "Estado" romano, para que não sofressem castigos ou recebessem recompensas de seus antigos senhores. Para garantir os escravos como testemunhas segundo a Lex Iulia de adulteriis, em um prazo de sessenta dias após o divórcio, eram proibidas a manumissão e a venda dos escravos que pertencessem à mulher acusada de adultério, ou ao seu pai, mãe, avô, desde que colocassem seus serviços à disposição da acusada. Veja-se Ulp. 4 adult. D.40,9,14,1: Et simpliciter quidem lex mulierem prohibuit intra sexagesimum diem divortii manumittere. "E a lei 
Nos 60 dias (dies utiles) após o divórcio (ex die divortii) corria o prazo em que o marido (e subsidiariamente, o pai da adúltera) ${ }^{432}$ tinha o direito exclusivo de mover uma ação contra a mulher (accusatio iure mariti vel patris). ${ }^{433}$

simplesmente proibiu que a mulher manumitisse dentro dos sessenta dias do divórcio". Conforme Coll. 4,11,1; PS 2,26,9 (= Coll. 4,12,8); Pap. 7 resp. D.31,76,4; Ulp. 5 de adult. D.40,9,12pr.;-7; Paul. 3 de adult. D.40,9,13; Ulp. 4 de adult. D.40,9,14pr.;1-4. Vejam-se S. RicCOBONo, La politica demografica cit. (nota 103 supra), p.577; H. ANKUM, La 'captiva adultera'cit. (nota 63 supra), pp.184-185; G. RIZZELLI, Alcuni aspetti dell'accusa cit. (nota 63 supra), pp.414-416; T. MOMMSEN, op.cit., pp.267-268;436. Na opinião de SCIASCIA, op.cit., p. 33, "era certamente um princípio revolucionário, contrário às tradições romanas, pois não somente lesava o poder absoluto do senhor, mas também, sob o aspecto político, lhe colocava numa condição de inferioridade perante seu escravo".

${ }^{432}$ Paul. 1 de adult. D.48,5,30pr.;-1: Pater sine periculo calumniae non potest agere. "O pai não pode exercer a ação sem a responsabilidade da calúnia"; 1. Sexaginta dies a divortio numerantur; in diebus autem sexaginta et ipse sexagesimus est. "Contam-se os sessenta dias desde o divórcio, mas nos sessenta dias contase também o próprio sexagésimo [dia]". Quanto à prioridade da acusação do marido em relação ao pai da adúltera, veja-se Ulp. 8 disp. D.48,5,2,8. Vejam-se G. Rizzelli, Alcuni aspetti dell'accusa cit. (nota 63 supra), p.416, nota 19; T. MOMMSEN, Römisches Strafrecht cit. (nota 96 supra), pp.435-436.

${ }^{433}$ De acordo com G. RIzZeLLI, Alcuni aspetti dell'accusa cit. (nota 63 supra), pp.411-412, é provável que a accusatio iure mariti vel patris estivesse disposta no décimo capítulo da Lex Iulia de adulteriis. A lei manteve a preferência, consolidada pelos costumes romanos, da iniciativa familiar na repressão ao adultério. Ulp. 8 disp. D.48,5,4,1: Extraneis autem qui accusere possunt, accusandi facultas post maritum et patrem conceditur; nam post sexaginta dies quattros menses extraneis dantur et ipsi utiles. "Aos terceiros, pois, que possam acusar, se concede a eles a faculdade de acusar após o marido e o pai; e de fato, após sessenta dias, são concedidos aos terceiros quatro meses, também úteis"; Scaev. 4 reg. D.48,5,14,2: Marito primum, vel patri eam filiam, quam in potestate habet, intra dies sexaginta divortii accusare permittitur nec ulli alii intra id tempus agendi potestas datur: ultra eos dies neutrius voluntas exspectatur. "Em primeiro lugar é permitido ao marido, ou ao pai acusar a filha que tenha in potestate, dentro de sessenta dias do divórcio e, nesse período de tempo, não é dado o poder de agir a nenhum outro: depois destes dias, não se espera a vontade nem de um nem de outro". Vejam-se também Ulp. 4 adult. D.40,9,14pr.;1-4; Pap. l. s. de adult. D.48,5,11,5-6; Ulp. 2 de adult. D. $48,5,15$ pr.

Outra situação que demonstra o interesse público no combate ao adultério é narrada em Ulp. 2 ad l. Iul. et Pap. D.48,5,25pr.;1-5 e em PS 2,26,3 que conferiam ao marido a faculdade de manter o adulter surpreendido em adultério por vinte horas contínuas, com o escopo de mostrá-lo às testemunhas. Dispõe PS 2,26,3: Capite quinto legis Iuliae cavetur, ut adulterum deprehensum viginti horas attestando vicinos retinere liceat. "No capítulo quinto da Lei Júlia [de Adulteriis] se estabelece que é lícito que os vizinhos prendam ao adúltero apanhado em flagrante, até vinte horas, para testemunhar".

Quanto ao prazo de sessenta dias para o marido mover a ação contra a adúltera, Tácito (Tac. Ann. 2,85,1-3) narra o caso da condenação (relegatio in insulam) de Vestília, mulher de origem nobre casada com Tídio Labeão e que tornou-se meretriz: (...) atque illo sexaginta dies ad consultandum datos necdum praeterisse, satis visum de Vistilia statuere; eaque in insulam Seriphon abdita est. “(...) E ele [Tídio Labeão] respondendo, 'que ainda não eram passados os sessenta dias, determinados na lei Júlia', contentaram-se com que só fosse condenada Vestília, a qual foi afastada para a ilha de Sérifo, para nunca mais tornar a ser vista". Vejam-se R. VILLERS, Le mariage envisagé cit. (nota 63 supra), p.298; H. ANKUM, La 'captiva adultera'cit. (nota 63 supra), pp.161-162;166;168;171;173, nota 108; V. ARANGIO-RUIZ, Storia del diritto romano cit. (nota 253 supra), p.260; A. GUARINo, Storia del diritto romano cit. (nota 103 supra), p.446; J. GAUDEMET, L'Apport du Droit Romain cit. (nota 59 supra), p.34; G. SCIASCIA, A lei romana sobre os Adultérios cit. (nota 313 supra), p.32; E. VOLTERRA, La conception du Mariage d'après les juristes romains cit. (nota 30 supra), p.36; Idem, Divorzio cit. (nota 70 supra), p.63; A. LóPEZ PedREIRA, Limitaciones a la 'libertas nuptialis' cit. (nota 40 supra), p.403; J. DAZA MARTíNEZ, La influencia cristiana cit. (nota 48 supra), p.133, nota 90; T. Spagnuolo Vigorita, Casta Domus cit. (nota 26 supra), pp.42;46;48; G. BRANCA, Adulterio cit. (nota 410 supra), p.621; L. ChIAZZESE, Adulterio cit. (nota 410 supra), p.322; K.C. CANELA, $O$ 'stuprum per vim' cit. (nota 96 supra), pp.95-96, nota 414; L.F. RADITSA, Augustus Legislation cit. (nota 49 supra), pp.311-312; A.A. CASTRO CoRRÊA, O Estoicismo no Direito Romano (nota 33 supra), p.93; B. BIONDI, La legislazione di Augusto cit. (nota 56 supra), p.156; R. Astolfi, La Lex Iulia et Papia cit. (nota 15 supra), p.105; G. RIzZELLI, Alcuni aspetti dell'accusa cit. (nota 63 supra), pp.412;419; T. MommSEn, Römisches Strafrecht cit. 
Nítido é o interesse público sobre o crime de adultério, pois a lei possibilita que qualquer cidadão romano (quivis de populo $)^{434}$, no prazo de quatro meses (menses utiles)

(nota 96 supra), pp.435-436; M.G. SCACCHETTI, La presunzione muciana cit. (nota 379 supra), pp.237-238, nota $376 ; 241-242$, nota 385 .

A Lex Iulia de adulteriis determinava que o divórcio sempre deveria preceder a acusação, conforme Pap. l. s. de adult. D.48,5,11,10. A traição realizada pela sponsa, pela mulher unida em matrimônio ilegítimo que não tivesse o ius connubii ou pela concubina não admitia a accusatio iure mariti vel patris, porém apenas a accusatio adulterii iure extranei conforme Ulp. 1 de adult. D.48,5,14,1,-4,-6;-8; Coll.4,5,1. Também no caso da captiva adultera, mulher que permaneceu um período em cativeiro e lá sofreu stuprum, era possível intentar tanto a accusatio iure extranei quanto a accusatio iure mariti. Neste sentido, Ulp. 2 de adult. D.48,5,13,7. Vejam-se H. ANKUM, La 'captiva adultera'cit. (nota 63 supra), pp.188-189;193-194;199;204205; R. Astolfi, La Lex Iulia et Papia cit. (nota 15 supra), p.139. M.B. FuMAGalli, Sponsali cit. (nota 51 supra), p.506 e G. Rizzelli, Alcuni aspetti dell'accusa cit. (nota 63 supra), pp.432-433 ao analisarem os passos Pap. 2 de adult. D.48,5,13,3;-6;9-10, confirmam que admitia-se a possibilidade de se mover a accusatio adulterii iure extranei contra a sponsa e a ex-concubina, ou seja, o adultério cometido antes do matrimônio. Polêmica é a aplicação da acusação iure extranei à menor de 12 anos conduzida à casa do marido (deductio in domum mariti), pois, além dela não ter o requisito da idade núbil, não existiam, neste caso, iustae nuptiae. Não existindo um matrimônio legítimo, o caso seria considerado um stuprum. Vejam-se Ulp. 2 de adult. D.48,5,13,8; Coll. 4,6,1. Veja-se G. RizzelLI, op.cit., pp.437-438.

${ }^{434}$ A prioridade da acusação era do marido, porém a lei mantinha a possibilidade tanto do marido, quanto do pai, moverem a ação, mesmo após o prazo de sessenta dias de sua exclusividade na acusação (quivis de populo). Em relação à mulher, ela não poderia mais ser acusada de adultério após seis meses utiles do divórcio. Na hipótese de stuprum a accusatio iure extranei poderia ser intentada no prazo de seis meses ex die comissis criminis (contados a partir da prática do delito). Vejam-se Coll.4,4,1; Ulp. 8 disp. D.48,5,2,1; Marcian. l. s. ad Senat. Turp. D.48,16,1,10. Decorridos cinco anos (anni continui), contados a partir do dia em que o delito foi cometido, o crime não poderia mais ser apenável, ou seja, nem a mulher, nem seu cúmplice, poderiam ser acusados, pois ocorria a praescriptio da ação penal. Sob Tibério (Suet. Tiberius 35,1 ) houve uma alteração da legislação matrimonial e estabeleceu-se que, na falta de acusação pública, a mulher poderia ser punida pelos seus parentes próximos (iudicium domestico), segundo os mores maiorum. Parece, porém, que esta punição da adúltera pelos propinqui foi de curta duração e posteriormente foi retomada a disposição da Lex Iulia de adulteriis. Vejam-se Pap. l.s. de adult. D.48,5,11,4: Adulterii reum intra quinque anos continuos a die criminis admissi, defuncta quoque muliere, postulari posse palam est. "É de conhecimento público, que o réu de adultério pode ser acusado dentro de cinco anos contínuos desde o dia em que se cometeu o crime, ainda que a mulher tenha falecido"; Ulp. 4 de adult. D.48,5,29,5-9. Também é importante salientar que a acusação de adultério contra uma mulher grávida deve ser diferida ne quod praeiudicium fieret nato (Paul. 1 de adult. D.37,9,8). Vejam-se T. Spagnuolo Vigorita, Casta Domus cit. (nota 26 supra), p.33; M. ZABŁOCKA, Le modifiche cit. (nota 103 supra), pp.398-401; L. ChIAZZESE, Adulterio cit. (nota 410 supra), p.322; K.C. CANELA, $O$ 'stuprum per vim' cit. (nota 96 supra), p.96; H. ANKUM, La 'captiva adultera'cit. (nota 63 supra), pp.162;168-170;178; M. MolÈ, Stuprum cit. (nota 96 supra), p.586, nota 2; P. CATALANO, El concebido 'sujeto de derecho' según el sistema jurídico romano, in Direito de Familia no Novo Milênio - Estudos em homenagem ao Professor Álvaro Villaça Azevedo, São Paulo, Atlas, 2010, p.396; G. Rizzelli, Alcuni aspetti dell'accusa cit. (nota 63 supra), pp.419-423; T. MommSEn, Römisches Strafrecht cit. (nota 96 supra), p.436. Na opinião de G. RIZZELLI, op.cit., p.413, é provável que esta prioridade do pai fosse estabelecida pela jurisprudência e não pela lei, de acordo com Ulp. 8 disp. D.48,5,2,8. Contra esta opinião, E. VolTERRA, Matrimonio cit. (nota 61 supra), p.770; Idem, Divorzio cit. (nota 70 supra), p.63, o qual defende que a prioridade em mover a ação cabia ao paterfamilias da adúltera e não ao marido.

A accusatio publica iure extranei é praticamente abolida por Constantino em 326, influenciado pelos princípios cristãos. Os próprios familiares da adúltera, parentes próximos, decidem se ela será acusada pelo crime ou se ela será perdoada e o casamento mantido. Constantino retoma a sanção da pena de morte para a adúltera e seu cúmplice. Veja-se Const. C.9,9,29pr.;-1 (326); (= C.Th. 9,7,2). No matrimônio justinianeu, que apresenta forte influência cristã, o marido não é obrigado a repudiar a esposa adúltera. Sobre a poena gladi veja-se Inst. 4,18,4 (nota 96 supra). Vejam-se G. BrancA, Adulterio cit. (nota 410 supra), p.621; L. CHIAZZESE, Adulterio cit. (nota 410 supra), pp.322-323; H. ANKUM, La 'captiva adultera'cit. (nota 63 supra), p.156, nota 13;166;175;195; E. VOLTERRA, La conception du Mariage d'après les juristes romains cit. (nota 30 supra), pp.37-38. Na Nov.117,8,2, o marido somente podia repudiar a esposa por adultério após a 
após 60 dias do divórcio (post sexaginta dies), possa mover uma ação pública (accusatio publica iure extranei) se o pai ou o marido não acusarem a adúltera. ${ }^{435}$

Observa-se neste caso que nos iudicia publica apenas os homens, cidadãos romanos, tinham o direito de acusação. A mulher, portanto, não poderia mover uma ação para acusar o marido de adultério (quaestio de adulteriis). ${ }^{436}$

Além disso, a mulher e o seu cúmplice não poderiam ser acusados concomitantemente, já que a mesma causa não poderia ter dois réus de adultério, pois era necessária uma determinada ordem na acusação. Essa ordem era optativa, não existindo prioridade. $^{437}$

O capítulo segundo da lei reconheceu, ao pai da adúltera (quer o pai tivesse sobre ela a patria potestas, quer ela estivesse submetida à manus de seu marido, quer fosse emancipada), o ius occidendi, ou seja, o direito de matar o adulter ${ }^{438}$ e simultaneamente a filha ${ }^{439}$, quando surpreendesse o casal em flagrante, em pleno ato sexual [in opere], na sua

condenação e se a acusasse injustamente sofreria as penas previstas para o adultério. Veja-se também neste sentido, Nov.117,9,4.

${ }^{435}$ Segundo uma observação de H. ANKUM, La 'captiva adultera' cit. (nota 63 supra), pp.166;173, as fontes romanas não mencionam que a accusatio iure extranei tenha sido utilizada em casos de stuprum. Neste caso, segundo M. ZABŁOCKA, Le modifiche cit. (nota 103 supra), p.398 utilizava-se uma accusatio iure publico. Para G. RIZZELLI, Alcuni aspetti dell'accusa cit. (nota 63 supra), p.412, a accusatio iure extranei também foi utilizada na repressão ao stuprum. É importante salientar que o terceiro não pode mover a acusação de adultério (accusatio publica iure extranei) sem que antes tenha sido comprovado o lenocinium do marido. Veja-se G. RIZZELLI, op. cit., p.424.

${ }^{436}$ Sev. et Anton. C.9,9,1 (197): Publicio iudicio non habere mulieres adulterii accusationem, quamvis de matrimonio suo violato queri velint, lex Iulia declarat, quae, cum masculis iure mariti facultatem accusandi detulisset, non idem feminis privilegium detulit. "Declara a Lei Júlia, que as mulheres não têm ação para acusar por adultério em juízo público, ainda que desejem queixar-se que foi violado seu matrimônio, porque como ela [a lex Iulia] concedeu aos homens a faculdade de acusar com base no direito marital, não outorgou o mesmo às mulheres". Vejam-se K.C. CANELA, $O$ 'stuprum per vim' cit. (nota 96 supra), p.96; H. ANKUM, La 'captiva adultera'cit. (nota 63 supra), pp.162-163;171; G. RIZZELLI, Alcuni aspetti dell'accusa cit. (nota 36 supra), pp.428;437. Estavam proibidos de fazer esta acusação as mulheres, os impúberes, os filiifamilias sem a autorização de seu pater, o liberto que tivesse um patrimônio inferior a 30.000 sestércios, o liberto em relação ao patrono, o acusado em juízo público e aqueles que participassem de jogos públicos e espetáculos, como atores e gladiadores (infames). Vejam-se Ulp. 1 ad l. Iul. et Pap. D.23,2,43,10; Pomp. 1 ad Sab. D.48,2,1; Ulp. 2 de adult. D.48,2,4; Macer 2 de publ. Iud. D.48,2,8; Ulp. 2 de adult. D.48,5,15,6; Coll. 4,4,1; Coll. 4,5,1. Há algumas exceções a estas regras em Pap. 5 quaest. D.48,5,37; Pap. 36 quaest. D.48,5,38,9, que admitem a acusação apenas iure extranei do liberto, do menor de vinte e cinco anos e do infame.

${ }^{437}$ Conforme Iul. 86 dig. D.48,5,5; Ulp. 2 adult. D.48,5,15,9; Ulp. 2 ad l. Iul. de adult. D.48,5,17,6; Ulp. 2 ad l. Iul. de adult. D.48,5,19,3; Alex. C.9,9,8 (224). De acordo com T. Mommsen, Römisches Strafrecht cit. (nota 96 supra), p.436, se a mulher adúltera tivesse se casado novamente, o antigo marido deveria mover a ação de adultério primeiro contra o marido atual e somente após a condenação deste, mover a acusação de adultério contra a mulher. Caso a ex-esposa não estivesse em um novo matrimônio, ficava ao arbítrio do autor acusar primeiro a mulher ou o seu cúmplice. Não pode, em hipótese nenhuma, exercer a ação contra os dois ao mesmo tempo.

${ }^{438}$ Segundo K.C. CANELA, $O$ 'stuprum per vim' cit. (nota 96 supra), p.95, o adulter era o homem que tinha relações sexuais ilícitas com a adultera, e esta, ao renunciar à sua pudicitia, provocava a pollutio de seu sangue e de sua honra.

${ }^{439}$ A. EsmeIn, Le délit d'adultére cit. (nota 338 supra), p.89; L. CHIAZZESE, Adulterio cit. (nota 410 supra), p.322. Vejam-se Pap. 1 adult. D.48,5,22,4: Ideo autem patri, non marito mulierem et omnem adulterium remissum est occidere, quod plerumque pietas paterni nominis consilium pro liberis capit; ceterum mariti 
própria casa ou na casa do genro. ${ }^{440}$

Caso o pai matasse apenas um dos adúlteros, seria punido como homicida, de acordo com a lex Cornelia de sicariis et veneficis. ${ }^{441}$

calor et impetus facile discernentis fuit refrenatus. "Mas ao pai, não ao marido, se consentiu matar a mulher e a qualquer adúltero, porque a maioria das vezes a piedade que deriva da condição de pai toma a decisão em favor dos filhos; porém, deve-se refrear o amor ardente e a impetuosidade do marido que ocorre com facilidade"; Coll. 4,7,1. A jurisprudência romana proibiu o marido de matar a adúltera, pois ele poderia agir de forma prematura, impelido pela paixão (impetus).

${ }^{440}$ PS 2,26,1: Capite segundo legis Iuliae de adulteriis permittitur patri tam adoptivo quam naturali adulterum cum filia cuiuscumque dignatatis domi suae vel generi sui deprehensum sua manu occidere. "No capítulo segundo da Lex Iulia de Adulteriis permite-se, tanto ao pai adotivo quanto ao natural, matar com as próprias mãos ao adúltero de qualquer categoria que seja surpreendido com sua filha dentro de sua casa ou daquela de seu genro". A Lex Iulia de maritandis ordinibus, diferentemente da Lex Iulia de adulteriis, não estabelecia nem por quem, nem o local onde a mulher deveria ser deprehensa, para ser notata secundum verba legis. Ulp. 1 ad l. Iul. et Pap. D.23,2,43,13: Non adiicitur hic, ut in lege Iulia de adulteriis, a quo, vel ubi deprehensa sit; proinde sive maritus, sive quis alius deprehendisse proponatur, videtur notata; sed et si non in domo mariti vel patris sui deprehensa sit, erit notata secundum verba legis. "Não é acrescentado aqui, como na Lex Iulia de adulteriis, por quem, ou onde foi surpreendida [a adúltera]; por consequência, seja que se dissesse que o marido, seja que qualquer outro a surpreendeu, considera-se condenada; porém, também será condenada conforme as palavras da lei, se não foi surpreendida na casa do marido ou de seu pai"; Pap. 1 de adult. D.48,5,22,2: Ius occidendi patri conceditur domi suae, licet ibi filia non habitat, vel in domo generi. Sed domus et pro domicilio accipienda est, ut in lege Cornelia de iniuriis. "Ao pai se concede o direito de matar em sua própria domus [casa], ainda que a filha não habite nela, ou na casa de seu genro. Porém, domus deverá ser entendida também por domicílio, como na lei Cornelia de iniuriis".

Vejam-se G. PUGLIESE - F. SiTZIA - L. VACCA, Istituzioni cit. (nota 63 supra), p.393; B. BIONDI, Istituzioni cit. (nota 22 supra), p.445; T. Spagnuolo Vigorita, Casta Domus cit. (nota 26 supra), p.33; H. AnKum, La 'captiva adultera'cit. (nota 63 supra), p.159; M. ZABŁOCKA, Le modifiche cit. (nota 103 supra), p.398. A jurisprudência admitia que o pater e o marido da adúltera poderiam matá-la, de acordo com esses pressupostos, mesmo que o matrimônio não estivesse de acordo com a Lex Iulia et Papia. Macer. 1 publ. D.48,5,25,3: (...) Item si filia ignominiosa sit, aut uxor contra leges nupta, an id ius nihilominus pater maritusve habeat? (...) Et rectius dicetur eos ius occidendi habere, qui iure patris maritive accusare possunt. “(...) do mesmo modo, sendo a filha ignominiosa ou sendo a esposa casada contra as leis [matrimoniais de Augusto], o pai e o marido têm igualmente este direito [ius occidendi]? (...) E é mais correto dizer que aqueles que podem acusar com direito de pai ou de marido têm o direito de matar". Neste sentido, R. Astolfi, La Lex Iulia et Papia cit. (nota 15 supra), p.106; S. Solazzi, Sui divieti matrimoniali delle leggi augustee cit. (nota 168 supra), p.98; E. NARDI, Sui divieti matrimoniali cit. (nota 109 supra), pp.130;133, nota $56 ; 136$.

${ }^{441}$ Conforme Coll. 4,2,6; 4,9,1; Ulp. 1 adult. D.48,5,23pr.; Macer 1 de publ. Iud. D.48,5,32pr. Ulpiano estabelece qual deve ser a atitude do pai nesta situação em Ulp. 1 adult. D.48,5,23,4: in continenti filiam occidat; "mate imediatamente a filha". Nesta situação, o "Estado Romano" retoma os hábitos dos antepassados, nos quais o adultério era punido no âmbito familiar e o paterfamilias era o juiz dos delitos e crimes cometidos pelos membros a ele submetidos (ius vitae ac necis). Esta possibilidade de matar disposta pela lei constitui a raiz ocidental do chamado "homicídio por causa da honra", da defesa da honra do cônjuge traído como um dever social, bastante difundido nas legislações medievais. Coll 4,2,3 (Paul. l.s.adult.): Secundo vero capite permittit patri, si in filia sua, quam in potestate habet, aut in ea, quae eo auctore, cum potestate esset, viro in manum convenerit, adulterum domi suae generive sui deprehenderit isque in eam rem socerum adhibuerit, ut is pater eum adulterum sine fraude occidat, ita in continenti occidat. "[A Lex Iulia de Adulteriis Coercendis], no segundo capítulo, permite que o pai que tenha a própria filha sob sua potestas ou que tendo-a sob potestas, colocou-a sob o poder (manus) do marido, assegurando-lhe a aquisição, e que tenha surpreendido um adúltero com ela na própria casa ou naquela do genro e este tenha solicitado a intervenção do sogro para este assunto, que este pai mate o adúltero sem que isto lhe seja imputável, desde que mate a filha em seguida"; Coll. 4,12,1-2: Permittitur [patri] tam adoptivo quam naturali, adulterum cum filia cuiusque dignitatis domi suae vel generi sui deprehensum sua manu occidere. Filius familias pater si filiam in adulterio deprehenderit, verbis quidem legis prope est, ut non possit occidere: permittitur tamen etiam ei, ut occidat. "Permite-se ao pai, tanto adotivo quanto natural, matar com a sua mão ao adúltero de qualquer dignidade surpreendido com a sua filha na sua casa ou na casa do genro. Um filiusfamilias que já é pai, se 
A lei não estabelece que o marido possa matar a mulher, e caso esse fato ocorresse, ele seria punido com o exílio. ${ }^{442}$

O marido poderia matar o adúltero, apenas se ele fosse de baixa condição social (alcoviteiro, aquele que exercia a arte lúdicra, o condenado em juízo público, o liberto) e caso lhe flagrasse dentro de sua própria casa. ${ }^{443}$

surpreendesse a filha em adultério, certamente está próximo das palavras da lei "que não possa matar": não obstante também permita-se àquele, que mate". Contrários à Coll. 4,12,2, Papiniano e Ulpiano defendem que o filiusfamilias não tem o ius occidendi, conforme Ulp. 1 de adult. D.48,5,21 e Pap. 1 de adult. D.48,5,22pr.;4. Vejam-se A. GUARINO, Storia del diritto romano cit. (nota 103 supra), p.446; G. RIZZELLI, Le donne nell'esperienza cit. (nota 411 supra), pp.43-45; Idem, Alcuni aspetti dell'accusa cit. (nota 63 supra), p.418; G. SCIASCIA, A lei romana sobre os Adultérios cit. (nota 313 supra), pp.33-34; E. VolterRA, Matrimonio cit. (nota 61 supra), p.770; L.F. RADITSA, Augustus Legislation cit. (nota 49 supra), p.292; G. PUGLIESE - F. SITZIA - L. VACCA, Istituzioni cit. (nota 63 supra), p.401; M. TALAMANCA, Istituzioni cit. (nota 12 supra), p.144; A. ESMEIN, Le délit d'adultére cit. (nota 338 supra), pp.89-90; G. BRANCA, Adulterio cit. (nota 410 supra), p.620; H. ANKUM, La 'captiva adultera'cit. (nota 63 supra), pp.159-160.

${ }^{442}$ Pap. 1 de adult. D.48,5,22,4. Veja-se o texto de Coll. 4,10,1 que menciona um trecho da obra de Papiniano libro singulari de adulteris: Si maritus uxoram suam in adulterio deprehensam occidit, an in legem de sicariis incidat, quaero; respondit: nulla parte legis marito uxorem occidere conceditur: quare aperte contra legem fecisse eum non ambigitur; sed si de poena tractas, non inique aliquid eius honestissimo calori permittitur, ut non quasi homicida puniatur capite vel deportatione, sed usque ad exilium poena eius statuatur. "Se um marido matou a sua esposa surpreendida em adultério, pergunto se incorre na Lex de sicariis. Respondeu (Papiniano): em nenhuma parte da lei foi concedido ao marido matar a esposa; pelo qual, francamente não se duvida que o fez contra a lei. Porém, se discute sobre a pena, iniquamente se permite algo disso em sua justa indignação, de modo que não seja castigado como homicida com a pena capital ou com a deportação, mas que se estabeleça sempre como sua pena o exílio". A deportação de um dos cônjuges dissolvia o matrimônio, pois o deportado sofria a perda do conubium. A deportatio só ocorria excepcionalmente e era aplicada aos casos considerados muito graves, pois além da imposição do domicílio perpétuo, o deportado também perdia a cidadania romana. Vejam-se C. PUJAL, La concepción jurídica cit. (nota 47 supra), p.620; G. BRANCA, Adulterio cit. (nota 410 supra), p.621; L. CHIAZZESE, Adulterio cit. (nota 410 supra), p.322; K.C. CANELA, $O$ 'stuprum per vim' cit. (nota 96 supra), pp.93-94; L.F. RADITSA, Augustus Legislation cit. (nota 49 supra), pp.312-313; A. EsMEIN, Le délit d'adultére cit. (nota 338 supra), p.88.

${ }^{443}$ PS 2,26,4 (= Coll. 4,12,3): Maritus, in adulterio deprehensos non alios quam infames et eos qui corpore quaestum faciunt, servos etiam, excepta uxore quam prohibetur, occidere potest. "O marido pode matar não a outros, senão aos infames surpreendidos em adultério e àqueles que lucram com o corpo, inclusive aos escravos, excetuada a esposa, à qual é proibido"; PS 2,26,7 (= Coll. 4,12,6): Inventa in adulterio uxore maritus ita demum adulterum occidere potest, si eum domi suae deprehendat. "Descoberta a esposa em adultério, o marido pode matar ao adúltero apenas com a condição de que o apanhe em flagrante na sua casa". Caso o marido matasse o adulter que não fosse da categoria mencionada (baixa condição social) ele era condenado por homicidium de acordo com a Lex Cornelia de sicariis et veneficiis. Vejam-se G. RIZZELLI, Le donne nell'esperienza cit. (nota 411 supra), p.43, nota 74; G. PUGLIESE - F. SiTZIA - L. VACCA, Istituzioni cit. (nota 63 supra), p.388; M. ZABŁOCKA, Le modifiche cit. (nota 103 supra), p.398; A. LÓPEZ PEDREIRA, Limitaciones a la 'libertas nuptialis' cit. (nota 40 supra), p.403; T. SPAGNUOlO Vigorita, Casta Domus cit. (nota 26 supra), p.33; L. CHIAZZESE, Adulterio cit. (nota 410 supra), p.322; L.F. RADITSA, Augustus Legislation cit. (nota 49 supra), p.312; H. ANKUM, La 'captiva adultera'cit. (nota 63 supra), p.161; S. SolAZZI, Glossemi nelle fonti giuridiche romane cit. (nota 169 supra), pp.53-54. Conforme Pap. 1 adult. D.48,5,23,3, aquele que pode matar o adúltero pode, com maior razão, infligir-lhe maus tratos de diversas naturezas. Cfr. Macer 1 adult. D.48,5,24pr.;-1: Marito quoque adulterum uxoris suae occidere permittitur, sed non quemlibet, ut patri: nam hac lege cavetur, ut liceat viro deprehensum domi suae (non etiam soceri) in adulterio uxoris occidere eum, qui leno fuerit quive artem ludicram ante fecerit in scaenam saltandi cantandive causa prodierit iudiciove publico damnatus neque in integrum restitutus erit, quive libertus eius mariti uxorisve, patris matris, filii filiae utrius eorum fuerit (nec interest, proprius cuius eorum, an cum alio communis fuerit) quive servus erit. 1.Et praecipitur, ut is maritus, qui horum quem occiderit, uxorem sine mora dimittat. "Também ao marido é permitido matar o adúltero de sua mulher, mas não a quem quer que seja, como ao pai: de fato, por esta lei se estabelece que é lícito ao marido matar em sua própria casa (não também na do sogro), ao homem que foi surpreendido em adultério com a sua esposa e que tenha sido 
As penas para o adultério e o lenocinium eram as seguintes:

(a) O marido tinha o direito de exigir a condenação da mulher adúltera, pois o adultério torna-se um crime público punível com o exílio, a relegatio in insulam, pena que substituiu a condenação à morte da adúltera e que consistia no desterro dos dois infratores para ilhas diferentes, mantendo o status civitatis dos punidos. ${ }^{444}$

Para os jovens das classes altas romanas, o modelo de vida proposto por Augusto era abominável. Chamava mais a atenção uma vida licenciosa e livre sexualmente, as apresentações na cenas teatrais e nas arenas, do que uma vida destinada à política, à glória militar, ao matrimônio e à procriação de muitos filhos.

Tibério em 19 d.C. manteve a política moralizadora de Augusto e publicou vários senatusconsultos para condenar ao exílio as mulheres ingênuas que, para fraudar as leis matrimoniais e escapar de suas sanções, dispensavam a dignitas matronalis e praticavam publicamente o lenocínio. Tibério incluiu nas sanções da lex Iulia de adulteriis coercendis as prostitutas que pertecessem às classes altas da sociedade romana. Conforme Suet. Tiberius 33: (...) atque etiam, si qua in publicis moribus desidia aut mala consuetudine labarent, corrigenda suscepit. “(...) contudo, além disso, se os costumes públicos desabavam ou por desídia ou por maus hábitos, assumiu corrigi-los".

Também eram punidos os jovens das classes senatorial e equestre que se exibissem em cena, como ator ou atriz, ou na arena, como gladiador (contratado com auctoramentum), para escaparem das sanções destes senatusconsultos. ${ }^{445}$

alcoviteiro ou tenha precedentemente exercido a arte lúdicra e tenha pisado nos palcos para dançar ou cantar ou tenha sido condenado em um juízo público e não tivesse sido reabilitado inteiramente ou, ainda, o que tivesse sido liberto do marido ou de sua esposa, do pai, da mãe, do filho, da filha, da filha de um dos dois (e não faz diferença se tenha sido de um deles ou em comum com um terceiro) ou o que será um escravo. 1. E ordene-se que o marido, que matou a algum destes, abandone sem demora sua esposa". Vejam-se Ulp. 2 ad $l$. Iul. et Pap. D.48,5,25pr.;1-5; Coll. 4,3,1-6.

${ }^{444}$ T. Spagnuolo Vigorita, Casta Domus cit. (nota 26 supra), pp.33;42-43;45-46;48;128, nota 133; M. ZABŁOCKA, Le modifiche cit. (nota 103 supra), pp.398-400;403-405; L.F. RADITSA, Augustus Legislation cit. (nota 49 supra), p.314; M. MolÈ, Stuprum cit. (nota 96 supra), p.586, nota 9; T. MOMMSEN, Römisches Strafrecht cit. (nota 96 supra), p.437; M.G. SCACCHETTI, La presunzione muciana cit. (nota 379 supra), p.238, nota 376. Na opinião de H. ANKUM, La 'captiva adultera'cit. (nota 63 supra), p.155, não há certeza que a relegatio in insulam já fosse prevista pela Lex Iulia de adulteriis. Segundo F. DELLA CoRTE, Le 'leges Iuliae' e l'elegia romana cit. (nota 47 supra), pp. 547-549;557, as penas aplicadas aos matrimônios entre cônjuges de diferentes classes e com algumas categorias de mulheres (meretrizes, alcoviteiras, atrizes, filhas de pais que trabalhavam no teatro, mulheres publico iudicio damnatae, adúlteras) tiveram o efeito contrário do escopo da Lex Papia Poppaea. Havia diversas formas de fraudes à legislação matrimonial. Uma delas era a dispensa da dignitas matronalis pelas ingênuas.

${ }^{445}$ Vejam-se Dio Cass. 43,23,5; 48,43,2-3; 54,2,5. Em 1978 foi publicado um fragmento de uma tábua de bronze descoberta em Larinum, que apresenta um senatusconsulto provavelmente promulgado nos seis primeiros meses de 19 d.C. (Tabula Larinas). Este senatusconsulto proibia ser ator ou gladiador, não apenas os senadores e todos os seus descendentes até o terceiro grau, mas qualquer ingênua, menor de vinte anos ou ingênuo, menor de vinte e cinco anos. Ou seja, as mesmas idades mínimas estabelecidas pela Lex Iulia de maritandis ordinibus para que homens e mulheres se casassem e tivessem filhos. 
Um desses senatusconsultos promulgados por Tibério previa a possibilidade dos próprios parentes, por decisão comum, punirem as matronas que praticassem qualquer crime sexual, retomando, desta forma, os rígidos costumes anteriores à própria legislação matrimonial de Augusto. ${ }^{446}$

Tabula Larinas (1-11;17-19): S(enatus) c(onsultum). / [- c. 10-12 -] l. in Palatio, in porticu quae est ad Apollinis. Scr(ibundo) ad(fuerunt) C. Ateius L. f. Ani(ensi) Capito, Sex. Pomp[eius Sex f. - c. 10-] / [- c. 12 -] Octavius C.f. Ste(llatina) Fronto, M. Asinius Curti f. Ar(nensi) Mamilianus, C. Gavius C.f. Pob(lilia) Macer q(uaestor), A. Did[ius --- f. --- Gallus q(uaestor).] / [Quod M. Silan]us L. Norbanus Balbus co(n)s(ules) $v($ erba) f(ecerunt) commentarium ipsos composuisse sic uti negotium iis [datum erat ?de s(enatus) c(onsultis) ad liberos] / [? Senato]rum pertinentibus aut ad eos qui contra dignitatem ordinis sui in scaenam ludumv[e ?se darent? - c. 7- ad] / [? vers]us s(enatus) c(onsulta), quae d(e) e(a) r(e) facta essent superioribus annis, adhibita fraude qua maiestatem senatus minuerent, $q(u i d) d(e) e(a) r(e) f($ ieri $) p($ laceret $), d(e) e(a) r(e) i(t a)$ censuere:] / [pla]cere ne quis senatoris filium filiam nepotem neptem pronepotem proneptem, neve que $[m$ ?cui ipsi? cuiusve patri aut avo] / [v]el paterno vel materno aut fratri, neve quam cuius viro aut patri aut avo $<$ vel $>$ paterno ve[l materno aut fratri ius] / fuisset unquam spectandi in equestribus locis in scaenam produceret auctoramentove rog[aret, ?neve, ut bestias confice]/ret aut ut pinnas gladiatorum raperet aut ut rudem tolleret aliove quod eius rei simile min[?isterium praestante operam] / praeberet, conduceret, neve quis eorum se locaret. (...) [Quodque s(enatus)] c(onsulto), quod M'. Lepido T. Statilio Tauro co(n)s(ulibus) referentibus factum esset, scriptum compre $<$ he $>n[$ sum ?esset?, ne cui ingenuae quae] / minor quam an(norum) $X X$ neve cui ingenuo qui minor quam an(norum) $X X V$ esset auctorare se operas[ve suas ?in scaenam - c.7-] / [- c.10 -]s locare permitteretur (...). "Senatusconsulto, no Palatino, no Pórtico que está junto ao templo de Apolo. Auxiliaram a redação escrita Caio Ateio Capitão, filho de Lúcio, da tribo Aniense; Sexto Pompeu [filho de Sexto, da tribo (...); ...(nome perdido).......]; Otávio Frontão, filho de Caio, da tribo Estelatina; Marco Asínio Mamiliano, filho de Cúrsio, da tribo Arnense; Caio Gávio Macro, filho de Caio, da tribo Publília, questor; Aulo Dídio [Gallo, filho de (...), da tribo (...), questor]. Os cônsules Marco Silano e Lúcio Norbano Balbo declararam, eles mesmos, ter escrito uma relação - em conformidade ao cargo deles [conferido -? sobre senatusconsultos] que se referem aos descendentes dos senadores ou àqueles que, contra a dignidade da sua ordem, se dedicassem à cena e aos jogos [dos gladiadores]; declararam, além disso, que alguns jovens tinham um comportamento contrário aos senatusconsultos que sobre este argumento foram feitos nos anos anteriores, valendo-se da fraude para diminuir a majestade do Senado. Interrogados sobre o que desejavam fazer em relação a este propósito, os senadores deliberaram desta forma: em relação ao filho, à filha, ao neto, à neta, ao bisneto, à bisneta de um senador; (e assim, em relação àquele) que pessoalmente ou cujo pai, avô - tanto paterno quanto materno - ou irmão; ou então àquela cujo marido, pai, avô - tanto paterno quanto materno - ou irmão, nunca teve [o direito] de assistir aos espetáculos nos lugares equestres; em relação a estas pessoas se estabelece que ninguém as apresente em cena ou empregue com auctoramentum, nem contrate para matar as feras ou arrancar os penachos dos gladiadores ou para elevar para o alto o bastão ou para auxiliar caso outro exerça algum trabalho semelhante a este; além disso, que nenhuma das pessoas supramencionadas aluguem o próprio trabalho.(...) E quanto a isto que está escrito e demonstrado no sentusconsulto, que foi submetido à deliberação dos cônsules Mário Lépido e Tito Estatílio Tauro, que à nenhuma ingênua menor de vinte e cinco anos e à nenhum ingênuo menor de vinte e cinco anos seja permitido ser contratado com auctoramentum ou locar o próprio trabalho para a cena(...)". Vejam-se T. Spagnuolo Vigorita, Casta Domus cit. (nota 26 supra), pp. 43;80;130-135; M. ZaBŁOCKA, Le modifiche cit. (nota 103 supra), pp.405-407.

${ }^{446} \mathrm{O}$ motivo para esta intervenção imperial ocorreu após uma mulher da classe senatorial, chamada Vestília, ter-se declarado publicamente adúltera. Na opinião de T. Spagnuolo Vigorita, Casta Domus cit. (nota 26 supra), p.128, nota 133, é possível que a relegatio tenha sido aplicada à Vestília por meio de um decretum senatorial e não de um senatusconsulto, que apenas posteriormente deve ter sido promulgado para sancionar as situações semelhantes. Veja-se Tac. Ann. 2,85,1-3: Eodem anno gravibus senatus decretis libido feminarum coercita cautumque ne quaestum corpore faceret cui avus aut pater aut maritus eques Romanus fuisset; nam Vistilia praetoria familia genita licentiam stupri apud aedilis vulgaverat, more inter veteres recepto, qui satis poenarum adversum impudicas in ipsa professione flagitii credebant; exactum et a Titidio Labeone Vistiliae marito cur in uxore delicti manifesta ultionem legis omisisset; atque illo sexaginta dies ad consultandum datos necdum praeterisse, satis visum de Vistilia statuere; eaque in insulam Seriphon abdita est. "Neste mesmo ano [19 d.C.] o senado promulgou leis muito severas contra a devassidão das mulheres, e proibiu, que nenhuma fizesse ganho com o corpo [meretriz], que fosse neta, filha ou esposa de homem da 
Suet. Tiberius 35,1-3: Matronas prostratae pudicitiae, quibus accusator publicus deesset, ut propinqui more maiorum de communi sententia coercerent autor fuit. Eq. R. iuris iurandi gratiam fecit, uxorem in stupro generi compertam dimitteret, quam se nunquam repudiaturum ante iuraverat. Feminae famosae, ut ad evitandas legum poenas iure ac dignitate matronali exolverentur, lenocinium profiteri coeperant, et ex iuventute utriusque ordinis profligatissimus quisque, quominus in opera scaenae harenaeque edenda senatus consulto teneretur, famosi iudicii notam sponte subibant; eos easque omnes, ne quod refugium in tali fraude cuiquam esset, exilio adfecit.

"Sob sua iniciativa [de Tibério] determinou-se que as matronas ${ }^{447}$ que prostituíssem a sua pudicícia, caso faltasse um acusador público, fossem punidas pelos parentes com decisão comum, segundo o costume dos antepassados. Desobriga um cavaleiro romano do juramento, permitindo-lhe afastar a esposa, surpreendida em adultério [stuprum] com o genro, se bem que, outrora, tivesse jurado não repudiá-la nunca. Mulheres difamadas começaram a praticar publicamente o lenocínio, de modo a liberar-se da condição jurídica e da dignidade matronal e evitar, assim, as penas estabelecidas pelas leis [matrimoniais] ${ }^{448}$;

classe equestre romana. Deu motivo a este decreto Vestília que, apesar de pertencer à uma famíla pretoriana, tinha levado a tanto o desaforo de sua impudicícia, que pediu ser registrada pelos edis na classe das meretrizes. Era este um costume, praticado por nossos antigos, que tiveram por castigo suficiente contra as impudicas obrigá-las a alistar-se nesta profissão vergonhosa. Perguntou-se também a Tídio Labeão, marido de Vestília, por que não tinha punido pela lei [Lex Iulia de Adulteriis] a sua mulher, publicamente convencida deste crime. E ele respondendo, 'que ainda não eram passados os sessenta dias, determinados na lei Júlia', contentaram-se com que só fosse condenada Vestília, a qual foi afastada para a ilha de Sérifo, para nunca mais tornar a ser vista". É possível que o termo veteres utilizado neste trecho indicasse uma retomada da vigilância dos lupanários, realizada durante o período republicano, pelos edis curuis. M. ZABŁOCKA, Le modifiche cit. (nota 103 supra), pp.399;404-405, ao comentar este trecho de Tácito, afirma que Tibério em 19 d.C. promulgou vários senatusconsultos para coibir a libido feminarum das mulheres pertencentes à classe equestre que se dedicassem à prostituição. Além disso, Tibério aplicou com maior rigor e severidade (e até modificou arbitrariamente, sem nenhuma justificativa) muitas disposições da legislação matrimonial de Augusto, como no caso de Aquília (acusada de adultério com Vário Ligur), que foi privada de todos os direitos da cidade e submetida à rígida pena do exilium e não da relegatio prevista na Lex Iulia de adulteriis. Veja-se Tac. Ann. 4,42,3.

${ }^{447}$ De acordo com M. ZABŁOCKA, Le modifiche cit. (nota 103 supra), p.402, o termo "matronas" não indicava as mulheres casadas, mas as mulheres pertendentes às classes senatorial e equestre, que deveriam apresentar um comportamento exemplar para toda a sociedade.

${ }^{448}$ De acordo com F. C. SAVIGNY, System des heutingen römischen Rechts cit. (nota 403 supra), pp.548-550, a capacitas das feminae probrosae teria sido plena e elas não poderiam ser atingidas pela Lex Iulia de adulteriis em razão de sua turpitudine. Por isso, as mulheres caelebs das classes privilegiadas exerciam o lenocínio para tornarem-se feminae probrosae e não ficarem submetidas à incapacitas prevista pela Lex Iulia et Papia. Além disso, era impossível o matrimônio legítimo com qualquer uma delas. As poena legum deste trecho de Suetônio eram as penas previstas pela Lex Iulia de maritandis ordinibus para os caelebs. Domiciano (Suet. Domitianus 8,4), elimina esta capacitas das feminae probrosae, ou seja, a fraude praticada pela mulheres seria inútil. Ver nota 92 supra. Veja-se, contra a opinião de SAVIGNY, R. Astolfi, Femina 
e os mais depravados dentre os jovens de ambas as ordens [senatorial e equestre] expunham-se espontaneamente à mancha de um juízo infamante, para que não fossem impedidos pelo senatusconsulto a apresentar-se em cena e na arena. A uns e outros ele atingiu com o exílio, a fim de que ninguém encontrasse qualquer refúgio em uma fraude tão desprezível”.

Papiniano, ao se referir às penas previstas por este senatusconsulto, não estabeleceu se elas eram aplicadas apenas às mulheres das altas classes sociais ou à todas as mulheres. $^{449}$

Pap. 2 de adult. D.48,5,10,2: Mulier, quae evitandae poenae adulterii gratia lenocinium fecerit, aut operas suas in scenam locavit, adulterii accusari damnarique ex Senatusconsulto potest.

“A mulher que, para evitar a pena de adultério, tiver cometido lenocínio, ou locou seus serviços para o teatro, pode ser acusada e condenada por adultério em virtude de um Senatusconsulto".

O ponto principal do trecho é a indicação da fraude que as mulheres poderiam

probrosa cit. (nota 96 supra), pp.16-18; 42-44. ASTOLFI defende que algumas das feminae probrosae poderiam casar-se com ingênuos e, neste caso, para as mulheres da alta sociedade que se tornassem feminae probrosae, nada seria alterado e elas não escapariam das penas infligidas às caelibes. As poenae legum não eram as penas relativas aos caelibes, mas as previstas na Lex Iulia de adulteriis. O autor é contrário à opinião de SAVIGNY, quanto ao trecho de Suet. Domitianus 8,4 combater uma fraude à Lex Iulia et Papia. Na opinião de R. AstolfI, op.cit., pp.48;51-52, o imperador Domiciano não teve por objetivo principal reprimir uma eventual fraude à Lex Iulia et Papia, nem o aumento demográfico ou a procriação. Seu escopo era combater a probrositas, piorando a situação das feminae probrosae para proteger os bons costumes na sociedade. Defende ASTOLFI, baseado em Quint. Inst. Orat. 8,5,19, que as feminae probrosae na Lex Iulia et Papia (denominadas neste trecho como diligentissimae pudores custodes) não tinham uma incapacidade sucessória total, mas reduzida a um quarto, se elas não estivessem na idade matrimonial ou gozassem da vacatio das viúvas e divorciadas, ou ainda, se elas fossem licitamente casadas com um liberto ou um ingênuo (quando permitido pela lei). Apenas tiveram sua capacitas totalmente excluída sob Domiciano. Veja-se Quint. Inst. Orat. 8,5,19: (...) Placet hoc ergo, o leges diligentissimae pudoris custodes, decimas uxores dari, quarta meretricibus. “(...) Portanto isto é estabelecido, ó leis diligentíssimas protetoras do pudor, que dava-se às esposas a décima parte, às prostitutas a quarta?”. No governo de Domiciano parece sobressair a intenção fiscal sobre a demográfica e o combate à probrositas em outro exemplo: as prostitutas deviam pagar 27 denários para viajarem entre os portos dos Mares Vermelho e o Copta, enquanto as outras mulheres pagavam um denário. Veja-se também R. Astolfi, La Lex Iulia et Papia cit. (nota 26 supra), pp.31;331; Idem, Note per una valutazione storica della 'Lex Iulia et Papia' cit. (nota 36 supra), p.216; E. NARDI, La 'incapacitas' delle 'feminae probrosae' cit. (nota 96 supra), pp.160-166. Trifonino narra que o imperador Adriano manteve a incapacitas total das feminae probrosae (Tryph. 18 disp. D.29,1,41,1) estabelecida por Domiciano.

449 M. ZABŁOCKA, Le modifiche cit. (nota 103 supra), p.405. Na opinião de M.G. SCACCHETTI, La presunzione muciana cit. (nota 379 supra), p.240, notas 379 e 380, acredita que a norma era destinada principalmente às mulheres das classes sociais elevadas. 
realizar para evitar as sanções da lex Iulia de adulteriis. As mulheres lenocinium fecerit, ou seja, desenvolviam atividades como prostituta, administradora de prostíbulos ou atriz mesmo pertencendo às classes romanas mais influentes politica e economicamente. ${ }^{450}$

Quanto à atitude dos imperadores sucessores de Tibério, houve uma diminuição na rigidez das sanções previstas pela lex Iulia de adulteriis. Calígula alterou um capítulo da lei e promulgou um imposto a ser pago pelas prostitutas, alcoviteiras e mulheres acusadas por lenocínio. Este imposto foi mantido pelos seus sucessores. Percebe-se neste caso, não apenas uma preocupação fiscal, mas moralizadora da sociedade. ${ }^{451}$

Cláudio defendia que o adultério não deveria ser considerado um crime público e voltaria a ser julgado no âmbito familiar (iudicium domesticum). Nero abrandou a pena daqueles que se exibissem nos teatros e na arena, pois ele mesmo, desde os quinze anos, exibia-se em cenas em vários espetáculos teatrais e incentivava vários membros da alta sociedade romana a também participar. ${ }^{452}$

(b) quando a mulher fosse culpada, poderia o marido exigir-lhe uma pena patrimonial, a retenção de metade do dote e o confisco de um terço do total do patrimônio (bens parafernais) ao Erário. Se o culpado fosse o marido, este era obrigado a restituir o dote à mulher e determinava-se o confisco da metade de seus bens. ${ }^{453}$

\footnotetext{
${ }^{450}$ F. C. SAVIGNY, System des heutingen römischen Rechts cit. (nota 403 supra), pp.549-550; E. NARDI, La 'incapacitas' delle 'feminae probrosae' cit. (nota 96 supra), p.157. De acordo com M. ZABŁOCKA, Le modifiche cit. (nota 103 supra), pp.405-406, em 19 d.C. o Senado votou pelo menos dois senatusconsultos que alteravam e agravavam algumas sanções determinadas pela Lex Iulia de adulteriis. O primeiro, referido por Suetônio, Papiniano e pela Tabula Larinas, proibia as exibições na cena e na arena dos homens e das mulheres pertencentes às classes sociais superiores. O segundo, recordado por Tac. Ann., 2,85,1-3 e também por Suetônio, proibia a libido feminarum, ou seja, a prostituição e o lenocínio das mulheres das classes senatorial e equestre.

${ }^{451}$ Suet. Caligula 40. Vejam-se M. ZABŁOCKA, Le modifiche cit. (nota 103 supra), pp.407-408;410; A. BOUCHÉ-LECLERCQ, Les lois démographiques d'Auguste cit. (nota 36 supra), p.278. Contra esta preocupação moralizadora da sociedade, afirma M.G. SCACCHETTI, La presunzione muciana cit. (nota 379 supra), p.243, que na dinastia Júlio-Cláudia (14 - 68 d.C.), as condenações por adultério não passaram de vinte casos.

${ }_{452}$ Suet. Claudius 16,2; Nero 7,1. De acordo com M. ZABŁOCKA, Le modifiche cit. (nota 103 supra), p. 409.

${ }^{453}$ PS 2,26,14: Adulterii convictas mulieres dimidia parte dotis et tertia parte bonorum ac relegatione in insulam placuit coerceri: adulteris vero viris pari in insulam relegatione dimidiam bonorum partem auferri, dummodo in diversas insulas relegantur. "Decide-se punir as mulheres consideradas culpadas de adultério com a perda da metade do dote e da terça parte do patrimônio e com a relegação a uma ilha: aos homens adúlteros, ao invés, decide-se infligir o confisco de metade dos bens, em conjunto com uma relegação análoga, desde que sejam desterrados para ilhas diferentes". Vejam-se G. RIZZELLI, Le donne nell'esperienza cit. (nota 411 supra), p.42; J. CARCOPINO, La vie quotidienne à Rome cit. (nota 72 supra)., p.122; A. BURDESE, Manuale cit. (nota 47 supra), p.277; A. GuARINO, Storia del diritto romano cit. (nota 103 supra), p.445; G. SCIASCIA, A lei romana sobre os Adultérios cit. (nota 313 supra), p.31; E. VOLTERRA, Matrimonio cit. (nota 61 supra), p.770; R. BESNIER, L'application des lois caducaires cit. (nota 10 supra), pp.114-115; M. MoLÈ, Stuprum cit. (nota 96 supra), p.586, nota 9; G. BRANCA, Adulterio cit. (nota 410 supra), p.621; L. ChiAZZESE, Adulterio cit. (nota 410 supra), p.322; B. BIONDI, La legislazione di Augusto cit. (nota 56 supra), p.155; H. ANKUM, La 'captiva adultera' 'cit. (nota 63 supra), p.155. De acordo com T. MOMmSEN, Römisches Strafrecht cit. (nota 96 supra), p.437, as penalidades da relegatio e do confisco do patrimônio e do dote não eram aplicadas aos cidadãos de condição inferior e utilizavam-se, neste caso, castigos corporais. K.C. CANELA, $O$ 'stuprum per vim' cit. (nota 96 supra), pp.92, nota 387, afirma que estas penalidades previstas na
} 
A condenação por adultério ou por stuprum ocasionava a infamia, mesmo se a mulher não tivesse sido surpreendida em flagrante; a intestabilitas (incapacidade de ser testemunha in iudicio e de participar de um ato per aes et libram) e a pollutio de sua domus (a contaminação de toda a sua família, pessoas e bens, principalmente se a consequência desse crime fosse a geração de prole incerta). ${ }^{454}$

Caso a mulher fosse a culpada (deprehensa in adulterio), estava proibida de contrair um novo matrimônio, sendo equiparada à prostituta e proibida de participar de festas e eventos religiosos e públicos que fossem reservados às mulheres honradas. ${ }^{455}$

Lex Iulia de adulteriis (principalmente o confisco da metade dos bens e a relegatio in insulam) também eram aplicadas no caso de stuprum. Veja-se ainda Inst. 4,18,4.

${ }^{454} \mathrm{H}$. ANKUM, La 'captiva adultera'cit. (nota 63 supra), p.156; K.C. CANELA, $O$ 'stuprum per vim' cit. (nota 96 supra), pp.93-94;101; M. MolÈ, Stuprum cit. (nota 96 supra), p.586. O matrimônio dos adúlteros foi considerado nulo para todos os efeitos e eles eram declarados indignos à sucessão testamentária recíproca. Nesta situação, a razão pela qual os bens hereditários eram retirados da adúltera, não era a incapacitas, mas a indignitas. Veja-se Pap. 32 quaest. 1 ad l. Iul. et Pap. D.34,9,13: Claudius Seleucus Papiniano suo salutem. Maevius in adulterio Semproniae damnatus eandem Semproniam non damnatum duxit uxorem: qui moriens heredem eam reliquit: quaero, an iustum matrimonium fuerit et an mulier ad hereditatem admittatur. Respondi neque tale matrimonium stare neque hereditatis lucrum ad mulierem pertinere, sed quod relictum est ad fiscum pervenire. Sed et si talis mulier virum heredem instituerit, et ab eo quasi ab indigno hereditatem auferri dicimus. "Cláudio Seleuco saúda Papiniano. Mévio, condenado por ter cometido adultério com Semprônia, casou-se com a própria Semprônia, que não foi condenada, e ao morrer deixou-a herdeira; pergunto, se será legítimo o matrimônio e se a mulher será admitida na herança. Respondo que tal matrimônio era inválido e nem pertencia à mulher a fortuna da herança, mas o que foi deixado ia para o Fisco. Mas, mesmo no caso em que esta mulher instituísse o marido herdeiro, afirmamos que a herança seria retirada dele, como indigno". Para Papiniano, o matrimônio com uma mulher adúltera era considerado um iniustum matrimonium. Neste caso, os dois adúlteros já estavam casados quando o ex-marido de Semprônia intentou a acusação. A Lex Iulia de adulteriis não permitia, neste caso, a acusação contra a adúltera, pois ela já se encontrava em outra relação matrimonial, apenas poderia ser chamado em juízo o cúmplice. A Lex Iulia de adulteriis não permitia a acusação contemporaneamente a ambos os co-réus, mas primeiro em relação a um e depois ao outro. Vejam-se R. Astolfi, La Lex Iulia et Papia cit. (nota 15 supra), pp.128-130; Idem, Femina probrosa cit. (nota 96 supra), pp.24-30; Idem, Note per una valutazione storica della 'Lex Iulia et Papia' cit. (nota 36 supra), pp.217-218; J. GAUDEMET, Justum matrimonium cit. (nota 51 supra), pp.134-135. $\mathrm{Na}$ opinião de S. SolazZI, Sui divieti matrimoniali delle leggi augustee cit. (nota 168 supra), pp.94-95, o fragmento é interpolado, pois o termo stare, acompanhado de outro substantivo (venditio, locatio, iudicium) com o sentido de "validade", indicaria uma interpolação. Além disso, a expressão an mulier ad hereditatem admittattur indica o direto de Semprônia adir a herança de Mévio em termos que não pertecem ao período clássico. Contra a opinião de SOlAZZI, E. NARDI, La 'incapacitas' delle 'feminae probrosae' cit. (nota 96 supra), p.158; Idem, Sui divieti matrimoniali delle leggi augustee cit. (nota 109 supra), pp.139-146, afirma que neste trecho a declaração de incapacitas é consequência necessária para a invalidade das núpcias. A adúltera era incapax se celebrasse novas núpcias. Semprônia, portanto, não tinha o direito de adir a herança de Mévio, pois tornou-se incapax quando celebrou novas núpcias e o matrimônio, nestas circunstâncias, era considerado inválido.

${ }^{455}$ Após o divórcio, havia a possibilidade da adúltera casar-se novamente, até com o próprio cúmplice, dependendo da demora do processo. Por isso, estabeleceu-se que, enquanto o marido estivesse vivo, a mulher acusada de adultério não podia casar-se com ninguém. Caso fosse condenada, o impedimento tornava-se definitivo. Mod. 5 resp. D.23,2,26: Reas adulterii factas nec ante damnationem vivente marito uxores duci posse. "Vivendo o marido, não se pode casar com aquelas que se tornaram rés de adultério, nem antes da condenação". Ulp. ad l. Iul. et Pap. D.23,2,43,10,-12,-13. Vejam-se G. RizzelLi, Le donne nell'esperienza cit. (nota 411 supra), p.42; R. Astolfi, La Lex Iulia et Papia cit. (nota 15 supra), pp.138-139; J. IGLESIAS, Derecho Romano cit. (nota 51 supra), p.343; E. RUIZ FERnÁNDEZ, El divorcio en Roma cit. (nota 234 supra), pp.47-48; A. ESMEIN, Le délit d'adultére cit. (nota 338 supra), p.86; G. BRANCA, Adulterio cit. (nota 410 supra), p.621; H. ANKUM, La 'captiva adultera'cit. (nota 63 supra), p.156; K.C. CANELA, $O$ 'stuprum per vim' cit. (nota 96 supra), p.92, nota 387. Quanto à proibição da adúltera contrair um novo matrimônio, esta 
Quanto ao marido adúltero, se se casasse novamente, pagava uma multa pecuniária.

Apesar da lex Iulia de adulteriis coercendis tratar de forma desigual homens e mulheres, alguns dispositivos nitidamente apresentaram algumas inovações em relação à proteção do patrimônio da $u x o r$.

Para proteger a restituição dos bens dotais para a uxor, a lex Iulia de adulteriis apresentava um capítulo (ou talvez tenha existido uma lei autônoma denominada lex Iulia de fundo dotali $)^{456}$, que organizou esta matéria. Neste capítulo, determinou-se a inalienabilidade dos terrenos dotais itálicos sem o consentimento da esposa (ne dotale praedium maritus invita muliere alienet). ${ }^{457}$

Gai 11 ad ed. prov. D.23,5,4: lex Iulia, quae de dotali praedio prospexit, ne id

disposição da Lex Iulia de adulteriis ainda estava em vigor no período dos Severos, conforme Alex. C.9,9,9 (224), neste trecho foi denominada Lex Iulia de pudicitia: Castitati temporum meorum convenit, lege Iulia de pudicitia damnatam in poenis legitimis perseverare. Qui autem adulterii damnatam, si quocumque modo poenam capitalem evaserit, sciens duxit uxorem vel reduxit, eadem lege ex causa lenocinii punietur. "Convêm à castidade de meus tempos, que a condenada pela Lex Iulia de pudicitia continue sempre submetida às penas legais. Mas aquele que, com pleno conhecimento, tomou ou voltou a tomar por esposa à condenada por adultério, se de qualquer modo escapasse da pena capital, será castigado pela mesma lei por causa de lenocínio".

${ }^{456}$ Defende A. NicoletTI, Dote cit. (nota 242 supra), p.259, a existência de uma lei promulgada por Augusto, denominada Lex Iulia de fundo dotali, sendo que um de seus capítulos era intitulado de adulteriis.

${ }^{457}$ Também estava proibido ao marido a constituição de um penhor ou hipoteca, a constituição ou a extinção de servidões (iura in re aliena) sobre os bens dotais sem o consentimento da uxor. Vejam-se R. AstolfI, La Lex Iulia et Papia cit. (nota 15 supra), pp.156-157;342; Idem, Note per una valutazione storica della 'Lex Iulia et Papia' cit. (nota 36 supra), p.202; G. PACCHIONI, Corso di diritto romano cit. (nota 29 supra), p.363; V. ARANGIO-RuiZ, Storia del diritto romano cit. (nota 253 supra), p.455; Idem, Istituzioni cit. (nota 53 supra), p.455; R. MONIER, Manuel cit. (nota 146 supra), pp.292;294; G. CoRNIL, Droit Romain cit. (nota 55 supra), pp.136-137; A. BURDESE, Manuale cit. (nota 47 supra), p.288; J. IGLESIAS, Derecho Romano cit. (nota 51 supra), p.353; R. VILleRs, Le mariage envisagé cit. (nota 63 supra), p.299; M. TALAMANCA, Istituzioni cit. (nota 12 supra), p.147; S. RicCOBONO, La politica demografica cit. (nota 103 supra), p.577; M.J.GarCía GARRIDO, v. Lex Iulia de Fundo Dotali cit. (nota 7 supra), p.219; T. MARKY, Curso Elementar de Direito Romano cit. (nota 166 supra), p.166. D. DALLA - R. LAMBERTINI, Istituzioni di diritto romano cit. (nota 10 supra), pp.113-114; F. SchUlz, Classical Roman Law cit. (nota 51 supra), p.119; F. SERAFINI, Istituzioni cit. (nota 53 supra), p.222; M.B. Fumagalli, Sponsali cit. (nota 51 supra), p.50; A. BouchéLECLERCQ, Les lois démographiques d'Auguste cit. (nota 36 supra), p.258. Vejam-se também, Gai.2,63: Nam dotale praedium maritus invita muliere per legem Iuliam prohibetur alienare, quamvis ipsius sit vel mancipatum ei dotis causa vel in iure cessum vel usucaptum. Quod quidem ius utrum ad Italica tantum praedia an etiam ad provincialia pertineat, dubitatur. "Pois a lei Júlia proibe ao marido alienar o imóvel dotal, sem o consentimento da mulher, embora pertença a ele, ou por mancipatio a título de dote, ou por in iure cessio, ou por ter adquirido pelo usucapião. Discute-se se tal direito é aplicável somente aos terrenos itálicos ou também aos provinciais"; Paul. Sent. 2,21b,2: Lege Iulia de adulteriis cavetur, ne dotale praedium maritus invita uxore alienet. "Está previsto pela Lei Júlia dos adultérios que o marido não aliene o fundo dotal contra a vontade da esposa"; Iust. C.5,13,1,15 (530): Et quum lex Iulia fundi dotalis Italici alienationem prohibebat fieri a marito non consentiente muliere, hypothecam autem, nec si mulier consentiebat, interrogati sumus, si oportet huiusmodi sanctionem non super Italicis tantummodo fundis, sed pro omnibus locum habere. "E como a Lex Iulia proibia que, não consentindo a mulher, se fizesse a alienação de um fundo dotal itálico pelo marido, e também a hipoteca, ainda se a mulher consentisse, temos sido interrogados sobre se convém que semelhante sanção ocorra não apenas em relação aos fundos itálicos, mas em relação a todos". Conforme Vat. Frag. 410; Inst.2,8pr. Esta disposição da Lex Iulia de fundo dotali tornou-se um legado que repercute em grande parte dos códigos civis contemporâneos. Nos artigos 1647 a 1650 do Código Civil Brasileiro de 2002, está presente a denominada "outorga uxória". 
marito liceat obligare aut alienare, plenius interpretanda est, ut etiam de sponso idem iuris sit, quod de marito.

“A lex Iulia, que prevê em relação ao terreno dotal que não seja lícito ao marido onerá-lo ou aliená-lo, será interpretada mais plenamente, de modo que também em relação ao marido haja o mesmo direito que ao sponsus".

Resumindo, a lex Iulia de adulteriis tinha como objetivos principais:

(a) reprimir o adultério (também indicado nesta lei com o termo stuprum), principalmente nas classes senatorial e equestre para garantir uma prole numerosa e legítima;

(b) regulamentar a restituição do dote para a proteção dos bens comuns aos cônjuges e a herança das futuras gerações; e

(c) punir os repúdios sem causa justificada.

Em suma, a lex Iulia de adulteriis coercendi é um exemplo de que em matéria de infidelidade conjugal, no período clássico romano, havia uma grande desproporção, neste âmbito, quanto às penalidades aos homens e às mulheres. ${ }^{458}$

\subsubsection{PROTEÇÃO DA PROLE EVENTUAL}

A política demográfica de Augusto, ao promover a procriação, fez com que os pretores $^{459}$ e os jurisconsultos do período clássico elaborassem diversas medidas para proteger o nascituro e que atendessem o interesse do "Estado", a fim de que nascesse não apenas para os seus pais e familiares, mas também para a res publica.

\footnotetext{
${ }^{458} \mathrm{Na}$ opinião de B. BIONDI, La legislazione di Augusto cit. (nota 56 supra), p.156, não existe uma desigualdade quanto às penalidades da Lex Iulia de adulteriis: L'uomo e la donna sono collocati sullo stesso piano, poichè la colpa dell'uomo non è meno riprovevole di quella della donna, e quindi entrambi gli adulteri sono accusati e puniti nello stesso modo. A infidelidade do marido apenas foi considerada adultério se fosse realizada com mulher casada (in nupta), até este instituto ser influenciado e reformulado pelos princípios cristãos no período pós-clássico. Neste caso, a Lex Iulia de adulteriis punia o marido adúltero com o desterro (exílio). Veja-se também F. Della CORTE, Le 'leges Iuliae' e l'elegia romana cit. (nota 47 supra), p.551; A. VILlaÇA AZEVEDo, Dever de Coabitação cit. (nota 61 supra), p.59.

${ }^{459}$ Ulp. 41 ad ed. D.37,9,1 pr.: Sicuti liberorum eorum, qui iam in rebus humanis sunt, curam Praetor habuit, ita etiam eos, qui nondum nati sint, propter spem nascendi non neglexit; nam et hac parte Edicti eos tuitus est, dum ventrem mittit in possessionem vice contra tabulas bonorum possessionis. "Assim como o Pretor manteve a proteção daqueles filhos que já existem in rebus humanis, assim também não negligenciou os que ainda não tenham nascido, por causa da esperança de nascer; pois também nesta parte do edito protegeu-os, enquanto envia o ventre à posse na forma de uma bonorum possessio contra tabulas". Conforme H.M.F. MADEIRA, O Nascituro no Direito Romano cit. (nota 8 supra), p.88: "Havendo, pois, a spes nascendi, o
} 
O jurista Ulpiano explicita as situações em que o pretor intervinha em favor do concebido mais que em favor do menino, a fim de que seja introduzido na família e, sobretudo, na Res publica. ${ }^{460}$

Ulp. 41 ad ed. D.37,9,1,15:

Et generaliter ex quibus causis Carbonianam bonorum possessionem puero praetor dare solitus est, ex iisdem causis ventri quoque subvenire praetorem debere non dubitamus, eo facilius, quod favorabilior est causa partus quam pueri: partui enim in hoc favetur, ut in lucem producatur, puero, ut in familiam inducatur: partus enim iste alendus est, qui et si non tantum parenti, cuius esse dicitur, verum etiam rei publicae nascitur.

"E geralmente, por estas causas que o pretor se acostumou dar a bonorum possessio Carboniana ao menino, pelas mesmas causas, não duvidamos que o pretor tenha que prestar ajuda também ao concebido, bem mais porque a sua causa deve ser mais favorecida do que aquela do menino; porquanto o concebido é protegido para que venha à luz, o menino para que seja introduzido na família; pois este concebido tem que ser nutrido porque nasce não somente para o pai, ao qual diz-se pertencer, mas também para a res publica".

Neste trecho Ulpiano enuncia o princípio da par conditio, ou seja, equipara o nascituro aos irmãos já nascidos. ${ }^{461}$

direito pretoriano protegia amplamente o nascituro".

${ }^{460}$ F. Betancourt, Derecho Romano Clásico, Sevilla, Universidad de Sevilla, 2001, pp.411-413; H.M.F. MADEIRA, O Nascituro no Direito Romano cit. (nota 8 supra), pp.90-91.

${ }^{461}$ H.M.F. MADEIRA, O Nascituro no Direito Romano cit. (nota 8 supra), pp.87-88. Veja-se Ulp. 41 ad ed. D.37,9,1pr.: Sicuti liberorum eorum, qui iam in rebus humanis sunt, curam praetor habuit, ita etiam eos, qui nondum nati sint, propter spem nascendi non neglexit. Nam et hac parte edicti eos tuitus est, dum ventrem mittit in possessionem vice contra tabulas bonorum possessionis. "Assim como o pretor manteve a proteção daqueles filhos que já existem in rebus humanis, assim também não negligenciou os que ainda não tenham nascido, por causa da esperança de nascer, pois também nesta parte do edito protegeu-os, enquanto envia o ventre à posse na forma de uma bonorum possessio contra tabulas". Outras fontes jurídicas expressam a idéia de equiparação entre o concebido e o nascido, sendo nestes casos considerado que o nascituro tinha uma existência independente da mãe: Gai.1,147; Paul. l. s. de port. quae lib. damn. conc. D.1,5,7; Paul. 69 dig. D.1,5,26; Cels. 28 dig. D.38,16,7. Veja-se também P. FERRETTI, In rerum natura esse in rebus humanus nondum esse - L'identità del concepito nel pensiero giurisprudenziale clássico, Milano, Giuffrè, 2008, pp.12-13. Salienta M.B. FuMAGALLI, Spes vitae cit. (nota 251 supra), pp.353-354, que o trecho demonstra a importância da mulher na res publica para a restauração dos mores e a procriação de muitos filhos. 
Na opinião de P. CATALANO ${ }^{462}$, o trecho indica que o Direito Romano "se remite pues conjuntamente al interés público y a la ventaja del concebido".

$\mathrm{O}$ descendente legítimo de um casamento entre dois cidadãos romanos obtém o status, de acordo com a sua condição jurídica no momento da concepção. Era o que estabelecia o princípio do ius gentium de que os nascituros seguem a condição do pai e seriam cidadãos romanos submetidos à patria potestas. ${ }^{463}$

Qualquer alteração na situação jurídica da mãe, durante a sua gravidez, que fosse desvantajosa para o nascituro (divórcio ${ }^{464}$, capitis deminutio maxima e media dos pais), não teria nenhuma influência sobre sua situação. ${ }^{465}$

O nascituro não sofre as desvantagens da mulher grávida, cidadã romana, que foi condenada à pena de morte ou à pena do exílio. ${ }^{466}$

$\overline{462}$ El concebido 'sujeto de derecho' cit. (nota 434 supra), p.396. Contra o que denomina "fervor ideológico individualístico" que desconsidera o nascituro como pessoa, P. Catalano, Diritto e Persone, Torino, Giappichelli, 1990, pp.214-215, salienta que a opinião de Ulpiano è un ammonimento permanente per tutti $i$ populi, non solo per i populi latini.

${ }_{463}$ E. Volterra, La nozione giuridica del 'conubium' cit. (nota 180 supra), pp.298;305;317.

${ }^{464}$ PS 2,24,5: Si mulier divortio facto gravidam se sciat, intra tricensimum diem viro denuntiare debet vel patri eius, ut ad ventrem inspiciendum observandumque custodes mittant: quo omisso partum mulieris omnimodo coguntur agnoscere. IP: Si quaecumque mulier matrimonio per divortium dissoluto praegnantem se esse senserit et hoc in notitiam mariti vel patris eius detulerit, ut ad inspiciendum vel observandum ventrem suum custodes mittant, quos dum miserint, partum mulieris, is est nativitatem sui heredis, compelluntur agnoscere. "Se uma mulher, realizado o divórcio, sabe que está grávida, deve declarar ao marido ou ao pai deste dentro de trinta dias para que enviem custodes [guardiães, defensores] para examinar e observar o ventre: isto omitido, são obrigados completamente a reconhecer o recém-nascido da mulher. IP: Se qualquer mulher, dissolvido o matrimônio por divórcio, perceber que está grávida e trouxer isto ao conhecimento do marido ou do pai deste para que enviem os custodes para examinar ou observar o ventre, enquanto os enviam, são obrigados a reconhecer o recém-nascido da mulher, isto é, o nascimento de seu herdeiro".

${ }^{465}$ PS 2,24,1: Si serva conceperit et postea manumissa pepererit, liberum parit. "Se uma escrava conceber e depois de ser manumitida der à luz, dá à luz um filho livre"; PS 2,24,2: Si libera conceperit et ancilla facta pepererit, liberum parit: id enim favor libertatis exposcit. "Se uma mulher livre conceber e der à luz feita escrava, dá à luz um filho livre, pois deste modo exige o favor da liberdade"; PS 2,24,3: Si ancilla conceperit et medio tempore manumissa sit, rursus facta ancilla pepererit, liberum parit: media enim tempora libertati prodesse, non nocere possunt. "Se uma escrava conceber e no intervalo fosse manumitida, e der à luz feita escrava novamente, dá à luz um filho livre, pois os intervalos podem beneficiar a liberdade, não prejudicála". Por "intervalo" (medio tempore) entende-se o período de tempo que transcorre entre a concepção, a manumissão e o parto. Vejam-se Marc. 1 inst. D.1,5,5,2; -3; UE 5,10: In his, qui iure contracto matrimonio nascuntur, conceptionis tempus spectatur: in his autem, qui non legitime concipiuntur, editionis veluti si ancilla conceperit, deinde manumissa pariat, liberum parit nam quoniam non legitime concepit, cum editionis tempore libera sit, partus quoque liber est. "Em relação aos nascidos de casamento contraído segundo o direito, considera-se o momento da concepção; em relação aos não legitimamente concebidos, o do nascimento. Por exemplo, se uma escrava concebeu e depois de alforriada der à luz, seu parto será livre; pois, desde que não concebeu legitimamente, sendo livre no momento de dar à luz, seu parto também será livre".

${ }^{466}$ O.M. PÉTER, Liberorum quaerendorum causa cit. (nota 21 supra), p.303; P. CATALANO, El concebido 'sujeto de derecho' cit. (nota 434 supra), p.396. Vejam-se Gai. 1,90: Itaque si cui mulieri civi Romanae praegnati aqua et igni interdictum fuerit, eoque modo peregrina facta tunc pariat, complures distinguunt et putant, si quidem ex iustis nuptiis conceperit, civem Romanum ex ea nasci, si vero vulgo conceperit, peregrinum ex ea nasci. "Portanto, se uma mulher cidadã romana, grávida, lhe for imposta a interdição da água e do fogo, e, tornada peregrina nessas condições, vier a parir, muitos distinguem e pensam que se concebeu em justas núpcias, o dela nascido é cidadão romano; se porém, concebeu ilegitimamente, o dela 
Por outro lado, para sua condição social, deve-se considerar também a situação no momento de sua concepção, v.g. a situação em que o filho de um senador nascido nesta ordem, ainda que seu pai fosse removido durante a gravidez de sua esposa, será considerado como da classe senatorial.

Ulp. 1 ad leg. Iul. et Pap. D.1,9,7,1: Item Labeo scribit etiam eum, qui post mortem patris senatoris natus sit, quasi senatoris filium esse. Sed eum, qui posteaquam pater eius de senatu motus est, concipitur et nascitur, Proculus et Pegasus opinantur non esse quasi senatoris filium, quorum sententia vera est: nec enim proprie senatoris filius dicetur is, cuius pater senatu motus est antequam iste nasceretur. Si quis conceptus quidem sit, antequam pater eius senatu moveatur, natus autem post patris amissam dignitatem, magis est ut quasi senatoris filius intellegatur: tempus enim conceptionis spectandum plerisque placuit.

"Igualmente, Labeão escreve que também é como um filho de senador aquele que nascer depois da morte do pai senador. Mas Próculo e Pégaso opinam não ser como filho de senador aquele que é concebido e nasce depois de seu pai ter sido removido do senado, opinião dos quais é verdadeira, pois não propriamente se diz filho de senador aquele cujo pai foi removido do senado antes de ele nascer. Na verdade se alguém foi concebido antes que o pai dele fosse removido do senado, mas nascido depois do pai ter perdido a dignidade, é melhor que ele seja considerado como filho de senador. Pois agradou à maioria que o tempo da concepção deveria ser observado".

Era suficiente que o pai fosse senador no momento da concepção, interpretação jurisprudencial benéfica ao aumento demográfico desta classe social e política.

Disto também decorriam os impedimentos matrimoniais relativos à lex Iulia de maritandis ordinibus, ou seja, quem era filho, filha, neto, neta, bisneto e bisneta de senador, não poderia casar-se com as libertas e as feminae probrosae. ${ }^{467}$

nascido é peregrino"; Ulp. 27 ad Sab. D.1,5,18: Imperator Hadrianus Publicio Marcello rescripsit liberam, quae praegnas ultimo supplicio damnata est, liberum parere et solitum esse servari eam, dum partum ederit. Sed si ei, quae ex iustis nuptiis concepit, aqua et igni interdictum est, civem Romanum parit et in potestate patris. "O imperador Adriano determinou em um rescrito a Publício Marcelo que, como livre, a grávida que for condenada ao último suplício dá à luz o filho livre e que é de costume que ela seja conservada até que venha o parto. Mas se deu a ela, que concebeu em justas núpcias, o interdito da água e do fogo, ela dá à luz um cidadão romano e sob a postestas do pai".

${ }^{467}$ R. Astolfi, Femina probrosa cit. (nota 96 supra), p.38, nota 47. Também permanecia como filho de senador, aquele que foi adotado por uma família de dignidade social inferior. Vejam-se Ulp. 1 ad l. Iul. et 
Em relação ao curator ventris, nomeado pelo praetor urbanus no interesse não apenas da família, mas de toda a res publica, deve estabelecer os alimentos (alimenta mulieri statuere debet) a fim de que o nascituro possa nutrir-se e evitar que a mulher sem condições econômicas suficientes, provoque um aborto. A exigência de garantir o sustento ao nascituro e conceder-lhe os alimentos é primordial, pois independe da incerteza sobre a situação jurídica daquele que nascerá (filia, plures filii, filius et filia). ${ }^{468}$

Ulpiano salienta em relação à missio in possessionem dada ao venter, Ulp. 41 ad ed. D.37,9,1,3:

Quare et si ita exheredatio facta sit: 'si mihi filius unus nascetur, exheres esto', quia filia nasci potest, vel plures filii, vel filius et filia, venter in possessionem mittetur; satius est enim sub incerto eius, qui edetur, ali etiam eum qui exheredatus sit, quam eum qui non sit exheredatus fame necari; ratumque esse debet, quod deminutum est, quamvis is nascatur, qui repellitur.

"Pelo qual, também se a deserdação tivesse sido feita assim: 'se me nascer um filho único, seja deserdado', como queria que pudesse nascer uma filha, ou vários filhos, ou um filho e uma filha, será colocado na posse aquele que está no ventre; porque é preferível que na incerteza do que nascerá também seja alimentado aquele que tenha sido deserdado, que não seja morto pela fome o que não tenha sido deserdado; e deve ser válido o que se tenha gasto, ainda que nasça aquele que é repelido".

Em outro trecho do Digesto, Ulp. 41 ad ed. D.37,9,1,5 estabelece o princípio relativo à relevância da alimentação do nascituro apesar de qualquer incerteza:

Sed et si sub conditione postumus sit exheredatus, pendente conditione Pedii sententiam admittimus existimantis, posse ventrem in possessionem mitti, quia sub incerto utilius est, ventrem ali.

"Porém, também se o póstumo fora deserdado sob condição, estando pendente a condição, admitimos a opinião de Pédio que considera que pode ser posto na posse aquele que está no ventre, porque na incerteza é mais conveniente que seja alimentado aquele que está no

Pap. D.1,9,5; Paul. 2 ad l. Iul. et Pap. D.1,9,6pr.;-1.

${ }^{468}$ Veja-se Ulp. 24 ad ed. D.25,4,1,1-15. De acordo com E. CANTARELla, Matrimonio e sessualità cit. (nota 36 supra), p.127, la gravidanza (...) non era una questione solo privata; e non era neppure una questione solo familiare. Era una questione di Stato. 
ventre".

Neste trecho verifica-se a importância da missio in possessionem ventris nomine, conforme estabelecido no Edito do pretor para a defesa da mulher grávida e do nascituro.

Ulpiano determina que o curator ventris deva providenciar os alimentos e as demais necessidades da mãe e do filho e, ao cumprir estas tarefas, deverá considerar as facultate do de cuius e também a dignitas deste e da mulher. ${ }^{469}$

Deve garantir à mulher, portanto, cibum, potum, vestitum, tectum, também com a finalidade de tutelar a sua dignidade. É evidente que o principal escopo da missio in possessionem e da instituição do curador seja o de garantir à mulher não só os alimentos, mas reconhecer a sua dignitas. ${ }^{470}$

Esta dignitas da mulher, que o curator deve tutelar, leva em consideração não apenas aspectos econômicos, mas o interesse do "Estado" romano na procriação de novos cidadãos.

O trecho de Ulp. 41 ad ed. D.37,9,1,19 relativo ao curator ventris que deve prover aos alimentos exige uma leitura paralela com o passo Gai. 14 ad ed. prov. D.37,9,5pr. Segundo Gaio, o curator ventris deve determinar os alimentos para a mulher prescindindo do dote com o qual ela poderia manter-se. O concebido é considerado, pelo menos implicitamente, como persona. ${ }^{471}$

Curator ventris alimenta mulieri statuere debet nec ad rem pertinet, an dotem habeat, unde sustentare se possit, quia videntur, quae ita praestantur, ipsi

\footnotetext{
${ }^{469}$ Ulp. 41 ad ed. D.37,9,1,19: "Mulier in possessionem missa ea sola, sine quibus fetus sustineri et ad partum usque produci non possit, sumere ex bonis debet: et in hanc rem curator constituendus est, qui cibum potum vestitum tectum mulieri praestet pro facultatibus defuncti et pro dignitate eius atque mulieris". "Porém a mulher que foi colocada na posse, deve tomar dos bens somente aqueles sem os quais o feto não poderia manter-se e utilizar até o parto; e para isto se nomeará um curador, que dê à mulher comida, bebida, vestuário e habitação, conforme os bens do morto e à dignidade deste e da mulher".

${ }^{470}$ De acordo com as possibilidades patrimoniais e a posição social do de cuius, os gastos com o nascituro (alimenta ventris) eram considerados como dívida da herança. Vejam-se M.P. BACCARI, Persona e famiglia cit. (nota 16 supra), pp.28-29; F. BETANCOURT, Derecho Romano Clásico cit. (nota 460 supra), pp.412-413; H.M.F. MADEIRA, O Nascituro no Direito Romano cit. (nota 8 supra), p.16; P. CATAlano, El concebido 'sujeto de derecho' cit. (nota 434 supra), p.396; M.H. RochA Pereira, Estudos de História da Cultura Clássica - Cultura Romana, cit. (nota 43 supra), pp.350-352.

${ }^{471}$ M.P. Baccari, Persona e famiglia cit. (nota 16 supra), p.31; P. Catalano, El concebido sujeto de derecho' cit. (nota 434 supra), p.396. Contra esta opinião, veja-se E. NARDI, Aborto e omicidio nella civiltà clássica cit. (nota 241 supra), pp.376-377, afirma que todos os juristas(!) e todos os imperadores, adotam a concepção estoica de que o nascituro não está in rebus humanis e só seria protegido pelo direito se nascesse e nascesse vivo. Reservam-se todos os direitos ao momento do nascimento. Se não nascer vivo (aborto), a esperança (spes) do nascimento não se realiza e extinguem-se todos os direitos, porque a sua utilização é condicionada ao nascimento. Se a mulher abortasse contra a vontade do marido, só lhe restaria o divórcio e reter um sexto do dote para cada aborto, como se o filho tivesse nascido.
} 
praestari, qui in utero est.

"O curador do ventre deve fixar os alimentos para a mulher, e não importa que tenha dote com o qual ela possa sustentar-se, porque se considera que os que neste caso se prestam, prestam-lhe ao mesmo que está no ventre materno".

Sobre a lex Iulia et Papia, é interessante salientar as "controvérsias jurisprudenciais" entre Paulo e Ulpiano em relação ao nascituro e a concessão do ius liberorum aos seus pais. ${ }^{472}$

A primeira questão divergente entre estes juristas foi se o filho póstumo, extraído excectio ventris da mãe mediante parto cesáreo (Caesarea sectio), poderia ser contado entre os filhos para que a mãe adquirisse a capacitas sucessória. ${ }^{473}$

Na opinião de Ulpiano, o filho deveria ser considerado. Paulo, neste caso, defende que a mulher morta da qual se extraiu um filho em parto cesáreo, não deu à luz.

Ulp. 8 ad l. Iul. et Pap. D.50,16,141: Etiam ea mulier cum moreretur creditur filium habere, quae exciso utero edere possit. Nec non etiam alio casu mulier potest habere filium quem mortis tempore non habuit, ut puta eum qui ab hostibus remeabit.

"Acredita-se que tem um filho inclusive a mulher que, ao morrer, pôde dar a luz abrindolhe o útero. E também em outro caso, uma mulher pode ter um filho que não teve no momento da morte, como o filho que regressa do inimigo [do cativeiro]".

Paul. 3 ad l. Iul. et Pap. D.50,16,132,1: Falsum est eam peperisse, cui mortuae filius exsectus est.

“É falso que tenha dado à luz aquela [mulher] à qual, já morta, tenha-se extraído o filho".

Para a lex Iulia et Papia e seu escopo demográfico, é provável que tenha vigorado a

\footnotetext{
${ }^{472}$ Salienta G. IMPALLOMENI, In tema di vitalità e forma umana cit. (nota 143 supra), p.282, que é possível identificar nestes textos de Ulpiano e Paulo uma preocupação da jurisprudência romana, desde o período clássico, na busca por uma interpretação mais benévola em relação ao nascituro, aos ostenta, monstra, prodigia, portenta e àqueles que nasceram.

${ }^{473} \mathrm{G}$. IMPALLOMENI, In tema di vitalità e forma umana cit. (nota 143 supra), p.284.
} 
interpretação benigna de Ulpiano que equiparava os filhos nonatos (aqueles que nasceram de parto cesáreo) aos neonatos. ${ }^{474}$

Para este jurista, qualquer nascimento é vantajoso para a mãe obter o ius liberorum:

Ulp. 4 ad l. Iul. et Pap. D.50,16,135: Quaeret aliquis, si portentosum vel monstruosum vel debilem mulier ediderit vel qualem visu vel vagitu novum, non humanae figurae, sed alterius, magis animalis quam hominis, partum, an, quia enixa est, prodesse ei debeat? Et magis est, ut haec quoque parentibus prosint: nec enim est quod eis imputetur, quae qualiter potuerunt, statutis obtemperaverunt, neque id quod fataliter accessit, matri damnum iniunge redebet.

“Alguém perguntará: se uma mulher der à luz um portentoso ou monstruoso ou débil, ou algum parto tal de aparência e vagido novo, de figura não humana, mais de animal do que de homem, acaso, porque deu à luz, deva favorecer-se a ela? E é mais [correto] que também estes [filhos] favorecem aos pais: e não há, pois, o que seja imputado a eles, os quais obedeceram aos estatutos [às coisas estabelecidas] como puderam e aquilo que fatalmente ocorreu não deve infligir um dano à mãe".

Neste trecho, Ulpiano ao referir-se aos statuta, refere-se ao sistema normativo do ius liberorum estabelecido pelas leis matrimoniais de Augusto. ${ }^{475}$

${ }^{474}$ H.M.F. MAdeIRA, O Nascituro no Direito Romano cit. (nota 8 supra), p.15, nota 12. Vejam-se Ulp. 9 ad Sab. D.28,2,12: (...) natum accipe et si exsecto ventre editus sit; Cels. 16 dig. D.50,17,187: Si quis praegnantem uxorem reliquit, non videtur sine liberis decessisse. "Se alguém deixa a esposa em gestação, não se considera que tivesse morrido sem filhos". De acordo com Marcell. 28 dig. D.11,8,2, proibia-se, desde a época da Realeza (leges regiae) o enterro da mulher grávida para que não morresse a spem animantis que trazia no ventre. Negat lex regia mulierem, quae praegnas mortua sit, humari, antequam partus ei excidatur: qui contra fecerit, spem animantis cum gravida peremisse videtur. "Uma lei régia proíbe que a mulher que tenha morrido grávida, possa ser enterrada antes que se retire-lhe o parto: aquele que fizer o contrário, considera-se que matou uma esperança de vida junto com a mulher grávida".

${ }^{475}$ Para D. DALlA, D. 50,16,135: Sui perché di uma 'Lex Specialis'cit. (nota 125 supra), p.348, seria possível a aplicação da regra benévola de D.50,16,135 em relação ao ostentum, não apenas em relação à exoneração da tutela das mulheres mas também para outros privilégios do ius liberorum, v.g., a dispensa do liberto da prestação das operae: Paul. 2 ad l. Iul. et Pap. D.38,1,27,1; -2. Também era considerado como filho aquele que nasceu no sétimo mês da gestação. Paul. 19 resp. D.1,5,12: Septimo mense nasci perfectum partum iam receptum est propter auctoritatem doctissimi viri Hippocratis: et ideo credendum est eum, qui ex iustis nuptiis septimo mense natus est, iustum filium esse. "Já se entende nascer perfeito o parto no sétimo mês, segundo a autoridade do doutíssimo varão Hipócrates: e por isso se deve crer que aquele que nasceu no sétimo mês de justas núpcias é um filho legítimo"; Ulp. 14 ad Sab. D.38,16,3,12: De eo autem, qui centesimo octogesimo secundo die natus est. Hippocrates scripsit, et Divus Pius pontificibus rescripsit, iusto tempore videri natum (...). "No entanto, em relação ao que nasceu aos cento e oitenta e dois dias, escreveu Hipócrates e respondeu por rescrito o Divino Pio, que considera-se que nasceu em tempo legítimo (...)". Veja-se também PS 4,9,5-6: 5. Septimo mense natus matri prodest: ratio enim Pythagoraei numeri hoc videtur admittere, ut aut septimo pleno aut decimo mense partus maturior videatur. 6. Aborsus et abactus venter partum efficere 
O debilis, o monstrum e o portentosus são contados para os efeitos do ius liberorum pelo fato de terem sido gerados, pois neste caso foi considerada uma interpretação favorável à mãe (quia enixa est). ${ }^{476}$

Divergente foi o entendimento de Paulo ao comentar o Senatusconsulto Tertuliano. Nos trechos das Sententiae, o jurisconsulto examinou a questão de um filho, vivo no momento do parto e que tenha morrido logo depois, deveria ser considerado vital ou aborto. $\mathrm{Na}$ interpretação deste jurisconsulto, não há o reconhecimento do monstrum ou prodigium como filho para o cômputo do ius liberorum:

PS 4,9,3: Mulier si monstruosum aliquid prodigiosum enixa sit, nihil proficit: non sunt enim liberi, qui contra formam humani generis converso more procreantur.

"Se a mulher tivesse dado à luz algo monstruoso ou prodigioso, de nada lhe aproveita [não se acrescenta ao número dos filhos]: de fato, não são filhos os que contra a forma do gênero humano são procriados por um costume diverso";

non videtur. "5. O [filho] nascido no sétimo mês é proveitoso à mãe: na verdade, o número de Pitágoras parece admitir que, ou ao sétimo mês, ou ao décimo, o parto encontra-se plenamente desenvolvido. 6 . $\mathrm{O}$ [filho] morto e o aborto não se consideram parto [nascidos]".

Na opinião de G. IMPALLOMENI, In tema di vitalità e forma umana cit. (nota 143 supra), p.274, nota 78 e J.C. Moreira Alves, Direito Romano cit. (nota 9 supra), pp.100-102, a solução dada por Paulo à questão foi deduzida da doutrina médica da Escola Pitagórica. Segundo os pitagóricos, a gravidez é suficiente para a sobrevivência do feto, quando ultrapassa o sétimo mês e tenha a duração máxima de dez meses. Se o nascido alcançou os sete meses de gestação, era contado para a concessão do ius liberorum aos pais; se não alcançou, era considerado aborto e não era contado.

De acordo com G. IMPALLOMENI, op.cit., pp.272-273;275-276, segundo o pensamento dos antigos e em particular de Hipócrates e do médico Sabino que fez comentários às suas obras, era possível à mulher dar à luz, com possibilidade de vida extra-uterina para o nascido, no sétimo, nono e décimo mês. O nascido no oitavo mês era considerado não-vital e destinado à morte. Era considerado aborto o feto nascido antes do sétimo mês de gestação. IMPALLOMENI acredita que, para os romanos dos primórdios da cidade, de acordo com a narrativa de Aulo Gélio (Gell. 3,16,1;7;21), o parto no oitavo mês era considerado contra naturam, incapaz de viver. Porém, Plínio combateu esta idéia, afirmando que muitos partos de crianças no Egito tiveram êxito com oito meses de gestação e que na Itália, contra a opinião dos antigos, considerava-se "vital" a criança nascida com oito meses. Plin. Nat. Hist. 7,38-39: Ceteris animantibus statum et pariendi et partus gerendi tempus est; homo toto anno et incerto gignitur spatio, alius septimo mense, alius octavo et usque ad initia undecimi. Ante septimum mensem haut umquam vitalis est. Septimo non nisi pridie posteriore pleniluni die interlunio concepti nascuntur. Tralaticium in Aegypto est et octavo gigni, iam quidem et in Italia tales partus esse vitales, contra priscorum opiniones (...) "Os demais seres vivos têm um tempo determinado para a gestação e para o parto; o homem nasce durante todo o ano e com um tempo de gestação incerto; um no sétimo mês, outro no oitavo; inclusive, até no início do décimo primeiro. Antes do sétimo mês, nunca é viável. No sétimo mês tampouco nascem, a não ser que tenham sido concebidos na véspera ou no dia seguinte do plenilúnio, ou no interlúnio. Segundo a tradição, no Egito se nasce no oitavo mês e, certamente tais partos são viáveis inclusive na Itália, contra a opinião dos antigos". Veja-se Gell. 3,16,9.

${ }^{476} \mathrm{G}$. IMPALLOMENI, In tema di vitalità e forma umana cit. (nota 143 supra), pp.277-278. 
PS 4,9,4: Partum, qui membrorum humanorum officia duplicavit, quia hoc ratione aliquatenus videtur effectum, matri prodresse placuit.

"O parto, no entanto, que aumentou as funções dos membros humanos, visto que até certo ponto se considera gerado, considerou-se ser útil à mãe”.

Nesta última hipótese de PS 4,9,4, encontravam-se o hermafrodita e também aquele que tivesse multiplicidade de um determinado órgão do corpo que ultrapassasse a sua quantidade normal, v.g., três braços, sete dedos (membrorum humanorum officia duplicavit; ampliatio membrorum). ${ }^{477}$

Paulo, portanto, separou esta questão da concessão do ius liberorum em dois problemas que deveriam ser analisados separadamente: a "forma humana" dos filhos nascidos e as vantagens para a mãe em relação à quantidade dos filhos.

Isto pode ser verificado em outro comentário de Paulo ao Senatusconsulto Tertuliano, para decidir o caso de direitos sucessórios de uma mulher grávida que perdeu o marido e que deu à luz a um natimorto. Paulo determina que as vantagens para a mãe em razão do ius liberorum apenas se verificariam no momento em que o filho nascesse com vida.

Neste caso a mãe não poderia ser chamada à sucessão em razão do ius liberorum e o princípio que beneficiava o nascituro (nasciturus pro iam nato habetur) não favorecia a mãe, visto que o nascituro não pode ser contado entre os filhos para a obtenção deste privilégio. $^{478}$

\footnotetext{
${ }^{477}$ Quanto à definição romana de ostentum, elaborada pelo jurista Labeão, vide Ulp. 25 ad ed. D.50,16,38: 'Ostentum' Labeo definit omne contra naturam cuiusque rei genitum factumque. Duo genera autem sunt ostentorum: unum, quotiens quid contra naturam nascitur, tribus manibus forte aut pedibus aut qua alia parte corporis, quae naturae contraria est: alterum, cum quid prodigiosum videtur, quae Graeci $\varphi \alpha v \tau \alpha ́ \sigma \mu \alpha \tau \alpha$ [fantásmata] vocant. "Labeão define como 'ostentoso' [portentoso, maravilhoso, ostentoso] tudo que feito e gerado de qualquer coisa contra a natureza. São dois os gêneros dos ostentosos: um, toda vez que nasce algo contra a natureza, como quando por acaso nasce com três mãos ou pés ou alguma outra parte do corpo que é

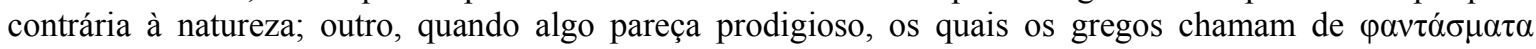
[fantasmas]".

${ }^{478}$ Conclui G. IMPALlOMENI, In tema di vitalità e forma umana cit. (nota 143 supra), p.281, que estes textos paulinos consideraram apenas a vitalidade do recém-nascido para que os pais adquirissem o ius liberorum. De acordo com J.C. MoReIRA ALVES, Direito Romano cit. (nota 9 supra), pp.100-102, no direito romano, o partus maturus ou perfectus para alguns romanistas, deveria ter a chamada "vitalidade própria", ou seja, a aptidão do recém-nascido para a vida. Conclui MOREIRA ALVES que: "Ao nosso ver (...) a vitalidade não era requisito para a existência do ser humano, mas requerida, às vezes, para que a mãe, em virtude do nascimento do filho, adquirisse certos direitos. Assim, por exemplo, o senatusconsulto Tertuliano exigia, para que a mãe herdasse dos filhos, que ela tivesse o ius liberorum, para cuja aquisição era necessário, entre outras condições, ter dado à luz, no mínimo, três ou quatro crianças (...) que fossem vitais. A exigência da vitalidade no caso, se explica, porque esse senatusconsulto estabeleceu o ius liberorum a fim de incentivar as mulheres romanas a darem mais filhos à pátria para que, com o aumento da natalidade, crescesse o poderio romano. $\mathrm{E}$
} 
Paul. l.s.ad Sc. Tert. D.50,16,231: Quod dicimus, eum, qui nasci speratur, pro superstite esse, tunc verum est, quum de ipsius iure quaeritur; aliis autem non prodest, nisi natus.

“O que dizemos é que aquele que é esperado nascer é tomado por nascido; isto é verdade naqueles momentos em que se pergunta sobre o seu próprio direito; a outros, porém não favorece, senão quando nascido".

Quanto àqueles que contra formam humani generis converso more procreantur (contra a forma do gênero humano são procriados), o direito justinianeu adotou a solução de Paulo, segundo Paul. 4 sent. D.1,5,14 e Iust. C.6,29,3pr. (530). Os compiladores suprimiram $^{479}$ as referências ao ius liberorum e a situação de vantagem da mãe. ${ }^{480}$

\subsubsection{O LEGADO DAS LEIS MATRIMONIAIS DE AUGUSTO}

Em relação aos resultados efetivos e a duração da aplicação das Leis Matrimoniais no Império, de acordo com os critérios temporal e espacial, diversas e contraditórias são as opiniões da doutrina moderna.

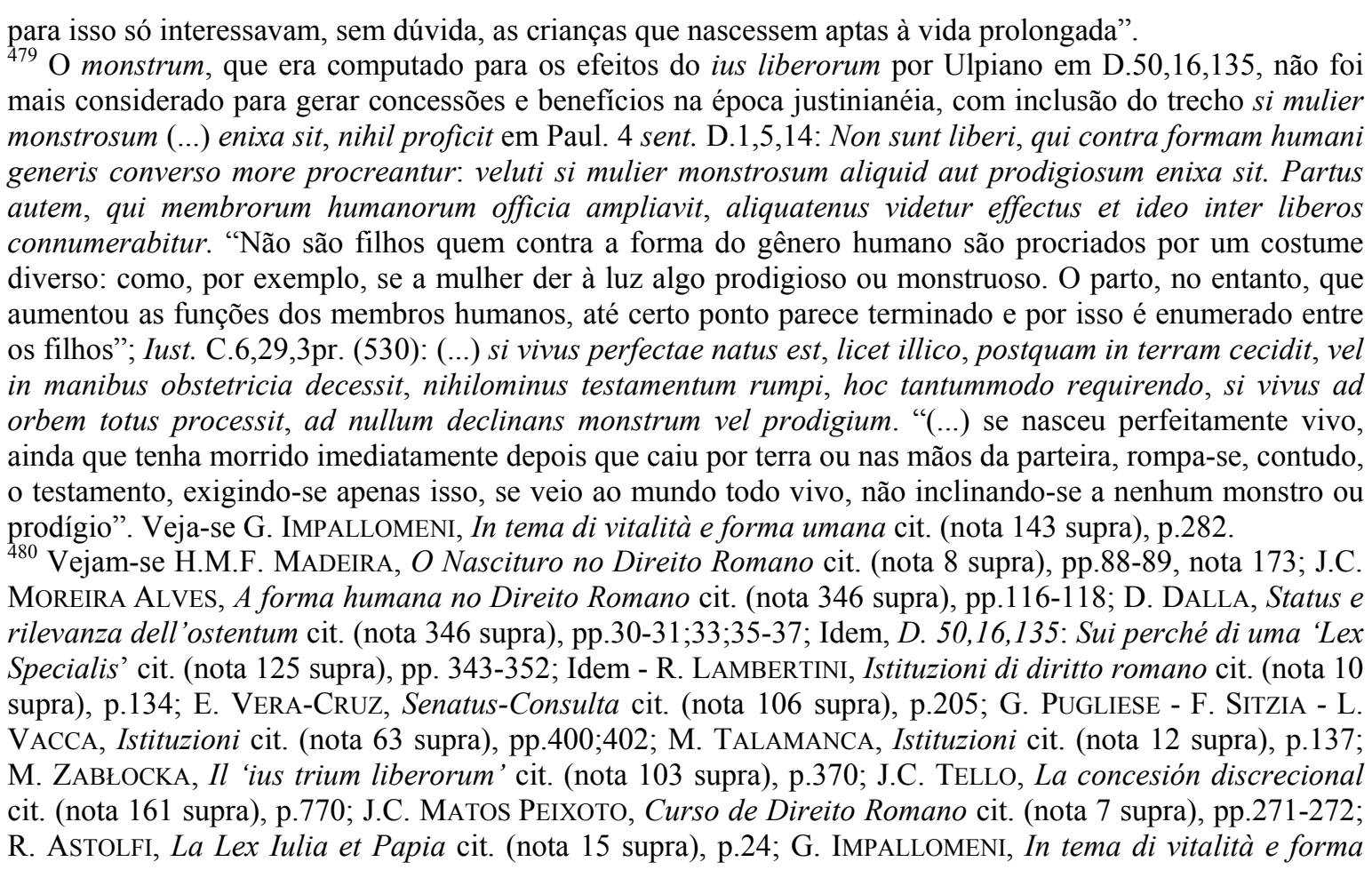


Uma certa repulsa social ocorreu, pois as Leis Matrimonias de Augusto interferiram amplamente nas relações familiares, relações em que os romanos dispunham de certa liberdade e que eram reguladas em grande parte pelos mores maiorum, como aquelas entre pais e filhos, patronos e libertos, testadores e herdeiros. ${ }^{481}$

Segundo J. Ellul, a legislação matrimonial era incompatível com os costumes do século I a.C. (que por sua vez, eram contrários aos costumes mais antigos da cidade) e foi hostilizada por parte do Senado, rejeitada pela classe equestre e ironizada por grande parte dos cidadãos. Porém, de acordo com o autor, não deve ser considerada uma total ineficácia. Se estas leis tivessem sido mantidas e respeitadas pelos imperadores posteriores, o trabalho de correção dos costumes, a solução da crise demográfica e a moralização, iniciados por Augusto, poderiam ser mais duradouros. ${ }^{482}$

Para F. Della CORTE ${ }^{483}$, cem anos após a promulgação das Leis Matrimoniais, muito pouco de seu conteúdo permaneceu em vigor, pois a reação social, testemunhada pelos elegíacos (principalmente Ovídio, Propércio e Tibulo), foi extremamente negativa

umana cit. (nota 143 supra), p.282.

${ }^{481}$ L.F. RADITSA, Augustus Legislation Concerning Marriage cit. (nota 59 supra), p. 284.

482 J. Ellul, Histoire des Institutiones cit. (nota 353 supra), pp.299-300. Veja-se também, com opinião semelhante, de que a legislação matrimonial ao estabelecer algumas disposições fundamentadas nos valores tradicionais entrou em conflito com outros costumes, D. NöRR, The Matrimonial Legislation of Augustus cit. (nota 54 supra), pp.355;361-363. Para este autor, na p.354, não há provas suficientes nas fontes literárias e jurídicas de que a legislação matrimonial motivou a população, principalmente na península itálica e nas províncias, a procriar um grande número de filhos. Também faltam informações quanto à difusão e aplicação do ius trium liberorum nas classes senatorial e equestre. Na p.361, NöRR conclui que a legislação não foi um instrumento apropriado para o desenvolvimento das reformas sociais que Augusto planejou alcançar, apesar de seu fundamento nos mores maiorum, na utilitas publica e no bem comum. Na opinião de C. ORTíN GARCÍA, Edad, Matrimonio cit. (nota 103 supra), p.518, as leis matrimoniais (...) no sólo por las progresivas reformas que a partir de Tiberio implican las decisiones senatoriales, sino porque eran contrarias al sentir social y ello provoco, evitar su uso, cayendo en el olvido. Para, A. LÓPEZ PEDREIRA, Limitaciones a la 'libertas nuptialis' cit. (nota 40 supra), pp.398 e 404, a política matrimonial de Augusto não foi bem aceita por uma grande parte da sociedade romana e gerou resultados adversos em relação ao seu escopo inicial. Tudo isto, devido à imposição do matrimônio e da procriação, com a interferência na esfera familiar e na vida particular dos romanos, visto que estes não admitiam qualquer ato contrário à libertas nuptialis. Conclui a autora que (...) toda la legislación de Augusto vendría necesariamente a alterar el régimen familiar y sucesorio de los ciudadanos romanos pero los objetivos inicialmente propuestos como eran el incremento de la población de las clases altas, y el refuerzo de los valores de la sociedad romana parece que ni uno ni outro se conseguirían (...) sin contribuir en nada a lograr la estabilidad familiar. Tradução: “(...) toda a legislação de Augusto viria necessariamente alterar o regime familiar e sucessório dos cidadãos romanos, porém, os objetivos propostos inicialmente, como eram o aumento da população das classes altas e o fortalecimento dos valores da sociedade romana, parece que não se conseguiriam nem um nem outro (...) sem contribuir em nada para conseguir a estabilidade familiar". Para J. GAUDEMET, Droit privé romain cit. (nota 65 supra), p.51, no final do século II d.C., pela excessiva rigidez e pela resistência do povo em aceitá-la, esta legislação matrimonial caiu em desuso. Quanto à Lex Iulia de adulteriis, J. CARCOPINO, La vie quotidienne à Rome cit. (nota 72 supra), pp.122-123, afirma que no fim do século I d.C. ela já tinha sido esquecida, após uma tentativa frustrada de Domiciano renovar as suas disposições. Na opinião "exagerada" de J. CARCOPINO, op.cit., p.126, a legislação de Augusto, apesar de sua importância em relação à política demográfica e do ponto de vista social, causou "a ruína do espírito de família entre os Romanos", pois fez com que os cônjuges procurassem apenas obter "um bom dote".

${ }^{483}$ Le 'leges Iuliae' e l'elegia romana cit. (nota 47 supra), pp. 547-549;557. 
em razão da severidade da legislação e do imperador, na tentativa de resgastar os mores maiorum, descaracteriza o modo de vida dos Romanos daquele período.

Também reforça o caráter repressor das leis matrimoniais e a sua intrusão excessiva na vida privada dos cidadãos romanos, L.F. RADITSA. ${ }^{484} \mathrm{O}$ autor afirma que the destruction of the Republic meant the destruction of the public sphere, ou seja, desaparece a distinção entre o âmbito público e privado, em função da concentração de poderes do princeps. Símbolo desta situação hipócrita da sociedade da época seriam as espionagens e intromissões dos delatores na vida privada dos cidadãos, "em nome da reforma dos mores maiorum, da retidão e da justiça”. A legislação não priorizou a utilitas publica, o bem comum, mas alternou normas equitativas e igualitárias com outras totalmente arbitrárias, que privilegiavam com prêmios e vantagens jurídicas apenas as classes senatorial e equestre. Além disso, com a divisão social que realizou, discriminou as feminae probrosae e incentivou o preconceito. Por imposição do "Estado", a liberdade sexual e amorosa dos romanos foi distorcida e a concepção de matrimônio tornou-se materialista, um mero ato mecânico para a procriação de filhos.

Para U. VINCENTI ${ }^{485}$, as leis matrimoniais foram de difícil aplicação prática, pois afirma que "atendo-se às fontes que dispomos, o programa augusteu de restauração do costume sexual e familiar tornou-se veleidoso".

$\mathrm{Na}$ opinião de J. GAUDEMET ${ }^{486}$, a legislação matrimonial, promulgada principalmente para restabelecer os valores éticos e os bons costumes das classes altas, não teve muita eficácia prática e no final do século II d.C., pela excessiva rigidez e pela resistência do povo, não parece ter sido bem aceita pela opinião pública.

Segundo V. ARANGIO-RUIZ ${ }^{487}$ não é possível determinar com certeza, em relação à queda demográfica, se o escopo da legislação foi atingido.

F. SCHULZ ${ }^{488}$ afirma que, apesar do grande esforço dos jurisconsultos na aplicação de seus dispositivos, a legislação matrimonial tornou-se ineficaz. ${ }^{489}$

\footnotetext{
${ }^{484}$ Augustus Legislation cit. (nota 49 supra), pp.329-338.

${ }^{485}$ Categorie del diritto romano cit. (nota 162 supra), p.31: A stare alle testemonianze di cui disponiamo, il programa augusteo di restaurazione del costume sessuale e familiare risultò velleitario.

${ }^{486}$ Droit privé romain cit. (nota 65 supra), p.51; Idem, Justum matrimonium cit. (nota 51 supra), pp.124;130. $\mathrm{O}$ autor fundamenta sua opinião em duas fontes principais: Tac. Ann. 3,25;3,28,4-6 e Tert. Apol. 4,8.

${ }^{487}$ Istituzioni di diritto romano cit. (nota 58 supra), p.443.

${ }^{488}$ Porém o autor não entra na questão temporal, ou seja, em qual período histórico ocorreu tal "ineficácia" da Lei. Veja-se Classical Roman Law cit. (nota 51 supra), p.103.

489 Sobre esta ineficácia, para L.F. RADITSA, Augustus Legislation cit. (nota 49 supra), p.305, as leis matrimoniais, pela sua "ferocidade" (ferocity) tiveram um efeito social contrário e aumentaram a degradação dos costumes que elas desejavam extinguir. Também com a mesma opinião, D. NöRR, The matrimonial Legislation of Augustus, cit. (nota 54 supra), pp.357-359; G.F. PUCHTA, Kursus der Institutionem, Leipzig, trad. it. A. Tenchiarulo, vol.1, Napoli, Diogene, 1854, pp.161-162. A intervenção excessiva na área social e
} 
Para A. BouCHÉ-LECLERCQ ${ }^{490}$, houve um crescimento na população das classes senatorial e equestre nos dois primeiros séculos da era cristã, porém não devido à procriação ou ao aumento no número de filhos nas famílias da "estirpe" itálica, mas pelo afluxo constante de nobres provenientes de outras regiões do Império. O autor defende que o principal escopo da legislação matrimonial não foi alcançado: aumentar o número de cidadãos com "sangue romano" formadores da aristocracia.

E. RUIZ FERNÁNDEZ opina que "as leis matrimoniais de Augusto não alcançaram o objetivo proposto e as frequentes sátiras dos escritores da época demonstram a notável divergência que se deu entre o legislado e a realidade da vida romana”. E o autor acredita que a aplicação das leis matrimoniais na sociedade romana fracassou porque Augusto não combateu as causas ou motivos que levavam os homens à degradação dos costumes, mas restringiu-se apenas em estabelecer formalidades a serem obedecidas: "Augusto estabeleceu as formalidades que deviam observar-se para obter o divórcio, porém não se atraveu a indicar as causas ou motivos pelos quais se daria o divórcio". 491

G.F. MARGADANT ${ }^{492}$ qualifica as leis matrimoniais como "imorais", pois tiveram um efeito social contrário e não teriam incentivado o matrimônio legítimo, pois ocorreu, na prática, um aumento nas demais relações de fato, como o concubinato.

J.A.FIELD JR. ${ }^{493}$ salienta que, quanto ao seu escopo principal, a legislação de

na observância ética, principalmente pela ação dos delatores, causou inúmeras dificuldades na realização das reformas propostas pela legislação matrimonial e em sua aplicação prática.

${ }^{490}$ Les lois démographiques d'Auguste cit. (nota 36 supra), pp.282-283. E, ao comparar a legislação de Augusto com a sociedade francesa do século XIX, conclui, na p.90, à comparer, dis-je, des temps et des esprits si divers, on trouverait probablement que pas un des remèdes imagines par Auguste n'aurait chance d'être efficace aujourd'hui.

${ }^{491}$ El divorcio en Roma cit. (nota 234 supra), pp.46 e 48: “(...) las leyes matrimoniales de Augusto no alcanzaron el objetivo propuesto y las frecuentes sátiras de los escritores de la época muestran la notable divergencia que se dio entre lo legislado y la realidad de la vida romana"; "Augusto fijó las formalidades que debian observarse para obtener el divorcio, pero no se atrevió a señalar las causas o motivos por los que se concedería el divorcio". Também conclui que as leis matrimoniais de Augusto tiveram um fracasso total em relação ao aumento da população, M.I. NÚÑEZ PAZ, Consentimiento Matrimonial y Divorcio en Roma, Salamanca, Universidad de Salamanca, 1988, pp.100-101.

${ }^{492}$ El Derecho Privado Romano cit. (nota 331 supra), p.213: La disolución de matrimonios estériles, aunque basados en un razonable grado de amor conyugal, y, por otra parte, matrimonios fingidos, paternidades simuladas, etc., fueron el ineludible fruto de esta legislación inmoral.

${ }^{493}$ The purpose cit. (nota 129 supra), p.414. O autor afirma na p.415, que o erro principal da legislação de Augusto foi colocar a falta de filhos como um fenômeno legislável: the central error made by Augustus in framing the laws was his assumption that childlessness is a legislatable phenomenon (...). Sobre esta severidade das normas restritivas dos direitos sucessórios dos caelibes e dos orbi, D. NÖRR, The matrimonial Legislation of Augustus, cit. (nota 54 supra), p.358, afirma que a legislação matrimonial estabeleceu um verdadeiro "código de conduta". Segue esta opinião do caráter oligárquico e eugênico das Leis Matrimoniais, E. MALdonado De LizALDE, Lex Iulia de Maritandis Ordinibus cit. (nota 122 supra), pp.557-559. Conclui a autora, que as Leis matrimoniais tiveram como escopo principal apenas aumentar e fortalecer as classes senatorial e equestre e não toda a população romana. Apesar dos incentivos legais, a taxa de natalidade decaiu. Além disso, o número de caelebs e orbi e as relações de concubinato aumentaram com a promulgação da lei. 
Augusto foi mais eugênica, beneficiando apenas as classes senatorial e equestre, que demográfica. Para o autor, a banalização do ius trium liberorum, concedido por alguns imperadores até para homens solteiros e a severidade das disposições sobre a capacitas sucessória, interferindo na liberdade testamentária, foram alguns indicadores do fracasso desta legislação.

Apesar dos atos reformadores dos costumes e da moralidade romana, D. NÖRR acredita que a vida privada do princeps não condizia com a sua legislação éticomatrimonial e que ele teria sido um curator dos costumes alheios, tendo, o próprio Augusto, comportamentos adúlteros. ${ }^{494} \mathrm{Na}$ própria família, Augusto aplicou rigorosamente a legislação matrimonial (lex Iulia de adulteriis) a sua filha ${ }^{495}$ e a sua neta, relegando-as às ilhas de Pandatária e Trimerus, e proibiu que fossem enterradas em seu Mausoléu. ${ }^{496}$

494 D. NÖRR, The matrimonial Legislation of Augustus cit. (nota 54 supra), p.357. Na opinião de T. Spagnuolo Vigorita, Casta Domus cit. (nota 26 supra), pp.47-52;141, nota 181, Tácito não defende que houve, no caso das duas Júlias, qualquer vínculo entre os crimes sexuais e alguma trama política contra Augusto. Veja-se Tac. Ann. 3,24,2: Casum eius paucis repetam. Ut valida divo Augusto in rem publicam fortuna, ita domi improspera fuit ob impudicitiam filiae ac neptis, quas urbe depulit adulterosque earum morte aut fuga punivit. Nam culpam inter viros ac feminas vulgatam gravi nomine laesarum religionum ac violatae maiestatis appellando clementiam maiorum suasque ipse leges egrediebatur. "Eu relembrarei o seu caso em poucas palavras. Como lhe foi próspero para a res publica, assim ao divino Augusto o destino foi infeliz no interior da sua casa pela impudicícia de sua filha e de sua neta, as quais ele expulsou da cidade, enquanto puniu com a morte ou com o exílio aqueles com os quais elas cometeram adultério. De fato, atribuindo a uma culpa tão comum entre homens e mulheres a grave denominação de religião ultrajada e majestade violada, ele excedia a clemência dos antigos e das suas próprias leis". Em oposição à opinião de NÖRR, alguns relatos de Ovídio, em Trist. 2,233 e Met. 15,833-835, confirmam o comportamento exemplar de Augusto e revelam que sua vida particular foi condizente com as reformas políticas e jurídicas que realizou. E que ele desejava que o comportamento dos súditos fosse semelhante ao seu em relação à legislação matrimonial. Veja-se Ovid. Met. 15,833-835: Pace data terris animum ad civilia vertet / iura suum legesque feret iustissimus autor / exemploque suo mores reget futuri (...) "Pacificada a terra, voltará o seu pensamento às questões civis: como justíssimo inspirador proporá leis e com o seu exemplo regerá os costumes (...)". B. BIONDI, La legislazione di Augusto cit. (nota 56 supra), pp.158-159, nota 1 defende que as relações adúlteras de Augusto ocorreram em sua juventude, na época do triunvirato, portanto antes de 27 a.C. Vejam-se Suet. Augustus 68-69; Tac. Ann. 3,34; Suet. Augustus 101; Dio Cass. 50,32.

${ }^{495}$ Júlia, filha única de Augusto, casou-se em 25 a.C. com Marco Cláudio Marcelo, que faleceu logo depois, em 23 a.C. Em seguida, casou-se com M. Vispanius Agrippa, com o qual teve cinco filhos. Após a morte de Agrippa em março de 12 a.C., Augusto força Tibério a romper o seu feliz casamento com Vipsania Agrippina e a desposar Júlia. Tibério separou-se de Júlia em 6 a.C. e partiu, por sua própria vontade, para um exílio na Ilha de Rhodes. Muitos autores narram que Júlia teve uma vida licenciosa, com inúmeras aventuras amorosas. Participava de orgias noturnas com vários amantes, dentre os quais destaca-se Iullo Antônio, pretor em 13 a.C., cônsul em 10 a.C. e Procônsul da Ásia em 7-6 a.C. Os amantes de Júlia foram julgados pelo Senado e receberam penas diferenciadas: para alguns, de acordo com a Lex Iulia de adulteriis, foi aplicada a relegatio; outros, como Iullo Antônio, foram condenados à morte. Júlia foi relegada para a ilha Pandatária, acompanhada de sua mãe Escribônia e posteriormente transferida, em 3 ou 4 d.C., para Reggio Calabria, onde morreu em 14 d.C. Vejam-se Suet. Augustus 65,1-10; Tiberius 11,7; Tac. Ann. 1,53,1-3; Velleius 2,100,3-5. Plínio, o Velho, Dio Cassio e Sêneca associam os amantes de Júlia a uma trama política contra Augusto e afirmam que Iullo Antônio tinha objetivos monárquicos. Vejam-se Sen. De benef. 6,32,1-2; Sen. De brev. vitae 4,6; Dio Cass. 55,10,12;15; 56,32,4; Plin. Nat. Hist. 7,95,149. Veja-se também M. ZABŁOCKA, Le modifiche cit. (nota 103 supra), pp.398-399.

${ }^{496}$ A neta de Augusto, Júlia Menor, nascida em 19-18 a.C., era filha de Júlia e Agrippa. Casou-se com seu primo, Lúcio Emílio Paulo em 5-4 d.C. Em 8 d.C., Júlia Menor foi condenada por adultério e relegada à ilha de Trimerus, onde morreu em 28 d.C., sustentada economicamente por Lívia, esposa de Augusto. Seu amante, Décimo Júnio Silano, teve sua amizade com Augusto revogada publicamente (renuntiatio amicitiae) 
De acordo com P. GIUNTI ${ }^{497}$, as medidas destinadas a retomar os costumes dos primórdios da cidade e o incentivo à procriação, agravados principalmente pela grande quantidade de guerras, foram de pouca eficácia: o discurso de Quinto Metello Macedônico, adotado posteriormente por Augusto, teria ficado apenas sobre o plano de uma "retóricapropagandística".

Contrários a estas opiniões, muitos autores consideram uma eficácia maior da legislação matrimonial na sociedade romana, não só no início do Principado, mas com grande influência nos períodos posteriores.

S. RICCOBONO ${ }^{498}$ defendeu o êxito e a importância das reformas sócio-políticas de Augusto, dentre elas, as leis matrimoniais, adjetivando-as como "construtivas" e "brilhantes". Complementa o autor que os efeitos e resultados positivos das leis demográficas são demonstrados pela grande quantidade de monumentos, obras de arte e de poesia dedicados a Augusto na época de sua promulgação.

M. ZABŁOCKA ${ }^{499}$, ao fundamentar sua opinião no trecho das Res Gestae 2,8,1-4 ${ }^{500}$, defende que a legislação matrimonial alcançou seu escopo principal: o de aumentar a procriação e elevar rapidamente o número de cidadãos romanos. $\mathrm{O}$ censo realizado em 28

em 8 d.C. Silano interpretou este gesto do princeps como um convite ao exílio. Voltou posteriormente à Roma, por uma permissão de Tibério, que aceitou o pedido de seu irmão, Marco Júnio Silano, cônsul suffecto desde 15 d.C. Vejam-se Tac. Ann. 3,24,3-4; 4,71,4; Suet. Augustus 65,2;8. Veja-se T. SpagnuOlo Vigorita, Casta Domus cit. (nota 26 supra), pp.53-54.

${ }_{497}$ Consors vitae cit. (nota 26 supra), pp.445-446.

${ }^{498}$ S. RicCOBONO, La politica demografica cit. (nota 103 supra), pp.578-579.

${ }^{499}$ Il 'ius trium liberorum' cit. (nota 103 supra), p.381. M. ZABŁOCKA, Le modifiche cit. (nota 103 supra), pp.398-399 afirma que, em relação à reforma dos costumes, Augusto foi incoerente e a legislação não teve êxito, principalmente em relação às classes senatorial e equestre.

${ }^{500}$ Patriciorum numerum auxi consul quintum iussu populi et senatus. Senatum ter legi. Et in consulatu sexto censum populi conlega M.Agrippa egi. Lustrum post annum alterum et quadragensimum feci. Quo lustro civium Romanorum censa sunt capita quadragiens centum millia et sexaginta tria millia. Tum iterum consulari cum imperio lustrum solus feci $C$. Censorino et C. Asinio cos. Quo lustro censa sunt civium Romanorum capita quadragiens centum millia et ducenta triginta tria millia. Et tertium consulari cum imperio lustrum conlega Tib. Caesare filio meo feci, Sex. Pompeio et Sex. Appuleio cos. Quo lustro censa sunt civium Romanorum capitum quadragiens centum millia et nongenta triginta et septem millia. "Em meu quinto consulado, aumentei o número de patrícios, com a autorização do povo e do Senado. Por três vezes fiz a lista do Senado e em meu sexto consulado, sendo meu colega Marco Agripa, fiz o lustrum do povo. Após quarenta e um anos, celebrei o lustro, no qual foram contados quatro milhões, sessenta e três mil cidadãos romanos. Depois, sendo cônsules Caio Censorino e Caio Asinio, celebrei de novo o lustrum, sozinho, com o poder consular e nele foram contados quatro milhões duzentos e trinta e três mil cidadãos romanos. E, pela terceira vez, sendo cônsules Sexto Pompeio e Sexto Apuléio, com poder consular, junto com meu colega Tibério César, meu filho, celebrei o lustrum, no qual foram contados quatro milhões novencentos e trinta e sete mil cidadãos romanos". O último censo que tinha sido realizado em Roma antes de Augusto ocorreu em 70 a.C., e contou 910.000 cidadãos, homens, maiores de 17 anos. Para explicar esta diferença significativa, do lustrum de 70 a.C, com menos de um milhão de habitantes, para o lustrum de 28 a.C. com mais de quatro milhões, B. BIONDI, La legislazione di Augusto cit. (nota 56 supra), p.129, nota 3; Idem, Istituzioni cit. (nota 22 supra), p.440, defende que no primeiro lustrum foram contados apenas os homens puberes, o que justifica o baixo número de cidadãos. Vejam-se também J.A. FIELD JR., The purpose cit. (nota 129 supra), p.410, nota 50; G. Pieri, L'Histoire du cens cit. (nota 221 supra), pp.185-187; A. MetTe-DitTMAnN, Die Ehegesetze des Augustus cit. (nota 366 supra), pp.207-208. 
a.C., registrava 4.063 .000 cidadãos romanos; o de 8 a.C., 4.233 .000 e um terceiro de 14 d.C., totalizou 4.937 .000 cidadãos.

B. BIONDI ${ }^{501}$ também apresenta uma opinião favorável ao êxito da legislação matrimonial de Augusto e salienta o aumento da população baseado em Res Gestae 2,8, do aumento de 874.000 cidadãos em aproximadamente 40 anos, entre o censo de 28 a.C. e o de 14 d.C., fato que indica um aumento de 1/4 dos cidadãos romanos. Este êxito só pode ser atribuído às reformas matrimoniais de Augusto, pois tanto as manumissões quanto as concessões da cidadania romana sofreram restrições no primeiro século da Era Cristã.

Na opinião de T. SPAGNUOLO VIGORITA ${ }^{502}$, apesar de uma certa resistência na aplicação da legislação ético-matrimonial por parte de alguns poetas e membros das classes senatorial e equestre, a grande maioria da população apoiava a política reformadora dos costumes realizada por Augusto, exigindo intervenções urgentes no âmbito familiar.

R. ASTOLFI ${ }^{503}$ sustenta não apenas o êxito das reformas matrimoniais de Augusto na

${ }^{501}$ La legislazione di Augusto cit. (nota 56 supra), pp.145-147. Na opinião de BIONDI, op.cit., p.145, è vana illusione suporre che in questa materia la legge abbia potuto adempire lo stesso ufficio dei 'boni mores', giacchè la coercizione esterna è meno efficiente del senso morale e di civismo; ma è evidentemente esagerato conclamare il fallimento della politica demografica di Augusto, la quale raggiunge quel tanto che possono conseguire leggi applicate rigorosamente. Porém, adverte o autor sobre a legislação matrimonial na p.157: qualli effetti abbia prodotto in pratica è difficile accertare. Sobre as restrições da concessão à cidadania romana no início do Principado, Suetônio narra que Calígula (Caligula 38) proibia a cidadania aos descendentes, além do grau de filho, daquele que se tornasse cidadão.

${ }^{502}$ Casta Domus cit. (nota 26 supra), pp.31;71;83. Porém, o autor, baseando-se em Dio Cass. 56,6,6, acredita que a lex Iulia de maritandis ordinibus não conseguiu moralizar a sociedade nem aumentar o número de matrimônios, fato que obrigou o princeps a promulgar uma lei mais severa em 4 d.C.: 'A $\lambda \lambda$ ' v $\mu \varepsilon \bar{\imath} \varsigma$ ov̉ $\tau \varepsilon$

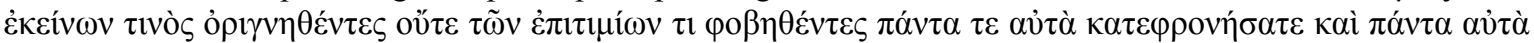

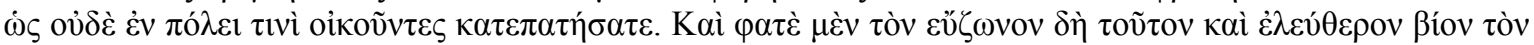

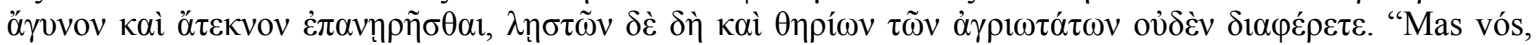
sem aspirar a nenhum prêmio, nem temer nenhuma pena, desprezastes todas estas disposições e espezinhastes [as leis] como se não vivestes numa comunidade citadina. E até dizeis tê-la escolhido, esta vossa vida livre, desimpedida de vínculos, sem mulher e sem filhos: mas não sois em nada diferentes dos bandidos e das bestas mais ferozes". O autor porém, na p.83, adota uma conclusão menos otimista em relação aos resultados alcançados por Augusto com a sua legislação matrimonial: (...) Probabilmente, egli [Augusto] non riusci a rinnovare nel profondo le convinzioni ethiche, e le speranze di un incremento demografico non si avverarono, o solo in misura modesta; ma certo le sue riforme dettero un'impronta nuova al diritto delle successioni e della famiglia, imposero l'osservanza di certi comportamenti a chi volesse partecipare con pienezza alla vita pubblica, o ne accentuarono la dipendenza dal principe come dispensatore delle esenzioni, contribuirono a rafforzare $i$ confini tra $i$ ceti. “(...) provavelmente ele [Augusto], não chegou a renovar profundamente as convicções éticas, e as esperanças de um aumento demográfico não ocorreram, ou apenas de forma modesta; mas é certo que as suas reformas deram um novo cunho ao direito das sucessões e de família, impuseram a observância de determinados comportamentos a quem quisesse participar com plenitude da vida pública, ou ressaltando-lhe a dependência do príncipe como distribuidor das isenções, contribuíram em aumentar os limites entre as classes".

${ }^{503}$ La Lex Iulia et Papia cit. (nota 15 supra), pp.351-352. Segundo o autor, (...) agli interessi contingenti del programma politico di Augusto, la 'lex Iulia et Papia' era in grado di soddisfare esigenze permanente della società romana e di adeguarsi al suo sviluppo. Veja-se também R.ASTOLFI, Note per una valutazione storica della 'Lex Iulia et Papia' cit. (nota 36 supra), pp.221 e especialmente, p.223: alla considerazione della 'lex Iulia et Papia' quale 'corpus' legislativo diretto a potenziare nell'ambito dell'impero l'elemento romanoitalico, si sostituisce la concezione della legge quale 'corpus' fondamentale di norme dirette a disciplinare istituti di diritto familiare, finanziario e delle successioni. 
época de sua promulgação, como também defende que a legislação era apta para satisfazer as exigências econômicas e sociais, também no decorrer do Principado, graças aos inúmeros comentários às leis matrimoniais realizados pelos jurisprudentes, além do ius honorarium e de inúmeras constituições imperiais se adequarem aos seus princípios. A concepção de que o matrimônio e a procriação são deveres públicos do cidadão estão de acordo com os costumes romanos e a ética estoica.

Estas são as conclusões de alguns romanistas contemporâneos.

Ao analisarmos o legado das Leis Matrimônias de Augusto, poderíamos afirmar que, independentemente de quanto tempo durou a sua eficácia e aplicação na sociedade romana, elas foram as primeiras de uma série de disposições legais e oficiais do "Estado romano", que estabeleciam imposições e condições ao matrimônio e ao conubium. ${ }^{504}$

No decorrer do Principado e no Dominato, esta influência do "Estado" Romano no Direito se tornará mais frequente, como uma força superior que modificará diversos institutos em prol da utilitas publica e do bem comum. ${ }^{505}$

Apesar de inúmeros poetas e historiadores como Virgílio, Sêneca ${ }^{506}$, Horácio $^{507}$, Plutarco, Plínio ${ }^{508}$, Tito Lívio, Propércio louvarem muitas obras da grandeza do Império e apoiarem as reformas dos costumes realizada pela legislação matrimonial de Augusto, neste período de transição, parte da sociedade romana, principalmente a classe equestre, sempre baseada no espírito de ampla libertas, foi resistente às mudanças e comprometeu o alcance dos objetivos principais da legislação, que foi refutada e até ironizada por Tibulo, Tácito, Juvenal ${ }^{509}$, Marcial e Ovídio. ${ }^{510}$

\footnotetext{
${ }^{504}$ R. VILLERS, Le mariage envisagé cit. (nota 63 supra), p.298.

505 J. Gaudemet, Utilitas Publica cit. (nota 44 supra), pp.163-197; P. CATAlano, Diritto, soggetti, oggetti cit. (nota 11 supra), p.113, conclui que, no sistema jurídico-religioso do ius-ars o ius publicum deve prevalecer sobre a utilitas singulorum.

${ }^{506}$ Sen. De benef. 3,33,4.

${ }^{507}$ Hor. Carm. 3,6,17-36; 45-48;3,24,55; 4,5,20-24; 4,15,4-14; epist. 2,1,3.

${ }^{508}$ Plin. Iun. Ep. 4,15; Paneg. 26,5.

${ }^{509}$ Iuv. Sat. 9.

${ }^{510}$ Havia, portanto, duas nítidas tendências na literatura romana: uma que é favorável e louva as reformas de Augusto e outra nitidamente contrária e crítica às alterações realizadas pela legislação matrimonial. Conforme F. DELla CORTE, Le 'leges Iuliae' e l'elegia romana cit. (nota 47 supra), pp.552 e 554. As obras de Ovídio foram consideradas criminosas, pois descreviam uma vida leviana, que recusava e criticava a vida política e militar romana. Foram consideradas como uma espécie de "traição à Pátria". Ovídio entra em choque com os costumes defendidos pela Legislação Matrimonial, pois em muitos trechos, fazia uma verdadeira apologia ao adultério e à sedução, em confronto com a moral familiar e pública que Augusto queria restaurar. $\mathrm{Na}$ verdade, Ovídio defendia que as tradições romanas sempre se basearam, quanto às relações amorosas, na liberdade e na tolerância e não em sanções legislativas estabelecidas pela res publica. Vejam-se, Ovid. amor. 3,14,5: Non peccat, quaecumque potest peccasse negare / solaque famosam culpa professa facit. "Quem pode negar a traição não trai de verdade, não comete um crime / apenas quando é admitida que a culpa torna-se infamante"; 2,4,10: Non est certa meos quae forma invitet amores: / centum sunt causae cur ego semper amem. "Não há uma forma certa que induza as minhas paixões: / cem são as razões que me fazem apaixonar-se sem cessar"; 3,4,17-18: Nitimur in vetitum semper cupimusque negata: /
} 
Tácito, com uma visão extremamente crítica e pessimista principalmente em relação ao comportamento ganancioso dos delatores, afirma que a legislação matrimonial não atingiu o seu escopo e o número de matrimônios e a procriação de mais filhos para a res publica não sofreram alterações. ${ }^{511}$

sic interdictis imminet aeger aquis. "Sempre aderimos ao proibido e desejamos aquilo que é negado: / assim o doente sempre se dirige à água que não pode beber". Ele sugeria que o homem não investigasse a vida da esposa, que não fizesse armadilhas (laquei) para surpreendê-la em flagrante e recomendava que o marido ignorasse ou fingisse ignorar o adultério. Ovídio tentou, em vão, demonstrar que a sua poesia não era contrária às leis matrimoniais de Augusto, principalmente em relação à Lex Iulia de adulteriis. Ovid. ars. 2,595-600: Nec vos rivali laqueos disponite nec vos / Excipite arcana verba notata manu. / Ista viri captent, si iam captanda putabunt. / Quos faciet iustos ignis et unda viros, / En, iterum testor, nihil hic nisi lege remissum. / Luditur; in nostris instita nulla iocis. "Não façam armadilhas ao redor de um rival e não interceptem as cartas secretas. Se desejarem apenas apanhá-las em flagrante, deixem-nas serem apanhadas pelos homens a quem a água e o fogo tornarão maridos legítimos. Eu declaro pela segunda vez. Não nos divertimos aqui com o que a lei ordena. Aos nossos divertimentos não se mistura nenhuma matrona". Neste caso, Ovídio se refere à stola, instita, vestido da matrona prolífica que tinha o ius trium liberorum.

Em razão de suas obras Ars Amatoria e Amores terem entrado em choque com as "virtudes antigas" (antiqua virtus) defendidas pela legislação ético-matrimonial, todas as obras de Ovídio foram retiradas das bibliotecas públicas e o imperador Augusto exilou-o em Tomi, na Mésia, onde permaneceu até a sua morte em 18 d.C. Ovídio nega ser um opositor político de Augusto e nunca foi abertamente contrário à sua legislação matrimonial (conforme alguns versos de elogio à reforma dos costumes, vejam-se Ovid. Met. 15,832-834; Fasti 2,127-144). Na opinião de T. Spagnuolo Vigorita, Casta Domus cit. (nota 26 supra), pp.25;3841;55-57, as suas principais obras (Ars Amatoria e Amores) tornaram-se referência e inspiração aos opositores do princeps, pois eram contrárias ao matrimônio e aos deveres públicos. Para R. AsTOLFI, La Lex Iulia et Papia cit. (nota 15 supra), p. 351, Ovídio representa a opinião dos grupos intelectuais do período. Conclui P. JöRs, Die Ehegesetze des Augustus cit. (nota 258 supra), p.65, sobre o triste destino de Ovídio após a publicação do Ars Amatoria, que Des Keisers Herz blieb hart, und der Dichter musstesline Verachtung der 'Lex de adulteriis' zehn Jahre nach der Entstelung jenes Buches schwer büssen: in Tomi is er gestorben. "O coração do imperador não amoleceu e dez anos após a composição daquele livro o poeta devia pagar duramente o desprezo pela Lex de adulteriis: ele morreu em Tomi".

Vejam-se Ovid. amor 1,4,51-70;3,4,1-12;25-48; 3,11,37-44; Ovid. trist. 2,207-212;2,131-138; Ovid. ars 2,151; 2,357-372; 2,669-692; 3,579-588; Apul. Apologia 88: miror tamen quod tuam villam tantopere abhorreas, qui plerumque rure versere, lex quidem Iulia de maritandis ordinibus nusquam sui ad hunc modum interdicit: uxorem in villa ne ducito. Vejam-se A. GUARINO, Storia del diritto romano cit. (nota 103 supra), p.351; L.R. ARgüEllo, Manual cit. (nota 12 supra), p.435; A. LóPEZ PedreIRA, Limitaciones a la 'libertas nuptialis' cit. (nota 40 supra), p.403; B. BIONDI, La legislazione di Augusto cit. (nota 56 supra), pp.145, notas 1 e 2;157; D. NöRR, The Matrimonial Legislation of Augustus cit. (nota 54 supra), p.353.

511 Tac. Ann. 3,25,1-2: Relatum dein de moderanda Papia Poppaea, quam senior Augustus post Iulias rogationes incitandis caelibum poenis et augendo aerario sanxerat; nec ideo coniugia et educationes liberum frequentabantur praevalida orbitate. Ceterum multitudo periclitantium gliscebat, cum omnis domus delatorum interpretationibus subverteretur, utque antehac flagitiis ita tunc legibus laborabatur; ea res admonet ut de principiis iuris et quibus modis ad hanc multitudinem infinitam ac varietatem legum perventum sit altius disseram. "Depois, discutiu-se [no Senado] algumas atenuações sobre a lei Papia Poppaea, que Augusto, já velho, tinha publicado depois das leis Iuliae, para agravar as penas contra os celibatários e ao mesmo tempo, aumentar o Erário; e nem por causa disto os matrimônios nem a educação dos filhos se tornaram mais frequentes e a privação de filhos era frequentemente uma vantagem. Além disto, crescia enormemente o número das vítimas e havia poucas casas que não ficassem arruinadas pelas interpretações subvertidas dos delatores; de maneira que os crimes, em outro tempo, causavam todo o mal [da res publica], agora eram as leis que o causavam. Relembrarei mais adiante aqueles fatos da origem do Direito e do modo pelo qual chegamos a esta multidão e variedade infinita de leis".

Em outra passagem, Tácito condena qualquer lei "moralizadora" e que estabeleça restrições sobre o amor, o matrimônio e as paixões. Tac. Ann. 3,54,3: Tot a maioribus repertae leges, tot quas divus Augustus tulit, illa oblivione, hae, quod flagitiosius est, contemptu abolitae securiorem luxum fecere. "Muitas leis para este 
Porém, contra este ponto de vista de Tácito, salientamos que houve um aumento demográfico significativo não apenas na época de Augusto, mas durante todo o início do Principado. Cláudio realiza um censo em 47 d.C. e a cidade de Roma, naquele período, tinha, segundo Tácito, 5.984.072 cidadãos, graças, em grande parte, à política e à legislação matrimonial iniciada por Augusto. ${ }^{512}$

Por razões ético-sociais ou prático-políticas fundamentadas sobretudo nas disposições da lex Iulia et Papia ${ }^{513}$, torna-se frequente durante o Principado a intervenção do "Estado" no matrimônio e diversos são os exemplos, v.g., um senatusconsulto de 49 d.C., promulgado pelo imperador Cláudio, permitia ao tio paterno casar-se com a sobrinha $^{514}$; Marco Aurélio e Cômodo proibiram o casamento entre tutor ou seus filhos e a

mesmo fim [a reforma dos costumes] propuseram nossos antepassados e outras muitas [leis] também propôs o divino Augusto: mas aquelas já estão no esquecimento; e estas, o que ainda é mais vergonhoso, caindo em desprezo, deram ao luxo maior segurança". Tácito, em outra passagem famosa, critica a corrupção da política e dos legisladores romanos da época e a grande quantidade de leis sem aplicação prática. Tac. Ann. 3,27,3: (...) et corruptissima re publica plurimae leges. "(...) quanto mais corrupta é a res publica, mais numerosas são as leis". Porém, em conflito com este ponto de vista, Tácito qualifica a legislação matrimonial em Germania 19,2 como bonae legis: (...) plusque ibi boni mores valent quam alibi bonae leges.

Plínio, o Jovem, louva Trajano por ter combatido a ação dos delatores. Plin. Iun. Paneg. 34,2: (...) excidisti intestinum malum et provida severitate cavisti, ne fundata legibus civitas eversa legibus videretur. "(...) eliminou um mal interno e com severidade providencial, evitou que uma cidade fundada pelas leis não parecesse destruída pelas leis". Vejam-se R. Astolfi, La Lex Iulia et Papia cit. (nota 15 supra), p.362; T. Spagnuolo Vigorita, Casta Domus cit. (nota 26 supra), pp.25;83, nota 358; M. ZabŁOCKA, Le modifiche cit. (nota 103 supra), p.394; A. BOUCHÉ-LECLERCQ, Les lois démographiques d'Auguste cit. (nota 36 supra), pp.277-278; P. JÖRS, Die Ehegesetze des Augustus cit. (nota 258 supra), pp.6-8; G.F. PUCHTA, Kursus der Institutionem cit. (nota 489 supra), pp.161-162.

${ }_{512}$ B. BIONDI, La legislazione di Augusto cit. (nota 56 supra), p.146; J.A. FIELD JR., The purpose cit. (nota 129 supra), p.410, nota 51. Veja-se Tac. Ann. 11,25,8: (...) condiditque lustrum quo censa sunt civium quinquagies novies centena octoginta quattuor milia septuaginta duo (...). “(...) Depois, [Cláudio] concluiu o lustrum, no qual se contaram cinco milhões, novecentos e oitenta e quatro mil, e setenta e dois cidadãos (...)". Na opinião de D. NÖRR, The Matrimonial Legislation of Augustus cit. (nota 54 supra), p.354, este aumento da população no censo de 47 d.C. não é suficiente para provar o êxito da legislação matrimonial, pois muitos destes novos cidadãos eram libertos, manumitidos de acordo com as formas do ius civile.

${ }^{513}$ De acordo com J. GAUDEMET, Justum matrimonium cit. (nota 51 supra), pp.139-140, le regime original de la loi 'Julia' servit de base à la notion du 'matrimonium iniustum', que Papinien appliquera au mariage de la femme adultère et Paul au mariage du gouverneur.(...) L'iniustum matrimonium était pour partie lié au régime des lois caducaires.

${ }^{514}$ Neste caso, o próprio imperador Cláudio pôde se casar com a sua sobrinha Agripina, filha de seu irmão Germânico. Vejam-se Gai.1,62-63; Tac. Ann. 15,5; Suet. Claudius 26,3; UE 5,6. Interessante a descrição de Marciano, sobre um caso narrado por Papiniano, em seu libro secondo de adulteriis, em que os filhos de um matrimônio entre tio e sobrinha são considerados legítimos por um rescrito dos imperadores Marco Aurélio e Verus, em razão da longa duração da união e da grande quantidade de filhos (numerum liberorum vestrorum). Marcian. 2 inst. D.23,2,57,1: In libro secundo de adulteriis Papiniani Marcianus notat: Divus Marcus et Lucius Imperatores Flavia Tertullae per Mensorem libertum ita rescripserunt: 'Movemur et temporis diuturnitate, quo ignara iuris in matrimonio avunculi tui fuist, et quod ab avia tua collocata es, et numerum liberorum vestrorum; idcircoque quum haec omnia in unum concurrunt, confirmamus statum liberorum vestrorum in eo matrimonio quaesitorum, quo ante annos quadraginta contractum est, perinde atque si legitime concepti fuissent. "No livro segundo de Papiniano sobre os adultérios, observa Marciano: $\mathrm{O}$ Divino Marco e Lúcio, imperadores, responderam por rescrito a Flávia Tértula por meio do liberto Mensor nestes termos: 'Nos manifestamos em teu favor, tanto pela longa duração do tempo que, ignorando o direito, permanecestes em matrimônio com o teu tio materno, quanto porque fostes casada pela tua avó e pelo 
tutelada $^{515}$; alguns mandata, promulgados no início do Principado, proibiram o casamento entre o governador de província e uma mulher nascida ou domiciliada na mesma. ${ }^{516}$

A legislação matrimonial de Augusto serviu de inspiração para Domiciano (81-96 d.C.) na renovação do "Estado" e da sociedade e para a reforma dos costumes. Neste período, confirmou-se a situação de incapacidade sucessória para as feminae probrosae, ou seja, elas não poderiam capere qualquer disposição testamentária. ${ }^{517}$

Esta "falsa moralidade" das famílias mais antigas sofreu duras críticas de Juvenal, pois ele considerava a legislação de Augusto muito severa. Juvenal pretendia demonstrar que nem o próprio Domiciano tinha uma vida de acordo com os antigos mores. ${ }^{518}$

número de vossos filhos; e por isto, concorrendo todas estas coisas em uma única, confirmamos a situação dos vossos filhos tidos neste matrimônio, que se contraiu a quarenta anos, a mesma que se fossem concebidos legitimamente".

${ }_{515}$ Paul. l.s. de assig. libert. D.23,2,59; Paul l.s. ad orat. divi Anton. et Comm. D.23,2,60pr.; Call. 2 quaest. D.23,2,64,1; Paul. 2 sent. D.23,2,66pr.; Tryph. 9 disp. D.23,2,67,3; Val. Et Gal. C.5,6,6 (260); Diocl. et Max. C. $5,6,7$.

${ }_{516}$ Paul. 2 sent. D.23,2,38pr.; -1;-2; Paul. 7 resp. D.23,2,65,1. Uma constituição imperial promulgada por Gordiano [Gord. C.5,4,6 (239)], declara que o matrimônio entre o governador e a mulher da província por ele administrada, transforma-se em iustae nuptiae com a cessação das funções do marido e a permanência da affectio maritalis entre os cônjuges. Outros funcionários imperiais, como o praefectus cohortis, o praefectus equitum e o tribuno, sofreram este impedimento de casar-se com um mulher da província na qual desempenhassem os seus cargos, conforme Pap. 1 def. D.23,2,63. Vejam-se B. BIondi, Istituzioni cit. (nota 22 supra), pp.443-444; J. IgLeSIAS, Derecho Romano cit. (nota 51 supra), p.343; V. ARANGiO-Ruiz, Istituzioni cit. (nota 53 supra), p.442; A. BURDESE, Manuale cit. (nota 47 supra), p.273; G. CORNIL, Droit Romain cit. (nota 55 supra), p.129. J. GAUDEMET, Justum matrimonium cit. (nota 51 supra), pp.135.

${ }^{517}$ Suet. Domitianus 8,4 (vide nota 96 supra). A incapacitas das feminae probrosae compreendia não apenas heranças e legados, mas qualquer disposição mortis causa. Para que a mulher possa ser qualificada como probrosae é necessário que o escândalo seja público, com um comportamento notoriamente reprovável. O próprio comportamento escandaloso do indivíduo torna-o desprezado por toda a sociedade. Sobre esta inspiração de Domiciano nos princípios da legislação de Augusto para a proteção do matrimônio, da procriação e no combate ao adultério, veja-se Martial. Epigr. 6,2;9,5;9,7. Vejam-se J.C. TELLO, La concesión discrecional cit. (nota 161 supra), p.775, nota 43; M. ZABŁOCKA, Il 'ius trium liberorum' cit. (nota 103 supra), p.378; R. Astolfi, La Lex Iulia et Papia cit. (nota 15 supra), pp.49;53;355; D. NöRR, The matrimonial Legislation of Augustus, cit. (nota 54 supra), p.358. Na opinião de R. Astolfi, Femina probrosa cit. (nota 96 supra), p.18, Domiziano non fece altro che inasprire il provvedimento già preso da Augusto nei confronti delle 'feminae probrosae'.

${ }_{518}$ Neste sentido, Suet. Domitianus 22. Narra Juvenal em suas Saturae, que Larônia, uma mulher considerada na época como probrosa, não suportou tamanha hipocrisia dos políticos e das classes dominantes da época, que não viviam de acordo com a lei e criticou, por meio de uma ironia, o comportamento de um membro da família dos Scauros que se lamentava da degradação dos costumes. Iuv. Sat. 2,29-40: Qualis erat nuper tragico pollutus adulter / concubitu, qui tunc leges revocabat amaras / omnibus atque ipsis Veneri Martique timendas, / cum tot abortivis fecundam Iulia vulvam / solveret et patruo similes effunderet offas. / Nonne igitur iure ac merito vitia omnia fictos / contemnunt Scauros et castigata remordent? / Non tulit ex illis torvum Laronia quendam / clamantem totiens: "Ubi nunc lex Iulia, dormis?" / atque ita subridens: "Felicia tempora, quae te / moribus opponunt. Habeat iam Roma pudorem, / tertius e caelo cecedit Cato". "Assim, ainda era muito recente o incesto da tragédia daquele adúltero [Domiciano], que enquanto isso, colocava novamente em vigor leis amargas e terríveis para todos, leis nas quais até mesmo Marte e Vênus tremeriam, enquanto Júlia abortava o fruto do útero fecundo, derramando pedacinhos semelhantes ao tio [Domiciano]. E não é justo, portanto, que também os piores depravados desprezem estes falsos Scauros e, repreendidos por eles vinguem-se com castigos? Com olhar terrível um deles não fazia mais que exclamar: " - Ó Lei Júlia, onde estás, dormes?". Nem mesmo Larônia pôde suportá-lo e sorrindo disse: “ - Ó tempos felizes, que tem um homem como você para se opor a estes costumes! Retorna pudica Roma, agora que do céu caiu um terceiro Catão!”. Juvenal critica a legislação matrimonial de Augusto e principalmente o ius trium liberorum. 
No principado de Trajano (98-117), Plínio (Paneg. 42,1), em 100 d.C., indica a importância do escopo fiscal da lex Iulia et Papia. A política demográfica de Trajano ampliou a distribuição de alimentos e de dinheiro às famílias numerosas, com a finalidade principal de aumentar o exército romano. Portanto, não considerava mais importante o incentivo à prole numerosa apenas nas classes senatorial e equestre, mas também nas famílias mais pobres. ${ }^{519}$

No Dominato, os principais objetivos das Leis Matrimoniais de Augusto, ou seja, combater o celibato, incentivar homens e mulheres a se unirem em matrimônio, os impedimentos matrimoniais entre pessoas de classes sociais diferentes e as segundas núpcias, chocavam-se diretamente com os princípios cristãos, favoráveis ao celibato e à castidade e contrários às segundas núpcias. ${ }^{520}$

A liberdade matrimonial proclamada pela doutrina da Igreja e a procriação como uma das finalidades essenciais do matrimônio cristão tornaram supérfluo o sistema de prêmios e penas da legislação demográfica. ${ }^{521}$

Os autores cristãos geralmente demonstraram grande aversão às leis matrimoniais de Augusto, pois concebiam o amor conjugal e o matrimônio como um remedium concupiscentiae. Além disso, dentro desta concepção cristã, não era função do "Estado" romano impor o matrimônio e a procriação como deveres públicos. Na doutrina da Igreja, o matrimônio já é destinado, pela sua própria natureza e por disposição divina, à

Iuv. Sat. 6,28-42;6, 593-597; 9,27;70-90. Vejam-se E. VOLTERRA, Matrimonio cit. (nota 61 supra), p.773; R. AStOLFI, La Lex Iulia et Papia cit. (nota 15 supra), p.355; J.A. FIELD JR., The purpose cit. (nota 129 supra), pp.413-414, notas 64 e 65; D. NÖRR, The matrimonial Legislation of Augustus, cit. (nota 54 supra), pp.357;359; M. ZABŁOCKA, Le modifiche cit. (nota 103 supra), pp.398-399. Sobre a vida pervertida de Domiciano, veja-se V. VANOYEKE, La prostitution en Grèce cit. (nota 140 supra), p.123.

${ }^{519}$ R. Astolfi, Note per una valutazione storica della 'Lex Iulia et Papia' cit. (nota 36 supra), p.216. Vide pp.116-117, nota 263 supra.

${ }^{520}$ A influência das novas idéias cristãs foram responsáveis por uma profunda transformação no instituto do matrimônio romano e a doutrina dos Padres da Igreja reprovava as segundas núpcias, comparando-as ao adultério. Vejam-se E. Volterra, La conception du Mariage à Rome cit. (nota 30 supra), pp.360-361; B. BIONDI, Istituzioni cit. (nota 22 supra), pp.440;446; A. BURDESE, Manuale cit. (nota 49 supra), p.276; A. Bouché-LeClerCQ, Les lois démographiques d'Auguste cit. (nota 36 supra), p.285; R. Astolfi, Note per una valutazione storica della 'Lex Iulia et Papia' cit. (nota 36 supra), pp.230;234-235. A viuvez consagrada a Deus era valorizada tanto no Antigo quanto no Novo Testamento. Tertuliano pedia para que os cristãos preferissem os casamentos com pagãos ou pessoas de classes consideradas inferiores (pobres, femina probrosae). O papa Calisto (217-222) reconhecia válido e de acordo com o Evangelho o casamento entre libertos e membros da classe senatorial. Porém, a Igreja não influenciou o direito laico. A tendência foi contrária, ou seja, o direito canônico adotou vários impedimentos matrimoniais previstos pelo direito laico. A Igreja, após a promulgação do Edito de Milão em 313 d.C., procura não entrar em conflito com o "Estado" romano.

${ }^{521}$ B. BIONDI, La legislazione di Augusto cit. (nota 56 supra), p.147; R. AstOLFI, Note per una valutazione storica della 'Lex Iulia et Papia' cit. (nota 36 supra), p.232, nota 198. Santo Agostinho defende que o matrimônio é um ato liberorum procreandorum causa (Serm. 91,12; PL, 38,345; Serm. 278,9; PL, 38,272). 
procriação. $^{522}$

As disposições previstas nas leis matrimoniais já tinham sido duramente criticadas por Tertuliano, em 197 d.C., denominando-as vanissimae leges. ${ }^{523}$

Muitos dispositivos da legislação matrimonial estavam em vigor nos séculos II e III d.C., como demonstram os numerosos comentários ${ }^{524}$ de Gaio, Mauriciano, Marcelo, Paulo, Ulpiano e Papiniano a estas leis, além de vários deles apresentarem-se recompilados pela comissão de Triboniano no Corpus Iuris Civilis. ${ }^{525}$

${ }^{522}$ Vejam-se Euseb. Vita Constant. 4,26; Sozom. Hist. Eccl. 1,9 (vide nota 331 supra). O livro do Gênesis já estabelecia a intenção divina em fundar a instituição do casamento e a procriação como finalidade principal da sexualidade: Gn.1,31;2,18-24;4.1.25. Em relação ao matrimônio, o Cristianismo baseava-se na indissolubilidade e na monogamia, conforme os ensinamentos de Jesus Cristo. Veja-se o Evangelho de Jesus Cristo segundo Mateus, Mt.19,1-9. Na opinião de R. Astolfi, La Lex Iulia et Papia cit. (nota 15 supra), p.368, (...) fondamentale motivo per cui la Chiesa si opponeva alla legge era l'avversione per l'idea stoica e romana di considerar la procreazione come l'adempimento di un dovere pubblico del citadino di incrementare lo Stato e quindi coercibile a opera dello Stato stesso. Veja-se também R. Astolfi, Note per una valutazione storica della 'Lex Iulia et Papia' cit. (nota 36 supra), pp.231-232.

523 Tert. Apol. 4,8: Nonne vanissimas Papias leges, quae ante liberos suscipi cogunt quam Iuliae matrimonium contrahi, post tantae auctoritatis senectutem heri Severus, constantissimus principum, exclusit? - "As Leis Pápias, leis vaníssimas, que obrigam à procriação de filhos, antes da época em que a lex Iulia exigia o casamento, apesar da autoridade que lhe concede sua antiguidade, não foi ela reformada recentemente por Severo, o mais conservador dos príncipes?". Tertuliano informava uma discrepância entre as leis matrimoniais de Augusto, pois a idade inicial que a Lex Papia Poppaea exigia para que homens e mulheres tivessem filhos, era inferior à estabelecida pela Lex Iulia de maritandis ordinibus para que os casais contraíssem matrimônio. Porém, não indicou qual seria o motivo e a importância dessa discrepância. É pouco provável que Augusto tenha admitido, com a promulgação da Lex Papia, que pudessem ser considerados legítimos e contados entre os filhos, aqueles nascidos fora do matrimônio (espúrios). Quanto ao imperador mencionado por Tertuliano, Septímio Severo, ele não ab-rogou as leis matrimoniais de Augusto e ainda estendeu o instituto das exceptae personae à tutela. Septímio Severo enfrentou uma das piores crises econômicas do Império, com uma grande desvalorização da moeda. Tertuliano é a imagem dos novos valores cristãos presentes na sociedade romana dos séculos II-III d.C. Ele reforça que não há caelibes ou orbus segundo o Evangelho de Jesus Cristo (de monog. 16). Vejam-se O.M. PÉTER, Liberorum quaerendorum causa cit. (nota 21 supra), p.326; E. VolTERRA, Matrimonio cit. (nota 61 supra), p.790, nota 145; C. ORTíN GARCÍA, Edad, Matrimonio cit. (nota 103 supra), p.511, nota 12; J. DAZA MARTíNEZ, La influencia cristiana cit. (nota 48 supra), p.125, nota 66; R. Astolfi, La Lex Iulia et Papia cit. (nota 15 supra), pp.2;39;337;355;367-368; Idem, Note per una valutazione storica della 'Lex Iulia et Papia' cit. (nota 36 supra), pp.198;219;230; J.A. FIELD JR., The purpose cit. (nota 129 supra), p.414, nota 66; M. ZABŁOCKA, Le modifiche cit. (nota 103 supra), p.381; A. BOUCHÉ-LECLERCQ, Les lois démographiques d'Auguste cit. (nota 36 supra), p. 285.

${ }_{524}$ De acordo com R. Astolfi, Note per una valutazione storica della 'Lex Iulia et Papia' cit. (nota 36 supra), p.227, a interpretação jurisprudencial no decorrer do período clássico e principalmente no período pós-clássico, tende a isolar uma norma ou grupo de normas das demais, alterando muitas vezes o seu significado originário, adaptando-a ao contexto político de cada período ou até associando-a à linhas de evolução histórica que não faziam parte da mente do legislador na época de Augusto. AsTolfi divide este grupo de normas em quatro tipos principais: (a) normas de natureza fiscal, que continuaram em vigor até o período justinianeu; (b) normas de escopo demográfico; (c) normas que tinham como principal finalidade a proteção da dignidade matrimonial e; (d) normas vinculadas aos institutos jurídicos do dote, tutela, patria potestas, em que o escopo demográfico é secundário e indireto. E conclui, sobre o grupo de normas mencionadas no item (d), que la storia di queste ultime norme in età postclassica non è più la storia speciale della 'lex Iulia et Papia', ma quella generale degli istituti, alla cui disciplina essi concorrono.

${ }^{525}$ E. Volterra, Matrimonio cit. (nota 61 supra), p.768; G. SCIASCIA, A lei romana sobre os Adultérios cit. (nota 313 supra), p.29; L.F. RADITSA, Augustus Legislation cit. (nota 49 supra), p.320. Salientam V. ARANGIO-RUIZ, Istituzioni cit. (nota 53 supra), p.443; B. BIONDI, La legislazione di Augusto cit. (nota 56 supra), p.146; Idem, Istituzioni cit. (nota 22 supra), p.440, que as leis matrimoniais de Augusto permanecem em "pleno vigor" (pieno vigore) seguramente por três séculos, graças aos comentários e interpretações 
Mesmo três séculos após a sua promulgação, as leis ético-matrimonais ou demográficas de Augusto eram consideradas fundamenta rei publicae, segundo um discurso, proclamado por um orador (anônimo) diante de Maximiano e Constantino em 307 d.C., para exaltar o incentivo ao matrimônio e à procriação na política destes imperadores. ${ }^{526}$

Paneg. Lat. 7(6),2,4: Quare si leges eae quae multa caelibes notaverunt, parentes praemiis honorarunt, vere dicuntur esse fundamenta rei publicae, quia seminarium iuventutis et quasi fontem humani roboris semper Romanis exercitibus ministrarunt, quod huic vestro in rem publicam merito possumus dignum nomen adscribere?

"Por isto, se aquelas leis [matrimoniais], que condenaram com uma multa os caelibes e honraram os pais com prêmios, são denominadas, justamente, os fundamentos da res publica, uma vez que elas sempre ofereceram aos exércitos romanos uma sementeira de jovens e, por assim dizer, uma fonte de força humana, quão digno nome podemos atribuir a este vosso serviço em favor da res publica?"

No século VI d.C., grande parte das disposições da lex Iulia et Papia que ainda encontravam-se em vigor $^{527}$ foram gradualmente ab-rogadas pelo desuso ${ }^{528}$ ou por

realizadas pelos jurisconsultos clássicos. Na opinião de K. GALINSKY, Augustan Culture cit. (nota 102 supra), p.128: (...) when you look forward in time, we find that the Augustan marriage laws, which remained in effect for over two hundred years, attracted more comment from the Roman jurists than did any other laws. Indicam R. Astolfi, La Lex Iulia et Papia cit. (nota 15 supra), pp.132-133;135;372; Idem, Note per una valutazione storica della 'Lex Iulia et Papia' cit. (nota 36 supra), pp.236-237 e A. BouCHÉ-LECLERCQ, Les lois démographiques d'Auguste cit. (nota 36 supra), p.288, que Constantino reforça e amplia, por meio de uma constituição imperial de 336 d.C., os impedimentos matrimoniais dos senadores, dos sacerdotes e dos duumviros com a liberta, a filha da liberta, a escrava, a tabernaria, a mulher quae mercimoniis publicis praefuit, a filha do tabernarius, do alcoviteiro, do harenarius, as feminae humiles e as abiectae. Os filhos gerados nestas relações eram considerados ilegítimos e seus direitos sucessórios eram destinados ao Fisco. Vejam-se C.Th. 4,6,3 (336); Const. C.5,27,1 (336). Estas proibições foram mantidas em 454 d.C. pelos imperadores Valentiniano III e Marciano em Valent. et Marcian. C.5,5,7 (454). O Código de Justiniano mantém as proibições das núpcias entre patrona e liberto e entre Senadores e altos funcionários do "Estado".

${ }^{526}$ Vejam-se T. Spagnuolo Vigorita, Casta Domus cit. (nota 26 supra), pp.13;89, nota 12; B. Biondi, La legislazione di Augusto cit. (nota 56 supra), p.147; R. Astolfi, La Lex Iulia et Papia cit. (nota 15 supra), p.371; Idem, Note per una valutazione storica della 'Lex Iulia et Papia' cit. (nota 36 supra), pp.214;233; A. BOUCHE-LECLERCQ, Les lois démographiques d'Auguste cit. (nota 36 supra), p.286.

${ }^{527}$ Conforme B. BIONDI, La legislazione di Augusto cit. (nota 56 supra), p.149, permaneceram em vigor no Direito Justinianeu: a obrigação do marido restituir o enriquecimento derivado da manumissão do servo dotal; a dispensa da tutela e da curatela para aquele que tivesse três filhos; disposições relativas ao matrimônio da liberta com o patrono; a isenção das operae libertorum; os impedimentos matrimoniais entre senadores, libertas e feminae probrosae.

${ }_{528}$ De acordo com R. Astolfi, Note per una valutazione storica della 'Lex Iulia et Papia' cit. (nota 36 


\section{constituições imperiais. ${ }^{529}$}

supra), pp.229-230, os costumes dos povos greco-orientais eram contrários, assim como o Cristianismo, à noção de matrimônio e procriação como deveres públicos. Estes costumes se chocaram com as normas da Lex Iulia et Papia, principalmente em relação à restrição do tempo dos esponsais para dois anos. Também algumas vantagens concedidas pela Lex Iulia et Papia às mulheres são contrárias aos costumes destas províncias da parte oriental do Império.

${ }_{529}$ Vejam-se E. VolterRA, Matrimonio cit. (nota 61 supra), p.798; p.800, nota 173; V. ArANGIO-RUIZ, Istituzioni cit. (nota 53 supra), p.444; D. DALlA, D. 50,16,135: Sui perché di uma 'Lex Specialis' cit. (nota 125 supra), p.347, notas 13 e 15; C. ORTín GARCíA, Edad, Matrimonio cit. (nota 103 supra), pp.516-517, notas 26 e 28; J.C. TELLO, La concesión discrecional cit. (nota 161 supra), pp.771;773; M. ZABŁOCKA, Il 'ius trium liberorum' cit. (nota 103 supra), pp.369;389-390; R. Astolfi, La Lex Iulia et Papia cit. (nota 15 supra), pp.39;43-45;76-80;132;366;368-369;372;374-375; Idem, Femina probrosa cit. (nota 96 supra), pp.39;50;59-60; Idem, Note per una valutazione storica della 'Lex Iulia et Papia' cit. (nota 36 supra), pp.214;231;234; B. BIONDI, La legislazione di Augusto cit. (nota 56 supra), p.147; Idem, B. BIONDI, Istituzioni cit. (nota 22 supra), pp.440-441; J.A. FIELD JR., The purpose cit. (nota 129 supra), p.409; G. IMPALLOMENI, In tema di vitalità e forma umana cit. (nota 143 supra), pp.282-283; J. GAUDEMET, Justum matrimonium cit. (nota 51 supra), pp.130;157; A. BOUCHÉ-LECLERCQ, Les lois démographiques d'Auguste cit. (nota 36 supra), pp.285-290; E. NARDI, La 'incapacitas' delle 'feminae probrosae' cit. (nota 96 supra), pp.174-178.

Apenas para enumerarmos resumidamente o período histórico em que as principais disposições das Leis Matrimoniais de Augusto foram ab-rogadas oficialmente, Constantino em 31 de janeiro de 320 (C.Th.8,16,1) ab-rogou as consequências jurídicas do ius liberorum em relação aos orbi (veja-se também Const. C.8,58,1 de 320); em 410 Arcádio, Honório e Teodósio estabeleceram que o ius liberorum podia ser concedido a qualquer cidadão que o solicitasse (C.Th. 8,17,3=Honor. et Theod. C.8,59,1: Nemo post haec a nobis ius liberorum petat, quod simul hac lege omnibus concedimus. "Após estas disposições ninguém nos solicite o ius liberorum, que por esta lei concedemos igualmente à todos”); Honório e Teodósio, no Império Romano do Oriente, determinaram a extinção das limitações caducárias quanto à sucessão recíproca dos cônjuges, a incapacidade sucessória para os cônjuges sem filhos, a lex decimaria (C.Th.8,17,2=Honor. et Theod. C.8,58,2); desapareceu definitivamente, em 412, a categoria dos caduca: Honor. et Theod. C.Th.8,17,4: Quod impetratum ius communium liberorum superstite Catullino clarissimo viro minus allegatum esse cognoscitur, nec succedenti obesse permittimus nec ulli umquam in simili causa statuimus nociturum. "Deduz-se que não foi alegado, quando Catullino, homem clarissimus, permaneceu supérstite, o pedido de ius communium liberorum: não permitimos que o ocorrido seja obstáculo ao seu herdeiro e estabelecemos que ele não prejudique qualquer outra pessoa que venha a encontrar-se em uma relação semelhante". Também foram abrogados os Senatusconsultos Persiciano, Tertuliano, Claudiano e Calvisiano em 531-532 d.C., com a promulgação de constituições que eliminavam a incapacitas dos caelibes, orbi e do pater solitarius. Além disso, foram eliminados os impedimentos referentes ao matrimônio entre idosos, homens maiores de sessenta anos e mulheres com mais de cinquenta. O filho de uma mulher que deu à luz com mais de cinquenta anos, foi considerado legítimo no período justinianeu. Vejam-se Iust. C.5,4,27;-28 (531-532); Iust. C.6,58,12,1 (532); Inst.3,3,4. Com a ab-rogação do ius liberorum, Justiniano também ab-rogou as disposições em relação aos direitos sucessórios entre patronos e libertos previstos na Lex Papia. Conforme Iust. C.6,4,4; Inst. 3,7,3. Os impedimentos matrimoniais entre senadores e libertas foram ab-rogados no direito justinianeu. Conforme Iust. C.5,4,28pr.; Nov.78,3;117,6. Justino autorizou o matrimônio entre os membros da classe senatorial e as atrizes. Retirou as limitações da capacidade das ex scaenicae [Iustinus C.5,4,23 (520-523)].

Em 458, Majoriano (457-461) reestabelece uma política demográfica para aumentar o número de nascimentos no Império e assegurar à prole vantagens patrimoniais. Mais uma vez, o "Estado" romano demonstra o seu interesse no incentivo às famílias com prole numerosa. Vejam-se Nov. Maior. 6,9: Et quia studiose tractatur a nobis utilitas filiorum, quos et numerosius procreatis competentia commoda perire non patimur, hoc necessario putavimus praecavendum, ut marem feminamque iungendos copula nuptiali par condicio utrimque costringat, id est ut numquam minorem quam exigit futura uxor sponsaliciam largitatem dotis titulo se noverit conlaturam, scituris puellis ac parentibus puellarum vel quibuscumque nupturis ambos infamiae maculis inurendos, qui fuerint sine dote coniuncti, ita uti nec matrimonium iudicetur nec legitimi ex his filii procreentur. Majoriano obrigou às viúvas que tivessem menos de quarenta anos e sem filhos, a se casarem e retomou desta forma o ius communium liberorum, prevista pela Nov. Valer. 21,1 de 446 d.C. As viúvas que não se casassem novamente no prazo de cinco anos contados a partir da data da morte do cônjuge, deveriam dividir o seu patrimônio com os parentes mais próximos ou com o Fisco: Mox cum germanibus vel sororibus eorumque filiis vel parentibus propinquisque (...) suas dividat facultates aut si hi fortasse 
Pode-se considerar que os últimos dispositivos da lex Iulia et Papia ainda em vigor, do regime caducário e com finalidades fiscais, foram derrogados por Justiniano após a promulgação de sua constituição imperial denominada de Caducis Tollendi, C.6,51 em $534 .^{530}$

Para Justiniano, estas leis deviam ser derrogadas porque foram medidas circunstanciais e excepcionais, ou seja, promulgadas em virtude das guerras civis e da decadência dos costumes no final da República. Além disso, o escopo demográfico foi corrompido pelo fiscalismo e pela ação dos delatores. ${ }^{531}$

A legislação justinianéia, no Digesto e nas Institutas, tende a recepcionar e conservar algumas disposições previstas nas obras clássicas que tratavam das leis matrimoniais de Augusto. As maiores alterações e inovações (que os modernos denominaram interpolações ou tribonianismos) foram promulgadas no Código (533 d.C.) e nas Novelas (535-565 d.C.). ${ }^{532}$

defuerint, cum fisco patrimonium partiatur.

${ }^{530}$ R. Astolfi, Note per una valutazione storica della 'Lex Iulia et Papia' cit. (nota 36 supra), pp.227;235.

${ }^{531}$ Sobre a Legislação matrimonial de Augusto e os bens caducos, Justiniano afirma na Constituição Tanta, Const. Tanta 6b: Sed in his nihil de caducis a nobis memoratum est, ne causa, quae in rebus non prospere gestis et tristibus temporibus Romanis increbuit calamitatibus, bello coalescens civili, nostris remaneat temporibus, quae favor caelestis et pacis vigore firmavit et super omnes gentes in bellicis periculis possuit, ne luctuosum monumentum laeta saecula inumbrare concedatur. "Mas nestes livros não recordamos nada em relação à legislação caducária [bens caducos], e para evitar este problema, quando os feitos eram desfavoráveis e os tempos eram tristes, aumentaram as desgraças dos Romanos durante a guerra civil, isso não permaneça nos nossos tempos, que o favor celeste assegurou com a força da paz e nos quais colocou-nos acima de todos os povos nos perigos da guerra, para não permitir que uma recordação de lutos lance sombra sobre uma época feliz". Vejam-se R. Astolfi, La Lex Iulia et Papia cit. (nota 15 supra), pp.374-375; Idem, Note per una valutazione storica della 'Lex Iulia et Papia' cit. (nota 36 supra), p.236; B. BIONDI, La legislazione di Augusto cit. (nota 56 supra), p.146; T. Spagnuolo Vigorita, Casta Domus cit. (nota 26 supra), p.19; P. Voci, Teoria dell'acquisto cit. (nota 381 supra), po.21-22.

${ }_{532}$ R. Astolfi, La Lex Iulia et Papia cit. (nota 15 supra), pp.80;375; Idem, Note per una valutazione storica della 'Lex Iulia et Papia' cit. (nota 36 supra), p.237; A. Bouché-LECLERCQ, Les lois démographiques d'Auguste cit. (nota 36 supra), pp.289-290; E. NARDI, La 'incapacitas' delle 'feminae probrosae' cit. (nota 96 supra), pp.173-174. Uma das disposições mantidas no Código de Justiniano, foi o caso do liberto ser exonerado dos ônus da manumissão, opera, dona, munera apenas por meio do ius liberorum. Permanece também a incapacitas das feminae probrosae, que se transformou na falta da testamentifactio passiva. As Novelas contêm inúmeras leis que beneficiam as mulheres em relação aos impedimentos matrimoniais. Em 539 d.C., Justiniano declarou válidas as núpcias entre membros da classe senatorial e libertas, e posteriormente, em 542 d.C., ele ab-rogou o impedimento matrimonial entre os senadores e altos funcionários do Império e as feminae humiles et abiectae (Nov.117,6). 


\section{PARTE III - CONCLUSÕES}

A procriação e a affectio maritalis eram elementos de suma importância para a existência do matrimônio romano. De acordo com o estoicismo, escola que influenciou grande parte das interpretações dos juristas romanos que trataram o assunto, a principal finalidade do matrimônio e o dever público de todo cidadão era a procriação de uma grande quantidade de filhos (indicada pela fórmula liberorum procreandorum causa).

Desde as origens da cidade de Roma e no decorrer de toda a sua História, matrimônio e procriação foram incentivados pela "propaganda oficial" do "Estado" romano.

No princípio da $U r b s$, a procriação foi estabelecida pelos mores maiorum (costumes dos antepassados). A primeira forma de intervenção pública de incentivo à procriação, ocorreu na Realeza, com a finalidade de aumentar o exército. Esse controle ocorreu por meio dos censores, a fim de que os matrimônios não se desviassem da sua principal finalidade natural, ou seja, da procriação.

Nos dois últimos séculos da República, em decorrência do desregramento social e das inúmeras guerras, torna-se maior a preocupação dos censores com o aumento da população, como demonstra, por exemplo, a Oratio pronunciada em 131 a.C. por Quinto Metelo Macedônico.

A filiação numerosa sempre foi um elemento essencial para o crescimento da civitas e da força político-militar romana.

É bem provável que a reforma moral familiar de Augusto (morum legumque regimen), em relação principalmente ao incentivo no aumento do número de matrimônios e de filhos, tenha se iniciado já em 28/27 a.C., nos primeiros anos do Principado, quando houve uma tentativa de promulgação de uma lex publica (lei comicial ou plebiscito).

Não se sabe ao certo se foi apenas um projeto de lei ou uma lei promulgada e logo em seguida ab-rogada (lex edicta, depois sublata).

Por sua severidade, esta lex edicta gerou uma reação negativa das classes dominantes.

Esta reforma era necessária em virtude dos danos, tanto ético-morais, quanto demográficos, que as Guerras Civis do final da República provocaram na sociedade romana. A reforma ético-matrimonial (e principalmente demográfica) de Augusto teve a 
função de manter a estabilidade do Império e garantir uma posição de supremacia políticoeconômica aos romano-itálicos sobre os provinciais.

Em 19 a.C., ao receber do senado e do populus Romanus a censoria potestas, Augusto exerceu a mesma tarefa dos censores republicanos, ou seja, o regimen morum (a vigilância dos costumes), examinando a quantidade de filhos, o patrimônio e os hábitos, principalmente dos membros das classes senatorial e equestre.

Gradualmente, por meio de inúmeras revisões, Augusto promulgou a lex Iulia de maritandis ordinibus (em 23 de maio de 17 a.C.) e a lex Iulia de adulteriis coercendis no mesmo ano.

É possível estabelecer três escopos principais na Legislação Matrimonial de Augusto:

(a) o aumento demográfico do Populus Romanus, principalmente das classes mais poderosas e ricas (classes senatorial e equestre), que sofreram um forte declínio em virtude das Guerras Civis e perturbações sociais do final da República;

(b) incentivo ao matrimônio legítimo. Os dispositivos previam a proteção da dignidade do matrimônio e dos esponsais, com normas que excluíam atos contrários ou impeditivos à constituição do matrimônio;

(c) a reforma dos costumes e da moralidade na familia romana (seminarium rei publicae) vinculada à sua tutela patrimonial.

$\mathrm{O}$ aumento demográfico dos cidadãos romanos obtém-se com o estímulo ao matrimônio legítimo (iustae nuptiae) e o dever de procriação como uma utilitas publica. Por isso, àqueles que tivessem uma prole numerosa eram atribuídos inúmeros prêmios e vantagens legais.

Em virtude da importante reforma ético-demográfica que realizou, as leis matrimoniais foram denominadas, no III século d.C., fundamenta rei publicae.

Aqueles que tinham o dever de ter filhos também estavam obrigados a contrair um iustum matrimonium: os homens entre os 25 e os 60 anos e as mulheres entre os 20 e os 50 anos. Os limites de idade superiores foram estabecidos pela presunção de que o homem com mais de 60 anos e a mulher com mais de 50, não têm a capacidade para procriar.

Não sofriam qualquer sanção ou penalidade os cônjuges que estivessem abaixo ou acima desta faixa etária estabelecida pela lex Iulia de maritandis ordinibus (homens menores de 25 e maiores de 60; mulheres menores de 20 e maiores de 50).

Apesar da crise econômica no último período do principado de Augusto, não é possível sustentar que o princeps buscasse, com a promulgação das Leis Matrimoniais, um 
meio para aumentar as rendas do "Estado". As classes que obtêm maiores privilégios políticos e econômicos também devem contribuir mais com as despesas do "Estado" e por isso sofrem sanções mais rígidas da lex Papia.

No decorrer do Principado, principalmente a partir de Nero, observa-se que, progressivamente, a legislação imperial subordina o escopo demográfico ao físcal. A jurisprudência, por outro lado, procura limitar esta finalidade fiscal, principalmente a atividade prejudicial dos delatores.

A lex Iulia et Papia utilizou-se de noções e termos técnicos, criados por leis republicanas (Furia, Voconia), para adaptá-los às necessidades políticas e legislativas que pretendia alcançar, como a figura da capacitas e o elenco das exceptae personae.

Apesar da difícil tarefa de identificar quais normas pertencem a cada uma das Leis matrimoniais, algumas disposições podem ser identificadas, estudadas isoladamente e atribuídas a uma determinada lei.

Augusto, ao promulgar a lex Iulia de maritandis ordinibus e proteger a dignidade familiar, estabeleceu taxativamente alguns impedimentos matrimoniais aos senadores em linha reta até o terceiro grau, divididos em duas categorias principais:

1) É proibido casar-se com a liberta;

2) É probido casar-se com as atrizes (scaenica), ex-atrizes e seus descendentes, a prostituta e a alcoviteira (lena), ou seja, as denominadas feminae probrosae.

O legislador preocupou-se também com a dignidade social e a família dos libertos, além de incentivar o seu matrimônio e a sua prole numerosa. O matrimônio entre ingênuos e libertos foi considerado legítimo.

A lex Iulia de maritandis ordinibus estabelecia que, após o divórcio invito patrono, ou seja, contra a vontade do patrono, a liberta não poderia contrair um novo matrimônio, pois o vínculo perdurava de acordo com o ius civile e a liberta perdia o connubium.

Quanto às vantagens no ius publicum, a lex Iulia de maritandis ordinibus, provavelmente em seu capítulo VII, estabelecia a procriação como critério para acelerar o cursus honorum dos candidatos que tivessem mais filhos e as preferências para assumirem os cargos públicos. O critério da ancianidade foi substituído pelo da prole numerosa.

A lex Iulia de maritandis ordinibus introduziu a figura do delator, ou seja, qualquer cidadão romano que, em nome do Aerarium (depois do Fisco), por meio da vindicatio caducorum, poderia obter como prêmio, em caso de vitória na lide, a metade dos bens reivindicados ou do seu valor, daqueles que não estivessem de acordo com as suas disposições. 
Além disso, a lex Iulia de maritandis ordinibus manifestou a utilitas publica na proteção do aspecto econômico e da estabilidade social nas famílias, ao determinar a obrigatoriedade da instituição do dote no matrimônio e aumentar os direitos da uxor sobre os bens dotais. Esta lei estabeleceu que o paterfamilias não poderia dissolver o matrimônio dos filhos sem uma justa causa, ou seja, fez restrições à patria potestas.

É provável que pertencesse à mesma lei a regra que isenta a liberta casada com o consenso do patrono de prestar as operae oficiales.

Em 17 a.C. foi promulgada a lex Iulia de adulteriis coercendis, cujo objetivo principal era restaurar moralmente a família, com sanções de natureza pública e privada. Combatia o adultério, o stuprum e o lenocínio com mulheres ingênuas honestas (nubentes e viúvas), considerando-os como crimina.

Algumas mulheres (principalmente as feminae probrosae) estavam dispensadas da lei, pois com elas não se cometia stuprum: as escravas, as prostitutas, as atrizes e exatrizes, as alcoviteiras e as mulheres condenadas por adultério.

Esta lei proibia que o marido matasse a esposa surpreendida em flagrante adultério, estabelecendo que ele deveria repudiá-la, sob pena de ser acusado por lenocinium se continuasse a conviver com ela. Ele deveria processar a esposa adúltera o mais rápido possível.

As penas estabelecidas eram graves: a relegatio in insulam e o confisco parcial dos bens. Além disso, a adúltera tornava-se infame e não poderia mais casar-se de acordo com o ius civile (perda do conubium).

É provável que uma lei matrimonial tenha sido promulgada em 4 d.C., mais severa que a lex Iulia de maritandis ordinibus e cuja aplicação foi suspensa primeiro por três anos e depois por mais dois. Esta dilação se justificaria pelos constantes protestos das classes senatorial e equestre devido à rigidez excessiva desta nova lei.

A lex Papia Poppaea, promulgada em 9 d.C., atribuia recompensas e prêmios aos pais com prole numerosa, decorrentes do ius liberorum e repetiu muitas disposições da lex Iulia de maritandis ordinibus.

Dentre as suas principais disposições, o ius liberorum era um prêmio à fecundidade atribuído aos homens com filhos e às mulheres ingênuas com três filhos e libertas com quatro filhos. Dentre as vantagens, este direito dispensava as mulheres da tutela mulierum e das sanções da Lei Vocônia; assegurava aos patres a capacitas sucessória testamentária total e dava direito aos bona caduca; garantia vantagens nas eleições e nos cargos públicos; ampliava ou restringia os direitos sucessórios dos patronos de acordo com a quantidade de 
filhos por ele procriados e pelo liberto (os direitos sucessórios dos patronos e dos libertos estavam subordinados à procriação e à quantidade de filhos).

Não se exigia, para a obtenção do ius liberorum, que os filhos permanecessem vivos, mas que nascessem vivos (vitalidade). A lei exige filhos legítimos para que os pais tenham direito aos benefícios do ius liberorum.

Os filhos adotivos eram contados da mesma forma que os filhos naturais, para que os pais gozassem das vantagens da Legislação Matrimonial.

Quanto aos direitos sucessórios, a lex Papia Poppaea mantém o ius antiquum para as sucessões ab intestato, mas modifica o regime em relação às sucessões testamentárias.

Para incentivar a procriação, a legislação matrimonial estabeleceu um sistema de sanção indireta, baseado principalmente na incapacidade sucessória testamentária (total ou parcial), por meio de prêmios aos casados com filhos e determinando penalidades patrimoniais e limitações aos caelibes e aos orbi (cônjuges sem filhos).

Os caelebs eram os homens não casados e sem filhos (dentro da faixa de idade entre os vinte e cinco e os sessenta anos para os homens e entre os vinte e os cinquenta anos para as mulheres) que sofriam inúmeras sanções sucessórias e de direito público da legislação matrimonial de Augusto: (a) se eles não se casassem ou contraíssem esponsais dentro de cem dias (cretio) não poderiam adquirir a herança ou o legado, prazo contado a partir da delatio hereditatis; (b) não poderiam adquirir a sucessão testamentária (tanto a título universal quanto particular), pois não tinham a solidi capacitas (poderiam suceder apenas $a b$ intestato); (c) não podiam assistir espetáculos públicos; (d) não tinham a prioridade para assumir cargos públicos.

Os orbi poderiam receber apenas a metade dos legados e heranças.

Os bens eram retirados daqueles que não tivessem filhos (caelibes e orbi) e destinados, primeiramente, segundo o ius antiquum, aos outros herdeiros com filhos (parentes até o terceiro grau, co-herdeiro ou co-legatário coniunctus, sucessores $a b$ intestato) e, na ausência destes, ao Aerarium (depois ao Fisco), como bona vacantia.

A lex Papia Poppaea é destinada não apenas a completar, mas também a corrigir a lex Iulia de maritandis ordinibus. Ela ampliou o rigor da lex Iulia de maritandis ordinibus, o que gerou a aversão das classes mais ricas e prejudicadas pelos delatores, principalmente a aristocracia senatorial. As sanções estabelecidas pela lex Iulia et Papia eram principalmente de ordem econômica e incindiam especialmente sobre as classes mais privilegiadas.

Na realização do programa político de Augusto para reformar os costumes (mores 
maiorum), tanto a lex Iulia quanto a lex Papia vinculavam-se harmonicamente com outras medidas legais, especialmente com a lex Aelia Sentia e com a lex Iulia de adulteriis.

Deves-se descartar a opinião de que a lex Iulia et Papia e a lex Aelia Sentia foram leis que procuraram obter uma "pureza racial" romana ao estabeleceram um controle das manumissões, pois o ius civile sempre reconheceu a importância dos libertos na sociedade e sua participação na gestão econômica e administrativa e em inúmeros casos concedeulhes a cidadania romana.

Alguns temas, como o concubinato, impedimentos de doações mortis causa, a indignitas, os limites da restituição do dote, as retenções propter liberos e propter mores, apesar dos inúmeros comentários jurisprudenciais referentes à lex Iulia et Papia, não foram tratados por ela expressamente.

Na época de Tibério, a lex Papia Poppaea sofreu um abrandamento, enquanto a lex Iulia de adulteriis tornou-se mais rígida. Tibério aumentou a punibilidade aos casos já previstos na lex Iulia de adulteriis e ampliou a sua aplicação para novas situações. Parece ter ocorrido um relaxamento da aplicação da legislação matrimonial e de outros senatusconsultos relativos, sob Calígula e Nero.

É possível perceber uma continuidade lógica entre os senatusconsultos Persiciano (34 d.C.), Claudiano (52 d.C.) e o Calvisiano (61 d.C.) e as leis matrimoniais de Augusto, pois corrigiram e aprimoraram, de acordo com a utilitas publica, os dispositivos da legislação do início do principado relativos às justas núpcias e à procriação.

Não é possível defender uma total ineficácia das leis matrimoniais de Augusto ou uma aplicação de seus dispositivos em um curto espaço temporal. Muitos foram os comentários da jurisprudência sobre a lex Iulia et Papia, o que indica sua importância e influência durante todo o Alto e o Baixo Império. Graças a esta legislação, foi possível, utilizando-se de uma terminologia moderna, a elucidação e a interpretação extensiva de diversos institutos de "direito" de família, das pessoas, sucessões e tributário romano.

Além disso, é um grande erro concluir que houve uma total rejeição social desta legislação, fundamentando-se em comentários ou obras que louvam uma vida licenciosa e promíscua e que representam uma pequena parcela de homens e mulheres das classes ricas e privilegiadas (senatorial e equestre), resistentes à carreira militar, ao matrimônio e à prole numerosa.

No início do Principado, grande parte da população romana apoiou a reforma dos costumes e o incentivo à procriação que Augusto realizou por meio da tribunicia potestas. Muitos escritores, sobretudo Horácio, auxiliaram na propaganda política de Augusto neste 
incentivo à procriação.

Conclui-se que Augusto conseguiu alcançar o principal escopo de sua legislação matrimonial, ou seja, o demográfico. É nitído um aumento na população durante todo o início do Império e certamente esta legislação atendeu exigências permanentes na sociedade, não apenas do principado de Augusto, mas durante todo o Império.

Pode-se também afirmar que os objetivos ético-demográficos sobrepõem-se aos fiscais pelo menos até o governo de Caracala, pois se o objetivo principal de Augusto com a legislação matrimonial, principalmente com a promulgação da lex Papia Poppaea, fosse o de obter mais rendas para o Erário, poderia utilizar-se de outros recursos, como leis ou senatusconsultos.

Em relação ao aspecto militar, ele sempre esteve em profunda relação com o estímulo e o auxílio legislativo à procriação, não apenas em Roma, mas em todos os grandes povos da Antiguidade. A preocupação em formar um exército jovem, numeroso e com cidadãos romanos sempre foi um dos principais escopos da res publica.

Por fim, é possível concluir que a Legislação matrimonial de Augusto foi benéfica à condição das mulheres em Roma: excluiu a tutela mulierum por meio do ius liberorum; limitou a patria potestas do paterfamilias em relação ao consentimento matrimonial dos alieni iuris, obrigando-o a permitir o matrimônio da filha quando não houvesse uma justa causa para impedi-la; restringiu os poderes do marido sobre o dote e garantiu maiores poderes patrimoniais às mulheres, com o escopo de garantir os meios econômicos para que elas pudessem contrair um novo matrimônio.

A lex Iulia de maritandis ordinibus estabeleceu que o marido só poderia manumitir o escravo dotal com o consentimento da uxor e deveria restituir-lhe uma parte do valor do escravo e os lucros por ele obtidos.

A lex Iulia de adulteriis coercendis determinou a proibição da alienação de um fundo dotal itálico pelo marido sem o consentimento da esposa, estabelecendo a regra ne dotale praedium maritus invita muliere alienet.

No período pós-clássico, o Cristianismo, forças políticas e os costumes dos povos greco-orientais foram os principais fatores que fizeram com que muitos dos dispositivos da lex Iulia et Papia perdessem a validade e fossem ab-rogados, porém não significa que a procriação tenha deixado de ser uma preocupação e o "Estado" romano tenha tornado secundário o interesse no seu controle e incentivo. 


\section{RESUMO}

O presente trabalho pretende apresentar um estudo das denominadas leis matrimoniais de Augusto à luz do interesse público, proposto como critério históricojurídico para expor e auxiliar a compreensão dos tão multifacetados quanto fragmentados textos que a nós chegaram.

Conhecidos assim, por diversos estudos notórios (de FERRINI, JÖRS, BOUCHÉLeclercQ, Nardi, Solazzi, Gaudemet, Orestano, Dalla, Volterra, Astolfi, ZabŁocka, Spagnuolo Vigorita) os escopos demográficos, moralizantes, matrimoniais, fiscais ou caducários, protetivos das ordens romanas, religiosos e outros, adotou-se metodologicamente a procreatio como um instituto propício, dada a sua natureza interdisciplinar e, ao mesmo tempo, um dos fundamenta rei publicae. Ou seja, os diversos assuntos inclusos na complexa legislação de Augusto são apresentados a partir deste que se apresenta como o mais genérico e recorrente interesse da res publica.

Na primeira parte do trabalho, faz-se a análise terminológica de procreatio e sua relação com a temática jurídica referente ao assunto (ius naturale, familia, matrimonium legitimum, ordines, civitas). Também se apresenta um estudo da expressão liberorum quaerendorum [procreandorum] causa que indicava a procriação como principal finalidade do matrimônio.

Na segunda parte, como corte temporal ao trabalho, propõe-se uma periodização apropriada especificamente à procreatio, desde as origens de Roma até o auge da predominância da utilitas publica sobre o instituto, ocorrido com a promulgação das leis matrimoniais, razão final do presente estudo.

Da análise das fontes literárias e jurídicas pertinentes a cada um dos períodos propostos, extraíram-se importantes consequências para a compreensão dos fenômenos e conceitos que exerceram influência nas politicas militares, censórias e imperiais. Conceitos como de nequitia, mali mores, matrimônio, materfamilias, adultério, stuprum, capacitas sucessória, ius liberorum e dote, harmonizaram-se em uma unidade histórica. 


\section{RIASSUNTO}

Questo lavoro oggettiva sviluppare um studio delle cosidette leggi matrimoniali di Augusto alla luce dell'interesse pubblico, proposto come critério storico-giuridico per esporre e ausiliare la comprensione degli abbastanza multifacettati e frammentari testi che ci sono arrivati.

Conosciuti, così, per diversi studii di notorietà (di FERRINI, JÖRS, BOUCHÉLeclercQ, Nardi, Solazzi, Gaudemet, Orestano, Dalla, Volterra, Astolfi, Zabeocka, Spagnuolo Vigorita) gli scoppi demografici, moralizanti, matrimoniali, fiscali oppure caducarii, protettivi delle ordine romane, religiosi ed altri, si è adopperato in linea di método la procreatio come un istituto propicio, data la sua natura interdisciplinare e, allo stesso tempo, uno dei fundamenta rei publicae. Ossia, i diversi temi inclusi nella complessa legislazione di Augusto sono presentati a partire di questo che si presenta come il più generico e ricorrente interesse della res publica.

Nella prima parte del lavoro, si fa l'indagine terminológica di procreatio ed il suo rapporto colla tematica giuridica riguardanti il tema (ius naturale, familia, matrimonium legitimum, ordines, civitas). Si presenta pure uno studio dell'espressione liberorum quaerendorum [procreandorum] che indicava la procreazione come il principale fine del matrimonio.

Nella seconda parte, come limite temporale del lavoro, si propone uma periodizazzione adatta specificamente alla procreatio, dalle origini di Roma fino all'apogeo della prevalenza dell'utilitas publica sull'istituto, averata colla promulgazione delle leggi matrimoniali, raggione finale di questo studio.

Dell'indagine delle fonti letterarie e giuridiche riguardanti ciascuno dei periodi proposti, si sono tolte rilevanti conseguenze per la comprensione dei fenomeni e concetti che hanno influenzato le politiche militari, censorie ed imperiali. Concetti come nequitia, mali mores, matrimonio, materfamilias, adulterio, stuprum, capacitas sucessoria, ius liberorum e dote, si sono armonizzati in una unità storica. 


\section{BIBLIOGRAFIA}

ACCARIAS, Calixte. Précis de Droit Romain, $4^{\mathrm{a} e d ., ~ t .1, ~ P a r i s, ~ C o t i l l o n, ~} 1886$.

Agati Madeira, Eliane Maria. A condição jurídica das sacerdotisas de Vesta, in Revista da Faculdade de Direito da USP 103 (2008), pp. 91-111.

- A Censura na Antiga Roma, in Revista da Faculdade de Direito de São Bernardo do Campo 14 (2008), pp.149-162.

. Advogadas Romanas Republicanas, in Revista da Faculdade de Direito da USP 101 (2006), pp.87-107.

. A 'Lex Oppia' e a condição jurídica da mulher na Roma republicana, in Revista da Faculdade de Direito de São Bernardo do Campo 12 (2006), pp.161-172.

Albertario, Emilio. Conceptus pro iam nato habetur, in Studi di diritto romano, vol.1, Milano, Giuffrè, 1933, pp.1-60.

. Honor matrimonii e affectio maritalis, in Studi di diritto romano, vol.1, Milano, Giuffrè, 1933, pp.197-210.

. Matrimonio (Roma), in Enciclopedia Italiana 12 (1934), pp.580-582;587-588.

. La definizione del Matrimonio secondo Modestino, in Studi di diritto romano, vol.1, Milano, Giuffrè, 1933, pp.181-193.

ALFONSI, Luigi. Tre aspetti del costume romano, in La rivoluzione romana Inchiesta tra gli antichisti, Napoli, Jovene, 1982. 
AmirAnte, Luigi. Una storia giuridica di Roma - Dai re a Cesare, Napoli, Jovene, 1987.

AnKum, Hans. La 'captiva adultera'. Problèmes concernant l'accusatio adulterii en droit romain classique, in RIDA 32 (1985), pp.153-205.

ARANGIO-RuIZ, Vincenzo. Istituzioni di diritto romano, 14ª ed., Napoli, Jovene, 2006. . Storia del diritto romano, $5^{\mathrm{a}} \mathrm{ed}$., Napoli, Jovene, 1947.

ArgüEllo, Luis Rodolfo, Manual de Derecho Romano - Historia e instituciones, $3^{\mathrm{a} e d .}$, Buenos Aires, Astrea, 1993.

ARIAS Ramos, José. Derecho Romano - Obligaciones (fuentes, garantía, cesion y extinción), Derecho de Familia, Derecho de Sucesiones. Madrid, vol.2, 4ªed., Revista de Derecho Privado, 1940.

ASTOLFI, Riccardo. Femina probrosa, concubina, mater solitaria, in SDHI 31 (1965), pp.15-60.

. I bene vacanti e la legislazione caducaria, in BIDR 68 (1965).

. Il matrimonio nel diritto romano classico, Padova, CEDAM, 2006.

. Il matrimonio nel diritto romano preclassico, Padova,

CEDAM, 2000.

. La Lex Iulia et Papia, 4ªd., Padova, CEDAM, 1996.

. Le exceptae personae nella lex Iulia et Papia, in BIDR 67 (1964), pp. 220-226. 
. Note per una valutazione storica della 'Lex Iulia et Papia', in SDHI 39 (1973), pp. 187-238.

BACCARI, Maria Pia. Persona e famiglia: concetti e principi giuridici contra le astrazioni e l'individualismo, in Revista Brasileira de Direito Comparado 27 (2005), pp.19-43.

Bailly, Anatole; Breal, Michel. Dictionnaire étymologique latin, $11^{\mathrm{a}} \mathrm{ed} .$, Paris, Hachette, [s.d.].

BESNIER, Robert. L'application des lois caducaires d'Auguste d'après le gnomon de l'idiologue, in RIDA 2 (1949), pp.93-118.

. L'extension des lois caducaires aux fidéicommis d'après Gaius Institutes II,286 et 286a, in Mélanges Henri Levy-Bruhl, Paris, Sirey, 1959, pp.25-28.

Betancourt, Fernando. Derecho Romano Clásico, Sevilla, Universidad de Sevilla, 2001.

BETTI, Emilio. Istituzioni di diritto romano, 2a ed., vol.1, Padova, CEDAM, 1947.

Bevilácqua, Clóvis. Direito de Família, 7ªed., Rio de Janeiro, Rio, 1976.

BIONDI, Biondo. La legislazione di Augusto. Leggi matrimoniali in Scritti Giuridici II - Diritto romano, Milano, Giuffrè, 1965, pp.128-161.

Istituzioni di diritto romano, Milano, Giuffrè, 1946.

Bonfante, Pietro. Corso di diritto romano - Diritto di famiglia, vol.1, Milano, Giuffrè, 1963.

. Istituzioni di diritto romano, Firenze, G. Barbèra, 1896.

. Storia del diritto romano, $4^{\mathrm{a}} \mathrm{ed}$., vol.1, Milano, Giuffrè, 1958. 
Bornecque, Henri; Mornet, Daniel. Rome et les Romains, Paris, Delagrave, s.d., trad. Port. De Alceu Dias Lima, Roma e os Romanos - Literatura, História, Antigüidades, São Paulo, EPU, 1977.

BouchÉ-LeClercQ, Auguste. Les lois démographiques d'Auguste, in RH 57 (1895), pp.241-292.

Bove, Lucio. Caduca, in NNDI 2 (1964), pp.661.

BRANCA, Giuseppe. Adozione (Diritto romano), in ED 1 (1958), pp.579-581. . Adulterio (Diritto romano), in ED 1 (1958), pp.620-622.

Bretone, Mario. Storia del diritto romano, trad. port. de Isabel Teresa Santos e Hossein Seddighzadeh Shooja, História do Direito Romano, Lisboa, Estampa, 1998.

BRINI, Giuseppe. Matrimonio e divorzio nel diritto romano, 3 vol., Bologna, Nicola Zanichelli, 1887.

BURDESE, Alberto. Il concetto di 'ius naturale' nel pensiero della giurisprudenza classica, in RISG 90 (1954), pp.407-421. . Manuale di diritto privato romano, Torino, UTET, 1964.

Calderini, Aristide. Antichità private, in Vicenzo UsSani e Francesco Grimaldi (org.), Guida allo studio della civiltà romana antica, vol.2, Napoli, Istituto Editoriale del Mezzogiorno, 1954, pp.9-63.

Canela, Kelly Cristina. $O$ 'stuprum per vim' no Direito Romano, Tese (Doutorado) - Faculdade de Direito da USP, São Paulo, 2009, pp.1-171.

CANTARella, Eva. Famiglia romana e demografia sociale - Spunti di riflessione critica e metodologica, in IURA 43 (1992), pp.99-111. 
- Matrimonio e sessualità nella Roma repubblicana: una storia romana di amore coniugale, in Diritto e sessualità in Grecia e a Roma, Milano, CUEM, 2003, pp.109-130.

. Sui rapporti fra matrimonio e 'conventio in manum', in RISG 93 (1959-1962), pp.181-228.

CARCOPINO, Jérôme. La vie quotidienne à Rome à l'apogée de l'Empire, 1937, trad. port. de António José Saraiva, A vida quotidiana em Roma no apogeu do Império, Lisboa, Livros do Brasil, s.d.

CASTELl, Giuseppe. Il concubinato e la legislazione augustea, in BIDR 27 (1915), pp.55-71.

CAstro CorrêA, Alexandre Augusto de. O Estoicismo no Direito Romano, Dissertação (Livre Docência) - Faculdade de Direito da USP, São Paulo, 1950, pp.1-123.

Catalano, Pierangelo. Diritto e Persone, Torino, G. Giappichelli, 1990.

. Diritto, soggetti, oggetti: um contributo alla pulizia concettuale sulla base di D.1,1,12, in Iuris Vincula - Studi in onore di Mario Talamanca II, Napoli, Jovene, 2001, pp. 97-117.

. El concebido 'sujeto de derecho' según el sistema jurídico romano, in Direito de Família no Novo Milênio - Estudos em homenagem ao Professor Álvaro Villaça Azevedo, São Paulo, Atlas, 2010, pp.393-414.

. 'La famiglia sorgente della storia' secondo Giorgio La Pira, in INDEX 23 (1995), pp.25-29.

. Populus romanus quirites, Torino, Giappichelli, 1974.

. Religione morale diritto nella prospettiva dello 'Ius 
Romanum' (Da Tertulliano ad Alfonso Maria de Liguori), in Nozione formazione e interpretazione del diritto. Dall'Età romana alle esperienze moderne - Ricerche dedicate al professor Filippo Gallo, vol.3, Napoli, Jovene, 1997, pp.393-404.

Cejador y Frauca, Julio. Diccionario Etimológico-Analítico Latino-Castellano, Madrid, Sucesores de Rivadeneyra, 1926.

Cerami, Pietro. Breviter su Iul. D.1,3,32 (Riflessioni sul trinômio 'Lex', 'Mos', 'Consuetudo'), in Nozione formazione e interpretazione del diritto. Dell'età romana alle esperienze moderne - Ricerche dedicate al professor Filippo Gallo, vol.1, Napoli, Jovene, 1997, pp.117-137.

Il 'princeps' e la cura 'legum et morum', in Pietro CERAMI, Alessandro Corbino, Antonino Metro e Gianfranco PURPuRA, Ordinamento costituzionale e produzione del diritto in Roma antica - Il fondamenti dell'esperienza giuridica occidentale, $2^{\mathrm{a}} \mathrm{ed}$., Napoli, Jovene, 2006.

CÉSAR Da Silveira, Valdemar. Dicionário de Direito Romano, vols.1 e 2, São Paulo, José Bushatsky, 1957.

ChIAZZeSE, Lauro. Adulterio (Diritto romano), in NNDI $1^{1}$ (1957), pp.322-323.

CIPRIANi, Giovanni e Fedeli, Paolo. Vivere a Roma antica - Antologia latina per il bienio, Roma-Bari, Laterza, 1995.

Cogliolo, Pietro. Storia del diritto privato romano (Dalle origini all'Impero), vol.2, Firenze, G. Barbèra, 1889.

CoRnIL, Georges. Droit Roman, Bruxelles, Medicale et Scientifique, 1921.

CôRreA, Alexandre, O conceito de 'ius naturale', 'gentium et civile' no Direito Romano, São Paulo, Odeon, 1934. 
correspondência com os artigos do Código Civil Brasileiro, vol.1, São Paulo, Saraiva, 1949. . Manual de Direito Romano: Institutas de Gaio e de Justiniano vertidas para o português, em confronto com o texto latino, vol.2, São Paulo, Saraiva, 1951.

CORTES, Viviana Cecilia. Alcance del 'consensus' del 'paterfamilias' en el matrimonio de su filia in potestate, in El Derecho de Familia: De Roma al Derecho actual, Huelva, Universidad de Huelva, 2004, pp.89-97.

CruZ, Sebastião. Direito Romano (Ius Romanum) - Introdução. Fontes, $4^{\mathrm{a}} \mathrm{ed}$. vol.1, Coimbra, Coimbra, 1984.

Cruz e Tucci, José Rogério; Azevedo, Luis Carlos de. Lições de História do Processo Civil Romano, São Paulo, RT, 2001.

CuencA, Humberto. Proceso Civil Romano, Buenos Aires, Jurídicas EuropaAmérica, 1957.

CUQ, Édouard. Les Institutions juridiques des romans, 2a ed., t.1, Paris, PlonNourrit, 1904.

. Les lois d'Auguste sur les declarations de naissance, in Mélanges Fournier, Paris, Sirey, 1929, pp.119-133.

Dalla, Danilo. D. 50,16,135: Sui perché di uma 'Lex Specialis', in Iuris VinculaStudi in onore di Mario Talamanca II, Napoli, Jovene, 2001, pp. 343-352. Introduzione a un Corso Romanistico, $3^{\mathrm{a}} \mathrm{ed}$., Torino, Giappichelli, 1997.

; LAMBertini, Renzo. Istituzioni di diritto romano, Torino, G. Giappichelli, 1996. 
. La vecchiaia nelle fonti giuridiche romane, in Ricerche di diritto delle persone, Torino, G. Giappichelli, 1995, pp.65-110.

. L'incapacità di procreare nell'adozione e nella tutela, in Ricerche di diritto delle persone, Torino, G. Giappichelli, 1995, pp.111-151.

- Status e rilevanza dell'ostentum, in Ricerche di diritto delle persone, Torino, G. Giappichelli, 1995, pp.29-46. ( = in, Sodalitas - Scritti in onore di Antonio Guarino, vol.2, Napoli, Jovene, 1984, pp.519-532).

D’Amati, Laura. Matrimonium e Postliminium: Brevi considerazioni, in Revista da Faculdade de Direito da USP 98 (2003).

Daviault, André. Le 'mos maiorum', in J. GAILlARD (org.) Rome Ier siècle av. J.C. - Ainsi périt la République des vertus..., Paris, Autrement, 1996, pp.58-71.

DAZA MARTíNEZ, Jesús. La influencia cristiana en la concepción postclásica y justinianea del matrimonio romano, in El Derecho de Familia: De Roma al Derecho actual, Huelva, Universidad de Huelva, 2004, pp.109-148.

Della Corte, Francesco. Le 'leges Iuliae' e l'elegia romana, in ANRW II.30 (1981), pp.539-558.

De MARTINO, Francesco. Famiglia (Diritto Romano), in NNDI 7 (1957), pp.42-46. . Individualismo e Diritto Romano Privato, in Annuario di Diritto Comparato e di Studi Legislativi, vol. 16, fasc. $1^{\circ}$, Roma, Istituto Italiano di Grazia e Giustizia, 1941, trad. esp. de Fernando Hinestrosa, Individualismo y Derecho Romano Privado, Bogotá, Universidad Externado de Colombia, 1991.

Storia della costituzione romana, vol.4.1, Napoli, Jovene, 1974. 
D’ERCOLE, Giuseppe. Il consenso degli sposi e la perpetuità del matrimonio nel diritto romano e nei padri della Chiesa, Roma, Apollinaris, 1939.

De Salvo, Lietta. Sul problema della 'vacatio' dei 'naviculari', in Sodalitas Scritti in onore di Antonio Guarino, vol.4, Napoli, Jovene, 1984, pp. 1645-1657.

DE VISSCHER, Fernand. 'Conubium' et 'Civitas', in IURA 2 (1951), pp.140-144.

Domínguez LóPeZ, Esther. La impotencia en las 'Leges Iulia et Papia Poppaea', in El derecho de Familia: De Roma al Derecho Actual, Huelva, Universidad de Huelva, 2004, pp. 167-175.

D’ORs, Álvaro. Elementos de Derecho Privado Romano, 2aed., Pamplona, EUNSA, 1975.

DURRY, Marcel. Le mariage des filles impubères dans la Rome Antique, in RIDA 2 (1955), pp.263-273.

. Sur le mariage romain - Autocritique et mise au point, in RIDA 3.3 (1956), pp.227-243.

Ellul, Jacques. Histoire des Institutions, Paris, Presses Universitaires de France, 1961-1972, trad. it. de Giovanni Ancarani e Elisa Nicolini, Storia delle instituzioni L'antichità, Milano, U.Mursia, 1981.

ERnout, Alfred e MeIllet, Antoine. Dictionnaire Etymologique de la Langue Latine - Histoire des mots, vol.1, 3ªed., Paris, C. Klincksieck, 1951.

ESMEIN, Adhémar. Le délit d'adultére a Rome et la loi Julia de Adulteriis, in Mélanges d'Histoire du Droit et de critique - Droit Romain, Paris, L. Lorose et Forcel, 1886, pp.71-169.

FAYER, Carla. La familia romana - Aspetti giuridici ed antiquari. Sponsalia matrimonio dote, vol.2, Roma, L’Erma di Bretschneider, 2005. 
Fernandez De Bujan, Antonio. Derecho Publico Romano, 2aed., Madrid, Civitas, 1997.

FERRETTI, Paolo. In rerum natura esse in rebus humanis nondum esse - L'identità del concepito nel pensiero giurisprudenziale classico, Milano, Giuffrè, 2008.

FERRINI, Contardo. I commentari di Terenzio Clemente e di Gaio 'ad legem Iuliam et Papiam', in Opere di Contardo Ferrini, vol.2, Milano, Ulrico Hoepli, 1929, pp.251-268. . I commentari di Ulpiano e di Paolo 'ad legem Iuliam et Papiam', in Opere di Contardo Ferrini, vol.2, Milano, Ulrico Hoepli, 1929, pp.237-249.

FIELD JR., James Alfred. The purpose of the 'Lex Iulia et Papia Poppaea', in CJ 40 (1945), pp.398-416.

FRANCIOSI, Gennaro. Clan gentilizio e strutture monogamiche - Contributo alla storia della famiglia romana. (Corso di diritto romano II), Napoli, Jovene, 1976. . Corso istituzionale di diritto romano, $2^{\mathrm{a}} \mathrm{ed}$, Torino, Giappichelli, 1997. . Famiglia e persone in Roma Antica - Dall' età arcaica al Principato, $3^{\mathrm{a}}$ ed., Torino, Giappichelli, 1995. . Manuale di storia del diritto romano, $3^{\mathrm{a}}$ ed., Napoli, Jovene, 2005.

FuMAgalli, Marcella Balestri. Spes vitae, in SDHI 49 (1983), pp.337-358. Sponsali (Diritto romano), in ED 43 (1990), pp.500509.

GAFFIOT, Félix. Dictionnaire Latin-Français, Paris, Hachette, 2000. 
GALINSKY, Karl. Augustan Culture, New Jersey, Princeton University, 1996.

. La ciudad de Roma en la epoca de Augusto, in Actas del XIII

Simposio Nacional de Estudios Clasicos (19-23 setiembre de 1994), vol.1, La Plata, Universidad Nacional de La Plata, 1996, pp. 13-26.

GARCÍA GARrido, Manuel Jesús. Diccionario de Jurisprudencia Romana, $3^{\mathrm{a} e d .}$, Madrid, Dykinson, 1990. . Minor Annis XII Nupta, in LABEO 3 (1957), pp.76-88.

Gaudemet, Jean. Droit privé romain, 2a ed., Paris, Montchrestien, 2000.

- Iustum Matrimonium, in Études de droit romain. III. Vie familiale et vie sociale, Napoli, Jovene, 1979, pp. 105-162 (= in RIDA 3 (1950), pp.309366).

. L'Apport du droit romain, in Claude Bontems (org.), MariageMariages, Paris, Presses Universitaires de France, 2001, pp.31-39.

. Originalité et destin du mariage romain, in L'Europa e il Diritto Romano. Studi in memoria di Paolo Koschaker, vol.2, Milano, 1954.

. Utilitas Publica, in Études de droit romain. II. Institutions et doctrines politiques, Napoli, Jovene, 1979, pp.163-197 (= RHD 29 (1951), pp.465-499).

GIL, Luis. Censura en el mundo antiguo, $2^{\mathrm{a}}$ ed., Madrid, Alianza, 1985.

GIUfFrè, Vincenzo. Il 'Diritto pubblico' nell'esperienza romana, 2a ed., Napoli, Jovene, 1989.

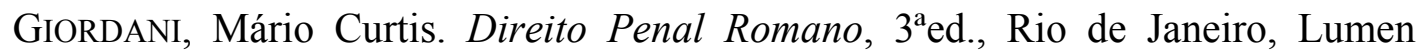


Juris, 1997.

. História de Roma, $16^{\mathrm{a}}$ ed., Petrópolis, Vozes, 2005.

. Iniciação ao Direito Romano, 5aed., Rio de Janeiro,

Lumen Juris, 2003.

. O Código Civil à Luz do Direito Romano. Parte Especial,

Livro I. Do Direito de Família, Rio de Janeiro, Lumen Juris, 1996.

. O Novo Código Civil à Luz do Direito Romano - Parte

Geral, Rio de Janeiro, Lumen Juris, 2005.

GIUNTI, Patrizia. 'Consors vitae' - Matrimonio e ripudio in Roma antica, Milano, Giuffrè, 2004.

- 'Mores' e 'Interpretatio prudentium' nella definizione di 'materfamilias' (una qualifica fra 'conventio in manum' $e$ 'status' di 'sui iuris'), in Nozione formazione e interpretazione del diritto. Dell'età romana alle esperienze moderne - Ricerche dedicate al professor Filippo Gallo, vol.1, Napoli, Jovene, 1997, pp.322-329.

Gourevitch, Danielle. Se marier pour avoir des enfants: le point de vue du Médecin, in Parenté et strategies familiales dans l'Antiquité romaine. Actes de la table ronde (Paris, 2-4 octobre 1986), Rome, École Française de Rome, 1990, pp.139-151.

GuARINO, Antonio. Diritto privato romano, 12a ed., Napoli, Jovene, 2001.

. Gli aspetti giuridici del principato, in ANRW II.13 (1980), pp.3-60.

. Profilo del diritto romano, $8^{\mathrm{a}}$ ed., Napoli, Jovene, 1994.

. Storia del diritto romano, $12^{\mathrm{a} e d ., ~ N a p o l i, ~ J o v e n e, ~} 1998$. 
HuMBERT, Michel. L'individu, l'État: quelle stratégie pour le mariage classique?, in Parenté et strategies familiales dans l'Antiquité romaine. Actes de la table ronde (Paris, 2-4 octobre 1986), Rome, École Française de Rome, 1990, pp.173-198.

IGLESIAS, Juan. Derecho Romano, 13ªed., Madrid, Ariel, 2001. Las fuentes del Derecho romano, Madrid, Civitas, 1989.

IMPALLOMENI, Giambattista. In tema di vitalità e forma umana come requisiti essenziali alla personalità, in Scritti di diritto romano e tradizione romanistica Giambatista Impallomeni, Padova, CEDAM, 1996, pp.269-285 ( = IURA 22 (1971), pp.99120).

JAGU, Amand. Musonius Rufus - Entretiens et Fragments. Introduction, traduction et comentaire, New York, Georg Olms, 1979.

JHERING, Rudolf von. Der Geist des römischen Rechts - Auf den Verschiedenen Stufen seiner Entwicklung, trad. port. Rafael Benaion, O Espírito do Direito Romano - Nas diversas fases de seu desenvolvimento, v.1, Rio de Janeiro, Alba, 1943.

JÖRS, Paul. Die Ehegesetze des Augustus, Marburg, N.G. Elwert, 1894.

JURET, Abel. Dictionnaire étimologique grec et latin, Macon, Protat Frères, 1942.

KASER, Max. Ius gentium, Köln, Böhlau, 1993, trad. esp. de Francisco Javier Andrés Santos, Ius gentium, Granada, Comares, 2004.

. Römisches Privatrecht, München, 1992, trad. port. de Samuel Rodrigues e Ferdinand Hämmerle, Direito Privado Romano, Lisboa, Fundação Calouste Gulbenkian, 1999.

Klabin, Aracy Augusta Leme. Estudos sobre as Leis Caducárias, in Revista da Faculdade de Direito da USP 92 (1997), pp.25-30. (= Revista de Direito Civil, Imobiliário, Agrário e Empresarial 72 (1995), pp.7-10). 
. Observações sobre a sanção ('sanctio') das leis em Direito Romano, in Revista de Direito Civil, Imobiliário, Agrário e Empresarial 68 (1994), pp.7-11.

LAMBrinI, Paola. L'elemento soggetivo nelle situazioni possessorie nel diritto romano classico, Padova, CEDAM, 1998.

LANFRANCHI, Fabio. Il diritto nei retori romani - Contributo alla storia dello sviluppo del diritto romano, Milano, Giuffrè, 1938.

. Le definizioni e il concetto del matrimonio nei retori romani, in SDHI 2 (1936), pp.148-157.

Langlands, Rebecca. Sexual Morality in Ancient Rome, Cambridge-New York, Cambridge University, 2006.

LAURENTI, Renato. Musonio, maestro di Epitteto, in ANRW II.36 (1989), pp.21052146

Lauria Tucci, Rogério. Lineamentos do Processo Penal Romano, São Paulo, José Bushatsky, 1976.

Lima Filho, Acácio Vaz de. As constituições imperiais como fonte do Direito Romano, São Paulo, Ícone, 2006.

LONGO, Giannetto. Affectio maritalis, in BIDR 46 (1939), pp.119-141.

. Lex Julia de Adulteris Coercendis; Lex Julia de Maritandis Ordinibus e Lex Papia Poppaea, in NNDI 9 (1957), pp.810-811.

. Per l'interpretazione del fr. 24 D.1,5, in IURA 18.1 (1967), pp.20-27. 
. Riflessioni critiche in tema di matrimonio, in Sodalitas - Scritti in onore di Antonio Guarino, vol.5, Napoli, Jovene, 1984, pp. 2357-2394.

- Sullo scioglimento del matrimonio per volontà del 'paterfamilias', in BIDR 40 (1932), pp.201-224. . Utilitas publica, in LABEO 18.1 (1972), pp.7-71.

LÓPEZ PEDREIRA, Adela. Limitaciones a la 'libertas nuptialis' en la legislación Augustea, in El Derecho de Familia: De Roma al Derecho actual, Huelva, Universidad de Huelva, 2004, pp.391-405.

LURASCHI, Giorgio. Sulla data e sui destinatari della 'Lex Minicia de liberis', in SDHI 42 (1976), pp.431-443.

MAdeIRA, Hélcio Maciel França. À História do Direito, in Revista da Faculdade de Direito de São Bernardo do Campo 10 (2004), pp.149-154.

. Digesto de Justiniano Liber primus - Introdução ao Direito Romano, $4^{\mathrm{a} e d}$., São Paulo, RT, 2009. (Prólogo de CATALANO, Pierangelo).

. O Nascituro no Direito Romano - Conceito,

Terminologia e Princípios, São Paulo, Editora Nacional, 2005.

Magdelain, André. Auctoritas principis, Paris, Les Belles Lettres, 1947.

MALdonAdo De LizALde, Eugenia. lex Iulia de maritandis ordinibus. Leyes de familia del emperador César Augusto, in Anuario Mexicano de Historia del Derecho 14 (2002), pp. 538-645.

ManCINI, Giovanna. Cives romani municipes latini, vol.1, Milano, Giuffrè, 1997.

MAnzo, Annamaria. Sull'origine del divieto di donazioni tra coniugi, in LABEO 37.3 (1991), pp. 342-350. 
MARCHI, Eduardo César Silveira. Matrimônio moderno e matrimônio romano clássico - divórcio e "Soneto de Fidelidade", in Direito de Família no Novo Milênio Estudos em Homenagem ao Professor Álvaro Villaça Azevedo, São Paulo, Atlas, 2010, pp.53-67.

Margadant, Guillermo Floris. El Derecho Romano como introducción a la cultura juridica contemporanea, $4^{\mathrm{a}}$ ed., Mexico D.F., Esfinge, 1970.

MARKY, Thomas. Appunti sul problema della retroattività delle norme giuridiche nel diritto romano, in BIDR 53-54 (1948), pp.241-271.

. Curso Elementar de Direito Romano, $8^{\mathrm{a} e d ., ~ S a ̃ o ~ P a u l o, ~ S a r a i v a, ~}$ 2007.

MARrone, Matteo. Istituzioni di diritto romano, $3^{\mathrm{a}}$ ed., Palermo, Palumbo, 2006.

Matos PeIXoto, José Carlos de. Convivência no matrimônio romano, in Romanitas 1, Rio de Janeiro, 1958, pp.19-30.

. Curso de Direito Romano - Tomo I - Partes introdutória e geral, Rio de Janeiro, Renovar, 1997.

MAY, Gaston. Éléments de Droit Romain a l'usage des étudiants des Facultés de Droit, $17^{\mathrm{a} e d .}$, Paris, Recueil Sirey, 1927.

MeIRA, Sílvio Augusto de Bastos. A legislação romana do divórcio, in RT 309 (1961), pp.7-25. . A Lei das XII Tábuas - Fonte do Direito Público e Privado, $3^{\mathrm{a}}$ ed., Rio de Janeiro, Forense, 1972. . Curso de Direito Romano - História e Fontes,

São Paulo, Saraiva, 1975. 
Mette-Dittmann, Angelika. Die Ehegesetze des Augustus - Eine Untersuchung im Rahmen der Gesellschaftspolitik des Princeps, Stuttgart, Franz Steiner, 1991.

MoLÈ, Marcello. Stuprum, in NNDI 18 (1957), pp.582-587.

MommSEN, Theodor. Römisches Strafrecht, Leipzig, 1899, trad. esp. de P. Dorado, Derecho Penal Romano, Santa Fé de Bogotá, Temis, 1999.

MONIER, Raymond. Manuel élémentaire de droit romain, 6aed., t.1, Paris, Domat Montchrestien, 1947.

Moreira Alves, José Carlos. A forma humana no Direito Romano, in Estudos de Direito Romano, Brasília, Senado Federal, 2009, pp.101-153.

- A natureza jurídica do Casamento Romano no Direito Clássico, in Estudos de Direito Romano, Brasília, Senado Federal, 2009 (= in Revista de Direito Civil, Imobiliário, Agrário e Empresarial, v.17, n.63, (1993), pp.7-36).

. Direito Romano, $14^{\mathrm{a}} \mathrm{ed}$., Rio de Janeiro, Forense, 2007.

. J.E. Labbé e a natureza jurídica do casamento romano, in Revista da Faculdade de Direito da USP 74 (1979), pp.109-117.

NARDI, Enzo. Aborto e omicidio nella civiltà classica, in ANRW II.13 (1980), pp.366-385.

. La 'incapacitas' delle 'feminae probrosae', in SSA 17 (1939), pp. $151-178$.

. La reciproca posizione succesoria dei coniugi privi di 'Conubium', Milano, Giuffrè, 1938. 
. Sui divieti matrimoniali delle leggi Augustee, in SDHI 7 (1941), pp.112-146.

NÉRAudAu, Jean-Pierre. Auguste - La Brique et le Marbre, Paris, Les Belles Lettres, 1996.

NicoletTI, Adele. Constitutiones Principum, in NNDI 4 (1957), p.295.

. Dote (Diritto romano), in NNDI 6 (1960), pp. 257-259.

NÖRR, Dieter. The Matrimonial Legislation of Augustus: An early instance of social engineering, in The Irish Jurist 16.1 (1981), pp.350-364.

NúÑez PAZ, María Isabel. Consentimiento Matrimonial y Divorcio en Roma, Salamanca, Universidad de Salamanca, 1988.

ONIDA, Pietro Paolo. Studi sulla condizione degli animali non umani nel sistema giuridico romano, Torino, Giappichelli, 2002.

Orestano, Riccardo. Alcune considerazioni sui rapporti fra matrimonio Cristiano e matrimonio romano nell'età postclassica, in Scritti di diritto romano in onore di Contardo Ferrini, Milano, Ulrico Hoepli, 1946, pp.343-382.

. La struttura giuridica del matrimonio romano - Dal diritto classico a diritto giustinianeo, in BIDR 47 (1940), pp.154-402; 48 (1941), pp. 88-133; 57 (1952), pp.185-395. (=La struttura giuridica del matrimonio romano - Dal diritto classico a diritto giustinianeo, Milano, Giuffrè, 1951).

Ortín García, Carmen. Edad, Matrimonio y 'Lex Iulia et Papia Poppaea', in El Derecho de Familia: De Roma al Derecho actual, Huelva, Universidad de Huelva, 2004, pp.507-518.

PACChIOnI, Giovani. Corso di diritto romano, vol.3, Roma-Torino-Napoli, UTET, 1922. 
PaOlI, Ugo Enrico. Matrimonio (Roma), in Enciclopedia Italiana 12 (1934), pp.581-582.

PePpe, Leo. Recensione a Patrizia Giunti, 'Consors vitae' - Matrimonio e ripudio in Roma antica, in IURA 55 (2004-2005), pp.237-249.

. Storie di parole, storie di istituti - Sul diritto matrimoniale romano arcaico, in SDHI 63 (1997), pp.123-196.

PerozZI, Silvio. Istituzioni di diritto romano, $2^{\mathrm{a} e d ., ~ v o l .1, ~ R o m a, ~ A t h e n a e u m, ~} 1928$.

Pessi, Maria Vittoria Giangrieco. Brevi riflessioni sul ruolo della censura nella dialettica costituzionale della prima repubblica, in Societas - Ius, Munuscula di allievi a Feliciano Serrao, Napoli, Jovene, 1999, pp.161-170.

PÉTER, Orsolya Marta. Liberorum quaerendorum causa - L’image idéale $d u$ mariage et de la filiation à Rome, in RIDA 38 (1991), pp.285-331.

Petit, Eugène Henri Joseph. Traité Élémentaire de Droit Romain, 9aed., Paris, Rousseau, 1925, trad. port. de Jorge Luís Custódio Porto, Tratado Elementar de Direito Romano, Campinas, Russell, 2003.

PIERI, Georges. L'Histoire du cens jusqu'a la fin de la République Romaine, Paris, Sirey, 1968.

Pontes De MirandA, Francisco Cavalcanti. Tratado de Direito de Família, vol.1, 3ed., São Paulo, Max Limonad, 1947.

Porchat, Reynaldo. Curso Elementar de Direito Romano, $2^{\mathrm{a} e d ., ~ v o l .1, ~ S a ̃ o ~ P a u l o, ~}$ Melhoramentos, 1937.

PuchtA, Georg Friedrich. Kursus der Institutionem, Leipzig, trad. it. de A. Tenchiarulo, Corso delle istituzioni, vol.1, Napoli, Diogene, 1854. 
Pugliese, Giovanni. Assistenza all'infanzia nel principato e 'piae causae' del diritto romano cristiano, in Sodalitas - Scritti in onore di Antonio Guarino, vol.7, Napoli, Jovene, 1984, pp. 3175-3189.

; SitzIA, Francesco; VACCA, Letizia. Istituzioni di Diritto Romano, 2aed., Torino, G.Giappichelli, 1990.

PUjal, Carmen. La concepción jurídica del matrimonio romano clásico, in El Derecho de Familia: De Roma al Derecho actual, Huelva, Universidad de Huelva, 2004, pp.605-620.

RaditsA, Leo Ferrero. Augustus Legislation Concerning Marriage, Procreation, Love, Affairs and Adultery, in ANRW II.13 (1980), pp.278-339.

RASI, Piero. Consensus facit nuptias, Milano, Giuffrè, 1946.

RATTI, Umberto. Studi sulla 'captivitas' e alcune repliche in tema di 'postlliminio', Napoli, Jovene, 1980.

Ribas-AlbA, José María. La desheredación injustificada en Derecho Romano Querella inofficiosi testamenti: Fundamentos y régimen clásico, Granada, Comares, 1998.

Riccobono, Salvatore. Il diritto romano in America - 'Consuetudo', 'exemplum' nelle fonti giuridiche romane, in BIDR 46 (1939), pp.328-343.

La politica demografica di Augusto, in Capitolium 12 (1937), pp.573-580.

RIzZELLI, Giunio. Alcuni aspetti dell'accusa privilegiata in materia di adulterio, in BIDR 89 (1986), pp.411-441.

. Le donne nell'esperienza giuridica di Roma antica - Il controllo dei comportamenti sessuali. Una raccolta di testi, Lecce, Del Grifo, 2000. 
RobledA, Olís. Cic. De Orat. 1,40,183; 56,283, y el divorcio de Mesalina, in SDHI 42 (1976), pp.424-430.

. El matrimonio en Derecho Romano - Esencia, Requisitos de Validez, Éfectos, Disolubilidad, Roma, Università Gregoriana, 1970.

. Il divorzio in Roma prima di Costantino, in ANWR II.14 (1981), pp.347-390.

. Intorno alla nozione di matrimonio nel diritto romano e nel diritto canonico, in Apollinaris 50 (1977), pp. 172-193.

. Sobre el Matrimonio en Derecho Romano, in SDHI 37 (1971), pp.337-350.

Rocha Pereira, Maria Helena da. Estudos de História da Cultura Clássica Cultura Grega, vol.1, 7ªed., Lisboa, Fundação Calouste Gulbenkian, 1993.

- Estudos de História da Cultura Clássica Cultura Romana, vol.2, Lisboa, Fundação Calouste Gulbenkian, 1984.

Rodrigues, Dárcio Roberto Martins. Aspectos de Interesse Atual do Matrimônio Romano, in Revista da Faculdade de Direito da USP 93 (1998), pp. 81-107.

RomAnO, Angela. Matrimonium Iustum - Valori economici e valori culturali nella storia giuridica del matrimonio, Napoli, Jovene, 1996.

. Omosessualità, amore e potere nella società romana, in LABEO 36.2 (1990), pp. 301-306.

Rotond, Giovanni. Leges publicae populi romani, Hildesheim, Georg Olms, 1966. 
RUIZ FERNANDEZ, Eduardo. El divorcio en Roma, Madrid, Universidad Complutense - Facultad de Derecho, 1988.

Russo RugGeri, Carmela. Ancora sulla donna adottante, in LABEO 36.1 (1990), pp.57-75.

SACCHI, Osvaldo. Il privilegio dell'esenzione della tutela per le vestali (Gai. 1,145), in RIDA 50.3, pp.317-359.

. Le nozioni di stato e di proprietà in Panezio e l'influenza della dottrina stoica sulla giurisprudenza romana dell'epoca scipionico-cesariana, in RIDA 52 (2005), pp.325-357.

SALVAdORE, Marcello. L'adozione di Clodio, in LABEO 38.3 (1992), pp.285-313.

SAMPER, Francisco. Sobre el destino del 'ius liberorum' en el tardo Derecho Romano Occidental, Santiago de Compostela, Universidad de Santiago de Compostela, 1972.

SAVIGNY, Friedrich Carl von. System des heutigen römischen Rechts, trad. it. de V. Scialoja, Sistema del diritto romano attuale, vol.2, Torino, UTET, 1888.

SCACCHETTI, Maria Grazia. La presunzione muciana, Milano, Giuffrè, 2002.

SCARANo UsSAnI, Vincenzo. Appunti di storia del diritto romano - Le origini. La monarchia. La repubblica, Torino, Giappichelli, 1996.

Schulz, Fritz. Classical Roman Law, Oxford, 1951, trad. esp. de José Santa Cruz Teigeiro, Derecho Romano Clásico, Barcelona, Bosch, 1960.

. Prinzipien des römischen Rechts, München-Leipzig, trad. esp. de Manuel Abellán Velasco, Princípios del Derecho Romano, Madrid, Civitas, 1990. 
SCIASCIA, Gaetano. A Concubina no Direito Romano Cristão, in Varietà Giuridiche - Scritti brasiliani di diritto romano e moderno, Milano, Giuffrè, 1956, pp.37-40.

- A lei romana sobre os adultérios, in Varietà Giuridiche Scritti brasiliani di diritto romano e moderno, Milano, Giuffrè, 1956, pp.29-35.

. Divórcio e Direito Romano, in Varietà Giuridiche - Scritti brasiliani di diritto romano e moderno, Milano, Giuffrè, 1956, pp.41-51.

. Eunucos, Castrados e Spadones no Direito Romano, in Varietà Giuridiche - Scritti brasiliani di diritto romano e moderno, Milano, Giuffrè, 1956, pp.111118.

. O Senatoconsulto das Bacanais, in Varietà Giuridiche - Scritti brasiliani di diritto romano e moderno, Milano, Giuffrè, 1956, pp.75-89.

. Regras de Ulpiano: Ulpiani liber singularis regularum, Bauru, EDIPRO, 2002.

SERAFINI, Filippo. Istituzioni di diritto romano comparato col diritto civile patrio, 10ªed., vol.1, Roma, Athenaeum, 1920.

Shotter, David Colin Arthur. Augustus Caesar, London-New York, RoutledgeClays, 1991.

SINI, Francesco. 'Initia Urbis' e sistema giuridico-religioso romano ('ius sacrum'e 'ius publicum' tra terminologia e sistematica), in Roma e America. Diritto romano comune. Rivista di diritto dell'integrazione e unificazione del diritto in Europa e in America Latina 18 (2004), pp.205-222.

SOLAZZI, Siro. Glossemi nelle fonti giuridiche romane, in BIDR 46 (1939), pp.4967.

La legge augustea sul divorzio della liberta e il diritto civile, in 
BIDR 51-52 (1948), pp.327-351.

La liberazione delle vestali dalla tutela in Gai. 1,145, in SDHI 9 (1943), pp.113-116.

. Sui divieti matrimoniali delle leggi augustee, in Scritti di diritto romano (1938-1947), vol.4, Napoli, Jovene, 1963, pp.81-98.

Spagnuolo Vigorita, Tullio. 'Casta domus' - Un seminario sulla legislazione matrimoniale augustea, $3^{\mathrm{a}} \mathrm{ed}$., Napoli, Jovene, 2010.

- La data della lex Iulia de Adulteriis, in Iuris Vincula - Studi in onore di Mario Talamanca VIII, Napoli, Jovene, 2001, pp. 81-96.

; MARotTA, Valerio. La legislazione imperiali. Forme e orientamenti, in Storia di Roma, vol.2, Torino, Giulio Einaudi, 1992.

Surgik, Aloísio. A 'Manus' e o 'Consensus' no Casamento Romano, in El Derecho de Familia: De Roma al Derecho actual, Huelva, Universidad de Huelva, 2004, pp.725741.

Deductio mulieris, in Enciclopédia Saraiva do Direito 23 (1977), pp.14-15.

Talamanca, Mario. Istituzioni di Diritto Romano, Milão, Giuffrè, 1990.

Tello, Juan Carlos. La concesión discrecional por 'princeps' del 'ius trium liberorum' y su reflejo en Marcial, in El Derecho de Familia: De Roma al Derecho actual, Huelva, Universidad de Huelva, 2004, pp.769-777.

VANOYEKE, Violaine. La prostitution en Grèce et à Rome, Paris, Les Belles Lettres, 1990.

Venturini, Carlo. Divorzio informale e 'crimen adulterii' (Per una 
riconsiderazione di D.48,5,44[43]), in IURA 41 (1990), pp.25-51.

VerA-Cruz, Eduardo. Senatus-consulta, in Estudos de Direito Romano, vol.2, Lisboa, Associação Acadêmica da Faculdade de Direito de Lisboa, 1991.

Veyne, Paul. L'Empire Romain. Histoire de la vie privée. I. De l'Empire Romain à l'an mil, Paris, Du Seuil, 1985, trad. it. de Maria Garin, La vita privata nell'impero romano, Roma-Bari, Laterza, 1992.

Villaça Azevedo, Álvaro. Casamento de Fato e Concubinato Atual: Influência do Casamento Romano, in RT 773 (2000), pp.11-37.

Deductio Mulieris in Domum Mariti, in Enciclopédia

Saraiva do Direito 23 (1977), pp.15-17.

. Dever de Coabitação - Inadimplemento, São Paulo,

José Bushatsky, 1976.

VILLERS, Robert. Le mariage envisagé comme institution d'Etat dans le droit classique de Rome, in ANRW II.14 (1981), pp.285-301.

VILLEY, Michel. Le Droit Romain, Paris, Universitaires de France, trad. port. de Fernando Couto, Porto, Resjuridica, 1991.

VINCENTI, Umberto. Categorie del diritto romano, Napoli, Jovene, 2007.

VocI, Pasquale. Istituzioni di diritto romano, Milano, Giuffrè, 2004.

. Teoria dell'acquisto del legato secondo il diritto romano, Milano,

Giuffrè, 1936.

VolTERRA, Edoardo. Adozione (Diritto romano), in NNDI $1^{1}$ (1957), pp.287-288.

. Ancora sull problema della 'familia' romana, in Scritti 
Giuridici II. Famiglia e successioni, Napoli, Jovene, 1991, pp.337-347.

. Concubinato (Diritto romano), in NNDI 3 (1957), pp.10521053. . Divorzio (Diritto romano), in NNDI 6 (1960), pp.62-64.

. Famiglia (diritto romano), in ED 16 (1967), pp.723-744 (= in Scritti Giuridici III. Famiglia e successioni, Napoli, Jovene, 1991, pp.133-153).

. Istituzioni di diritto privato romano, Roma, La Sapienza, "s.d.".

. La conception du Mariage à Rome, in Scritti Giuridici II.

Famiglia e successioni, Napoli, Jovene, 1991, pp.349-361 (= RIDA 2 (1955), pp. 365-379).

. La conception du Mariage d'après les juristes romains, in Scritti Giuridici II. Famiglia e successioni, Napoli, Jovene, 1991, pp.3-68.

. La 'conventio in manum' e il matrimonio romano, in Scritti

Giuridici III. Famiglia e successioni, Napoli, Jovene, 1991, pp.155-176.

. La nozione giuridica del 'conubium', in Scritti Giuridici II.

Famiglia e successioni, Napoli, Jovene, 1991, pp.283-320.

. Les formes du Mariage chez les Romains, in Scritti Giuridici II. Famiglia e successioni, Napoli, Jovene, 1991, pp.277-282.

. Matrimonio (Diritto Romano), in ED 25 (1975), pp.726-807

(= in Scritti Giuridici III. Famiglia e successioni, Napoli, Jovene, 1991, pp. 223-304).

. Nuove osservazioni sulla 'conventio in manum', in Scritti

Giuridici II, Napoli, Jovene, 1991, pp.199-215. 
. Sui 'mores' della 'familia' romana, in Scritti Giuridici II. Famiglia e sucessioni, Napoli, Jovene, 1991, pp. 179-197.

ZABŁOCKA, Maria. Il 'ius trium liberorum' nel diritto romano, in BIDR 91 (1988), pp. 361-390.

. Le modifiche introdotte nelle leggi matrimoniale Augustee sotto la dinastia Giulio-Claudia, in BIDR 89 (1986), pp. 379-410. 
BOETHIUS

\section{Índice de Fontes}

Comment. in Cic. Topica

3,14 p. 37

\section{I) FONTES LITERÁRIAS}

CASSIODORUS

PSEUDO-ACRON

Chronica

$562-563$ p. 135

Expositio in Horatii Carmen saeculare

20 pp.124;141

Historia ecclesiastica

$1,9,16$ p.149

AeLianus

Catullus

Varia historia

6,6 p. 24

\section{Carmina}

68,15 p. 48

APPIANUS

\section{CICERO}

De bello civili

2,99 p.78

I. Epistulae

$2,10,35$ p. 117

Ad Atticum

$14,20,2$ p. 78

ApUlEIUS

II. Orationes

Apologia

De domo sua

88 p. 225

14-34,36 pp.62;65

Augustinus

Phillipicas

1,12,29 p.137

Sermones

2,18 p.49

91,12; PL, 38,345 p.228

278,9; PL, 38,272 p.228

Pro Cluentio

12,35 p.46 
Pro Marcelo

8,23 p. 117

Pro Murena

Cic. Mur. 12,27 p.37

III. Philosophica

De finibus

5,27,81-82 p.115

De legibus

$2,10,23$ p. 23

$3,3,7$ p.112

De officiis

1,4,11-12 p.12

$1,7,22$ p. 30

1,17,53-54 p.20

1,33,121 p.137

$1,43,153$ p. 45

$2,9,31$ p. 137

3,11-12 p.30

3,20-21 p.30

3,27 p. 30

De re publica

$1,25,39$ p. 19

1,31,47 p.106

2,22,39-40 p.101

2,33 p. 130

2,36-37;61;63 p.94

$3,11,19$ p. 12

Laelius de amicitia

6,20 p. 45

IV. Rhetorica
De inventione

2,22,67 p.23

De oratore

$1,40,183$ pp. $26 ; 70$

$1,56,238$ pp. $26 ; 70$

2,64,260 p.107

Rhetorica ad Herennium

2,19 p. 23

3,3 p.89

\section{Topica}

3,14 pp. $17 ; 37$

4,20 p. 94

6,17,65 p.167

DIONYSIOS HALICARNASENSIS

Antiquitates romanae

2,25,2 p.36

$2,25,7$ p. 111

2,35,1-6 p.99

$3,22,10$ p. 101

4,14,1-2 p.101

4,16,2-5 p.101

4,17,1-4 p.101

4,18,1-3 p.101

4,19,1-2 p.101

4,20,3-5 p.101

Dio CASSIUS

Historiae romanae

10,60 p.94

$38,7,3$ p. 117

43,23,5 p.200

43,25,2 pp.112;118 
48,43,2-3 p.200

$53,13,2$ p. 135

53,21,3-5 p.146

$54,2,5$ p.82

54,10,5-7 p.128

$54,16,1$ pp. $150 ; 186$

$54,16,2$ p. 85

54,16,3-4 p.152

$54,16,6$ p. 186

$54,16,7$ p. 153

$54,30,1$ p.129

$54,30,5$ p. 141

$55,10,12 ; 15$ p.221

$55,13,6$ p. 128

$55,22,5$ p.164

56,1,1-2 p.145

56,2,2 p.99

56,3,1-2 p.145

56,3,1-9 p.145

56,4,1-6 p.145

56,4,2-3 p. 145

56,5,1-3 p.123

56,5,4-7 p.98

$56,6,4$ p.99

$56,6,5$ p. 140

$56,6,6$ p. 223

$56,7,2$ p.85

56,7,3-4 p.146

$56,7,6$ p. 18

56,8,2-3 p.118

$56,10,1$ p. 148

56,10,2 pp.164;176

$56,10,3$ p. 147

$56,23,3$ p. 148

$56,32,4$ p.221

$56,41,6$ p. 119

$56,41,8$ p. 120

$58,2,3$ p. 120

$59,15,1$ p.156

$68,5,4$ p. 121
69,23 p. 160

EUSEBIUS

\section{Vita Constantini}

4,26 p.229

EUTROPIUS

Breviarium historiae romanae

$1,4,7$ p. 101

\section{FESTUS}

De verborum significatu (ed. Lindsay)

Nuptias p.39

Quaeso p.67

Rapi p.98

FLORUS

Epitome T. Livii

4,12,64-65 p.121

59 p. 115

60 p. 115

\section{GELLIUS}

Noctae atticae

1,6,1-2 p.114

$1,12,8$ p.163

1,12,11 p.164

2,15,3-8 p.165

$2,15,4$ p. 61

$3,16,1 ; 7 ; 21$ p.215

$3,16,9$ p. 215

4,3,2 pp.108;109 
4,3,3 p.90

4,20,1-6 p.106

5,19,9 p.65

10,2,2 p.145

$10,15,22$ p.36

10,20,1-3 p.131

$10,23,5$ p. 185

12,10,9 p.24

$17,21,44$ pp.67;109

$18,6,8-9$ p. 16

HoRATIUS

Carmen saeculare

20 pp. $124 ; 143$

\section{Carmina}

3,6,17-20;33-48 p.118

$3,6,17-36 ; 45-48$ p. 125

3,24,17-36 p.125

3,24,25-34 p.118

$3,24,55$ p. 224

4,5,20 p.187

4,5,20-24 p.224

4,15,1-20;25-32 p.122

4,15,4-14 p.224

4,17,13-20 p.141

Epistulae

2,1,1-4 p.122

2,1,3 pp. $122 ; 224$

HIERONYMUS

\section{Chronicon}

ad annum 1971 p.118
ISIDORUS

Etymologiae

5,15,2-5 p.148

9,5,8 p. 17

9,7,3 p.17

IUVENALIS

Satirae

2,29-40 p.227

2,43-47 p.48

6,28-42 p.228

6, 593-597 p.228

9,27;70-90 pp.224;228

LACTANTIUS

Divinae institutiones

$1,16,10$ p.54

LIVIUS

Ab urbe condita

1,9 pp.98;99

1,9,11 p.98

1,43,1-10 p.101

4,1,1 p.94

4,2,6 p.94

4,3,4 p.94

4,4,5 p.94

39,24 p.97 
MACROBIUS

Comment. in somn. Scipionis

$1,6,71$ p.49

Saturnalia

$1,15,19$ p.36

$1,15,22$ p. 46

$1,16,18$ p. 67

$1,16,30$ p. 36

$2,4,18$ p. 135

$2,4,25$ p. 128

$3,8,8$ p. 24

$7,7,6$ p. 50

MARTIALIS

Epigrammata

2,91-92 p.156

3,95 pp. $154 ; 156$

8,31 pp. $154 ; 156$

9,66-67 p.154

10,60 pp. $154 ; 156$

11,12 p. 154

MusONIUS Rufus

diatribe XII pp.41;42

diatribe XIII A p.42

diatribe XIII B p.42

diatribe XIV pp.13;41;44;138

diatribe XV A pp.42;142

OROSIUS

6,22,1-3 p.122
OvIDIUS

Amores

1,4,51-70 p.225

2,4,10 p.224

$3,4,1-12 ; 25-48$ p.225

$3,14,5$ p. 224

3,4,17-18 p.224

$3,11,37-44$ p. 225

Ars amatoria

1,503-522 p.47

1,521-522 p.47

2,151 p. 225

2,357-372 p.225

2,595-600 p.225

2,669-692 p.225

$3,579-588$ p. 225

Metamorphoses

$15,832-834$ p. 130

$15,833-835$ p. 221

Fasti

3,771-788 p.48

Tristia

2,207-212 p.225

2,131-138 p.225

2,233 p. 221

Plautus

Aulularia

2,1,25 p.67

\section{Captivi}

4,2,109 p.67 
PLINIUS SENIOR

Naturalis historia

7,14,61-62 p.54

7,38-39 p.215

$7,95,149$ p.221

8,$48 ; 74 ; 194$ p.36

14,5 p. 181

$18,3,10$ p. 36

$25,7,25$ p. 114

PLINIUS IUNIOR

Epistulae

4,15,1-3 p.24

6,31,4-6 p. 190

$7,16,2$ p.164

10,95 p. 156

Panegyricus

2,15 p.156

26,5-6 pp.120;224

27,1 p. 120

28,6-7 p. 120

34,2 p.226

42,1 pp. $171 ; 228$

PLUTARCHUS

Quaestiones romanae

30 p.36

Vitae parallelae

Camillus

2,3-4 p.103
Cato maior

16 p.106

Cato minor

25,3-12 p.78

Gaius Gracchus

19 p.116

Lycurgi

15,2 p. 112

Numa

12,3 p. 183

26,1-3 p.152

Romulus

22 p.36

29 p. 108

Tiberius Gracchus

1 p.116

POLYBIUS

Historiae

$37,4,6$ p.97

PROPERTIUS

\section{Elegiae}

2,7, 1-6 p.126

2,7,13-14 p.127

4,11,33-48;55-70 p.137

$4,11,68$ p. 183 
SENECA RHETOR

QUINTILIANUS

Institutiones oratoriae

4,2,69 p.47

$5,10,13$ p. 24

$5,11,32$ p. 26

$7,4,42$ p. 48

$8,5,19$ p.203

PSEUDO QUINTILIANUS

Declamationes

247 p.66

251 p. 110

306 p. 26

Declamatio minor

12,22 p.51

SALLUSTIUS

De coniuratio catilinae

9,1-2 p.124

SENECA PHILOSOPHUS

De beneficiis

$3,16,2$ p.113

$3,33,4$ p. 224

6,32,1-2 p.221

De brevitate vitae

4,6 p.221

\section{Controversiae}

1,83 p.22

$2,5,13$ p. 22

SERVIUS

In Vergilii aeneida

1,73 p. 93

2,476 p.37

4,29 p.36

4,103 pp.36;37

9,374 p.36

11,476 pp.17;37

In Vergilii georgica

1,31 pp.36;37

\section{SOZOMENUS}

Historiae ecclesiastica

1,9 pp.149;229

1,9,1-2 p.149

Suetonius

De vita Caesarum

Augustus

7,2 p. 134

27,10 p. 129

27,11 p. 128

28,1-4 p.133

34,1-4 p.144

34,4 p. 154

40,3 p. 78 
41,4-5 p.119

43 p.81

45 p.81

46,2 p.119

65,$2 ; 8$ p.222

89 pp. $126 ; 130$

89,5 p. 126

\section{Caligula}

38 p.223

Claudius

18,2 p. 165

23,3 p.58

26 p.70

26,3 p. 226

29 p. 70

Domitianus

8,4 pp.48;82;202;207

22 p. 227

Galba

4 pp.62;64

14,3 p. 157

Iulius Caesar

20,5 p. 117

52, 5-6 p.67

Tiberius

33 p. 200

35,1-3 p.202

35,5 p. 164

47,2-3 p. 120
TACITUS

Annales

2,37-38 p. 120

2,51,1-2 p.164

2,85,1-3 pp.195;201

3,24,2 p.221

3,24,3-4 p.222

3,25,1-2 p.225

3,27,3 p.226

3,28,1-4 p. 180

3,28,3 p. 171

$3,54,3$ p. 225

4,16,2-3 p.36

4,42,3 p.202

4,71,4 p.222

$11,25,8$ p.226

11,27 p.70

11,$30 ; 37$ p.70

$12,43,1$ p. 165

15,5 p. 226

15,19,1 p.164

$15,19,3$ p.64

\section{Germania}

19,2 pp.226

Tertullianus

Apologeticum

4,8 pp. $219 ; 229$

De monogamia

16 p.229 
VALERIUS MAXIMUS

Facta et dicta memorabilia

2,1,4 p. 110

$2,9,1$ p. 104

$2,9,2$ p. 107

$7,1,1$ p.106

$7,7,4$ p.68

VELLEIUS

2,89,3-4 p.121

VERGILIUS

Aeneidos

1,286-290 p.13

8,$314 ; 327$ p. 136

XII PANEGYRICI LATINI

7(6),2,4 p.230
25 p.56

26 p.56

27 pp. $171 ; 174$

28 p.56

29 pp. $181 ; 182$

30 pp. $158 ; 182$

32 pp. $158 ; 182$

Pap. Ber.

11753,3 p.179

Pap. Mich.

3,169 pp. $73 ; 160$

7,436 pp.73;160

PSI

730,48 p.71

Laudatio Turiae

1,27 p.183

1,35 p.192

2, 26-28 p.192

2,31-36 p.192

Res gestae divi Augusti

2,8,1-4 p.222

$2,8,5$ p. 131

5,1 p. 130

5,2 p.138

5,3 p. 130

6,1-2 p. 129

34,1-2 p.134

34,3 p. 130

Tabula Larinas

1-11 p.201

17-19 p.201 


\section{III) FONTES JURÍDICAS}

\section{A) Fontes pré-justinianéias}

Gai Institutiones

1,2 pp. $23 ; 71$

1,13-31;37

1,29 pp.72;95;146;192

1,30 p.146

1,37-38 p.146

1,32-c p.165

1,53 p. 13

1,55-95 p.38

1,56 p. 94

1,59 p.189

1,60 p.189

1,61 p.189

1,62 p.226

1,63 pp. $26 ; 226$

1,64 pp.91;189

1,67 p.94

1,75 p. 95

1,76 p.94

1,77 p.5

1,78 pp.94;95

1,80 p. 94

1,89 p.95

1,90 p.209

1,92 p.94

1,103 p.62

1,106 p.65

1,111 pp.37;171

1,112 p.36

1,113 p.37

1,114 p.37

1,115-b p.37
1,118 p.37

1,123 p.37

1,136 pp.36;37

1,137a p.37

1,144 p.179

1,145 pp.154;164

1,147 p.208

1,148 p.179

1,156 p. 17

1,157 p.7

1,166a p.37

1,178 p. 28

1,179 p.7

1,180 p.167

1,183 p.167

1,190 p.53

1,194 p. 156

1,195a p.37

1,196 p.51

2,111 pp.171;172

2,114 p.151

2,139 p.179

2,144 p.178

2,150 p. 177

2,159 p.179

2,199 p.171

2,205 p.171

2,206 pp.150;171;178

2,207 pp.172;174

2,208 p.172

2,225 p.173

2,263-265 p.171

2,285 p. 178

2,286 pp.150;172;175

2,286-a pp.55;151;171;175

3,41 p. 179

3,42 p.159

3,43 p.161

3,44 p.159

3,45 p. 158 


\begin{tabular}{|c|c|}
\hline 3,51 p.159 & 16,1-a pp.7;175 \\
\hline 3,72 p.5 & 16,2 pp. $84 ; 85$ \\
\hline \multirow[t]{2}{*}{3,109 p.7 } & 16,3 pp. $56 ; 57 ; 58$ \\
\hline & 16,4 p. .56 \\
\hline Epitome Gai & 17,1 pp. $170 ; 173$ \\
\hline 1,4,8 p.189 & 17,2 p.178 \\
\hline \multirow[t]{2}{*}{1,5 pr. p. 62} & 17,3 p. 171 \\
\hline & 18,1 pp. $173 ; 174 ; 179$ \\
\hline \multirow[t]{3}{*}{ Epitome Ulpiani } & 19,17 p.171 \\
\hline & 22,3 p. 170 \\
\hline & 22,14 p.179 \\
\hline 1,2 pp. $171 ; 172 ; 173 ; 178$ & 24,12 pp. $171 ; 173$ \\
\hline 1,4 p.23 & 24,13 p. 173 \\
\hline 1,21 pp. $171 ; 172 ; 178$ & 24,31 p. 170 \\
\hline 3,1 p.96 & 25,17 p. 172 \\
\hline 3,3 pp.71;72 & 26,8 p. 161 \\
\hline 3,6 p.166 & 28,7 p. 177 \\
\hline 5,1 pp.92;209 & 29,3 p.159 \\
\hline 5,2 p.93 & 29,4 pp. $157 ; 159$ \\
\hline 5,3 p. 93 & 29,5 p. 157 \\
\hline 5,4 p.94 & 29,6 p.159 \\
\hline 5,5 p. 94 & 29,7 p.159 \\
\hline \multicolumn{2}{|l|}{ 5,6 pp.94;189;226 } \\
\hline 5,7 p.189 & Pauli Sententiae \\
\hline 5,8 p.95 & \\
\hline \multicolumn{2}{|l|}{5,9 p.94 } \\
\hline 5,10 p.209 & 1,1,6 p.168 \\
\hline 7,1 p.169 & 1,21 p.184 \\
\hline 8,6 p.62 & 2,19,1 p.153 \\
\hline 9,1 p.36 & 2,19,2 pp. $29 ; 31$ \\
\hline 11,20 p.167 & 2,19,3;5 p.189 \\
\hline 11,21 p.167 & $2,19,8$ p.34 \\
\hline 11,22 p.167 & 2,20,1 p.90 \\
\hline 11,27 p.53 & 2,24,1 p.209 \\
\hline 11,28 p.52 & 2,24,2 p.209 \\
\hline 13,1 pp. $82 ; 84$ & 2,24,3 p.209 \\
\hline 13,2 p.82 & 2,24,5 p.209 \\
\hline 14,1 p. 183 & 2,26,1 pp.48;49;188;189;198;204 \\
\hline 15,1 pp. $176 ; 184$ & $2,26,3$ p.195 \\
\hline 15,2 pp. $155 ; 176$ & 2,26,4 p.199 \\
\hline 16,1 pp. $7 ; 53 ; 171 ; 172 ; 173 ; 175$ & 2,26,7 p.199 \\
\hline
\end{tabular}


2,26,8 p. 191

2,26,9 p.195

2,26,12 pp.48;49

2,26,13 p.49

2,26,14 p.204

2,26,15 p.189

3,4b,2 p.177

4,5,2 p.5

4,8,4 pp.91;154

4,9 p.161

4,9,1 p.155

4,9,2 p.155

4,9,3 p.215

4,9,4 p.216

4,9,5 p. 214

4,9,6 pp.214;215

4,9,7 p.96

4,9,8 p.96

4,9,9 p.156

4,10 p.161

5,4,1 pp.48;189

5,4,4 p.189

5,4,14 p.48

5,6,15 pp. $27-28$

$5,22,5$ p. 188

Vaticana Fragmenta

104 p.34

168 pp. $91 ; 163 ; 173$

169 p.163

170 p.163

194 p.163

195 p.172

197 pp.163;165

262 p.169

273 p.169

301 p. 173

302 p.169

320 p. 183
410 p.206

\section{Collatio}

3,3,1-3 p.13

3,3,5-6 p.13

4,2,3 p.198

4,2,6 p.198

4,3,1-6 p.200

4,4,1 p.196

4,5,1 p.196

4,6,1 p.196

4,7,1 p.198

4,9,1 p.198

4,10,1 p.199

4,11,1 p.195

4,12,1 p.198

4,12,2 pp.198;199

4,12,3 p.199

4,12,6 p.199

4,12,7 p.191

4,12,8 p.195

5,1,1 p.49

5,2,1-2 p.49

$5,3,1$ p.49

6,2,4 p.189

6,3,1;-3 p.189

16,2,3 p. 179

$16,3,4$ p. 154

Codex Theodosianus

4,6,2 p.6

4,6,3 p. 230

5,1,9 p.169

$8,4,7$ p.6

$8,16,1$ p. 231

$8,17,2$ p. 231

$8,17,3$ p. 231

$8,17,4$ p. 231 


$$
\begin{aligned}
& \text { 9,7,2 p.196 } \\
& 9,7,3 \text { p.49 } \\
& 9,7,6 \text { p. } 49 \\
& 9,42,24,1 \text { p.6 } \\
& \text { 12,1,49,1 p.6 } \\
& \text { 12,1,74pr. p.6 } \\
& \text { 12,1,93 p.6 } \\
& \text { 13,5,7 p.166 } \\
& \text { 16,2,27pr. p.6 }
\end{aligned}
$$

Lex XII Tabularum

IV,4 p.183

VI,6 p.37

NovellaE POSTTHEOD.

Novellae Leonini

109 p.50

Novellae Maioriani

6,9 p.231

Novellae Theodosiani

22,2,1 p.6

Novellae Valeriani

Nov. Valer. 21,1 p.231

Novellae Valentiniani

Nov. Valent. 31,2 p.6

\section{B) Fontes justinianéias}

CORPus IURIS CIVILIS

Institutiones

1,2pr. p.5

$1,2,3$ p.24

$1,8,2$ p.13

$1,9,1$ pp. $46 ; 47$

1,10 pr. p. 27

$1,10,13$ p. 5

$1,11,4$ p. 65

$1,11,9$ p. 62

$1,11,10$ p.62

1,22 pr. p. 52

1,25 pr. p. 163

2,8pr. p.206

$2,13,5$ p. 5

2,22pr. p. 173

$3,2,1$ p. 5

$3,2,2$ p. 160

$3,2,4$ p. 6

3,3 p.161

$3,3,1 \quad$ p. 161

3,3,4 pp.161;231

$3,3,6$ p. 6

$3,6,10$ p. 5

$3,7,2$ p. 158

$3,7,3$ p. 231

$3,19,10$ p. 7

4,18,4 pp.48;196;205

\section{Digesta}

Const. Tanta $6 \mathrm{~b}$ p.232

1,1,1pr. pp.5;8

$1,1,1,1$ p.120 


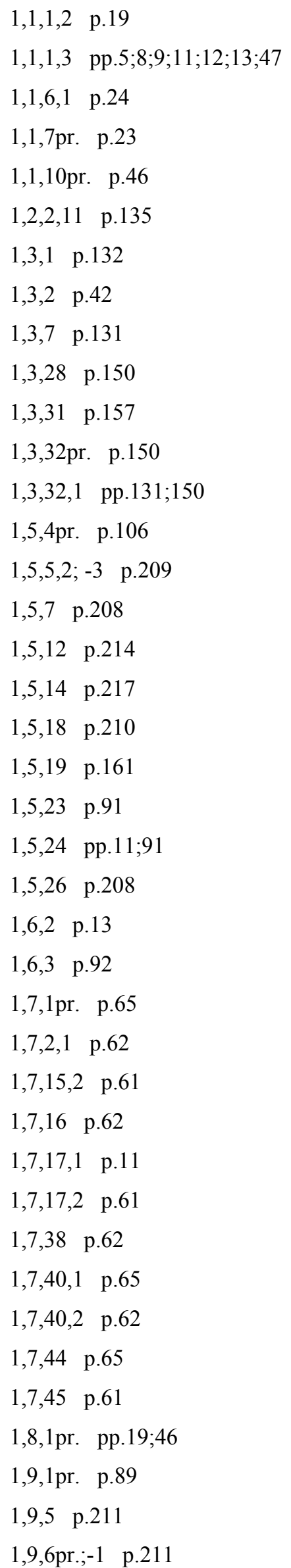

$1,9,7,1$ p. 210

$1,9,8$ p.89

$1,9,9$ p. 81

$1,9,10$ p. 85

$1,9,12$ pr. p. 89

1,12,1,1 p.13

$3,2,1$ pp.26;183

3,2,11,1 p.183

3,2,13,1-4 p.26

$4,4,2$ p. 164

4,4,37,1 p.191

$4,6,19$ p. 33

4,6,38,1 p.172

8,5,2,2 p.189

$9,2,5,2$ p. 7

$10,4,3,15$ p. 11

$11,8,2$ p. 214

$12,6,26,12$ p. 11

$19,1,21$ pr. p.54

$21,1,14,1$ p.111

$21,1,14,3$ p.111

$21,1,17,12$ p.13

$23,1,6$ p. 27

$23,1,7,1 \quad$ p. 27

23,1,9 pp.46;50;51

$23,1,12$ pr. p. 27

23,1,14 pp.51;152

23,1,16 p.80

23,1,17 p.154

23,2,1 pp.39;41;46;47

$23,2,2$ p. 27

$23,2,4$ pp. $50 ; 51$

$23,2,5$ p. 34

$23,2,9,1$ p.29

23,2,11 pp.27;29

$23,2,14,2$ pp.17;189

$23,2,14,2$ p.189

$23,2,14,3$ p. 189

$23,2,14,4$ p. 189

$23,2,16$ pr. pp. $28 ; 80$ 


\begin{tabular}{|c|c|}
\hline $23,2,19$ pp.29;166 & $23,2,57,1$ p.226 \\
\hline $23,2,21 \quad$ p. 27 & $23,2,59$ p.227 \\
\hline $23,2,23$ pp.81;85 & $23,2,60$ pr. p. 227 \\
\hline $23,2,24$ p.84 & $23,2,61$ p.56 \\
\hline $23,2,26$ p.205 & $23,2,62,1 \quad$ p.87 \\
\hline $23,2,27$ p.81 & $23,2,63$ p.227 \\
\hline $23,2,28$ pp. $86 ; 87$ & $23,2,64,1 \quad$ p. 227 \\
\hline $23,2,29$ pp.86;87 & $23,2,65,1 \quad$ p. 227 \\
\hline $23,2,31$ p.81 & $23,2,66$ pr. p. 227 \\
\hline $23,2,32$ p.81 & $23,2,67,3$ pp.59;227 \\
\hline $23,2,33$ p.69 & $23,3,2$ p.167 \\
\hline $23,2,34,1$ p. 82 & $23,3,10,2$ p.6 \\
\hline $23,2,34,3$ p. 81 & $23,3,39,1$ p.60 \\
\hline 23,2,38pr.; $-1 ;-2$ p.227 & $23,3,61,1 \quad$ p. 28 \\
\hline $23,2,41$ pr. p. 81 & $23,3,68$ pp. $.50 ; 51$ \\
\hline $23,2,42,1 \quad$ p.81 & $23,3,74$ p. 51 \\
\hline $23,2,43$ pr. $\quad$ pp. $81 ; 82 ; 84$ & $23,3,75$ p.167 \\
\hline $23,2,43,4$ pp.81;85 & $23,4,8$ p.29 \\
\hline $23,2,43,6$ pp. $82 ; 85$ & $23,5,4$ p.206 \\
\hline $23,2,43,9$ p.85 & 24,1,1 p.169 \\
\hline $23,2,43,10$ pp.82;197;205 & 24,1,3pr. p.169 \\
\hline $23,2,43,12$ pp.84;205 & $24,1,3,1 \quad$ pp. $59 ; 81 ; 90$ \\
\hline $23,2,43,13$ pp.198;205 & $24,1,9$ p.169 \\
\hline $23,2,44$ pr. pp. $.83 ; 84 ; 85$ & $24,1,10$ p.169 \\
\hline $23,2,44,1 \quad$ pp.81;84 & $24,1,31,7$ p.169 \\
\hline $23,2,44,6$ pp. $5 ; 82$ & $24,1,32,13$ pp. $25 ; 34$ \\
\hline $23,2,44,7 \quad$ p.82 & $24,1,32,19$ p.27 \\
\hline $23,2,44,8$ p.84 & $24,1,32,27$ p. 51 \\
\hline $23,2,45$ pr. p. 86 & $24,1,35$ p.193 \\
\hline $23,2,45,2$ p.86 & 24,1,51 p.169 \\
\hline $23,2,45,4$ p. 86 & $24,1,62,1$ p.86 \\
\hline $23,2,45,5$ p. 86 & $24,1,64$ p.169 \\
\hline $23,2,45,6$ p. 86 & $24,1,65$ p. 51 \\
\hline $23,2,46$ p.86 & $24,1,66,1 \quad$ p.47 \\
\hline $23,2,47$ pp. $82 ; 85$ & $24,2,1 \quad$ p.26 \\
\hline $23,2,48$ pr. p.86 & $24,2,6$ p.33 \\
\hline $23,2,48,1$ p. 86 & $24,2,9$ p.193 \\
\hline $23,2,49$ p.85 & $24,2,10$ p.86 \\
\hline $23,2,50$ p.86 & $24,2,11$ pr., -2 p.86 \\
\hline $23,2,51$ pr. p. 87 & $24,2,11,2$ p.193 \\
\hline
\end{tabular}


24,3,1 pp.6;86;87

24,3,11,1 pp.86;87

$24,3,11,2$ p. 87

24,3,22,7 pp.6;109

$24,3,35$ p. 86

$24,3,61$ p. 168

$24,3,64$ pr. p. 168

24,3,65 p.168

$25,2,1$ pp. $34 ; 35$

$25,2,15$ pr. p. 34

$25,3,5,6$ p. 5

25,4,1,1-15 p.211

$25,7,1$ pr. p. 86

$25,7,1,1$ p.89

$25,7,1,2$ p. 82

25,7,1,4 p.51

$25,7,3$ pr. pp.82;90;189

$25,7,3,1$ p.89

$25,7,4$ p. 90

$26,5,7$ p. 167

$26,7,1,2$ p. 7

$27,1,2,2-8$ p.162

$27,1,18$ p.163

$28,1,20$ pr. p. 7

$28,2,6$ pr. p.61

$28,2,6,1$ p. 61

$28,2,12$ p.214

$28,5,72$ p. 175

$29,2,68$ p. 170

$30,96,1$ p. 178

$31,32,6$ p. 5

$31,76,4$ p. 195

$31,88,7$ p. 7

$32,49,4$ p.89

32,80 p. 172

32,89 p. 172

$34,9,10$ p. 139

$34,9,13$ p.205

$34,9,14$ p. 173

$34,9,16,1$ p. 161
$35,1,15$ p. 25

$35,1,21$ p. 170

$35,1,63,1$ p. 177

$35,1,64,1 \quad$ pp.6;22;143

$35,1,71,1$ p.177

$35,1,72,4$ p. 177

$35,1,101$ pr. p. 51

$35,2,14,3$ p. 7

$36,2,30$ pp. $47 ; 51 ; 153$

$37,4,6,4$ p. 88

$37,9,1$ pr. pp. $207 ; 208$

$37,9,1,3$ p. 211

$37,9,1,5$ p.211

$37,9,1,15$ p.208

$37,9,1,19$ p.212

$37,9,5$ pr. p. 212

$37,14,6,4$ p. 88

$37,14,16$ pr. pp. $158 ; 160$

$38,1,27,1 ;-2$ p.214

$38,1,35$ p. 87

$38,1,37$ pr. p. 162

$38,2,39$ p. 158

$38,10,4,2$ p. 17

$38,11,1$ pr. p. 174

38,11,1,1 pp.86;193

$38,16,3,12$ p. 214

$38,16,7$ p. 208

38,17 p. 161

$38,17,1,2$ p.162

$38,17,1,3$ p. 5

$38,17,2,1 \quad$ p. $5 ; 161$

$38,17,2,4$ pp. $161 ; 176$

$40,2,13$ pp. $86 ; 87$

40,2,14,1 p.61

40,9,12pr.;-7 p.195

40,9,13 p.195

40,9,14pr.;1-4 p.195

40,9,14,1 p.194

40,9,21 pp.86;87

40,9,32pr. pp.88;89 


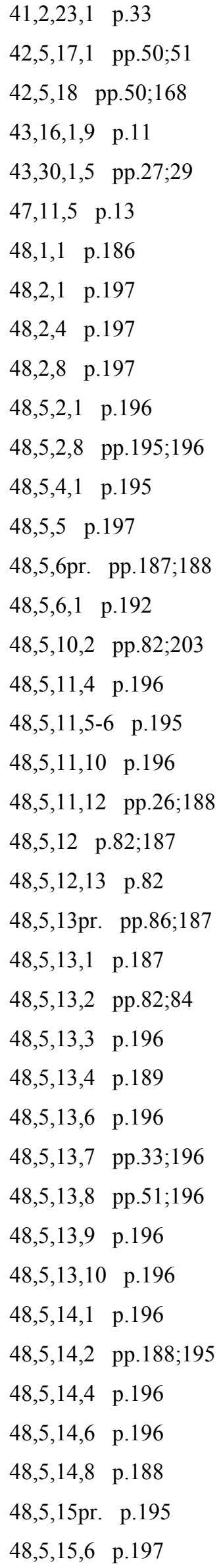

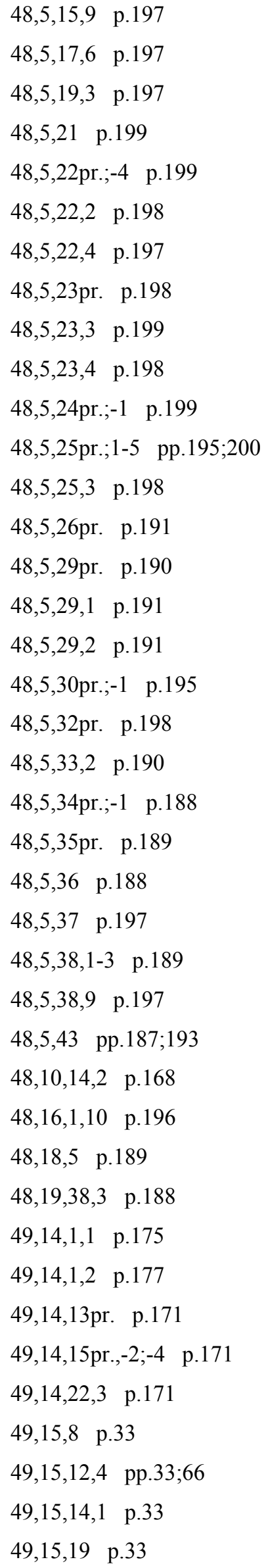




\begin{tabular}{|c|c|}
\hline $49,15,22,1 \quad$ p.33 & Codex \\
\hline $49,15,23$ p.29 & \\
\hline 50,2,9pr. p.5 & 1,3,4,2 p.6 \\
\hline $50,4,2$ p.61 & $1,9,7$ p. 70 \\
\hline $50,5,8$ p. 164 & 2,41,1,1 p.6 \\
\hline $50,6,5,2$ p.163 & $5,1,5,3$ p.6 \\
\hline $50,15,7$ p.139 & $5,3,5$ p. 26 \\
\hline $50,16,10$ pp. $11 ; 192$ & $5,4,6$ p. 227 \\
\hline $50,16,38$ p.216 & 5,4,9 pp.66,74 \\
\hline $50,16,46,1$ pp.16;188 & $5,4,23$ p. 231 \\
\hline 50,16,101pr. p.192 & $5,4,27$ p.59;231 \\
\hline $50,16,128$ pp.59;60 & 5,4,28pr. pp.81;85;231 \\
\hline $50,16,129$ pp.5;155 & $5,5,1$ p. 86 \\
\hline $50,16,132,1 \quad$ p.213 & $5,5,2$ p. 70 \\
\hline $50,16,134$ p.71 & $5,5,7$ p. 230 \\
\hline $50,16,135$ pp. $214 ; 217$ & $5,6,6$ p. 227 \\
\hline $50,16,137$ p.155 & $5,6,7$ p. 227 \\
\hline $50,16,138$ p.174 & $5,6,8$ p.6 \\
\hline $50,16,141$ p.213 & $5,9,2$ p. 183 \\
\hline $50,16,142$ p.172 & $5,13,1,15$ p.206 \\
\hline $50,16,144$ p.90 & $5,17,5$ pr. pp. $27 ; 29$ \\
\hline $50,16,148$ p.155 & 5,17,6 p.193 \\
\hline $50,16,149$ p.155 & $5,17,8$ pp.32;194 \\
\hline $50,16,150$ p.139 & $5,17,8,4$ p. 183 \\
\hline $50,16,152$ p.139 & $5,17,9$ p.183 \\
\hline $50,16,195,2$ p.15 & $5,17,10$ p. 60 \\
\hline $50,16,201$ p.171 & 5,27,1 pp.6;230 \\
\hline $50,16,209$ p.7 & $5,27,3,2$ p.6 \\
\hline 50,16,220pr. p.6 & 5,27,5pr. p. 6 \\
\hline $50,16,220,3$ pp.14;66 & 5,27,6pr. p.6 \\
\hline $50,16,231$ p.217 & 5,27,8pr. p. 6 \\
\hline 50,16,239pr. p.7 & $5,27,11,3$ p. 6 \\
\hline $50,17,2,1 \quad$ p.7 & $5,27,12,3$ p.6 \\
\hline $50,17,5$ p.7 & $5,60,3$ p. .52 \\
\hline $50,17,30$ p. 25 & $6,3,6,1$ p.162 \\
\hline $50,17,140$ p.173 & $6,3,9$ p.86 \\
\hline $50,17,187$ p.214 & $6,4,4$ pp. $158 ; 231$ \\
\hline \multirow[t]{3}{*}{$50,17,191$ p.157 } & $6,25,1$ p.177 \\
\hline & 6,25,2pr. p.177 \\
\hline & 6,26,9pr. p.6 \\
\hline
\end{tabular}


6,29,3pr. p.217

6,40,2;-3 p.107

6,51,1pr.; -1;-2 p.171

$6,51,1,1$ p. 170

6,56 p.161

6,57 p.161

$6,58,12$ pr. pp.6;55;59

$6,58,12,1$ p.231

$6,58,12,2$ p. 57

6,58,14,2 p.6

6,58,14,6 p.6

$6,58,15$ pr. p. 6

6,59,11,1 p.6

7,15,3pr. p.6

7,15,3,1 p.6

$7,38,1$ p. 6

$8,47,2$ p. 6

$8,47,5$ pp. $6 ; 62$

$8,51,2$ pr. p. 6

$8,58,2$ pp. $161 ; 231$

$8,59,1$ p. 231

9,9,1 p.197

9,9,8 p.197

9,9,9 p.205

$9,9,17$ p. 190

$9,9,18$ pr. pp.26;70 9,9,29pr.;-1 p.196

9,9,34 p.70

9,32,4pr. p. 45

9,49,10,2 p.6

$10,32,67,4$ p. 6

11,7,7 p.6

$11,10,5$ pr. p. 6

$11,48,16$ p.6

$11,48,21$ pr. p. 6

$11,48,23$ pr. p. 6

$11,48,23,3$ p. 6

$11,48,23,5$ p. 6

$12,1,13$ p. 89

Novellae

22,43 pp. $107 ; 184$

22,44 p. 184

74,4 p. 49

77 p. 49

78,3 p. 231

117,6 pp. $231 ; 232$

117,8,2 p.196

117,9,4 p.197

141 p.49 


\section{Índice de Autores}

ACCARIAS, 7, 8, 29, 34, 35, 38, 44, 45, 47, 49, 51, $56,60,61,93,189$

Agati Madeira, 78, 102, 106, 112, 116, 118, 164, 189

Albertario, 32, 34, 35, 40, 43, 44, 45, 46, 47, $60,85,89,92,182,184$

AMIRANTE, 101, 102

ANKUM, 33, 48, 85, 86, 149, 185, 186, 187, 188, 190, 192, 194, 195, 196, 197, 198, 199, 200, 204, 205

ARANGio-Ruiz, 28, 29, 30, 32, 33, 36, 37, 45, 51, $56,60,72,76,81,85,86,90,91,94,95,113$, $115,124,138,139,142,148,149,156,166$, $171,174,175,176,179,182,183,189,190$, 193, 194, 195, 206, 219, 227, 229, 231

ARGÜELlo, 9, 53, 75, 138, 175, 178, 193, 225

ARIAS RAMOS, 29, 32

Astolfi, 3, 8, 11, 20, 21, 27, 28, 30, 31, 32, 35, $39,41,43,44,45,48,50,53,54,55,56,59$, $60,61,64,67,69,71,72,73,74,78,79,80$, $81,82,83,84,85,86,87,88,89,90,91,92$, 93, 96, 97, 101, 102, 103, 105, 109, 113, 114, $117,118,119,123,124,125,126,129,138$, $139,140,141,142,143,144,146,147,149$, $150,151,152,153,154,155,156,157,158$, $159,160,161,162,163,164,165,166,167$, $168,169,170,171,172,173,174,175,176$, 177, 178, 179, 180, 181, 182, 183, 184, 186, 187, 188, 189, 190, 191, 193, 194, 195, 196, 198, 202, 205, 206, 210, 217, 223, 225, 226, $227,228,229,230,231,232,241$

AzEVEDO, 32, 47, 124

BACCARI, 11, 12, 13, 15, 40, 43, 66, 212

BAILLY, 6, 7

BESNIER, 8, 11, 20, 21, 22, 38, 53, 55, 56, 77, 78, $79,103,140,142,143,148,150,155,158$,
160, 168, 172, 174, 176, 179, 181, 182, 204

BetANCOURT, 39, 208, 212

BETTI, 16, 20, 94

BIONDI, 14, 16, 21, 22, 24, 26, 27, 28, 30, 32, 33, $35,36,37,44,53,62,63,65,74,77,80,81$, $85,86,87,90,91,92,96,113,114,117,120$, $122,124,131,136,137,138,139,142,145$, $149,154,156,162,163,164,165,166,167$, $168,169,174,175,176,179,180,182,183$, 184, 186, 190, 191, 192, 193, 195, 198, 204, 207, 221, 222, 223, 225, 226, 227, 228, 229, 230, 231, 232

BONFANTE, 9, 15, 16, 32, 35, 36, 39, 43, 44, 46, $75,133,135,169$

BORNECQUE, 13

BOUCHÉ-LECLERCQ, 20, 30, 36, 54, 55, 57, 61, $64,71,72,77,78,79,81,85,88,89,96,97$, $102,103,105,112,114,117,119,121,126$, $128,130,134,135,136,138,139,142,146$, $147,148,149,150,154,156,157,158,159$, $160,162,163,164,165,166,171,174,175$, 176, 179, 181, 183, 184, 185, 186, 204, 206, $220,226,228,229,230,231,232,241$

BOve, 178

BRANCA, 62, 185, 190, 191, 195, 196, 199, 204, 205

BREAL, 6,7

BRETONE, 10

BRINI, 36, 44, 45, 108, 186

BuRdESE, 9, 17, 25, 26, 27, 32, 33, 34, 35, 36, 37, $40,69,81,86,90,91,92,93,94,95,108,109$, $138,142,149,163,166,182,185,193,204$, 206, 227, 228

CALDERINI, 13, 34, 35, 49, 74, 107, 110

Canela, 49, 187, 188, 189, 192, 195, 196, 197, 199, 204, 205 
Cantarella, 20, 28, 35, 78, 113, 168, 185, 192, 211

CARCopinO, 37, 154, 162, 204, 218

CAstelli, 48, 80, 82, 84, 86, 90, 91, 188

CAstro CorrêA, 19, 29, 34, 36, 41, 42, 46, 69, $113,162,185,193,195$

Catalano, 5, 8, 15, 21, 22, 40, 66, 196, 209, 212,224

CEJAdOR y FraucA, 6, 7

Cerami, 92, 130, 131, 135, 142, 151

CÉSAR DA SilveIRA, 7, 73, 130, 181, 188

Chiazzese, 185, 187, 189, 190, 194, 195, 196, 197, 199, 204

Cipriani, 6, 7, 13, 22, 93

Cogliolo, 100

CoRNIL, 28, 30, 35, 36, 44, 49, 51, 76, 81, 90, 206, 227

CORTES, 26, 27, 28, 29, 32

CRUZ, 27, 46, 124

CRUZ E TUCCI, 124

CUENCA, 124

CuQ, 36, 72, 73, 74, 76, 155, 166, 167, 176

DALlA, 8, 22, 25, 26, 29, 33, 47, 49, 50, 53, 54, $59,61,62,63,64,69,77,81,83,90,91,92$, 94, 97, 108, 130, 155, 162, 163, 166, 175, 184, 193, 206, 214, 217, 231, 241

De Martino, 18, 107, 127, 129, 132, 134, 136

DE SALVO, 166

DE VISSCHER, 95

Della CoRTe, 25, 36, 53, 77, 78, 80, 85, 94, 139, 142, 147, 148, 154, 179, 188, 200, 207, 218, 224

DomíNGUEZ LÓPEZ, 54, 55, 56, 59, 60, 61, 142, $174,175,176$

DURRY, 26, 49, 51, 52, 53, 152

ELLUL, 158, 179, 218

ERNOUT, 5, 6, 7, 10, 26, 66

ESMEIN, 152, 185, 186, 188, 194, 197, 199, 205

FAYER, 129, 142, 143, 146, 148

FEDELI, 6, 7, 13, 22, 93
FERNANDEZ DE BuJAN, 102, 106

FERRETTI, 208

FERRINI, 26, 139, 140, 159, 241

FIELD JR, 64, 79, 83, 96, 112, 114, 117, 118, 124, $125,126,135,140,142,143,147,148,152$, $156,163,164,166,171,179,180,181,186$, 220, 222, 226, 228, 229, 231

FRANCIOSI, 16, 21, 32, 39, 40, 44, 98

FuMAGALli, 27, 51, 114, 152, 153, 154, 182, 196, 206, 208

GAFFIOT, 6

GALINSKY, 53, 80, 81, 114, 117, 119, 123, 131, $136,145,183,194,230$

GARCÍA GARRIDO, 7, 206

GAUDEMET, 24, 27, 30, 32, 33, 34, 35, 38, 40, 43, $46,50,51,57,59,69,73,77,81,82,83,84$, $85,86,93,94,108,139,142,167,174,185$, 189, 190, 191, 195, 205, 218, 219, 224, 226, $227,231,241$

GIL, 106

GIORDANI, 13, 15, 17, 33, 73, 92, 101, 102, 105, $132,155,194$

GIUFFRÈ, 19, 20, 92

GIUNTI, 16, 17, 22, 34, 36, 37, 38, 46, 50, 65, 67, 75, 78, 103, 104, 105, 107, 108, 109, 110, 111, $112,113,114,222$

GOUREVITCH, 50, 114

GuARINO, 3, 9, 26, 53, 56, 75, 85, 95, 107, 119, $124,130,131,133,134,135,140,142,147$, $158,163,165,166,173,178,190,195,199$, 204, 225

HuMBert, 31, 89, 109

IGLESIAS, 27, 36, 40, 86, 95, 132, 138, 142, 151, $165,166,174,179,182,193,205,206,227$

IMPALLOMENI, 71, 155, 156, 162, 174, 213, 215, $216,217,231$

JAGU, 41, 42, 138, 142

JHERING, 7, 106, 132

JÖRS, 117, 125, 131, 142, 225, 226, 241

JURET, 6, 7 
KASER, 8, 11, 12, 75, 193

KLABIN, 170

LAMBERTINI, 8, 22, 25, 26, 29, 33, 47, 49, 50, 53, $54,61,62,63,65,69,77,81,83,90,91,92$, 94, 97, 108, 163, 166, 175, 184, 193, 206, 217

LAMBRINI, 32

LANFRANCHI, 40, 41, 66, 67, 92, 110, 193

LAURENTI, 13, 41, 43, 122, 136, 138

LAURIA TUCCI, 124

LIMA FILHO, 130

LONGO, 11, 24, 26, 28, 29, 30, 32, 33, 34, 35, 39, $40,44,53,69,81,85,89,90,95,130,149$, 155, 160,162,163,172, 184, 186, 188, 192

LÓPEZ PEDREIRA, 22, 23, 26, 27, 29, 32, 34, 39, $45,47,51,79,81,85,89,91,94,111,114$, $117,123,124,130,133,139,140,142,148$, $149,154,169,171,175,178,179,182,186$, $195,199,218,225$

MADEIRA, 7, 155, 162, 207, 208, 212, 214, 217

MAGDELAIN, 130

MALDONADO DE LizALDE, 61, 78, 85, 96, 122, $125,126,134,135,136,139,142,148,149$, $150,156,157,162,163,165,176,177,179$, $184,186,220$

MANCINI, 93, 95

MANZO, 169

MARCHI, 32, 34, 35, 40, 44, 70, 77, 85

MARGADANT, 149, 220

MARKY, 80, 142, 151, 161, 206

MARotTA, 80, 114, 126, 127, 129, 142

MARRONE, 26, 32, 34, 35, 40, 41, 45, 51, 69, 85, 89, 92, 94, 97, 108, 113, 155, 156, 182, 185, 193

Matos Peiхото, 7, 9, 25, 32, 35, 156, 217

MAY, 39

Meillet, 5, 6, 7, 10, 26, 66

MEIRA, 37, 101, 102, 106, 183

Mette-DittmanN, 166, 222

MoLÈ, 48, 83, 90, 188, 189, 196, 200, 204, 205

Mommsen, 48, 83, 91, 94, 185, 186, 187, 188,
189, 190, 192, 194, 195, 196, 197, 200, 204

MONIER, 73, 75, 81, 89, 166, 182, 185, 190, 193, 206

Moreira Alves, 7, 16, 20, 26, 32, 37, 50, 80, 89, $101,135,155,162,215,216,217$

MORNET, 13

NARDI, 48, 50, 57, 79, 80, 81, 82, 83, 84, 85, 91, 108, 161, 173, 192, 198, 203, 204, 205, 212, $231,232,241$

NÉRAUDAU, 114

NicOLETTI, 109, 130, 166, 167, 206

NÖRR, 28, 48, 55, 64, 77, 81, 83, 97, 112, 118 , $121,124,130,139,142,147,148,149,155$, $156,159,164,174,175,178,179,180,181$, $182,218,219,220,221,225,226,227,228$

NúÑEZ PAZ, 220

ONIDA, 9, 12, 13, 21, 22

ORESTANO, 3, 25, 26, 34, 43, 44, 66, 67, 75, 92, 108,241

Ortín GARcÍA, 53, 54, 55, 56, 63, 138, 149, 156, $174,176,179,218,229,231$

PACCHIONI, 18, 29, 34, 36, 37, 91, 94, 206

PAOLI, 34, 35

PEPPE, 36, 37, 38, 53, 71, 98, 103, 108, 110, 183

PerozZI, 16, 25, 36, 37, 38, 51, 60, 76

PESSI, 102, 106, 132

PÉTER, 14, 20, 34, 36, 41, 43, 66, 67, 78, 105, $111,114,118,124,174,182,209,229$

PETIT, 9

PIERI, 79, 101, 105, 114, 115, 127, 129, 130, 136, 222

PONTES DE MiRANDA, 3

PORCHAT, 9, 46

PuCHTA, 219, 226

Pugliese, 33, 36, 37, 40, 43, 85, 119, 121, 138, 178, 190, 193, 198, 199, 217

PujAL, 25, 32, 33, 40, 43, 44, 46, 47, 69, 77, 85, 89, 199

RADITSA, 26, 27, 28, 29, 51, 55, 56, 74, 77, 79, $80,81,83,85,86,91,108,124,127,129,130$, 
$133,136,138,148,149,159,160,162,164$, $165,166,171,174,178,179,181,182,186$, 188, 189, 190, 193, 194, 195, 199, 200, 218, 219, 229

RASI, 193

RATTI, 29, 33, 86, 163

RIBAS-ALBA, 69

RiccoBono, 53, 77, 80, 103, 114, 118, 124, 142, $147,156,162,165,169,175,178,193,195$, 206, 222

RIZZELLI, 33, 185, 186, 187, 188, 189, 190, 191, 192, 194, 195, 196, 197, 199, 204, 205

RoBledA, 8, 12, 25, 27, 28, 32, 34, 36, 38, 39, 45, 47, 50, 66, 69, 70, 108, 109, 110, 111, 187, 192, 193, 194

ROCHA PEREIRA, 23, 46, 106, 130, 134, 136, 137 , 138,212

RODRIGUES, 8, 35, 40, 43, 44

RomANo, 16, 17, 18, 19, 20, 33, 34, 35, 36, 37, $39,47,48,49,90,92,93,94,95,98,99,106$, 118, 169, 182, 188.

RuIZ FERNANDEZ, 105, 107, 114, 127, 193, 205, 220

RuSSO RUGGERI, 62, 64, 65, 162

SACCHI, 19, 41

SALVADORE, 62, 63, 64

SAMPER, 54, 55, 56, 57, 138, 149, 156, 159, 162 , 173,182

SAVIGNY, 9, 182, 183, 202, 204

SCACCHETTI, 169, 185, 186, 190, 191, 195, 200, 203, 204

SCARANO USSANI, 131, 142

SCHULZ, 23, 27, 28, 29, 35, 36, 37, 41, 60, 81, 87, $90,91,92,113,123,136,166,169,182,188$, 189, 194, 206, 219

SERAFINI, 28, 36, 39, 142, 149, 179, 184, 206

SHOTTER, 130, 133

SINI, 134, 137

SitZIA, 33, 36, 37, 40, 43, 85, 138, 178, 190, 193, $198,199,217$
SolAzZI, $80,81,82,84,85,86,87,91,188,191$, 194, 198, 199, 205, 241

Spagnuolo Vigorita, 17, 18, 20, 69, 73, 74, 79, $80,81,83,85,86,98,103,112,114,117,118$, $120,121,123,124,125,126,127,128,129$, $130,133,134,135,136,137,138,139,140$, $141,142,145,146,147,148,149,152,154$, $155,157,162,163,165,169,171,173,174$, $176,178,179,180,181,182,185,186,188$, 189, 193, 195, 196, 198, 199, 200, 201, 221, $222,223,225,226,230,232,241$

SURGIK, 35, 36, 40, 87

TALAMANCA, 8, 9, 40, 53, 62, 95, 127, 142, 199, 206, 217

TELLO, 78, 154, 157, 162, 163, 166, 179, 217, 227,231

VACCA, 33, 36, 37, 40, 43, 138, 178, 190, 193, 198, 199, 217

VANOYEKE, 69, 228

VERA-CRUZ, 55, 56, 156, 162, 217

VEYNE, 13, 41, 66, 111

Villaça AZEVEdo, 32, 33, 34, 35, 36, 40, 44, 47, $61,196,207$

VILLERS, 33, 35, 37, 38, 77, 113, 115, 126, 136, $138,195,206,224$

VILLEY, 10

VINCENTI, 78, 219

VocI, 9, 21, 32, 36, 107, 114, 124, 170, 179, 232

VOLTERRA, 9, 17, 18, 20, 23, 26, 32, 33, 34, 35, $36,37,38,40,43,44,45,47,50,51,56,57$, $60,62,66,67,69,71,72,73,75,76,77,79$, $81,83,85,86,87,89,91,92,93,94,95,96$, $103,106,107,108,110,138,139,140,142$, $151,162,169,174,175,178,179,182,187$, 188, 189, 190, 193, 194, 195, 196, 199, 204, 209, 228, 229, 231, 241

ZABŁOCKA, 53, 54, 55, 56, 57, 58, 59, 64, 72, 73, $78,80,81,83,85,92,97,117,130,138,140$, $142,149,151,152,153,154,155,156,159,160$, $162,163,165,166,171,174,175,176,179,181$, 
182, 184, 185, 186, 187, 190, 196, 197, 198, 199, $228,229,231$

200, 201, 202, 203, 204, 217, 221, 222, 226, 227 , 